\title{
PUBLIEK BELANG: HOE HOUD JE HET OP DE RAILS?
}

EEN STUDIE NAAR DE EFFECTIVITEIT EN LEGITIMITEIT VAN PLANVORMING VOOR STATIONSLOCATIES 


\section{Promotiecommissie}

$\begin{array}{lll}\begin{array}{ll}\text { Voorzitter/secretaris } \\ \text { Promotor }\end{array} & \text { prof. dr. F. Eising } & \text { Universiteit Twente } \\ & \text { prof. dr. G.P.M.R. Dewulf } & \text { Universiteit Twente } \\ & \text { prof. dr. S.A.H. Denters } & \text { Universiteit Twente } \\ \text { Leden } & \text { prof. dr. ir. A.G. Dorée } & \text { Universiteit Twente } \\ & \text { prof. mr. dr. M.A. Heldeweg } & \text { Universiteit Twente } \\ & \text { prof. dr. C.J. van Montfort } & \text { Universiteit van Tilburg } \\ & \text { prof. dr. J.F.M. Koppenjan } & \text { Erasmus Universiteit Rotterdam }\end{array}$




\title{
PUBLIEK BELANG: HOE HOUD JE HET OP DE RAILS?
}

\author{
EEN STUDIE NAAR DE EFFECTIVITEIT EN LEGITIMITEIT \\ VAN PLANVORMING VOOR STATIONSLOCATIES
}

\section{PROEFSCHRIFT}

ter verkrijging van,

de graad van doctor aan de Universiteit Twente,

op gezag van de rector magnificus,

prof.dr.ir. H. Brinksma,

volgens besluit van het College voor Promoties,

in het openbaar te verdedigen

op woensdag 22 december 2010 om 11.00 uur

door

Marnix Smit

geboren op 10 december 1975

te Almelo 


\section{Dit proefschrift is goedgekeurd door de promotoren}

Prof. dr. G.P.M.R. Dewulf

Prof. dr. S.A.H. Denters
Universiteit Twente

Universiteit Twente

ISBN: $978-90-365-3137-5$

Copyright (C) M. Smit, Almelo, 2010

Alle rechten voorbehouden. Niets uit deze uitgave mag op enigerlei wijze openbaar worden gemaakt en/of vermenigvuldigd zonder voorafgaande schriftelijke toestemming van de auteur.

All rights reserved. No part of this publication may be used and/or reproduced in any manner without written permission from the author.

Geprint en gebonden door Gildeprint, Enschede, Nederland. 


\section{Voorwoord}

Voor u ligt een proefschrift over het borgen van het publiek belang in stationslocatieprojecten. Het is het fysieke resultaat van een boeiend proces dat promoveren heet. Ruim acht jaar geleden begon ik als afgestudeerd bestuurskundige aan dit traject vanuit de behoefte om naast een voetbalcarrière een intellectuele uitdaging te hebben en mijn kennis over de rol van de overheid in ruimtelijke ontwikkelingen te verbreden en verdiepen. Een uitdaging was het zeker. Ondanks momenten van frustratie, die volgens diverse voorgangers onlosmakelijk verbonden zijn aan het promotieproces, is het onderwerp me nooit gaan vervelen. Getuige vele recente publicaties staat het borgen van het publiek belang ook nog steeds volop in de belangstelling. Ook zullen in de komende decennia ruimtelijke projecten in Nederland meer en meer bestaan uit stedelijke herontwikkelingsopgaven, zoals stationslocatieprojecten zijn. Dit proefschrift vormt dan ook zeker geen sluitstuk van het debat, maar levert naar ik hoop een waardevolle bijdrage aan een aanpak van het sturingsvraagstuk van stedelijke herontwikkelingsopgaven.

Gedurende mijn promotietraject heb ik de steun en inspiratie van diverse mensen ervaren. Allen die op de één of andere wijze hebben bijgedragen aan de totstandkoming van dit proefschrift dank ik hiervoor dan ook van harte. Voor een aantal van hen wil ik dit hierna graag expliciteren.

Om bij het begin te beginnen. Mirjam, zonder jou was ik naast een voetbalcarrière überhaupt nooit begonnen aan een promotietraject. Dank dat je me die uitdaging aan hebt laten gaan. Realiseer je wel dat ik dankzij jou jaren lang in mijn andere (werk)wereld heb moeten uitleggen dat ik niet in een witte jas met stethoscoop of reageerbuizen in de weer was...Geert, jij was onmisbaar voor de totstandkoming van dit boek. Je hebt als promotor een lange adem nodig gehad, ik hoop dat je het de moeite waard vond. Dank voor je steun, behulpzame commentaar en aanhoudende vertrouwen dat ik het tot een goed einde zou brengen. Bas, ik heb veel waardering voor de wijze waarop jij de rol van tweede promotor hebt ingevuld. Jouw vermogen om complexe theoretische discussies aan de hand van eenvoudige metaforen te verhelderen, heeft op diverse momenten bijgedragen aan mijn begrip hiervan. Dank voor je waardevolle inbreng in mijn promotietraject en het vrijmaken van tijd op soms ongebruikelijke tijdstippen. Voor jullie beide geldt daarnaast, dat ik me afvraag wiens passie voor de voetbalsport groter is; die van jullie of de mijne. Hoewel het onze onderzoeksbesprekingen standaard met een kwartier verlengde en jullie hoogleraarschap hier geen betrekking op heeft, heb ik genoten van de vele discussies hierover.

Dit onderzoek had ook niet tot resultaten geleid zonder de medewerking van vele personen die zich in de praktijk bezig houden met de herontwikkeling van stationslocaties. Hoewel ik hen niet allen persoonlijk kan noemen, wil ik graag alle geïnterviewden danken voor het delen van hun kennis en ideeën. Daarnaast gaat mijn dank uit naar het ministerie van Verkeer en Waterstaat en het ministerie van VROM voor de financiële ondersteuning van dit onderzoeksproject.

Verder een woord van dank aan mijn collega's van de Afdeling Bouw/Infra, voor het creëren van een aangename werksfeer en jullie belangstelling in een individueel traject zoals promoveren is. In het bijzonder gaat hiervoor mijn dank uit naar Inge, Maarten en Erwin: het mede-oudeilandbewonerschap schept zeker een speciale band. Robin, planvorming is en blijft jouw specialty. Dank voor je feedback op mijn hoofdstuk hierover. Anneloes, brainstormen met jou beperkt zich 
niet tot enige context. Thanks! Bram, jouw liquide consumpties hielpen me de eindstreep te halen. Succes met jouw eindspurt. Yolanda en Jacqueline, jullie zorgen ervoor dat het leven van een promovendus wat gestroomlijnder verloopt. Dank voor jullie ondersteuning gedurende dit traject.

Tenslotte gaat mijn dank uit naar mijn familie en vrienden voor de vreugdevolle afleiding en hun warmte. Het is een voorrecht te weten dat er mensen zijn op wie je altijd kunt terugvallen, wat er ook gebeurt. Carmen, hoe interessant onderzoek ook kan zijn, jij laat me zien dat het leven uit meer en belangrijkere dingen dan promoveren en sport bestaat. Dank voor je relativering, bemoediging en de vele kleine opofferingen die je hebt gemaakt, zodat ik in staat was dit promotietraject te volbrengen. De laatsten zijn de eersten. Pa en ma, jullie vertrouwen en steun heeft me altijd gestimuleerd het beste uit mezelf te halen. Mijn activiteiten aan de universiteit waren voor jullie wellicht niet altijd helder. Welnu, hopelijk biedt dit boek uitkomst.

Marnix Smit

December 2010 


\section{Inhoudsopgave}

Voorwoord

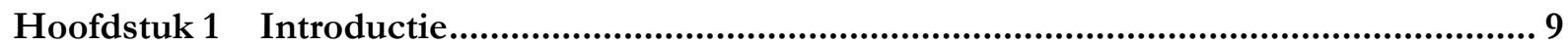

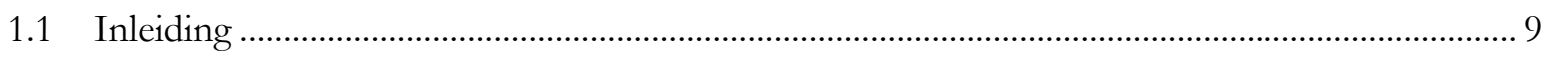

1.2 Governance en sturing in ruimtelijke ontwikkeling ............................................................. 9

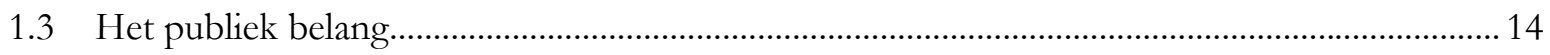

1.4 Een specifieke soort ruimtelijke projecten: stationslocaties ....................................................... 17

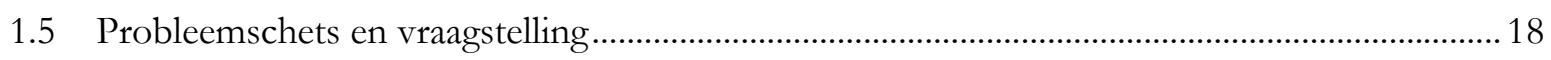

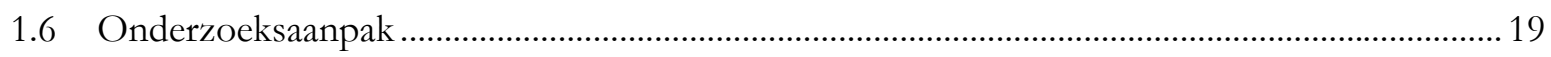

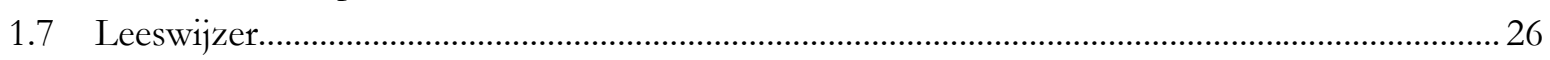

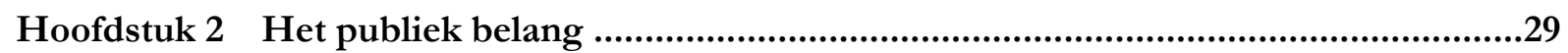

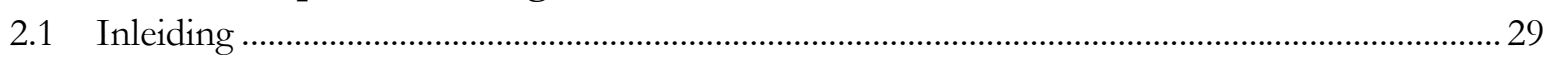

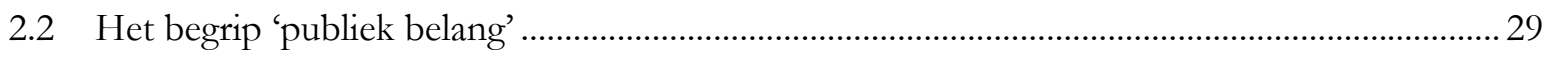

2.3 Politiek-filosofisch perspectief: alomvattend doel of betekenisloos concept? ........................... 31

2.4 Economisch perspectief: externe effecten als bron voor publieke belangen? ............................ 34

2.5 Evaluatie van het publiek belang in complexe ruimtelijke projecten ............................................36

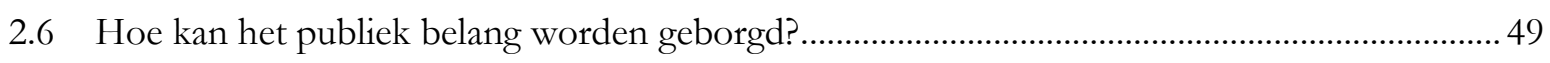

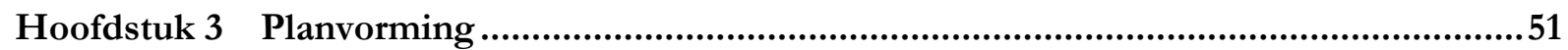

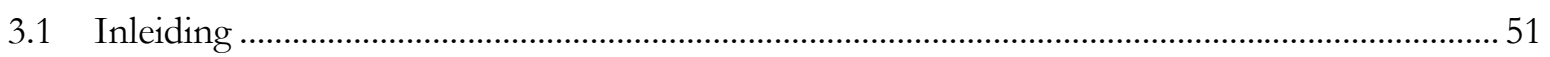

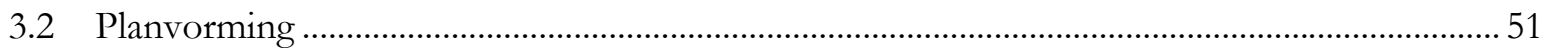

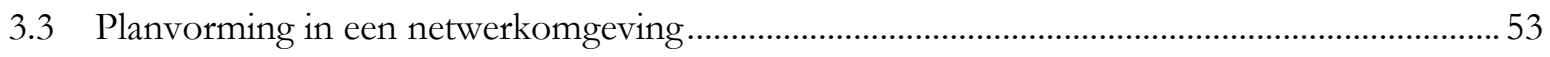

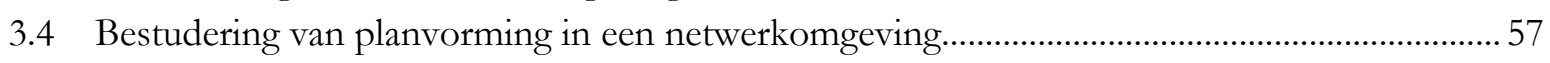

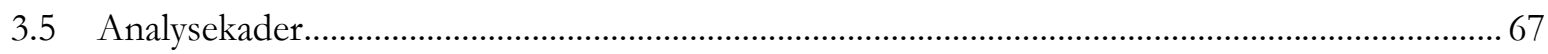

Hoofdstuk 4 Conceptueel raamwerk \& aanpak case analyse ................................................69

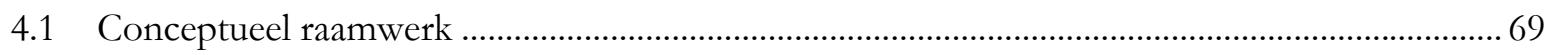

4.2 Aanpak case analyse .......................................................................................................... 80

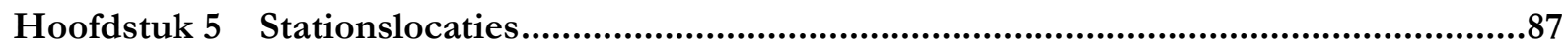

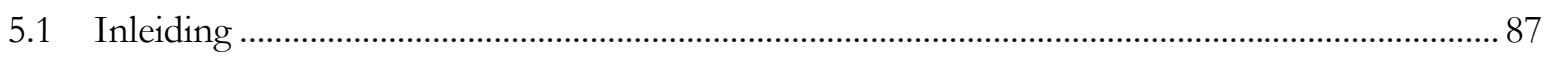

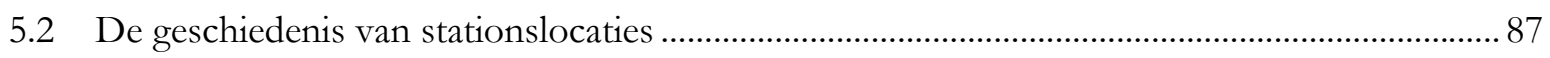

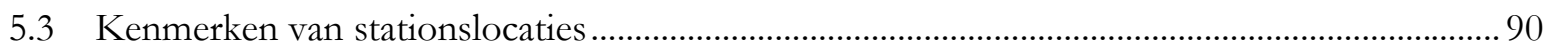

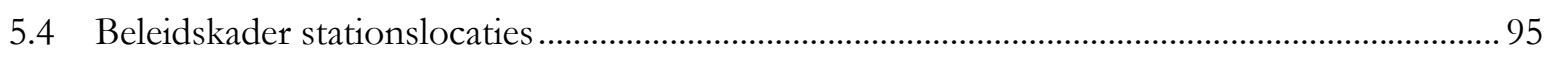

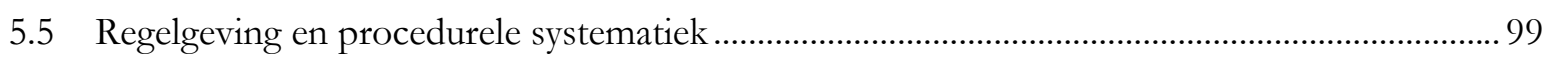

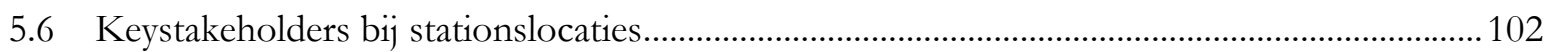

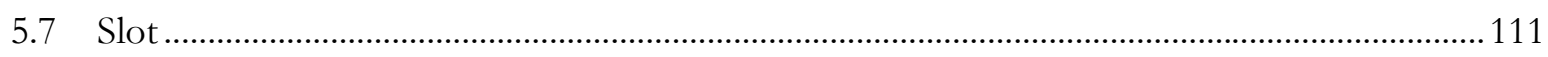




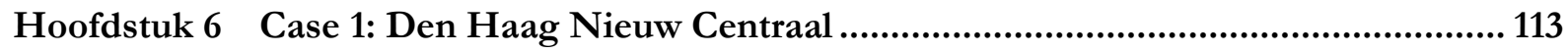

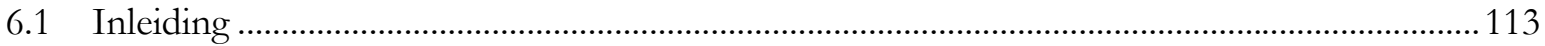

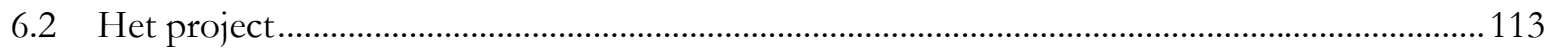

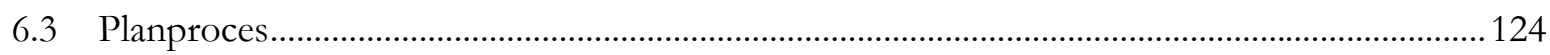

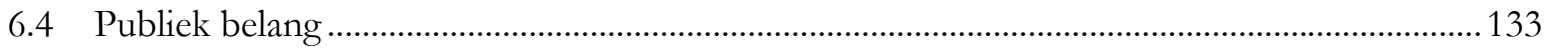

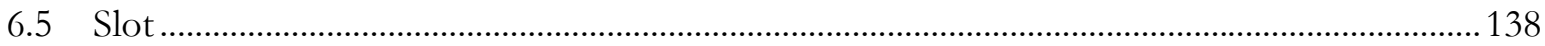

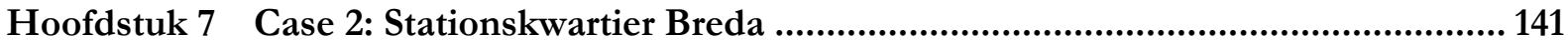

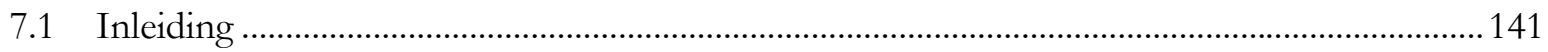

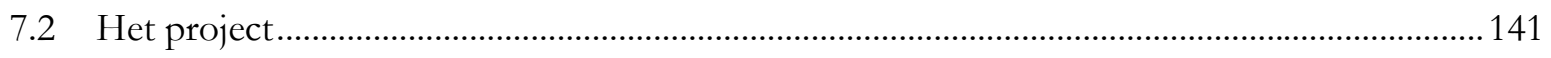

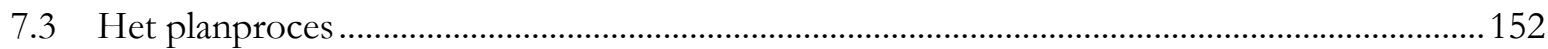

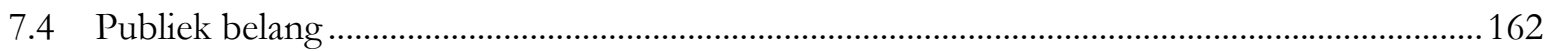

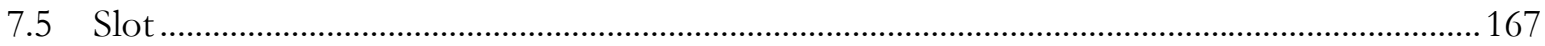

Hoofdstuk 8 Case 3: Spoorzone Delft ............................................................................. 169

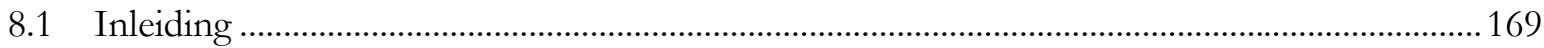

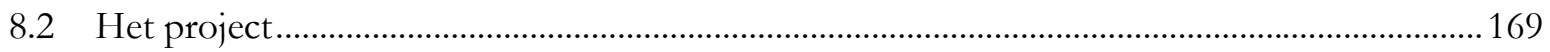

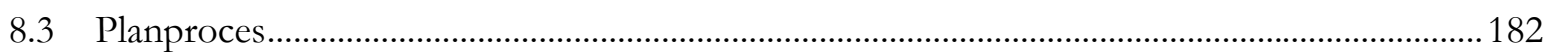

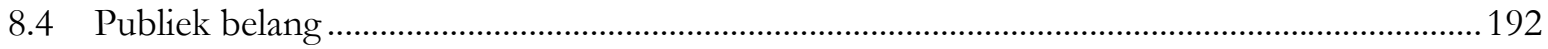

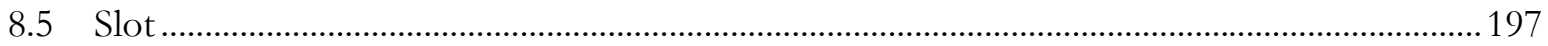

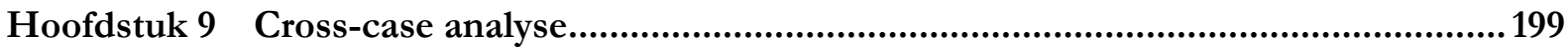

9.1 Analyse van verschillen en overeenkomsten in projectkenmerken .......................................... 199

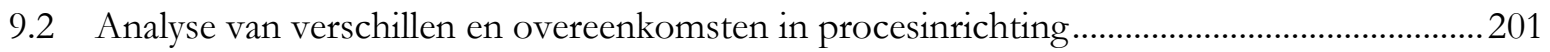

9.3 Analyse op de criteria voor de borging van het publiek belang .................................................211

9.4 Analyse van relaties tussen procesinrichting en borging publiek belang....................................218

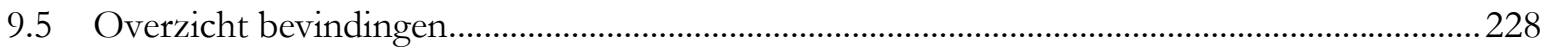

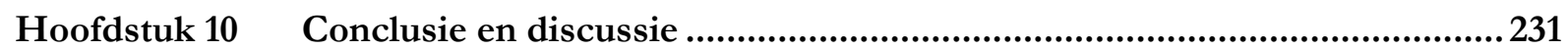

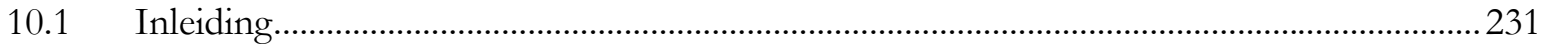

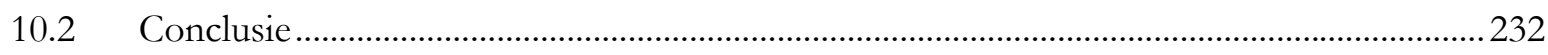

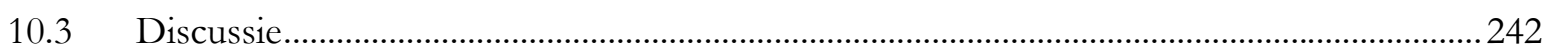

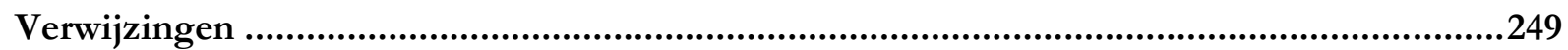

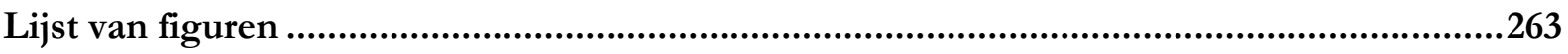

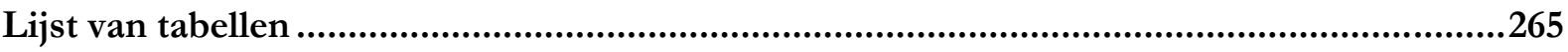

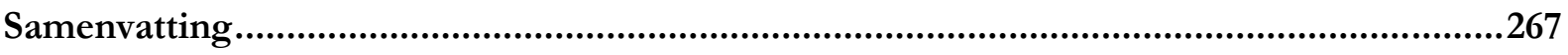

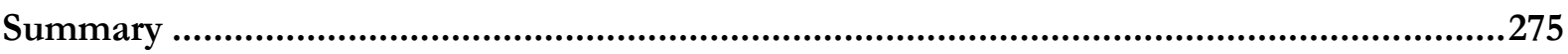

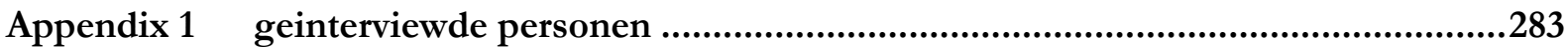

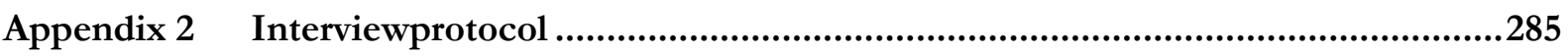

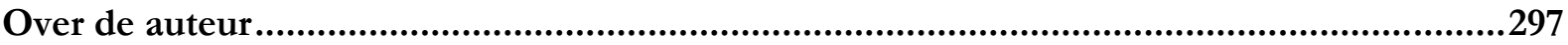




\section{Hoofdstuk 1}

\section{Introductie}

\subsection{Inleiding}

Diverse ontwikkelingen in de samenleving en de ruimtelijke sector hebben er de afgelopen decennia toe geleid dat sturing door de overheid in het ruimtelijke domein complexer is geworden (VROMraad, 2004). ${ }^{1}$ Het beeld van de overheid die unicentrisch en top-down de normen stelt voor ruimtelijke ontwikkelingen, heeft afgedaan. Een goed samenspel met andere actoren in het speelveld wordt in toenemende mate noodzakelijk geacht om oplossingen te vinden voor hedendaagse ruimtelijke problemen. Zeker in veel stedelijke projecten is er sprake van complexe en nauw verweven problemen (Van Twist, 2004) en wordt een integrale benadering als noodzaak gezien (De Kort, 2009). In de beleidspraktijk en wetenschap wordt daarom gezocht naar samenwerkingsvormen tussen verschillende lagen en sectoren van de overheid en tussen overheden en andere maatschappelijke actoren, die beter zijn toegesneden op de toegenomen complexiteit.

In een bredere context wordt deze verschuiving - waarbij in plaats van sturing vanuit de enkele overheid de nadruk wordt gelegd op de (probleemgestuurde) interactie respectievelijk het samenspel tussen verschillende actoren - aangeduid als de shift van government naar governance. Ondanks deze verschuiving blijft de heersende opvatting dat de overheid in de constellatie van actoren die betrokken zijn bij ruimtelijke projecten dé partij is die het publiek belang dient te waarborgen. De vraag hoe, tegen de achtergrond van de veranderde context, het publiek belang in ruimtelijke projecten gewaarborgd kan worden staat centraal in het onderzoek dat hier wordt beschreven.

Dit hoofdstuk beschrijft de achtergrond en aanleiding voor het onderzoek en geeft aan welke aanpak is gehanteerd. Er wordt gestart met een inleiding over de veranderende opvattingen over de rol en het functioneren van de overheid in de maatschappij (1.2). Vanuit deze algemene inleiding wordt gefocust op de ruimtelijke sector, waarbij een aantal ontwikkelingen in de verhoudingen tussen actoren in deze sector wordt beschreven. Deze ontwikkelingen en de veranderende opvattingen en over de rol van de overheid hangen direct samen met de discussie over de borging van het publiek belang. Paragraaf 1.3 besteedt daar aandacht aan. Aansluitend wordt het object van onderzoek, de herontwikkeling van stationslocaties als specifiek type ruimtelijk project, belicht (1.4). Vanuit deze achtergrond wordt de centrale onderzoeksvraag geformuleerd (1.5) en wordt de gehanteerde onderzoeksaanpak toegelicht (1.6). Het hoofdstuk wordt afgesloten met een leeswijzer voor het vervolg (1.7).

\subsection{Governance en sturing in ruimtelijke ontwikkeling}

\subsubsection{Het governancedebat}

Twee eeuwen geleden vormde de introductie van de gekozen volksvertegenwoordiging een mijlpaal in de democratische ontwikkeling van moderne westerse samenlevingen. Het zogenaamde 'verlichtingsdenken' kreeg vorm via een parlementaire democratie waarin door rechtstreekse 
verkiezingen gekozen politieke vertegenwoordigers wetten en beleid bepalen en een bureaucratie die dit democratisch gelegitimeerde beleid correct, effectief en efficiënt uitvoert. Het primaat van de gekozen volksvertegenwoordiging domineert nog steeds het denken over maatschappelijke sturing (Oosten, 2005). Als gevolg van sociale, maatschappelijke en economische ontwikkelingen heeft de samenleving zich de laatste decennia echter ontwikkeld richting een netwerksamenleving (Castells, 1996) ${ }^{2}$. De verwevenheid en afhankelijkheid tussen ondernemingen, groepen, gebieden en populaties is sterk toegenomen. Dit dwong overheden tot het relativeren van hun sturingspretenties. Ontevredenheid over de prestaties van de overheid heeft daarnaast geleid tot grotere betrokkenheid van de private sector bij de uitvoering van publieke taken. Dit ging onder andere in de vorm van privatisering, verzelfstandiging, publiek-private samenwerking of toepassing van uit de private sector afkomstige managementtechnieken. De opkomst van het 'New Public Management' als tegenwicht voor de traditionele inputgerichte overheidsdenken, leidde tot meer aandacht voor prestaties (outputsturing), evaluaties en scheiding van beleid en uitvoering, waarbij de laatste meer op private leest werd geschoeid.

Deze en andere factoren 3 zorgden er voor dat de aandacht voor zogenaamde 'governancevraagstukken' het afgelopen decennium toe nam (Pierre en Peters, 2000). Vanuit governance perspectief heeft modern openbaar bestuur betrekking op de interactie tussen overheid, bedrijfsleven, maatschappelijke organisaties en burgers en is gericht op het realiseren van maatschappelijke doelstellingen en waarden waaronder overheidsdoelstellingen (Rhodes, 2000). De kernfunctie van de overheid verandert van het ontwikkelen en uitvoeren van overheidsbeleid naar het samen met maatschappelijke organisaties, bedrijven en burgers leveren van een bijdrage aan een proces van publieke beleidsvorming. Een verschuiving van top-down hiërarchische sturing gebaseerd op grondwettelijke bevoegdheden naar het stimuleren, organiseren en faciliteren van de coördinatie tussen actoren (Pierre et al., 2000). In toenemende mate wordt nadruk gelegd op deze nieuwe rol voor de overheid (Salet et al., 2003).

In de discussie over governance vormen de veranderende verhoudingen tussen actoren en de wijze waarop deze verhoudingen op verschillende beleidsterreinen worden vormgegeven met het oog op meer effectiviteit en legitimiteit een rode draad (Pierre, 2000). In het ene geval ligt daarbij de nadruk op de werking van sturings- en coördinatiemechanismen, terwijl in andere gevallen individuele organisaties of maatschappelijke partijen als uitgangspunt worden genomen (Giulani, 2001). ${ }^{4}$ In alle gevallen staat de wisselwerking tussen actoren die op het betreffende niveau actief zijn centraal (Montfort, 2004). Deze wisselwerking verloopt, zeker bij complexe vraagstukken, lang niet altijd naar wens. Complexe vraagstukken worden gekenmerkt door de betrokkenheid van meerdere organisaties, verschillende percepties van oorzaak en gevolg, onvermogen om (beleids)programma's te integreren en door onvolmaakte communicatie tussen beleid en uitvoering (Steward, 2005). Het besef dat geen van de overheidsorganisaties op zichzelf voldoende sturingsmogelijkheden heeft om bevredigende oplossingen te bewerkstelligen voor vervlochten geraakte probleemvelden zoals milieu, ruimtelijke planning, economie en transport, heeft een zoektocht op gang gebracht naar nieuwe verbindende concepten (Klaassen en Teisman, 1997). In deze zoektocht zijn ruwweg twee benaderingen van de oplossingsrichting te onderscheiden (Oosten, 2005). ${ }^{5}$

De eerste benadering is erop gericht de organisatie van maatschappelijke sturing verder te rationaliseren. Onduidelijkheden hebben volgens deze benadering een groot aandeel in het gebrek aan 
effectiviteit en legitimiteit en de oplossing wordt gezocht in het scheiden van actoren en processen. Objectiviteit, scherpe afbakening van bevoegdheden, eenduidige formulering van opdrachten en een heldere relatie tussen doelen, middelen en aspecten van openbaar bestuur vormen de voorgeschreven medicamenten.

De tweede benadering beklemtoont de interdependentie en de herpositionering van actoren in het publieke domein. Het uitgangspunt is dat alleen een technisch-rationele benadering niet volstaat omdat de samenleving meer onzekerheid en ambiguiteit kent dan centrale planning toelaat. Dit verlangt een meer open en discursieve benadering van probleem- en oplossingsformulering. Complexe relaties van wederzijdse afhankelijkheid en subjectiviteit laten zich niet wegrationaliseren. Daarom is het verbinden van processen en actoren belangrijker dan het scheiden daarvan. Hierbij passen termen als open planproces, communicatieve planning, interactieve planning, publiek-private samenwerking (PPS), etc.

Beide benaderingen zetten de democratisch-rechtstatelijke traditie onder druk. Enerzijds is krachtiger optreden van de overheid mogelijk strijdig met noties van decentrale autonomie en rechtsbescherming van burgers. Anderzijds ondermijnt interactieve beleidsvorming en PPS wellicht de posities van bewindspersonen en parlementariërs. Dergelijke ontwikkelingen problematiseren de legitimiteit van nieuwe sturingsvormen (Oosten, 2005).

Ook in de ruimtelijke sector wordt uitgebreid aandacht besteed aan de veranderende context waarin de overheid functioneert en de gevolgen daarvan. Samenhangend met algemene sociale, maatschappelijke en economische ontwikkelingen zijn ook in de ruimtelijke sector een aantal ontwikkelingen te onderkennen.

\subsubsection{Ontwikkelingen in de ruimtelijke sector}

Economische en demografische groei hebben ertoe geleid dat Nederland zich de afgelopen decennia heeft ontwikkeld tot een sterk stedelijke samenleving. Een verkenning van de toekomstige vraag naar ruimte laat voor tal van functies een toename zien (Ministerie VROM, 2000; Bouma, 2005). Tegelijkertijd worden steeds hogere eisen gesteld aan de kwaliteit van ruimtelijke ontwikkelingen. Om op efficiente wijze gebruik te kunnen maken van de aanwezige ruimte en tegelijkertijd duurzame, kwalitatief hoogwaardige ruimtelijke ontwikkelingen tot stand te brengen, is er in toenemende mate aandacht voor een integrale gebiedsgerichte benadering van ruimtelijke ontwikkeling. Zeker in een stedelijke omgeving strijden functies als vastgoed, infrastructuur en millieu om ruimte, maar zijn deze tegelijkertijd sterk verweven. Het pleidooi voor een integrale benadering is gebaseerd op deze verwevenheid, waarbij het uitgangspunt is dat het versterken van de samenhang tussen verschillende ruimtelijke functies bijdraagt aan een hogere kwaliteit in ruimtelijk-functionele zin. Het versterken van de samenhang impliceert dat afstemming tussen verschillende niveaus, sectoren en fasen van de ontwikkeling en de partijen die daarbij betrokken zijn noodzakelijk is. De Westerse samenleving is echter gebaseerd op specialisatie in verschillende sectoren en disciplines met bijbehorende wet- en regelgeving. Investeringen zijn in eerste aanleg veelal gebaseerd op specifieke functionele overwegingen en slechts beperkt op basis van mogelijkheden om functies te combineren. Een gebiedsgerichte benadering van ruimtelijke vraagstukken vereist echter adequate samenwerking tussen actoren vanuit verschillende sectoren, disciplines en niveaus. Als gevolg van algemene maatschappelijke ontwikkelingen, veranderingen in de context van ruimtelijk beleid ${ }^{6}$ en om de uitdaging - het combineren van de kwantitatieve vraag naar ruimte met de toenemende eisen aan 
ruimtelijke kwaliteit - te kunnen effectueren, hebben zich in de verhoudingen tussen actoren in de ruimtelijke sector een aantal tendensen voorgedaan. Deze tendensen hangen nauw samen met een veranderende sturingsfilosofie bij de overheid waarin in toenemende mate de nadruk wordt gelegd op de noodzaak van samenspel tussen overheden, maatschappelijke organisaties, burgers en bedrijven om ruimtelijke problemen effectief aan te pakken (Ministerie VROM, 2004).

Een eerste tendens heeft betrekking op de relaties binnen de publieke sector. Belangrijk daarbij is de overheid niet als een enkele actor te beschouwen, maar als een institutionele structuur waarin verschillende bestuurslagen en -sectoren te onderkennen zijn. In formeel-juridische zin is Nederland een gedecentraliseerde eenheidsstaat. Dat betekent dat er een zekere eenheid van beleid moet zijn, waarvoor de regie bij de centrale overheid ligt, maar dat er op een lager schaalniveau zaken kunnen spelen, waarover beter op dat niveau besloten kan worden. De Wet Ruimtelijke Ordening is een uiting van deze gedachte (Teisman et al., 2001). Traditioneel was in ruimtelijke planvorming sprake van een sterke hiërarchische sturing. Het accent is de laatste jaren echter verschoven van gedetailleerde centrale sturing via voorschriften en regels naar sturing op hoofdlijnen. De noodzaak tot decentralisatie van bevoegdheden en verantwoordelijkheden wordt erkend omdat centraal geformuleerd beleid onder andere op het terrein van huisvesting en infrastructuur ineffectief werd (Salet et al., 2003). Tegenwoordig wordt bepleit de decentrale bestuurslagen meer mogelijkheden te geven om dicht bij de burgers maatwerkoplossingen te vinden voor maatschappelijke problemen (VNG, 2006; VNG, 2007). Verdere decentralisatie wordt in het huidige beleid voorgestaan (Coalitieakkoord CDA, PVDA en CristenUnie, 2007; Bestuursakkoord Rijk en gemeenten 2007). In de ruimtelijke sector komt de decentralisatietendens nadrukkelijk naar voren in de Nota Ruimte (Ministeries VROM, LNV, V\&W en EZ, 2004). Het basisprincipe 'decentraal wat kan, centraal wat moet' staat daarin beschreven als uitgangspunt van ruimtelijk beleid. In de praktijk vertaalt dit uitgangspunt zich onder andere in een vermindering van de prestatievereisten die door rijksoverheden gekoppeld zijn aan de toekenning van financiële middelen aan lagere overheden, in de vorm van zogenaamde generieke of brede doeluitkeringen ${ }^{7}$.

Naast decentralisatie wordt tevens een toename van de samenwerking tussen bestuurssectoren bepleit. De Nederlandse bestuurlijke organisatie kent binnen één bestuurslaag verschillende functionele werkeenheden, zoals verkeer en vervoer, landbouw, milieu en ruimtelijke ordening. Deze eenheden hebben in de loop van de jaren een eigen positie, eigen wetgeving en werkwijzen opgebouwd. Intensivering van de samenwerking tussen deze eenheden wordt noodzakelijk geacht om tot oplossingen te komen voor hedendaagse ruimtelijke problemen. In diverse strategische beleidsdocumenten, waaronder de Nota Ruimte (Ministeries VROM, LNV, V\&W en EZ, 2004) en de Nota Mobiliteit (Ministerie V\&W, 2004) wordt dit benadrukt. Concrete initiatieven om dit te bewerkstelligen komen onder andere naar voren in de Uitvoeringsagenda Nota Ruimte, waarin invulling wordt gegeven aan de gecoördineerde en gebundelde inzet van rijksmiddelen en de recente oprichting van het rijksbreed opererende Rijks Vastgoed en OntwikkelingsBedrijf (RVOB). Met het toevoegen van de 'Ruimte' component aan het Meerjarenprogramma Infrastructuur en Transport is tevens een stap gezet richting interdepartementale programmering van ruimtelijke projecten. Hiermee wordt getracht de organisatie van budgetten en uitvoeringsprogrammering beter aan te laten sluiten bij een intergrale gebiedsgerichte benadering van ruimtelijke vraagstukken. 
De veranderingen in de relaties binnen de publieke sector hangen samen met een tweede tendens; een verschuiving in de verhoudingen tussen overheden en marktpartijen. In de periode na de Tweede Wereldoorlog was er in ruimtelijke ontwikkeling sprake van sterke sturing vanuit de overheid. Tot recent was in ruimtelijke planvorming deze hiërarchische benadering dominant en werden oplossingen voor ruimtelijke problemen voornamelijk gepland en bepaald door overheden. De rechtvaardiging daarvan was gebaseerd op het idee van het bestaan van een zeker 'publiek belang'. Het bestaan van dat belang waarvoor de overheid verantwoordelijk was, werd als vanzelfsprekend beschouwd. Deze eenzijdige sturing vanuit de overheid is in de afgelopen decennia sterk bekritiseerd, zowel in termen van legitimiteit als effectiviteit (Teisman, 1997; Kreukels, 1999) ${ }^{8}$. Op verschillende beleidsterreinen heeft in de jaren tachtig en negentig van de vorige eeuw een herschikking van publieke en private taken en verantwoordelijkheden plaats gevonden 9. Dat geldt ook voor de ruimtelijke sector. Veranderende visie op het functioneren van de economie en afnemende kennis en middelen aan publieke zijde zorgden ervoor dat veelvuldig een pleidooi werd gehouden voor vroegtijdige en intensievere betrokkenheid van private partijen om tot effectievere en efficiëntere oplossingen voor complexe ruimtelijke problemen te komen.

De afgelopen decennia zijn in de regeerakkoorden van diverse kabinetten expliciet passages gewijd aan de noodzaak hiertoe. ${ }^{10}$ Het publieke debat over de toedeling van verantwoordelijkheden tussen publieke en private partijen lijkt zeker nog niet voorbij. De verwachtingen van samenwerking met private partijen zijn nog onverminderd hoog. Zo pleit de Nota Ruimte (Ministeries VROM, LNV, $\mathrm{V} \& \mathrm{~W}$ en EZ, 2004) voor betere en snellere inschakeling van private partijen met als oogmerk een doelmatigere uitvoering en een betere prijs-kwaliteitverhouding. Ook in rapporten van diverse door de overheid ingestelde adviescomissies wordt de noodzaak en meerwaarde van intensieve samenwerking met private partijen benadrukt (zie o.a. Adviescomissie Gebiedsontwikkeling, 2005; Comissie Fundamentele Verkenning Bouw, 2008). Het huidige overheidsbeleid is er op gericht de samenwerking tussen publiek en privaat van incidenteel naar structureel te brengen. In dat kader wordt gestreefd naar standaardisering, verbreding en structurele inbedding ervan in de besluitvorming (Ministerie van Financiën, 2004; Ministerie van Financiën e.a., 2007). Ter uitvoering van dit streven maakt bijvoorbeeld onderzoek naar de mogelijkheden voor publiek-private samenwerking tegenwoordig integraal onderdeel uit van het spelregelkader van het Meerjarenprogramma Infrastructuur Ruimte en Transport (MIRT). ${ }^{11}$

Een derde tendens in de verhoudingen tussen actoren is te vinden in de toegenomen aandacht voor participatie van burgers en gebruikers in het planvormingsproces. Lindblom (1965) argumenteerde al dat participatie in belangrijke mate bijdraagt aan de effectiviteit van bestuur. Ook door verschillende Nederlandse wetenschappers worden voordelen van een interactieve benadering naar voren gebracht. Vier dominante motieven worden daarbij vaak genoemd; het vergroten van het draagvlak voor beslissingen, het streven naar integraliteit in beleid, het vergroten van het probleemoplossend vermogen en het verbeteren van de beleidskwaliteit (Edelenbos, 2000). In de beleidspraktijk komt het pleidooi voor een meer interactieve werkwijze bijvoorbeeld naar voren in het Grote Steden Beleid waarin een interactieve benadering, lokaal draagvlak, participatie, dialoog, coproductie en commitment sleutelwoorden zijn. Ook in de convenanten die zijn getekend voor de implementatie van dit beleid en in zogenaamde meerjarenontwikkelingsprogramma's (MOP's) wordt met grote regelmaat de samenwerking met andere actoren benadrukt (Denters, 2002). Hoewel vanuit het 
oogpunt van bestuurlijke effectiviteit en legitimiteit diverse argumenten voor participatie aan te dragen zijn, worden er ook enkele kanttekeningen geplaatst. Zo wordt gesteld dat zich bij het interactieve proces nogal eens problemen voordoen met de mobilisatie van burgers die representatief zijn voor de gehele populatie waarop het betreffende plan betrekking heeft (Wille, 2001, e.a.). Tevens wordt naar voren gebracht dat het niet altijd duidelijk in hoeverre interactieve beleidsprocessen burgers daadwerkelijk invloed geven op de politieke besluitvorming en wordt opgemerkt dat een interactieve benadering tevens kan leiden tot een grote variëteit aan wensen of eisen en een ongecontroleerd proces (Dewulf, 2001).

De geschetste ontwikkelingen zorgen voor verschuivingen in rollen en organisatievormen bij ruimtelijke projecten. Domeinen van overheid, markt en burgers raken meer en meer verweven. Ruimtelijke projecten vinden plaats in een interorganisatorische setting waarbij verschillende overheden, marktpartijen en burgers van elkaar afhankelijk zijn om te komen tot resultaten. Niettemin wordt van de overheid verwacht dat zij in de constellatie van betrokken actoren in deze projecten het publiek belang waarborgt. Naar de gevolgen van deze veranderende context voor het waarborgen van het 'publiek belang' bij ruimtelijke projecten is weinig onderzoek verricht.

\subsection{Het publiek belang}

In veel studies die aandacht besteden aan de borging van het publiek belang staat de structurele toedeling of herordening van taken en verantwoordelijkheden centraal. Op nationaal niveau zijn de liberalisering van de energiesector, de introductie van marktwerking in de zorgsector en de verzelfstandiging en privatisering van onderdelen van de Nederlandse Spoorwegen voorbeelden hiervan (WRR, 2000; Ministerie van Economische Zaken, 2004; e.a.). Op lokaal niveau valt onder meer te denken aan de privatisering van de markt voor re-integratiediensten, thuiszorg en afvalinzameling. De vraag welk institutioneel systeem of arrangement het beste in staat is op een efficiënte wijze de publieke belangen in deze sectoren te waarborgen staat veelal centraal (Hoogendijk, 2000). Dit onderzoek richt zich op de ruimtelijke sector. Kenmerk van deze sector is dat het - in tegenstelling tot structurele toedeling - vooral gaat om projectmatige toedeling van taken en verantwoordelijkheden tussen partijen. De focus is daarmee op projectniveau en niet zozeer op de institutionele hervorming van een sector.

In literatuur en bij het overheidsbestuur is in de ruimtelijke sector in toenemende mate aandacht voor veranderende rollen van partijen. Het empirisch bewijs over de impact ervan op prestaties is echter beperkt. Het geringe aantal empirische studies betreft vaak de beschrijving van ontwikkelingen in specifieke cases en/of deelaspecten. In plaats van aandacht te besteden aan de vraag op welke wijze in ruimtelijke projecten het 'publiek belang' adequaat kan worden gewaarborgd, wordt in veel studies de aandacht gericht op het genereren van extra middelen of de verdeling van risico's over publieke en private partijen. Dit pleit voor verder onderzoek:

- om inzicht te verkrijgen in de keuzen wie betrokken worden in het proces, op welke wijze(n) zij betrokken worden, wanneer zij betrokken worden en waarom;

- om inzicht te verkrijgen in de effecten van deze keuzen op de prestaties van ruimtelijke planprocessen in termen van de borging van het publiek belang 
Systematische analyse van prestaties van ruimtelijke planprocessen is echter problematisch, omdat consensus over te hanteren criteria en de wijze waarop prestaties moeten worden gemeten ontbreekt (De Graaf, 2005). Wat voor de ene partij (in context A) geldt als een prestatie of een succes hoeft voor de andere partij in diezelfde context in het licht van diens doelstellingen geen prestatie of succes te zijn. De zaak wordt nog complexer als via vergelijkend empirisch onderzoek getracht wordt te komen tot conclusies die ook generaliseerbaar zijn buiten een beperkte context. Dit maakt empirisch gefundeerd praktisch bruikbaar onderzoek naar factoren die bijdragen aan het succes of falen van ruimtelijk planprocessen moeilijk uitvoerbaar. Men kan immers niet volstaan met een vergelijkend onderzoek of case-studies die zich richten op wat er is gebeurd, maar er dient tevens te worden stilgestaan bij de vraag welke effecten kunnen gelden als positief (succes) of negatief (falen). Was het project een succes of niet? Waren bepaalde acties effectief en waarom? Echter, omdat evaluatie in complexe situaties waarin veel actoren betrokken zijn en veel factoren een rol spelen moeilijk is wordt dit nogal eens vermeden (Alexander, 2000). Niettemin, als we prestaties willen verbeteren, is het vergroten van het inzicht in het verloop van ruimtelijke planprocessen en de effecten daarvan noodzakelijk.

Voorgaande vragen rijzen evenzeer als we abstraheren van wat betrokken actoren (in het licht van hun doeleinden) wensen te zien als succes en de vraag stellen of intensievere samenwerking en participatie een bijdrage leveren aan de borging van het publieke belang. Immers in de context van het openbaar bestuur is het ook verre van evident wat dient te worden verstaan onder dit publiek belang. De discussie over de borging van het publiek belang is onlosmakelijk verbonden met de rol voor de overheid. Veel aandacht richt daarbij op de verhouding tussen overheden en private partijen (WRR, 2000).

Intensieve en vroegtijdige betrokkenheid van private partijen wordt zoals hiervoor beschreven veelvuldig bepleit. De effecten zijn veelal niet volledig duidelijk. Het Ministerie van Financiën (1999) stelt als cruciale succesfactor dat de doelen van de betrokken overheden in overeenstemming moeten worden gebracht met het winststreven van marktpartijen. Betrokkenheid van private partijen zou moeten bijdragen aan de behartiging van publieke belangen (Canoy et al., 2001; Van der Heijden en Spiering, 2002). Er bestaat echter geen duidelijkheid wat dat publiek belang exact is en of die verwachtingen worden waargemaakt. ${ }^{12}$ In dit verband wordt gewezen op het gevaar van corporatisme ${ }^{13}$ en te grote machtsconcentratie door intensieve samenwerking tussen overheden en private partijen (Dubbink, 1999; Van Tatenhoven et al., 2000). De overheid zou zich te gemakkelijk identificeren met de belangen van private partijen en de verleiding om die (financiële) belangen te laten prevaleren boven publieke belangen is groot (WRR, 2000). Gevreesd wordt dat het publiek belang in gevaar komt omdat het winstoogmerk van de private sector kan conflicteren met publieke belangen en waarden (Bult-Spiering et al., 2005), ofwel dat de overheid een deel van haar zeggenschap en autoriteit in moet ruilen voor samenwerking met private partijen. Vervagende grenzen tussen de publieke en private sector kunnen in potentie een aantasting betekenen van zaken als verantwoordelijkheid en toerekenbaarheid, transparantie en democratische keuze. Tegen de achtergrond van de democratische rechtstaatgedachte is de vrees dat dit leidt tot een uitholling van publieke en politieke verantwoording (Bovens en Scheltema, 1999, WRR, 2000). De democratische rechtstaatgedachte veronderstelt een zekere scheiding tussen overheid en markt (Van Wijk et al., 2002). Bij deze gedachte gaat het in grote lijn om de democratische legitimatie van openbaar bestuur. Democratische legitimatie vereist 
democratische sturing en verantwoording bij de behartiging van publieke belangen, de uitoefening van publieke bevoegdheden en de besteding van publieke middelen, zo wordt gesteld. Deze verantwoording dient bovendien controleerbaar te zijn. In complexe samenwerkingen kan onduidelijkheid ertoe leiden dat verantwoordelijkheden worden ontlopen (Stoker, 1998). Niettemin worden er veel voordelen gezien in samenwerking met private partijen en zorgt de fragmentatie van kennis en middelen over partijen dat samenwerking niet alleen wenselijk maar tevens noodzakelijk is. Een vergelijkbare discussie vindt plaats waar het gaat om verhoudingen tussen overheden onderling. In veel ruimtelijke projecten is het de gemeente, als meest direct representatief overheidsorgaan, die in de planvorming eenduidig de regie voert. De gedachte is dat gemeenten taken efficiënter, effectiever en democratischer kunnen vervullen dan centrale overheden, omdat zij beter zicht hebben op de lokale situatie en daardoor beter tot maatwerkoplossingen in staat zijn (Boogers, 2009). Diverse ruimtelijke projecten kennen echter gemeentegrens overschrijdende belangen en onderdelen waarvoor andere bestuursniveaus een directe verantwoordelijkheid hebben. Hoe in de uitvoering van deze projecten invulling dient te worden gegeven aan de rollen van de verschillende publieke partijen en aan de onderlinge samenwerking blijkt soms minder duidelijk (Ministerie VROM, 2009; TK 20022003, 28753; Laverman, 2003; Van Hoof, 2003).

In de discussie lijkt het type project een belangrijke rol te spelen. Voor een aantal typen ruimtelijke projecten lijkt het mogelijk het 'publiek belang' te vertalen naar criteria waaraan het resultaat dient te voldoen en die in contracten kunnen worden opgenomen. In deze context verwijst het begrip 'publiek belang' naar het beoogde resultaat en randvoorwaarden van de publieke opdrachtgever(s). Uitbesteding van taken en verantwoordelijkheden aan private partijen is zo beschouwd een reële mogelijkheid. In onder andere het Verenigd Koninkrijk is hiermee in de vorm van Private Finance Initiative (PFI) contracten bij infrastructurele en huisvestingsprojecten al de nodige ervaring opgedaan. Bij PFI-projecten organiseert een private onderneming de financiering voor de bouw of aanleg van een dergelijk project, waarna zij vervolgens een prestatieafhankelijke vergoeding krijgt van een overheidsinstantie voor het beheer en onderhoud daarvan. Bij deze contractvormen wordt de financiering door de private sector verzorgd, maar is er geen sprake van privatisering. De eindverantwoordelijkheid blijft namelijk bij de overheid. De andacht voor PFI-contracten (in Nederland wordt gesproken van concessiecontracten) is de laatste jaren sterk toegenomen. Een vraag die zowel in Nederland als het Verenigd Koninkrijk speelt, is of overheden in hun rol als opdrachtgever of concessieverlener voldoende in staat zijn te specificeren wat er geproduceerd of geleverd moet worden en goed genoeg in staat zijn te beoordelen of het gerealiseerde aan de eisen die hieraan gesteld worden, voldoet. In dergelijke projecten gaat het er vooral om dat de overheid, beschouwd vanuit het publiek belang, optreed als een 'smart buyer' (Porter, 1990).

Voor diverse andere ruimtelijke projecten geldt dat het proces wordt gekarakteriseerd door een hoge mate van onzekerheid en ambiguiteit met betrekking tot de aard van het gewenste product en de wijze waarop dit tot stand komt. Dit geldt in het bijzonder indien het gaat om zeer complexe ruimtelijke projecten zoals gebiedsontwikkelingen. Een voorbeeld hiervan is de herontwikkeling van stationslocaties. Verschillende functies in een bepaald gebied worden in onderlinge samenhang ontwikkeld en een groot aantal stakeholders speelt daarbij een rol. Diverse ministeries en (gemeentelijke) diensten zijn betrokken en uiteenlopende private partijen zoals (grond)eigenaren, huurders, winkeliers en particulieren hebben posities in het gebied. Door de fragmentatie van 
middelen zijn deze partijen wel afhankelijk van elkaar. Geen van de actoren is alleen in staat deze integrale ruimtelijke ontwikkeling tot stand te doen komen maar ieder levert een stukje van de puzzel. Gevolg is dat er sprake is van een groot aantal uiteenlopende belangen en doelstellingen. Aan het begin van het proces kunnen deze veelal niet worden vervat in een concrete specificatie voor het gewenste eindresultaat die in een contract kan worden gegoten ${ }^{14}$. De vraag wat in een dergelijke situatie het publiek belang is en hoe dit belang in het ontwikkelingsproces gewaarborgd kan worden laat zich dan niet eenvoudig beantwoorden.

In het kader van onderzoek zijn daarom twee vragen van belang. In de eerste plaats dient gekeken te worden naar de wijze waarop het proces wordt vormgegeven en in de tweede plaats gaat het om de wijze waarop in de loop van het proces beslissingen worden genomen over criteria waaraan het eindresultaat dient te voldoen. Belangrijk voor de overheid is de vraag welke effecten keuzen ten aanzien van de inrichting van dit proces en hebben voor de borging van het 'publieke belang'. Deze studie richt zich op het vergroten van het inzicht hierin. Dit betekent dat er naar gestreefd wordt helder te krijgen welke beoordelingscriteria (proces- en resultaatcriteria) voor de borging van het publiek belang in dergelijke projecten relevant zijn en welke invloed de procesinrichting heeft op deze criteria.

Tegen de achtergrond van de huidige aandacht voor gebiedsontwikkeling richt deze studie zich op ruimtelijke projecten die de integrale ontwikkeling van infrastructuur, vastgoed en openbare ruimte betreft ${ }^{15}$. Meer specifiek wordt de herontwikkeling van stations en de directe omgeving daarvan bestudeerd. De komende jaren zullen grote investeringen in deze gebieden noodzakelijk zijn en de kenmerken van dit soort projecten zorgen ervoor dat het juist in deze projecten lastig is het 'publiek belang' te typeren en te borgen.

\subsection{Een specifieke soort ruimtelijke projecten: stationslocaties}

Stationslocaties zijn de afgelopen jaren weer nadrukkelijk in de belangstelling komen te staan. Naast het Nederlandse overheidsbeleid dat is gericht op milieuvriendelijk duurzaam transport en ruimtegebruik en het stimuleren van lokale economieen door het herstructureren van stedelijk gebied, liggen de ontwikkeling van modaliteiten als hogesnelheidslijn systemen en regionale netwerken, institutionele veranderingen, ontwikkelingen op de vastgoedmarkt en internationalisering en metropolisering hieraan ten grondslag (Bertolini en Spit, 1998). Zowel bij publieke als private partijen bestaat een besef dat rondom de hernieuwde stations een aantrekkelijk stedelijk gebied met hoge dichtheid kan ontstaan. Inzet van het rijksbeleid is om stations te verbouwen tot multimodale knooppunten die het hart vormen van vitale centrumgebieden waar gewoond en gewerkt wordt (Ministerie van VROM, 2006). Het streven is de aanpak van stations te combineren met het verhogen van de ruimtelijke kwaliteit in de directe omgeving. Deze ambitie blijft niet alleen beperkt tot grote internationale stations, maar geldt tevens voor stations in middelgrote gemeenten. In tal van plaatsen is of wordt aan de verbetering van het station en de omgeving gewerkt. Dit is onder andere het geval in Den Bosch, Eindhoven, Almere, Lelystad, Enschede, Nieuwegein, Dordrecht, Gouda en Delft. Zes stationslocaties zijn daarnaast door de rijksoverheid tot zogenaamde Nieuwe Sleutelprojecten benoemd: Amsterdam, Arnhem, Breda, Den Haag, Rotterdam en Utrecht. In het kader van de aanleg van de hogesnelheidslijn (HSL) wordt getracht om de investeringen hierin te koppelen aan een 
economische impuls voor de halteplaatsen, zodat deze een zogenaamd multipliereffect bewerkstelligen in de stedelijke centra. In het regeerakkoord van het tweede paarse kabinet (Kok II) stond als opgave voor de Nieuwe Sleutelprojecten het creëren van vestigingslocaties met internationale uitstraling vermeld. In het beleid en de concrete plannen wordt dus breder gekeken dan het station an sich. Getracht wordt door een integrale benadering meer samenhang te creëren tussen verschillende functies in het gebied zodat deze elkaar meer versterken. Recent is in het Meerjarenprogramma Infrastructuur Ruimte en Transport (MIRT) het programma Spoorzoneontwikkeling opgenomen. In het kader van dit programma werken het ministerie van VROM en het ministerie van Verkeer en Waterstaat samen met de Nederlandse Spoorwegen en ProRail om gemeenten te ondersteunen in het proces van herontwikkeling van binnenstedelijke stationsgebieden en zijn vier voorbeeldprojecten (Groningen, Nijmegen, Amersfoort, Zwolle) geselecteerd. De herstructurering van binnenstedelijke stationsgebieden en spoorzones kon in de visie van het kabinet Balkenende IV een belangrijke bijdrage leveren aan de verstedelijkingsopgave, waarbij de doelstelling was om $25-40 \%$ van de nieuwe woningen binnen bestaand stedelijk gebied te realiseren. Het (rijks)beleid is er daarbij omverminderd op gericht spoorzones en stationslocaties te ontwikkelen tot sociaaleconomisch vitale stadsgebieden. In die filosofie vervult het station weer de rol van 'poort naar de stad' met een OV-terminal die hernieuwde invulling moet geven aan de kathedralen die de stationsgebouwen van vroeger waren.

\subsection{Probleemschets en vraagstelling}

Herontwikkelingen van stationslocaties zijn complexe projecten, zowel inhoudelijk als procesmatig. Deze complexiteit ontstaat doordat veel ruimtelijke functies zoals wonen, werken, transport en leisure in het gebied samenkomen. De daarmee samenhangende vraagstukken overlappen elkaar. Veel actoren - waaronder meerdere overheidslagen en overheidssectoren - hebben een belang in het gebied en het feit dat stationslocaties zich in stedelijk gebied bevinden, betekent dat de inbreng en betrokkenheid van deze partijen noodzakelijk is om tot resultaten te komen (Van Twist et al., 2004). De onderlinge afhankelijkheid tussen actoren zorgt ervoor dat specifieke arrangementen van procesmanagement noodzakelijk zijn en actoren in wisselende samenstellingen interacteren. Vaak kan er niet rechtlijnig gehandeld worden van doel naar middel (zelfs al is men het met elkaar eens) omdat onverwachte gebeurtenissen die geen onderdeel uitmaken van het technisch-rationele stappenplan interfereren. De uiteenlopende belangen en doelstellingen van actoren en hun vaak meervoudige oriëntaties maken planvorming in deze projecten een complex proces.

De complexiteit van stationslocaties heeft ervoor gezorgd dat de uitvoering van het beleid achter blijft bij de verwachtingen. Op de traagheid van de besluitvorming en de rol van verschillende partijen daarin is aanzienlijke kritiek. ${ }^{16}$ Veel discussie vindt plaats over wie exact de probleemeigenaar is; welke partij waarvoor en in welke mate (financieel) verantwoordelijk is; en hoe het opdrachtgeverschap in de plan- en realisatiefase moet worden vormgegeven. Met andere woorden; welke inbreng moeten welke partijen hebben in het herontwikkelingsproces? Tegelijkertijd worden hoge eisen gesteld aan de kwaliteit van de ontwikkeling van stationslocaties. De aanpak van deze locaties vormen een speerpunt in het nationaal ruimtelijk beleid. Een integrale benadering waardoor samenhang tussen projectonderdelen en bijbehorende functies ontstaat, wordt noodzakelijk geacht om een kwalitatief hoogwaardig gebied te realiseren (Ministerie VROM, 2002). De afstemming tussen 
betrokken actoren waartoe dit noodzaakt schiet echter nogal eens tekort (Taskforce gebiedsontwikkeling, 2003: p.37).

Binnen deze context van toenemende kwaliteitseisen en veranderende rollen en organisatievormen wordt van de overheid verwacht dat zij sturing geeft en het publiek belang borgt. De vraag is wat deze veranderingen betekenen voor de borging van het publiek belang. Centraal in deze studie staat daarom de vraag:

\section{Bij welke inrichting van het planproces is de kans op succesvolle borging van het publiek belang bij de herontwikkeling van stationslocaties groot?}

Deze centrale onderzoeksvraag is uit te splitsen in een aantal deelvragen:

1. Wat zijn de kenmerken van stationslocaties?

2. Welke procesinrichtingen worden in deze context gehanteerd?

3. In hoeverre voldoen de stationslocaties aan de criteria voor borging van het publiek belang?

4. In hoeverre bestaat er een samenhang tussen de inrichting van het proces en de criteria voor de borging van het publiek belang?

Om deze vragen te kunnen beantwoorden dient eerst duidelijk te zijn wat het publiek belang is. Daarom gaan we in hoofdstuk 2 in op wat in theorie onder het publiek belang wordt verstaan en welke criteria relevant zijn voor een oordeel hierover.

In hoofdstuk 3 wordt in theoretische zin ingegaan op tweede en vierde onderzoeksvraag. Tegen de achtergrond van de discussie over het publiek belang, wordt in dat hoofdstuk getracht middels het bestuderen van theoretische gezichtspunten te komen tot selectie van aantal cruciale elementen voor het beschrijven van de inrichting van processen in ruimtelijke projecten.

De eerste onderzoeksvraag, de kenmerken van de stationslocatieprojecten, geeft de context waarin deze processen verlopen. De algemene kenmerken die voor alle stationslocatieprojecten gelden, staan in hoofdstuk 5 beschreven en kenmerken die specifiek voor een bepaald stationslocatieproject van toepassing zijn in afzonderlijke casehoofdstukken belicht.

Aan de hand van de theoretische inzichten uit hoofdstuk 2 en 3 is een conceptueel raamwerk opgesteld dat is gebruikt voor de evaluatie van stationslocatieprojecten. Op basis van de bevindingen die daaruit naar voren komen zijn conclusies getrokken die betrekking hebben op de samenhang tussen de procesinrichting en de borging van het publiek belang. Op deze wijze wordt getracht zowel conceptueel als empirisch bij te dragen aan de kennis over de borging van het publiek belang in ruimtelijke projecten.

\subsection{Onderzoeksaanpak}

In de voorgaande paragrafen is de achtergrond, aanleiding en vraagstelling van het onderzoek geformuleerd. Deze paragraaf beschrijft de onderzoeksaanpak die is gehanteerd. Achtereenvolgens wordt het wetenschapsfilosofische uitgangspunt, de onderzoeksmethode, -validiteit en -strategie toegelicht. 


\subsubsection{Wetenschapsfilosofisch uitgangspunt}

In de wetenschap bestaan er verschillende opvattingen over de wijze waarop onderzoeksresultaten kunnen worden verkregen. Daarbij worden verschillende indelingen gebruikt (zie Chua, 1986; Orlikowski en Baroudi, 1991; Guba en Lincoln, 1994; Gummesson, 2000). In de sociale wetenschappen wordt vooral het onderscheid tussen een positivistische en constructivistische (ook wel aangeduid als interpretatieve) wetenschapsopvatting vaak benadrukt (Van der Zijde, 1998; De Kort, 2009).

Vanuit een positivistische zienswijze wordt getracht te verklaren en te voorspellen wat in de sociale wereld gebeurt door te zoeken naar regelmatigheden en causale relaties tussen elementen. De wereld wordt beschouwd als een kenbare objectieve werkelijkheid en kennisontwikkeling is gebaseerd op objectieve waarneming en analyse van relaties tussen aspecten en variabelen. Deze zienswijze is gebaseerd op de traditionele benadering van wetenschap die vooral in de fysieke wetenschappen dominant is (Burrel en Morgan, 1979). Belangrijk verschil tussen fysieke en sociale wetenschappen is dat in de laatste mensen centraal staan. Mensen zijn reflectief. Dat wil zeggen dat ze overwegen, anticiperen, in staat zijn te werken om hun sociale en materiële omgeving te veranderen, en dat ze zowel lange termijn intenties hebben als directe wensen en behoeften. De constructivistische wetenschapsopvatting legt sterk de nadruk op de betrokkenheid van mensen en beschouwt de wereld als een 'sociaal construct'. Het uitgangspunt is dat er niet zoiets bestaat als een objectief kenbare werkelijkheid, maar dat bepaalde verschijnselen op verschillende wijze geïnterpreteerd kunnen worden. Sociale instituties zoals contracten, geld en organisaties bestaan omdat mensen denken dat ze bestaan er er in geloven. De werkelijkheid is sociaal geconstrueerd door intensieve en langdurige communicatie. Kennis kan verworven worden door het interpreteren van de communicatie en het handelen van actoren (De Kort, 2009).Als gevolg daarvan kunnen verschijnselen onder studie slechts worden begrepen vanuit het perspectief van de individuen die daar direct bij betrokken zijn. De constructivistische opvatting houdt daarom voor onderzoek te richten op motieven en betekenisgeving in sociale interacties, naast of in plaats van causaliteit in relaties.

In de praktijk van sociaal-wetenschappelijk onderzoek is het onderscheid in wetenschapsfilosofisch uitgangspunt minder absoluut. De onderverdeling in stromingen sluit niet altijd naadloos aan bij onderzoek dat wordt gedreven door concrete praktijkproblemen. Dat geldt ook voor dit onderzoek. In deze studie wordt er naar gestreefd meer inzicht te krijgen in de samenhang tussen de inrichting van planprocessen en de borging van het publiek belang. Het gaat dan om het zoeken naar mechanismen die, onder bepaalde omstandigheden, een verklaring kunnen vormen voor het verloop van deze processen en de resultaten daarvan. Het zoeken naar regelmatigheden en verbanden op grond van empirische data past meer bij een positivistische wetenschapsopvatting. Bij de aanpak van stationslocatieprojecten zijn echter diverse actoren betrokken, die moeten interacteren en samenwerken om het project tot stand te brengen, maar tegelijkertijd acties en gebeurtenissen gedurende dat proces op verschillende wijze percipiëren. De context waarin deze actoren opereren speelt voor hun percepties een belangrijke rol. Het onderkennen van het belang van verschillen in perspectief van actoren, zoals in deze studie, sluit meer aan bij een constructivistische wetenschapsopvatting. Naast 'objectieve' waarneming is voor het reconstrueren van het verloop van processen daarom in belangrijke mate gebruik gemaakt van de percepties van direct betrokken 
actoren. Om dezelfde reden is voor het bepalen van prestaties in termen van de borging van het publiek belang het oordeel van dezelfde actoren gebruikt in plaats van deze als onderzoeker 'objectief te bepalen.

\subsubsection{Onderzoeksmethode}

De beschikbaarheid van theorie speelt een belangrijke rol bij de wijze waarop een onderzoek wordt benaderd. In 'traditionele' wetenschap wordt theorie ontwikkeld door incrementele empirische testen en uitbreiding (Kuhn, 1970) ${ }^{17}$. Het proces van theorieontwikkeling is aangewezen op bestaande literatuur, empirische observaties of ervaringen en het inzicht van de theoreticus om op incrementele wijze sterkere theorieën te ontwikkelen (Eisenhardt, 1989: p.548). De bestaande literatuur over het publiek belang is bijna eindeloos. Deze is echter slechts beperkt gestoeld op empirisch onderzoek. Verschillende theorieën, zoals de economische welvaartstheorie, geven een normatief-theoretische oriëntatie op het publiek belang. Voor zover er sprake is van empirisch onderzoek gaat het veelal om in één of een zeer beperkt aantal cases of om specifieke deelaspecten en niet om factoren die bepalend zijn voor de keuze voor een bepaalde procesinrichting vanuit het oogpunt van de borging van het publiek belang (vgl. Van den Hof, 2006).

In literatuur wordt het publiek belang onlosmakelijk verbonden met de rol van de overheid in relatie tot andere actoren. Er zijn verschillende theorieën voorhanden die ingaan op afzonderlijke dimensies van relaties tussen actoren. Organisatietheorieën, sociologische en economische theorieën die het gedrag van actoren beschrijven en verklaren; coördinatie-, besluitvormings- en netwerktheorieën die de samenwerking tussen actoren en organisaties beschrijven; en projectmanagementtheorieën die inzicht geven in de specifieke aandachtspunten bij de realisatie van projecten (Bult-Spiering, 2003). Al deze theorieën bieden algemene kaders die op allerlei concrete toepassingsgebieden kunnen worden 'losgelaten'. Empirisch gefundeerde theorie, die een dusdanig brede scope heeft dat het de variatie en complexiteit van het object van onderzoek dekt en tegelijkertijd specifiek genoeg is om hypothesen te bevatten die direct empirisch kunnen worden getoetst, ontbreekt echter. Dit pleit voor een explorerende benadering. ${ }^{18}$ Een explorerende benadering is het meest geschikt:

\footnotetext{
'Wanneer men op een relatief breed gebied, waarover weinig bruikbare theorie bestaat, met een veelheid aan observatiegegevens of variabelen te maken heeft over wier relatieve relevantie weinig bekend is. Men heeft echter wel - óf op grond van theoretische gezichtspunten, óf van duidelijke praktische vraagstellingen - een betrekkelijk gerichte belangstelling voor bepaalde typen samenhangen, met bijbehorende ideeën en relatief vage verwachtingen' (Bruinsma en Zwanenburg, 1992: p.229)
}

Het explorerende karakter van de studie wil niet zeggen dat het onderzoek volledig open wordt ingestoken. ${ }^{19} \mathrm{Er}$ is wel degelijk rudimentaire theorie aanwezig op grond waarvan een aantal plausibele verwachtingen te formuleren zijn. Het gaat dan niet om een volledig uitgewerkte theorie, maar om een raamwerk dat helpt de exploratie te sturen (vgl. Ostrom, 1994). Het is echter niet de bedoeling dat deze theorie het onderzoek op enige wijze conditioneert (Eisenhardt, 1989). Het gebruik van theorie moet in deze studie worden gezien als een manier om te focussen op bepaalde onderwerpen en om handelingen te begrijpen en te interpreteren. Het vormt met andere woorden een leidraad voor het bepalen van de prioriteit in de gegevensverzameling en voor de strategie om de data te analyseren (Hutjes en Van Buuren, 1992; Yin, 1994). Op basis van theoretische inzichten is een raamwerk 
opgesteld waarin factoren zijn benoemd die relevant zijn bij het bestuderen van de relatie tussen de inrichting van planprocessen en de borging van het publiek belang.

Voor het bestuderen van voorgenoemde relatie zijn er meerdere mogelijkheden om het onderzoek vorm te geven.Voor vraagstellingen die betrekking hebben op causale effecten dient de voorkeur te worden gegeven aan een experiment als onderzoeksontwerp (Swanborn, 1987). De grote kracht van het experiment is dat 'randomisering' kan worden toegepast. Randomisering houdt in dat eenheden volgens toeval (aselect, at random) worden toegewezen aan een experimentele en een controlegroep. Daarmee wordt bereikt dat de experimentele en de controlegroep op alle bekende en onbekende variabelen slechts op basis van een toevalsverdeling van elkaar verschillen (Swanborn, 1987). De beide groepen zijn dan op allerlei variabelen zoveel mogelijk gelijk. Hiermee wordt het gevaar bestreden van derde variabelen die de samenhang tussen variabele X en Y teweeg brengen. Vaak is randomisering echter niet mogelijk. Dat geldt ook voor deze studie. Ruimtelijke projecten kunnen niet uit hun context worden gehaald en in een experimentele setting worden geplaatst. Als niet gerandomiseerd kan worden, kan soms een quasi-experimentele aanpak worden gehanteerd 20.

In een quasi-experimentele aanpak (Cook en Campbell, 1979) ligt de nadruk op de vraag of een verandering in proceskenmerk (hier de onafhankelijke variabele) gevolgen heeft voor een verandering op de doelstellings- (of effects-) variabele. Evenals experimenten vereisen quasi-experimenten dat er slechts een zeer beperkt aantal variabelen van belang zijn (Yin, 1993). Daarnaast veronderstelt deze aanpak een groot aantal cases om samenhangen geldig en betrouwbaar te kunnen vaststellen en zegt de aanwezigheid van een samenhang nog niet direct iets over een causaal effect. Het gebrek aan een groot aantal te evalueren cases en de noodzaak van een diepgaande nauwkeurige analyse zorgt ervoor dat moeilijk aan de voorwaarden voor een quasi-experimentele aanpak valt te voldoen. Gevolg is dat 'gedwongen' een keuze moet worden gemaakt voor de case-studie als onderzoeksmethode. ${ }^{21}$

\section{Case studie (small-N)}

Indien onderzoekseenheden niet of zeer moeilijk kunnen worden gescheiden van de context en het aantal te onderzoeken eenheden klein is in verhouding tot het aantal te onderzoeken factoren dan is case-studie de meest geëigende methode (Yin, 1994; Hutjes en Van Buuren, 1992). 22 Bij een casestudie gaat het om:

\footnotetext{
'An empirical inquiry, that

- investigates a contemporary phenomenon within its real-life context, especially when

- the boundaries between phenomenon and context are not clearly evident'. (Yin, 1994; p.13)
}

Case-studies zijn er op gericht een uitgebreide analyse van het te bestuderen fenomeen te geven. Door gebruik te maken van verschillende databronnen en analysetechnieken wordt op een andere wijze getracht aannemelijk te maken dat de verschillen in inrichting van het proces (als onafhankelijke variabele) effect heeft op de borging van het publiek belang (als afhankelijke variabele), namelijk door te beschrijven hoe onder invloed van bepaalde procescondities actoren zich anders opstellen en hoe daardoor het proces op een theoretisch interpreteerbare, plausibele wijze anders verloopt dan onder andere condities. In literatuur worden verschillende typen case-studies onderscheiden (zie o.a. Jensen en Rogers, 2001: p.237-239). Deze verschillen op een aantal dimensies. 
Een eerste dimensie waarop case-studie onderzoeken verschillen is of het gaat om een enkelvoudige of een meervoudige case-studie benadering. "Rationale for single-case study designs are critical cases, unique or extreme cases and revelatory cases (Yin, 1994, p. 47).” Aan de andere kant kan de methode van meervoudige case-studie worden gebruikt. Argumentatie vanuit een meervoudige case-studie wordt vaak als overtuigender beschouwd. Indien een keuze mogelijk is, moet deze de voorkeur kriigen boven een enkelvoudige case-studie (Yin, 1994, p. 53). Een essentiële gedachtegang dient echter te zijn dat een meervoudige case-studie net zo moet worden beschouwd als men meerdere experimenten zou beschouwen (Yin, 1994: p. 47). Om deze reden speelt bij de selectie van cases het replicatieprincipe een belangrijke rol. Het gaat dan om letterlijke replicatie - om gelijke resultaten te voorspellen - of theoretische replicatie - om verschillende resultaten te produceren op basis van vooraf gespecificeerde plausibele redenen - als basis voor de selectie van meerdere cases (Yin, 1994: p.47).

Een tweede dichotomie heeft betrekking op de eenheid van analyse. Wat is de 'case' die zal worden onderzocht? Indien deze eenheid van analyse de globale aard van een programma of organisatie wordt beschouwd, dan wordt gesproken van een holistische case studie benadering. Deze benadering is toepasselijk indien er geen logische sub-eenheden kunnen worden geïdentificeerd. Gaat de aandacht uit naar meer dan één analyse-eenheid dan wordt gesproken van een ingebedde benadering (Yin, 1994: p.43-45).

Het gevaar van een holistische benadering is dat het onderzoek op een te hoog abstractieniveau wordt uitgevoerd en er fouten ontstaan ten aanzien van de aard van de studie, omdat geen bijzonder fenomeen in detail wordt bestudeerd dat de onderzoeker op het juiste pad houdt. De ingebedde benadering vermindert de gevoeligheid voor deze fouten, maar kan daarentegen een probleem vormen indien het oorspronkelijke fenomeen waarin men geïnteresseerd was de context wordt en niet het doel van de studie. In dat geval concentreert de case-studie zich slechts op het sub-niveau en slaagt het er niet in terug te komen tot de grotere eenheid van analyse (Yin, 1994, p. 45).

Tegen de achtergrond van de doelstelling van dit onderzoek, ligt een meervoudige ingebedde case studie het meest voor de hand. Op basis van vergelijkende case-studies kan inzicht ontstaan over de relatie tussen de inrichting van het proces en de de borging van het publiek belang in het brede veld van stationslocatieherontwikkelingen. Inzicht in de factoren die ten grondslag liggen aan keuzen hierin en opvattingen over de gevolgen daarvan voor de borging van publieke belangen dragen bij aan de doelstelling van het onderzoek. Het zal ook om een ingebedde case-studie moeten gaan omdat zowel de rol en inbreng van verschillende individuele actoren als de inrichting van het proces als geheel dient te worden beschouwd.

Een derde onderscheid in de wijze waarop cases kunnen worden bestudeerd, is cross-sectioneel of longitudinaal. Bij longitudinale case-studies worden herhaaldelijk in de tijd observaties gedaan. Wanneer een cross-sectie of dwarsdoorsnede van een beoogde populatie op één moment bevraagd wordt, spreekt men van éénmalig cross-sectioneel. Bij een explorerende onderzoeksbenadering is het laatste het meest gebruikelijk en ook gehanteerd in dit onderzoek. Omdat een klein aantal cases wordt bestudeerd (small-N design) is het extra belangrijk aandacht te besteden aan de criteria waaraan een wetenschappelijk onderzoeksontwerp dient te voldoen. Validiteit en betrouwbaarheid zijn juist bij een explorerende onderzoeksbenadering zeer belangrijk. 


\subsubsection{Validiteit}

Validiteit heeft te maken met bedreigingen en vooringenomenheid die de betekenis van het onderzoek en de conclusies die daaruit voortvloeien kunnen ondermijnen. Er zijn diverse vormen van validiteit die worden aangeduid met verschillende labels. Veelal wordt een onderscheid gemaakt naar construct-validiteit, interne validiteit en externe validiteit (Yin, 2003).

Bij 'construct-validiteit', ofwel inhoudelijke validiteit, gaat het erom dat de gebruikte technieken het bedoelde concept goed weerspiegelen terwijl anderzijds geen overbodige aspecten worden gemeten (Yin, 2003; Cook en Campbell, 1979; e.a.). Om bedreigingen voor de inhoudelijke validiteit tegen te gaan onderscheid Yin (2003) drie onderzoekstactieken: bronnentriangulatie, ketenargumentatie en verificatie van de case-beschrijving door respondenten. In deze studie is gebruik gemaakt van bronnentriangulatie en zijn case beschrijvingen geverifieerd.

Voor case-studies op basis van een beperkt aantal cases dienen ook bedreigingen ten aanzien van de interne en externe validiteit van het onderzoek in ogenschouw worden genomen. Bij interne validiteit gaat het om de vraag of er iets anders is dan de manipulatie van de onafhankelijke variabele, dat een verklaring kan vormen voor de veranderingen in de afhankelijke variabele. Yin (2003, p.36) geeft aan dat interne validiteit een zorg is voor causale of verklarende case-studies waarin de onderzoeker tracht te bepalen of gebeurtenis $x$ leidt tot gebeurtenis $y$. Indien een onderzoeker incorrect concludeert dat er een causale relatie is tussen $x$ en $y$ zonder te weten dat er een derde factor $z$ is die heeft geleid tot $y$ dan is het onderzoek er niet in geslaagd de bedreigingen voor de interne validiteit tegen te gaan. Deze logica is niet van toepassing op beschrijvende en verkennende studies, zoals het onderhavige onderzoek, omdat daarin geen harde causaliteit wordt geclaimd (Yin, 1994, p.35). ${ }^{23}$

De zorg over de interne validiteit van case studie onderzoek kan echter worden uitgebreid naar het bredere probleem van gevolgtrekkingen. Het beperkte aantal gevallen dat bestudeerd wordt, maakt het aantonen van verbanden lastig. Niettemin zijn bij een zorgvuldige opzet van case studies wel degelijk uitspraken te doen over effecten. In de eerste plaats kan, in overeenstemming met de aanbevelingen van King e.a. (1994: 208-230), getracht worden het aantal bruikbare waarnemingen te maximaliseren door gebruik te maken van de omstandigheden dat elke case uit een aantal onderdelen bestaat waarop wordt samengewerkt (vgl.: embedded cases, Yin, 1994: p.41-44). Door gebruik te maken van bepaalde case analysetechnieken is het vervolgens mogelijk om verbanden door middel van een zorgvuldige procesanalyse aannemelijk te maken. Voorbeelden van deze technieken zijn pattern matching, explanation building, adressing rival explanations, logic models (Yin, 2003) ${ }^{24} \mathrm{en} \mathrm{de}$ case-ordered predictor outcome matrix (Miles en Hubermann, 1994). In deze studie is vooral gebruik gemaakt van de case-ordered predictor outcome matrix en pattern-matching.

Externe validiteit heeft betrekking op de mate waarin resultaten van een onderzoek kunnen worden gegeneraliseerd buiten de context van het onderzoek, naar algemenere begrippen, populaties, andere settings en andere tijdsperiodes (Swanborn, 1994, Cook and Campbell, 1979). Critici vinden de resultaten verkregen uit case-studie niet extern valide. In tegenstelling tot willekeurige steekproeven uit een bepaalde populatie zijn case-studies niet representatief voor gehele populaties. Generalisatie op basis van case studie in de zin van statistische generalisatie is dan ook niet mogelijk. Echter, de benadering op basis waarvan een bepaald begrip of verklaring ontstaat, kan wel in andere situaties 
worden gebruikt. Met andere woorden: in statistische analyse generaliseert men naar een populatie, gebaseerd op een representatieve steekproef uit die populatie. In case-studies wordt - in vergelijking gegeneraliseerd naar een theorie gebaseerd op de geselecteerde cases die dimensies van die theorie representeren (Yin, 1994). De methode om te generaliseren is dan 'analytische generalisatie' waarin de eerder ontwikkelde basale theorie wordt gebruikt als een mal waarmee de empirische resultaten worden vergeleken. Om die reden vormt het replicatieprincipe bij de selectie van cases een belangrijk element (Yin, 2003, p.34; Cook and Campbell, 1979, p.78, e.a.). In hoofdstuk 4 zijn de in deze studie gebruikte technieken om bedreigingen ten aanzien van de validiteit van de onderzoeksresultaten tegen te gaan nader uitgewerkt.

Tenslotte is ook betrouwbaarheid een criterium voor een wetenschappelijk onderzoeksontwerp. Bij betrouwbaarbeid gaat het om de mate waarin een meting vrij is van toevalsfouten, ofwel om de mate van consistentie van de onderzoeksresultaten gedurende een aantal metingen. In dit onderzoek is getracht aan dit criterium tegemoet te komen door geldigheid en controleerbaarheid. Door correcte argumentatie en het vastleggen van procedures (voor dataverzameling \& data-analyse) en bevindingen in een onderzoeksontwerp is getracht toevalsfouten uit te sluiten.

\subsubsection{Onderzoeksstrategie}

Om in een complexe omgeving, waarin we unieke cases bestuderen, tot waardevolle inzichten te komen is het allereerst noodzakelijk dat we een gericht idee hebben waar we naar moeten kijken (zie ook 1.6.2). Daarom is op basis van literatuur over publiek belang en literatuur over planvorming gestart met het ontwikkelen van een conceptueel raamwerk (zie figuur 1.1) ${ }^{25}$.

In het conceptueel raamwerk zijn factoren benoemd die relevant zijn bij het bestuderen van verbanden tussen de kenmerken van planprocessen en de borging van het publiek belang. Deze factoren zijn geoperationaliseerd en vervolgens is beschreven op welke wijze data hierover is verzameld en welke criteria zijn gehanteerd voor de selectie van cases.

Voorafgaand aan het empirische deel van het onderzoek zijn de kenmerken van stationslocatieprojecten beschreven. Praktijkliteratuur is bestudeerd en een aantal pilot-interviews met professionele experts zijn uitgevoerd om inzicht te krijgen in de specifieke problematiek die speelt bij de herontwikkeling van stationslocaties. Met het beschrijven van de kenmerken van dergelijke projecten wordt de algemene context waarin planvorming voor herontwikkeling verloopt gegeven.

Door middel van een meervoudige case-studie zijn vervolgens empirische gegevens verzameld over de factoren uit het conceptueel raamwerk. Hiervoor is gebruik gemaakt van projectdocumentatie en interviews. Voor elke case zijn de resultaten van de dataverzameling en -analyse beschreven in een afzonderlijke rapportage.

Het derde deel start met een vergelijking van de bevindingen uit de individuele cases. Daarvoor zijn de overeenkomsten en verschillen op de in het conceptueel raamwerk benoemde factoren geanalyseerd. Deze cross-case analyse heeft geleid tot een aantal conclusies. Deze zijn geconfronteerd met mogelijke verwachtingen op basis van theoretische inzichten die in de eerste hoofdstukken zijn beschreven. Op basis daarvan zijn conclusies geformuleerd die betrekking hebben op de relatie tussen 
de inrichting van het proces en de borging van het publiek belang. De gehanteerde onderzoeksstrategie is schematisch weergegeven in figuur 1.1.

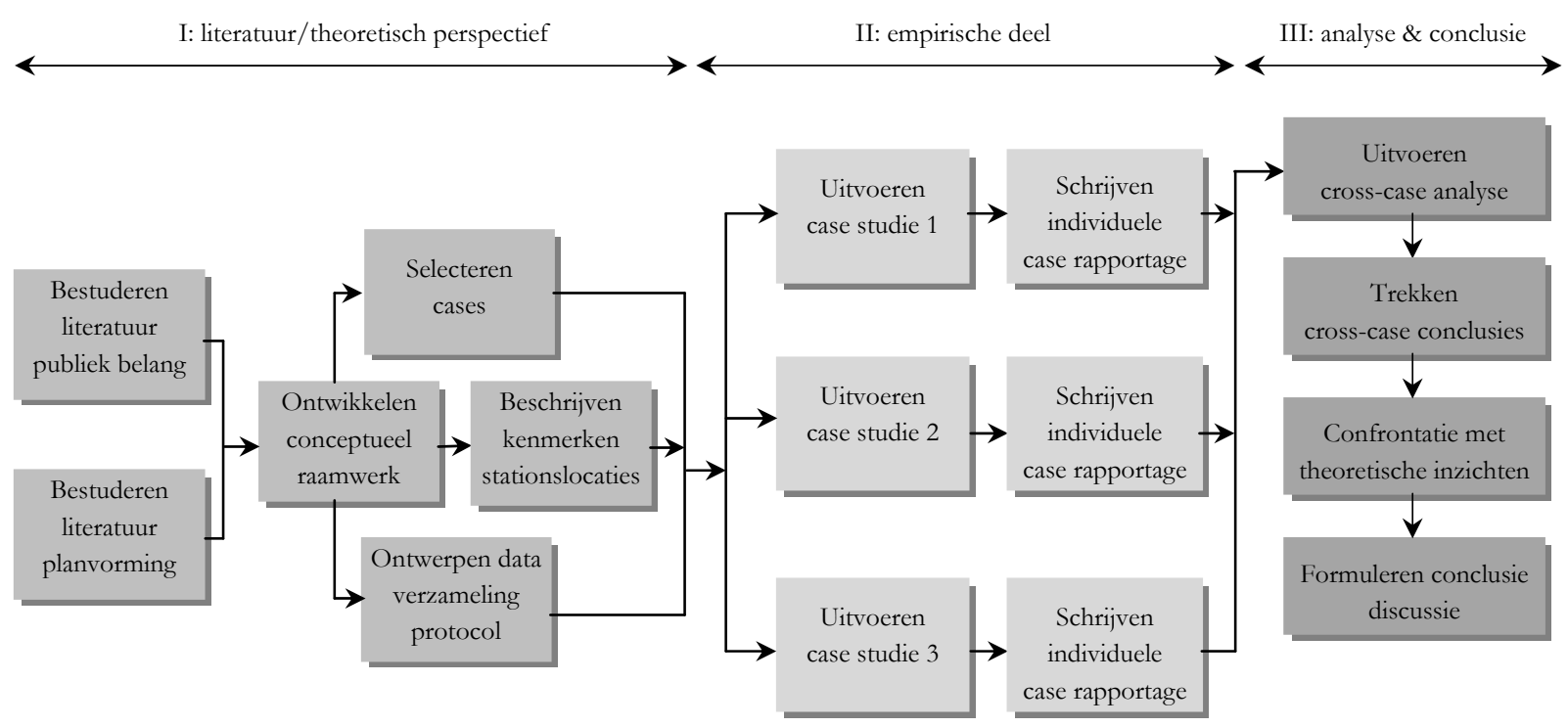

Figuur 1.1 Onderzoeksstrategie (gebaseerd op Yin, 1994)

\subsection{Leeswijzer}

In overeenstemming met de gehanteerde onderzoeksstrategie kan dit boek worden opgedeeld in drie delen. Deel I (hoofdstuk $1 \mathrm{t} / \mathrm{m}$ 5) behandelt de hoofdconcepten in de centrale onderzoeksvraag vanuit een theoretisch perspectief. Daarvoor worden de hoofdlijnen in de huidige discussie over de borging van het publiek belang en ruimtelijke planvorming en de kenmerken van het object van onderzoek, stationslocaties, beschreven. Naast het verschaffen van inzicht in het huidige debat over deze concepten wordt tevens aandacht besteed aan de definiëring daarvan en de wijze waarop deze in het onderzoek gebruikt zijn.

Hoofdstuk 2 start met een analyse van de term 'publiek belang'. Na een kort overzicht van bestaande definities wordt vanuit politiek-filosofisch en economisch perspectief ingegaan op het gebruik en misbruik van de term. Vervolgens wordt beargumenteerd waarom in deze studie effectiviteit en legitimiteit als hoofdpijlers worden gehanteerd voor de evaluatie van de borging van het publiek belang, op welke wijze deze pijlers in relatie tot elkaar staan en hoe ze operationeel gebruikt worden.

Hoofdstuk 3 verkent allereerst de bestaande benaderingen in de literatuur over planvorming en vanuit de verschuivingen in de oriëntatie op sturing en beheersing belicht het de ontwikkelingen die zich hierin over de jaren hebben voorgedaan. Uitgaande van vraagstukken van legitimiteit en effectiviteit in een multi-actor omgeving wordt toegewerkt naar een passend raamwerk voor de beschrijving van planprocessen. Een onderscheid wordt daarbij gemaakt naar algemene en projectspecifieke contextfactoren die sturend zijn voor de inrichting van het planproces en het feitelijke verloop van het planproces met de inbreng van verschillende actoren daarin. 
Hoofdstuk 4 fungeert als overgang tussen het theoretische deel van het boek en de empirische evaluatie van een drietal stationslocaties. Een overzicht wordt gegeven van het conceptueel raamwerk dat op basis van de voorgaande hoofdstukken voor deze evaluaties is opgesteld. Tevens wordt de selectie van cases en de aanpak die is gehanteerd bij de uitvoering van de case studie beschreven.

Hoofdstuk 5 is van belang om voorafgaand aan het empirische deel van de studie de algemene context waarin planprocessen bij de herontwikkeling van stationslocaties zich afspelen te begrijpen. Naast een kort overzicht van de geschiedenis van de ontwikkeling van stationslocaties voorziet het hoofdstuk daarvoor in een beschrijving van de kenmerken dit type ruimtelijke projecten, het relevante beleidskader, de van toepassing zijnde wettelijke regelgeving en procedures en de betrokken share- en stakeholders.

Deel II (hoofdstuk 6 t/m 8) presenteert de empirische hoofdstukken. Het empirische deel bestaat uit een individuele analyse van een drietal cases. Naast een beschrijving van de context van de projecten worden de inrichting van het planproces en de mate waarin het publiek belang is geborgd, bestudeerd. Hoofdstuk 6 is het eerste hoofdstuk van het empirische deel van dit boek en geeft een beschrijving van de analyse van het project Den Haag Nieuw Centraal. Dit is een van de zes stations die onder de noemer van Nieuwe Sleutelprojecten in het kader van de aanleg van het Nederlandse deel van de hogesnelheidslijn (HSL) integraal worden aangepakt.

Hoofdstuk 7 beschrijft de analyse van een ander Sleutelproject, Stationskwartier Breda. In het kader van de bredere aanpak van het gehele spoorzonegebied in Breda en door de aanleg van de shuttleverbinding met de HSL wordt hier het station herontwikkeld tot een integrale OV-terminal en wordt de directe omgeving daarvan eveneens aangepakt.

Hoofdstuk 8 behandelt onder de naam Spoorzone Delft de integrale herontwikkeling van een gebied van circa 30 hectare tussen de binnenstad van Delft en de woonwijken ten westen en zuiden daarvan. Centraal in de plannen voor dit gebied staat de ontwikkeling van een nieuw openbaar vervoersknooppunt ter vervanging van het bestaande centraal station.

Het boek sluit af met deel III (hoofdstuk 9 en 10), waarin de resultaten van de rapportages uit deel II worden geïnterpreteerd en vergeleken en op basis van de bevindingen conclusies worden getrokken over de relatie tussen de inrichting van het proces en de borging van het publiek belang.

Daartoe worden in hoofdstuk 9 in een cross-case analyse de resultaten van de evaluatie van de drie projecten geanalyseerd. De overeenkomsten en verschillen worden beschreven en de gevolgen daarvan in termen van de borging van het publiek belang worden verkend.

Afgesloten wordt met hoofdstuk 10 waarin de conclusies van het onderzoek worden getrokken. Tevens wordt aandacht besteed aan de beperkingen van de gehanteerde onderzoeksstrategie en de gemaakte keuzes en worden enkele aanbevelingen voor de inrichting van planprocessen en vervolgonderzoek gegeven. 


\section{Hoofdstuk 2}

\section{Het publiek belang}

\subsection{Inleiding}

$\mathrm{Er}$ is in het openbaar bestuur geen belangrijker onderwerp dan het publiek belang (Beck Jorgensen en Bozeman, 2007). ${ }^{26}$ De literatuur over het publiek belang is dan ook bijna eindeloos. Daarin wordt het publiek belang onlosmakelijk verbonden met de discussie over de rol en het functioneren van de overheid in de maatschappij. Zoals in het eerste hoofdstuk beschreven, hebben diverse ontwikkelingen er voor gezorgd dat de traditionele domeinen van overheid, markt en burgers meer verweven zijn geraakt. Om oplossingen te vinden voor hedendaagse ruimtelijke problemen wordt een adequaat samenspel tussen actoren vanuit deze domeinen in toenemende mate als noodzaak gezien. Niettemin blijft de heersende opvatting dat de overheid dé partij is, die in het krachtenveld rond ruimtelijke projecten het publiek belang dient te waarborgen. Tegen deze achtergrond staat de vraag, bij welke inrichting van het proces de kans op succesvolle borging van het publiek belang groot is, in deze studie centraal. Om de kennis hierover te vergroten dient in de eerste plaats meer helderheid te worden verkregen over wat het publiek belang is en welke criteria voor een evaluatie van de borging daarvan, van belang zijn.

In de eerste paragraaf van dit hoofdstuk wordt aandacht besteed aan het begrip 'publiek belang' (2.1). Een aantal definities en interpretaties komt daarbij aan de orde. Vervolgens wordt getracht het inzicht in het concept publiek belang te vergroten door aan te geven op welke wijze het vanuit verschillende invalshoeken in de literatuur wordt benaderd. Een politiek-filosofisch (2.2) en economische invalshoek (2.3) is onderscheiden. Aansluitend wordt bezien hoe evaluatie van het publiek belang in deze studie plaats kan hebben (2.4). Hiervoor wordt stilgestaan bij verschillende criteria die in literatuur van belang worden geacht voor een oordeel over de borging van het publiek belang. $\mathrm{Na}$ argumentatie resulteert dit in een keuze voor een tweetal hoofdconcepten en criteria die in het vervolg van het onderzoek gehanteerd zullen worden voor de evaluatie van het publiek belang. Afgesloten wordt met de vraag hoe het publiek belang in de context van complexe ruimtelijke projecten kan worden geborgd (2.5).

\subsection{Het begrip 'publiek belang'}

Diverse wetenschappers vanuit verschillende academische disciplines hebben gezocht naar mogelijkheden het publiek belang te definiëren. De gebruikte concepten variëren daarbij en bestaan uit termen als 'services of general interest' (EC, 2004), 'public values' (Kirlin, 1996), 'public objectives' (Noam en Nishuilleabhain, 1996) en 'public interests' (Blumstein, 1999). Zelfs als dezelfde concepten worden gebruikt kan het zijn dat verschillende dingen worden bedoeld (Charles et al., 2007, 
Koppenjan et al., 2008). Critici stellen vaak dat het gebruik van deze concepten geen wezenlijke bijdrage levert aan het debat. Deze studie negeert deze kritiek. Hoe diffuus deze concepten ook zijn, ze bevatten allen een bepaalde karakteristieke verwachting: de publieke sector moet geen belangen van individuen of groepen in het bijzonder dienen, maar moet de samenleving als geheel dienen (Beck Jorgensen en Bozeman, 2007).

In Nederland heeft de Wetenschappelijke Raad voor Regeringsbeleid (WRR) met haar rapport 'het borgen van het publiek belang' (WRR, 2000) een wezenlijke rol gespeeld in de discussie over het publiek belang. De WRR stelt dat belangen maatschappelijke belangen zijn als de behartiging van deze belangen voor de samenleving als geheel gewenst is. Het is bijvoorbeeld maatschappelijk wenselijk dat er brood wordt gemaakt, treinen rijden, de straten verlicht zijn en dijken het water tegenhouden.

Niet al deze belangen hoeven echter door de overheid te worden behartigd. Volgens de WRR (2000) is er sprake van een publiek belang, indien de overheid zich de behartiging van een maatschappelijk belang aantrekt op grond van de overtuiging dat dit belang anders niet goed tot zijn recht komt. ${ }^{27}$ Het publiek belang wordt daarmee door de WRR onlosmakelijk verbonden met een rol voor de overheid. Het uitgangspunt van democratische legitimatie vergt naar de mening van de WRR dat de politiek aanspreekbare overheid de partij is die de politieke keuze moet maken aan welke belangen zij zich wil committeren.

Voorbeelden van terreinen waar belangen spelen waar de overheid zich aan heeft gecommiteerd, zijn onder andere gecodificeerd in de Nederlandse Grondwet. Met diverse formuleringen geeft de Grondwet aan dat de overheid op terreinen van werkgelegenheid, sociale zekerheid, leefmilieu, volksgezondheid, volkshuisvesting, maatschappelijke en culturele ontplooiing en onderwijs een verantwoordelijkheid heeft. ${ }^{28} \mathrm{Er}$ staat echter niet omschreven in welke mate de overheidsbemoeienis is geboden. Er staat bovendien niet bij op welke wijze de overheid haar zorg tot uitdrukking moet brengen (Wilmink, 1998). Ook op verschillende beleidsterreinen worden bepaalde belangen aangemerkt als 'publiek belang', bijvoorbeeld:

- Energie: goed functionerende energiemarkt, ongestoorde beschikbaarheid van energie, een acceptabele natuur en milieubelasting (Energieraad, 2001);

- Drinkwater: iedere Nederlander moet kunnen beschikken over betrouwbaar drinkwater tegen tarieven en voorwaarden die transparant, redelijk en niet-discriminerend zijn (Waterleidingwet);

- Volkshuisvesting: bevordering van een evenwichtige en rechtvaardige verdeling van schaarse woonruimte (Huisvestingswet);

- Media: onafhankelijkheid, verscheidenheid, kwaliteit en toegankelijkheid (Ministerie OCW, 2006).

Het publieke debat richt zich vooral op de vraag hoe de verdeling van verantwoordelijkheden tussen overheid en markt bij de behartiging van publieke belangen in verschillende sectoren moet zijn (Raad voor Openbaar Bestuur, 1998; Algemene Rekenkamer, 1998; WRR, 2000; Raad voor Verkeer en Waterstaat, 2000; Van Damme, 2001; et al.). Aan de vraag hoe het publiek belang het beste gewaarborgd kan worden, gaat echter de vraag wat het publiek belang is vooraf (Van Wijnbergen, 2002; Teulings et al., 2003). ${ }^{29}$ Zoals de voorgaande voorbeelden laten zien, wordt het 'publiek belang' vooral ruim omschreven in termen van ambities of doelstellingen die onderling soms op gespannen voet staan of zelfs tegenstrijdig zijn. Daarnaast (en daardoor) leiden wijzigende maatschappelijke 
omstandigheden of technische ontwikkelingen tot dynamiek in wat wordt aangemerkt als publiek belang (Heldeweg, 2010; De Bruijn en Dicke, 2003). ${ }^{30}$

Het definiëren van het publieke belang is, zoals blijkt, geen eenvoudige opgave. Dit geldt nog sterker voor de vertaalslag van het publiek belang in meetbare prestatieindicatoren. De centrale gedachte achter het meten van de prestaties is op zich een eenvoudige. De beoogde prestaties worden geformuleerd en vervolgens wordt bepaald hoe deze prestaties kunnen worden gemeten door indicatoren te definiëren. Nadat bepaalde acties zijn ondernomen, kan duidelijk worden gemaakt of de beoogde prestaties zijn gerealiseerd. Er zijn echter diverse factoren te onderkennen die het meten van prestaties problematiseren (De Bruijn, 2002). Dat geldt zeker ook voor complexe ruimtelijke projecten die - net als andere moderne open of interactieve beleidsprocessen - veelal een dynamisch planproces kennen, waarbij uiteenlopende belangen moeten worden vertaald in beoogde prestaties die pas gedurende dat proces helder en concreet worden. Voordat wordt getracht criteria te formuleren die in een dergelijke context van belang zijn bij uitspraken over het publiek belang lijkt het daarom zinvol om allereerst de vraag te stellen of het überhaupt zin heeft het concept 'publiek belang' te evalueren. In meer politiek-filosofische literatuur is uitgebreid aandacht besteed aan deze vraag.

\subsection{Politiek-filosofisch perspectief: alomvattend doel of betekenisloos concept?}

In politiek-filosofische literatuur zijn er substantiële verschillen in definitie en interpretatie van het publiek belang te onderkennen. Sommigen beschouwen het publiek belang als de hoogste ethische norm voor alle politieke handelingen (o.a. Casinelli, 1962). Anderen argumenteren dat het publiek belang een betekenisloos concept is (o.a. Schubert, 1957; Sorauf, 1957, e.a.). Door diverse auteurs zijn classificaties gemaakt van de theoretische gezichtspunten op het publiek belang (Sorauf, 1957, Cochran, 1974, Beck Jorgensen en Bozeman, 2007, e.a.). Door het behandelen van deze gezichtspunten wordt hier getracht antwoord te geven op de vraag, of en zo ja, onder welke condities het zin heeft het publiek belang te evalueren. Een onderscheid kan gemaakt worden naar vier categorieën (vgl. Cochran, 1974).

Een eerste categorie bestaat uit benaderingen waarin het publiek belang wordt beschouwd als een normatief concept (Cassinelli, 1962). Als relevante norm geldt het algemene welzijn van de gemeenschap. Het normatieve criterium op basis waarvan plannen moet worden beoordeeld is of ze meer aan het algemeen welzijn bijdragen dan alternatieve plannen. Het bestaan van een normatief criterium - buiten het politieke proces - aan de hand waarvan het publiek belang zou kunnen worden beoordeeld wordt door andere benaderingswijzen om diverse redenen verworpen.

Dat geldt onder andere voor politicologische theoretici die tot een tweede categorie gerekend worden. Om uiteenlopende redenen ontkennen zij dat het concept publiek belang betekenis of geldigheid heeft. Volgens hen kan er geen sprake zijn van een publiek belang, omdat er geen 'publiek' of 'gemeenschap' is dat één enkel belang bezit. Er zijn slechts belangengroepen die verschillende belangen bezitten (Bentley, 1908; Truman, 1951).31 Om deze reden kan er volgens hen - in tegenstelling tot de vorige benaderingswijze - geen ethische inhoud worden gegeven aan het publiek belang. Plannen moeten worden beschouwd als de resultante van conflicten die bestaan tussen 
belangen die worden voorgestaan door belangengroepen. ${ }^{32}$ Het heeft geen zin dit resultaat te benoemen als publiek belang.

Een derde categorie bestaat uit benaderingen waarin het publiek belang wél wordt beschouwd als waardevolle term, maar dan vooral omdat het de aandacht vestigt op belangen die breder zijn dan die van verschillende belangengroeperingen (Downs, 1957; Pfiffner en Presthus, 1967; Flathman, 1966). Het publiek belang wordt vanuit deze invalshoek gezien als een concept dat gebruikt wordt voor het selecteren en rechtvaardigen van plannen. Het heeft weliswaar geen algemene, onveranderlijke, beschrijvende betekenis die gebruikt kan worden bij alle keuzen, maar wel is het mogelijk voor specifieke situaties op niet-willekeurige wijze het publiek belang te beschrijven. Deze beschrijving kan volgens deze invalshoek worden gevonden door middel van argumentatie, waarin wordt getracht de verwachte gevolgen van plannen te relateren aan de geldende waarden binnen een bepaalde gemeenschap (Flatman, 1966). Indien er echter geen criteria zijn gegeven waarmee goede en slechte argumenten en belangrijke en onbelangrijk argumenten kunnen worden onderscheiden, dan zal vanuit dit perspectief het publiek belang in de praktijk gewoon het resultaat van een politiek proces zijn.

Een vierde categorie wordt gevormd door benaderingen die de bruikbaarheid van het concept publiek belang eveneens wél erkennen, maar het vooral beschouwen in termen van conflict tussen belangen. Het publiek belang wordt vanuit deze invalshoek gedefinieerd door te verwijzen naar processen aan de hand waarvan plannen tot stand komen. Uitgangspunt is dat er meerdere 'publieken' zijn, in plaats van één gemeenschap of publiek en vele belangen, in plaats van één gemeenschapsbelang.

Een invalshoek binnen deze categorie is het publiek belang te definieren in termen van 'de som of de aggregatie van individuele belangen'. Dit sluit aan bij Bentham ${ }^{33}$ en de zogenaamde 'utilitaristen' voor wie het doel 'the greatest happiness of the greatest number' was. De kritiek op deze benadering richt zich vooral op de (on)mogelijkheid van interpersonele nutsvergelijking (Arrow, 1951) en de fundamentele strijdigheid van sommige belangen waardoor aggregatie niet realistisch is.

Voor anderen binnen deze vierde categorie heeft het publiek belang alleen betekenis als 'slogan' voor het compromisresultaat dat voortkomt uit de interactie tussen belangengroepen. Het publiek belang is het resultaat van het democratische proces met conflicterende belangen, voor zover dat resultaat recht doet aan de substantiële consensus van de gemeenschap. ${ }^{34}$ Kritiek op deze benaderingswijze is dat het publiek belang in dat geval niet meer iets is waar naar wordt gestreefd en geen leidraad meer is bij het ontwikkelen van plannen, maar slechts een post-hoc label is voor het product dat het resultaat is van een proces (Cochran, 1974). Om deze reden zouden alle plannen, mits tot stand gekomen via democratische procesregels, in het publiek belang zijn (Sorauf, 1957).

Tenslotte is binnen de uitgangspunten van de vierde categorie een invalshoek te onderkennen die probeert de moeilijkheden die voortvloeien uit het identificeren van het publiek belang met de uitkomsten van het proces te voorkomen door te verklaren dat het proces zelf het publiek belang is, onder voorwaarde dat bepaalde criteria voor deze processen in acht worden genomen. Groepsconflicten zijn - evenals in de andere invalshoeken binnen deze categorie - het centrale element. Het belangrijkste dat deze benadering toevoegt is, het argument dat procedures moeten worden geïnstitutionaliseerd om ervoor te zorgen dat alle groepen waarop beleid betrekking heeft toegang hebben tot de maker van plannen. Deze benadering wordt ook wel het pluralistische model van de moderne politicologische wetenschap genoemd (Schumpeter, 1942, Dahl, 1956). 35 Voor 
pluralisten is het uit het proces resulterende product, als men dit als een normatief fenomeen opvat, het juiste, zolang het maar het resultaat is van een concurrerende configuratie van groepsbelangen. Plannen die via belangenstrijd tot stand zijn gekomen hoeven niet aan een onafhankelijke normatieve standaard anders dan het criterium van gelijkwaardigheid van de burger onderworpen te worden. De democratische besluitvormingsprocedures die de regels van politiek handelen leveren en daarmee legitimiteit aan dat handelen geven, dragen deze legitimiteit over aan het resultaat dat het gevolg is van dit handelen (Lehning, 1991). In de praktijk blijkt - zo is de kritiek - de procedure niet in overeenstemming met het ideaalbeeld van het pluralisme te werken (Dahl en Lindblom, 1976). ${ }^{36}$ Naast het verwijt dat pluralisten hebben verzuimd nauwkeurig de relatie tussen het algemeen en het groepsbelang te analyseren is het belangrijkste kritiekpunt, dat de resultaten van het proces niet altijd het predicaat 'goed' verdienen. Deze resultaten bedreigen de legitimiteitsaanspraken van de publieke besluitvormers, omdat tussen burgers onderling en tussen burgers en representanten verschil van inzicht bestaat over wat het kenmerk van 'goed resultaat' is. Kennelijk garandeert een democratische procedure niet dat er zonder meer sprake zal zijn van een aanvaardbaar resultaat. Maar doordat de procedure tot enig beoordelingscriterium is verheven, kan geen normatieve uitspraak worden gedaan over het resultaat, terwijl erkend moet worden, dat het resultaat soms tot probleem is geworden. Daar staat echter tegenover dat over een beschrijvende inhoudelijke definitie van het publiek belang geen consensus bestaat en dat iedere poging om op basis van individuele opvattingen op niet arbitraire wijze een dominante opvatting af te leiden op gespannen voet staat met een aantal elementaire regels van fatsoenlijke besluitvorming (vgl. Arrow, 1951). ${ }^{37}$

\section{$\underline{\text { Resumé }}$}

Uit de beschouwing van de theoretische gezichtspunten blijkt, dat er een spanning bestaat tussen het definiëren van publiek belang in termen van het resultaat of in termen van het proces. Richt het proces zich op een bepaald resultaat of niet? Als een proces wordt gezien als zijnde gericht op een bepaald substantieel resultaat en het proces zal worden geëvalueerd aan de hand van het succes in het behalen van dat resultaat, dan kan het voorziene resultaat niet worden gedefinieerd in termen van het proces omdat het proces per definitie al het resultaat zou bevatten. Als het proces niet is gericht op een substantieel resultaat, dan is het dus slechts gericht op zichzelf, of op niets. Als dat zo is, waarom moeite doen om dit het publiek belang te noemen. Kortom, naast een oordeel over het proces dient dus tevens een oordeel uitgesproken te worden over het resultaat dat aan de hand van een bepaald proces tot stand is gekomen. Er is een niet procesmatige norm nodig die verder gaat dan de democratische norm van gelijke weging van de stem van iedere burger (vgl. Dahl, 1985). ${ }^{38}$

Een tweede spanning doet zich voor tussen het belang van een bepaalde gemeenschap en belangen van specifieke groepen binnen deze gemeenschap. Als er niet zoiets is als een eenduidig gemeenschapsbelang, is er dan wel zoiets als een eenduidig groepsbelang? In principe is de kritiek dat er geen sprake is van één gemeenschap of één 'publiek' evenzeer van toepassing op groepen. Ook binnen groepen zal er sprake zijn van belangenverschillen. Een verschil zal echter zijn, dat het gedeelde belang van een groep op een lager abstractieniveau geformuleerd kan worden.

De conclusie, dat een eenduidige beschrijvende definitie van het publiek belang niet mogelijk is tenzij hierover (quasi-)unanimiteit bestaat, lijkt op grond van de voorgaande overwegingen gerechtvaardigd. Op een hoger abstractieniveau - denk bijvoorbeeld an de steun voor de principes van de 
democratische rechtsstaat als een procesgerelateerde aanduiding van het publiek belang - zal binnen een bepaalde gemeenschap eerder sprake zijn van (quasi-)unanimiteit dan op een lager abstractieniveau. Het publiek belang is zoals blijkt, geen eenduidig en objectief begrip. Het is aan de andere kant ook geen louter subjectief begrip, maar is in de moderne samenleving wellicht het best te typeren als 'intersubjectief gedeelde waarden'. Definiëring van deze waarden zal in concrete situaties zowel procesmatige als inhoudelijke (resultaat) elementen moeten bevatten.

\subsection{Economisch perspectief: externe effecten als bron voor publieke belangen?}

Om inhoud te kunnen geven aan het concept 'publiek belang' dient het dus te worden opgevat als intersubjectief gedeelde waarden binnen een bepaalde gemeenschap. De definiëring van criteria in concrete situaties dient zowel betrekking te hebben op het proces als op het resultaat. Vragen die vervolgens opkomen, zijn; wie moet die criteria definiëren (proces) en welke inhoudelijke specificatie krijgt het publiek belang tijdens het proces (inhoud)?

De WRR (2000) is van mening dat de overheid de enige partij is die democratisch gelegitimeerd is om namens de samenleving als geheel deze afweging te maken. Het publiek belang wordt daarmee onlosmakelijk verbonden aan een rol voor de overheid. Dit roept de vraag op waarom de overheid hierbij een dergelijk prominente rol zou moeten vervullen. Waarom volstaat het vrij spel van maatschappelijke krachten waarbij via marktwerking of sociale netwerken zonder overheidsinterventie maatschappelijke processen worden gecoördineerd niet? En in welke situatie is dat het geval? Voor de beantwoording van deze samenhangende vragen levert de economische literatuur interessante inzichten.

\subsubsection{Marktfalen als argument voor overheidsingrijpen}

In de economische literatuur is marktfalen reden om te kijken naar andere institutionele arrangementen en een rol voor de overheid. In navolging van Musgrave (1959) kan het functioneren van de markt worden beoordeeld op drie criteria (zie ook: Musgrave \& Musgrave, 1976). Een eerste criterium is Pareto-efficiëntie: Daar is sprake van indien de markt, gegeven de beschikbaarheid van de productiefactoren arbeid en kapitaal, een allocatie van goederen en diensten voortbrengt waarbij het niet meer mogelijk is om door herallocatie het welvaartsniveau van een individu te verhogen zonder dat dit ten koste gaat van het welvaartsniveau van een ander. Marktfalen doet zich voor wanneer het prijsmechanisme er niet in slaagt om een Pareto optimale allocatie te realiseren. Daarbij kunnen diverse gevallen worden onderscheiden (Groenendijk, 2005: p.14).

- Onvoldoende concurrentie, waardoor de markt prijs-hoeveelheidscombinaties tot stand brengt die maatschappelijk gezien minder gewenst zijn;

- Collectieve goederen. Daar is sprake van indien de markt bepaalde goederen waar wel behoefte aan is niet voortbrengt, als gevolg van niet-uitsluitbaarheid van consumenten;

- Externe effecten. In dat geval komen de prijzen die op de markt tot stand komen niet overeen met maatschappelijk relevante kosten of opbrengsten verbonden aan de productie van de goederen in kwestie;

- Informatiegebreken. Als de ene partij meer informatie heeft dan de ander bestaat de kans op opportunistisch gedrag en suboptimaal keuzegedrag; 
- Grootschaligheid van productie. Hierbij valt te denken aan inspanningen op het terrein van onderzoek en ontwikkeling, die de mogelijkheden van individuele producenten (ook van grote monopolisten) te boven gaan.

Naast Pareto-efficiency kan een markt tevens worden beoordeeld op billijkheid. Ook al komt een optimale mix van goederen en diensten tot stand, dan kan het nog zo zijn dat de verdeling van die goederen en diensten over leden van de samenleving (of van het inkomen ter verwerving daarvan) niet strookt met collectieve rechtvaardigheidsgevoelens (Groenendijk, 2005: p.14). Als derde criterium is er de bestendigheid. De economie ontwikkelt zich niet lineair maar cyclisch; perioden van economische bloei worden afgewisseld met recessies, met bijvoorbeeld (frictie-)werkloosheid als gevolg. Ook dat kan overheidsingrijpen rechtvaardigen (Groenendijk, 2005: p.14).

In ruimtelijke projecten is vooral het optreden van externe effecten als oorzaak voor marktfalen een situatie die frequent voorkomt. Externe effecten doen zich voor wanneer een actie van één partij of een transactie tussen twee (of meer) partijen positieve of negatieve gevolgen heeft voor een andere belanghebbende die niet rechtstreeks betrokken is bij die actie of transactie. Het gevolg is dat het private belang niet samenvalt met het maatschappelijke belang, omdat de externe effecten niet worden meegewogen. Indien externe effecten kwantificeerbaar zijn en er sprake is van slechts weinig belanghebbenden, kunnen de externe effecten worden geïnternaliseerd door aanvullende privaatrechtelijke transacties waarbij ook de andere belanghebbende(n) wordt betrokken. Het inzicht dat de betrokken partijen zelf een prikkel hebben om de ontbrekende markt te creëren via aanvullende transacties is de kern van het zogenaamde Coase-theorema. Ondoelmatigheid vanwege ontbrekende markten impliceert potentiële win-win situaties die door onderlinge ruil kunnen worden gerealiseerd. In dat geval hoeft er geen aanleiding te zijn voor overheidsingrijpen.

Indien de externe effecten gecompliceerd zijn, in die zin dat er veel partijen betrokken zijn, dan zijn die aanvullende transacties moeilijk te realiseren vanwege het free-rider probleem. De niet-uitsluitbaarheid van de baten verbreekt de directe band tussen betalen en genieten. In die gevallen wordt vanuit de economische invalshoek gesteld dat er sprake is van een publiek belang, dat behartigd kan worden door publieke interventie (Teulings et. al., 2003). ${ }^{39}$ De overheid kan in dat geval bijvoorbeeld interveniëren door regulering, door het zelf ter hand nemen van productie, door belastingheffing, door subsidiëring, door te schuiven met de eigen overheidsbestedingen, door belastingen of uitkeringen te verlagen of juist te verhogen, etc. (Groenendijk, 2005). Of publieke interventie efficiënt is, hangt af van de omvang van de externe effecten in vergelijking tot de transactiekosten van publieke interventie (Teulings et al., 2003).

Deze benadering ligt in lijn met het Hicks-Kaldor criterium: het maximeren van de som van het 'vermogen' (nut) voor alle burgers. Hier komt dan ook hetzelfde dilemma naar voren als in de vorige paragraaf beschreven, namelijk de onmogelijkheid van interpersonele nutsvergelijking en de vraag hoe je de belangen van verschillende groepen ten opzichte van elkaar wilt wegen. In de praktijk spelen naast overwegingen van allocatieve efficiency ook herverdelingsoverwegingen soms een rol. Het belang van de ene groep wordt in dat geval zwaarder gewogen dan dat van een andere groep. Elke pareto-efficiënte verdeling correspondeert dan met gewogen 'vermogensmaximilisatie' met specifieke gewichten voor verschillende groepen. Daarom is ook in economische theorie de inrichting van de collectieve besluitvorming van belang. Op basis van het Arrow-theorema ${ }^{40}$ concludeert Riker (1988) 
echter dat de betekenis van de uitkomsten van democratische besluitvorming gerelativeerd moet worden. Geen enkele besluitvormingsregel biedt in alle gevallen een adequate vertaling van de individuele preferenties in een 'sociale keuze'. De 'wil van het volk' als interpretatie van het resultaat van collectieve besluitvorming is niet mogelijk.

Dat de overheid in geval van marktfalen een bepaalde taak heeft, wil nog niet zeggen dat de bijbehorende diensten of werken ook door de overheid zelf moeten worden geleverd resp. gerealiseerd. Overheidsingrijpen zelf kan namelijk ook negatieve implicaties hebben. Volgens Wolf (1993) zijn er vier vormen van overbeidsfalen. Zo impliceert ingrijpen door de overheid een scheiding tussen 'betalen' en 'genieten', die kan leiden tot bureacratische inefficienty; kunnen interne organisatiedoelen van overheidsorganen in de plaats komen van de publieke belangen waarvoor ze zijn opgericht; is politieke macht niet altijd evenredig verdeeld; en kan overheidsingrijpen ook niet voorziene en onbedoelde neveneffecten veroorzaken. Of en wanneer dergelijke situaties zich voordoen, schrijft de theorie niet voor. Vanuit economische perspectief is de centrale afweging die tussen de positieve gevolgen van correctie van marktfalen en de negatieve welvaartsgevolgen. Het gaat dan steeds om een keuze tussen twee imperfecte alternatieven, waarvan de minst slechte moet worden gekozen (Wolf, 1990). ${ }^{41}$

\section{$\underline{\text { Resumé }}$}

Economische literatuur levert interessante inzichten voor het aanduiden van publieke belangen. Tegelijkertijd wordt duidelijk dat ook met behulp van argumenten vanuit deze invalshoek niet eenduidig en objectief kan worden vastgesteld, wanneer de noodzaak van overheidssturing of ingrijpen wel of niet aanwezig is. De behoefte aan bepaalde (quasi-)collectieve goederen, welke externe effecten moeten worden ondervangen, e.d. zijn, zoals eerder vanuit politiek-filosofische invalshoek is geconstateerd, uiteindelijk normatieve afwegingen. Daarbij blijkt in beide concepties bij de beantwoording van de vraag naar de wijze waarop het publiek belang het beste inhoudelijk gedefinieerd en daarmee samenhangend geborgd kan worden, onvermijdelijk ook de vraag aan de orde naar de inrichting van de collectieve besluitvorming over wat het publiek belang inhoud.

\subsection{Evaluatie van het publiek belang in complexe ruimtelijke projecten}

Tegen de achtergrond die in de vorige paragrafen is geschetst, wordt duidelijk waarom de discussie in veel publicaties over het publiek belang gericht is op de toedeling van taken en verantwoordelijkheden tussen publieke en private partijen. Het beeld van wat publieke belangen zijn en welke rol overheden en marktpartijen moeten hebben bij het behartigen daarvan heeft in de loop van de afgelopen decennia aanzienlijke veranderingen ondergaan. Een belangrijke verschuiving ontstond in de jaren tachtig van de vorige eeuw. Het Keynesiaanse economisch denken, als beweegreden voor een interveniërende rol van de overheid, werd vervangen door het neoklassieke economisch gedachtegoed, waarin een beperktere omvang van de publieke sector ten opzichte van de private sector werd bepleit. Het resultaat was een grootschalige verschuiving van bezittingen en activiteiten van de publieke naar de private sector door mechanismen als privatisering, uitbesteding en inkrimping. In Nederland is deze kentering te vinden in het beleid van het eerste kabinet Lubbers. Om de rol van de overheid en het financieringstekort terug te dringen werd door dit kabinet een 
privatiseringsbeleid aangekondigd. ${ }^{42}$ Ook in het regeerakkoord van het tweede kabinet Lubbers werd nadrukkelijk gesproken over een fundamentele heroverweging van de grenzen van het publieke domein. ${ }^{43}$ Door de paarse kabinetten werd het privatiserings- en marktwerkingsbeleid verder geïntensiveerd. De niet altijd positieve ervaringen, de praktische onomkeerbaarheid en het feit dat essentiële publieke belangen in het geding zijn heeft geleid tot een herbezinning (WRR, 2000; Van Damme, 2001). ${ }^{44}$ Voor diverse netwerksectoren vindt ook meer recent discussie plaats over de wijze waarop publieke belangen geborgd kunnen worden (Ministerie Economische Zaken, 2004; Stout, 2007; Heldeweg, 2010; e.a.).

Deze studie richt zich niet op structurele toedeling van verantwoordelijkheden zoals in netwerksectoren, maar op het analyseren van de wijze waarop het publiek belang kan worden geborgd in concrete ruimtelijke projecten. Het gaat dan om de rol van partijen op projectniveau. Bij uitstek in concrete ruimtelijke projecten komt bij de beantwoording van de vraag naar de wijze waarop het publiek belang het beste inhoudelijk kan worden gedefinieerd, de vraag naar de inrichting van het proces aan de orde. Juist bij complexe ruimtelijke projecten gaat het namelijk niet om één organisatie met een enkelvoudige doelstelling maar om een netwerk van wederzijds afhankelijke actoren, die in coproductie tot realisatie van hun doelstellingen moeten komen. Doelstellingen die deels overeenkomen maar ook deels tegenstrijdig kunnen zijn. De vraag is dan wat in deze context intersubjectief gedeelde waarden zijn, die betrekking hebben op zowel de vormgeving van het proces als op het uiteindelijke resultaat?

\subsubsection{Borging: proces- en resultaatcriteria}

Beschouwen we het publiek belang als intersubjectief gedeelde waarden, dan kan in de Nederlandse context het idee van de democratische rechtstaat, waarvan de maatschappelijke en politieke aanvaarding stevig verankerd is, als uitgangspunt worden genomen. Representatie van burgers door democratisch gelegitimeerde organen is een fundamenteel kenmerk van het Nederlandse politiek systeem. De democratische rechtstaatgedachte wordt door de WRR vertaald in een aantal criteria voor het publiek belang. Deze zijn democratische legitimiteit, rechtsgelijkheid, rechtszekerheid, effectiviteit en efficiency (WRR, 2001). ${ }^{45}$

De criteria die door andere nationale en internationale instellingen worden gehanteerd voor de uitvoering van publieke taken liggen sterk in lijn met de voorgenoemde begrippen. Zo hanteert de Raad voor Openbaar Bestuur (ROB, 1998) betrouwbaarheid, effectiviteit, efficiency en rechtvaardigheid als criteria en stelt de Raad dat transparantie een additioneel criterium moet zijn omdat doorzichtigheid van de markt en marktwerking geboden is om te kunnen vergelijken, ook in het kader van de legitimiteit. De International Federation of Accountants (IFAC, 2001) - die de principes voor corporate governance zoals benoemd in het Cadbury-rapport (Committee on Financial Aspects of Corporate Governance,1992) heeft vertaald naar de publieke sector - stelt dat openheid, integriteit en rekenschap de drie leidende principes voor moeten zijn (IFAC, 2001). De Australian National Audit Office (2003) hanteert een verwante invalshoek en benoemt 'accountability, transparancy/openness, integrity, stewardship and leadership als criteria. Ook andere organisaties hebben het concept van 'good governance' ontwikkeld (zie tabel 2.1). 
Criteria Good Governance

VN/UNDP (1997)

VN-Azie (2002)

OECD/ PUMA

EU (2001)

Participation

Rule of law

$\mathrm{X}$

$\mathrm{X}$

Transparancy/openness

Responsiveness

$\mathrm{X}$

Consensus orientation

Equity ( $\&$ inclusiveness)

Effectiveness

Efficiency

Accountability

9 Strategic/forward vision

10 Coherence

$\mathrm{X}$

$\mathrm{X}$

$\mathrm{X}$

$\mathrm{X}$

$\mathrm{X}$

$\mathrm{X}$

$\mathrm{X}$

$\mathrm{X}$
$\begin{array}{cc}X & X \\ X & (X)\end{array}$

$\begin{array}{cc}X & X \\ X & (X)\end{array}$

$\mathrm{X}$

$\mathrm{X}$
$\mathrm{X}$

$\mathrm{X}$

$\mathrm{X}$

$\mathrm{X}$

X X
X

$\begin{array}{ll} & \mathrm{X} \\ \mathrm{X} & \mathrm{X} \\ \mathrm{X} & \\ & \\ \mathrm{X} & \mathrm{X} \\ \mathrm{X} & \\ \mathrm{X} & \mathrm{X} \\ \mathrm{X} & \mathrm{X}\end{array}$

Tabel 2.1 Voorbeelden van criteria voor good governance (overgenomen uit Van Montfort, 2004)

In Nederland rekent de Algemene Rekenkamer vier aspecten uit de VN definitie (zie tabel) tot haar domein: transparantie, publieke verantwoording, effectiviteit \& efficiency en vraaggerichtheid. ${ }^{46}$ Een internationaal voorbeeld waarin wordt getracht het concept publiek belang meer concreet handen en voeten te geven is te vinden in het door de Australische staat Victoria gehanteerde overheidsbeleid (zie tekstbox).

\section{Partnerships Victoria}

In juni 2000 is door de Australische staat Victoria een overheidsbeleid gelanceerd genaamd 'Partnerships Victoria' dat voorziet in een raamwerk voor partnerships tussen de publieke en private sector bij (publieke) infrastructuur. Bij de keuze voor een bepaalde vorm waarin de service wordt geleverd let de overheid op drie centrale vragen:

- Is het een kerntaak van de overheid?

Voor elk project dient de overheid zich af te vragen en te beslissen of het een kerntaak is die de overheid zelf moet verzorgen of dat taken overgenomen kunnen worden door de private sector.

- Zorgt betrokkenheid van de private sector voor meer 'value for money'?

Biedingen van private partijen worden vergeleken ten opzichte van een publieke sector benchmark om ervoor te zorgen dat er sprake is van value for money. Hiervoor wordt gebruik gemaakt van een Public Sector Comparator die de volledige kosten over de gehele levenscyclus van het project inclusief de kosten voor risico's berekent. Daarnaast worden niet-kwantificeerbare risico's en verschillen in kwaliteit in beschouwing meegenomen.

- Voldoet het project aan de criteria voor het publiek belang die kernonderdeel vormen van het 'Partnerships Victoria' beleid? Hiervoor is een 'public-interest' test ontwikkeld. Deze test wordt gedaan voordat een project eventueel in de markt wordt gezet en de toepassing ervan kan ervoor zorgen dat bepaalde contractuele of regulatieve mechanismen worden gebruikt om het publiek belang voldoende te waarborgen.

Het Partnerships Victoria beleid voorziet in een assesment van de impact van het project op acht elementen van het publiek belang:

(1) Effectiveness: draagt het project op een effectieve manier bij aan overheidsdoelstellingen?

(2) Accountability en transparancy: verzekeren de samenwerkingsarrangementen dat de gemeenschap correct geïnformeerd kan worden over de verplichtingen van de overheid en de private sector partner en dat toezicht hierop plaats van vinden door de Auditor-General?

(3) Affected individuals and communities: zijn diegenen die de effecten onder vinden van het project op een effectieve manier in staat bij te dragen in de planvormingsfase en worden hun rechten beschermd door eerlijke bezwaar- en beroepsprocessen en conflict oplossingsmechanismen?

(4) Equity: zijn er adequate regelingen die ervoor zorgen dat achtergestelde groepen op een effectieve wijze toegang hebben tot de infrastructuur of voorzieningen.

(5) Consumer rights: voorziet het project in voldoende waarborgen voor gebruikers, vooral diegenen voor wie de overheid in sterke mate verantwoordelijk is en die het meest kwetsbaar zijn.

(6) Public acces: zijn er waarborgen die er voor zorgen dat er sprake is van duurzame toegang tot de essentiële infrastructuur/voorzieningen? (7) Security: voorziet het project er in dat de gezondheid en veiligheid gemeenschap wordt verzekerd?

(8) Privacy: voorziet het project in een adequate bescherming van het recht van gebruikers op privacy?

Ieder potentieel project dient te worden getest tegen elk van de acht elementen en op basis daarvan kan worden gekeken of adequate maatregelen kunnen worden getroffen om het publiek belang te beschermen. De resultaten van de volledige test moeten worden meegenomen in de business case van het project die goedgekeurd moet worden voordat 'expressions of interest' worden gedaan. 
De criteria die door de WRR en andere instellingen zijn geformuleerd worden ook in verschillende relevante wetenschappen expliciet dan wel impliciet als aannames gehanteerd. Dit geldt bijvoorbeeld in de institutionele bestuurskunde (zie Downs, 1957; Buchanan en Tullock, 1962; Ostrom, 1973). ${ }^{47}$ Naar de mening van institutionele bestuurskundigen gaat het niet alleen om de doelmatigheid en effectiviteit van voorzieningen waarvoor de overheid de verantwoordelijkheid op zich heeft genomen, maar tevens om de mate waarin deze voorziening voorziet in de behoeften van het publiek. In de woorden van Ostrom (1973, p.62): 'efficiency in the absent of consumer utility is without economic meaning'. Dit impliceert dat er overeenstemming bestaat tussen preferenties van burgers enerzijds en de gerealiseerde voorzieningen anderzijds (consumentensoevereiniteit). Vraag is dan hoe op een efficiënte en effectieve wijze recht kan worden gedaan aan de consumentenvoorkeuren, oftewel hoe de consumentensoevereiniteit kan worden gewaarborgd in complexe ruimtelijke projecten. Voor zover van consumentensoevereiniteit in deze zin sprake is spreken economen ook wel van allocatieve efficiëntie en politicologen van (democratische) responsiviteit. Naast effectiviteit, doelmatigheid en responsiviteit wordt door institutionele bestuurskundigen ook nadrukkelijk aandacht besteed aan rechtstatelijke beginselen ${ }^{48}$ als waarborgen tegen een 'democratische' dictatuur van de meerderheid (Buchanan en Tullock, 1962). De door de institutionele bestuurskunde gehanteerde eisen democratische responsiviteit, rechtsstatelijkheid, effectiviteit en doelmatigheid liggen daarmee sterk in lijn met de eisen van democratische legitimiteit, rechtsgelijkheid, rechtszekerheid, effectiviteit en efficiency die de WRR (2001) op basis van de beginselen van de democratische rechtstaat hanteert. Gesteld wordt dat de waarden van de democratische rechtstaat in de Nederlandse context intersubjectief worden gedeeld. De publieke normering van een maatschappelijk belang komt in Nederland tot stand in de democratische rechtsstaat. De daarmee samenhangende criteria kunnen als basis dienen voor een oordeel over de borging van het publiek belang.

\subsubsection{Analysekader: effectiviteit en legitimiteit als hoofdconcepten}

In deze studie is voor een oordeel over de borging van het publiek belang de nadruk gelegd op de criteria 'effectiviteit' en 'legitimiteit'. De reden hiervoor is tweeledig.

In de eerste plaats vormt in literatuur waarin de veranderende verhoudingen tussen actoren op verschillende beleidsterreinen centraal staat, de discussie over de wijze waarop deze verhoudingen dienen te worden vormgegeven met het oog op meer effectiviteit en legitimiteit de rode draad (Scharpf, 1997; Pierre, 2000; Haus et al., 2005). Ook in de ruimtelijke sector, waar oplossingen voor complexe ruimtelijke problemen voornamelijk bepaald en gepland werden door overheden, kreeg de kritiek op deze wijze van planvorming vooral vorm in termen van een gebrek aan legitimiteit en effectiviteit (Teisman, 1997; Kreukels, 1999).

Een tweede reden om de aandacht primair te richten op effectiviteit en legitimiteit is gelegen in de samenhang tussen de concepten. Zo dragen effectiviteit en efficiency bij aan de legitimiteit van beleid, is legaliteit onlosmakelijk verbonden met legitimiteit en impliceert legaliteit rechtsgelijkheid en rechtszekerheid. Behoudens in het geval van basisvoorzieningen die van overheidswege tegenover iedere burger wordt gegarandeerd, worden de laatste twee beginselen veelal beschouwd als randvoorwaarde. Bovendien zijn er beleidsterreinen waar rechtsgelijkheid niet eens de status van dwingende randvoorwaarde haalt (WRR, 2000: p.36). In ruimtelijke projecten krijgt rechtszekerheid en -gelijkheid onder meer vorm door formele mogelijkheden voor inspraak, bezwaar en beroep. In algemene zin gaat het om de vraag of de van toepassing zijnde (besluitvormings)regels en procedures 
op correcte wijze gehanteerd en doorlopen zijn. Het legaliteitsbeginsel verlangt namelijk dat verplichtende overheidsoptreden op een wettelijke basis berust. Met de opmars van kaderwetgeving en meer horizontale bestuursvormen is de wet echter in afnemende mate van belang als basis voor overheidsoptreden. Dit geldt zeker ook bij open planprocessen waarin normstelling niet eenzijdig door de overheid plaats vindt, maar in samenspraak met de betrokken maatschappelijke partijen en burgers. In dat geval zijn normen van procesopenheid en transparantie procedurele substituten voor de inhoudelijke normstelling via het legaliteitsbeginsel. Deze begrippen spelen zoals verderop duidelijk zal worden gemaakt een belangrijke rol bij het concept legitimiteit.

Ook efficiency in de zin van productieve (of kosten-)efficiëntie kan worden gezien als een belangrijke randvoorwaarde. Het gaat dan om de vraag of de (publieke) voorzieningen tegen de laagst mogelijke prijs worden gerealiseerd. Voor allocatieve efficiëntie ligt dit anders. Dan gaat het om de vraag of de middelen ook daar worden ingezet waar ze het meeste effect sorteren. In de context van ruimtelijke planvorming betekent deze definitie dat een traject niet efficiënt kan zijn als het niet in enige mate effectief is. De vraag naar allocatieve efficiëntie kan dus pas worden beantwoord als eerst duidelijk is welke trajecten voor welke partijen effectief zijn. In zekere mate incorporeert het legitimiteitsbegrip ook efficiëntie. Inefficiënt (of ineffectief) optreden kan ertoe leiden dat het vertrouwen verdwijnt. Rosenthal et al. (1996) zien vertrouwen als basis voor acceptatie of aanvaarding van plannen en daarmee voor legitimiteit.

De concepten zijn dus gerelateerd en bevinden zich in een zeker spanningsveld ten opzichte van elkaar. De nadruk op effectiviteit en legitimiteit als hoofdconcepten betekent dus niet dat de andere concepten volledig buiten beschouwing blijven. Evaluatie van de borging van het publiek belang in ruimtelijke projecten impliceert niettemin in eerste instantie een oordeel over de effectiviteit en legitimiteit van de totstandkoming van de gerealiseerde voorzieningen.

\section{Effectiviteit}

Het bepalen van de effectiviteit impliceert meten in welke mate bepaalde prestaties het gevolg zijn van bepaalde acties. Om effectiviteit te operationaliseren voor onderzoek speelt de context een belangrijke rol. Traditioneel gaat het bij effectiviteit om doelbereiking. Doelen zijn de wensen die een persoon of organisatie heeft besloten te verwezenlijken (Hoogerwerf, 1993: p.53). Doelbereiking is de mate waarin deze wensen worden gerealiseerd, waarbij in het midden wordt gelaten of dit al dan niet het gevolg is van de ondernomen acties. Doelbereiking als zodanig is in ruimtelijke projecten pas vast te stellen als het project gerealiseerd en in gebruik is. Voor projecten die nog niet gerealiseerd zijn, kan slechts worden gekeken naar de verwachte doelbereiking. Daarnaast veronderstelt een oordeel over doelbereiking dat doelen specifiek, meetbaar, acceptabel, realistisch en tijdsgebonden zijn. ${ }^{49}$

Kenmerk van complexe ruimtelijke projecten is, dat een groot antal actoren met uiteenlopende belangen betrokken is, omdat taken, verantwoordelijkheden, competenties en middelen verdeeld zijn over verschillende partijen. In de beginfase van deze projecten zijn doelen veelal nog niet volledig helder en de eerste fasen worden dan ook gekarakteriseerd door interactie, doelvervlechting en onderlinge afstemming. Een gezamenlijk doel is er in de beginfase vaak nog niet. Op een hoog abstractieniveau streven alle overheden in de ruimtelijke sector echter ruimtelijke kwaliteit na. Dit is de centrale doelstelling van het Nederlandse ruimtelijk beleid (Ministerie VROM, 2004). Ook private partijen streven naar ruimtelijke kwaliteit als afgeleide van de primaire doelstellingen; winst, omzet en continuiteit. De waarde van vastgoed hangt bijvoorbeeld in belangrijke mate samen met de kwaliteit van de directe omgeving (ORI, 1991). In de ruimtelijke sector kan ruimtelijke kwaliteit worden gezien 
als een inhoudelijke typering van een intersubjectief gedeelde waarde. In deze studie wordt voor een oordeel over de effectiviteit van het proces daarom gekeken naar de verwachte bijdrage van de plannen aan het realiseren van een hogere ruimtelijke kwaliteit. Voor ruimtelijke projecten gaat het er bij de beslissing over een ruimtelijke ingreep om dat de bestaande ruimtelijke kwaliteit niet aansluit bij de gewenste ruimtelijke kwaliteit. Verschillende overheden zullen vanuit de bestuurlijke verantwoordelijkheden die aan hen zijn toebedeeld op projectniveau echter de nadruk leggen op verschillende dimensies van ruimtelijke kwaliteit. Dit heeft te maken met de verschillende 'publieken' waarvoor zij 'spelen'. Dit geldt eveneens voor andere stakeholders. Dit vereist een kader om naar ruimtelijke kwaliteit te kijken.

\section{Ruimtelijke kwaliteit}

Ruimtelijke kwaliteit is - evenals het publiek belang - niet een eenduidig objectief definieerbaar concept. Het pluriforme karakter blijkt uit de verschillende invalshoeken die worden gebruikt om het begrip te definiëren. Meestal wordt in de literatuur waarin ruimtelijke kwaliteit centraal staat, verwezen naar het klassieke boek van de Romeinse architect Vitrivius uit de eerste eeuw voor Christus, te weten De architectura (Bruil, e.a., 2004; Hooimeijer et al., 2001). Vitrivius definieerde de kwaliteit van een bouwwerk als de onlosmakelijke samenhang tussen de begrippen firmitas (degelijkheid), utilitas (bruikbaarheid) en venustas (schoonheid). Deze driedeling heeft over de eeuwen stand gehouden, maar de exacte invulling verschilt per periode. Bepaalde aspecten van kwaliteit worden steeds genoemd in verschillende plaatsen en verschillende tijden, maar de invulling is sterk afhankelijk van de context (Lautenbach, 2008).

De overheid heeft in belangrijke mate bijgedragen aan het verkennen en definiëren van het begrip ruimtelijke kwaliteit. Als hoofddoelstelling van het ruimtelijk beleid werd het geïntroduceerd op het moment dat daarin fundamentele veranderingen plaatsvonden (WRR, 1998). De sturingsambities van de overheid verminderden en de inrichting van Nederland werd meer en meer gezien als een gemeenschappelijke verantwoordelijkheid van rijksoverheid, lagere overheden, marktpartijen, belangenorganisaties en bevolking. De rol van de overheid en in het verlengde daarvan de rol van plannen stond niet meer centraal, maar het handelen van verschillende actoren en de motieven die daaraan ten grondslag liggen. In de Vierde Nota Ruimtelijke Ordening (Ministerie VROM, 1988) werd het begrip ruimtelijke kwaliteit alsvolgt geïntroduceerd: " Het ruimtelijk beleid is er op gericht de gebruikswaarde van een gebied te vermeerderen, de belevingswaarde te verhogen, en de toekomstwaarde te vergroten. De concrete invulling van die ruimtelijke kwaliteit zal daarbij van geval tot geval verschillen." ${ }^{5}$

Deze driedeling naar gebruikerswaarde, belevingswaarde en toekomstwaarde ligt in lijn met de driedeling die Vitrivius al hanteerde. De Rijksplanologische Dienst (RPD, 1996) heeft deze drie aspecten uitgewerkt. Gebruikerswaarde heeft volgens de RPD betrekking functionele geschiktheid, doelmatig gebruik, doelmatige aanleg, doelmatig beheer, samenhang, bereikbaarheid en interferentie. Belevingswaarde heeft betrekking op identiteit, diversiteit, herkenbaarheid en zingeving. En toekomstwaarde verwijst naar aspecten als sturende werking, doelmatigheid in de tijd, uitbreidbaarheid en aanpasbaarheid. 
Het is de vraag of deze uitwerking van de drie hoofdcategorieën helpt om ruimtelijke kwaliteit adequaat te definiëren. Wat ontbreekt, is dat een ruimtelijke ontwikkeling vaak meerdere functies of belangen moet dienen om conflicten te vermijden of om te zorgen voor onderlinge versterking (Hooimeijer et al, 2001). De voorgenomen Vijfde Nota Ruimtelijke Ordening introduceerde 'ruimtelijke kwaliteit' als uiteindelijke doelstelling van ruimtelijke ordening. Ruimtelijke kwaliteit werd samengevat in zeven dimensies die richting moesten geven aan de ruimtelijke inrichting van Nederland. Deze waren: ruimtelijke diversiteit, economische en maatschappelijke functionaliteit, culturele diversiteit, sociale rechtvaardigheid, duurzaamheid, aantrekkelijkheid en menselijke maat. Dat de Vijfde Nota een groot aantal doelen noemt, die niet zelden conflicteren, ligt in de rede. Diverse beleidsterreinen zoals rond wonen, werken, infrastructuur, natuur, landschap, milieu en veiligheid kennen immers een ruimtelijke dimensie. Hooimeijer e.a. (2001) concluderen dat de zeven dimensies uit de Vijfde Nota Ruimtelijke Ordening niet voldoen omdat belangen (economische, sociale, culturele) en ontwerpeisen (diversiteit, identiteit, menselijke maat) door elkaar lopen of omdat ontwerpeisen tot publiek belang worden verklaard.

In de Nota Ruimte (Ministerie VROM, 2004), waarin de huidige overheidsvisie op de ruimtelijke ontwikkeling van Nederland is beschreven, is teruggekeerd naar de drie dimensies; gebruikerswaarde, belevingswaarde en toekomstwaarde. Volgens de Nota Ruimte is sprake van een hogere gebruikswaarde, indien 'de ruimte op een veilige wijze gebruikt kan worden voor verschillende functies $(. .$.$) , deze functies elkaar niet hinderen, ze elkaar zo mogelijk versterken en ze toegankelijk$ zijn voor alle bevolkingslagen en -groepen. Belevingswaarde speelt een belangrijke rol in de leefomgeving. Daarbij gaat het om cultureel besef en diversiteit, menselijke maat, aanwezigheid van karakteristieke kenmerken - identiteit - en afleesbaarheid van (cultuur)historie en schoonheid. Ook moet in dit verband volgens de Nota Ruimte gedacht worden aan variatie (...). Bij toekomstwaarde gaat het om kenmerken als duurzaamheid, biodiversiteit, robuustheid, aanpasbaarheid en flexibiliteit in de tijd, zowel wat betreft geschiktheid voor nieuwe gebruiksvormen als ontvankelijkheid voor nieuwe culturele en economische betekenissen.'

De voorgaande specificatie van de trits belevingswaarde, gebruikerswaarde en toekomstwaarde als criteria van ruimtelijke kwaliteit is echter onvolledig en bijna willekeurig (Daamen, 2005). Wie de literatuur over ruimtelijke kwaliteit overziet kan niet anders dan concluderen dat het onmogelijk blijkt om een algemeen aanvaardbare definitie van ruimtelijke kwaliteit te geven (Reijndorp, 1998). Er bestaat een spanning tussen individuele wensen, zoals de behoefte aan ruimte voor wonen, werken en infrastructuur en collectieve waarden als natuur en openbare ruimte. Het gebruik voor de ene functie gaat meestal ten koste van de andere functie. Men is het er over eens dat ruimtelijke kwaliteit een gebiedsgericht begrip is, waarbij de invulling van de dimensies per situatie bezien moet worden. Daarbij zal de ene keer het accent meer op de ene waarde liggen, de andere keer op de andere waarde. Belangrijk is dat deze waarden niet van bovenaf worden opgelegd, maar dat betrokken partijen een stem hebben in het bepalen van wat ruimtelijke kwaliteit in het betreffende gebied is (WRR, 1998: p.22). Een normatieve analyse is dan nodig om de aard en de hierarchie in specifieke situaties te bepalen. Juist het normatieve en voor een deel inherent subjectieve karakter vereist min of meer interactieve processen. Met andere woorden, het realiseren van ruimtelijke kwaliteit stelt eisen aan het proces van planvorming. Vanuit deze achtergrond is het concept ruimtelijke kwaliteit voor deze studie geoperationaliseerd. Daarbij is gebruik gemaakt van een analysekader van Hooimeijer et al. 
(2001) waarin ontwerpeisen worden gekoppeld aan uiteenlopende belangen. ${ }^{51}$ De waardering van partijen voor diverse elementen kan hierdoor in de beoordeling worden meegenomen en kunnen spanningen daarin zichtbaar worden. ${ }^{52}$

\begin{tabular}{|c|c|c|c|}
\hline & Gebruikerswaarde & Belevingswaarde & Toekomstwaarde \\
\hline Economisch & $\begin{array}{l}\text { 1. Functionaliteit } \\
\text { Allocatie-efficiency } \\
\text { Bereikbaarheid } \\
\text { Externe-effecten } \\
\text { Multi-purpose }\end{array}$ & $\begin{array}{l}\text { 2. Aantrekkelijkheid } \\
\text { Imago } \\
\text { Attractiviteit }\end{array}$ & $\begin{array}{l}\text { 3. Flexibiliteit } \\
\text { Stabiliteit/flexibiliteit } \\
\text { Agglomeratie } \\
\text { Cumulatieve attractie }\end{array}$ \\
\hline Sociaal & $\begin{array}{l}\text { 4. Beschikbaarheid } \\
\text { Toegang } \\
\text { Verdeling } \\
\text { Deelname } \\
\text { Keuze }\end{array}$ & $\begin{array}{l}\text { 5. Vitaliteit } \\
\text { Ongelijkheid } \\
\text { Verbondenheid } \\
\text { Veiligheid }\end{array}$ & $\begin{array}{l}\text { 6. Stabiliteit } \\
\text { Insluiting } \\
\text { Cultures of poverty }\end{array}$ \\
\hline Ecologisch & $\begin{array}{l}\text { 7. Leefbaarheid } \\
\text { Veiligheid, hinder } \\
\text { Verontreiniging } \\
\text { Verdroging } \\
\text { Versnippering }\end{array}$ & $\begin{array}{l}\text { 8. Diversiteit } \\
\text { Ruimte, rust } \\
\text { Schoonheid } \\
\text { Gezondheid }\end{array}$ & $\begin{array}{l}\text { 9. Duurzaamheid } \\
\text { Voorraden } \\
\text { Ecosystemen }\end{array}$ \\
\hline
\end{tabular}

Tabel 2.2 Dimensies van ruimtelijke kwaliteit (Hooimeijer et al., 2001)

De matrix moet worden gezien als een conceptueel hulpmiddel voor een analyse van de belangrijke dimensies van ruimtelijke kwaliteit in een specifieke situatie. Het beantwoord niet de vraag hoe ruimtelijke kwaliteit bepaald kan worden. Daarvoor zijn verschillende benaderingen te onderkennen (zie o.a. Garvin, 1984). ${ }^{53}$

In deze studie wordt ruimtelijke kwaliteit opgevat als een subjectgebonden, contextafhankelijk begrip met een relatief karakter. Dit betekent in de eerste plaats dat subjecten een oordeel uitspreken over wat belangrijke eigenschappen van ruimtelijke kwaliteit zijn en zij vervolgens de kwaliteit op de (mate van) realisering van die eigenschappen beoordelen. Niet ieder subject hoeft daarbij tot hetzelfde oordeel te komen. Naarmate er meer overeenstemming bestaat treed 'intersubjectiviteit' op. In de tweede plaats betekent de contextafhankelijke opvatting dat ruimtelijke kwaliteit wordt gezien als een 'sociaal construct'. Het is in die opvatting afhankelijk van tijd, plaats en betrokkenen en krijgt betekenis in de afstemmings- en onderhandelingsprocessen tussen betrokkenen en belanghebbenden (Lautenbach, 2008). Het relatieve (in tegenstelling tot absolute) karakter van ruimtelijke kwaliteit komt tenslotte tot uiting als gebieden worden vergeleken op de realisatie van ruimtelijke kwaliteit. Het ene gebied kan beter scoren op de ene eigenschap van ruimtelijke kwaliteit en het andere gebied op een andere eigenschap. In tegenstelling tot de vraag of een gebied al dan niet ruimtelijke kwaliteit heeft, gaat het dan om de mate waarin ruimtelijke kwaliteit aanwezig is. Aansluitend bij deze opvatting van ruimtelijke kwaliteit wordt in deze studie voor evaluatie het oordeel van de partijen die betrokken zijn in het planproces gebruikt. Dan gaat het om de verwachte bijdrage van de plannen aan het verbeteren van de verschillende dimensies/eigenschappen van ruimtelijke kwaliteit zoals geformuleerd in tabel 2.2. Omdat verwachte doelbereiking in termen van de verwachte realisatie van ruimtelijke kwaliteit niet veel zegt als de in plannen vervatte doelen niet of onvoldoende aansluiten bij de wensen en eisen van betrokkenen is legitimiteit van planvorming een minstens zo belangrijk element voor een oordeel 
over het publiek belang. Juist wanneer wensen en eisen niet volledig overeen komen, is het van het grootste belang dat men het ten minste eens is over de wijze waarop op legitieme wijze tot beslissingen kan worden gekomen (WRR, 1998: p.13).

\section{Legitimiteit}

Legitimiteit is een moeilijk te vatten begrip. Als gesteld wordt dat iets legitiem is, dan bedoeld men vaak dat iets goed is, einde discussie. Het omgekeerde kan echter ook het geval zijn, namelijk dat twee of meer partijen elkaar bestrijden omdat ze een andere claim op legitimiteit doen. In die zin is legitimiteit geen objectief maar een relatief begrip die partijen - binnen bepaalde grenzen - naar eigen goeddunken kunnen invullen (Tirion, 2006: p.93). Legitimiteit wordt in dat geval afhankelijk van de situatie.

In literatuur zijn over de jaren verschillende definities van legitimiteit geformuleerd. Dowling en Pfeffer (1975: p.122) definiëren legitimiteit als "congruence between the social values associated with or implied by (organizational) activities and the norms of acceptable behavior in the larger social system". Een andere definitie wordt geformuleerd door Suchman (1995: p.574) die legitimiteit definieert als "a generalized perception or assumption that the actions of an entity are desirable, proper or appropriate within some socially constructed system of norms, values, beliefs and definitions". In beide definities gaat het dus om de overeenstemming tussen het handelen van organisaties en de normen en waarden die in een bepaalde gemeenschap als aanvaard worden beschouwd. In de bestuurswetenschappen wordt legitimiteit vaak in verband gebracht met aanvaardbaarheid of acceptatie. Hoogerwerf (1998: p.61) definieert legitimiteit bijvoorbeeld als volgt: "de legitimiteit van een beleid is de aanvaardbaarheid van het beleid voor de betrokkenen. Het gaat daarbij om de mate waarin het beleid door de betrokkenen als juist, gerechtvaardigd of althans acceptabel wordt beschouwd of gesteund." ${ }^{44}$ Ook Suchman (1995) stelt dat legitimiteit in ieder geval verwijst naar acceptatie en steun door diegenen die gevolgen ondervinden van bepaalde maatregelen en legitimering verwijst naar de wijze waarop die steun en acceptatie gegenereerd wordt. Omdat legitimiteit een moeilijk te vatten begrip is, wordt het echter vaker omschreven dan gedefinieerd. ${ }^{55}$ Op basis van een analyse van bestaande literatuur onderscheidt Suchman (1995) drie vormen van organisationele legitimiteit. Suchman (1995) duidt deze aan met de termen; pragmatische legitimiteit, morele legitimiteit en cognitieve legitimiteit.

Pragmatische legitimiteit berust op de berekening van het eigen belang. Op het eenvoudigste niveau komt het neer dat acceptatie en steun voor plannen of activiteiten van een organisatie afhangt van de mate waarin deze bijdragen aan het eigen belang van degenen die deze evalueert. Het kan daarnaast ook zijn dat steun voor plannen of activiteiten niet het gevolg is van de directe voordelen voor het eigen belang, maar omdat de betreffende organisatie laat zien dat zij ontvankelijk is voor haar bredere belangen.

Morele legitimiteit berust niet op oordelen over de mate waarin activiteiten in het voordeel zijn van degene die deze evalueert, maar op de oordelen of de activiteiten 'het juiste' zijn om te doen. Deze oordelen zijn gebaseerd op de opvattingen of de activiteiten op een effectieve wijze bijdragen aan het maatschappelijke welzijn. Deze altruïstische grondslag betekent niet dat morele legitimiteit volledig vrij is van belangen. Volgens Scott en Meyer (1991) is morele legitimiteit gebaseerd op drie gronden: 
(1) evaluaties van output en consequenties (consequential legitimacy), (2) evaluaties van technieken en procedures (procedural legitimacy) en (3) evaluaties van structuren (structural legitimacy). In het eerste geval worden organisaties beoordeeld op basis van wat ze bereiken. Organisaties kunnen echter ook morele legitimiteit verkrijgen door sociaal geaccepteerde technieken en procedures te gebruiken. Deze tweede vorm wordt belangrijker indien de mogelijkheden om op een heldere wijze de output te meten afwezig zijn (Scott, 1992). Echter zelfs als de resultaten wel goed te beoordelen zijn, is het nog steeds gebruikelijk dat de juiste middelen en procedures een positieve bijdrage leveren aan de legitimiteit. Deze procedurele legitimiteit loopt over in de evaluatie van structuren. Echter, waar legitimiteit op basis van procedures gericht is op het specifieke onderdeel (is voor het project de juiste procedure op correcte wijze doorlopen?) is structurele legitimiteit meer gericht op de algemene kenmerken van een organisatie als bepaalde zaken zich in de tijd herhalen (is er een standaard procedure die de organisatie altijd volgt bij dit type projecten?). Structuren dienen, evenals procedures, als eenvoudig te monitoren volmachten voor minder zichtbare richtpunten, zoals strategieën, doelen en resultaten (Scott \& Meyer, 1991). Soms wordt er nog een vierde grond voor morele legitimiteit onderscheiden die conceptueel interessant kan zijn, namelijk 'personal legitimacy'. Daarbij gaat het om de evaluatie van leiders en vertegenwoordigers. ${ }^{56}$

De derde vorm, cognitieve legitimiteit, is gebaseerd op cognitie in plaats van direct belang of morele evaluatie. Twee varianten onderscheid Suchman (1995): legitimiteit gebaseerd op alomvattendheid en legitimiteit gebaseerd op vanzelfsprekendheid. In het eerste geval vloeit legitimiteit voort uit culturele modellen die zorgen voor plausibele verklaringen voor de organisatie en haar inspanningen. In het tweede geval komt legitimiteit voort uit de perceptie dat een andere situatie letterlijk ondenkbaar is.

De vormen van legitimiteit die Suchman (1995) onderscheid richten zich op de legitimiteit van organisaties. In het werk van Weber (1922) en diverse andere auteurs (Easton, 1965; Hoogerwerf, Arentsen en Klok, 1993; e.a.) wordt bij legitimiteit de koppeling gelegd met gezag. In dat geval gaat het veelal om de acceptatie of aanvaarding van overheidsbeleid. In deze studie gaat het voor de borging van het publiek belang bij ruimtelijke ontwikkelingsprojecten om de legitimiteit van het planproces. In literatuur wordt voor de analyse van processen nogal eens verwezen naar de systeembenadering van politieke besluitvorming, waarbij legitimiteit gekoppeld wordt aan verschillende deelprocessen. Zo kan een onderscheid worden gemaakt naar input-, throughput- en outputlegitimiteit (Easton, 1965; Scharpf, 1997, Bekkers en Edwards, 2007: p.43-46). ${ }^{57}$ Hoewel de beschreven vormen van organisationele legitimiteit hier deels mee in lijn liggen, wordt dit spoor hier gevolgd en is getracht een aantal indicatoren te benoemen die iets zeggen over de legitimiteit van planvorming. ${ }^{58}$

\section{Inputlegitimiteit}

Inputlegitimiteit heeft betrekking op hoe beslissingen tot stand komen. Volgens Scharpf (1997) gaat het hier om de vraag in hoeverre er sprake is van 'government by the people'? Beslissingen zijn vanuit dit perspectief legitiem als en omdat ze zijn afgeleid uit de autentieke voorkeuren van een bepaalde gemeenschap. Het gaat met andere woorden om de wijze waarop de invoer van wensen, voorkeuren en belangen in het proces plaats vindt. Voorwaarde voor legitimiteit is dan dat het verloop van het proces niet in strijd mag zijn met geldende wettelijke regelgeving (vgl. Beetham, 1991; Morris, 1998: 
p.103). ${ }^{59}$ Daarom dient in de eerste plaats aan bepaalde institutionele eisen, zoals democratische procedures voor besluitvorming, te worden voldaan. Legitimiteit is dus nauw verweven met legaliteit. Naast juridische normen kunnen er echter ook niet-juridische normen voor de invoer van wensen, voorkeuren en belangen in het proces. Vanuit het inputgeorienteerde perspectief op legitimiteit gaat het erom dat plannen, die volgens een bepaald legaal verlopen proces tot stand zijn gekomen, worden geaccepteerd door stakeholders onafhankelijk van de mate waarin hun individuele wensen en voorkeuren in de plannen terug komen (Luhman, 1969). De openheid van het proces ofwel participatiemogelijkheden spelen in dit verband een belangrijke rol. Voorstanders van participatie argumenteren dat hierdoor dichter in de buurt wordt gekomen van het ideaal van de directe democratie en dat er een lerend proces ontstaat, omdat stakeholders hun eigen percepties kunnen confronteren met die van anderen (Barnes, 1999). ${ }^{60}$ Het gaat er voor de openheid van het proces in de eerste plaats om dat het proces toegankelijk is voor relevante partijen (toegankelijkheid), zodat deze in staat zijn hun wensen, en voorkeuren inzichten, ervaringen en ideeën tot uitdrukking te brengen. Daar bovenop gaat het in de tweede plaats om dat er ook daadwerkelijk mogelijkheden bestaan om het planproces te beïnvloeden. Zijn partijen in voldoende mate in staat hun standpunten en belangen voor het voetlicht te brengen en bestaat er ruimte voor concurrerende probleempercepties, nieuwe ideeën en oplossingsrichtingen. Voor een oordeel over inputlegitimiteit zijn legaliteit en openheid van het proces belangrijke indicatoren.

\section{Outputlegitimiteit}

Scharpf (1999: p.6) onderscheidt naast inputlegitimiteit tevens outputlegitimiteit. In tegenstelling tot inputlegitimiteit benadrukt het outputgeorienteerde perspectief op legitimiteit de mate waarin er sprake is van 'government for the people'. Volgens Scharpf (1999) is het bestaan van outputlegitimiteit afhankelijk van de mate waarin geleverde prestaties effectief zijn in de zin dat ze leiden tot een verbetering van de welvaart van leden van een bepaalde gemeenschap. Er kan worden gesteld dat deze component verwijst naar de mate waarin plannen een effectieve oplossing bieden voor problemen. Met andere woorden, meer legitimiteit door meer effectiviteit. In literatuur wordt gebruikelijk een onderscheid gemaakt tussen legitimiteit en overheidseffectiviteit ('state effectiveness') of overheidsprestaties (zie Lipset, 1958). In de praktijk is er een verband tussen effectiviteit en legitimiteit, omdat de prestaties van de overheid een belangrijke bijdrage leveren aan haar legitimiteit (Beetham, 1991). Ook door anderen wordt gesteld dat de grondslag voor legitimiteit in belangrijke mate gelegen is in het vermogen om problemen zo niet op te lossen, dan toch te bestrijden en in de hand te houden (Scharpf, 1997; Hoppe et al., 1998). ${ }^{61}$

Effectiviteit is dus een belangrijke factor voor outputlegitimiteit. In deze studie wordt effectiviteit gerelateerd aan een concreet ruimtelijk probleem; de bestaande ruimtelijke kwaliteit sluit niet aan bij de gewenste ruimtelijke kwaliteit. Outputlegitimiteit is echter niet gelijk aan effectiviteit. Outputlegitimiteit is vooral subjectief georiënteerd en heeft betrekking op perceptie van effectiviteit op het niveau van individuen. Prestaties kunnen gerelateerd aan het concrete ruimtelijke probleem en naar bepaalde maatstaven heel behoorlijk zijn, zonder dat dit echter als zodanig door partijen wordt ervaren. De subjectieve kant verwijst naar de mate waarin partijen positief oordelen over de inhoud van de plannen. 
Vanuit het outputgeorienteerde perspectief wordt de legitimiteit dus niet zozeer ontleend aan normen voor het proces, maar vooral aan de mate waarin erin geslaagd wordt om complexe ruimtelijke opgaven zo te benaderen dat verschillende partijen zich in de voorgestelde oplossingen kunnen vinden (Reijndorp en Nio, 1997). Zeker in een netwerkomgeving waarin partijen met uiteenlopende belangen en doelstellingen moeten samenwerken om te komen tot resultaten is de steun van partijen die cruciaal zijn voor de succesvolle implementatie van plannen van onmisbaar belang (Stone en Brush, 1996). In de planvormingsfase gaat het dan onder meer om aspecten als het perspectief dat wordt gezien in de voorgenomen plannen, de bereidheid van partijen om te helpen zoeken naar oplossingen voor problemen, het vertrouwen dat zij hebben in het vervolg, de verwachtingen over het bereiken van de doelstellingen. Deze steun is waarschijnlijker indien partijen hun wensen en voorkeuren ten aanzien van een concreet project vertaald zien in de plannen (Potman, 1989). Zij zullen in dat geval eerder geneigd zijn zich te committeren aan de plannen. Legitimiteit is onwaarschijnlijk zonder commitment (Stone en Brush, 1996: p.634). Bij commitment gaat het om verbondenheid qua gedrag, het gevoel dat er sprake is van een staat van verplichting. Naast pragmatische overwegingen kunnen hierbij ook morele overwegingen een rol spelen (Suchman, 1995). Wanneer partijen dezelfde waarden en normen met elkaar delen, dan draagt dit bij aan de steun die zij verlenen aan plannen, ook al worden hun individuele belangen hierdoor wellicht geschaad. De steun die partijen verlenen, wordt mede bepaald door het structurele vertrouwen dat ze hebben in het systeem; vertrouwen dat wordt belichaamd door de afwezigheid van arbitrair, oneerlijk en corrupt gedrag (Beetham, 1991: p.141). Naast effectiviteit en steun omdat partijen hun eigen wensen en voorkeuren terug zien in plannen wordt outputlegitimiteit dus ook ondersteund, omdat de plannen aan de morele waarden van partijen voldoen. Het moet zogezegd door de beugel kunnen (Tirion, 2006: p.96). Partijen zijn zich bewust van het gegeven dat er meerdere belangen een rol spelen bij de totstandkoming van plannen en kunnen, ondanks dat de eigen wensen en voorkeuren wellicht niet of slechts beperkt daarin tot uitdrukking komen, het plan steunen indien zij dit beschouwen als een aanvaardbaar compromis tussen de diverse betrokken belangen. Op grond van voorgaande redenering dient voor outputlegitimiteit gebruik te worden gemaakt van de subjectieve beoordeling van stakeholders. De steun van deze partijen kan worden afgeleid uit (1) de mate waarin zij hun wensen en voorkeuren vertaald zien in de plannen; (2) de mate waarin zij zich gecommitteerd hebben aan de plannen; (3) de mate waarin zij de plannen beschouwen als een aanvaardbaar compromisresultaat.

\section{Throughputlegitimiteit}

Naast input- en outputlegitimiteit wordt er soms nog een derde vorm van legitimiteit onderscheiden namelijk throughputlegitimiteit (Haus et al., 2000: p.15). Hierbij gaat het vooral om de transparantie van instituties en processen. Transparantie van het proces wordt wel gezien als een vorm van openheid (Pröpper en Steenbeek, 1999; Edelenbos, 2000). ${ }^{62}$ Omdat het delen van waarden en normen in een bepaalde gemeenschap geen gegeven is, worden procedures ontwikkeld en instituties gecreëerd die niet alleen gericht zijn op het legitimeren van de inhoud, maar ook op het legitimeren van het proces dat tot die inhoud moet leiden. Legitimiteit wordt aldus verkregen door te verwijzen naar argumenten die iets zeggen over de kwaliteit van het proces, dat aan de totstandkoming van bepaalde plannen ten grondslag ligt (Bekkers, 2007: p.35). Het geven van inzicht in deze processen draagt bij aan de legitimiteit. Duidelijk dient te zijn welke partijen in het planvormingsproces 
betrokken zijn, wat de rolverdeling tussen partijen is, welke afwegingen dienen te worden gemaakt, welke argumenten zijn gebruikt in de besluitvorming daarover en welke actor(en) voor welke maatregelen verantwoordelijk zijn, zodat deze toerekenbaar zijn en de keuze in alternatieven begrijpbaar is. Toerekenbaarheid is dan ook een conditie voor de evaluatie van de prestaties van actoren. Throughputlegitimiteit kan aldus worden bereikt door transparantie. Transparantie is een essentieel aspect, omdat wordt verondersteld dat de overheid handelt namens de samenleving als geheel en geld uitgeeft dat niet is verdiend door de eigen organisatie. Transparantie betekent dus het geven van inzicht in de afwegingsprocessen die hebben plaatsgevonden, de prioriteiten die bij deze afwegingen zijn gesteld en de argumenten die daarvoor zijn gebruikt. Dit vereist dat helder is welke partij waarover en op welk moment in het planproces beslissingen neemt (Van den Hof, 2006).

Samengevat kan worden gesteld dat positieve legitimiteitsoordelen in de eerste plaats worden bevorderd door outputlegitimiteit. Dus als plannen in overeenstemming zijn met de wensen en voorkeuren van betrokken actoren. In Westerse samenlevingen nemen maatschappelijke actoren in toenemende mate een functioneel-rationele houding aan; zij laten de aanvaarding van plannen steeds meer afhangen van de mate waarin het bijdraagt aan de effectieve en efficiënte realisatie van hun eigen doeleinden (Potman en Wolters, 1992; Boedeltje, 2009). Dit zorgt ervoor dat de opvatting van wat legitiem is grillig en vrijblijvend kan worden en de stap naar een vrijblijvende en grillige opvatting van rechtvaardigheid is volgens sommige auteurs dan snel gemaakt (Adriaansen en Zijderveld, 1982: p.56). Vertegenwoordigers moeten daarom soms verder kijken dan de directe belangen van stakeholders. ${ }^{63}$ Daarnaast zijn wensen en voorkeuren van betrokkenen veelal tegengesteld. Dit is zeker van toepassing bij complexe ruimtelijke projecten. In een dergelijk geval moet worden bezien hoe dat vertaald kan worden naar een collectieve keuze. Zoals eerder - onder verwijzing naar sociale keuzetheorie (Riker, 1988) is aangegeven - is er geen geschikte besluitvormingsregel voor de aggregatie van individuele voorkeuren. Het kost daarnaast veel tijd voordat een project gerealiseerd is. Voor een legitimiteitoordeel wordt er daarom vaak gekeken naar het proces van totstandkoming. Voldoet het aan van toepassing zijnde rechtsbeginselen (legaliteit) en in welke mate is het proces open en transparant voor de verschillende stakeholders.

\begin{tabular}{|l|l|}
\hline Legitimiteitsvorm & Maatstaf/criterium \\
\hline Input-legitimiteit & Legaliteit/openheid \\
Throughput-legitimiteit & Transparantie/toerekenbaarheid \\
Output-legitimiteit & Effectiviteit/steun stakeholders \\
\hline
\end{tabular}

Tabel 2.3 Vormen van legitimiteit (zie: Haus et al., 2005)

In de praktijk liggen de verschillende vormen van legitimiteit erg dicht bij elkaar (Scharpf, 1999: p.12). ${ }^{64}$ Outputlegitimiteit kan deels worden ontleend aan de effectiviteit van plannen. Effectiviteit heeft echter slechts betekenis als het in relatie staat tot de wensen en voorkeuren van partijen. Om effectieve resultaten te produceren zijn daarom procedures en mechanismen nodig om wensen en voorkeuren te vertalen in beslissingen over de inhoud. Verantwoording, door inzicht te verschaffen over de wijze waarop dit gebeurt, draagt bij aan de aanvaarding of acceptatie ervan. 


\subsection{Hoe kan het publiek belang worden geborgd?}

Zoals in het begin van het hoofdstuk is aangegeven, wordt de overheid beschouwd als de enige partij die democratisch gelegitimeerd is om namens de samenleving als geheel een integrale afweging te maken welke publieke belangen worden behartigd. Echter overheden als representatieve instituties kunnen niet eenzijdig problemen oplossen door gebruik te maken van hun macht, omdat deze problemen slechts kunnen worden opgelost door het samenvoegen van de hulpbronnen van publieke en private partijen, zodat de noodzaak tot horizontale coördinatie ontstaat. Dit is de hoofdgedachte van het governance perspectief op sturing. ${ }^{65} \mathrm{In}$ lijn hiermee is door Smitter (2002) beargumenteerd dat deze vorm van sturing slechts een aantrekkelijk alternatief vormt als er duidelijk sprake is van markt- of overheidsfalen. Als er sprake is van marktfalen en een publiek belang dan hebben overheden de neiging om in eerste instantie hun hiërarchische macht te gebruiken, gelegitimeerd door democratische procedures en zullen slechts afwijken van deze strategie door noodzaak. Die noodzaak ontstaat slechts omdat de (gepercipieerde) mogelijkheid om problemen op te lossen een noodzakelijk onderdeel vormt als basis voor hun legitimiteit. Met andere woorden legitimiteit moet deels worden ontleend aan de mogelijkheid resultaten (output) te realiseren en niet slechts door te handelen in overeenstemming met formele en informele procedurele normen (input/throughput) (Klausen en Sweeting, 2005).

In complexe ruimtelijke projecten is voorgenoemde noodzaak zeker aanwezig. Er is sprake van fragmentatie van noodzakelijke hulpbronnen over een groot aantal partijen en geen van de partijen is in staat om de ontwikkeling alleen tot stand te doen komen, maar ieder leveren ze een stukje van de puzzel. Dit noodzaakt dus tot coördinatie tussen diverse publieke en private actoren om tot effectieve oplossingen voor ruimtelijke problemen te komen. Tegelijkertijd betekent dit dat planvorming voor een deel plaats vindt buiten de grenzen van de macht die is toebedeeld aan betrokken overheden als representatieve instituties. Binnen andere arrangementen dient een andere vorm van representatie plaats te vinden en om die reden spelen openheid en participatiemogelijkheden een belangrijke rol ${ }^{66}$. Zeker in complexe ruimtelijke projecten, die gekenmerkt worden door dynamiek en een lange doorlooptijd, waarin (1) de probleemperceptie van betrokkenen kan verschillen, (2) doelen in het beginstadium vaak nog niet volledig helder zijn (3) belangen van partijen op projectniveau uiteenlopen en mogelijk zelfs conflicteren en (4) doelen gegeven gewijzigde omstandigheden (technologisch, economisch, politiek) kunnen veranderen, lijkt er daarom een belangrijke relatie tussen de procesbenadering en het publiek belang (Dewulf en Smit, 2002).

Op grond van de beschouwingen in dit hoofdstuk kan worden gesteld dat een volledig eenduidig antwoord op de vraag wat het publiek belang is, niet mogelijk is. Vanuit economisch perspectief vormt het falen van de markt aanleiding voor een publiek belang en vanuit het politicologische perspectief zal voor de invulling van het publiek belang worden gekeken naar wat door de politiek, in het democratische proces, is benoemd als publiek belang. Postmodernisten zullen stellen dat het überhaupt niet mogelijk is handelen in het publiek belang te onderscheiden van handelen in strijd met het publiek belang. In deze studie wordt de stelling verdedigd dat het wel degelijk mogelijk is om voor bepaalde dimensies van het publiek belang aan te geven of hier in meer of mindere mate aan is voldaan. 
Het zou echter een te simplistische weergave van de werkelijkheid zijn om achtereenvolgens het publiek belang te specificeren, borgingsmechanismen te inventariseren en een goede afweging te maken. Het publiek belang is, zo komt in dit hoofdstuk naar voren, een multidimensionaal begrip. Zeker bij complexe ruimtelijke projecten is er geen sprake van een enkel of een eenduidig publiek belang, maar veelal van een complex van publieke belangen. Wat in het publiek belang is kan alleen intersubjectief worden vastgesteld. Dit heeft consequenties voor de manier waarop het publiek belang dient te worden geëvalueerd. Tenslotte zal optimaal handelen in het publiek belang nooit volledig worden bereikt. Nooit zal op alle dimensies een honderd procent score mogelijk zijn, alleen al door de onderlinge spanning tussen de dimensies (vgl. Dahl, 1994). ${ }^{67}$

In deze studie wordt voor evaluatie van de borging van het publiek belang gekeken naar de effectiviteit (in termen van de verwachte bijdrage van plannen aan ruimtelijke kwaliteit) en de legitimiteit van planvorming. In dit hoofdstuk zijn aandachtspunten benoemd en indicatoren beschreven. Een eenduidig antwoord op de vraag welke normen in acht moeten worden genomen om te garanderen dat planprocessen ook daadwerkelijk effectief en legitiem zijn, is niet gegeven. Het antwoord kan ook niet worden gegeven omdat dit afhankelijk is van de (normatieve) procesbenadering die men wenst te hanteren. In elke benadering worden namelijk andere waarden en daarmee ook andere accenten gehanteerd ten aanzien van de inhoud en het gewicht dat aan de indicatoren wordt meegegeven. Het volgende hoofdstuk besteedt uitgebreid aandacht aan verschillende benaderingen van planprocessen. Dit hoofdstuk wordt afgesloten met een overzicht van de indicatoren die in deze studie als criteria voor de evaluatie van de borging van het publiek belang zijn gehanteerd (figuur 2.1).

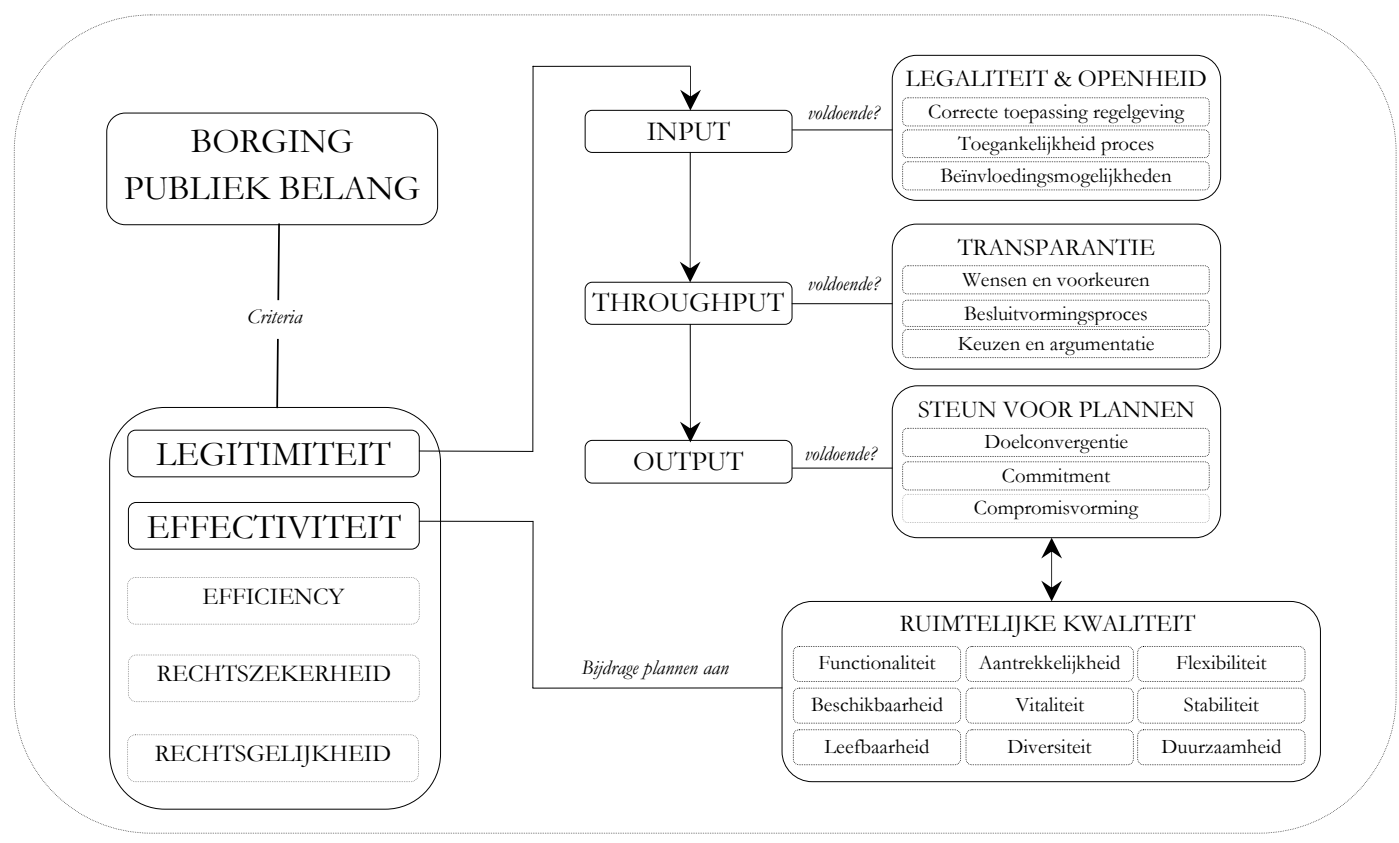

Figuur 2.1 Criteria voor borging publiek belang in ruimtelijke projecten 


\section{Hoofdstuk 3 \\ Planvorming}

\subsection{Inleiding}

In het vorige hoofdstuk zijn effectiviteit en legitimiteit van planvorming benoemd als de twee centrale criteria voor een oordeel over de borging van het publiek belang. Afgesloten is met de vraag in hoeverre wijze waarop de inrichting van planprocessen is vormgegeven hiermee samenhangt. Doel van dit hoofdstuk is om, tegen de achtergrond van de discussie over het publiek belang, te komen tot selectie van aantal cruciale elementen voor het beschrijven van planprocessen. Daarvoor wordt allereerst een aantal theoretische benaderingen van planvorming geschetst. De ontwikkelingen die zich hierin over de jaren hebben voorgedaan, hangen nauw samen met verschuivingen in de oriëntatie op beheersing en sturing en daarin vervatte visies op vraagstukken van legitimiteit en effectiviteit. Vanuit de theoretische beschouwingen over planvorming wordt toegewerkt naar een analysekader voor planprocessen.

\subsection{Planvorming}

Het 'klassieke' theoretische perspectief op planvorming wordt veelal weergegeven onder de noemer 'rational comprehensive planning' (Forester, 1989; De Graaf, 2005). ${ }^{68}$ Deze benadering is sterk gericht op het fysieke resultaat. Planvorming wordt gezien als een objectief-rationeel proces waarbij een aantal fasen doorlopen wordt. Het proces mondt uit in een rationele keuze voor de 'beste' aanpak voor een bepaald probleem. In de benadering formuleert de maker van de plannen de doelen, identificeert alle mogelijke alternatieven, evalueert welke consequenties alternatieve keuzes (voor bepaalde acties/instrumenten) hebben voor de realisatie van de doelen, kiest het alternatief dat het hoogst scoort en implementeert deze beslissing met feedbackmechanismen. Zijn de resultaten niet tevredenstellend, dan kan het proces worden herhaald. (Hudson, 1979, p.388). ${ }^{69}$ De maker van de plannen tracht dus volledig inzicht te krijgen in alle alternatieven en alle daarbij relevante factoren en actoren zodat een keuze kan worden gemaakt voor de beste wijze van handelen. Hierbij wordt veelal uitgebreid gebruik gemaakt van conceptuele of mathematische modellen, in welke doelen gekoppeld worden aan middelen en sterk vertrouwd wordt op kwantitatieve analyses (Hudson, 1979, p.388). Het bestaan van uiteenlopende waarden tracht de benadering te ontwijken door te veronderstellen dat er een kenbaar gemeenschappelijk belang is. Uitgangspunt is dat de gemeenschappelijke doelen van een gemeenschap op een effectieve wijze kunnen worden gemeten (Altschuler 1965). De rational comprehensive benadering streeft er naar objectieve beslissingen te nemen en subjectieve en emotionele discussie die mogelijk ontstaat door uiteenlopende probleempercepties uit te sluiten. Twee 
veronderstellingen spelen in de benadering een hoofdrol. In de eerste plaats gaat de benadering er vanuit dat de planner beschikt over volledige informatie. Hij kent de uitgangsituatie, alle beschikbare alternatieven en overziet in detail de gevolgen. In de tweede plaats kan de planner verschillende waarden volledig met elkaar integreren, onder een noemer brengen en daardoor onderling afwegen. De benadering gaat daarmee uit van een monocentrisch systeem en consensus over de gewenste eindsituatie. Deze wordt als bekend verondersteld en het proces is dan ook vooral gefocust op het zo efficiënt mogelijk doorlopen ervan in termen van tijd en geld. Gedurende de jaren is er kritiek geweest op de deze benadering en zijn de veronderstellingen van de benadering onder druk komen te staan.

Kritiekpunt 1: Beperkingen van de rationaliteit

De kritiek op de rational comprehensive benadering richt zich vooral op de informatieveronderstelling waarbij wordt gewezen op cognitieve beperkingen en beperkte rationaliteit van actoren (Simon, 1945: p.80-84). ${ }^{70}$ Lindblom en Dahl (1953) argumenteerden dat het niet mogelijk is om alle keuzes en mogelijke oplossingen af te wegen zoals de benadering stelt. Niet alleen omdat er sprake is van beperkte informatie en capaciteiten om die te overzien, maar tevens omdat er beperkingen zijn in termen van beschikbare hulpbronnen zoals tijd en geld. ${ }^{71}$ Ook Etzioni (1967) stelde dat de onmogelijkheid om alle consequenties te voorspellen of alle variabelen te bevatten en het gebrek aan middelen en tijd om informatie te verzamelen de toepasbaarheid van de benadering beperkt. Het rationele model heeft een sterke assumptie van maakbaarheid. In planvorming uit dat zich in lange termijn masterplannen waarin gedetailleerde blauwdrukken voor de toekomstige inrichting van hele gebieden worden neergelegd. Deze functioneren als gids voor toekomstige acties. Plannen hebben echter een lange tijdshorizon, waarin allerlei sociale en economische ontwikkelingen plaats kunnen vinden. Deze dynamiek neemt de benadering niet in haar beschouwing mee (De Graaf, 2005).

In deze discussie over rationaliteit in planvorming en de zoektocht naar oplossingen hebben Lindblom (1959) met zijn 'disjoined incrementalism' en Etzioni (1967) met de 'mixed scanning approach' een belangrijke rol gespeeld. Belangrijk element in de benadering van Lindblom is een pluralistische visie op de maatschappij die bestaat uit concurrerende belangengroepen. Volgens zijn model worden plannen niet ontworpen volgens een strikt proces, maar door een serie van consultaties gebaseerd op ervaringen van diegenen die de consequenties ondervinden. In plaats van alomvattendheid en rationaliteit gaat het model uit van twee mechanismen die helpen om het probleem van beperkte informatie te overwinnen. Disjoined "samen weten we meer" en incrementalisme "over de dingen die dan onduidelijk blijven weten we uit onze ervaring dat de consequenties van kleine veranderingen ten opzichte van de bestaande situatie beter voorspelbaar zijn".

Het belangrijkste kritiekpunt op de benadering van Lindblom is dat deze gericht is op een korte termijn oplossing voor een probleem. Door slechts alternatieven in beschouwing te nemen die maar marginaal afwijken van de status quo staat de benadering geen fundamentele veranderingen toe (Faludi, 1973: p.119). Planning is er, aldus de critici van Lindblom, juist op gericht om huidige problemen en mogelijke oplossingen te bezien in het licht van lange termijn doelen en de toekomstig gewenste eindsituatie (Etzioni, 1967). Daarnaast is de kritiek dat de benadering machtsverschillen in 
de samenleving buiten beschouwing laat. Tegenstanders argumenteren dat de maatschappij wordt gedomineerd door bepaalde groepen waardoor plannen vooral de belangen van de sterkeren en politiek georganiseerden reflecteren in plaats van die van de gemeenschap als geheel. Etzioni (1967) presenteerde als middenweg tussen de rational comprehensive benadering en de incrementele benadering de 'mixed scanning approach' ${ }^{72}$ en gaandeweg ontstonden ook andere visies op planvorming (De Graaf, 2005). ${ }^{73}$

Kritiekpunt 2: Consensus niet haalbaar

Het ontstaan van deze nieuwe visies op planvorming had naast de kritiek op de informatieveronderstelling tevens te maken met de tweede veronderstelling van de rational comprehensive benadering. De benadering gaat er namelijk vanuit dat consensus kan worden bereikt over de normen en waarden waaraan het plan dient te voldoen. Volgens critici is consensus echter lang niet altijd haalbaar en de benadering, zo wordt gesteld, zou geen oog hebben voor de sociale, politieke en economische diversiteit en belangentegenstellingen in de maatschappij. Waarden en belangen zijn pluralistisch en deze pluraliteit maakt het lastig om te bepalen wat de doelen van planvorming moeten zijn (Rittel en Webber, 1973). ${ }^{74}$

Kritiekpunt 3: Scheiding planvorming en implementatie

Het derde kritiepunt betreft de zorg over de implementatie van plannen. Het rationele model van planning impliceert een scheiding tussen de fase van planvorming en de realisatie van plannen. De resultaten bleken echter lang niet altijd overeen te komen met de ideeën die planners voor de tijd hadden. Friedman (1973) stelde dat bij het maken van plannen meer rekening moest worden gehouden met implementatievraagstukken en dus meer aandacht moest worden besteed aan de besluitvormingsarena waarin planvorming plaats vond. De planner wordt op die manier geconfronteerd met de stakeholders die sleutelpartijen zijn voor de implementatie van plannen. Voor succesvolle implementatie zou de planner effectief moeten communiceren met deze partijen (Friedman, 1973). Dit betekende een veranderende rol van de planner, van een meer technisch rationele naar een die tevens afstemming en samenwerking tussen actoren moest creëren. Tegenwoordig wordt geargumenteerd dat plannen worden gevormd in de interactie tussen verschillende stakeholders (Salet en Faludi, 2000, Driessen e.a., 2001, Healey, 2006). In toenemende mate wordt onderlinge afhankelijkheid tussen stakeholders onderkend als uitgangspunt in een continu onderhandelingsproces. In tegenstelling tot de rational-comprehensive benadering wordt door recentere benaderingen van planvorming de nadruk gelegd op de communicatie, interactie en participatie van en tussen deze stakeholders (De Kort, 2009). De focus is daarmee gericht op de netwerkomgeving waarin planvorming plaats vindt.

\subsection{Planvorming in een netwerkomgeving}

In een netwerkomgeving worden plannen niet verklaard vanuit de intenties van één of twee centrale actoren, maar wordt uitgegaan van een situatie waarin meerdere partijen noodzakelijk zijn voor succesvolle ontwikkeling en implementatie van plannen. Deze partijen kunnen in een democratische samenleving ingedeeld worden binnen drie kerndomeinen: overheid, markt en burgers. 
De overheid is in het Nederlandse constitutioneel bestel het domein waarin instellingen actief zijn die direct dan wel indirect democratisch gelegitimeerd zijn een zeker gezag uit te oefenen. De overheid als collectief van instellingen dient de belangen van de samenleving als geheel te representeren. Het is echter niet noodzakelijk dat de overheid het waarborgen van publieke belangen zelf effectueert. Zij kan daarvoor ook andere partijen inschakelen, maar blijft wel eindverantwoordelijk (WRR, 2001). De term 'markt' kent uiteenlopende betekenissen. Hier wordt met markt het domein bedoeld waarin partijen actief zijn die primair gericht zijn op commerciële belangen en worden gestuurd wordt door economische rationaliteit en marktwerking. Marktwerking stimuleert actoren tot een voortdurend streven naar innovatie en verhoging van efficiency, zonder dat zij daartoe door regels of procedures gedwongen worden. Evenals de overheid en marktpartijen heeft ook het derde kerndomein, burgers, een pluriform karakter. Er kan voor ruimtelijke ontwikkelingen bijvoorbeeld een onderscheid gemaakt worden naar (toekomstige) gebruikers, omwonenden en belangenorganisaties die maatschappelijke doelen nastreven.

Van de overheid wordt verwacht dat zij in de constellatie van actoren die betrokken is bij ruimtelijke projecten het publiek belang waarborgt. Uitgaande van een situatie waarin de inbreng van meerdere partijen noodzakelijk is voor succesvolle ontwikkeling en implementatie van plannen betekent dat enigerlei vorm van coördinatie vereist is. In governance literatuur worden drie coördinatiemechanismen onderscheiden; markt, hiërarchie en netwerk.

\subsubsection{Coordinatiemechanismen}

Markt

In een 'markt' worden relaties tussen actoren autonoom gecoördineerd. In eerste aanleg is sprake van concurrerende interactie tussen vragers en aanbieders die onderhandelen over mogelijkheden om bepaalde middelen te ruilen. In tweede aanleg worden ze het hierover eens. De markt als coördinatiemechanisme is afhankelijk van contracten en eigendomsrechten om te kunnen functioneren en het belangrijkste communicatiemiddel is de prijs. Conflictbeslechting tussen organisaties vindt veelal plaats via de rechtsgang, het commitment tussen partijen is over het algemeen laag en organisaties worden gezien als volledig onafhankelijke actoren (Powell, 1991).

\section{Hierarchie}

Zoals in het vorige hoofdstuk aangegeven faalt het marktmechanisme in sommige situaties. Coördinatie van activiteiten kan dan bewust plaats vinden door hiërarchieën. In tegenstelling tot het marktmechanisme gaat het bij hiërarchieën als coördinatiemechanisme om de werkrelaties. Conflictbeslechting vindt plaats door supervisie, oftewel instructies door diegene die de autoriteit daartoe bezitten. De overheid is op basis van rechtsregels een specifieke autoriteit toegekend en de machtspositie die dit de overheid geeft wordt tevens gelimiteerd door het recht. In de sturing van markt en burgers heeft de overheid daarom een institutioneel bepaalde voorkeur voor toepassing van juridische vormen van sturing (Driessen en Glasbergen, 2002). Dit sluit aan bij een hiërarchisch coördinatiemechanisme. Ook coördinatie door middel van hiërarchie faalt soms en betekent ook in situaties waarin het marktmechanisme faalt dus niet per definitie een beter alternatief. Hier is in het vorige hoofdstuk vanuit economisch perspectief op publieke belangen al uitgebreid bij stilgestaan. 
Belangrijke kritiek op markten en hiërarchieën is daarnaast dat persoonlijke relaties, reputatie en vertrouwen in beide structuren niet tot uitdrukking komen (Hakansson, 1989; Johansen et al.,1991; Douma et al., 1998).

Netwerk

Het 'netwerk' heeft juist een platte vorm, waarin onderling afhankelijke actoren informele relaties onderhouden met een basis van vertrouwen en meer coöperatief handelen dan competitief (Douma et al., 1998). Analoog aan de kernkenmerken van markten en hiërarchieën beschrijft Powell (1991) netwerken als coördinatiestructuren waarbij de reputatie van partijen als belangrijkste conflictbeslechtingsmechanisme geldt. Communicatie is gebaseerd op de relaties tussen partijen en het commitment tussen partijen is gemiddeld tot hoog. De netwerkstructuur betekent dat men complementaire kwaliteiten bezit die men gebruikt om wederzijdse opbrengsten te verkrijgen in een situatie waarin men onderling afhankelijk is. In de onderstaande tabel staat een vergelijking van een aantal kenmerken van de drie coördinatiestructuren.

\begin{tabular}{llll} 
& Markt & Hiërarchie & Netwerk \\
\hline Normatieve basis & Contracten / eigendomsrecht & Werkrelaties & Complementaire kwaliteiten \\
Communicatiemiddel & Prijzen & Routine & Relaties \\
Conflictbeslechtingsmechanisme & Rechtsgang & Supervisie / instructie & Reputatieoverwegingen \\
Commitment tussen actoren & Laag & Gemiddeld - hoog & Gemiddeld - hoog \\
Afhankelijkheid tussen actoren & Onafhankelijk & Afhankelijk & Onderling afhankelijk \\
\hline
\end{tabular}

Tabel 3.1 Markten, hiërarchieën, netwerken (gebaseerd op Powell, 1991)

Coordinatiemechanismen en publiek belang

De beschrijving van de coördinatiestructuren verwijst naar ideaaltypische structuren. In de praktijk zal het vaak een combinatie van verschillende coördinatiemechanismen zijn die de relaties tussen actoren bepaald (Kickert et al., 1997; March, 1998). Partijen die betrokken zijn bij de ruimtelijke projecten opereren in een setting waarin coördinatie door middel van hiërarchie, markt en netwerken naast elkaar bestaan.

In ruimtelijke planvorming was tot recent het hiërarchische coördinatiemechanisme overheersend. De vrees dat publieke belangen niet kunnen worden gewaarborgd door marktpartijen leidt vaak tot de suggestie dat deze belangen moeten worden beschermd door ze helder te definiëren en neer te leggen in eenduidige en afdwingbare voorwaarden (De Bruin en Dicke, 2006). Diverse redenen worden genoemd waarom deze werkwijze niet adequaat is om in ruimtelijke projecten publieke belangen te borgen. Het zou onder andere leiden tot ongewenste prioritering van belangen, weinig beleidsruimte op uitvoeringsniveau, juridificering van relaties en uitnodigen tot strategisch gedrag (Charles et al., 2007). Algemene sociale, maatschappelijke en (sociaal-)economische ontwikkelingen en sterke kritiek in termen van legitimiteit en effectiviteit hebben er voor gezorgd dat de hierarchische wijze van coördinatie meer en meer ter discussie is komen te staan en een verschuiving is opgetreden van sturing via het hiërarchische mechanisme naar sturen in het netwerk van de bij de ruimtelijke ontwikkeling betrokken partijen (VROM-raad, 2009). 


\subsubsection{Coördinatie in een netwerk}

Een netwerk wordt gedefinieerd als een min of meer stabiel patroon van sociale relaties tussen onderling afhankelijke actoren, dat vorm krijgt rond een bepaald beleidsprobleem of -programma (Klijn, 1997, p.30). Uitgangspunt is dat in een netwerkomgeving plannen niet worden ontwikkeld en geïmplementeerd door één centrale actor maar dat de inbreng van meerdere actoren noodzakelijk is (Bressers et al., 1994). Een netwerk heeft een aantal kenmerken waarvan er twee in het navolgende worden besproken.

Posities en afhankelijkheden

Netwerken ontstaan en blijven bestaan omdat deze actoren van elkaar afhankelijk zijn voor het realiseren van hun doeleinden. ${ }^{75}$ Dit brengt voor actoren een bepaalde mate van onzekerheid met zich mee. Deze onzekerheid is het gevolg van een gebrek aan informatie over toekomstige gebeurtenissen, zodat alternatieven en de resultaten daarvan onvoorspelbaar worden. Deze gebeurtenissen kunnen in dit verband worden gezien als het gevolg van acties van andere actoren die zich in de directe omgeving bevinden (Chisholm, 1989: p.42). Het handelen van actoren in een netwerk kan dus niet in isolement worden beschouwd.

Niet alle actoren in een netwerk zijn echter even afhankelijk van elkaar. ${ }^{76}$ Posities van actoren verschillen. De afhankelijkheden worden bepaald door de verdeling van hulpbronnen, de doelen die actoren nastreven en hun perceptie van de eigen afhankelijkheid van hulpbronnen (Kickert et al., 1999). Hoewel er niet een enkel en eenduidig machtscentrum aan te wijzen is, zijn er wel degelijk machtsverschillen. ${ }^{77}$ Sommige actoren, zoals overheden, hebben de beschikking over specifieke hulpbronnen die hen in staat stellen het gedrag van andere actoren en netwerken in zekere mate te sturen. Of in de woorden van Le Gales (2002):

\footnotetext{
"Even though public policy networks may have the importance that writers ascribe to them - a matter that merits close examination from an empirical standpoint - it remains the case that steering or linking together of networks cannot be reduced to simple resolution of coördination problems. Some actors - governments for example - have particular resources although perhaps not a monopoly of them - for directing the behavior of actors and networks, for arbitrating between different networks, and for legitimizing their choices. Governance has not replaced government.” (Le Gales, 2002: p.17)
}

\section{Perceptieverschillen}

Naast machtsposities verschillen veelal ook de probleempercepties van actoren en is de noodzakelijke informatie om een weloverwogen afweging te maken verspreid over actoren (Forester, 1989). Actoren verschillen in hun probleemperceptie en belangen, en in hun mogelijkheden deze helder te beschrijven en in het proces opgenomen te krijgen (Scharpf, 1997). De onderlinge afhankelijk tussen actoren zorgt er echter voor dat er niet één actor volledig eenzijdig een doelstelling op kan leggen en het resultaat is een proces waarin onderhandeld dient te worden en compromissen dienen te worden gesloten. Om diezelfde reden kan coördinatie in een netwerkomgeving niet slechts gericht zijn op effectiviteit en efficiency, maar speelt legitimiteit eveneens een belangrijke rol.

In concrete ruimtelijke projecten waarin meerdere functies in samenhang worden ontwikkeld zijn veelal diverse actoren betrokken. Elke actor heeft zijn eigen beeld van het ruimtelijk probleem en zijn eigen doelen en belangen bij de aanpak ervan. De perceptie van de wederzijdse afhankelijkheid om tot realisatie van hun doelstellingen te komen is wat actoren motiveert om te interacteren en hun acties te coördineren. 


\subsection{Bestudering van planvorming in een netwerkomgeving}

Binnenstedelijke gebiedsontwikkelingen worden bij uitstek gekenmerkt door het veelvoud aan actoren en de onderlinge afhankelijkheid tussen hen. De vraag hoe in een dergelijke netwerkomgeving het planproces en de coördinatie tussen betrokken actoren moet worden vormgegeven om het publiek belang, in termen van effectieve en legitieme (vorming van) plannen, te waarborgen staat centraal in deze studie. Voor het bestuderen van deze relatie kunnen globaal twee invalshoeken worden onderscheiden; de institutionele benadering en de (relationele) procesbenadering (Van den Hof, 2006).

In de politieke wetenschappen krijgt de institutionele benadering veel aandacht (March en Olson, 1989; De Jong, 1999). ${ }^{78}$ Vanuit deze invalshoek wordt voorgestaan het verloop van processen en het handelen van actoren daarin vanuit een institutioneel perspectief te bekijken (De Jong en Salet, 2001; Klijn en Teisman, 2002). De institutionele benadering onderscheidt zich van de relationele procesbenadering door de systemen en mechanismen die de interactie tussen actoren sturen centraal te stellen, niet de interactie zelf. Zonder de betekenis van individuele wil of relationele aspecten te ontkennen, wordt de verklaring voor het handelen van actoren grotendeels gezocht in institutionele factoren. ${ }^{79}$ In de procesbenadering wordt er vanuit gegaan dat de relaties en interacties tussen actoren van doorslaggevend belang zijn voor het verloop van processen. Deze benadering heeft minder aandacht voor de betekenis van structurele factoren op het handelen en het verloop van processen (Bult-Spiering, 2003; Kouwenhoven, 1991).

In deze studie hebben institutionele factoren niet de status van variabelen die gestructureerd en geoperationaliseerd kunnen worden om als verklarende factoren te dienen voor de effectiviteit en legitimiteit van het planproces. Uitgangspunt is dat de institutionele context weliswaar de handelingsruimte van actoren beperkt, maar binnen deze handelingsruimte voor actoren de mogelijkheid bestaat subjectieve keuzen te maken (Ostrom et al.,, 1994; Scharpf, 1997). ${ }^{80}$ De invloed die institutionele factoren hebben, zal per actor verschillen naar gelang het inzicht, de kennis en de informatie waarover de actor beschikt (Scharpf, 1997). ${ }^{81}$ Voorkeuren van actoren, beschikbare informatie en strategische overwegingen spelen eveneens een belangrijke rol in de wijze waarop actoren hun handelen feitelijk vorm geven. In dit onderzoek ligt de nadruk niet zozeer op de institutionele setting maar op de wijze waarop verschillende actoren hun feitelijke handelen in planprocessen vorm geven. Het onderkennen van contextafhankelijkheid voor het handelen is echter voor de praktische bruikbaarheid van onderzoeksresultaten van belang (Mayntz \& Scharpf, 1995; Scharpf, 1997). ${ }^{82}$ Voordat aandacht wordt besteed aan de wijze waarop in deze studie de feitelijke inrichting van planprocessen is geanalyseerd, wordt om die reden eerst ingegaan op de contextfactoren en actoren.

\subsubsection{Contextfactoren}

Context heeft betrekking op de kenmerken van de setting waarin gebeurtenissen plaats vinden. Het gaat om factoren die van invloed zijn op het proces of het resultaat daarvan, maar waarover geen directe controle bestaat. Deze factoren kunnen politieke, economische, sociale, technologische en fysieke omgevingskenmerken en trends betreffen (Bryson, 2004). Ostrom et al. (1994: p.37) 
onderscheiden drie clusters van exogene factoren die van invloed zijn op de interacties tussen actoren: de kenmerken van de gemeenschap, de kenmerken van de fysieke omgeving en de gebruikte regels.

Bij kenmerken van de gemeenschap gaat het vooral om de dominerende waarden en normen. Verschillende waardesystemen kunnen van invloed zijn op de wijze waarop mensen in een bepaalde gemeenschap interacteren. Waar het bijvoorbeeld in sommige landen de normaalste zaak van de wereld is om over de prijs van bepaalde producten te onderhandelen is dat in andere landen wellicht hoogst ongebruikelijk. Meer specifiek kan voor ruimtelijke projecten bijvoorbeeld gedacht worden aan de heersende (publiek-private) samenwerkingscultuur in een bepaalde gemeente.

Bij kenmerken van de fysieke omgeving kan gedacht worden aan zaken als geografische ligging, ecologische structuur, mate van bebouwing, etc. In deze studie gaat het dan om de kenmerken van stationslocaties. Stationslocaties hebben een aantal algemene kenmerken die voor ieder project gelijk zijn. Zo is er in alle gevallen sprake van een knooppunt van transportmodaliteiten. Per project zullen tevens een aantal projectspecifieke kenmerken te onderscheiden zijn. Bevindt de locatie zich bijvoorbeeld in het centrum van een grote stad of is er sprake van een klein suburbaan station.

De van toepassing zijnde regels vormen veelal een centraal onderdeel in analyses van de institutionele context. De term 'regels' wordt daarin nogal eens gebruikt om te verwijzen naar diverse concepten met uiteenlopende betekenissen. Scharpf (1997: p.39) definieert regels als 'socially constructed agreements and prescriptions; they refer to common knowledge among actors in specific networks on how to behave'. Het gaat dus om het gedeeld begrip bij actoren over de voorschriften die bepalen welke acties (of uitkomsten daarvan) zijn vereist, verboden of toegestaan, alsmede om de sancties die kunnen worden uitgevoerd als die regels niet worden opgevolgd (Ostrom et al., 1994: p.38). De gebruikte regels bepalen onder andere wat de posities en de handelingsmogelijkheden van actoren zijn, maar ook wat de condities voor toegang van actoren tot het proces zijn, hoe individuele voorkeuren worden vertaald in collectieve beslissingen, wat de inhoudelijke grenzen van oplossingsrichtingen zijn, welke informatie voor welke actoren beschikbaar is en hoe kosten en baten worden verdeeld over de verschillende betrokken actoren (Ostrom et al., 1994). ${ }^{83}$ Een analyse van de van toepassing zijnde regels kan betrekking hebben op zeer verschillende niveaus. Zo zijn eigendomsrechten die actoren een bepaalde positie geven in een project gebaseerd op algemeen geldende wettelijke regelgeving die is neergelegd in de Grondwet, geeft de Wet Ruimtelijke Ordening een algemeen spelregelkader voor de totstandkoming van plannen in de ruimtelijke sector en kent de Spoorweg- en Concessiewet onder andere bepaalde taken, bevoegdheden en verantwoordelijkheden toe aan spoorgerelateerde partijen.

De gebruikte formele en informele regels beperken en structureren de mogelijke handelingen van actoren. Als zodanig beïnvloeden ze het gedrag van actoren en hoe men via interactie tot resultaten komt. Op een abstracter niveau geldt dit tevens voor de kenmerken van de gemeenschap en de kenmerken van de fysieke wereld. Planvorming vindt namelijk plaats in interactie met de fysieke en culturele wereld er om heen, waarvan het input krijgt, en welke zal worden veranderd en getransformeerd door de acties van actoren. Uitgangspunt is dat situationele en institutionele context het kader vormt. Zowel het Institutional Analysis and Development raamwerk van Ostrom et al. (1994) als het Actor Centered Institutionalism (Mayntz en Scharpf, 1995; Scharpf, 1997) zijn binnen het kader, gegeven door de fysieke en culturele omgeving en de gehanteerde regels, gericht op de 
acties van actoren (Hermans, 2005: p.13). Centraal in het raamwerk staat de zogenaamde 'actie-arena' die bestaat uit een actie-situatie en actoren.

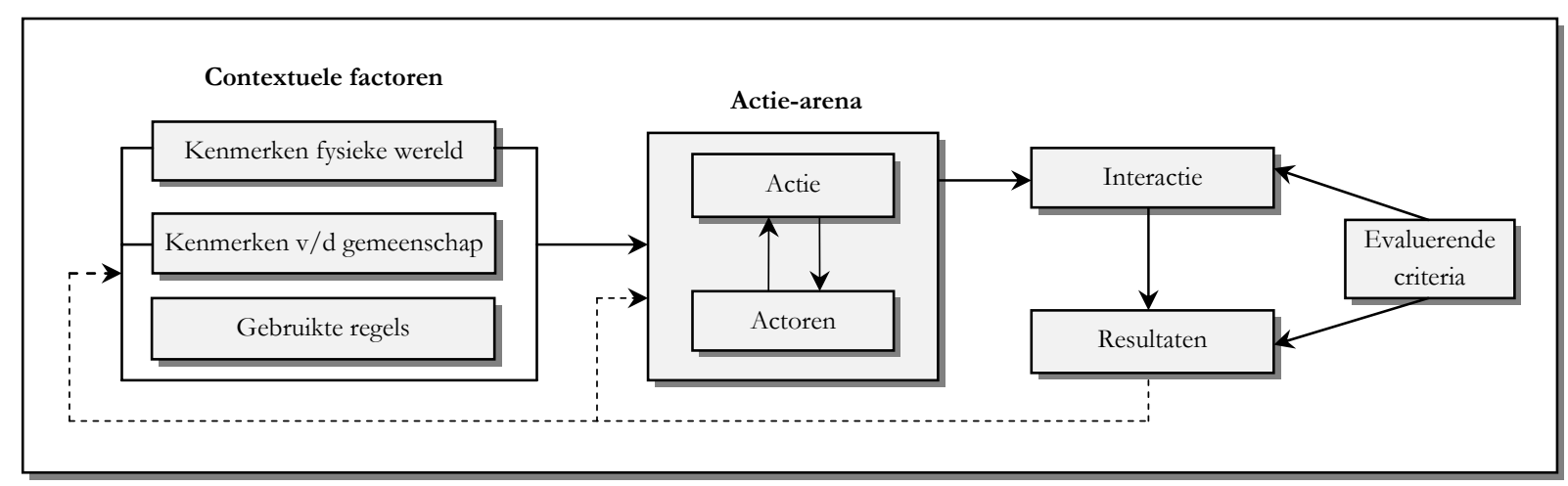

Figuur 3.1 Institutional Analysis and Development Framework (Ostrom e.a., 1994)

Arena's zijn de plaatsen waar actoren op basis van hun visie op wat problemen en oplossingen zijn, keuzes maken. Het kan worden gezien als het geactiveerde deel binnen een netwerk, geformeerd rondom een bepaald probleem of een doel (Klijn, 1999: p.7). De gebruikte regels geven de structuur van het netwerk en bieden een kader waarbinnen acties en interactie plaats kunnen vinden, kunnen worden geïnterpreteerd en zinvol kunnen zijn (Klijn, 1996: p.63). Deze regels bieden ook aanknopingspunten voor het beïnvloeden van het klimaat waarin dat gebeurt. Zo wordt in literatuur over het managen van netwerken veel aandacht besteed aan het scheppen van condities om succesvolle samenwerking mogelijk te maken. Theorie over netwerken is dan ook veel gebruikt om te beschrijven en te verklaren hoe processen zijn verlopen en heeft geïnspireerd tot het ontwikkelen van regels en richtlijnen voor het managen van processen (Kickert et al., 1997; De Bruijn et al., 2002). ${ }^{84}$ Veel van het verklarende werk wordt echter gedaan in termen van de kenmerken van actoren in plaats van de kenmerken van de institutionele setting c.q. netwerk (Dowding, 1995; Scharpf; 1997). ${ }^{85}$ In deze studie wordt de institutionele setting niet als variabele beschouwd, maar worden de algemene en projectspecifieke context van stationslocaties beschreven om het kader waarbinnen actoren handelen en planprocessen verlopen te beschrijven.

\subsubsection{Actoren}

Het model van Ostrom et al. (1994) is toegepast in de analyse van diverse grote ruimtelijke projecten (Denters en Klok, 2003; Klijn, 2001; e.a.). Het model is bedoeld om te begrijpen op welke wijze de gebruikte regels, samen met de kenmerken van de gemeenschap en fysieke omgeving, leiden tot een bepaalde situatie waarin acties van actoren plaats vinden. Deze actie-situatie wordt gekenmerkt door; participanten; met bepaalde posities; die moeten kiezen uit verschillende handelingen met behulp van; informatie die zij bezitten over hoe handelingen; gerelateerd zijn aan; mogelijke uitkomsten en; de kosten en baten die worden toegeschreven aan deze acties en uitkomsten (Ostrom et al., 1994: p.2933).

Participanten zijn actoren die onderdeel zijn geworden van een bepaalde actie-situatie. Dit kunnen personen, groepen en organisaties betreffen die in staat zijn tot het nemen van beslissingen en 
gecoördineert handelen (Burns et al., 1985). Teisman (1992) definieert actoren als: 'eenheden die zich door een zekere eenheid van handelen opstellen als beïnvloedende partij'. Het zijn met andere woorden handelingseenheden (Klijn en Teisman, 1992: p.8). Ostrom e.a. (1994) karakteriseren actoren als participanten die beschikken over voorkeuren; capaciteiten om informatie te verwerven, verwerken en toe te passen; selectiecriteria en; hulpbronnen (Ostrom et al., 1994: p.33-35). Het gaat daarmee vooral om de mogelijkheden waarover actoren beschikken en hun oriëntatie (percepties en preferenties) ten aanzien van mogelijk te ondernemen acties (Scharpf, 1997: p.43).

De mogelijkheden van actoren zijn gebaseerd op het bezit van hulpbronnen. Hulpbronnen zijn kritisch voor elke verklaring van uitkomsten van een proces, omdat bij afwezigheid van hulpbronnen die noodzakelijk zijn om actie te ondernemen de percepties en preferenties van een actor in de praktijk geen verschil zullen maken (Scharpf, 1997: p.51). Hulpbronnen verwijzen naar de middelen of instrumenten waarover actoren beschikken om hun doelstellingen te realiseren. Fenger (2001) definieert ze als: zaken van materiële of immateriële aard die een actor kan benutten om te functioneren. Hulpbronnen stellen actoren in staat hun omgeving te beïnvloeden. Daarmee zijn hulpbronnen dus sterk gerelateerd aan macht. Vanuit theoretisch oogpunt bezien zijn de mogelijkheden van actoren sterk afhankelijk van de context. Welk middel of instrument effectief zal zijn onder welke condities zal namelijk afhangen van de kenmerken van de specifieke situatie (Scharpf, 1997: p.51).

Naast mogelijkheden kunnen actoren tevens worden gekarakteriseerd aan de hand van hun oriëntatie ten opzichte van mogelijke acties. Bij benaderingen waarin actoren centraal staan moeten verklaringen voor het handelen van actoren gezocht worden in hun intenties welke onvermijdelijk gebaseerd zijn op subjectiviteit. Acties van actoren worden dan niet gemotiveerd vanuit hun objectieve belangen, maar vanuit het mentale beeld van actoren over oorzaak en verwachte gevolgen en hun subjectieve voorkeuren op dat gebied (Scharpf, 1997). Alle actoren hebben hun eigen beelden en opvattingen op basis waarvan ze de werkelijkheid interpreteren, hun strategieën kiezen en uitkomsten evalueren. ${ }^{86}$

Deze percepties van actoren zijn gebaseerd op bepaald raamwerken die functioneren als filters waardoor informatie over een bepaalde situatie wordt geïnterpreteerd. Deze raamwerken bevatten ideeen van actoren over feiten, belangen, normen en waarden met betrekking tot hun omgeving en de problemen en mogelijkheden die zich daarin voordoen (Koppenjan en Klijn, 2004; Sabatier, 1998; e.a.). ${ }^{87}$

Complexe ruimtelijke opgaven vinden plaats in een netwerk van wederzijds afhankelijke actoren. Het oplossen van deze opgaven is dan ook niet slechts een intellectuele ontwerpactiviteit met als doel een technische oplossing te bieden en om te gaan met onzekerheden, maar tevens een strategisch spel in een multi-actor setting, waarbij meerdere belangen, doelen en interpretaties samenkomen. Percepties van actoren hebben in deze setting vooral betrekking op de afhankelijkheid van andere actoren, de ambities en strategieën van andere actoren, en het beleidsveld en de problemen die in dat veld spelen (Klijn et al., 1992). Indien meerdere wederzijds afhankelijke actoren bepaalde zaken op verschillende wijze percipiëren is ambivalentie het gevolg (Hommes, 2008). Naast verschil in kaders op basis waarvan actoren de werkelijkheid interpreteren kan ambivalentie tevens ontstaan als gevolg van een overvloed aan informatie, verwarring en conflicterende kennis of informatie (Dewulf et al, 2005; Koppenjan en Klijn, 2004). 
Naast de perceptie van een actor wordt zijn orientatie ten aanzien van mogelijke acties tevens gevormd door zijn preferenties. Preferenties van actoren worden beïnvloed door belangen, normen, identiteiten en interactieoriëntaties (Mayntz en Scharpf, 1995: p.52-58; Scharpf, 1997: p.63-66). Actoren zullen trachten hun doelen te bereiken door op basis van hun belangen, hun normatieve voorkeuren en de mate waarin zij de uitkomsten passend vinden bij hun identiteit te kiezen voor de optie die het meest tegemoet komt aan hun doelen (Hermans, 2005). Normen, waarden, belangen en identiteit spelen meer op een abstracter niveau. Voorkeuren en posities zijn vaak een meer concrete vertaling, waarbij voorkeuren betrekking hebben op een rangschikking van de gewenste resultaten en positie betrekking heeft op het meest gewenste resultaat. De klassieke rationele keuzebenadering veronderstelt dat actoren daarbij altijd uitgaan van hun directe eigen belang. Tevens is echter van belang of, en zo ja, in welke richting (positief of negatief) een actor de belangen van andere actoren betrekt in zijn overwegingen. Zo kan een actor ook solidair zijn met andere actoren of zelfs een altruïstische interactieoriëntatie hebben (Scharpf, 1997: p.84-89). Het laatste zal in de praktijk van gebiedsontwikkeling niet snel het geval zijn. ${ }^{88}$

De percepties en preferenties van actoren vormen samen dus de oriëntatie die actoren hebben ten aanzien van mogelijke acties. Deze oriëntatie kan echter niet in isolement worden bepaald. Dit leidt ertoe dat actoren een 'spel' gaan spelen, waarbij keuzes strategische keuzes worden waarbij niet alleen rekening gehouden wordt met eigen voorkeuren en mogelijkheden, maar ook met die van andere actoren. De interacties tussen actoren kunnen worden gezien als een spel van strategisch gedrag en uitwisseling van hulpbronnen. De strategieën waaruit gekozen kan worden zijn veelal interdependent. De uitkomst van een bepaalde strategie zal mede afhangen van de keuzes van andere actoren en vice versa (Scharpf, 1997).

Dat een strategie in een bepaalde constellatie van actoren met bepaalde percepties, preferenties en mogelijkheden en bepaalde regels en fysieke en culturele omstandigheden kan werken, zegt nog niet direct iets over de werking in een andere context. Deze constellatie vormt het kader waarbinnen actoren hun interacties feitelijk vorm geven. In die zin zijn de regels, fysieke en culturele omstandigheden sturende factoren die het handelen van actoren en het verloop van het planproces in zekere mate voorspelbaar maken. Contextfactoren werken door in het proces van interactie tussen actoren en zijn daarmee mede bepalend voor het resultaat. Andersom geldt ook dat de interactie tussen actoren en het verloop van het proces van invloed is op de context. Hoewel de laatste moeilijk te veranderen is kan het zijn dat op termijn actoren bereid zijn nieuwe instituties zoals andere wetten of regels te ontwikkelen (zie: figuur 3.1).

\subsubsection{Planproces}

Contextfactoren spelen dus een belangrijke rol voor het handelen van actoren in planprocessen. Keuzen van actoren zijn echter subjectief. Zoals aangegeven verschilt de invloed van institutionele factoren per actor naar gelang inzicht, kennis, informatie en mogelijkheden waarover actoren beschikken en spelen hun percepties en preferenties eveneens een belangrijke rol. Het is de perceptie van afhankelijkheid van de hulpbronnen van andere actoren om tot realisatie van hun eigen doelstellingen te komen wat actoren in een netwerk motiveert om te interacteren (Kickert et al.,, 1999). Deze interactie zit in de dagelijkse handelingen van actoren. Het vindt in de praktijk plaats doordat partijen informatie delen en feedback geven, elkaar consulteren en door verschillende 
vormen van onderhandeling (Glasbergen en Driessen, 2005). Hierdoor worden kwesties naar voren gebracht, verwerkt en gevormd tot strategieën en mogelijke acties van waaruit vervolgens een gezamenlijk plan wordt ontwikkeld (Glasbergen en Driessen, 2005).

Vertaald naar het model (figuur 3.1) van Ostrom et al., (1994) betekent dit dat acties van actoren leiden tot interacties tussen actoren die vervolgens bepaalde uitkomsten hebben. Deze uitkomsten zijn in planvorming te zien als planproducten die het resultaat zijn van een proces waarin diverse actoren in verschillende vorm en in meer of mindere mate een inbreng hebben gehad. Analyse van literatuur over planvorming in ruimtelijke projecten laat zien dat de focus daarin tegenwoordig vooral ligt op benaderingen die uitgaan van een stakeholdersperspectief en zich daarmee richten op de inbreng van verschillende stakeholders in het proces (Salet en Fauldi, 2000; Driessen et al, 2001; Albrechts, 2004, De Kort, 2009; e.a.). Diverse (normatief) theoretische benaderingen van planvorming leggen verschillende nadrukken ten aanzien van de wijze waarop deze inbreng er op een aantal thema's uit dient te zien (De Graaf, 2005; De Kort, 2009). ${ }^{99}$ Drie kernthema's waarop benaderingen verschillen, zijn: (1) visievorming; (2) zeggenschap; en (3) middelen.

\section{Thema 1: Visievorming}

Met het eerste thema, visievorming, wordt gedoeld op het proces waarin een (gemeenschappelijk) beeld wordt gevormd van het probleem, een gewenste en haalbaar geachte toekomstige situatie en het veranderingstraject dat nodig is om daar te komen. ${ }^{90}$

Om in ruimtelijke ontwikkeling in een netwerkomgeving überhaupt iets gerealiseerd te krijgen zullen partijen op enigerlei wijze in gezamenlijkheid tot een beeld moeten komen hoe dat 'iets' er uit ziet. In dat proces vindt continue iteratie van een drietal aktiviteiten plaats; analyse (onderzoeken van informatie en selecteren doelen); synthese (ontwikkelen van oplossingsrichtingen) en evaluatie (afwegen van oplossingen tegenover doelen).

Ondanks het iteratieve karakter van dit proces zijn er wel verschillende fasen, stadia of deelprocessen te onderkennen met elk haar eigen plannen. ${ }^{91}$ Deze plannen worden gedurende het proces gedetailleerder, waarbij steeds meer over de te realiseren oplossing wordt vastgelegd. Het proces van visievorming moet echter niet worden gezien als een volledig lineaire en sequentiële opeenvolging van plannen van een hoger abstractieniveau naar een lager abstractieniveau. Tegenwoordig worden plannen veelvuldig parallel aan elkaar ontwikkeld en worden globale plannen soms pas worden vastgesteld nadat meer gedetailleerde plannen bekend zijn.

Vanuit het perspectief van stakeholders vormen plannen - als concrete tussenresultaten - een referentiepunt waarin bij de ruimtelijke ontwikkeling betrokken stakeholders, hun belangen en voorkeuren in terug kunnen zien. Tegelijkertijd kan een bepaald plan worden gezien als een momentopname in de onderhandelingen tussen onderling afhankelijke stakeholders (Peek, 2006). Enerzijds worden in de plannen die het resultaat zijn van visievorming dus beslissingen over de oplossing van het ruimtelijk probleem vastgelegd. Anderzijds moeten de plannen, zeker in een netwerkomgeving, een perspectiefvol beeld schetsen voor de mogelijkheden in het gebied, zodat partijen zich ook in het verdere verloop van het proces willen committeren aan de ontwikkeling ervan. 
Bij stationslocaties heeft herontwikkeling betrekking op de ruimtelijk-functionele inrichting van het station en de directe omgeving daarvan. Omdat posities en betrokken actoren nogal verschillen voor beide onderdelen is het - hoewel de scheidslijnen in de praktijk soms een grijs gebied zijn - van belang in de analyse van het proces van visievorming onderscheid te maken naar twee fasen of onderdelen.

Het eerste deel heeft betrekking op het plangebied als geheel, inclusief het station. De visie daarvoor wordt meestal beschreven in de vorm een masterplan. In het masterplan worden de programmatische uitgangspunten en de kwaliteitsambities voor de herontwikkeling van het gehele gebied vastgelegd. De richtinggevende keuzes die daarin worden gemaakt vormen de basis voor Programma's van Eisen, stedenbouwkundige deelplannen en sectorale ontwikkelingsplannen.

Een tweede deelproces heeft betrekking op de herontwikkeling van deelgebieden. Hier wordt gefocused op het planproces voor een van deze deelgebieden, de OV-terminal. Dit vormt bij stationslocaties veelal het centrale onderdeel in het masterplan en is aanjager voor herontwikkelingen in het omliggende gebied. Juist binnen de OV-terminal is sprake van een situatie waarin meerdere publieke en private actoren een positie en belang hebben, waardoor samenwerking bij de ontwikkeling en realisatie van plannen sterk noodzakelijk is. Daarom is het tegen de achtergrond van de discussie over de borging van het publiek belang ook interessant om naast het masterplan ook te kijken naar de inbreng van actoren in het proces van visievorming voor de OV-terminal.

Thema 2: Inbreng van middelen

Een tweede thema betreft de inbreng van middelen door actoren. Het initiëren, uitwerken en daadwerkelijk realiseren van een visie vraagt namelijk om de inzet van middelen. Visies onstaan niet vanzelf. De opdracht om plannen te ontwikkelen is gebaseerd op beslissingen die daartoe worden genomen. Partijen die belangen hebben in een gebied maken afspraken over de eisen en wensen waaraan plannen dient te voldoen en onder welke voorwaarden zij bereid zijn de hun ter beschikking staande middelen voor de realisatie ervan in te zetten. Middelen zijn cruciaal om actie te kunnen ondernemen. De percepties en preferenties van actoren die niet over waardevolle middelen beschikken zullen in de praktijk weinig verschil maken voor de uitkomsten van het proces (Scharpf, 1997: p.51).

Bij middelen gaat het om datgene dat een actor gebruikt of kan gebruiken om het bereiken van zijn doeleinden te bevorderen (Hoogerwerf, 1989). Soms wordt hiervoor ook wel de termen 'instrument' of 'hulpbron' gebruikt (Teisman, 1992). De allocatie van middelen over verschillende actoren zorgt voor afhankelijkheidsrelaties en de noodzaak tot samenwerking om tot realisatie te komen. In literatuur (Aldrich, 1979; Teisman, 1992; Koppenjan en Klijn, 2004; e.a.) worden verschillende typen middelen onderscheiden. Voor de afhankelijkheden tussen actoren spelen vooral vier cruciale middelen een rol; autoriteit, financiën, grond-/vastgoedeigendom en specifieke kennis en capaciteiten (Teisman, 1998; De Bruijn en Ten Heuvelhof, 1999). De mate van afhankelijkheid van het middel hangt af van het belang ervan en de vervangbaarheid (Scharpf, 1997). Partijen zullen bereid zijn middelen toe te kennen wanneer dit hun belangen dient. Deze bijdrage kan samenhangen met het te realiseren eindresultaat zelf, met de wijze waarop het tot stand komt of met het feit dat zodoende geen andere plannen worden gerealiseerd (Peek, 2006). Middelen verschaffen actoren daarmee een basis voor zeggenschap in het proces. 
Thema 3: Zeggenschapsverdeling

Een derde thema is de wijze van zeggenschapsverdeling in het proces. Het gaat dan om de mate waarin actoren de mogelijkheid hebben over iets (mee) te beslissen. ${ }^{92}$ Zeggenschap heeft net als visievorming betrekking op verschillende fasen van het herontwikkelingsproces. In iedere fase dienen beslissingen te worden genomen die al dan niet worden vastgelegd in overeenkomsten, plannen, vergunningen, e.d. In de initiatieffase hebben deze beslissingen vooral betrekking op wat in hoofdlijnen gerealiseerd moet worden en welke rol verschillende partijen in het proces vervullen. Producten kunnen dan onder andere een nota van uitgangspunten, een globaal stedenbouwkundig plan met grondexploitatie en risicoanalyse, afspraken over grondverwerving en afspraken over de verdere organisatie van het proces zijn. Veelal worden de afspraken hierover tussen partijen vastgelegd in de vorm van een intentie- of procesovereenkomst. In de volgende fase, waarin de haalbaarheid en voorbereiding voor de realisatie centraal staat, worden de resultaten gebruikt, plannen verder uitgewerkt en afspraken vastgelegd in een samenwerkings- en realisatieovereenkomst. Door de beslissingen die gedurende het proces worden genomen worden de randvoorwaarden voor de visievorming gegeven. Daarmee krijgen verschillende belangen al dan niet een plek in de plannen. Het meenemen van bepaalde belangen, betekent dat kansen voor het bundelen van voldoende middelen om oplossingen voor ruimtelijke problemen te realiseren toeneemt, maar tevens dat aanvullende eisen worden gesteld aan het plan (Peek, 2006). Nieuwe oplossingen moeten worden bedacht en omdat niet alle belangen daarin een (even grote) plek kunnen krijgen, vereist dit dat hierin keuzen worden gemaakt. De zeggenschap die diverse partijen in deze keuzen hebben, zal verschillen. Daarmee is het proces van visievorming, de inbreng van middelen door actoren en de beslissingen die hierover worden genomen met elkaar verbonden. Hoewel de thema's verbonden zijn is het onderzoeksmatig van belang ze te onderscheiden. Het kan voor het oordeel over de legitimiteit van het planproces bijvoorbeeld van belang zijn als een actor op basis van politiek-bestuurlijke bevoegdheden of een sterke grond- of vastgoedpositie veel zeggenschap heeft gehad, maar in het proces van visievorming geen of slechts een beperkte rol heeft gespeeld.

\section{$\underline{\text { Kenmerken van de actorconstellatie }}$}

Het is tegen de achtergrond van de discussie over de borging van het publiek belang, waarin rollen en verhoudingen tussen actoren centraal staan, interessant om te kijken naar de gevolgen van de kenmerken van de actorconstellatie op de drie beschreven thema's voor de effectiviteit en legitimiteit van het proces. In de discussie daarover worden een aantal stellingen betrokken.

Een eerste punt waarop de discussie zich richt en aan de hand waarvan het samenstel van actoren in een planproces getypeerd kan worden is het aantal actoren dat betrokken is. Diverse argumenten worden aangedragen ter onderbouwing van de stelling dat meer samenwerking, participatie en overleg noodzakelijk is om te komen tot effectieve en legitieme oplossingen voor ruimtelijke problemen. Daarbij wordt verwezen naar de toenemende complexiteit van ruimtelijke vraagstukken en afhankelijkheden tussen actoren. Verondersteld wordt dat de effectiviteit van een probleemoplossing in hoge mate afhankelijk is van de betrokkenheid van alle relevante partijen bij het proces van probleemdefiniëring en bij de keuze van een oplossing. Op deze manier wordt gegarandeerd dat de relevante feiten, omstandigheden en belangen in ogenschouw worden genomen, hetgeen de kwaliteit en legitimiteit van het proces ten goede komt (vgl. De Bruijn e.a. 2002). Een meer hiërarchische 
benadering leidt vaak tot de dominantie van een bepaald belang of redeneerwijze, en tot de uitsluiting van andere, zo wordt wel gesteld (Van Gestel e.a., 2008). Dit zou kunnen leidden tot slechte resultaten (Koppenjan en Klijn, 2004). Simplistisch gesteld wordt verondersteld dat een grotere inbreng van alle relevante partijen in het planproces de effectiviteit en legitimiteit ten goede komt. Als keerzijde wordt gesteld dat intensieve betrokkenheid van een groot aantal partijen kan leiden tot een grote variëteit aan wensen of eisen en een ongecontroleerd proces (Dewulf, 2001). Zeker complexe gebiedsontwikkelingen kennen een groot aantal stakeholders met uiteenlopende percepties en preferenties. Een grote inbreng van veel stakeholders heeft tot gevolg dat planvorming deels plaats vindt buiten de macht die is toebedeeld aan representatieve instituties. Legitimiteit kan in dat geval minder worden ontleend aan de overheid als democratisch gelegitimeerd orgaan, maar dient zijn grondslag vooral te vinden in de geproduceerde resultaten en de openheid van het planproces.

Een tweede punt van discussie richt zich op de verhoudingen tussen actoren met verschillende karakters en belangenposities. Tegen de achtergrond van de vraag naar de borging van het publiek belang is het logisch om te kijken naar de wijze waarop rollen en verhoudingen tussen deze partijen moeten worden vormgegeven. Veelal gaat het in de discussie om verhoudingen tussen actoren met een publiek dan wel privaat karakter (WRR, 2000; Canoy et al, 2001, Van der Heijden en Spiering, 2002), maar ook de verhoudingen tussen overheden onderling krijgen de nodige aandacht (Ministeries VROM, LNV, V\&W en EZ, 2004; Teisman et al., 2001).

Een gangbare veronderstelling is dat het benutten van private verantwoordelijkheden de efficiency en effectiviteit van de behartiging van het publiek belang ten goede komt, omdat in dat geval de voordelen van het marktmechanisme kunnen worden gebruikt (WRR, 2000: p.31). ${ }^{93}$ Hiertegenover staat veelal de spiegelbeeldige gedachte dat democratische legitimatie en sturing beter uit zijn wanneer publiek belang door publieke actoren wordt behartigd. De argumenten die daarbij naar voren worden gebracht benadrukken dat door samenwerking met private partijen de overheid een deel van haar zeggenschap en autoriteit inruilt en vervagende grenzen tussen het publiek en private domein in potentie een aantasting betekenen van zaken als verantwoordelijkheid en toerekenbaarheid, transparantie en democratische keuze (Bovens en Scheltema, 1999, WRR, 2000; Van Wijk et al., 2002). ${ }^{94}$

Een vergelijkbare discussie vindt plaats waar het gaat om verhoudingen tussen partijen met enkel een publiek karakter. In algemene zin gaat het veelal om de vraag op welk schaalniveau bepaalde taken en verantwoordelijkheden het beste kunnen worden behartigd, centraal of decentraal. Het beginsel van subsidiariteit leert dat belangen waarvoor de overheid zich verantwoordelijk acht bij voorkeur dienen te worden verricht door de bestuurslaag die het dichtst bij de burger staat, tenzij er argumenten zijn het betreffende (publieke) belang en de daaruit voortvloeiende taak op een hoger schaalniveau of door een functionele bestuursvorm uit te laten voeren. De gedachte is dat decentrale overheden bepaalde taken efficiënter, effectiever en democratischer kunnen vervullen, omdat zij beter zicht hebben op de lokale situatie en daardoor beter tot maatwerkoplossingen in staat zijn (Boogers, 2009). Voor projecten waarin meerdere bestuursniveaus een directe verantwoordelijkheid hebben, blijkt de vraag op welke wijze de verschillende publieke partijen een inbreng moeten hebben en hoe onderlinge verhoudingen moeten worden vormgegeven minder duidelijk (Ministerie VROM, 2009; TK 2002-2003, 28753; Laverman, 2003; Van Hoof, 2003). 
In veel stedelijke projecten is het de gemeente die in de ruimtelijke planvorming eenduidig de regie voert. $\mathrm{Zij}$ is het meest directe representatieve overheidsorgaan. In diverse ruimtelijke projecten is er echter sprake van gemeentegrens overschrijdende of zelfs nationale belangen, spelen meerdere beleidsvelden een rol en zijn diverse andere stakeholders te onderkennen. Dit is zeker het geval bij grootschalige stationslocaties. Naast het karakteriseren van de constellatie van actoren aan de hand van de verhoudingen tussen publieke en private en centrale en decentrale overheden pleit dit ervoor expliciet aandacht te besteden aan de rol van de gemeente.

Een derde punt aan de hand waarvan het samenstel van actoren in het planproces getypeerd kan worden is de mate van ambivalentie. Dit heeft betrekking op de mate waarin relevante partijen bepaalde zaken op verschillende wijze percipiëren. In algemene zin kan worden gesteld dat in de discussie over de wijze waarop taken en verantwoordelijkheden tussen partijen moeten worden verdeeld - zeker waar het gaat om de verhoudingen tussen publieke en private actoren - ideologische argumenten nogal eens lijken te overheersen (Ter Bogt, 1995; WRR, 2000). Of veronderstellingen die betrekking hebben op het effect van het aantal of het karakter van actoren en hun wijze van betrokkenheid in het planproces opgaan, is ook afhankelijk van plaats- en tijdsgebonden factoren. Zo is bijvoorbeeld na de bouwfraude de roep om een sterkere controlefunctie van de overheid in het bouwproces weer sterker geworden en bepalen de kenmerken van het specifieke project in belangrijke mate de inhoudelijke invulling die wordt gegeven aan het publieke belang in kwestie. Deze studie focust op grootschalige binnenstedelijke stationslocaties in de Nederlandse context. Deze projecten worden bij uitstek gekenmerkt door de verwevenheid van verschillende functies en actoren. Omdat naast de mogelijkheden van actoren ook hun percepties en preferenties verschillen zal over criteria aan de hand waarvan men de resultaten evalueert een zekere mate van consensus en dissensus bestaan. Dit geldt evenzeer voor hun beeld van de inbreng van partijen in het planproces. Dit pleit ervoor om naast het aantal en het karakter van de partijen dat betrokken is tevens te kijken in hoeverre de mate van overeenstemming over de inbreng van deze partijen bijdraagt aan de effectiviteit en legitimiteit van planvorming. Enerzijds zou een goed debat over deze verschillen van inzicht bij kunnen dragen aan een effectiever dan wel legitiemer proces. Anderzijds kan worden verondersteld dat indien bij sleutelpartijen die beschikken over de middelen en instrumenten die noodzakelijk zijn voor de ontwikkeling en implementatie van plannen een zeer uiteenlopend beeld bestaat van de feitelijke of wenselijke situatie, de kans, dat gekomen wordt tot een succesvolle samenwerking in termen van effectieve en legitieme (vorming van) plannen geringer is (vgl. Freeman, 1994). ${ }^{95}$ In de analyse van het proces staan in deze studie daarom de volgende kenmerken van de constellatie van actoren centraal:

\begin{tabular}{|l|l|} 
Kenmerk & Specificatie \\
\hline Aantal actoren & Aantal keystakeholders met substantiële inbreng \\
\hline Verhouding actoren & $\begin{array}{l}\text { Verhouding inbreng publieke en private keystakeholders } \\
\text { Verhouding inbreng centrale en decentrale keystakeholders } \\
\text { Verhouding inbreng gemeente en overige keystakeholders }\end{array}$ \\
\hline Ambivalentie & $\begin{array}{l}\text { Consensus/dissensus over de wenselijke situatie } \\
\text { Consensus/dissensus perceptie feitelijke situatie }\end{array}$ \\
\hline
\end{tabular}

Tabel 3.2 Kenmerken actorconstellatie 


\subsection{Analysekader}

De voorgaande beschouwing leidt tot een aantal fundamentele concepten voor de analyse van planvorming in een netwerkomgeving. Een onderscheid is gemaakt naar contextfactoren, kenmerken van actoren en de inrichting van het planproces.

Contextfactoren geven de setting waarin handelen van actoren plaats vindt. Ze zijn daarmee van invloed op het proces of het resultaat daarvan, maar er bestaat geen directe controle over vanuit de projectorganisatie. Vanuit het IAD-raamwerk (Ostrom et al., 1994) en zijn drie typen contextfactoren onderscheiden; kenmerken van de gemeenschap; kenmerken van de fysieke omgeving en van toepassing zijnde regels. Voor het verloop van processen bij stationslocaties zijn vooral de laatste twee typen interessant. Kenmerken van de fysieke omgeving hebben - vanuit het object van het onderzoek bezien - betrekking om de fysieke kenmerken van stationslocaties. De gebruikte regels geven de institutionele context. Voor stationslocaties gaat het dan vooral om het geldende (macro)beleid, relevante procedures en regelgeving en de actoren die bij de aanpak van dit type projecten betrokken zijn. Deze contextfactoren hebben dimensies die algemeen geldend zijn, onafhankelijk van de projectspecifieke situatie en dimensies die specifiek voor een bepaald project van toepassing zijn.

De context kadert de handelingsmogelijkheden van actoren in. De invloed van contextfactoren op het handelen, verschilt echter per actor naar gelang hun mogelijkheden en hun oriëntatie ten aanzien van alternatieve acties. De mogelijkheden van actoren worden bepaald door de middelen waarover actoren beschikken. Hun oriëntatie wordt bepaald door het mentale beeld over oorzaak en verwachte gevolgen en hun subjectieve voorkeuren op dat gebied. De perceptie van afhankelijkheid om tot realisatie van hun voorkeuren te komen in een specifiek project, is wat actoren in een netwerkomgeving - zoals het geval bij stationslocaties - motiveert om te interacteren. Deze interacties leiden tot bepaalde uitkomsten, die in planvorming te zien zijn als planproducten die het resultaat zijn van een proces waarin diverse actoren in verschillende vorm en in meer of mindere mate een inbreng hebben gehad. Het effect van keuzen van actoren in de wijze waarop zij hun inbreng concreet vorm geven in het proces staat in deze studie centraal.

Deze keuzen worden op een drietal kernthema's van het proces beschreven. Deze thema's zijn; de inbreng in het proces van visievorming; de middeleninbreng en de zeggenschapsverdeling. Deze thema's worden beschreven an de hand van de kenmerken en specificatie die staat weergegeven in tabel 3.2. Het gaat dan om de vraag of het aantal actoren, de verhouding tussen verschillende typen actoren of de mate van ambivalentie in het beeld van actoren op deze thema's verband houdt met de borging van het publiek belang in termen van effectieve en legitieme planvorming. In dat planproces is een onderscheid gemaakt naar het deelproces voor het ontwikkelen van een masterplan voor de overkoepelende gebiedsontwikkeling en het deelproces specifiek voor de OV-terminal. Schematisch kan het analysekader worden weergegeven als in figuur 3.2.

Dit hoofdstuk vormt samen met het vorige hoofdstuk, waarin indicatoren voor de borging van het publiek belang zijn benoemd, het analytisch-evaluatief raamwerk. Het volgende hoofdstuk geeft een overzicht van dit raamwerk en beschrijft de aanpak die voor de case-analyse is gehanteerd. 


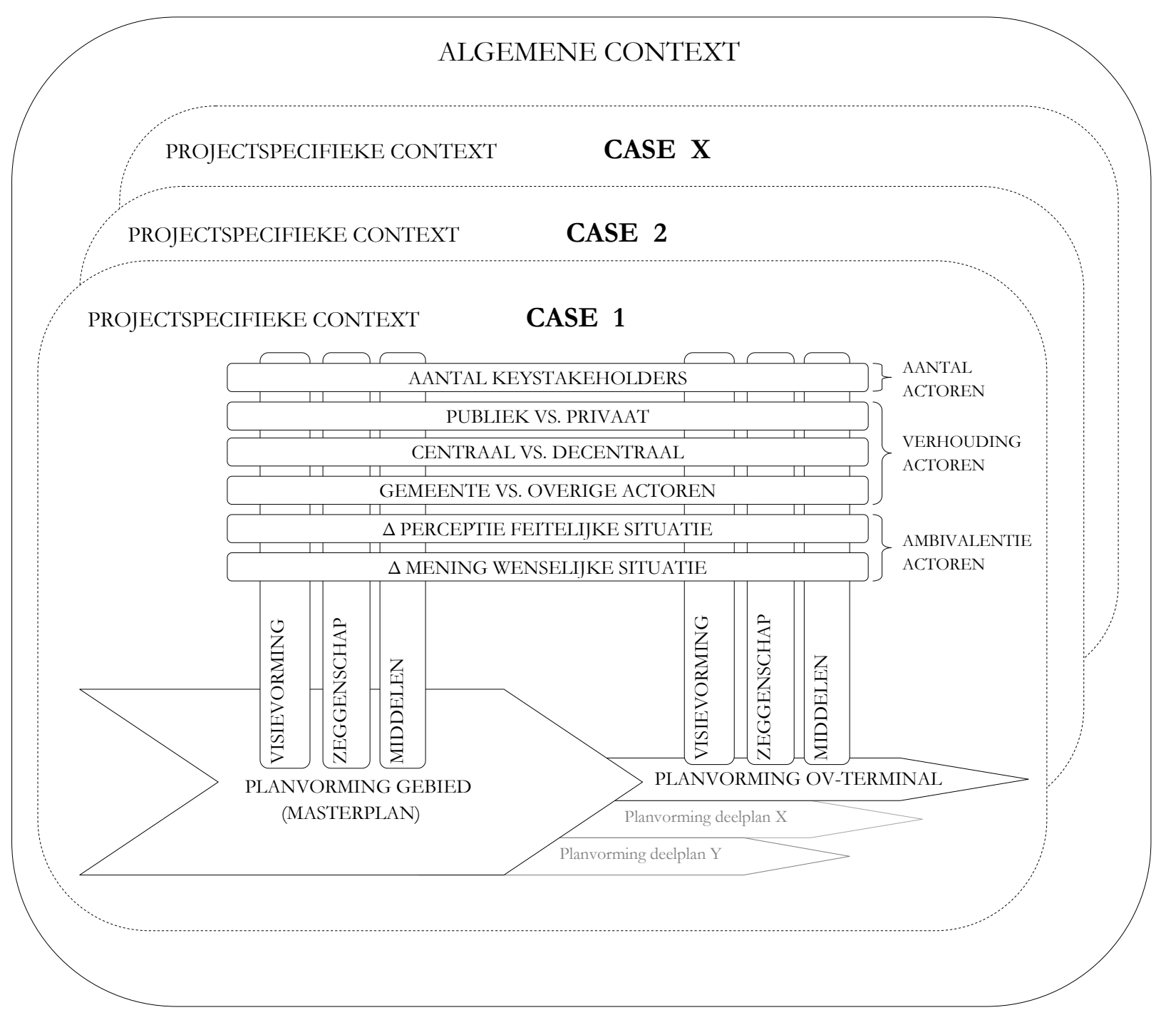

Figuur 3.2 Analysekader planprocessen 


\section{Hoofdstuk 4 \\ Conceptueel raamwerk \& aanpak case analyse}

In de vorige twee hoofdstukken zijn op basis van inzichten uit literatuur relevante factoren benoemd voor een analyse van de inrichting van processen en de borging van het publiek belang. Dit hoofdstuk start met een tekstuele samenvatting en een schematisch overzicht van deze factoren (4.1). In het tweede deel wordt de werkwijze die is gehanteerd voor de empirische analyse beschreven (4.2).

\subsection{Conceptueel raamwerk}

In hoofdstuk twee is beargumenteerd dat voor een oordeel over de borging van het publiek belang bij de herontwikkeling van stationslocaties de effectiviteit en legitimiteit van planvorming als criteria kunnen worden gehanteerd. Uitgangspunt in deze studie is dat naarmate de planvorming effectiever en legitiemer is, het publiek belang beter gewaarborgd is.

\subsubsection{Publiek belang: effectiviteit en legitimiteit}

Via planvorming krijgt de oplossing voor een ruimtelijk probleem vorm. De mate waarin de gevormde plannen bijdragen aan een oplossing kan worden beschouwd als een maatstaf voor de effectiviteit. Op een hoog abstractieniveau gaat het er dan om dat de bestaande ruimtelijke kwaliteit in een plangebied niet aansluit bij de gewenste ruimtelijke kwaliteit. Uitgangspunt is dat ruimtelijke kwaliteit in de ruimtelijke sector een intersubjectief gedeelde waarde is. Ruimtelijke kwaliteit vormt de centrale doelstelling van het Nederlandse ruimtelijk beleid en in principe streven alle overheden die actief zijn in de ruimtelijke sector ruimtelijke kwaliteit na. Ook andere actoren zijn direct dan wel indirect gebaat bij een verhoging van de ruimtelijke kwaliteit.

Ruimtelijke kwaliteit is echter geen eenduidig objectief definieerbaar concept. Actoren die betrokken zijn bij stationslocaties zullen vanuit hun verschillende belangenposities de nadruk leggen op verschillende dimensies van ruimtelijke kwaliteit. Om die reden is het concept ruimtelijke kwaliteit nader geoperationaliseerd door te kijken wat in het specifieke project de relevante dimensies zijn. Daarvoor is een reeks ontwerpeisen (gebruikerswaarde, belevingswaarde en toekomstwaarde) gekruist met een reeks belangen (economisch, sociaal, ecologisch). Dit leidt tot een matrix waarin de kruispunten zijn ingekleurd met trefwoorden, oftewel dimensies van ruimtelijke kwaliteit. Deze dimensies zijn: (1) functionaliteit, (2) aantrekkelijkheid, (3) flexibiliteit, (4) beschikbaarheid, (5) vitaliteit (6) stabiliteit (7) leefbaarheid, (8) diversiteit en (9) duurzaamheid.

Of door de uitvoering van de plannen daadwerkelijk een verhoging van de ruimtelijke kwaliteit op deze dimensies is gerealiseerd kan in ruimtelijke projecten pas definitief worden vastgesteld als het project gerealiseerd is. Dit betekent dat voor projecten die nog niet zijn afgerond slechts kan worden 
gekeken naar verwachtingen. Om inhoud te geven aan effectiviteit is in deze studie daarom de verwachte bijdrage van de voorliggende plannen aan het realiseren van ruimtelijke kwaliteit op de relevante dimensies in het betreffende plangebied geanalyseerd.

Een tweede criterium voor een oordeel over de borging van het publiek belang vormt de legitimiteit van planvorming. Legitimiteit hangt samen met de aanvaarding, acceptatie of steun door diegenen die de gevolgen ondervinden. Een belangrijke indicator hiervoor is de mate van steun van stakeholders voor de voorliggende plannen. Deze steun kan worden bevorderd als (effectieve) plannen in overeenstemming zijn met de wensen en voorkeuren van stakeholders. Dit blijkt onder andere uit de mate waarin zij zich aan de plannen gecommiteerd voelen en deze beschouwen als aanvaardbare compromis tussen betrokken partijen. In deze context gaat het om outputlegitimiteit. Legitimiteit kan echter ook zijn grondslag vinden in het proces zelf. Wensen en voorkeuren van stakeholders zijn nogal eens tegengesteld. Dit is zeker van toepassing bij complexe ruimtelijke projecten. In een dergelijke situatie moet worden bezien hoe die tegengestelde wensen en voorkeuren vertaald kunnen worden naar een collectieve keuze. Daarom zijn procedures en mechanismen nodig om wensen en voorkeuren te vertalen in beslissingen over de inhoud. Dit is het inputgeoriënteerde perspectief op legitimiteit. Vanuit dit perspectief dient in de eerste plaats aan bepaalde institutionele eisen te worden voldaan. Zo dienen democratische procedures voor besluitvorming te worden gevolgd en dient relevante regelgeving op correcte wijze te zijn gehanteerd (legaliteit). Belangrijk is dat stakeholders de mogelijkheid hebben om hun instemming met of afkeuring van voorgenomen plannen kenbaar te maken en de beslissing die daarover wordt genomen te beïnvloeden. Naast legaliteit is openheid een belangrijke factor voor inputlegitimiteit. Toegankelijkheid van het planproces en beinvloedingsmogelijkheden voor stakeholders zijn daarvoor als indicatoren gehanteerd. Tenslotte kan legitimiteit worden bevorderd door inzicht te geven op welke wijze uiteenlopende wensen en voorkeuren van partijen zijn vertaald naar beslissingen over de inhoud en welke argumentatie daaraan ten grondslag ligt. Vanuit dit throughputperspectief wordt legitimiteit dus bevorderd door transparantie van het proces. Omdat wordt verondersteld dat de overheid handelt namens de samenleving als geheel en geld uitgeeft dat niet is verdiend door de eigen organisatie is in planvorming waarin publieke partijen een belangrijke rol spelen, transparantie essentieel voor verantwoording. Het gaat er dan om dat de afwegingsprocessen die hebben plaatsgevonden, de prioriteiten bij deze afwegingen zijn gesteld en de argumenten die daarvoor zijn gebruikt, helder zijn. Aldus is voor de analyse van de legitimiteit van het planproces onderscheid gemaakt naar input-, throughput- en outputlegitimiteit (vgl; Scharpf, 1999; Haus et al., 2005).

Voor prestaties in termen van de borging van het publiek belang is in deze studie dus primair gekeken naar de effectiviteit en legitimiteit van planvorming. De vraag is, welke normen ten aanzien van de inrichting van het proces in acht moeten worden genomen om te garanderen dat de planvorming ook daadwerkelijk effectief en legitiem verloopt.

\subsubsection{Planprocessen}

Literatuur geeft op de hiervoor beschreven vraag geen eenduidig antwoord. In een representatieve democratie zullen overheden de neiging hebben om in eerste instantie hun hiërarchische macht te gebruiken, gelegitimeerd door democratische besluitvormingsprocedures en zullen slechts afwijken 
van deze strategie door noodzaak. In complexe ruimtelijke projecten is die noodzaak aanwezig. Fragmentatie van noodzakelijke hulpbronnen over een groot aantal partijen zorgt ervoor dat geen van de partijen in staat is om een ontwikkeling alleen tot stand te doen komen, maar ieder leveren ze een stukje van de puzzel. Om tot oplossingen voor ruimtelijke problemen te komen is adequaat samenspel tussen diverse publieke actoren en tussen diverse publieke en (semi-)private actoren noodzakelijk. Tegelijkertijd betekent het dat planvorming voor een deel plaats vindt buiten de grenzen van de macht die is toebedeeld aan betrokken overheden als representatieve instituties. Binnen andere arrangementen dient een andere vorm van representatie plaats te vinden en om die reden speelt de inrichting van het proces een belangrijke rol voor de borging van het publiek belang.

De inrichting van het proces en de inbreng van actoren daarin wordt in belangrijke mate beïnvloed door de context waarin het plaats vindt. Contextfactoren geven de setting waarin handelen van actoren plaats vindt. Ze zijn daarmee van invloed op het proces of het resultaat daarvan, maar er bestaat geen directe controle over vanuit de projectorganisatie. In deze studie is onderscheid gemaakt naar factoren die onafhankelijk van de projectspecifieke situatie van toepassing zijn en factoren die specifiek voor een bepaald project gelden. De eerste categorie is de algemene context genoemd. Deze context is in beeld gebracht door de fysieke kenmerken van stationslocaties, het beleidskader, de relevante regelgeving en de actoren die normaliter betrokken zijn bij de aanpak van stationslocaties te beschrijven. Dit gebeurt in het volgende hoofdstuk (5). Voor zover factoren specifiek betrekking hebben op een bepaald project wordt in deze studie gesproken van de projectspecifieke context. Per project zijn daarvoor de projectgeschiedenis, het procesverloop, de ruimtelijke opgave, de keystakeholders en de samenwerkingsorganisatie beschreven.

Uitgangspunt in deze studie is dat contextfactoren het handelen van actoren inkaderen, maar dat de invloed van deze factoren verschilt per actor naar gelang hun mogelijkheden en oriëntatie ten aanzien van alternatieve acties. De mogelijkheden van actoren worden bepaald door de middelen waarover actoren beschikken. Hun actie-oriëntatie wordt bepaald door de subjectieve percepties van actoren over oorzaken en verwachte gevolgen en hun subjectieve voorkeuren op dat gebied.

In deze studie staat het effect van de inrichting van het proces centraal. Keuzen ten aanzien van de inrichting van het proces zijn op een drietal kernthema's van het herontwikkelingsproces beschreven. Deze thema's zijn; (1) het visievormingsproces; (2) de zeggenschapsverdeling (3) de middeleninbreng. Tegen de achtergrond van de borging van het publiek belang is beargumenteerd dat het logisch is deze kernthema's te beschrijven aan de hand van een aantal kenmerken van de actorconstellatie. Dit zijn; (a) het aantal keystakeholders dat een substantiële inbreng heeft; (b) de verhouding tussen keystakeholders met uiteenlopende karakters en belangenposities (publiek-privaat; centraal-decentraal; gemeente-overige); en (c) de mate van ambivalentie ( $\Delta$ perceptie; $\Delta$ mening) in het beeld bij deze keystakeholders.

Deze kernthema's en kenmerken zijn geanalyseerd voor twee te onderscheiden fasen en onderdelen in planvorming voor stationslocaties. De eerste fase heeft betrekking op het ontwikkelen van het masterplan voor de gebiedsontwikkeling als geheel. De tweede fase heeft betrekking op een onderdeel daarbinnen, de planvorming specifiek voor de OV-terminal. De voorgaande tekstuele beschrijving van het raamwerk dat voor de analyse is gehanteerd staat schematisch weergegeven in figuur 4.1. 


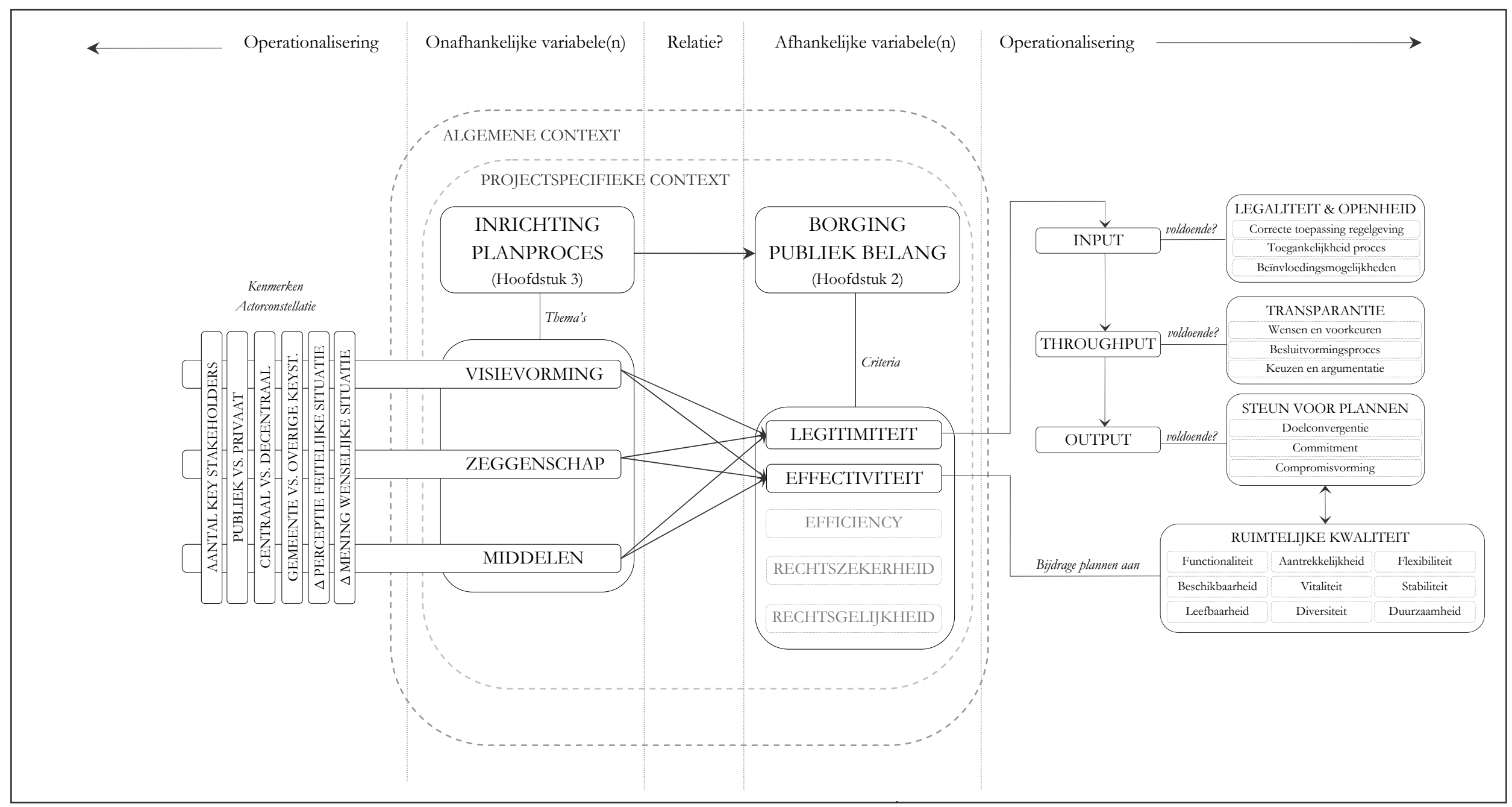

Figuur 4.1 Conceptueel raamwerk 


\subsubsection{Operationalisering}

Figuur 4.1 laat zien dat de inrichting van het planproces in deze studie is bestudeerd op een drietal thema's; (1) visievorming; (2) zeggenschap; en (3) middelen. Deze thema's zijn getypeerd aan de hand van een aantal kenmerken van de actorconstellatie. Deze kenmerken zijn; (a) het aantal actoren dat een inbreng heeft; (b) de verhoudingen tussen actoren met uiteenlopende karakters en belangenposities; en (c) de mate van ambivalentie (consensus/dissensus) in het beeld van actoren. Hier wordt uiteen gezet op welke wijze deze elementen in het onderzoek operationeel zijn gehanteerd.

\section{Thema 1: visievorming}

Visievorming betreft het proces waarin een beeld wordt gevormd van het probleem, een gewenste en haalbaar geachte toekomstige situatie en het veranderingstraject dat nodig is om daar te komen. Om de constellatie van actoren in dit proces te kunnen typeren, is eerst de inbreng van de verschillende actoren afzonderlijk bestudeerd. In deze studie is gefocust op organisaties waarvan toestemming en/of investeringen vanwege de op grond van wettelijke regelgeving toegekende bevoegdheden of vanwege eigendomsposities, minimaal noodzakelijk zijn voor de implementatie van plannen. Deze organisaties zijn cruciaal in de besluitvorming over het project en hebben een sterk belang bij het resultaat. ${ }^{96}$ Deze organisaties zijn benoemd als keystakeholders. Bij grootschalige stationslocatieprojecten gaat het dan om de gemeente, de provincie/regio, het ministerie van VROM, het ministerie van Verkeer en Waterstaat, ProRail, NS en eventuele private eigenaren/ontwikkelaars met een positie in het plangebied.

Aan de inbreng van deze actoren in het proces van visievorming is een waarde toegekend. Hiervoor is een 5-punts Likertschaal gehanteerd, waarbij de waarde kan variëren van zeer groot (5) tot zeer klein (1). Voor het bepalen van deze waarde, is aangesloten bij de opvattingen van direct betrokken projectmanagers vanuit dezelfde organisaties. ${ }^{97}$ Hen is gevraagd voor elk van de actoren (inclusief de eigen organisatie) een waarde (1-5) toe te kennen.

Op basis van de waarden die door de projectmanagers zijn toegekend is per keystakeholder een gemiddelde berekend. Dit gemiddelde geeft een beeld van de inbreng van verschillende keystakeholders in het proces van visievorming. De mate waarin projectmanagers onafhankelijk van elkaar hetzelfde beeld hebben van de inbreng van actoren in het proces, is een maatstaf voor de betrouwbaarheid. Indien de verschillen in perceptie groot zijn dan bestaat er bij direct betrokkenen blijkbaar een zeer uiteenlopende interpretatie van de feitelijke situatie (vgl. Weick, 1995). Naast het reconstrueren van de inbreng per actor is tevens de mate waarin percepties van informanten verschillen geanalyseerd. Voor het analyseren van deze perceptieverschillen is de standaarddeviatie gebruikt, zijnde een maat voor de variatie in de toegekende waarden. Aan de hand van een voorbeeld wordt de hiervoor beschreven werkwijze verhelderd.

Stel de waarden 4, 5, 5, 3, 2, 4 en 5 worden door zeven projectmanagers toegekend aan de inbreng van actor $\mathrm{X}$ in het proces van visievorming, waarbij een 5 staat voor een zeer grote inbreng en een 1 voor een zeer kleine inbreng. Het gemiddelde is in dit geval 4,0 en de standaarddeviatie 1,2. ${ }^{98}$

Per actor is op deze wijze de inbreng gereconstrueerd en het verschil in perceptie geanalyseerd. Deze bevindingen zijn gepresenteerd in figuren. Figuur 4.2 laat hiervan een voorbeeld zien. Uit de figuur 
valt af te leiden dat actor 1 een zeer grote inbreng heeft gehad en dat het beeld hiervan bij projectmanagers volledig eenduidig is. De overige actoren hebben volgens direct betrokken projectmanagers allen een aanzienlijk kleinere inbreng gehad in het proces van visievorming. Het beeld van hun inbreng loopt ook nogal uiteen, getuige de standaarddeviaties en het gemiddelde $(1,3)$ daarvan.

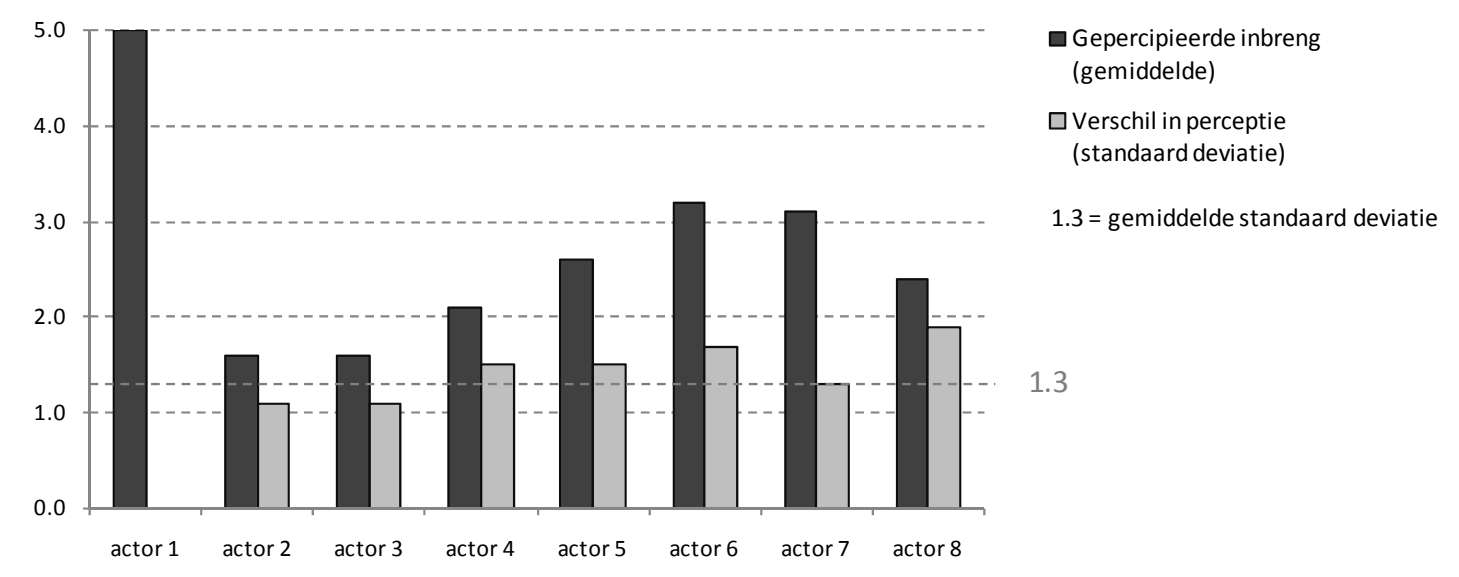

Figuur 4.2 Voorbeeldfiguur presentatie empirische data

De inbreng van verschillende actoren is dus in belangrijke mate gereconstrueerd door gebruik te maken van percepties van personen, die vanuit de organisaties die aangemerkt zijn als keystakeholders het meest direct betrokken waren in de tijdsperiode waarop de analyse betrekking had. Dat betekent dat het gaat om een beperkte groep van relatief nauw betrokkenen. Nauw betrokkenen hebben soms de neiging tot zelfrechtvaardiging waardoor bevooroordeelde resultaten kunnen ontstaan en daarnaast kan er bij personen sprake zijn van leemten in hun geheugen, (Bartlett, 1954). Niettemin wordt het gebruik van retrospectieve data waarin personen het proces reconstrueren beschouwd als een zeer geschikte werkwijze (vgl. Nutt, 2000). Om de gevaren van restrospectieve data voor de validiteit van de onderzoeksresultaten tegen te gaan is het beeld dat ontstaat van de inbreng van afzonderlijke actoren bezien in het licht van de mate van convergentie daarin en is het in de case beschrijvingen geconfronteerd met kwalitatieve data uit documenten. Met het laatste zijn de percepties (subjectieve feitelijkheid) van de inbreng van actoren bezien in het licht van feitelijke acties en gebeurtenissen. De conceptteksten die op basis van de interviews zijn opgesteld zijn tevens voor correctie van onjuistheden voorgelegd aan de geïnterviewden (vgl. Miller, 1997) ${ }^{99}$.

Naast het reconstrueren van de inbreng van keystakeholders in het proces op basis van de percepties daarvan bij projectmanagers, is tevens geanalyseerd welke inbreng projectmanagers voor deze actoren wenselijk achten. De gehanteerde werkwijze is identiek aan de aanpak die hiervoor is beschreven.

De constellatie van actoren in het proces van visievorming is vervolgens getypeerd door te kijken naar;

(A) het aantal keystakeholders dat een grote inbreng heeft;

(B) de verhoudingen tussen keystakeholders (publiek-privaat; centraal-decentraal; gemeente-overige);

(C) de mate van ambivalentie ( $\Delta$ perceptie; $\Delta$ mening) bij keystakeholders. 


\section{A. Het aantal keystakeholders dat een grote inbreng heeft.}

Gesteld is dat er sprake is van een grote inbreng in de planvorming als het gemiddelde van de percepties van procesmanagers een waarde groter dan ' 3 ' laat zien. In figuur 4.2 is dat het geval voor 3 partijen.

\section{B. De verhoudingen tussen keystakeholders met verschillende karakters en belangenposities}

Hiervoor is gekeken naar de verhouding tussen (B1) de inbreng van publieke en private partijen; (B2) de inbreng van centrale en decentrale overheden; en (B3) de inbreng van de gemeente en andere keystakeholders.

- B1: Publiek vs. Privaat

Aan publieke zijde zijn bij de aanpak van stationslocaties vanuit hun bestuurlijke verantwoordelijkheid en/of eigendomspositie in ieder geval altijd de betreffende gemeente, het ministerie van Verkeer en Waterstaat en ProRail betrokken. Verder zijn provincies, regionale openbare lichamen en het ministerie van VROM relevante actoren. Tegen de achtergrond van de discussie over democratische legitimatie en sturing bij de borging van publieke belangen is vanuit publieke zijde vooral gekeken naar de inbreng van representatieve instituties. Het gaat dan om de gemeente, de provincie en beide ministeries. ${ }^{100}$

Aan private zijde is bij de aanpak van stations altijd NS betrokken. NS heeft het exclusieve recht op benutting van de commerciële mogelijkheden van stations, is eigenaar van het niet-transfergedeelte en bezit diverse gronden in de directe omgeving van stations. Voor de herontwikkeling van stationslocaties speelt vooral organisatieonderdeel NS Poort, een belangrijke rol. NS Poort houdt zich bezig met het ontwikkelen, beheren en exploiteren van stations en stationsomgevingen. Hoewel de aandelen van NS volledig in handen zijn van de Staat der Nederlanden zorgen deze activiteiten ervoor dat NS in haar handelen aangemerkt kan worden als een private partij. Naast NS zijn er in binnen het plangebied veelal ook andere private eigenaren/ontwikkelaars.

De verhouding tussen de inbreng van publieke en private partijen in het proces van visievorming is geanalyseerd. Dit is gedaan door de inbreng van de gemeente, provincie en beide ministeries enerzijds en de inbreng van NS en private eigenaren/ontwikkelaars anderzijds tegenover elkaar te stellen. Naast een kwalitatieve beschrijving is een kwantitatieve indicator bepaald door het gemiddelde van de inbreng voor deze twee groepen te berekenen en het verschil hiertussen te bepalen.

\section{- B2: Centraal vs. Decentraal}

De verhouding tussen de inbreng van centrale en decentrale overheden is geanalyseerd door de inbreng van gemeenten in het proces van visievorming af te zetten tegen de inbreng vanuit het Rijk in dit proces. Voor de laatste wordt gekeken naar de inbreng van het ministeries VROM en het ministerie van Verkeer en Waterstaat. Een kwantitatieve indicator is bepaald door het gemiddelde te berekenen en het verschil hiertussen te bepalen.

- B3: Gemeente vs. Overige keystakeholders

Als meest direct representatief overheidsorgaan en veelal regisseur in stedelijke projecten wordt de rol van de gemeente expliciet beschouwd. Omdat gemeenten voor de implementatie van plannen in meer of mindere mate afhankelijk zijn van de diverse andere keystakeholders is haar inbreng in het proces 
beschouwd in relatie tot de inbreng van andere keystakeholders. Een kwantitatieve indicator is bepaald door het gemiddelde te berekenen en het verschil hiertussen te bepalen.

\section{De mate van ambivalentie}

Hiervoor is gekeken naar (C1) de mate waarin percepties van projectmanagers van de feitelijke inbreng van keystakeholders verschillen en (C2) de mate waarin de meningen van projectmanagers over de wenselijke inbreng voor keystakeholders verschillen.

- C1: $\Delta$ perceptie van de feitelijke situatie

Per keystakeholder is door projectmanagers een waarde (1-5) toegekend aan de inbreng die de betreffende partij volgens hen heeft gehad in het proces van visievorming. Per keystakeholder is de standaard deviatie berekend als maatstaf voor het verschil in perceptie tussen projectmanagers. Het gemiddelde van de standaarddeviaties voor alle keystakeholders is gehanteerd als indicator voor de mate waarin de percepties van de feitelijke situatie verschillen. In voorbeeldfiguur 4.2 heeft deze de waarde 1.3 .

- C2: $\Delta$ mening over de wenselijke situatie

Per actor is door projectmanagers een waarde (1-5) toegekend an de inbreng die zij voor de betreffende actor wenselijk achten in het proces van visievorming. Per actor is de standaard deviatie is berekend als maatstaf voor het verschil van mening hierover tussen projectmanagers. Het gemiddelde van deze standaarddeviaties voor alle keystakeholders is gehanteerd als indicator voor de mate van consensus/dissensus in de mening over de wenselijke situatie.

\section{Thema 2: zeggenschap}

Zeggenschap heeft in deze studie betrekking op de mate waarin actoren in het proces mee hebben beslist over de inhoud van plannen. De verdeling van zeggenschap in de actorconstellatie is evenals bij het vorige thema getypeerd door te kijken naar (A) het aantal keystakeholders dat een grote mate van zeggenschap heeft gehad; (B) de verhoudingen qua zeggenschap tussen keystakeholders met verschillende karakters en belangenposities; en (C) de mate van ambivalentie ( $\Delta$ perceptie; $\Delta$ mening). De aanpak die daarvoor is gehanteerd is identiek als bij thema 1: visievorming.

\section{Thema 3: middelen}

Hier gaat het om de mate waarin verschillende keystakeholders middelen toekennen voor de ontwikkeling en realisatie van plannen. Omdat de specifieke kenmerken van een project van invloed zullen zijn op de inbreng van middelen door keystakeholders is deze inbreng afgezet tegen wat op grond van de kenmerken van het project van de betreffende partij naar de mening van de projectmanagers verwacht mag worden. Dit betekent dat aan de inbreng van een keystakeholder vijf mogelijke waarden kunnen worden toegekend; veel meer dan mag worden verwacht (5); meer dan mag worden verwacht (4), in overeenstemming met wat mag worden verwacht (3); minder dan mag worden verwacht (2); en veel minder dan mag worden verwacht (1).

Evenals bij de vorige twee thema's wordt voor het bepalen van de waarde angesloten bij de opvattingen van de projectmanagers. Dit betekent dat aan de hand van het gemiddelde van de meningen van respondenten per actor de (toegekende) inbreng van middelen is beschreven. 
Daarnaast is per actor de standaarddeviatie berekend als maatstaf voor de mate waarin projectmanagers hierover van mening verschillen. Het beeld dat hieruit naar voren komt is toegelicht en geconfronteerd met kwalitatieve data uit de interviews en documenten. De aanpak voor het typeren van de constellatie van actoren is vrijwel hetzelfde als de hiervoor beschreven aanpak bij thema 1 (visievorming) en thema 2 (zeggenschap). Enig verschil is dat niet is gevraagd naar de mening over de wenselijke situatie, omdat verondersteld wordt dat men een grotere inbreng van middelen door andere actoren dan de eigen organisatie vrijwel altijd wenselijk acht.

De inrichting van het proces is in deze studie dus bestudeerd aan de hand van de kenmerken van de actorconstellatie. Een overzicht van de kenmerken waarvoor een relatie met de criteria voor de borging van het publiek belang is geanalyseerd, staat weergegeven in tabel 4.1.

\begin{tabular}{|c|c|c|c|c|}
\hline \multirow{17}{*}{ 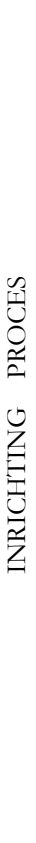 } & \multirow{6}{*}{ VISIEVORMING } & A & Aantal actoren met grote inbreng & aantal actoren met inbreng in visievorming groter dan ' 3 ' \\
\hline & & B 1 & Verhouding publiek - privaat & verschil tussen inbreng publiek en inbreng privaat \\
\hline & & B 2 & Verhouding centraal - decentraal & verschil tussen inbreng centrale en decentrale overheid \\
\hline & & B 3 & Verhouding gemeente - overigen & verschil tussen inbreng gemeente en andere keystakeholders \\
\hline & & C 1 & $\Delta$ perceptie feitelijke situatie & waarden standaard deviatie (gemiddelde) \\
\hline & & C 2 & $\Delta$ mening wenselijke situatie & waarden standaard deviatie (gemiddelde) \\
\hline & \multirow{6}{*}{ ZEGGENSCHAP } & A & Aantal actoren met grote inbreng & aantal actoren met zeggenschap groter dan ' 3 ' \\
\hline & & B 1 & Verhouding publiek - privaat & verschil tussen zeggenschap publiek en zeggenschap privaat \\
\hline & & B 2 & Verhouding centraal - decentraal & verschil tussen zeggenschap centrale en decentrale overheid \\
\hline & & B 3 & Verhouding gemeente - overigen & verschil tussen zeggenschap gemeente en keystakeholders \\
\hline & & C 1 & $\Delta$ perceptie feitelijke situatie & waarden standaard deviatie (gemiddelde) \\
\hline & & C 2 & $\Delta$ mening wenselijke situatie & waarden standaard deviatie (gemiddelde) \\
\hline & \multirow{5}{*}{ MIDDELEN } & A & Aantal actoren met grote inbreng & aantal actoren met inbreng van middelen groter dan ' 3 ' \\
\hline & & B 1 & Verhouding publiek - privaat & verschil tussen inbreng publiek en inbreng privaat \\
\hline & & B 2 & Verhouding centraal - decentraal & verschil tussen inbreng centrale en decentrale overheid \\
\hline & & B 3 & Verhouding gemeente - overigen & verschil tussen inbreng gemeente en andere keystakeholders \\
\hline & & C 1 & $\Delta$ perceptie (per actor) & waarden standaard deviatie (gemiddelde) \\
\hline
\end{tabular}

Tabel 4.1 Operationalisering planproces

Hiervoor is beschreven op welke wijze de onafhankelijke variabele is geanalyseerd. In het vervolg van deze paragraaf wordt hetzelfde gedaan voor de afhankelijke variabele, de borging van het publiek belang. Voor de borging van het publiek belang zijn effectiviteit en legitimiteit van het planproces als criteria gehanteerd.

\section{4: Effectiviteit}

Voor het bepalen van de effectiviteit van het planproces is gekeken naar de bijdrage van de plannen aan het realiseren van een hogere ruimtelijke kwaliteit in het gebied. Ruimtelijke kwaliteit wordt beschouwd als een subjectgebonden, contextafhankelijk begrip. Dit betekent dat subjecten een oordeel uitspreken over wat belangrijke dimensies van ruimtelijke kwaliteit zijn in het specifieke project. Vervolgens zullen zij de de mate waarin de voorliggende plannen bijdragen aan het verbeteren van die dimensies beoordelen. De onderscheiden dimensies zijn; functionaliteit, aantrekkelijkheid, flexibiliteit, beschikbaarheid, vitaliteit, stabiliteit, leefbaarheid, diversiteit en duurzaamheid. De zwaartepunten in deze dimensies voor de projecten zijn geanalyseerd aan de hand 
van het oordeel van projectmanagers vanuit keystakeholders. Dit zijn dezelfde organisaties als genoemd onder thema 1 (visievorming). Hen is gevraagd wat in het betreffende project de drie belangrijkste dimensies van ruimtelijke kwaliteit zijn. Vervolgens is gevraagd in hoeverre de plannen volgens hen hieraan een bijdrage leveren. Aan die bijdrage kunnen vijf waarden worden toegekend variërend van zeer groot (5) tot zeer klein (1). Omdat plannen nog niet gerealiseerd zijn kan slechts worden gekeken naar de verwachte bijdrage. Het gemiddelde van de toegekende waarden is gehanteerd als indicator voor effectiviteit van planvorming.

\section{5: Legitimiteit}

De factor legitimiteit is opgedeeld in een drietal vormen; (A) inputlegitimiteit, (B) throughputlegitimiteit en (C) outputlegitimiteit.

\section{A: Inputlegitimiteit}

Voor het bepalen van de inputlegitimiteit is beargumenteerd dat legaliteit en openheid van het planproces als criteria worden gehanteerd. We beslissen dat het planproces legaal is verlopen op het moment dat de van toepassing zijnde (democratische) besluitvormingsprocedures en regelgeving naar de mening van alle partijen op correcte wijze is doorlopen. De mate van openheid van het planproces is bepaald door te kijken of (1) alle relevante actoren toegang hebben gehad tot het planproces, (2) de mate waarin relevante actoren mogelijkheden hebben gehad om het planproces te beïnvloeden. Daarbij gaat het zowel om de eigen organisatie als om andere actoren. Voor een oordeel over deze elementen is aangesloten bij de opvattingen van projectmanagers vanuit keystakeholders. Het gemiddelde van de toegekende waarden is gehanteerd als indicator.

\section{B: Throughputlegitimiteit}

Voor het bepalen van de throughputlegitimiteit is beargumenteerd dat de transparantie van het planproces als criterium wordt gebruikt. We beslissen dat het planproces transparant is als (1) helder was welke partij beslissingen nam, (2) helder was waarover werd besloten, (3) helder was wanneer werd besloten, (4) helder was wat de wensen en voorkeuren van verschillende actoren waren en (5) helder was welke van de wensen en voorkeuren van actoren werden gehonoreerd en waarom. Aan deze elementen kunnen vijf mogelijke waarden worden toegekend, variërend van zeer helder (5) tot zeer onhelder (1). Voor een oordeel hierover wordt aangesloten bij de oordelen van projectmanagers vanuit keystakeholders. Het gemiddelde van de toegekende waarden is gehanteerd als indicator voor de throughputlegitimiteit.

\section{C: Outputlegitimiteit}

Voor het bepalen van de outputlegitimiteit is de steun van actoren voor de voorliggende plannen als criterium gebruikt. We beslissen dat actoren de plannen steunen, indien (1) in de plannen rekening is gehouden met hun wensen en doelstellingen, (2) zij zich gecommitteerd voelen aan de plannen en (3) zij de plannen beschouwen als aanvaardbaar compromissen voor de in het planproces participerende actoren. Aan deze elementen zijn waarden op een vijfpuntschaal toegekend door projectmanagers vanuit keystakeholders. Het gemiddelde van de toegekende waarden is gehanteerd als maatstaf voor de outputlegitimiteit. Een overzicht van de wijze waarop de borging van het publiek belang is bestudeerd staat weergegeven in tabel 4.2 . 
Toelichting op de perioden waarvoor de waarden van de variabelen gelden

De variabelen die hiervoor zijn uitgewerkt, zijn geanalyseerd voor twee deelprocessen/fasen in planvorming. Het gaat om (1) het deelproces gericht op planvorming voor de integrale gebiedsontwikkeling, dat vorm krijgt in een masterplan en (2) het deelproces van planvorming specifiek voor de OV-terminal.

Het eerste deelproces heeft betrekking op de periode tussen de fase waarin door een of meerdere partijen het initiatief is genomen om het plangebied aan te pakken en het vaststellen van het masterplan. Hiermee wordt de periode bedoeld waarin een startvisie wordt vertaald in een ruimtelijkfunctioneel ontwerp. Het ruimtelijk-functioneel ontwerp kriigt veelal de vorm van een masterplan waarin het Stedenbouwkundig Programma van Eisen is neergelegd. Als startpunt voor deze periode is de intentie- of procesovereenkomst genomen die overheden aan het einde van de initiatieffase hebben gesloten. De goedkeuring van het masterplan door het Rijk nadat deze in de gemeenteraad is vastgesteld geldt als eindpunt.

Het tweede deelproces heeft betrekking op de periode tussen vaststelling van het masterplan en het vaststellen van een deelplan voor de OV-terminal. In de gebiedsontwikkeling zijn veelal diverse deelplannen te onderscheiden. Van deze deelplannen is bij de OV-terminal de interbestuurlijke samenwerking het sterkst noodzakelijk. Voor de OV-terminal volgt na een schetsontwerp (SO) dat soms onderdeel uit maakt van het Masterplan een traject waarin het schetsontwerp wordt uitgewerkt tot een voorlopig ontwerp (VO) en vervolgens tot definitief ontwerp (DO). Afhankelijk van het stadium waarin het betreffende project zich ten tijde van de empirische dataverzameling bevond, is de overeenstemming tussen partijen over het schetsontwerp, het voorlopig ontwerp of het definitief ontwerp als eindpunt voor deze periode genomen.

\begin{tabular}{|c|c|c|c|c|}
\hline \multirow{19}{*}{ 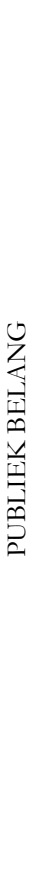 } & \multirow{9}{*}{ 4. EFFECTIVITEIT } & \multirow{9}{*}{ Ruimtelijke kwaliteit } & Bijdrage plannen aan functionaliteit & zeer groot - zeer klein \\
\hline & & & Bijdrage plannen aan aantrekkelijkheid & zeer groot - zeer klein \\
\hline & & & Bijdrage plannen aan flexibiliteit & zeer groot - zeer klein \\
\hline & & & Bijdrage plannen aan beschikbaarheid & zeer groot - zeer klein \\
\hline & & & Bijdrage plannen aan vitaliteit & zeer groot - zeer klein \\
\hline & & & Bijdrage plannen aan stabiliteit & zeer groot - zeer klein \\
\hline & & & Bijdrage plannen aan leefbaarheid & zeer groot - zeer klein \\
\hline & & & Bijdrage plannen aan diversiteit & zeer groot - zeer klein \\
\hline & & & Bijdrage plannen aan duurzaamheid & zeer groot - zeer klein \\
\hline & \multirow{4}{*}{$\begin{array}{l}\text { 5A. INPUT- } \\
\text { LEGITIMITEIT }\end{array}$} & \multirow{4}{*}{ Legaliteit \& Openheid } & Toepassing wet- en regelgeving & zeer correct - zeer incorrect \\
\hline & & & Toegang alle relevante actoren & $\mathrm{ja} / \mathrm{nee}$ \\
\hline & & & Beïnvloedingsmogelijkheden e.o. & zeer groot - zeer klein \\
\hline & & & Beïnvloedingsmogelijkheden a.o. & zeer groot - zeer klein \\
\hline & \multirow{3}{*}{$\begin{array}{l}\text { 5B. THROUGHPUT- } \\
\text { LEGITIMITEIT }\end{array}$} & \multirow{3}{*}{ Transparantie } & Helderheid wie, wanneer, waarover beslist & zeer helder- zeer onhelder \\
\hline & & & Helderheid wensen \& voorkeuren actoren & zeer helder-zeer onhelder \\
\hline & & & Helderheid honorering \& argumentatie & zeer helder- zeer onhelder \\
\hline & \multirow{3}{*}{$\begin{array}{l}\text { 5C. OUTPUT- } \\
\text { LEGITIMITEIT }\end{array}$} & \multirow{3}{*}{ Steun voor plannen } & Rekening met wensen/voorkeuren & zeer veel - zeer weinig \\
\hline & & & Mate van commitment & zeer sterk - zeer zwak \\
\hline & & & Aanvaardbaarheid als compromis & zeer groot - zeer klein \\
\hline
\end{tabular}

Tabel 4.2 Operationalisering publiek belang 


\subsection{Aanpak case analyse}

Het ontwikkelde conceptueel raamwerk is gebruikt in de empirische analyse. Het raamwerk dient als basis voor de structurering van de data-verzameling en data-analyse. Het vervolg van dit hoofdstuk geeft de aanpak van de case analyse weer. Allereerst wordt aandacht besteed aan de selectie van cases.

\subsubsection{Case-selectie}

In het eerste hoofdstuk is beargumenteerd dat als onderzoeksmethode een meervoudige case-studie wordt uitgevoerd. In case-studie onderzoek dat is gericht op het ontwikkelen van theorie is het gebruikelijk de cases te selecteren op basis van theoretische overwegingen (Eisenhardt, 1989). Letterlijke replicatie - om gelijke resultaten te voorspellen - of theoretische replicatie - om verschillende resultaten te produceren op basis van vooraf gespecificeerde plausibele redenen - dient de basis zijn voor de selectie van meerdere cases (Cook en Campbell, 1979: p.78; Yin, 1994: p.47; e.a.). In dit onderzoek is letterlijke of theoretische replicatie echter om een aantal redenen problematisch.

Een eerste reden is dat het replicatieprincipe veronderstelt dat men op grond van beschikbare theorie geïnteresseerd is in het effect van een zeer beperkt aantal variabelen en cases daarop selecteert. In deze studie is echter sprake van een redelijk groot aantal mogelijk relevante variabelen over wier relatieve relevantie op grond van beschikbare theorie weinig bekend is. Het publiek belang kent meerdere dimensies en ten aanzien van de vraag op welke wijze het samenstel van actoren in het planproces ingrijpt op deze dimensies, zijn er een behoorlijk aantal factoren dat mogelijk een rol speelt. Het explorerende karakter van het onderzoek en het grote aantal variabelen dat mogelijk een rol speelt, noodzaakt ertoe cases in de diepte te bestuderen. Praktische beperkingen van tijd, geld en energie zorgen er echter voor dat slechts een zeer beperkt aantal cases bestudeerd kan worden.

Een tweede reden is dat het planproces van stationslocatieprojecten is bestudeerd op het moment dat de projecten zich aan het einde van de fase van planvorming bevinden. De keuze om het planproces te bestuderen op het moment dat het nog loopt, is gemaakt omdat reconstructie nadat het project volledig gerealiseerd is, kan leiden tot bevooroordeelde resultaten. Het succes of falen van het totale project kan in dat geval het oordeel over de mate waarin het publiek belang in de fase van planvorming wordt gewaarborgd, beïnvloeden. Daarnaast is een praktische overweging dat de informanten veelal nog actief zijn binnen dezelfde organisatie en daardoor eenvoudiger benaderbaar zijn.

Een derde reden is gelegen in het gegeven dat er slechts weinig cases beschikbaar zijn. In principe gelden er voor het aantal cases dat in het onderzoek wordt betrokken geen theoretische beperkingen. Integendeel; hoe meer cases, hoe groter de controle op de betrouwbaarheid van de resultaten (Swanborn, 1994; p.327; Yin, 2003: p.51). Het aantal projecten dat de grootschalige herontwikkeling van een station en de directe omgeving daarvan betreft en zich in de fase van planvorming bevindt, is in Nederland echter beperkt. 
Voorgaande redenen zorgen ervoor dat replicatie moeilijk realiseerbaar is in deze studie. Indien cases niet geselecteerd kunnen worden op basis van dit principe is een risico dat variabelen door elkaar heen lopen. In dat geval bestaat het gevaar dat slechts factoren worden beschreven die tegelijk als 'positief' gelden en situaties waarin het omgekeerde geldt, maar dat inzicht in de relatieve sterkte van deze factoren, hun onderlinge verwevenheid en mogelijke interacties, niet kan worden verworven (Swanborn, 1995). Om dit gevaar tegen te gaan adviseren Miles en Hubermann (1994) om een caseordered predictor outcome matrix te gebruiken. Deze matrix geeft een eerste inzicht in de wijze waarop diverse factoren gezamenlijk bijdragen aan verschillende waarden op een bepaald criterium (Miles en Hubermann, 1994: p.217). Vervolgens kunnen uitspraken worden gedaan over het relatieve gewicht van verschillende factoren door te kijken naar 'het verhaal' van de case waaruit veelal blijkt welke relaties in het bijzonder van belang zijn (Miles en Hubermann, 1994: p.237).

Om aan de hand van de empirische data van een beperkt aantal cases gericht de relatie tussen $\mathrm{X}$ (het samenstel van actoren in het planproces) en $\mathrm{Y}$ (de effectiviteit en legitimiteit van planvorming) te kunnen bestuderen, dient de invloed van de context waarin de cases zich bevinden zo veel mogelijk gelijk te zijn (ceteris paribus).

Daarom geldt als eerste criterium dat alleen projecten worden bestudeerd die de integrale herontwikkeling van een Nederlands treinstation en de directe omgeving daarvan betreffen. In hoofdstuk vijf worden de kenmerken van deze projecten nader beschreven. Vanuit het argument van een vergelijkbare context is alleen gekeken naar de herontwikkeling van (zeer) grote stationslocaties in centra van (middel)grote steden. Juist deze projecten kennen een hoge mate van inhoudelijke en procesmatige complexiteit doordat veel ruimtelijke functies in het gebied aanwezig zijn, daarmee samenhangende vraagstukken verweven zijn, veel actoren - waaronder meerdere bestuurslagen - een belang hebben in het project en de inbreng van verschillende partijen noodzakelijk is om tot herontwikkeling te komen. Deze kenmerken zorgen ervoor dat het bij uitstek in deze projecten lastig is het publiek belang te typeren en te borgen.

Een tweede criterium is dat de projecten zich nog in de planvormingfase te bevinden. Dit voorkomt dat de opvattingen over het uiteindelijke resultaat, zijnde de gerealiseerde projecten, de perceptie van (de effecten van) de inrichting van planprocessen bevooroordelen (Van de Ven, 1992). Daarnaast is juist in de fase van planvorming de interactie tussen (bestuurlijke) partijen vaak groot en kan retrospectief oordeel na langere tijd lastiger worden. Een meer pragmatische reden is dat de zeer lange doorlooptijd van deze projecten ervoor zorgt dat de destijds betrokken personen niet meer verbonden zijn aan dezelfde organisatie. Op basis van deze criteria zijn in dit onderzoek een drietal cases bestudeerd; Den Haag Nieuw Centraal, Stationskwartier Breda en Spoorzone Delft.

Den Haag Nieuw Centraal betreft de integrale herontwikkeling van een gebied van ongeveer zestien hectare in en rondom het Haagse Centraal Station. Het is een van de zes stations die onder de noemer van Nieuwe Sleutelprojecten in het kader van de aanleg van het Nederlandse deel van de hogesnelheidslijn (HSL) wordt aangepakt.

De herontwikkeling van het Stationskwartier Breda maakt onderdeel uit van de bredere aanpak van het gehele spoorzonegebied in Breda. Mede door de aanleg van de shuttleverbinding met de hogesnelheidslijn wordt hier het station herontwikkeld tot een integrale OV-terminal en wordt de directe omgeving eveneens aangepakt. 
Het project Spoorzone Delft behelst de integrale herontwikkeling van een gebied van circa 30 hectare, tussen de binnenstad van Delft en de woonwijken ten westen en zuiden daarvan. Centraal in de plannen voor dit gebied ligt de ontwikkeling van een nieuw openbaar vervoersknooppunt ter vervanging van het bestaande centraal station.

\subsubsection{Data verzameling}

Het opgestelde conceptueel raamwerk vormt een leidraad voor de dataverzameling. De data over de elementen uit het raamwerk is verzameld door gebruik te maken van twee bronnen: interviews en documenten analyse.

\section{Interview data}

De factoren aan de hand waarvan de inrichting van het planproces en de borging van het publiek belang in deze studie zijn bestudeerd, zijn vertaald naar een vragenlijst. De hanteerbaarheid van de vragenlijst is getest in een pilot. Daarvoor is in het project Den Haag Nieuw Centraal een eerste interviewronde uitgevoerd begin 2006. Op basis hiervan is het protocol voor de case studies en de vragenlijst aangepast. Medio 2007 is voor de drie cases een uitgebreide interviewronde uitgevoerd. Daarvoor zijn in totaal 21 interviews uitgevoerd met projectmanagers van organisaties die op grond van bestuurlijke verantwoordelijkheden of eigendomsposities betrokken zijn in het planproces. Concreet betekent dit dat voor elke case interviews zijn gehouden met de betreffende gemeente, de regio en/of de provincie, het ministerie van Verkeer en Waterstaat, het ministerie van VROM, ProRail, NS Poort en een of meerdere private ontwikkelaar(s). Het gehanteerde protocol, de vragenlijst voor de interviews en de namen van de personen die zijn geinterviewd zijn opgenomen in de bijlage. De kwalitatieve en kwantitatieve resultaten van de interviews zijn vervolgens per case gedigitaliseerd en opgenomen in een database. De conceptteksten, die op basis van interviews zijn opgesteld, zijn ter controle aan de geïnterviewden voorgelegd.

\section{Schriftelijke documenten}

Gedurende het ontwikkelingsproces van ruimtelijke projecten worden veelal een groot aantal documenten opgesteld. Deze documenten beschrijven bijvoorbeeld ruimtelijk-functionele programma's, economische haalbaarheid, beleidskader, milieu- en omgevingsaspecten, enzovoort. Voor deze studie is gebruik gemaakt van o.a. bestemmingsplannen, masterplannen, intentie-, proces-, en samenwerkingsovereenkomsten, bestuurs-/voortgangsrapportages en documenten waarin de projectorganisatie wordt beschreven. Om de feitelijke inbreng van de verschillende keystakeholders in het proces te beschrijven, zijn vooral formele overeenkomsten en andere officiële documenten waarin afspraken tussen partijen zijn vastgelegd, bestudeerd.

\subsubsection{Data analyse}

Het analyseren van de verzamelde data vormt de kern van het ontwikkelen van theorie op basis van case-studie onderzoek (Eisenhardt, 1989). In het onderhavige onderzoek is elke case in de diepte bestudeerd om bekend te geraken met de case als een op zichzelf staande eenheid (within-case analyses). Daarnaast zijn de cases vergeleken met elkaar (cross-case analyse). 


\section{Within-case analyse}

Het primaire uitgangspunt van de case-studie is de bestudering van het onderzochte verschijnsel in zijn context (Hutjes en Van Buuren, 1992: p.155). In het raamwerk dat geconstrueerd is op basis van de aan het slot van de hoofdstukken twee en drie onderscheiden factoren is een onderscheid gemaakt naar de algemene context en een projectspecifieke context (zie figuur 4.1). De algemene context voor stationslocatieprojecten wordt beschreven in het volgende hoofdstuk. Voor elke afzonderlijke case is de projectspecifieke context beschreven.

Een van de eerste stappen is dan ook het in kaart brengen van de betrokken actoren en hun positie en onderlinge relaties door middel van organisatie- of structuurschema's. Miles en Hubermann (1994) spreken in dit verband ook wel van een 'context chart'. Daarbij gaat het erom in beeld te krijgen welke actoren betrokken zijn en wat hun (organisatorische) positie is. Hiervoor zijn per case de betrokken actoren en de samenwerkingsorganisatie beschreven. Naast de organisatorische context is ook de ruimtelijke context is een belangrijke invalshoek om het onderzochte in kaart te brengen. Bij onderzoek in de sfeer van ruimtelijke ordening is dat een onmisbaar onderdeel (Hutjens en Van Buuren, 1992: p.155). Per case is daarom tevens de ruimtelijke opgave beschreven. Tenslotte is ook de reconstructie van de opeenvolging van bepaalde ontwikkelingen en gebeurtenissen in de tijd een belangrijk ordeningsprincipe voor de case-studie (Hutjens en Van Buuren, 1992: p.156). Een casestudie is namelijk geen momentopname, maar beschrijft het procesmatige karakter in de tijd. Per case is de projectgeschiedenis en het procesverloop aan de hand van belangrijke gebeurtenissen beschreven en ingedeeld in fasen.

Het tweede deel van de within-case studie analyse beschrijft de inrichting van het planproces, de onafhankelijke variabele. De factoren aan de hand waarvan de inrichting van het planproces is beschreven zijn in de vorige paragraaf uitgewerkt. Het gaat dan om de kenmerken (aantal, verhoudingen, ambivalentie) van het samenstel van actoren op drie thema's; visievorming (2) zeggenschap (3) middelen. Zowel voor het deelproces gericht op de totstandkoming van de masterplannen als voor het deelproces gericht op de totstandkoming van de plannen voor de OVterminal is de data die over deze factoren in de interviews en documenten is verzameld, geanalyseerd.

Het derde deel van de within case analyse belicht de borging van het publiek belang, de afhankelijke variabele. De factoren aan de hand waarvan een oordeel wordt gevormd over de borging van het publiek belang zijn in de vorige paragraaf geoperationaliseerd. Het gaat dan om een analyse van de effectiviteit en legitimiteit van de planvorming van de masterplannen en van de planvorming voor de OV-terminal. Voor een analyse van effectiviteit is per case de (verwachte) bijdrage van de plannen aan het realiseren van een hogere ruimtelijke kwaliteit bestudeerd. Voor een analyse van de legitimiteit is per case de legaliteit, openheid, transparantie en steun van betrokken actoren voor de voorliggende plannen bezien.

\section{Cross-case analyse}

De basisfilosofie van de in deze studie gekozen analysetechniek bestaat uit het vergelijken van de cases op een aantal relevant geachte factoren. In het voorgaande zijn deze factoren en de wijze waarop analyse van gegevens in de afzonderlijke cases plaats heeft beschreven. Zoals Hutjes en Van 
Buuren (1992: p.168) stellen is de grote lijn daarbij dat, uitgaande van een voorlopig conceptueel model, getracht wordt het verzamelde materiaal van relatief eenvoudige beschrijvende weergaven steeds verder in te dikken naar meer complexe representaties die een interpretatie inhouden van de processen die in het betreffende geval aan de orde zijn.

In de cross-case analyse wordt door vergelijking van cases op een aantal relevant geachte variabelen gezocht naar mogelijke relaties. Een belangrijke vraag daarbij is of er andere variabelen dan de onderscheiden onafhankelijke variabelen, een verklaring kunnen vormen voor verschillen in de afhankelijke variabele. Het gaat hier om de interne validiteit van de onderzoeksresultaten. Hoewel het beperkte aantal cases dat bestudeerd wordt het aantonen van verbanden niet eenvoudig maakt, kunnen door zorgvuldige procesanalyse en gebruik te maken van bepaalde case analysetechnieken verbanden aannemelijk worden gemaakt. Voorbeelden van deze technieken zijn 'pattern matching', 'explanation building', 'factor theory', 'adressing rival explanations', 'logic models' (Yin, 1989; Yin, 2003) en de 'case-ordered predictor outcome matrix' (Miles en Hubermann, 1994). Al deze technieken starten met een of andere vorm van voorgedefinieerd concept (bijvoorbeeld een veronderstelling op basis van bepaalde theoretische inzichten) Dat betekent dat de 'grounded theorie' benadering van Glaser en Strauss, buiten beschouwing blijft. In deze studie is vooral gebruik gemaakt van de techniek van pattern-matching en de 'case-ordered predictor-outcome matrix' van Miles en Hubermann (1994). ${ }^{101}$ Miles en Hubermann (1994: p.213) omschijven een predictor outcome matrix als: "a multivariate prediction mode, taking those predictor or antecent variables that we have good reason to believe are contributing to the outcomes, and assessing their separate and combined effects." Zij bevelen het gebruik van de case-ordered predictor outcome matrix aan als we willen zien hoe verschillende factoren samen functioneren in relatie tot de waarde van de afhankelijke variabele. Het is een op variabele georiënteerde analysetechniek, maar bewaart de configuratie van variabelen voor iedere case (Miles en Hubermann, 1994: p. 219).

Een belangrijke eerste stap in deze systematische vergelijking van cases is de ordening van de cases naar de afhankelijke variabele. Miles en Hubermann (1994) geven hiervoor enkele aanwijzingen en benadrukken dat: "the researcher has to define decision rules and march the data through them to be sure the ordering is not being skewed in the direction of a favoured insight of arresting empirical cluster" (Miles en Hubermann, 1994: p. 214). Aan de hand van beslisregels wordt aangegeven onder welke omstandigheden de afhankelijke variabele een van haar mogelijke waarden heeft. Vervolgstap is dat ook voor de onafhankelijke variabelen wordt bepaald welke waarden zij an kunnen nemen. Als de onderzochte cases zijn gegroepeerd op de waarde van de afhankelijke variabele en de waarden van de onafhankelijke variabelen zijn ingevuld ontstaat een verzamelmatrix. Een voorbeeld van een lege verzamelmatrix staat weergegeven in tabel 4.3 .

\begin{tabular}{l|l|l|l|l|l|l}
\multicolumn{2}{|c}{ Variabele A } & Variabele B & Variabele C & Variabele D & Variabele E & Variabele Z \\
Case 1 & & & & & & \\
\hline Case 2 & & & & & & \\
\hline Case 3 & & & & & & \\
\hline Case X & & & & & \\
\hline
\end{tabular}

Tabel 4.3 Lege verzamelmatrix 
Deze (quasi-)kwantitatieve analyse biedt de mogelijkheid een eerste inzicht te verkrijgen in het overheersende beeld dat in de afzonderlijke cases te onderkennen is. Vervolgens is de vraag in hoeverre in die gevallen bepaalde patronen zijn te ontdekken die onderling vergelijkbaar zijn of verschillen. Dit kan worden gedaan door per kolom de waarden van de betreffende onafhankelijke variabele en de waarde van de afhankelijke variabele na te gaan (iedere kolom van de matrix geeft de waarden aan van een bepaalde variabele over alle cases). Vervolgens kunnen de kolommen worden vergeleken.

In aansluiting hierop kan de analyse verschillende vormen aannemen. Met erkenning van het feit dat er in elke case projectspecifieke contextfactoren te onderkennen zijn, gaat het er bij Miles en Huberman (1994) dan om dat door ordening, indikking, abstractie en interpretatie gekomen worden tot uitspraken over verbanden. Uiteindelijk kan de meer variabelen georiënteerde aanpak verschuiven naar een meer case-georiënteerde aanpak.

Wordt de case-analyse techniek van Miles en Hubermann (1994) toegepast op dit onderzoek dan is de eerste stap dus een vergelijking van cases op de afhankelijke variabele, de borging van het publiek belang in termen van effectieve en legitieme vorming van plannen. De beslisregels waaronder deze subvariabelen effectiviteit en legitimiteit bepaalde waarden kunnen aannemen zijn beschreven in paragraaf 4.1.3. Als vervolgstap wordt dan bezien in hoeverre de cases ook verschillen op kenmerken waarvan verwacht wordt dat die ermee samenhangen. In deze studie gaat het dan om kenmerken van het samenstel van actoren. Daarvoor is gekeken naar de inbreng van actoren in het proces van visievorming, de verdeling van zeggenschap in dit proces en de middelen die door actoren worden ingebracht.

Als - zoals in dit onderzoek - het publiek belang wordt gezien als een concept dat meerdere dimensies kent en die dimensies intersubjectief gedeelde waarden betreffen, dan is het voor een oordeel over de borging van deze waarden logisch te kijken naar het geaggregeerde oordeel van partijen op de afzonderlijke dimensies. Om dezelfde reden zijn de kenmerken van het samenstel van actoren in het planproces ook mede gereconstrueerd door aggregatie van de percepties van betrokken partijen. Analyse op het niveau van individuele actoren betekent namelijk dat de inbreng van een actor in het planproces gerelateerd wordt aan het oordeel van de betreffende actor over de borging van het publiek belang. Conclusies zijn in dat geval in de trant van: "als een actor een grote inbreng heeft gehad in het planproces dan is het oordeel over de borging van het publiek belang positief" of "naarmate een actor een grotere inbreng heeft gehad in het planproces is het oordeel over de borging van het publiek belang positiever". Dergelijke conclusies geven geen antwoord op de vraag die centraal staat in de studie. De analyse van cross-case patronen is daarom gebeurd op geaggregeerd niveau. Indien de analyse aanleiding gaf bepaalde patronen te veronderstellen, is op het niveau van de individuele case(s) gekeken of hiervoor er een logische verklaring bestaat (Eisenhardt, 1989: p.540).

\subsubsection{Van data analyse naar theorieontwikkeling}

$\mathrm{Na}$ de within case-analyse en het zoeken naar cross-case patronen is het vormen van hypothesen de vervolgstap om theorie te ontwikkelen vanuit case studie onderzoek (Eisenhardt, 1989). Een vergelijking van opkomende ideeën, theorie of hypothesen met bestaande literatuur vormt een essentieel onderdeel van theorievorming (Yin, 1994). Er dient te worden vergeleken waar de bevindingen gelijk aan zijn, wat ze tegenspreken en waarom (Eisenhardt, 1989). De gaat er hier om of 
empirische bevindingen corresponderen met (theoretische) verwachtingen. Dit wordt ook wel pattern-matching genoemd (Yin, 1994). Het vergelijken van de bevindingen met bestaande literatuur die niet overeenkomen met de bevindingen kan het onderzoek versterken omdat het de onderzoeker dwingt buiten de grenzen van zijn eigen onderzoek te kijken. Literatuur die vergelijkbare bevindingen beschrijft is belangrijk om de interne validiteit van het onderzoek te vergroten. De empirische bevindingen uit deze studie zijn vergeleken met verwachtingen op grond van literatuur. Dit laat tevens zien hoe de bevindingen bijdragen aan bestaande kennis. 


\section{Hoofdstuk 5 \\ Stationslocaties}

\subsection{Inleiding}

In het vorige hoofdstuk is het raamwerk voor de empirische analyse en de aanpak daarvan beschreven. Onderdeel van het raamwerk vormt een beschrijving van de context. Een onderscheid is daarin gemaakt naar de algemene en de projectspecifieke context. De concepten uit de projectspecifieke context en de analyse van de inbreng van actoren in planvorming worden in de case-hoofdstukken (6-8) behandeld. In dit hoofdstuk wordt de algemene context van planprocessen bij de herontwikkeling van stationslocaties, geschetst. Daarvoor worden achtereenvolgens de kenmerken van stationslocatieprojecten als vorm van gebiedsontwikkeling (5.3), het beleidskader op rijksniveau (5.4), relevante procedures en regelgeving (5.5) en keystakeholders beschreven (5.6). Gestart wordt met een korte schets van de geschiedenis van stationslocaties (5.2).

\subsection{De geschiedenis van stationslocaties}

De geschiedenis van stationslocaties is terug te voeren tot 1814. Nadat George Stephenson in dat jaar de eerste praktisch bruikbare stoomlocomotief gebouwd had, kwamen er al snel spoorlijnen en werden stations gebouwd waar men kon op- en afstappen. In Nederland werden de eerste stations gebouwd in 1839 in Amsterdam en Haarlem. ${ }^{102}$ De eerste stationsgebouwen waren eenvoudige gebouwtjes want de vervoersstromen waren aanvankelijk beperkt. Met de toename van de populariteit van het vervoer per spoor namen stations niet alleen in omvang toe, maar werd ook meer aandacht besteed aan de architectuur ervan. Vooral in grote Europese steden, waar diverse spoorwegmaatschappijen hun belangrijkste stations hadden, werden stations gebouwd waarmee de betreffende maatschappij door omvang, vormgeving en detaillering een solide aanzien trachtte te verwerven: het station fungeerde als visitekaartje van de spoorwegmaatschappij. In Nederland werd omstreeks 1860 gekozen voor het uitgangspunt om de aanleg van nieuwe spoorlijnen niet meer aan particulier initiatief over te laten maar van overheidswege te sturen. Hiermee werd voorkomen dat er op trajecten parallelle verbindingen zouden ontstaan. Het beginsel van 'aanleg door de staat, exploitatie door particulieren' leidde niet alleen tot de aanleg van nieuwe spoorlijnen, maar tevens van een groot aantal stations. Vanaf 1863 werden de meeste hiervan geëxploiteerd door de Maatschappij tot Exploitatie van de Staatsspoorlijnen en de bouw van stations werd - volgens standaardontwerp met vijf klassen afhankelijk van de grootte van de plaats - gedaan door de overheidsdienst Waterstaat. Stations werden in die periode gezien als voorbodes en symbool van vooruitgang. Stations als Gare du Nord Parijs, Victoria Station Londen, Antwerpen Centraal die in de tweede helft van de 19e eeuw in gebruik werden genomen zijn gebouwd als ware kathedralen. ${ }^{103}$ Het vervoer per spoor begon in die periode aan een ware opmars en spoorgerelateerde ondernemingen vestigden zich in de directe omgeving van stations. In veel grote Europese steden werden stations gebouwd aan de rand van de stad waar de oude stadsmuren hun functie hadden verloren. Alle grote Europese steden hebben dan 
ook eindstations in hun buitenwijken. Voorbeelden hiervan zijn St. Pancras station Londen en Gare $\mathrm{du}$ Nord in Parijs. Steden groeiden snel, zowel qua inwonersaantal als qua ruimtegebruik. Binnen steden werden openbaar vervoerssystemen opgezet, om spoorstations te verbinden en transport binnen de steden te verbeteren. Een voorbeeld hiervan is de Circle Line van de Londen Underground (Wagenaar, 1998). Aan het begin van de twintigste eeuw ging de bouw van stations onverminderd door. De eerste wereldoorlog en de crisisjaren zorgden echter ook voor een crisis bij de spoorwegmaatschappijen. Hoewel er nog diverse stations gebouwd werden was het tijdperk van de grootse stations voorbij. $\mathrm{Na}$ de Tweede Wereldoorlog waren veel stations gedeeltelijk of totaal verwoest. Al snel werd echter begonnen met de wederopbouw. Vanaf midden jaren zestig van de vorige eeuw en waren ook in Nederland de gloriedagen van het spoorvervoer echter voorbij. Er ontstond een trek naar stadsranden, sub-urbs en buitengebieden. De auto werd hét vervoermiddel van de moderne tijd en monumentale stationsgebouwen werden op diverse plaatsen gesloopt of gereduceerd tot halteplaatsen voor groepen die zich geen auto konden permitteren. Vervoer per spoor was uit en daarmee het station als icoon en symbool van vooruitgang (Ministerie van VROM, 2006).

Economische, ruimtelijke en maatschappelijke ontwikkelingen hebben er echter voor gezorgd dat stations de afgelopen decennia min of meer zijn herontdekt (Bertolini en Spit, 1998). ${ }^{104}$ Vestigingspatronen zijn diffuser geworden, een ontwikkeling die ook wel wordt aangeduid als 'urban sprawl', files op de wegen zorgden voor steeds grotere problemen rondom de steden en meer aandacht ontstond voor de negatieve millieueffecten van autogebruik. Gaandeweg begon een hernieuwde belangstelling voor spoorvervoer te ontstaan en werd er weer geïnvesteerd in diverse vormen van railinfrastructuur. In het kader van het Trans Europese Transport Netwerk (Europese Commissie, 2005) wordt een netwerk voor hogesnelheidstreinen aangelegd en bij de halteplaatsen worden diverse stations en omliggende gebieden herontwikkeld. Londen en Parijs, maar ook Euralille (Lille) en diverse stations in Duitsland in het kader van het zogenaamde Projekte 21 laten grootschalige voorbeelden hiervan zien. Niet alleen in Europa, maar ook in de Verenigde Staten is onder de noemer van Transit Orientated Development ${ }^{105}$ tegenwoordig veel aandacht voor hoge bebouwingsdichtheden rondom stationslocaties en ook in Azië heeft vastgoedontwikkeling op en rondom grote stations een grote vlucht genomen. ${ }^{106}$

Deze studie richt zich op de herontwikkeling van binnenstedelijke stationslocaties in de Nederlandse context. Hier zijn de hernieuwde en hoge ambities voor stationslocaties ingezet met de Vierde Nota Ruimtelijke Ordening, waarin de ontwikkeling van deze locaties werd gezien als een belangrijk wapen tegen onnodige automobiliteit en voor stedelijke vernieuwing (Peek, 2006; Ministerie VROM, 1988). Deze ambities zijn sinds het verschijnen van deze Vierde Nota alleen maar gegroeid. Terwijl de Nota Mobiliteit (2004) voor de periode 2000-2020 nog uit ging van een gemiddelde groei van het personenvervoer per spoor van $1 \%$ per jaar ${ }^{107}$, gaat NS op basis van marktinschattingen en voorgenomen inspanningen al uit van een jaarlijkse groei van $2,5 \%$ tot $3 \%$ en stond in het coalitieakkoord van het kabinet Balkenende IV opgenomen dat "de ambitie voor de groei van het openbaar vervoer per spoor wordt bijgesteld naar $5 \%$ per jaar, de realisatie van de afgelopen twee jaar". Het bijstellen van de groeiverwachting uit de Nota Mobiliteit blijkt ook uit de Landelijke Markten Capaciteitsanalyses (Ministerie V\&W, 2007a). Ook voor het goederenvervoer per spoor is de verwachting dat deze zich in de periode tot 2020 zal verdrievoudigen, de bovenkant van de 
verwachting in de Nota Mobiliteit. ${ }^{108}$ Naast de toenemende vraag naar mobiliteit is er ook een toenemende vraag naar ruimte. ${ }^{109}$ In de Vijfde Nota Ruimtelijke Ordening (Ministerie van VROM, 2000) werd beschreven dat nieuwe ruimte voor kantoren, wonen en winkels moest worden gevonden binnen de 'rode contouren', het bestaande stedelijke gebied. De Nota Ruimte (Ministerie VROM, e.a., 2004) maakte dat beleid wat minder rigide, maar vereist nog steeds dat $40 \%$ van alle nieuwe stedelijke ontwikkeling plaats vindt binnen stedelijke grenzen. Ook in recentere nota's wordt dit percentage als streven gehanteerd (Ministerie VROM, 2008; VROM-raad, 2009). Dat betekent dat een belangrijke ruimtelijke opgave is gelegen in transformatie van bestaand stedelijk gebied. Railned (onderdeel van ProRail) becijferde dat er 40.000 hectare grond ligt naast sporen waarvoor geen ontwikkelingsplannen bestaan (Brandsma, 2001). Een substantieel deel van die gronden ligt in stedelijk gebied. Ontwikkeling van deze gronden sluit aan bij de verstedelijkingsopgave waarvoor het kabinet Balkenende IV zich gesteld heeft. Speerpunt van het huidige nationaal ruimtelijk beleid is de ontwikkeling van stedelijke netwerken. Centrumvorming en knooppuntontwikkeling wordt voor de kracht van deze netwerken essentieel geacht.

Tezamen verklaren deze factoren de recente aandacht voor stationslocaties en spoorzones. In diverse steden wordt tegenwoordig dan ook gestreefd naar het verhogen van de ruimtelijke kwaliteit in en rond stations en in de directe omgeving daarvan. Prioriteit wordt daarbij gegeven aan de zogenaamde Nieuwe Sleutelprojecten, een zestal stationslocaties in het kader van de aanleg van de Hogesnelheidslijn (HSL). In navolging van Frankrijk en Duitsland werd ook in Nederland de ontwikkeling van de HSL als concurrent voor het vliegtuig op de middellange afstand in Europa aangegrepen voor de verbouwing van de bestaande stations tot nieuwe openbaar vervoersterminals. De Nederlandse overheid tracht investeringen in de HSL te koppelen aan een economische impuls voor de halteplaatsen, zodat deze een zogenaamd 'multipliereffect' bewerkstelligen in de stedelijke centra. In het regeerakkoord van het tweede paarse kabinet stond als opgave voor de Nieuwe Sleutelprojecten het creëren van vestigingslocaties met internationale uitstraling vermeld.

Tegenwoordig is de inzet van het rijksbeleid om stations te verbouwen tot multimodale knooppunten die het hart vormen van vitale centrumgebieden waar gewoond en gewerkt wordt (Ministerie van VROM, 2006). Deze ambitie blijft niet alleen beperkt tot grote internationale stations, maar een zelfde benadering geldt voor stations in middelgrote gemeenten. Gemeenten zien de herontwikkeling van hun binnenstedelijke stationslocatie veelal als een kans om een gat in de stad te vullen, de spoorbarrière te doorbreken, het netwerk van lokaal openbaar vervoer te verbeteren, een aantrekkelijke locatie aan de kantorenmarkt toe te voegen en, bij gemeentelijk grondeigendom op de stationslocatie, grondopbrengsten te genereren; bovenal wil men een aangename entree naar het stadscentrum creëren (Peek, 2006). In tal van grote en minder grote plaatsen is of wordt aan de verbetering van het station en de omgeving gewerkt. ${ }^{110}$ Samen vormen de plannen een groot deel van de binnenstedelijke herontwikkelingsopgave in Nederland. Het gaat om grote investeringen en programma's. Tabel 5.1 geeft een beeld van de ontwikkelingsopgave en de investeringen van het Rijk bij de nieuwe sleutelprojecten. Totaal gaat het om een rijksbijdrage van ongeveer 1,5 miljard euro. De totale investeringen (publiek en privaat) in openbaar gebied bedraagt naar schatting vier miljard euro en de investeringen in vastgoed door private partijen zijn een veelvoud hiervan (Ministerie VROM, 2003). 


\begin{tabular}{llllllll} 
& Amsterdam & Rotterdam & Den Haag & Utrecht & Arnhem & Breda & Totaal \\
Kantoren (m2) & 985.000 & 183.000 & 114.500 & 178.500 & 80.000 & 117.000 & 1.685 .000 \\
Woningen (m2) & 1.000 .000 & 84.000 & 53.000 & 247.400 & 7000 & 74.000 & 1.465 .400 \\
Voorzieningen (m2) & 320.000 & 19.000 & 132.000 & 145.400 & 5.900 & 14.500 & 636.800 \\
Totaal (m2) & 2.362 .000 & 220.000 & 299.500 & 571.300 & 97.000 & 205.000 & 3.760 .200 \\
Plangebied & $225 \mathrm{ha}$. & $20 \mathrm{ha}$. & $16 \mathrm{ha}$. & $100 \mathrm{ha}$. & $24 \mathrm{ha}$. & $12,6 \mathrm{ha}$. & $397,6 \mathrm{ha}$. \\
Rijksbijdrage (€) & $653 \mathrm{mln}$. & $215 \mathrm{mln}$. & $130 \mathrm{mln}$. & $307 \mathrm{mln}$. & $84 \mathrm{mln}$. & $62 \mathrm{mln}$. & $1.435 \mathrm{mln}$. \\
Initiatief & 1994 & 1995 & 1996 & 1086 & 1989 & 1998 & \\
Start & & 2005 & 2004 & 2007 & 1997 & 2006 & \\
Realisatie & 2030 & 2020 & 2011 & 2017 & 2011 & 2015 & \\
\hline
\end{tabular}

Tabel 5.1 Nieuwe Sleutelprojecten (Ministerie VROM, 2006)

Zowel bij publieke als private partijen bestaat tegenwoordig een besef dat rondom hernieuwde stations een aantrekkelijk stedelijk gebied met hoge dichtheid kan ontstaan. Het station moet in die filosofie weer de rol van 'poort naar de stad' krijgen met een OV-terminal die hernieuwde invulling geeft aan de kathedralen die de stationsgebouwen van vroeger waren. Veel aandacht gaat daarbij uit naar het combineren van de transportfunctie met stedelijke ontwikkeling met een hoge dichtheid in de directe omgeving van de openbaar vervoersknooppunten.

\subsection{Kenmerken van stationslocaties}

De toenemende vraag naar ruimte en mobiliteit gecombineerd met steeds hoger wordende eisen ten aanzien van ruimtelijke kwaliteit heeft ertoe geleid dat er gestreefd wordt naar het combineren, transformeren en intensiveren van functies in bestaand stedelijk gebied (VROM, 2000). Stationslocaties zijn voorbeelden bij uitstek waar verschillende functies samenkomen. Voor de aanpak van stations en het omliggende gebied wordt daarom een gebiedsgerichte benadering voorgestaan.

\subsubsection{Integrale gebiedsontwikkeling: multi-functie en multi-actor}

Een integrale gebiedsgerichte benadering heeft betrekking op het afstemmen van ontwikkelingen in ruimtelijk functionele zin, maar betekent tevens afstemming tussen verschillende niveaus, sectoren en fasen van de ontwikkeling en tussen de partijen die daarbij betrokken zijn. Een dergelijk integrale benadering van een gebied waarin functies in onderlinge samenhang worden ontwikkeld werd door het voormalige kenniscentrum PPS (Ministerie van Financiën, 2003: p.11) gedefinieerd als:

"het komen tot afstemming van relevante functies (wonen, werken, recreëren, mobiliteit, etc.) en belangen (publiek en privaat) leidend tot de beste totaaloplossing voor het betreffende plangebied. De beste totaaloplossing is die oplossing, waarin voor elke belanghebbende de verhouding tussen de potentiële meerwaarde en gevraagde investering is geoptimaliseerd."

Bruil et al. (2004: p.397) definiëren integrale gebiedsontwikkelingen als:

\footnotetext{
"opgaven die leiden tot de functionele en fysieke verandering van een (stedelijk) gebied, waarbij de mate van integraliteit wordt bepaald door de mate waarin het bestaande wordt veranderd en waarin diverse ruimtelijke schaalniveaus, wijzigingen van eigendomsverhoudingen, randvoorwaarden en expertise uit verschillende beleidssectoren, belangen van betrokken partijen, fysiekruimtelijke aspecten en technische, juridische, politieke, economische, demografische, ecologische en sociaal-culturele voorwaarden met elkaar in verband worden gebracht en als één opgave worden opgepakt."
} 
De achterliggende gedachte bij het pleidooi voor een integrale gebiedsgerichte benadering is dat verschillende functies in een gebied onderling een grote samenhang kennen. Ruimtelijke kwaliteit lijkt positief samen te hangen met een hoge mate van diversiteit en een belangrijke determinant van diversiteit is functiemenging (Van der Wouden, 1999). Zeker in een stedelijke omgeving zorgt dit voor een hoge mate van complexiteit. Projecten in een stedelijke omgeving kenmerken zich namelijk door een aantal aspecten (Van Twist et al., 2004). In de eerste plaats gaat het om vraagstukken die elkaar overlappen. Problemen zijn vaak niet los van elkaar te zien. Ze hebben dezelfde oorzaken, te maken met dezelfde effecten van andere problemen of hebben andere raakvlakken met elkaar. In de tweede plaats is er sprake van schaalvariëteit. Meerdere overheden op verschillende bestuurslagen spelen een rol. Ook al speelt het project zich af op één schaalniveau, er zullen toch andere overheden betrokken zijn voor bijvoorbeeld goedkeuring van plannen of het (mede) beschikbaar stellen van financiële middelen. Een ander aspect is de benodigde ruimte voor betrokkenen. Vaak gaat het om fysieke ruimte en ruimte in het proces. Veel partijen hebben een belang in stedelijke projecten en er is ruimte voor inbreng en betrokkenheid van deze partijen nodig om het project te realiseren. Daarnaast worden stedelijke projecten gekenmerkt doordat aspecten vanuit verschillende invalshoeken zijn te bekijken. Elke actor zal anders tegen een bepaald vraagstuk aankijken en betrokkenen hebben verschillende wensen en voorkeuren ten opzichte van het project. Doordat stedelijke gebieden verschillende functies vervullen, zijn er ook meerdere doelstellingen aan het gebied toe te schrijven. Deze doelstellingen hebben vaak een verschillende tijdshorizon. Tenslotte is dynamiek een belangrijk aspect. Beleid kan gedurende de looptijd van het project veranderen en door de raakvlakken met de omgeving en de ontwikkelingen en trends die zich daarin voordoen wordt het project tevens beïnvloed.

De beschreven kenmerken van stedelijke gebiedsontwikkeling zorgen ervoor dat door een integrale benadering meer samenhang tussen de verschillende functies in het gebied ontstaat, waardoor synergie kan worden bereikt in ruimtelijke, functionele en/of financiële zin. Samenhang heeft betrekking op de ruimtelijke en functionele integratie van projectonderdelen, maar ook met de wisselwerking van het project als geheel met voorzieningen in de omgeving (ORI, 1991). ${ }^{111}$ Voor vastgoed geldt bijvoorbeeld dat de functionaliteit en waarde(ontwikkeling) in sterke mate wordt bepaald door de relatie met de directe omgeving.

De afstemming tussen de diverse partijen, die betrokken zijn vanuit verschillende bestuursniveaus, (beleids)sectoren en in verschillende fasen van de ontwikkeling een rol spelen, wordt als essentieel gezien om genoemde synergie te bereiken (Taskforce PPS en gebiedsontwikkeling, 2002). Er is echter een duidelijke spanning te onderkennen tussen enerzijds het streven naar samenhang door een integrale aanpak en anderzijds de fragmentatie in partijen, doelen, middelen, investeringsmogelijkheden en tijdpaden. De betrokkenheid van een groot aantal actoren met uiteenlopende belangen en doelstellingen zorgt voor een hoge mate van complexiteit. Uit praktijkonderzoek komt naar voren dat de afstemming tussen de diverse betrokken partijen nogal eens te wensen overlaat (P3BI, 2001, 2002; Canoy et al., 2001). De wijze waarop de bestuurlijke organisatie is geregeld en de wijze waarop het bestaande instrumentarium is vormgegeven sluit meer aan bij separate ontwikkeling dan bij een integrale aanpak. Er zijn niettemin diverse initiatieven te onderkennen waarmee wordt getracht een integrale aanpak te bevorderen. Voorbeelden hiervan zijn 
de integratie van de 'Ruimte component' in het $\mathrm{MI}(\mathrm{R}) \mathrm{T}$ en het samenvoegen van het rijksvastgoed en ontwikkelingsbedrijf (RVOB).

Naast afstemmingsproblemen kunnen ook andere argumenten worden aangedragen die pleiten voor separate ontwikkeling van functies. Zo wordt onder andere gesteld dat integratie van functies in een keten kan leiden tot een vermindering van marktspanning (Dorée, 2001). Twee factoren worden daarvoor aangedragen; In de eerste plaats kan het aantal aanbieders door integratie van activiteiten beperkter worden en in de tweede plaats bestaat bij vergaande integratie het risico dat de uitvoerende partij door (zelfgeïntroduceerde) complexiteit en samenhang zichzelf onmisbaar maakt. Tevens wordt als tegenargument aangedragen dat de transparantie het grootst is indien functies helder van elkaar te onderscheiden zijn. Zodra diverse functies opgaan in een integrale aanpak bestaat het risico dat prestatie-indicatoren lastiger traceerbaar zijn.

Ondanks tegenargumenten is het pleidooi voor integrale anpak en een gebiedsgerichte benadering sterk. In de Nota Ruimte, waarin een sturingsfilosofie en een ruimtelijke visie op de ontwikkeling van Nederland voor de komende decennia wordt beschreven, wordt voor de uitvoering van beleid een integrale aanpak nadrukkelijk bepleit. Ook in de uitwerking van deze nota in vier andere nota's, waaronder de Nota Mobiliteit (Ministerie V\&W, 2004) komt dit pleidooi veelvuldig terug. ${ }^{112}$ Coördinatie van rijksbeleid en bundeling van rijksmiddelen, meer ruimte voor decentrale overheden en doelbewuste samenwerking tussen overheden en private partijen worden beschouwd als noodzakelijke elementen voor een succesvolle uitvoering van beleid. ${ }^{113}$ Het pleidooi voor een meer gebiedsgerichte integrale benadering is ook in uitvoeringsinstrumenten terug te vinden. In de Wet Stedelijke Vernieuwing ${ }^{114}$ wordt gesteld dat een samenhangende aanpak vereist is om de aantrekkelijkheid van de steden voor zowel bedrijven als bewoners te vergroten en wordt onder andere door middel van het Investeringsbudget Stedelijke Vernieuwing (ISV) ${ }^{115}$, het Investeringsbudget Landelijke Gebied (ILG) en de Brede Doel Uitkering (BDU) getracht de versnipperde inzet van rijksinvesteringsbudgetten tegen te gaan. Ook in publicaties van adviesraden en kenniscentra van de overheid wordt gepleit voor een gebiedsgerichte werkwijze (Raad voor Verkeer en Waterstaat, 1998; Ministerie van Financiën, 2004; e.a.). ${ }^{116}$

\subsubsection{Het gebiedsontwikkelingsproces}

Het proces van gebiedsontwikkeling is in te delen in vier fasen; initiatief, voorbereiding, uitvoering en gebruik (Peek, 2006; Ministerie van Financiën, 2004). ${ }^{117}$ In de praktijk van gebiedsontwikkeling zullen deze vier fasen elkaar niet volledig sequentieel opvolgen, maar zal er sprake zijn van parallelle trajecten, waarbij verschillende delen van een gebied zich in verschillende fasen bevinden. In de initiatief- of verkenningsfase leggen de initiatiefnemers de ambities voor de gebiedsontwikkeling vast. Dit kan bijvoorbeeld in de vorm van een startvisie of nota van uitgangspunten. Stakeholders proberen in deze fase veelal een positie in het proces te verwerven. In de voorbereidings- of planvormingsfase worden de voorbereidingen voor de realisatie van de ruimtelijke ingreep getroffen. De geformuleerde uitgangspunten worden vertaald in een ruimtelijk-functioneel ontwerp. Deze krijgt veelal de vorm van een Masterplan waarin het Stedenbouwkundig Programma van Eisen is neergelegd. Dit Masterplan vormt de basis voor deelplannen en sectorale ontwikkelingsplannen voor bijvoorbeeld de buitenruimte en verkeerscirculatie. Het is echter ook mogelijk dat in het verleden al plannen voor bepaalde onderdelen of deelgebieden zijn ontwikkeld en dat deze plannen worden 
opgenomen in het Masterplan. Parallel aan de ruimtelijke vormgeving worden vrijwel altijd exploitatieplannen gemaakt, die zicht moeten bieden op het functioneren van het gebied in de gebruiksfase en eveneens parallel verloopt het planologisch-juridische traject. In de uitvoerings- of realisatiefase gaat het om grond- en opstalontwikkeling. Na de realisatie breekt de gebruiksfase aan, waarin de opstallen en de inrichting van de openbare ruimte door de eigenaren worden geëxploiteerd. De exploitatie, het beheer en het onderhoud van de opstallen zijn vaak in handen van private eigenaren en/of gebruikers, die deze taken meestal uitbesteden aan derden. De overheid is veelal verantwoordelijk voor het beheer en het onderhoud van de openbare ruimte (Peek, 2006).

Gedurende het proces van gebiedsontwikkeling vindt op verschillende momenten besluitvorming plaats. Tevens gaan partijen overeenkomsten aan waarin wordt vastgelegd wat de eisen en wensen zijn waaraan het plan moet voldoen en hoe de partijen de hun ter beschikking staande hulpbronnen aan het project zullen toekennen. Er zijn drie typen overeenkomsten te onderscheiden, namelijk privaatrechtelijke overeenkomsten tussen publieke en private partijen, privaatrechtelijke overeenkomsten tussen publieke partijen onderling en publiekrechtelijke overeenkomsten. De initiatieffase wordt afgesloten met een of meerdere intentie- of voorovereenkomst(en), waarin is vastgelegd welke producten de volgende fase moet opleveren en wat de rolverdeling tussen partijen daarbij moet zijn.

In de voorbereidings- of planvormingsfase worden de resultaten van de in de intentie- of voorovereenkomst(en) afgesproken producten gebruikt om te komen tot realisatieovereenkomsten, of samenwerkingsovereenkomsten wanneer de realisatie niet direct op deze fase volgt of gefaseerd over een langere periode zal plaatsvinden.

In de uitvoeringsfase is, behalve het uitvoeren van de afspraken uit de realisatieovereenkomsten, het opstellen van beheersovereenkomsten aan de orde. Hierin worden afspraken vastgelegd over het beheer van de openbare ruimte en de exploitatie van het gerealiseerde vastgoed. Naast privaatrechtelijke overeenkomsten zijn er tevens publiekrechtelijke overeenkomsten. Dit zijn plannen en vergunningen die onderdeel uitmaken van het publiekrechtelijk ruimtelijkeordeningsinstrumentarium. Voorbeelden hiervan zijn het bestemmingsplan, maar ook bouw-, milieu-, kap-, exploitatie- en overige vergunningen. Figuur 5.1 geeft een schematisch overzicht van het gebiedsontwikkelingsproces.

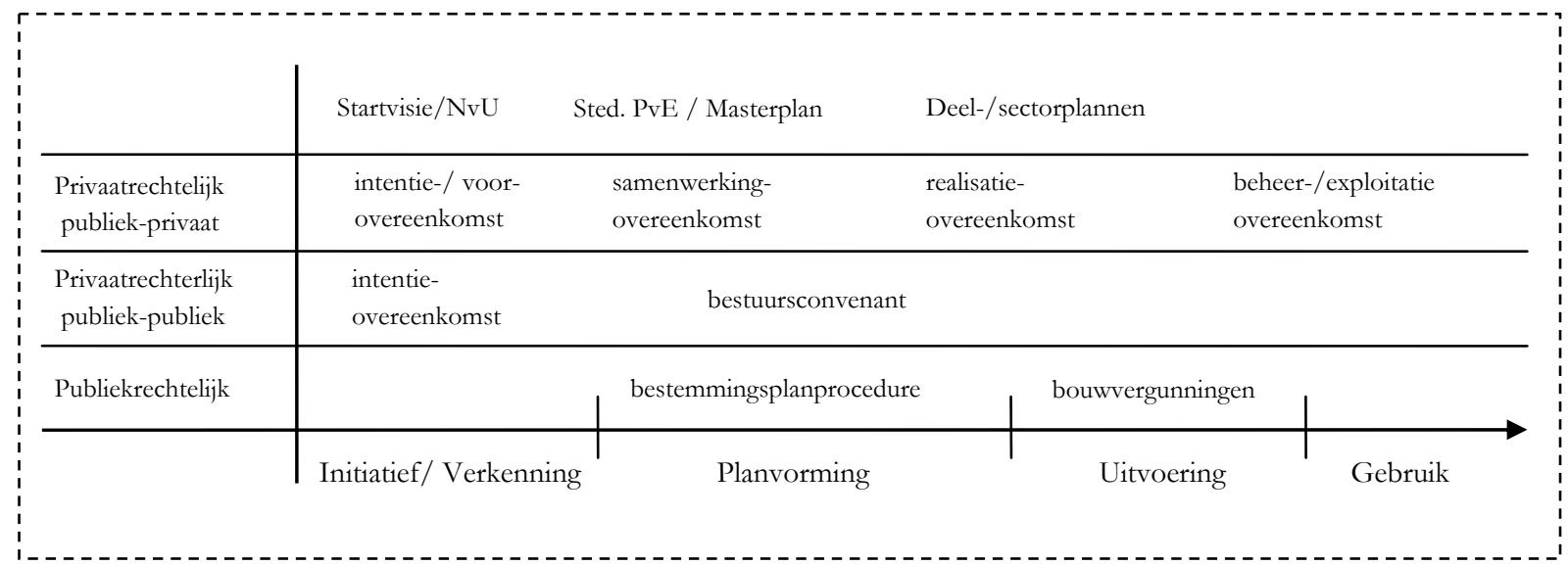

Figuur 5.1 Het gebiedsontwikkelingsproces 
In stedelijk gebied zijn er verschillende typen gebiedsontwikkelingsprojecten te onderscheiden. Zo kan het gaan om centrumprojecten, woon-/werkgebieden, de ontwikkeling of herstructurering van bedrijventerreinen, etc. (zie: Taskforce PPS en Gebiedsontwikkeling, 2002). De (her)ontwikkeling van stationslocaties kan worden gezien als een specifieke vorm van gebiedsontwikkeling waarbij de transportfunctie wordt gecombineerd met stedelijke ontwikkeling.

\subsubsection{Stationslocaties als specifieke vorm van gebiedsontwikkeling}

Bovenop de algemene kenmerken van gebiedsontwikkelingsprojecten in een stedelijke omgeving, gaat het bij een stationsgebied ook om een knooppunt. Een knooppunt kan worden gedefinieerd als "een samenkomst van vervoermodaliteiten en ruimtelijke ontwikkelingen" (Bertolini en Spit, 1998; Bertolini, 1999). Peek (2006: p.135-139) onderscheidt vier ideaaltypische benaderingen van knooppunten. Een eerste benadering is die van vervoersplanologen het station vooral zien als verbindingsschakel tussen verschillende vervoersnetwerken. Stationsontwerpers echter zien het station vooral als een overstapmachine, die een snelle en prettige transfer tussen verschillende modaliteiten mogelijk dient te maken. Een derde is die van stadseconomen die een stationslocatie zien als stadscentrum, waar door de combinatie van multimodale bereikbaarheid, de binnenstedelijke ligging en de aanwezigheid van voorzieningen een unieke vestigingslocatie kan ontstaan. Sociologen zien de stationslocatie vooral als ontmoetingsplek, een plek in de stad waar mensen elkaar ontmoeten en stedelijke ervaringen opdoen. De vier perspectieven leveren uiteenlopende definities van stationslocaties op.

In deze studie worden stationslocaties beschouwd als een bepaald type binnenstedelijke herontwikkelingsopgave. Bij deze benadering is de stationslocatie gelijk aan het gebied dat valt binnen een specifiek (her)ontwikkelingsinitiatief met een directe relatie met het station. Onderscheidend kenmerk van stationslocaties ten opzichte van andere binnenstedelijke herontwikkelingsprojecten is dat de openbaar vervoers (OV) terminal als knooppunt van vervoersstromen/modaliteiten een cruciaal onderdeel van het project is. Veelal heeft de aanpak van de OV-terminal en de daaraan gekoppelde voorzieningen een aanjagende functie voor de herontwikkeling van het omliggende gebied. Dit onderscheid tussen enerzijds de vernieuwing of upgrade van het station als knooppunt van vervoersstromen/modaliteiten en anderzijds de herontwikkeling van het omliggende gebied is, hoewel de scheidslijnen soms een grijs gebied zijn, vrijwel altijd te herkennen. In lijn hiermee definiëren Bertolini en Spit (1998) een stationslocatie als "een geografische entiteit met twee identiteiten; knoop en plaats". Aan de ene kant is het treinstation een begin- en/of eindpunt in een netwerk van treinen en andere vervoersmodaliteiten. Aan de andere kant is het een 'plaats' in een stad met een concentratie van infrastructuur, vastgoed en openbare ruimte. ${ }^{118}$

\section{Typen stationslocaties}

De Nederlandse Spoorwegen (NS) hebben stations ingedeeld in zes verschillende typen (NS Commercie, 2001). Stations zijn daarbij gecategoriseerd aan de hand van hun positie ten opzichte van het centrum van de stad en aan de hand van het typen treinen dat het station aan doet. De positie ten opzichte van het stadscentrum is geclassificeerd als: in het stadscentrum, aan de rand van de stad en buiten de stadsgrenzen. De verschillende typen treinen zijn: hogesnelheidstrein (HST), intercity en sprinter. Combinatie van deze parameters leidt tot negen mogelijke stationstypen, waarvan er tot op 
heden zes relevant zijn in de Nederlandse context (NS Commercie, 2001; Van Hagen en De Bruyn, 2002).

\begin{tabular}{|c|c|c|}
\hline Type & Treinen & Voorbeelden \\
\hline 1. zeer groot station in centrum van een grote stad & HST, intercity, sprinter & A'dam Centraal, Den Haag CS \\
\hline 2. groot station in het centrum van een middelgrote stad & intercity en sprinter & Leiden, 's-Hertogenbosch \\
\hline 3. suburbaan station & intercity en sprinter & Duivendrecht, A'dam Sloterdijk \\
\hline 4. station in een kleine stad of dorp & sprinter & Maarssen, Purmerend, Woerden \\
\hline 5. suburbaan station met vertrekfunctie & sprinter & Delft-Zuid \\
\hline 6. station buiten een kleine stad of dorp & sprinter & Abcoude, Breukelen \\
\hline
\end{tabular}

Tabel 5.2 Typen stations (NS Commercie, 2001)

In deze studie wordt gekeken naar de herontwikkeling van stations van het type 1 en 2, omdat deze stations knooppunten zijn in een centrumstedelijke omgeving. Juist deze projecten kennen een hoge mate van inhoudelijke en procesmatige complexiteit doordat veel ruimtelijke functies in het gebied aanwezig zijn, vraagstukken elkaar overlappen, veel actoren - waaronder meerdere bestuurslagen - een belang hebben in het project en de inbreng en betrokkenheid van diverse partijen noodzakelijk is. Juist in deze omgeving is het lastig het publiek belang te typeren en te waarborgen.

In literatuur zijn ook andere indelingen van stationslocaties te onderkennen. Zo delen Krings (1985) en Vákár \& Snijder (2001) stations in aan de hand van hun functionele arrangement en onderscheiden drie typen: a) 'terminus stations' die het eind of beginpunt van een spoorlijn vormen, b) 'through stations' waar een trein stopt en zijn reis in dezelfde richting vervolgt en c) 'cross stations' die gesitueerd zijn bij kruisende spoorlijnen. Veruit de meeste Nederlandse stations zijn van de tweede categorie. ${ }^{119}$

Naast voorgenoemde indelingen zijn in literatuur diverse andere typologieën van stationslocaties te vinden (zie Raad voor Verkeer en Waterstaat, 1996; CROW, 2002). Het lastige van de indeling van verschillende typen stationslocaties is dat ze nauwelijks staan voor proces- of institutionele variabelen, zoals de relevante regelgeving en betrokken partijen. Voor analyse van planprocessen is een typering waarin rekening wordt gehouden met deze factoren wel noodzakelijk. Daarom wordt aan de hand van het beleidskader en in een later stadium de keystakeholders de typering van stationslocaties nader ingekaderd.

\subsection{Beleidskader stationslocaties}

Centraal in het Nederlandse ruimtelijk beleid staat de Wet ruimtelijke ordening (Wro). Op basis van de Wro stelt de Ministerraad ten behoeve van een goede nationale ruimtelijke ordening voor het gehele land of ten behoeve van bepaalde aspecten van ruimtelijk beleid een of meerdere structuurvisies vast. ${ }^{120}$ Vanuit het Rijksbeleid spelen voor het nationale strategische ruimtelijke beleid vooral de Nota Ruimte (VROM), maar ook de Nota Mobiliteit (V\&W), Nota Pieken in de Delta (EZ) en de Agenda voor een Vitaal Platteland (LNV) een belangrijke rol. Deze nota's beschrijven de 
ruimtelijke inrichting van Nederland voor de lange termijn en op nationaal niveau. Het beleid is er op gericht verstedelijking en infrastructuur zoveel mogelijk te bundelen in nationale stedelijke netwerken, economische centrumgebieden en langs hoofdverbindingsassen. In de Nota Ruimte staat beschreven dat voor de ontwikkeling en kracht van de nationale stedelijke netwerken, centrumvorming essentieel is. Opgave is het versterken van bestaande centra en betere benutting van het bestaand bebouwd gebied in samenhang met infrastructuur en verkeers- en vervoersknooppunten. Het Rijk heeft aangegeven daarbij prioriteit te verlenen aan de centra die zijn aangewezen als Nieuwe Sleutelprojecten (NSP). In het kader van de aanleg van de hogesnelheidslijn heeft een zestal stationslocaties de status van Nieuw Sleutelproject. Naast deze Sleutelprojecten worden vanuit het Budget Investeringen Ruimtelijke Kwaliteit (BIRK) een aantal centrumstedelijke ontwikkelingen in de nationale stedelijke netwerken extra financieel ondersteund vanuit het Rijk. Enkele andere stationslocaties maken deel uit van deze beleidsregeling.

\subsubsection{Nieuwe Sleutelprojecten (NSP)}

De term sleutelprojecten is geïntroduceerd in de Vierde Nota Ruimtelijke Ordening die uitkwam in 1988. Daarin werden de eerste generatie sleutelprojecten opgenomen. Dit betrof acht voornamelijk stedelijke transformatieopgaven zoals Kop van Zuid (Rotterdam), Ceramique (Maastricht) en Brabantse Poort (Nijmegen). Het is de bedoeling dat deze projecten bij dragen aan de internationale concurrentiekracht van de Nederlandse economie. Daarmee raken ze de kern van het nationaal ruimtelijk beleid. Bij de actualisering van de Vierde Nota Ruimtelijke Ordening werd er sterk op aangedrongen nieuwe sleutelprojecten te benoemen. Dit zijn uiteindelijk de zes stations geworden waar de hogesnelheidstrein in Nederland stopt. Dit zijn Amsterdam (Zuid/WTC), Rotterdam, Den Haag, Utrecht, Arnhem en Breda. In 1997 is het Rijksproject Nieuwe Sleutelprojecten van start gegaan. De kerndoelstellingen van het Rijk voor de nieuwe sleutelprojecten staan in tabel 5.3.

\section{Doelstellingen van het Rijk met de nieuwe Sleutelprojecten}

1. Integrale ontwikkeling van de zes stationslocaties tot hoogwaardige, multimodale OV-knooppunten en tot toplocaties voor wonen, werken en voorzieningen.

2. Maximale spin-off van investeringen in HSL-infrastructuur op stedelijke vernieuwing en intensief ruimtegebruik

3. Maximale spin-off van investeringen in commercieel vastgoed op stedelijke vernieuwing en verhoging van de kwaliteit van de fysieke omgeving.

Tabel 5.3 Rijksdoelstellingen sleutelprojecten (Ministerie van VROM, 2002)

In de filosofie van het Rijk zijn de sleutelprojecten primair gemeentelijke projecten. De kwaliteit van openbaar stedelijk gebied geldt als een primaire verantwoordelijkheid van gemeenten. Het Rijk ziet gemeenten als eindverantwoordelijk voor de realisering van de sleutelprojecten en in die visie dienen zij de regie en het initiatief te nemen in de samenwerking met andere partijen (Ministerie VROM, 2002: p. 23). Gemeenten dienen tevens een projectorganisatie op te zetten waarin alle partijen goed vertegenwoordigd worden: de eigen gemeentelijke diensten, provincies en regionale vervoersautoriteiten, marktpartijen, NS, andere vervoersbedrijven, infrastructuurbeheerders en relevante ministeries. 
De aanwezigheid van nationale belangen vormt een grondslag voor een actieve inzet van de Rijksoverheid. Vanuit het Rijk zijn zes departementen betrokken bij de nieuwe sleutelprojecten; VROM, Verkeer en Waterstaat, Financiën, EZ, Binnenlandse Zaken en Koninkrijkrelaties en Algemene zaken. Bij de start van de $2^{\text {e }}$ generatie sleutelprojecten in 1997 werd er bij het Rijk een centrale stuurgroep opgericht met vertegenwoordigers vanuit de diverse departementen. In 2001 zijn in de organisatie van de sleutelprojecten bij het Rijk een aantal wijzigingen doorgevoerd. ${ }^{121}$ Eén vrijgestelde projectdirecteur NSP werd aangesteld die een nieuwe interdepartementale projectorganisatie aanstuurde, namens het Rijk onderhandelde en toegang had tot bewindslieden en Directeuren Generaal van de departementen. Op lokaal niveau werden departementale projectleiders gedetacheerd die verantwoordelijk waren voor hun projectdeel, daarbij verantwoording afleggend aan de centrale NSP-projectorganisatie. De minister van VROM was politiek verantwoordelijk voor de sleutelprojecten en dat ministerie trad op als coördinerend departement. Nadat het Rijk het initiatief had genomen voor het benoemen van de zes sleutelprojecten zag zij haar eigen rol bij de realisatie als een actief ondersteunende. In de procesarchitectuur van het Rijk voor de Nieuwe Sleutelprojecten worden vier fasen onderscheiden die elk worden afgesloten met afspraken tussen Rijk en gemeente (Ministerie VROM, 2006).

- Fase 1: verkenning: in deze fase beoordeelt het Rijk het project op de mogelijke bijdrage aan de rijksdoelstellingen voor de nieuwe sleutelprojecten. Op basis hiervan wordt besloten of het project de NSP-status krijgt. Is dit het geval, dan wordt een startovereenkomst gesloten.

- Fase 2: factfinding: in deze fase doen gemeente en Rijk gezamenlijke onderzoek en schetsen een inhoudelijk, financieel en procedureel kader voor de planvorming. Indien hierover overeenstemming is bereikt wordt de afspraken vastgelegd in een intentieovereenkomst.

- Fase 3: planvorming: in deze fase stelt de gemeente, al dan niet samen met andere partijen, een masterplan op. Het Rijk is betrokken bij deze planvorming en toetst vervolgens de stedenbouwkundige, vervoerskundige en financiële onderbouwing van het masterplan. In deze beoordeling staan een aantal thema's centraal. Deze zijn; het doen ontstaan van een hoogwaardig stedelijk centrumgebied; een efficiënte organisatie van de OV-Terminal en een optimale aansluiting van de terminal op het stedelijk gebied en hoge kwaliteit van de openbare ruimte en aandacht voor de menselijke maat. Daarnaast worden de plannen getoetst op randvoorwaarden van financiële haalbaarheid; veiligheid en duurzaamheid; procesmatige oplossingen en uitvoeringsaspecten (Ministerie VROM, 2002: p.14-17). ${ }^{122}$

- Fase 4: uitvoeringsafspraken: na toetsing van de plannen door het Rijk worden op basis van onderhandeling afspraken gemaakt over de hoogte en vorm van de bijdragen en de voorwaarden die daaraan worden verbonden. Het resultaat van onderhandeling wordt voor definitieve besluitvorming voorgelegd aan het kabinet. $\mathrm{Na}$ instemming door het kabinet worden de uitvoeringsafspraken contractueel vastgelegd in een bestuurlijke uitvoeringsovereenkomst. Vervolgens wordt de Tweede Kamer hierover geïnformeerd. Na ondertekening veranderd de rol van het Rijk en wordt de realisatie meer op afstand gevolgd. ${ }^{123}$

De financiële bijdragen van het Rijk komen vanuit verschillende budgetten. In het Fonds Economische Structuurversterking (FES) is geld gereserveerd voor de nieuwe sleutelprojecten. Hierbij wordt een onderscheid gemaakt naar zogenaamde NSP-1 en NSP-2 gelden. NSP-1 gelden zijn 
vooral bedoeld voor verbetering van de fysieke kwaliteit van de stedelijke omgeving en NSP-2 gelden zijn bedoeld voor het oplossen van knelpunten in de kwaliteitsverbetering van de OV-terminals. Naast deze budgetten wordt vanuit het Meerjarenprogramma Infrastructuur en Transport (MIT-grote stations/MIT-gerelateerde infrastructuur) ${ }^{124}$ tevens een bedrag gereserveerd voor de basisvoorzieningen van de stations en infrastructuur. Voor de indicatieve verdeling van het NSP budget heeft het Rijk het Afwegingskader Nieuwe Sleutelprojecten (1999) vastgesteld. Centraal criterium is de nationale meerwaarde, ofwel de bijdrage die het project levert aan een (inter)nationaal hoogwaardig vestigingsklimaat voor bedrijvigheid. Daarbij worden vijf aspecten op waarde geschat:

- De aantrekkelijkheid van het vestigingsmilieu voor internationale ondernemingen en vestigingen;

- De toevoeging van functies die zorgen voor vernieuwing van het bestaande ec. pakket;

- De mate waarin functies van de zes sleutelprojecten complementair zijn aan elkaar;

- De kwaliteit van ruimte en gebouwen binnen het plangebied;

- De mate van functiemenging; wonen, werken en voorzieningen.

Bij de indicatieve toekenning van middelen uit het MIT is hetzelfde afwegingskader gehanteerd. Daarnaast wordt speciaal rekening gehouden met de zwaarte van de transferfunctie van het betreffende station en de daarbij behorende basisvoorzieningen (Ministerie VROM, 2002, p.27-28). Voor de daadwerkelijke toekenning van middelen worden de plannen door het Rijk getoetst. Aan de hand van het Masterplan en het Programma van Eisen en Schetsontwerp voor de OV-terminal toetst het Rijk aan welke onderdelen zij concreet zal bijdragen. Het Rijk heeft toetsingsvragen ontwikkeld om de plannen te beoordelen (zie: Ministerie VROM, 2002: p.30). In een bestuurlijke uitvoeringsovereenkomst tussen het Rijk en de betreffende gemeente worden vervolgens de procedure en voorwaarden geregeld op basis waarvan het Rijk bijdragen vanuit het budget NSP en vanuit het MIT levert. Toekenning van deze middelen gebeurt op basis van een besluit van de ministers van V\&W, Financiën en VROM en krijgt vorm in een subsidiebeschikking.

\subsubsection{Budget Investeringen Ruimtelijke Kwaliteit (BIRK)}

Naast stationslocaties die de status van sleutelproject hebben, zijn er ook nog diverse andere herontwikkelingen van stationslocaties die door het Rijk worden ondersteund. Het Budget Investeringen Ruimtelijke Kwaliteit is daarvoor beleidsmatig van belang.

In 2002 kondigde het Kabinet aan een impuls te willen geven aan ruimtelijke investeringsprojecten die de doelen van het nationaal ruimtelijke beleid ondersteunen. Daarvoor beschikt het Ministerie van VROM over $€ 418 \mathrm{mln}$. in de periode 2001-2010 uit het Fonds Economische Structuurversterking: het Budget Investeringen Ruimtelijke Kwaliteit (Kamerstukken II, 2001/02 27 578, nr. 13). ${ }^{125}$ De Minister kan subsidies verstrekken ten behoeve van projecten of activiteiten die voor de uitvoering van nationaal ruimtelijk beleid van strategisch belang zijn. ${ }^{126}$

Speerpunt van nationaal ruimtelijk beleid vormt de ontwikkeling van stedelijke netwerken. Met het BIRK wordt getracht voorstellen van lagere overheden voor gebiedsoverstijgende investeringsprojecten die passen binnen de uitvoering van dit beleid te ondersteunen. In de Rijksbegroting 2004 stond voor de beoordeling van projectvoorstellen de volgende tekst: "Projectvoorstellen die vallen in het toepassingsgebied centrumvorming in nationale stedelijke 
netwerken worden vanuit de bijdrage aan de duurzame ontwikkeling van het betreffende stedelijk netwerk beoordeeld op mogelijkheden voor intensivering van ruimtegebruik en functiemenging, door onder andere te kijken naar de mate waarin oplossingen worden gevonden voor knelpunten met externe veiligheid, fysieke barrières van bijvoorbeeld infrastructuur en suboptimaal ruimtegebruik."

Centrumvorming, of knooppuntontwikkeling wordt in het nationaal ruimtelijk beleid gedefinieerd als intensivering en herstructurering rond knooppunten van openbaar vervoer. Een projectvoorstel draagt volgens de BIRK-normen in potentie bij aan centrumontwikkeling als het zwaartepunt van het plangebied binnen de invloedssfeer van een knooppunt van openbaar vervoer ligt, d.w.z. binnen een straal van circa 700 meter van een treinstation. De beoordelingscriteria voor voorstellen zijn nader uitgewerkt in een aantal kwalitatieve en kwantitatieve criteria. In totaal zijn negentien projecten geselecteerd, waaronder diverse projecten die de directe aanpak van stations en/of spoorzones betreffen. ${ }^{127}$ Ook voordat de beleidsregeling van kracht ging is door eerdere kabinetten al geld uit het BIRK beschikbaar gesteld voor de aanpak van knelpunten. De spoorzone Delft is een voorbeeld van deze pré-BIRK projecten. ${ }^{128}$

Naast het hiervoor geschetste algemene beleidskader op rijksniveau speelt voor de aanpak van stationslocaties ook provinciaal, regionaal en gemeentelijk beleid een belangrijke rol. Algemeen ruimtelijke beleid op provinciaal of regionaal niveau wordt neergelegd in streekplannen of regionale structuurplannen. Op gemeentelijk niveau krijgt het beleid veelal vorm in ontwikkelingsvisies, gemeentelijke structuurplannen of masterplannen. Naast ruimtelijk beleid in algemene zin wordt veelal voor specifieke sectoren beleid geformuleerd. Daarbij valt bijvoorbeeld te denken aan provinciale, regionale en lokale verkeers- en vervoersplannen of regionale kantorenstrategie. Voor zover in het kader van deze studie relevant wordt dit in de case beschrijvingen vermeld.

\subsection{Regelgeving en procedurele systematiek}

De realisatie van beleid wordt ondersteund door instrumenten die overheden daartoe ter beschikking staan. Publiekrechtelijke regelgeving vormt een van deze instrumenten. Daarmee wordt het juridische kader waarbinnen de voorbereiding en uitvoering van overheidsbeleid moet of mag plaatsvinden, gegeven. Hiermee wordt het verloop van ruimtelijke planprocesen in zekere mate ingekaderd.

Het juridische instrumentarium voor de uitvoering van ruimtelijk beleid is voor een belangrijk deel gecodificeerd in de Wet ruimtelijke ordening (Wro). De Wro geeft een algemeen spelregelkader voor de totstandkoming van ruimtelijke plannen en regelt in belangrijke mate de bevoegdheden en verantwoordelijkheden van diverse overheden bij de totstandkoming van ruimtelijke plannen. De toestemming voor concrete bouwaktiviteiten wordt geregeld door de Wet algemene bepalingen omgevingsrecht (Wabo). Deze wet integreert de diverse vergunningen die voor de realisatie van projecten noodzakelijk zijn tot één omgevingsvergunning. Omdat de Wabo pas per 1 oktober 2010 in werking is getreden, deze studie betrekking heeft op de periode daaraan voorafgaand en de wet voor het gehanteerde conceptueel model geen gevolgen heeft, zal deze niet nader worden behandeld.

Naast een algemeen juridisch kader, zijn er tevens specifieke aspecten van ruimtelijk beleid waarvoor het publiekrecht regelgeving kent. Hierbij kan onder andere worden gedacht aan de Onteigeningswet ${ }^{29}$ of de Wet Milieubeheer. Op grond van de Wet Milieubeheer en het Besluit 
Milieueffectrapportage kan - afhankelijk van de kenmerken van de opgave - de herontwikkeling van een stationsgebied bijvoorbeeld m.e.r.-plichtig of m.e.r.-beoordelingsplichtig. ${ }^{130} \mathrm{In}$ de strekking van deze studie past het niet uitgebreid in te gaan op regelgeving voor alle specifieke deelaspecten van ruimtelijk beleid. Wel worden de Wet ruimtelijke ordening en de Spoorweg- en Concessiewet behandeld om de huidige institutionele ordening rondom Nederlandse stationslocaties te verhelderen.

\subsubsection{Wet ruimtelijke ordening (Wro) ${ }^{131}$}

Ruimtelijke beslissingen worden in Nederland op drie niveaus genomen - landelijk, regionaal en lokaal. Voor de inrichting van gebieden stellen rijk, provincie en gemeenten een structuurvisie op. Deze bevat de hoofdlijnen van de voorgenomen ontwikkeling in een gebied, alsmede de hoofdzaken van het te voeren ruimtelijk beleid ${ }^{132}$. De structuurvisie komt in de plaats van de planologische kernbeslissing (Rijk), het streekplan (provincie) en het structuurplan (gemeente) waarmee onder de 'oude' Wet op de Ruimtelijke Ordening (WRO), die tot 1 juli 2008 van toepassing was, invulling werd gegeven aan het ruimtelijk beleid. ${ }^{133}$

Met het bestemmingsplan worden de beleidsdoelen uit de structuurvisie vertaald naar bindende voorschriften voor de inrichting, bebouwing en het gebruik van grond en bebouwing voor het daarin begrepen gebied. Het bestemmingsplan is daarmee hét instrument om de bestemming, de inrichting en het beheer van de gronden te regelen. Het bestemmingsplan wordt in principe opgesteld door de gemeente. Hoewel onder de nieuwe Wro goedkeuring van het bestemmingsplan door provincies geen onderdeel meer uitmaakt van de procedure kunnen de minister van VROM en Gedeputeerde Staten wel aanwijzingen geven die de gemeente in acht moet nemen. ${ }^{134}$ Vinden Rijk en provincie dat ze zelf verantwoordelijk zijn voor een bepaalde ontwikkeling of gebied, dan kunnen zij daarvoor ook zelf een inpassingsplan vaststellen. ${ }^{135}$

Onder de 'oude' WRO waren er een aantal mogelijkheden voor vrijstelling van de bepalingen in het bestemmingsplan. De bekendste was de artikel 19 procedure die de gemeenteraad 136 voor het realiseren van een project de bevoegdheid gaf vrijstelling te verlenen van het bestemmingsplan, mits dat project voorzien is van een goede ruimtelijke onderbouwing. ${ }^{137} \mathrm{Bij}$ voorkeur werd daaronder een gemeentelijk, intergemeentelijk of regionaal structuurplan verstaan, maar ook een masterplan, bijvoorbeeld voor het stationsgebied, kon dienen als ruimtelijke onderbouwing voor een nieuw bestemmingsplan. In de praktijk van ruimtelijke projecten in de bouw- en utiliteitssector was het bestemmingsplan dan ook vaak volgend op de planontwikkeling. Het vormde de planologischjuridische vertaling van voornemens die waren neergelegd in bijvoorbeeld een stedenbouwkundig masterplan. Als er sprake was van samenwerking tussen publieke en private partijen was het bestemmingsplan vrijwel altijd volgend. In samenwerkingsovereenkomsten werd dan vaak een voorbehoud gemaakt ten aanzien van de publiekrechtelijke basis voor het project.

In de nieuwe Wro bestaat met het zogenaamde projectbesluit ${ }^{138}$ nog steeds de mogelijkheid om ten behoeve van een specifiek project af te wijken van het bestemmingsplan ${ }^{139}$. Daarnaast is nog in een beperkt aantal gevallen ontheffing van het bestemmingsplan mogelijk ${ }^{140}$. Hoewel planologischjuridisch het rijk en provincies een substantiële rol spelen in ruimtelijke planvorming geeft het ontwikkelen en vaststellen van het bestemmingsplan en de bevoegdheid tot vergunningverlening ${ }^{141}$ de gemeente een belangrijke bestuurlijk-juridische bevoegdheid bij de herontwikkeling van stationslocaties. 


\subsubsection{Spoorweg- en Concessiewet}

De Spoorweg- en Concessiewet regelen in belangrijke mate de institutionele ordening in de spoorsector. Als het startpunt van de ontwikkeling naar de huidige Nederlandse situatie in de spoorsector kan de Europese Richtlijn 91/440 worden genomen. Deze richtlijn uit 1991 was gericht op harmonisering en liberalisering van de spoorwegsector in Europa. Voor de organisatie van de spoorsector werd in deze richtlijn onder meer een boekhoudkundige scheiding tussen vervoer (exploitatie) en infrastructuur voorgeschreven.

Voor de inpassing van Richtlijn 91/440 in de Nederlandse situatie werd in 1992 een advies uitgebracht door de commissie Wijffels. Deze commissie stelde voor om de verschillende functies

van de Nederlandse Spoorwegen (NS), zoals reizigersvervoer, goederenvervoer, capaciteitsmanagement, railverkeerleiding, vastgoed en infrastructuur onder te brengen in aparte bedrijfsonderdelen. Het doel hiervan was om een einde te maken aan de gecompliceerde onderlinge verwevenheid van alle bedrijfsactiviteiten binnen NS. In haar adviesrapportage stelde de commissie dat het loslaten van de invloed van het ministerie van Verkeer en Waterstaat op de bedrijfsmatige aspecten van de exploitatie van het spoor een voorwaarde was voor succes. Naast dit advies was bij de overheid onvrede ontstaan over de jaarlijkse subsidies aan NS. De opvatting was dat het niet meer bij het tijdsbeeld paste om voor een maatschappelijke functie een generieke subsidie toe te kennen. Bovendien was het beeld dat de subsidies door de NS niet altijd efficiënt besteed werden. Het Kabinet ging mee met het advies van de commissie Wijffels en besloot, met het oog op toekomstige concurrentie op het spoor, tot verzelfstandiging van de NS en tot ontvlechting van het NS-concern. Dat had tot gevolg dat de NS werd opgedeeld in een aantal marktgerichte bedrijfsonderdelen (reizigersvervoer, goederenvervoer, stations, vastgoed) en dat de taakorganisaties Railinfrabeheer, Railned en Railverkeersleiding werden uitgeplaatst. De nieuwe lijn werd dat de overheid verantwoordelijk zou blijven voor de railinfrastructuur maar dat de exploitatie van vervoerdiensten op commerciële basis moest gebeuren. Waar vervoerdiensten niet rendabel zouden zijn, maar uit maatschappelijke overwegingen wel wenselijk, zou de overheid specifieke contracten met vervoerders kunnen afsluiten. NS werd dus gesplitst in een taaksector en een marktsector. In de taaksector werden de onderdelen ondergebracht die werden gezien als overheidstaak, namelijk de infrastructuur. In de marktsector werden de onderdelen ondergebracht die op bedrijfseconomische basis moesten opereren.

Op 1 januari 1995 werd de nieuwe structuur formeel van kracht. Voor de taakorganisaties betekende de ontvlechting dat zij inhoudelijk met regelgeving en beschikkingen aangestuurd zouden worden door het Ministerie van Verkeer en Waterstaat, maar dat ze wel onderdeel bleven van het NSconcern. In 1999 werd in de Nota Derde Eeuw Spoor (Ministerie van Verkeer en Waterstaat, 1999) een nieuw model voor de toekomstige marktordening van de spoorsector neergelegd. In de Nota werd conform de Europese Richtlijn gevolg gegeven aan decentralisatie van de zogenaamde contractsectorlijnen en werd gekozen voor concurrentie op het spoor voor zowel goederenvervoer als personenvervoer, waarvoor met concessies zou worden gewerkt. Ook werd in de Nota aangekondigd dat voor de juridische vertaling van de nieuwe marktordening de bestaande Spoorwegwet zou worden herzien. In het kader van deze herziening, werd begin 2001 door het Ministerie van Verkeer en Waterstaat een wetgevingspakket naar de Tweede Kamer gestuurd. Hierin was onder meer opgenomen, dat de taakorganisaties (Railned, Railverkeersleiding en Railinfrabeheer) samen één 
spoorwegbeheerorganisatie zouden worden die zou worden vormgegeven als een zelfstandig bestuursorgaan. Operationele problemen op het spoor zorgden er echter voor dat de minister van Verkeer en Waterstaat aanleiding zag om zich te bezinnen op de voorgenomen veranderingen in de spoorsector. Hiervoor stuurde zij een herbezinningsbrief naar de Tweede Kamer, waarin het fundament werd neergelegd voor de wijze waarop de uiteindelijke verhoudingen in de spoorsector zouden worden vastgelegd. Uiteindelijk zijn in 2003 de Spoorwegwet en de Concessiewet aangenomen door de Tweede Kamer. De beheer- en vervoerconcessie, die met de institutionele ordening samenhangen, werden in 2004 in de Tweede Kamer behandeld en goedgekeurd. Deze wetten en concessies traden vervolgens per 1 januari 2005 in werking, waarmee de institutionele verhoudingen in de spoorsector vastlagen.

Met de inwerkingtreding van de Spoorwegwet en de Concessiewet personenvervoer per trein is invulling gegeven aan een institutionele ordening van de spoorsector. ${ }^{142}$ Hiermee zijn zowel de verhouding tussen de overheid en de spoorsector als de rollen en verantwoordelijkheden van de verschillende partijen binnen de spoorsector vastgelegd. ${ }^{143}$ De minister van Verkeer en Waterstaat is verantwoordelijk voor de spoorweginfrastructuur en opdrachtgever voor het personenvervoer over het hoofdrailnet. Het werk wordt gedaan door uitvoerende spoororganisaties (de beheerder en de vervoerders), die door de overheid zijn gereguleerd (wet- en regelgeving) en binnen gestelde kaders worden gestuurd (concessies). De samenwerking tussen ProRail, vervoerders en overheden staat in de Spoorwegwet bekend als de institutionele driehoek.

\subsubsection{Resumé}

Publiekrechtelijk regelgeving en procedures kaderen het verloop van processen in en kennen bepaalde bevoegdheden en verantwoordelijkheden toe aan partijen. De Wro geeft een algemeen juridisch kader voor ruimtelijke planvormingsprocessen. Sectorale wetgeving formuleert specifieke eisen om bepaalde belangen in het proces een plaats te geven en de Spoorweg- en Concessiewet verzorgen in belangrijke mate het kader voor de institutionele ordening in de spoorsector. In deze studie wordt het effect van de inrichting van het proces op de borging van het publiek belang bestudeerd. Naast betrokkenheid vanuit formele bevoegdheden en verantwoordelijkheden kunnen partijen ook door te beschikken over andere hulpbronnen of op grond van een bepaald belang relevant zijn bij de aanpak van stationslocaties.

\subsection{Keystakeholders bij stationslocaties}

Veelal worden actoren ingedeeld in stakeholders en shareholders (Peek, 2006). Een veel gebruikte definitie van een stakeholder is: "any group or individual who can affect or is affected by the achievement of the organization's objectives" (Freeman, 1984: p.46). In plaats van de doelen van de organisatie kunnen tevens de ontwikkelde plannen als indelingscriterium worden gebruikt. In lijn daarmee definieert Edelenbosch (2000: p.104) stakeholders als: "personen die door positieve of negatieve effecten van voorgestelde plannen geraakt kunnen worden".

Shareholders zijn actoren die eigendommen te verdedigen hebben, terwijl stakeholders belangen in brede zin behartigen (Edelenbos, 2000: p.104). Als, zoals in deze studie, de aandacht uit gaat naar de 
inbreng van actoren in het planproces dan zijn niet alleen de belangen van actoren, maar meer nog de hulpbronnen die actoren ter beschikking staan voor het behartigen van die belangen relevant.

Teisman (1992) onderscheidt zes hulpbronnen die noodzakelijk zijn voor ontwikkeling en implementatie van plannen en welke partijen een zekere macht en invloed geven: autoriteit, financiën, informatie, grond, steun en legitimiteit. Autoriteit gebaseerd op wettelijke regelgeving kan dus worden beschouwd als een van de noodzakelijke hulpbronnen. Verbart (2004: p.85-86) vat deze hulpbronnen samen onder de noemers 'investeringen' en 'toestemming'. Toestemming handelt over de inzet van autoriteit, via publiekrechtelijke regels en bevoegdheden en privaatrechtelijke afspraken, juridische en maatschappelijke legitimatie en commitment in de vorm van politieke steun. Toestemming maakt de weg vrij voor herontwikkeling, maar brengt deze nog niet tot stand. Daarvoor zullen partijen investeringen moeten doen (Peek 2006: p.29).

De actoren die betrokken kunnen zijn bij de aanpak van stationslocaties kunnen worden ingedeeld in vier groepen: overheden, spoorwegpartijen, eigenaren/ontwikkelaars en belangengroeperingen (De Wilde, 2006: p.14). In de eerste categorie spelen vanuit de overheid vooral het Ministerie van Verkeer en Waterstaat en het Ministerie VROM een rol. Daarnaast heeft de betreffende gemeente aanzienlijke invloed op de ontwikkeling en kunnen de provincie, de regio of andere bestuurlijke (overleg)organen een rol vervullen. In de tweede categorie kan een onderscheid worden gemaakt naar beheerders en vervoerders. Het beheer van het spoor is in Nederland een taak van ProRail en veruit de grootste vervoersmaatschappij per spoor is de Nederlandse Spoorwegen (NS). Tot de derde categorie behoren vastgoedontwikkelaars/-beleggers en grond-/vastgoedeigenaren. Organisatieonderdelen van de NS kunnen deel uitmaken van deze categorie evenals de Rijksgebouwendienst (onderdeel van het Ministerie van VROM). Tot de vierde categorie kunnen o.a. gebruikersgroeperingen, zoals ROVER, omwonenden die zich verenigd hebben in buurtcomités en milieugroeperingen worden gerekend.

$\mathrm{Al}$ deze partijen zijn stakeholders in het project. De partijen die het project concreet aanpakken en investeringen kunnen doen behoren tot de eerste drie categorieën. Om tot implementatie van plannen te komen zijn minimaal toestemming en/of investeringen van deze partijen noodzakelijk. Deze partijen worden in deze studie keystakeholders genoemd. Deze paragraaf beschrijft deze keystakeholders en hun positie bij de herontwikkeling van stationslocaties. Belangrijk daarbij is om het onderscheid tussen enerzijds de vernieuwing of upgrade van het station als knooppunt van vervoersstromen/modaliteiten en anderzijds de herontwikkeling van het omliggende gebied te onderkennen. Hoewel de scheidlijn tussen station ${ }^{144}$ en omgeving soms enigszins diffuus is, valt deze toch altijd wel te herkennen. Dit onderscheid is belangrijk, omdat de bevoegde en verantwoordelijke partijen bij deze onderdelen verschillen. De volgende keystakeholders worden hier belicht:

1. Gemeente

2. Provincie/Regio

3. Rijksoverheid

4. ProRail

5. Nederlandse Spoorwegen

6. Projectontwikkelaars/eigenaren

7. Overige (stakeholders) 


\subsubsection{Gemeente}

De taken, verantwoordelijkheden en bevoegdheden van gemeenten ten aanzien van stations zijn op basis van wettelijke regelgeving beperkt. Gemeenten hebben binnen stations geen eigendomspositie. Wel hebben gemeenten direct buiten stations de verantwoordelijkheid voor het beheer en onderhoud van de openbare ruimte. Dit geldt bijvoorbeeld voor de stationspleinen. Tevens is de kwaliteit van openbaar stedelijk gebied primair de verantwoordelijkheid van de betreffende gemeente. Met de bevoegdheid tot het bestemmen van gronden en als bevoegd gezag voor het verlenen van vergunningen ${ }^{145}$ voor bouwaktiviteiten, beschikken gemeenten over het juridisch instrumentarium om invulling aan deze verantwoordelijkheid te geven. Daarnaast vallen bepaalde voorzieningen voor lokaal openbaar vervoer, zoals bussen en trams onder verantwoordelijkheid van de gemeente en voor zover (fietsen)stallingen buiten het stationsgebouw gelegen zijn, ligt het juridisch eigendom van de grond bij de gemeente. Het Rijk beschouwt de herontwikkeling van stationslocaties primair als gemeentelijke projecten (VROM, 2004).

\subsubsection{Provincie/Regio}

Provincies worden vaak gezien als verbinding tussen de rijksoverheid en gemeenten. Als ruimtelijk beleid gemeentegrens overschrijdend is komt er tevens een rol voor de provincie of de regio in beeld. De directe betrokkenheid van provincies en regio's bij stationslocaties komt in eerste aanleg voort uit hun bestuurlijke verantwoordelijkheid voor regionaal openbaar vervoer. Indien bij stationslocaties investeringen gepleegd worden in voorzieningen daarvoor impliceert dit een bijdrage van de betreffende provincie of regio. Als er er sprake is van een zogenaamde plusregio, dan valt dit onder de verantwoordelijkheid van de regio. Anders is dit een verantwoordelijkheid van de provincie. Daarnaast spelen regio en provincie mogelijk een rol vanuit regionale en of provinciale belang van stationslocaties. Ter bevordering van de daarvoor geformuleerde beleidsdoeleinden kunnen zij stationslocatieprojecten onder meer financieel ondersteunen. Daarnaast beslissen zij over investeringen voor regionale/provinciale infrastructuur (GDU/BDU). Tenslotte bestaat er voor de provincie nog de mogelijkheid tot het geven van een aanwijzing aan de gemeente in de bestemmingsplanprocedure.

\subsubsection{Rijksoverheid}

Grondslag voor de betrokkenheid van het Rijk bij de herontwikkeling van stationslocaties is de aanwezigheid van belangen die het gemeentelijke en provinciale niveau overschrijden. Het stimuleren van de ontwikkeling van stedelijke netwerken en centra wordt gezien als van groot belang voor de (internationale) concurrentiepositie van Nederlandse steden. Het Rijk geeft daarbij zoals hiervoor beschreven prioriteit aan de centra die zijn aangewezen als Nieuwe Sleutelprojecten (NSP). Daarnaast ondersteunt het Rijk vanuit dit beleid met het Budget Investeringen Ruimtelijke Kwaliteit (BIRK) een aantal stationsontwikkelingen van beperktere omvang en is zij verantwoordelijk voor een adequate transfercapaciteit van stations als vervoersknooppunten. De rijksoverheid kan vanuit diverse departementen betrokken zijn bij de aanpak van stationslocaties. Voor het optimaal functioneren van de OV-terminal is in eerste instantie het ministerie van Verkeer en Waterstaat vanuit haar verantwoordelijkheid voor rijksinfrastructuur en de transferfunctie van de OV-terminal betrokken. Het ministerie van VROM is betrokken vanuit haar coördinerende rol in de ruimtelijke ordening en is coördinerend rijksdepartement voor de integrale aanpak, de stedelijke herstructurering en beheert het 
NSP-budget (ministerie van VROM, 2003). Stationslocaties geven ook invulling aan de economische en sociale rijksdoelstellingen. De nieuwe sleutelprojecten vormen een onderdeel van het Grotestedenbeleid en in dat verband speelt ook het ministerie van binnenlandse zaken (GSB, extern veiligheidsbeleid) nog een rol. Het ministerie van Economische Zaken is betrokken vanuit het economische facetbeleid. Hierbinnen valt infrastructuur als instrument voor "economische vliegwieleffecten". Samen met VROM en V\&W vertegenwoordigt EZ rijksinfrastructuur in de ministerraad. Tenslotte kan het ministerie van Financiën nog genoemd worden als mogelijk betrokken departement. De meest direct betrokken departementen zijn echter Verkeer en Waterstaat en VROM. De positie en rol van deze twee departementen zal afzonderlijk worden toegelicht.

\section{Ministerie van Volkshuisvesting, Ruimtelijke Ordening en Milieubeheer (VROM)}

Het Ministerie van VROM is verantwoordelijk voor ruimtelijke ordening op rijksniveau. Centrale doelstelling van VROM is het streven naar een duurzame kwaliteit van de leefomgeving. In tegenstelling tot het ministerie van Verkeer en Waterstaat is het ministerie van VROM niet zozeer een uitvoerend, maar meer een beleidsmakend departement en beschikt het over bepaalde budgetten (NSP, BIRK, ISV, etc.) om dat beleid te stimuleren. Voor de Nieuwe Sleutelprojecten is, om een gecoördineerd optreden van verschillende departementen mogelijk te maken, een aparte interdepartementale projectorganisatie opgezet. De betrokken departementen nemen daarin deel en de minister van VROM is coördinerend bewindspersoon. Deze structuur wordt gebruikt om sectorinvesteringen en sectorprocedures op elkaar af te stemmen. Ook tracht men hiermee de beoordeling van plannen op hun bijdrage aan rijksdoelen en de toewijzing van financiële bijdragen beter te coördineren. De minister van VROM is vanuit het Rijk verantwoordelijk voor de integrale aanpak van de sleutelprojecten, de stedelijke herstructurering en de besteding van het NSP-budget. De bij de sleutelprojecten betrokken departementen zijn via hun directeuren-generaal vertegenwoordigd in een DG-beraad. De DG Ruimtelijke Ordening is voorzitter van dit beraad en is opdrachtgever van de projectorganisatie NSP. De projectorganisatie is angehecht aan het ministerie VROM en wordt geleid door de projectdirecteur NSP. Deze vormt het aanspreekpunt voor de gemeenten binnen het Rijk. Deze projectdirecteur is verantwoordelijk voor de organisatie van de integrale rijksinbreng in de verschillende sleutelprojecten. De projectdirecteur brengt de beleidsprioriteiten van de betrokken departementen met elkaar in verband en tracht besluitvorming mogelijk te maken. De departementen blijven zelf verantwoordelijk voor hun beleidsveld en budgetten. Zo blijft de minister van Verkeer en Waterstaat verantwoordelijk voor besteding van gelden uit het Meerjarenprogramma Infrastructuur en Transport (MIT) ${ }^{146}$. Naast deze rol zijn bij de herontwikkeling van stationslocaties soms nog andere onderdelen van VROM betrokken; de Rijksgebouwendienst en de Rijksbouwmeester. Deze laatste vormde voor de sleutelprojecten samen met de spoorbouwmeester en de stedenbouwmeester kwaliteitsteams met als doel de architectonische en stedenbouwkundige kwaliteit van de plannen te stimuleren en te bewaken (Ministerie VROM, 2006: p.10). Hiermee had het Rijk ook invloed op het ontwerp en de ruimtelijke kwaliteit van de plannen.

\section{Ministerie van Verkeer en Waterstaat ( $V \ll W)$}

Het Ministerie van Verkeer en Waterstaat is verantwoordelijk voor het mobiliteitsbeleid in Nederland en voor de duurzame bescherming tegen water. In de Spoorwegwet ${ }^{147}$ is neergelegd dat de Minister 
van Verkeer en Waterstaat zorg draagt voor de aanleg, het beheer en het onderhoud van hoofdspoorweginfrastructuur. In stations betekent dit dat zij verantwoordelijk is voor de voorzieningen die reizigers nodig hebben om veilig en vlot van en naar de trein te komen. Onder verantwoordelijkheid wordt daarbij zowel de verantwoordelijkheid verstaan voor de financiering van de bouw, het onderhoud en de instandhouding, als de verantwoordelijkheid voor de aard en de omvang ervan. ${ }^{148}$ Het rapport 'Basisstation' (Railned, 1999) geeft antwoord op de vraag welke voorzieningen reizigers nodig hebben om veilig en vlot van en naar de trein te komen. Uitgangspunt van de systematiek is het 'maximale station'. Dat wil zeggen dat alle voor reizigers belangrijke functies en processen die op stations voorkomen benoemd worden. Of ze daar ook daadwerkelijk voorkomen hangt af van een aantal factoren. De belangrijkste factor is daarbij het aantal reizigers dat van een specifiek station gebruik zal maken. ${ }^{149}$ Van 'hét basisstation' of 'soorten basisstation' is dus geen sprake. Voor elk specifiek station moet aan de hand van de functionele eisen bepaald worden wat de noodzakelijke voorzieningen voor reizigers zijn.

Bij de uitoefening van deze verantwoordelijkheid wordt het Ministerie terzijde gestaan door ProRail. De eerste stap op weg naar de inrichting van een nieuw station of een grootschalige verbouwing van een bestaand station is normaliter de opdracht van het Ministerie van Verkeer en Waterstaat aan ProRail om te adviseren over de aard en de omvang van de benodigde voorzieningen (de zogenaamde 'verkenningsfase'). Het Ministerie beoordeelt vervolgens dit advies ${ }^{150}$. Als het op basis van dit advies tot de conclusie komt dat voortgang van het project zinvol is dan geeft het ProRail de opdracht om op basis van het advies een concreet ontwerp van het station uit te werken (de 'planstudiefase'). Als de minister an het einde van deze fase een 'projectbesluit' neemt worden middelen gereserveerd vanuit het Meerjarenprogramma Infrastructuur Ruimte en Transport (MIRT) en kan het project doorgang vinden.

De functionele eisen ten aanzien van de voorzieningen die een transferfunctie hebben bepalen dus de inzet van het ministerie van Verkeer en Waterstaat en haar (financiële) verantwoordelijkheid. Stationsdelen met een hoofdzakelijk commerciële functie vallen onder de verantwoordelijkheid van de Nederlandse Spoorwegen en de ruimten waarin dergelijke activiteiten plaats vinden zijn ook juridisch eigendom van NS. Een bijzondere plaats wordt ingenomen door ruimten die deels een transferfunctie en deels een commerciële functie hebben. Stationshallen en stationsstallingen zijn daar de beste voorbeelden van. De rijksoverheid is niet de eigenaar van die ruimten maar betaald wel voor bouw, onderhoud en instandhouding van de delen die een transferfunctie hebben en die bij de splitsing in 1995 bij NS in eigendom zijn gebleven. NS is verplicht om ervoor te zorgen dat die delen ook op een vlotte en veilige manier door reizigers gebruikt kunnen worden en ProRail heeft tot taak om daar op toe te zien. In concrete projecten is het Ministerie veelal de opdrachtgever van ProRail die voor de uitvoering zorgt. Binnen het ministerie is de directie Spoor van het directoraat-generaal Personenvervoer het onderdeel van dat met de coördinatie en het toezicht is belast. Naast deze directie is veelal ook de regionale directie van Rijkswaterstaat betrokken om te zorgen dat de spoorinfrastructuur zo goed mogelijk aansluit bij de infrastructuur voor de overige vervoersvormen.

\subsubsection{ProRail}

ProRail ondersteunt het ministerie van Verkeer en Waterstaat bij het uitvoeren van haar verantwoordelijkheid voor de hoofdspoorweginfrastructuur die het op grond van de Spoorwegwet heeft. Op basis van diezelfde wet dient de minister van Verkeer en Waterstaat één of meer concessies 
te verlenen voor het beheer daarvan. ${ }^{151} \mathrm{Om}$ uitvoering te geven aan die verplichting heeft de minister per 1 januari 2005 een concessie verleend aan ProRail (Ministerie van Verkeer en Waterstaat, 2005). Formeel is ProRail een dochteronderneming van Railinfratrust BV (RIT), maar voor de dagelijkse bedrijfsvoering wordt de naam ProRail gebruikt. ${ }^{152}$ RIT is een zelfstandig bedrijf waarvan de aandelen in handen zijn van de Staat der Nederlanden. In juridische zin is RIT eigenaar van het overgrote deel van de spoorweginfrastructuur. Dochteronderneming ProRail is de economische eigenaar van de spoorweginfrastructuur. De concessie die aan ProRail is verleend heeft een looptijd van tien jaar en strekt ertoe ProRail het exclusieve recht te verlenen en daarnaast de plicht op te leggen om de hoofdspoorweginfrastructuur te beheren. ${ }^{153}$ De fysieke elementen die door ProRail beheerd dienen te worden, zijn bepaald door de definitie van 'spoorweginfrastructuur' in de Spoorwegwet. ${ }^{154}$ Dit betekent concreet, dat naast de railinfrastructuur tevens het beheer van perrons en van laad- en loswegen onder de concessie vallen, evenals het beheer van 'wegen op spoorwegterreinen ten dienste van reizigers- en goederenvervoer, met inbegrip van toegangswegen', zoals de voor reizigers bestemde stationshal, tunnels, trappen, liften, hellingbanen en loopbruggen. Daarnaast beheert ProRail ook een aantal objecten dat niet onder de definitie van spoorweginfrastructuur valt, zoals fietsenstallingen bij stations. ${ }^{155}$

Om nadere invulling te geven aan haar zorgplicht stelt ProRail na overleg met gerechtigden (o.a. NS) een beheersplan op. Hierin staat beschreven op welke wijze zij van plan is invulling aan haar zorgplicht te geven en welke maatregelen zij van plan is daarvoor te nemen. Het beheersplan wordt samen met de subsidieaanvraag ingediend bij de minister van Verkeer en Waterstaat en vereist op onderdelen de instemming van de minister. ProRail dient in de aanvraag niet alleen aan te geven welke activiteiten het gaat uitvoeren voor het subsidiebedrag maar tevens welke gedetailleerde prestatie-indicatoren daarbij gehanteerd gaan worden. De prestaties die ProRail aan kan leveren, worden randvoorwaardelijk bepaald door de financiële middelen die het ter beschikking krijgt. Deze middelen bestaan uit de gebruiksvergoeding die ProRail ontvangt van de gebruikers van de infrastructuur, de subsidie voor werkzaamheden op basis van de Wet Infrastructuurfonds en het Besluit Infrastructuurfonds via het MIT wordt toegekend door de Minister van Verkeer en Waterstaat en eventuele andere inkomstenbronnen.

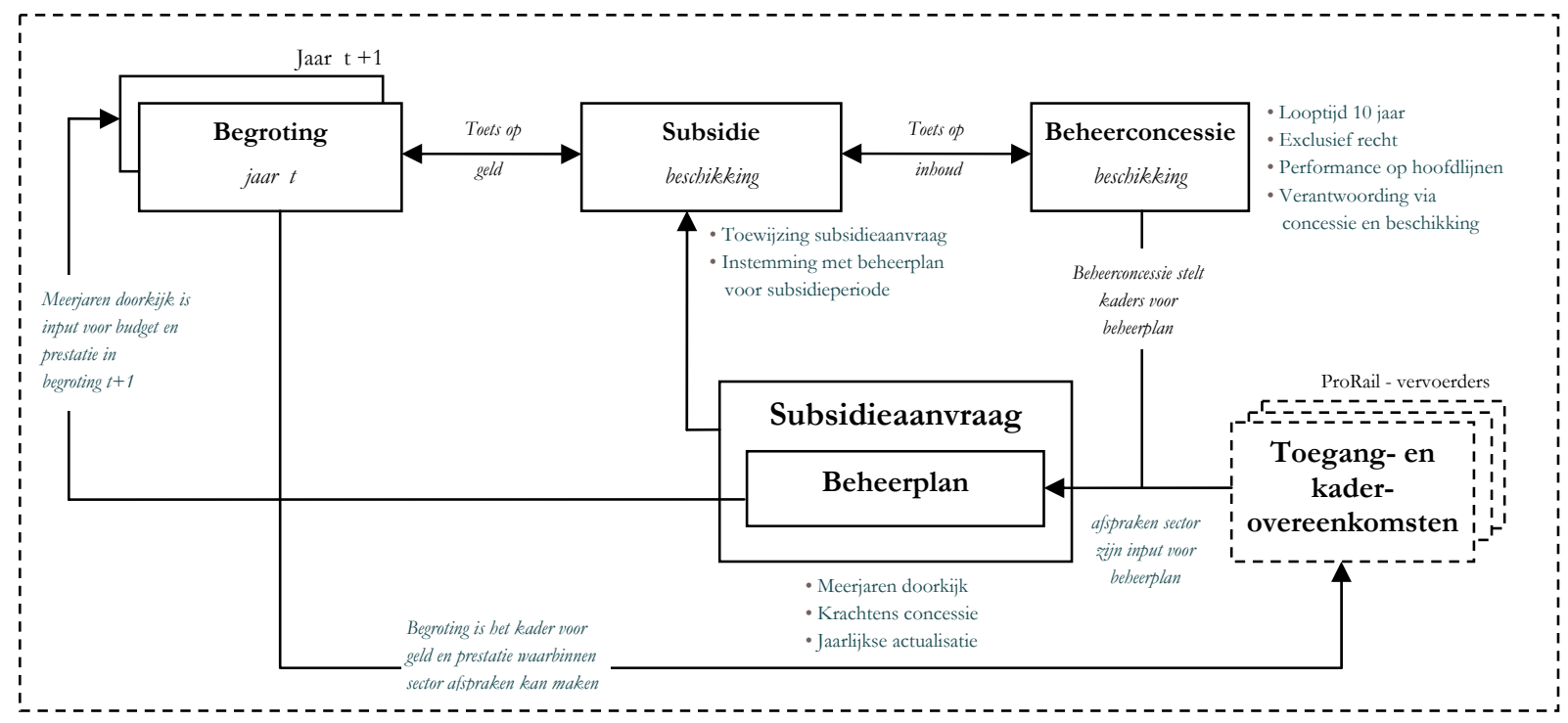

Figuur 5.2 Beheersconcessie van ProRail 
ProRail is belast met de uitvoering van beheerstaken. Als beleidsmaker stelt het Ministerie van Verkeer en Waterstaat de kaders vast en is in projecten veelal opdrachtgever van ProRail. Naast haar beheerstaken voor het spoor bouwt en beheert ProRail tevens de zogeheten transferruimten, zoals de stationshallen, (rol)trappen, liften en perrons. In projecten verzorgt zij daarvoor de voorbereiding door onderzoek en planvorming en heeft een coördinerende rol in de uitvoering. Het dagelijkse beheer van stations is tegen een vergoeding overgedragen aan NS Poort (voorheen NS Stations). Binnen ProRail worden zes verschillende bedrijfseenheden onderscheiden. De bedrijfseenheid Infraprojecten is belast met de (her)ontwikkeling van stations en aanverwante voorzieningen. ProRail is kortom verantwoordelijk voor de niet-commerciële publieke ruimte en voorzieningen terwijl NS de commerciële ruimte exploiteert.

\subsubsection{Nederlandse Spoorwegen (NS)}

De Nederlandse Spoorwegen ontstonden in 1937 als gevolg van de concentratie van verschillende spoorwegmaatschappijen. Het staatsbedrijf werd vanaf dat moment volledig door de overheid geëxploiteerd en gefinancierd. In 1995 werd als gevolg van hoge exploitatiekosten en de Europese Richtlijn 91/440 begonnen met de ontvlechting en verzelfstandiging van de NS. Er kwam een scheiding tussen infrastructuur en exploitatie. Dat had tot gevolg dat de NS werd opgedeeld in marktgerichte bedrijfsonderdelen en taakgerichte onderdelen, waaronder het beheer van de railinfrastructuur (ProRail). De aandelen van NS bleven echter volledig in handen van de Staat der Nederlanden en worden beheerd door het Ministerie van Financiën. ${ }^{156}$ De belangrijkste activiteiten van NS zijn tegenwoordig reizigersvervoer per spoor, exploitatie van stations en vastgoedontwikkeling. Voor het reizigersvervoer heeft NS tot 2015 het exploitatierecht van het hoofdrailnet. Daarnaast beschikt NS over een concessie voor een aantal regionale lijnen (contractsectordiensten). Deze activiteiten verwijzen naar het bekendste onderdeel, NS Reizigers. Voor de herontwikkeling van stations speelt vooral een ander bedrijfsonderdeel, NS Poort, een belangrijke rol.

NS Poort is op 1 januari 2007 ontstaan uit het samenvoegen van de bedrijfsonderdelen NS Stations, NS Vastgoed en een deel van NS Commercie. NS Stations was het bedrijfsonderdeel van de Nederlandse Spoorwegen, dat verantwoordelijk was voor het dagelijkse beheer van stations. Hiervoor kreeg zij via ProRail een (genormeerde) vergoeding van de Rijksoverheid. Daarnaast had NS Stations het exclusieve exploitatierecht voor de commerciële benutting van alle bestaande en nieuwe stations. NS Stations was verantwoordelijk voor het beheer, de exploitatie, kaartverkoop en de service en informatievoorziening op stations. Het bedrijfsonderdeel NS Vastgoed was de vastgoedontwikkelaar en belegger op knooppunten van openbaar vervoer en eigenaar van diverse gronden in de directe omgeving van stations en daarbuiten, zoals verlaten rangeerterreinen, stukken grond langs het spoor en kavels waar in het verleden spoorlijnen liepen. Binnen de stationsomgeving, inclusief de stations zelf, had NS Vastgoed een preferente positie, wat betekent dat zij het exclusieve recht had tot benutting van de commerciële mogelijkheden (zogenaamde over- en onderbouwingsrechten). NS Commercie was het onderdeel dat vooral diensten en producten voor de reiziger bedacht en daarvoor de sales en marketing deed. 
Het huidige NS Poort waar de drie bedrijfsonderdelen in zijn opgegaan is de exclusieve exploitant van alle circa 375 spoorwegstations in Nederland. Sinds de verzelfstandiging is deze activiteit van NS sterk uitgebreid en tegenwoordig is stationsexploitatie de activiteit waar de NS het meeste geld mee verdient. Het staat de NS vrij om op stations voor eigen rekening commerciële activiteiten te ontwikkelen. Wensen op dat gebied moeten dan door ProRail in een vroegtijdig stadium bij de advisering over de nieuwe inrichting van het station worden betrokken. Uitgangspunt daarbij is dat commerciële voorzieningen niet mogen leidden tot hinder voor de transfervoorzieningen. ${ }^{157} \mathrm{Bij}$ de aanpak van stations komen de kosten die niet samenhangen met de transferfunctie van het station in principe voor rekening van NS. Voor delen van het station met een gemengde (transfer en commerciële) functie, zoals het dak of de gevel van een stationsgebouw is een directe toewijzing niet mogelijk. In dat geval dient voor de toedeling van kosten een verdeelsleutel te worden bepaald, bijvoorbeeld gebaseerd op de verhouding vierkante meters transferruimte/commerciële ruimte. ${ }^{158} \mathrm{NS}$ Poort is naast stationsexploitant tevens eigenaar van $48 \mathrm{~km} 2$ grond in Nederland. Naast het beleggen en het managen van vastgoed voor zowel de NS als voor de institutionele beleggingsmarkt ontwikkeld het vastgoed op bestaande en nieuwe stationslocaties. Tabel 5.4 geeft een overzicht van de eigendomsverhoudingen rond spoorstations. Het juridisch eigendom betreft de partij op wiens naam (dat deel van) het station staat, terwijl het bij het economisch eigendom gaat om de vraag welke partij (dat deel van) het station mag exploiteren.

\begin{tabular}{lll} 
& Juridisch eigendom & Economisch eigendom \\
Grond onder de sporen en perrons & RailInfratrust BV (ProRail) & Raillnfratrust BV (ProRail) \\
Transferruimten en voorzieningen in stations & NS Poort & RailInfratrust BV (ProRail) \\
Looproutes en transfervoorzieningen in stationshal & NS Poort & NS Poort \\
Grond onder stationsgebouwen en gebouwen zelf & NS Poort & NS Poort \\
Gemengde infrastructuur (stallingen en perrongebouwen) & NS Poort & NS Poort \\
Stationsfietsenstallingen buiten stationsgebouw & Gemeente & NS Poort \\
\hline
\end{tabular}

Tabel 5.4 Eigendomsverhoudingen bij treinstations

\subsubsection{Projectontwikkelaars/eigenaren}

Naast NS Poort en de Rijksgebouwendienst zijn er ook andere partijen die vastgoed kunnen ontwikkelen in de directe omgeving van stations. Veelal gaat het dan om private ontwikkelaars die tevens een grond- en of vastgoedpositie in het plangebied hebben. Het doel van een private ontwikkelaar is volgens Kohnstamm et al. (1994); het voorbereiden en realiseren van projecten om deze vervolgens met winst te verkopen. Er kunnen verschillende soorten projectontwikkelaars onderscheiden worden, namelijk:

- Ontwikkelaars verbonden aan beleggingsmaatschappijen, die ontwikkeling gebruiken als acquisitie voor de eigen vastgoedportefeuille;

- Ontwikkelaars gelieerd aan een bouwbedrijf met het genereren van bouwcapaciteit voor zusterondernemingen als belangrijkste motief;

- Ontwikkelaars gelieerd aan financiële instellingen, die belang hebben bij de financiering van projecten door middel van het verstrekken van leningen. 
Het verwachte rendement of de verwachte winst is het belangrijkste criterium voor ontwikkelaars bij het nemen van een initiatief, c.q. de keuze voor een project. De aard van het gewenste rendement verschilt er type ontwikkelaar. Voor de ontwikkelaars gelieerd aan beleggingsmaatschappijen is het potentiële rendement van het beleggingsobject van belang, terwijl voor de ontwikkelende financier de potentiële verkoop van financieringen van belang is. De eerste benadert een vastgoedontwikkeling vanuit een lange termijnvisie en streeft daarbij veelal een zo hoog mogelijk rendement van het project op lange termijn na. De visie van een ontwikkelende financier is daarentegen meer gericht op de kortere termijn; deze is specifiek geïnteresseerd in projectfinanciering en het verstrekken van hypotheken tegen een zo hoog mogelijke rente. Risico's worden hierbij verdisconteerd in de rentevoet. Diverse ondernemingen vervullen beide rollen. De ontwikkelende bouwer streeft naar het genereren van bouwvolume voor een zusterbedrijf en winstmaximalisatie om de bedrijfscontinuïteit te waarborgen. Daarnaast spelen zaken als prestige, het opbouwen en behouden van naamsbekendheid en vooral locatie een belangrijke rol bij de acquisitiebeslissing.

\subsubsection{Overige actoren}

In de vorige subparagrafen zijn de keystakeholders die minimaal noodzakelijk zijn voor implementatie van plannen voor de aanpak van een stationsgebied beschreven. Daarnaast zijn er mogelijk ook nog andere partijen die als 'gewone' stakeholder in het planproces participeren. Het gaat daarbij om:

- Vervoersmaatschappijen (Connexion, HTM, etc.)

- Exploitanten/huurders

- Gebruikers

- Belangengroeperingen (Omwonenden/ROVER/Milieugroeperingen/ANWB)

- Architecten

- Adviseurs

- Bouwondernemingen

- Woningcorporaties

Alle in deze paragraaf genoemde partijen, stakeholders interacteren op verschillende wijze met elkaar in het planproces. Hiervoor zijn verschillende overlegstructuren te onderkennen (Driesen, 2001).

- Stuurgroep: Deze groep bestaat veelal uit besluitvormers en stelt de condities waaraan het project dient te voldoen en monitort of hieraan wordt voldaan. Daarnaast draagt het de eindverantwoordelijkheid in de besluitvorming.

- Projectgroep: Deze groep bestaat uit vertegenwoordigers vanuit de verschillende partijen en bereid besluiten voor die uiteindelijk worden bekrachtigd door de stuurgroep.

- Werkgroepen: Deze kunnen worden gevormd rond diverse probleemgebieden en kunnen een substantiële bijdrage leveren aan het project op deze deelterreinen.

- Klankbordgroep: Deze groep bestaat uit experts en vertegenwoordigers die geen direct onderdeel uit maken van de projectorganisatie of een rol spelen in het besluitvormingsproces. 


\subsection{Slot}

In dit hoofdstuk is de context van stationslocatieprojecten geschetst. Het afbakenen van deze context is een lastig punt. Het hoofdstuk heeft dan ook niet de illusie honderd procent volledig te zijn. Getracht is de meest relevante situationele en institutionele factoren te belichten. Zoals in hoofdstuk drie is beargumenteerd zijn deze contextfactoren van invloed op het proces of het resultaat daarvan. Het beperkt de handelingsmogelijkheden van actoren in concrete stationslocatieprojecten. De volgende drie hoofdstukken behandelen de empirische data in drie cases verzameld is. Daarmee wordt onder meer het feitelijk verloop van planprocessen in de drie cases uitvoerig beschreven. 


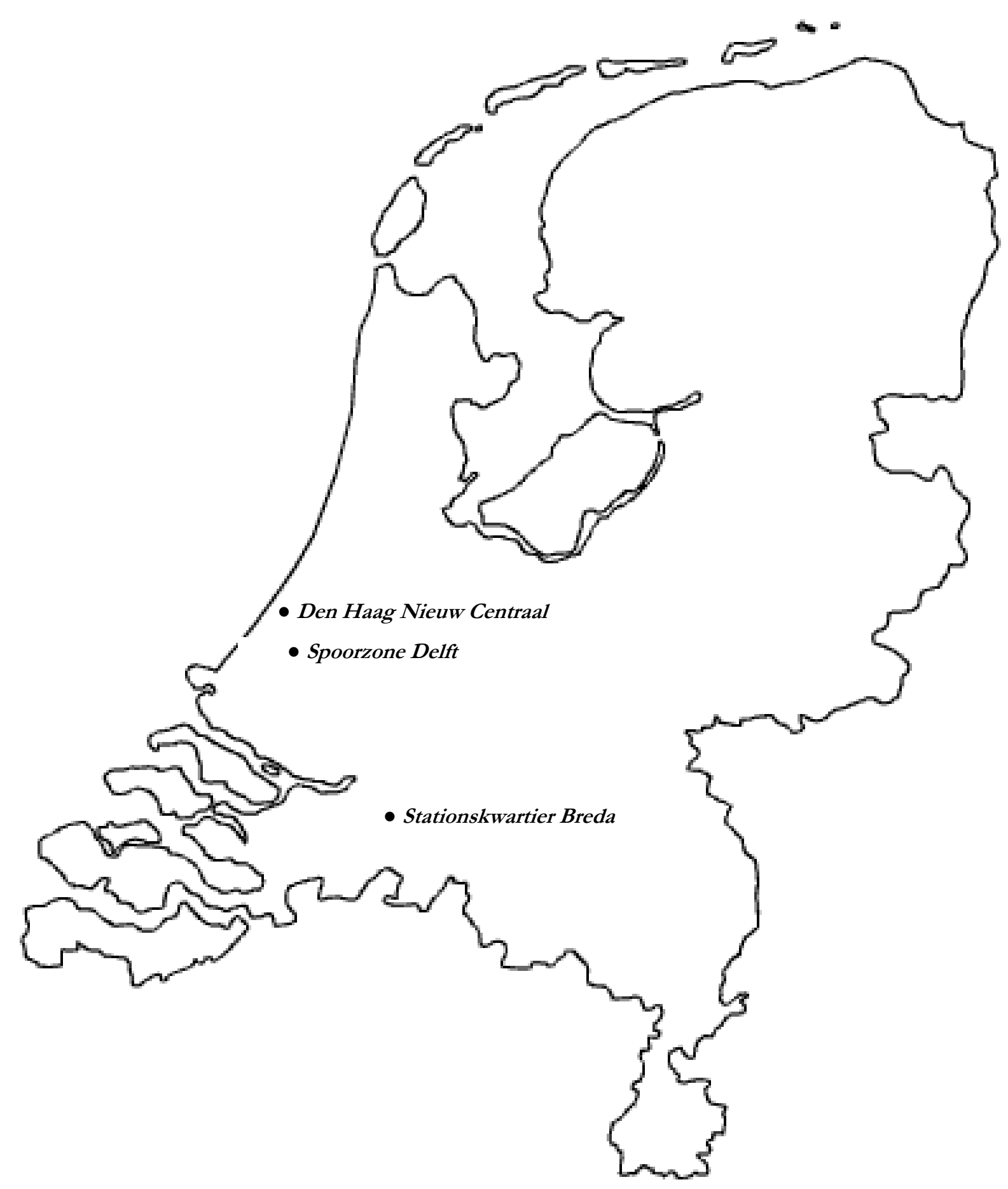




\section{Hoofdstuk 6}

\section{Case 1: Den Haag Nieuw Centraal}

\subsection{Inleiding}

Dit hoofdstuk beschrijft de data die zijn verzameld voor het project Den Haag Nieuw Centraal. Er wordt gestart met een beschrijving van het project (6.2). Het tweede deel van het hoofdstuk beschrijft de inbreng van keystakeholders in de planvorming (6.3) en de borging van het publiek belang in termen van effectieve en legitieme planvorming (6.4). Afgesloten wordt met een kort resumé van de bevindingen (6.5)

\subsection{Het project}

Deze paragraaf beschrijft de projecthistorie en het procesverloop (6.2.1), de ruimtelijke opgave (6.2.2), de posities van (key)stakeholders (6.2.3) en de samenwerkingsorganisatie (6.2.4).

\subsubsection{Projecthistorie en procesverloop}

Het project Den Haag Nieuw Centraal vormt de afronding van Den Haag Nieuw Centrum, een verzamelnaam voor een breed palet aan stedelijke projecten die de afgelopen vijftien jaar in en rond het centrum van Den Haag zijn gerealiseerd. De aanleiding hiervoor is terug te voeren tot 1993. De gemeente Den Haag sloot in dat jaar een convenant met de Rijksoverheid, het Algemeen Burgerlijk Pensioenfonds (ABP) en de Nederlandse Spoorwegen (NS) om het verblijfsklimaat in het gebied van het Centraal Station tot aan het Spui te verbeteren (gemeente Den Haag, 2001). Als vervolg op de plannen en projecten in het kader van Den Haag Nieuw Centrum werd in 1997 het Masterplan Hoog Hage (gemeente Den Haag, 1997) gepresenteerd. Dit Masterplan heeft tot doel Den Haag te versterken als (inter)nationale aanbieder van toplocaties voor kantoren en te versterken als economisch belangrijk centrum in de Randstad. Tevens is het doel om de kwaliteit van de openbare ruimte te verbeteren en de positie van het Centraal Station te versterken als belangrijkste knooppunt voor openbaar vervoer in stad en regio. Het Centraal Station Kwadrant vormt een deelgebied binnen het Masterplan Hoog Hage.

Voor de ontwikkeling van het zogenaamde Centraal Station Kwadrant sloot de gemeente in 1997 een intentieovereenkomst met de NS, Multi-Vastgoed en Winkel Beleggingen Nederland. In dezelfde periode werd vanuit het Rijk begonnen met een nieuwe generatie sleutelprojecten die - evenals de eerste generatie sleutelprojecten - het internationale vestigingsklimaat en de uitstraling op stad en stedelijke omgeving moeten versterken. Den Haag Centraal was een van de zes stations die in het kader van de aanleg van de Hogesnelheidslijn (HSL) als sleutelproject werd benoemd. Daarop vroeg de gemeente Den Haag medio 1999 het Rijk om een bijdrage in het kader van het rijksbeleid voor deze Nieuwe Sleutelprojecten en koos de gemeente er voor om het project Hoog Hage te faseren en het Centraal Station en omgeving als eerste te ontwikkelen. Daarmee ontstond een duidelijk afgebakend plangebied dat als zelfstandig project ontwikkeld kon worden. 
$\mathrm{Al}$ voor de aanwijzing als sleutelproject had de gemeente Den Haag in het kader van de aanleg van RandstadRail, een snelle openbaar vervoersverbinding tussen een aantal stations in de Zuidvleugel van de Randstad, plannen ontwikkeld voor de vernieuwing van het tramplatform in het Haagse Centraal Station. Met de aanwijzing als sleutelproject werd het programma voor de OV-terminal verbreed en werd ook de directe omgeving van het station in de planvorming betrokken. Voor het gehele gebied presenteerde de gemeente, in samenwerking met Kraaijvanger Urbis, eind van de vorige eeuw de zogenaamde uitwerkingsstudie CS kwadrant. Vervolgens ging de gemeente het planproces in met marktpartijen NS vastgoed, NS stations (tegenwoordig samen NS Poort), Multi Vastgoed, CV Babylon en het Stadsgewest Haaglanden. De resultaten van dit planproces werden gebundeld in het Werkschrift CS kwadrant dat in oktober 2000 verscheen.

In juli 2000 kende het Rijk onder voorwaarden geld toe in het kader van het beleid voor de Nieuwe Sleutelprojecten en in oktober van hetzelfde jaar ondertekenden het Rijk en de gemeente Den Haag hiertoe een intentieovereenkomst. In februari 2002 werd vervolgens het nieuwe Ontwerp-Masterplan voor het stationsgebied onder de naam 'Den Haag Nieuw Centraal' gepubliceerd en werd een definitieve aanvraag voor subsidie in het kader van het MIT en NSP beleid bij het Rijk ingediend. Tegelijkertijd werd een intentie-ontwikkelingsovereenkomst (IOO) getekend tussen de gemeente Den Haag, NS vastgoed, Multi-Vastgoed BV en Babylon Den Haag BV. Basis voor deze overeenkomst vormde de intentieovereenkomst die reeds in 1997 was gesloten. In februari 2003 stelden B\&W het Masterplan Den Haag Nieuw Centraal definitief vast. Het Rijk stemde in juni van datzelfde jaar onder voorwaarden in met dit masterplan en reserveerde hiervoor gelden in het kader van het MIT en het NSP beleid.

Op 18 december 2003 sloten de gemeente Den Haag en het Rijk in de persoon van de Minister van VROM en de Minister van V\&W de Bestuurlijke Overeenkomst Uitvoering (BOU) Den Haag Nieuw Centraal (BOU). In deze overeenkomst werd de scope en de financiering van onder andere de OVterminal vastgelegd. Daarin werd tevens overeengekomen dat het OV-terminal deel van het project in twee fasen, OVT I en OVT II, gerealiseerd zou worden. OVT I betreft de verbouwing van het tramplatform in het kader van het project Randstadrail en OVT II betreft de verbouwing van de stationshal zelf.

In 2004 is gestart met OVT I en in 2009 is dit deel afgerond. Na de ondertekening van de BOU tussen Rijk en gemeente is in 2004 tevens het ontwerpproces voor OVT II gestart met de vertaling van het programma van eisen in een schetsontwerp. Na een financiële analyse van het schetsontwerp werd geconstateerd dat de benodigde investering boven het beschikbare budget lag. Besloten werd het ontwerpproces op te schorten totdat er meer duidelijkheid was over de plannen van NS ten aanzien van de invulling van de commerciële ruimtes, die niet tot scope van de OVT behoorden. In overleg met NS is toen besloten om eerst een Schetsontwerp van de ontwikkeling van de commerciële onderdelen binnen het stationscomplex te maken.

Begin 2005 is gestart met het maken van een schetsontwerp van de commercie, het zogenaamde plan Stichthage en medio 2005 werd besloten het schetsontwerp van de OVT en Stichthage uit te werken tot een integraal voorlopig ontwerp OVT II / Stichthage. Medio 2006 werd dit voorlopig ontwerp afgerond. Hoewel het plan nog niet geheel financieel dekkend was heeft de stuurgroep waarin Rijk, gemeente en NS vertegenwoordigd waren, besloten om het ontwerpproces te vervolgen en het voorlopig ontwerp uit te werken in een definitief ontwerp en tegelijkertijd te zoeken naar 
bezuinigingsmogelijkheden. Op basis van het VO heeft in de zomer van 2008 de aanbesteding van de OVT II / Stichthage plaats gevonden. Door overdruk in de markt heeft dit niet tot het gewenste resultaat geleid. Slechts één aannemer was bereid in te schrijven op het werk. Ondanks optimalisaties en onderhandelingen met deze aannemer is uiteindelijk in overleg tussen ProRail, gemeente Den Haag en NS besloten niet tot gunning over te gaan. Er is vervolgens voor gekozen om het werk in uitgewerkte bestekken op de markt te zetten. Omdat marktomstandigheden gewijzigd zijn en met uitgewerkte bestekken meer concurrentie kan worden georganiseerd tussen aannemers is de verwachting dat hernieuwde aanbesteding betere resultaten oplevert.

Parallel aan de ontwikkeling van de plannen voor de OVT werden voor de overige deelgebieden van het Masterplan Den Haag Nieuw Centraal eveneens plannen uitgewerkt. Een MER ${ }^{159}$ werd opgesteld, de bestemmingsplanprocedure 160 werd doorlopen en de gemeente sloot diverse overeenkomsten met eigenaren en ontwikkelaars in deelgebieden. In 2004 werd een overeenkomst gesloten met Babylon Den Haag BV voor de ontwikkeling van New Babylon en een deel van het Anna van Buerenplein en in 2005 werd een samenwerkingsovereenkomst gesloten met de CV KJplein voor de ontwikkeling van het KJ-plein. De laatste overeenkomst is in een later stadium ontbonden omdat het voorgenomen plan niet haalbaar bleek. Ten tijde van schrijven is een aantal deelprojecten in uitvoering en voor andere deelprojecten geldt dat plannen in een vergevorderd stadium verkeren. De voorgaande globale beschrijving van de projectgeschiedenis staat in een overzicht in figuur 6.1 weergegeven.

\subsubsection{De ruimtelijke opgave}

De aanleiding voor het project Den Haag Nieuw Centraal is meervoudig. In de eerste plaats wordt het huidige station Den Haag Centraal niet geschikt bevonden om de toenemende passagiersstromen die het gevolg zullen zijn van de komst van RandstadRail en de Hogesnelheidslijn (HSL) door te voeren. De verwachting is dat het aantal reizigers dat het station aan doet in de periode van 2000 tot 2020 verdubbelt. Ook wordt verwacht dat de residentie mede door de aansluiting op de HSL en RandstadRail als internationale stad zal groeien en een hoogwaardige verbinding tussen het Nederlandse regeringscentrum en de Europese hoofdstad Brussel belangrijker wordt. Grondige verbetering, aanpassing en modernisering van het Haagse Centraal Station wordt om deze redenen noodzakelijk geacht. Een tweede aanleiding is gelegen in het verbeteren van het ruimtegebruik rond het station. De huidige situatie wordt niet in overeenstemming met de sociaal-economische potentie van dit gebied geacht. Bovendien wordt de kwaliteit van het vastgoed benoemd als matig tot slecht (Masterplan Den Haag Nieuw Centraal). De opgave staat in het Masterplan Den Haag Nieuw Centraal als volgt omschreven: 'Het komen tot integrale ontwikkeling van het stationsgebied tot Nieuw Centraal, zodat ook dit deel van de stad past bij het karakter van de stad'. Daartoe moet zowel ruimtelijk als functioneel de samenhang in het gebied versterkt worden. De scope van het plangebied is in het masterplan begrenst tot het gebied dat gelegen is tussen de Utrechtsebaan-Rijnstraat en Bezuidenhoutseweg-Prins Bernhardviaduct. Het masterplan beschrijft de stedenbouwkundige randvoorwaarden voor de inrichting van dit gebied waarin ook het centraal station zich bevindt. Het plangebied heeft een omvang van ongeveer vierhonderd bij vierhonderd meter waarbinnen vijf planonderdelen worden onderscheiden. ${ }^{161}$ 


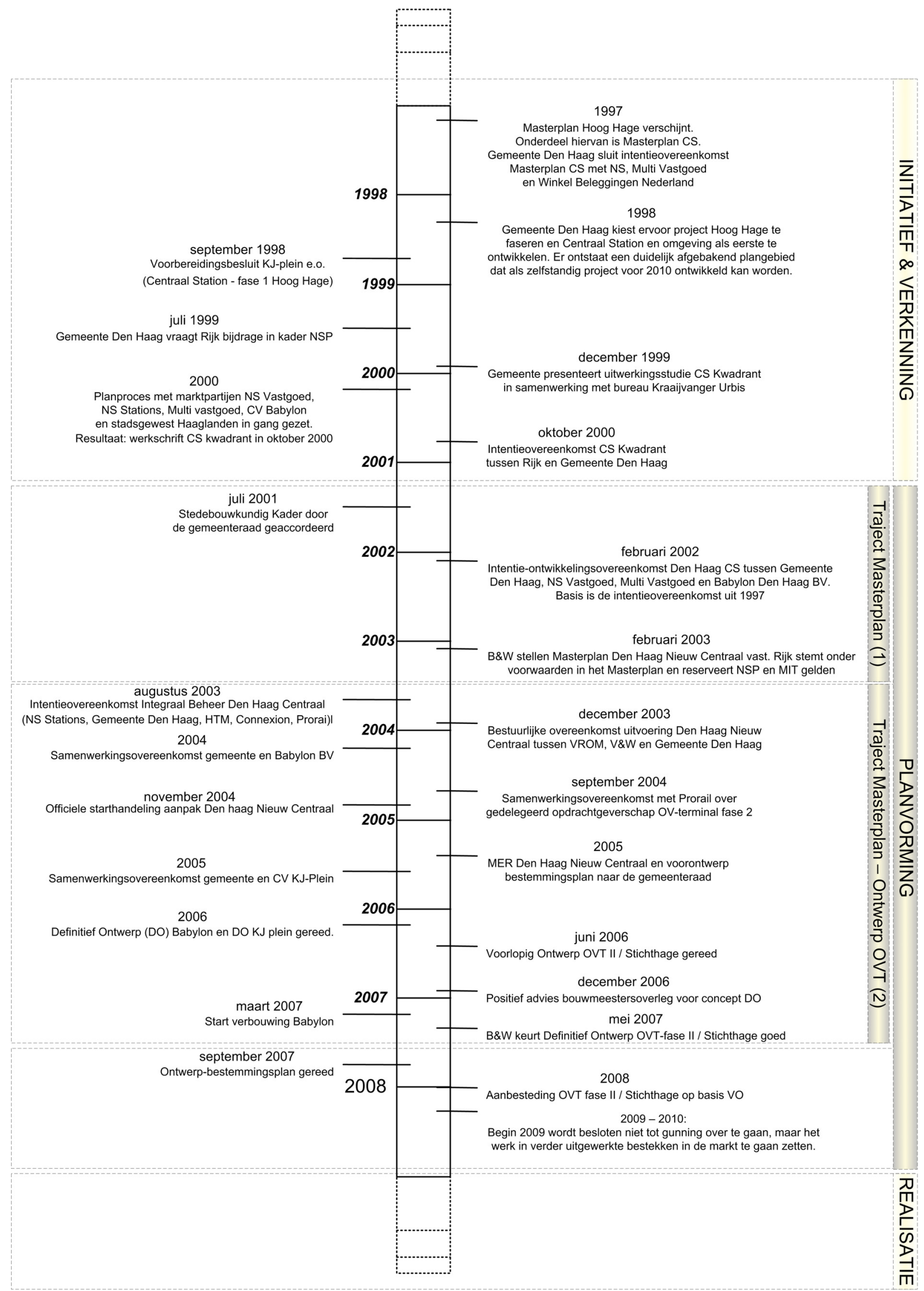

Figuur 6.1 Den Haag Nieuw Centraal - Procesverloop 


\section{OV-terminal}

Mede door de komst van de HSL en de ontwikkeling van Randstadrail, de light-rail verbinding tussen de steden Den Haag, Rotterdam en Zoetermeer, is de verwachting dat het aantal reizigers dat gebruik maakt van het Haagse Centraal Station de komende twintig jaar verdubbelt. In zijn huidige vorm zal het vervoersknooppunt dan niet meer voldoen aan de eisen die gesteld worden aan de transfercapaciteit. Tevens wordt gesteld dat de kwaliteit van het station niet meer aan sluit bij het omliggende gebied. Het is de bedoeling dat de centrale stationshal lichter, overzichtelijker en groter wordt met als oogmerk dat reizigers hun weg naar trein, tram, bus, taxi, auto of fiets makkelijker en sneller kunnen vinden. Daartoe wordt tevens de positionering van winkels, horeca en andere functies veranderd, het tramplatform opnieuw ingericht, taxistandplaatsen en kiss \& ride plekken gecreëerd en wordt het aantal stallingplekken voor fietsen ondergronds sterk uitgebreid.

De opdrachtverstrekking van de OV-terminal is onder te verdelen in twee fases. De eerste fase (OVT I) richt zich op het tramplatform. De tweede fase (OVT II) heeft betrekking op de inrichting van de hal, de gevels, de vloer en het dak van de terminal en de fietsenstalling. Daarnaast maakt de aanpak van de commerciële ruimte in het onderste deel van het gebouw Stichthage onderdeel uit van de tweede fase. In 2004 is gestart met OVT I. Deze fase is afgerond en het tramplatform is gereed voor ingebruikname door RandstadRail. In 2007 is het ontwerp van Bethem Crouwel architecten voor OVT II en Stichthage afgerond. Omdat de aanbesteding uiteindelijk niet het gewenste resultaat had is in 2009 besloten het werk verder uit te werken en de uitgewerkte bestekken in de markt te zetten. Gunning is gepland voor 2010 en oplevering voor 2013.

\section{Koningin Julianaplein (KJ plein)}

Het KJ-plein ligt voor het station. Sinds 2003 is gewerkt aan het sluiten van een overeenkomst tussen de gemeente Den Haag en de CV KJ-plein voor de ontwikkeling van dit deelgebied. CV KJ is een samenwerking tussen NS Poort en Multi-Vastgoed BV. NS Poort had een intentieovereenkomst met de gemeente waarin zij als eerste gegadigde voor ontwikkeling op of onder het plein werd aangemerkt. De combinatie van een aantal knelpunten en het ontbreken van geschikte afnamekandidaten (zowel beleggers als gebruikers) voor de geplande ontwikkeling zorgde ervoor dat uiteindelijk pas op 18 december 2008 een samenwerkingsovereenkomst (SOK) werd gesloten tussen de gemeente Den Haag en CV KJ.

Op het $\mathrm{KJ}$-plein moet volgens de plannen een multifunctioneel gebouw worden gerealiseerd waarin kantoren (ca $43.000 \mathrm{~m}^{2}$ bvo), woningen (ca. $31.000 \mathrm{~m}^{2}$ bvo) en winkels (ca. $4.000 \mathrm{~m}^{2}$ bvo) een plek krijgen met ondergronds een parkeergarage voor 450 auto's met ruimte voor fietsparkeren (6.000). In opdracht van de ontwikkelingscombinatie CV KJ-plein is door architectenbureau OMA het ontwerp gemaakt. Door de kredietcisis bleek het voor de CV KJ lastig om de financiering rond te krijgen. De samenwerkingsovereenkomst tussen de gemeente Den Haag en CV KJ is daarop ontbonden. Het oorspronkelijke ontwerp is aangepast en met een nieuwe ontwikkelaar (Eurocommerce) wordt het project alsnog gerealiseerd. NS Poort en Multi Vastgoed blijven wel betrokken bij het project en ontwikkelen de winkels aan de onderkant van het gebouw. Eurocommerce ontwikkelt de kantoren en de woningen, waarbij overeengekomen is dat de gemeente Den Haag garant staat voor de afname van $12.500 \mathrm{~m}^{2}$ kantoorruimte. Volgens de oorspronkelijke planning moest de nieuwbouw in 2011 gereed zijn. De huidige planning gaat uit van oplevering in 2014. 


\section{New Babylon}

Het huidige multifunctionele complex Babylon wordt deels gesloopt, gemoderniseerd en uitgebreid. Het ontwerp van Meyers en Van Schrooten architecten voorziet in de bouw van twee woontorens (van 100 en 100-150 meter hoogte die ruimte bieden aan 350 appartementen), uitbreiding van het kantorenprogramma met $31.000 \mathrm{~m}^{2}$ bvo en het vernieuwen van het winkelcentrum. Het bestaande hotel wordt uitgebreid en overbouwd. De huidige parkeergarage wordt aangepast en ondergronds verbonden met de te ontwikkelen parkeergarage onder het Anna van Buerenplein. In 2006 is het definitief ontwerp vastgesteld. De bouwvergunning is verleend aan ontwikkelingscombinatie Babylon Den Haag BV (fortress en SNS Property Finance) en in 2007 is gestart met de uitvoering. De eerste delen zijn al opgeleverd en volgens de planning moet in 2012 New Babylon volledig gereed zijn.

\section{Anna van Buerenplein (AvB-plein)}

Het Anna van Buerenplein vormt de verbinding tussen de stationshal en de omringende ministeries en culturele instellingen. De bovengrondse parkeergarage is gesloopt en vervangen door een drielaagse parkeergarage gerealiseerd met ruimte voor ongeveer duizend auto's. Op de plek van de voormalige bovengrondse parkeergarage wordt een grote openbare ruimte ontwikkeld die toegang biedt tot de instellingen en voorzieningen die aan het plein grenzen, of in de nabije omgeving liggen. Aan het plein wordt het nieuwe Anna van Buerengebouw gerealiseerd dat de uitstraling van het plein moet versterken door de bijzondere architectuur. Na beëindiging van de gesprekken met de Rijksgebouwendienst over de ontwikkeling van dit gebouw heeft de gemeente Den Haag de mogelijkheden voor de ontwikkeling van de locatie samen met Fortress Projectontwikkeling BV verkend. Op 18 december 2008 hebben beide partijen een samenwerkingsovereenkomst (SOK) gesloten. De planontwikkeling behelst $22.500 \mathrm{~m}^{2}$ bvo bestaande uit plintfuncties (max. $1.000 \mathrm{~m}^{2}$ bvo), recreationele voorzieningen (max. $3.500 \mathrm{~m}^{2}$ bvo), kantoren (max. $11.500 \mathrm{~m}^{2}$ bvo) en woningen $(\max$. $6.500 \mathrm{~m}^{2}$ bvo). Het is de bedoeling dat de onderste lagen een publieke culturele invulling krijgen. De start van de bouw staat gepland voor 2010 en de geplande oplevering is eind 2011.

\section{Overbouning busplatform}

Boven het busplatform is het de bedoeling dat kantoren worden gerealiseerd. Het programma gaat uit van ca. $70.000 \mathrm{~m}^{2}$ bvo. De maximale hoogte van de gebouwen is 70 meter. Onder de kantoorgebouwen houden de bussen, auto's en taxi's rechtstreeks toegang tot het busplatform en de ingang van het station. De realisatie van het busplatform staat gepland voor de periode na 2012.

\subsubsection{Actoren}

\section{Gemeente Den Haag}

De gemeente Den Haag voert de regie over de integrale herontwikkeling van het plangebied Den Haag Nieuw Centraal. In de Intentieontwikkelingsovereenkomst (IOO) tussen de gemeente Den Haag, NS Vastgoed, Multi-Vastgoed BV en Babylon Den Haag BV, is de betrokkenheid van de gemeente gemotiveerd vanuit de uitoefening van haar publiekrechtelijke taak op het gebied van ruimtelijke ordening en openbare ruimte, alsmede haar grondeigenaarsrol van deelproject KJ-plein en eigenaar van het erfpachtrecht van Babylon. Voor de ontwikkeling van de OV-terminal fungeert de gemeente zowel voor de eerste als de tweede fase als risicodragend opdrachtgever. Het projectmanagement voor de eerste fase werd gedaan door de projectorganisatie RandstadRail die was 
ondergebracht bij de dienst Stadsbeheer van de gemeente. ${ }^{162}$ Voor de tweede fase is intensief gezocht naar een samenwerkingsvorm die voor alle partijen aanvaardbaar was. Overeengekomen was dat de gemeente (voor OVT II) en NS Poort (voor het deel Stichthage) opdrachtgevers waren voor ProRail die het projectmanagement zou doen. Omdat beide deelplannen dusdanig met elkaar verweven zijn hebben NS Poort en de gemeente Den Haag een samenwerkingsovereenkomst hiervoor gesloten. ${ }^{163}$ De gehanteerde organisatievorm waarbij de gemeente en NS Poort opdrachtgevers waren voor ProRail is in een later stadium weer verlaten. NS Poort heeft ervoor gekozen om zelfstandig het projectmanagement ter hand te nemen. Na het beëindigen van de aanbesteding in 2009 is NS Poort weer verantwoordelijk voor Stichthage en richt de gemeente zich met ProRail op het uitwerken van OVT II. Ook contractueel zijn de twee onderdelen van de tweede fase ontvlochten.

Naast het opdrachtgeverschap voor de OV-terminal berust ook de regie over de verwezenlijking van de deelgebieden KJ-plein, Babylon, het Anna van Buerenplein en busplatform bij de gemeente. Dit betekent onder andere dat de gemeente als initiator of opdrachtgever voor deelgebieden architecten of aannemers selecteert, overeenkomsten sluit met andere overheden over de uitoefening van publiekrechtelijke bevoegdheden, overeenkomsten sluit met ontwikkelaars en andere private partijen voor de uitgifte van gronden en de ontwikkeling van deelgebieden, overeenkomsten sluit met eigenaren en andere belanghebbende partijen binnen het projectgebied. De gemeente Den Haag neemt als publieke eindverantwoordelijke plaats in de stuurgroep Den Haag Nieuw Centraal. Hierin wordt zij vertegenwoordigd door de wethouders van Ruimtelijke Ordening, Stadsvernieuwing en Volkshuisvesting (ROSV) en van Verkeer, Binnenstad en Beschermde Stadsgezichten (VBBS). De centrale projectorganisatie is geplaatst bij de dienst stedelijke ontwikkeling van de gemeente Den Haag. De gemeente investeert in totaal circa 100 miljoen euro in het project (Factsheet Den Haag Nieuw Centraal, juli 2007). Deze bijdrage is voor een groot deel afkomstig uit vastgoedontwikkelingen.

\section{Stadsgewest Haaglanden en provincie Zuid-Holland}

Het stadsgewest Haaglanden (SGH) is een samenwerkingsverband van negen gemeenten in de regio Haaglanden waar een aantal taken en bevoegdheden zijn ondergebracht. ${ }^{164} \mathrm{SGH}$ is voornamelijk betrokken bij de ontwikkelingen in het stationsgebied als uitvoerend orgaan van het regionaal afgestemde mobiliteits- en bereikbaarheidsbeleid. Zo is het SGH opdrachtgever voor het tram- en busvervoer in de regio en draagt het, in samenwerking met de gemeenten, zorg voor de aanleg van nieuwe tram en buslijnen en het onderhoud van lokale railinfrastructuur. Relevant voor de rol van het SGH bij de aanpak van het Haagse centraal station is de integrale verantwoordelijkheid van SGH voor de aanleg en het beheer van het Haagse deel van RandstadRail waarvoor het subsidie heeft ontvangen vanuit het Rijk. Een van de deelprojecten is de aanpassing van het tramplatform in de stationshal (OVT-fase I). SGH heeft de opdracht voor de uitvoering van de bouw van het Haagse deel van RandstadRail in 2003 aan de gemeente Den Haag gedelegeerd. De afspraak daarbij tussen SGH en de gemeente Den Haag is dat dit project voor rekening en risico van de gemeente Den Haag gerealiseerd zou worden. De gemeente Den Haag werd gezien als de enige organisatie met voldoende ervaring en vermogen om dergelijke risico's te nemen. Bovendien moesten de meeste werkzaamheden op Haags grondgebied plaatsvinden. Omdat SGH voor RandstadRail de formele contractpartner was van het Rijk diende het wel daarover te rapporteren. SGH geldt tevens als opdrachtgever voor het lokaal en regionaal openbaar vervoer en vertegenwoordigd als zodanig ook de belangen van de 
verschillende leveranciers van openbaar vervoersdiensten (HTM/Connexion). Een goede afstemming van vervoersstromen is daarbij de inzet (Daamen, 2005). Als uitvoerend orgaan voor het regionale mobiliteits- en bereikbaarheidsbeleid is het tevens budgetbeheerder van de regionale mobiliteitssubsidie (onderdeel MIT). De financiële bijdrage van het van SGH bedraagt in totaal 72 miljoen euro (Factsheet Den Haag Nieuw Centraal, juli 2007). De provincie Zuid-Holland speelt een relatief beperkte rol bij het project, voornamelijk in het kader van het uitoefenen van haar publiekrechtelijke bevoegdheden.

\section{Ministerie van VROM}

Het Rijk heeft via de ministeries van Verkeer en Waterstaat en Volkshuisvesting, Ruimtelijke Ordening en Milieubeheer zijn belangen direct gekoppeld aan de ontwikkeling van Den Haag Nieuw Centraal. Hiertoe hebben het Rijk en gemeente Den Haag in oktober 2000 een intentieovereenkomst gesloten die in december 2003 is uitgemond in een Bestuurlijke Uitvoeringsovereenkomst. In deze uitvoeringsovereenkomst zijn gezamenlijke ambities en randvoorwaarden voor de toekenning van rijksmiddelen opgenomen. VROM draagt 34 miljoen bij in het kader van NSP 1 (kwaliteitsverbetering stedelijke omgeving) en 15 miljoen voor NSP 2 (OV-terminal fase 1). Voor toekenning van deze bijdragen is het Masterplan Den Haag Nieuw Centraal getoetst op de bijdrage aan het realiseren van de rijksdoelstellingen voor de Nieuwe Sleutelprojecten. In de bestuurlijke overeenkomst tussen Rijk en gemeente is voorwaarde voor deze bijdragen dat de gemeente zich maximaal inspant om zogenaamde NSP-kwaliteit te realiseren, waarvan de uitgangspunten zijn neergelegd in het Masterplan en het schetsontwerp. Vanuit het Ministerie van VROM is de Rijksbouwmeester verantwoordelijk voor de toets op de stedenbouwkundige kwaliteit. Hierover brengt de Rijksbouwmeester advies uit aan het Directoraat Generaal Ruimte van het Ministerie van VROM. De Rijksgebouwendienst (RGD) is als onderdeel van het ministerie van VROM en eigenaar van de gebouwen van het Ministerie van Binnenlandse Zaken, het Letterkundig Museum, de Koninklijke Bibliotheek en het Nationaal Archief (het zogenaamde Rijkscluster) een duidelijke stakeholder in het gebied. Zij heeft geen grondpositie, maar is wel als ontwikkelaar betrokken bij het deelproject Anna van Buerenplein. Waarvoor eind 2003 een intentie-ontwikkelingsovereenkomst is gesloten met de gemeente Den Haag.

\section{Ministerie van Verkeer en Waterstaat}

Het ministerie van V\&W is bij het project betrokken vanuit haar verantwoordelijkheid voor de transferfunctie van stations en de aanleg van de Hogesnelheidslijn. Zij stuurt taakorganisatie ProRail aan en neemt deel aan de stuurgroep Rijk-gemeente. Vanuit het MIT-grote stations draagt het ministerie 79 miljoen euro bij aan de verbouwing van de stationshal (OVT-fase 2; prijspeil 1 januari 2002). In de eerste plaats is die bijdrage gericht op het bereiken van een adequate transfercapaciteit voor de treinreizigers. Samen met de bijdrage van VROM en geïndexeerd voor het deel van V\&W is de totale bijdrage vanuit het Rijk 145 miljoen (Factsheet Den Haag Nieuw Centraal, juli 2007). ${ }^{165}$

\section{ProRail}

ProRail, taakorganisatie van het Ministerie van V\&W, beheert de perrons en sporen in Den Haag Centraal. Daarnaast is zij verantwoordelijk voor de transfervoorzieningen in de stationshal. In dat verband is ook een beheersovereenkomst gesloten met de NS en de gemeente Den Haag. ProRail fungeert normaliter als gedelegeerd opdrachtgever van het ministerie van Verkeer en Waterstaat. In 
dit project heeft het ministerie echter de financiële middelen voor de aanpak van de OV-terminal onder voorwaarden overgedragen aan de gemeente Den Haag. In verband met subsidiebepalingen heeft de gemeente het opdrachtgeverschap voor de tweede fase van de OV-terminal weer aan Prorail gedelegeerd. De primaire belangen van ProRail zijn een efficiënte organisatie van de OV-terminal en een optimale aansluiting daarvan op het stedelijke gebied. ProRail participeert in de coördinatiegroep van Nieuw Centraal, waar onder andere de raakvlakken tussen het OV-terminal gedeelte en de rest van het plangebied worden besproken en besluiten worden voorbereid.

\section{Nederlandse Spoorwegen (NS)}

Het bestaande gebouw Stichthage dat de verbinding vormt tussen de OV-terminal en het KJ-plein is eigendom van NS Poort. ${ }^{166}$ De voet van dit gebouw maakt onderdeel uit van het integraal ontwerp voor OVT II / Stichthage en vormt tevens een belangrijk raakvlak tussen de OV-terminal en de plannen voor het KJ-plein. NS Poort doet de commerciële ontwikkeling van Stichthage voor eigen rekening en risico. NS heeft een sterke positie binnen de OV-Terminal. De grond onder de OVterminal is eigendom van NS en zij beschikt over de overbouwingsrechten. NS Poort is tevens vanuit haar kerntaken beheer, exploitatie, kaartverkoop, service \& informatievoorziening betrokken bij de herontwikkeling en verzorgt de schoonmaak, het onderhoud en de veiligheid van stations en hun directe omgeving: van stationshal en perrons tot fietsstallingen. Ook valt het aanbod van diensten en de commerciële exploitatie van winkels op stations onder de verantwoordelijkheid van NS Poort.

Naast NS Poort zijn vanuit de NS tevens NS Commercie (ontwikkeld de commerciële strategie voor reizigersvervoer en knooppuntontwikkeling) en NS projectconsult (levert een bijdrage aan het ontwikkelen en realiseren van stationsgerelateerde reizigersvoorzieningen) betrokken. Volgens de intentieverklaring (IOO) treed NS Vastgoed (tegenwoordig NS Poort) op als vertegenwoordiger voor het gehele NS concern. Hiertoe heeft NS als ontwikkelaar ook een plek in de stuurgroep. Vanuit haar betrokkenheid bij de OV-terminal vertegenwoordigt zij ook de belangen van de gebruiker, de beheerder en de commerciële exploitanten in de coördinatiegroep. Voor de ontwikkeling van het KJplein participeert NS Poort in de CV KJ.

\section{KJ / Eurocommerce}

NS Poort was de eerste gegadigde voor de bebouwing op of onder het KJ-plein. ${ }^{167}$ Hiervoor heeft CV KJ, waarin NS Poort en Multi Vastgoed BV beide voor 50\% participeerden in 2008 een samenwerkingsovereenkomst gesloten met de gemeente Den Haag. Omdat de plannen niet haalbaar bleken is deze overeenkomst ontbonden. De bedoeling is nu dat CV KJ doen de exploitatie voor de onderste deel van het nieuwe gebouw en de verdiepingen daarboven zullen worden geëxploiteerd door Eurocommerce.

\section{Babylon Den Haag BV (Fortress en SNS Property Finance)}

Ter plaatse van het deelgebied Babylon is nu een winkelcentrum met hotel gelegen dat door Fortress en SNS Property Finance wordt beheerd en in eigendom is. ${ }^{168}$ Fortress is een vastgoedonderneming die zich enerzijds richt op de aankoop, herpositionering en het beheren van vastgoed(portefeuilles) en anderzijds op binnenstedelijke (her)ontwikkeling. SNS Property Finance is als vastgoedbelegger een partij die meer op de achtergrond opereert en streeft naar een maximaal lange termijn rendement op haar vastgoedbeleggingen. Beide partijen werken samen in de joint venture Babylon Den Haag BV. 
De gemeente Den Haag zal samen met deze partijen het deelplan Babylon en de parkeergarage onder het Anna van Buerenplein ontwikkelen. De huidige parkeergarage, onder het Anna van Buerenplein, die wordt gesloopt en verkocht, is in eigendom en exploitatie van Q-park. Daarvoor wordt een drietal nieuwe parkeerkelders gerealiseerd; het belang van Q-park ligt bij de toekomstige exploitatie daarvan.

\section{Overige actoren}

In de tabel 6.1 staan voor de afzonderlijke planonderdelen de actoren die een rol spelen in de planvorming en hun positie weergegeven.

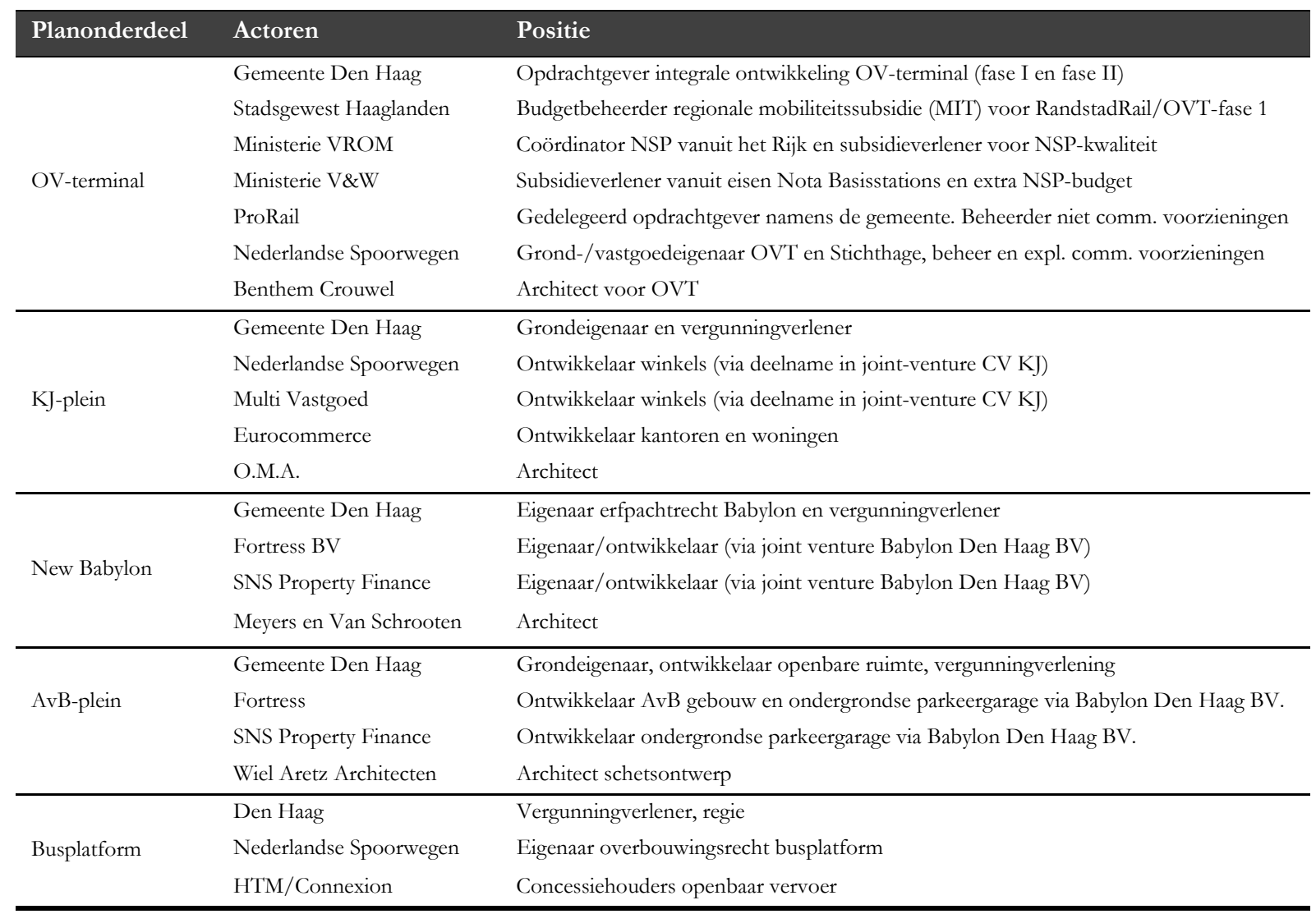

Tabel 6.1 Den Haag Nieuw Centraal: actoren per planonderdeel

Naast de beschreven actoren kunnen tevens nog een aantal andere typen actoren worden onderscheiden die een rol spelen in de totstandkoming van het project Den Haag Nieuw Centraal. Verschil met de eerder beschreven partijen is dat deze niet op basis van een bestuurlijke verantwoordelijkheid of als eigenaar/ontwikkelaar betrokken zijn in de herontwikkeling van Den Haag Nieuw Centraal. Hierbij kan onder meer worden gedacht aan andere vervoerders dan NS, zoals HTM en Connexion. HTM is een NV waarvan alle aandelen in handen zijn van de gemeente Den Haag. HTM beschikt tot 2017 over een railconcessie voor de regio Haaglanden bestaande uit het tramvervoer en de Zoetermeerlijn en een busconcessie voor het stadsnet die duurt tot 2012. Connexxion verzorgt onder andere het taxivervoer en de Interliner. De belangen van de vervoerders worden via de concessieovereenkomst vertegenwoordigd door het stadsgewest Haaglanden. Als 
vervoerders zijn zij ook betrokken bij het beheer van de integrale OV-terminal waarvoor afspraken met NS Stations, ProRail en de gemeente gemaakt zijn.

Niet zozeer als stakeholder, maar wel als relevante actor in de planvorming kan hier ook het bouwmeestersoverleg worden genoemd. Dit overleg, waarin de stadsbouwmeester, ${ }^{169}$ de rijksbouwmeester ${ }^{170}$ en de spoorbouwmeester ${ }^{171}$ zitting hebben, adviseert de stuurgroep Rijkgemeente met betrekking tot vraagstukken over ruimtelijke kwaliteit en stedenbouwkundige aspecten. Dit is vooral van belang omdat voorafgaand aan subsidieverstrekking vanuit het Rijk door het bouwmeestersoverleg getoetst wordt of de plannen zullen zorgen voor de realisatie van zogenaamde NSP-kwaliteit.

Andere partijen zijn bijvoorbeeld bouwers en vastgoedbeleggers. Bouwcombinatie New Babylon B.V., een samenwerkingsverband van Boele \& van Eesteren en Ballast Nedam die de uitvoering van de werkzaamheden voor New Babylon verricht en Amvest BV die voor 51\% eigenaar wordt van de gerealiseerde woningen van New Babylon zijn hier voorbeelden van.

\subsubsection{Samenwerkingsorganisatie}

De gemeente Den Haag, NS Vastgoed, Multi-Vastgoed en Babylon Den Haag BV (Fortress en SNS Property Finance) hebben al op 28 februari 2002 een intentieontwikkelingsovereenkomst (IOO) gesloten. Deze overeenkomst beschrijft de juridische posities van de partijen en legt de programmatische en financiële kaders vast waarbinnen samenwerkingsovereenkomsten zullen worden gesloten. Per deelgebied zijn en worden vervolgens samenwerkingsovereenkomsten (SOK) gesloten. In een dergelijke SOK worden onder andere de samenwerking op juridisch, organisatorisch en fiscaal gebied, de vorm van de uitgifte, de verplichtingen van partijen, de juridische/planologische randvoorwaarden, de fasering van het deelproject en een geschillenregeling vastgelegd. Basis voor de samenwerkingsovereenkomsten is een door de betrokken private partij op te stellen schetsontwerp, dat goedkeuring behoeft van de gemeente. In de IOO hebben partijen vastgelegd dat de ontwikkeling van de OV-terminal een ander tijdpad kent. Dit onderdeel is ook al in een vroeg stadium uit de gehele gebiedsexploitatie gehaald. Hoewel er sprake is van één integrale exploitatie voor de overige delen en één bestemmingsplan voor heel Den Haag Nieuw Centraal, is niet gekozen voor een integrale publiek-private samenwerking, maar voor afzonderlijke overeenkomsten per deelgebied.

De samenwerking tussen Rijk en gemeente is vastgelegd in een bestuurlijke uitvoeringsovereenkomst van 18 december 2003. Hierin zijn gezamenlijke ambities en de voorwaarden voor rijksbijdragen in het kader van het NSP-beleid en het MIT opgenomen. De organisatie van de samenwerking is voor een belangrijk deel vastgelegd in de IOO en is in een later stadium verder uitgewerkt. Voor de verschillende deelprojecten zijn er planteams opgericht. Ieder planteam rapporteert aan de coördinatiegroep waarvan het voorzitterschap door de gemeente wordt vervuld. De coördinatiegroep stuurt werkgroepen zoals de communicatiegroep aan en bereid besluiten van de stuurgroep voor. Binnen de stuurgroep kan, afhankelijk waar de besluitvorming betrekking op heeft, een onderscheid gemaakt worden naar de stuurgroep rijk-gemeente, de stuurgroep intern-gemeente en de stuurgroep gemeente-privaat. In de stuurgroep rijk-gemeente zitten twee vertegenwoordigers van de gemeente en de ministeries VROM en V\&W hebben ieder een vertegenwoordiger. Het secretariaat ligt ook bij de gemeente. Deze stuurgroep heeft tot taak toe te zien op de uitvoering van de bestuurlijke overeenkomst en de voortgang van het project en fungeert als primaire overlegvorm tussen gemeente 
en Rijk. De stuurgroep beslist bij unanimiteit. Figuur 6.2 geeft een overzicht van de overlegstructuren in de planvormingsfase.

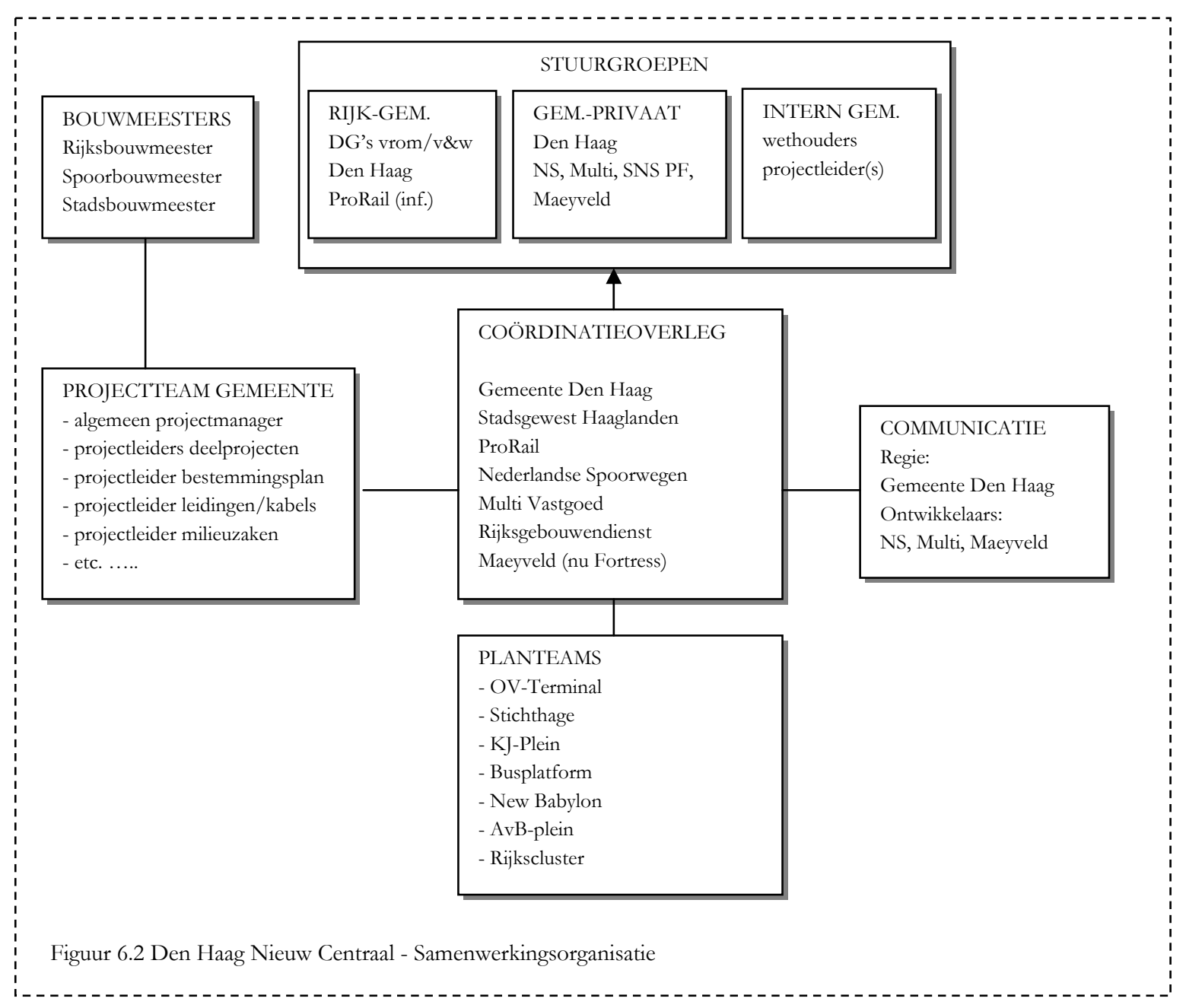

\subsection{Planproces}

In de vorige paragraaf is op basis van projectdocumentatie een beeld geschetst van het project Den Haag Nieuw Centraal. Daarbij zijn de posities van diverse betrokken actoren belicht. Deze paragraaf beschrijft de inbreng van keystakeholders in het proces van planvorming. Zoals in hoofdstuk vier beschreven is voor het typeren van de inbreng van keystakeholders in belangrijke mate gebruik gemaakt van de percepties hiervan bij betrokkenen. De inbreng van keystakeholders is beschreven op drie thema's:

- Visievorming (6.3.1)

- Zeggenschap (6.3.2)

- Middelen (6.3.3) 
Nadat de inbreng van de afzonderlijke actoren op deze thema's is beschreven, is het samenstel van actoren getypeerd door te kijken naar (a) het aantal actoren dat een substantiële inbreng heeft; (b) de verhoudingen tussen actoren met uiteenlopende karakters en belangenposities (publiek-privaat; centraal-decentraal; gemeente-overige); en (c) de mate waarin er sprake is van ambivalentie in het beeld bij actoren. Dit is gedaan in paragraaf 6.3.4.

Belangrijk is de tijdsperiode waarop de analyse betrekking heeft af te bakenen. In deze studie is een onderscheid gemaakt naar (1) het deelproces gericht op de totstandkoming van het masterplan voor de gebiedsontwikkeling als geheel en (2) het deelproces gericht op het ontwikkelen van een ontwerp voor de OV-terminal.

Voor het eerste deelproces is de ondertekening van de intentieovereenkomst tussen Rijk en gemeente Den Haag van oktober 2000 als startpunt genomen en de goedkeuring van het Masterplan door het Rijk in februari 2003 als eindpunt. Voor het tweede deelproces is de periode tussen goedkeuring van het Masterplan en de vaststelling van het definitief ontwerp voor OVT fase 2 / Stichthage door B\&W in mei 2007 beschouwd (zie figuur 6.1).

\subsubsection{Visievorming}

Met de komst van RandstadRail, de aanwijzing als Sleutelproject en de wens van de gemeente Den Haag om in het kader van de ontwikkeling van het Haagse centrum het verblijfsklimaat in de omgeving van het Centraal Station te verbeteren, is de aanleiding voor het project Den Haag Nieuw Centraal drieledig. De gemeente presenteerde in samenwerking met het architectenbureau Kraaivanger Urbis in 1999 de uitwerkingsstudie CS Kwadrant. In vervolg daarop heeft de gemeente in samenwerking met NS Stations, NS Vastgoed, Multi Vastgoed, CV Babylon en het stadsgewest Haaglanden het Werkschrift CS Kwadrant opgesteld. Ondanks de betrokkenheid van meerdere partijen in deze eerste fase wordt de gemeente Den Haag door het overgrote merendeel van de partijen gezien als de partij die een startvisie heeft geformuleerd.

\section{Visievorming in het masterplanproces}

Het Werkschrift CS Kwadrant is uitgewerkt tot het Masterplan Den Haag Nieuw Centraal. Dit Masterplan, dat in 2003 door de Haagse gemeenteraad is vastgesteld, beschrijft de ruimtelijkfunctionele ontwikkeling van het Centraal Station en omgeving voor de komende decennia. Het Masterplan is opgesteld door architectenbureau Kraaivanger Urbis in samenwerking met de dienst stedelijke ontwikkeling (DSO) van de gemeente Den Haag. De opdracht daarvoor is gegeven door de gemeente Den Haag, NS, Multi Vastgoed, Babylon Den Haag BV en het stadsgewest Haaglanden.

In de perceptie van alle betrokken keystakeholders heeft de gemeente Den Haag in dit proces veruit de grootste inbreng gehad. Verschillende partijen met posities in het plangebied nemen deel in het coördinatieoverleg, de stuurgroepen en de planteams, maar de gemeente voert de regie in het proces en de projectorganisatie is gevestigd bij de dienst stedelijke ontwikkeling van de gemeente. De inbreng van alle overige actoren in het proces van visievorming wordt aanzienlijk kleiner beschouwd. De beelden bij informanten daarvan blijken echter nogal uiteen te lopen, zoals uit figuur 6.3 blijkt. Slechts over de zeer grote inbreng van de gemeente Den Haag in dit visievormingproces is het beeld volledige eenduidig. ${ }^{172}$ 


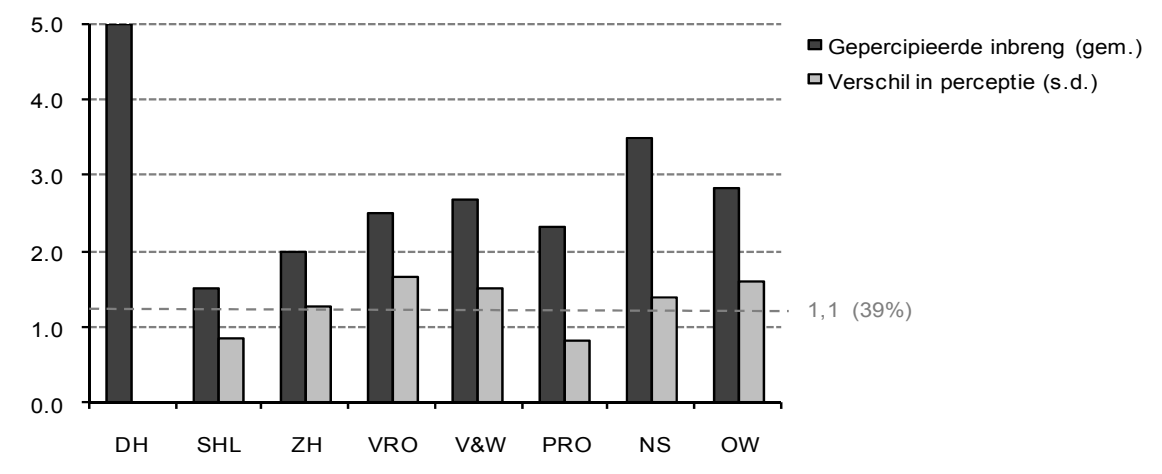

$\begin{array}{lll}\text { DH } & \text { Den Haag } & 5=\text { zeer grote inbreng } \\ \text { SHL } & \text { Stadsgewest Haaglanden } & 4=\text { grote inbreng } \\ \text { ZH } & \text { Provincie Zuid-Holland } & 3=\text { redelijke inbreng } \\ \text { VRO } & \text { Ministerie VROM } & 2=\text { kleine inbreng } \\ \text { V\&W } & \text { Ministerie V\&W } & 1=\text { zeer kleine inbreng } \\ \text { PRO } & \text { ProRail } & \\ \text { NS } & \text { NS Poort } & 1,1=\text { gemiddelde standaard deviatie } \\ \text { OW } & \text { Private ontwikkelaars } & (39 \%)=\text { variatiecoëfficiënt }\end{array}$

Figuur 6.3 Masterplan DHNC - inbreng van stakeholders in visievorming en perceptieverschillen

De perceptie van de inbreng van partijen in dit proces kan ook ingegeven zijn door een bepaalde verwachting of beeld van een wenselijke situatie. ${ }^{173}$ Daarom is tevens gevraagd welke inbreng men voor de diverse partijen wenselijk vindt. De grote rol van de gemeente blijkt dan zonder uitzondering door alle partijen als wenselijk te worden gezien. Ook voor de andere partijen correspondeert het beeld van de feitelijke en de wenselijke situatie redelijk. Wel blijken er aanzienlijke verschillen van mening te bestaan over de wenselijke inbreng van deze partijen in het proces. (figuur 6.4).

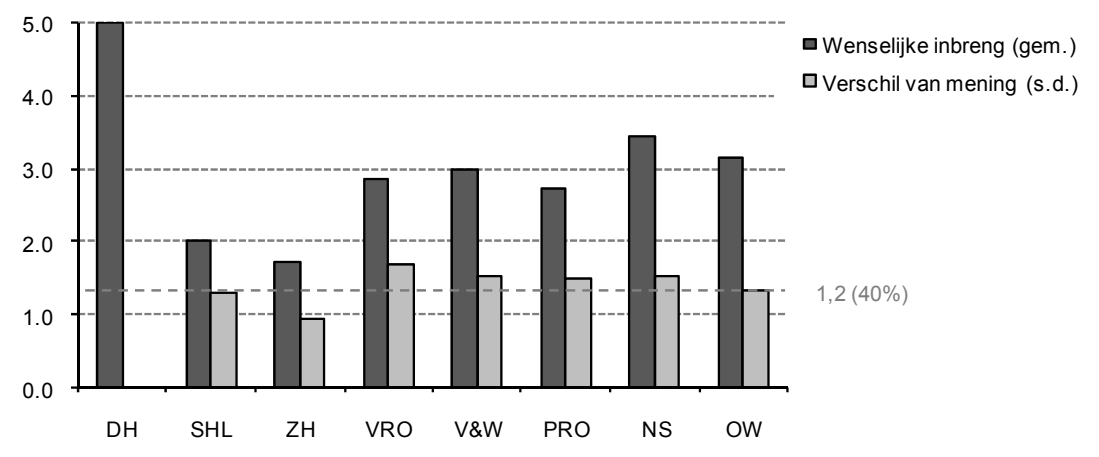

Figuur 6.4 Masterplan DHNC - wenselijke inbreng van stakeholders in visievorming en meningsverschillen

De conclusie dat de gemeente Den Haag een dominante rol heeft gehad bij het ontwikkelen van het Masterplan Den Haag Nieuw Centraal lijkt te rechtvaardigen. Deze dominante rol van de gemeente in dit proces wordt wel door alle partijen als wenselijk beschouwd. Voor alle overige partijen geldt dat er behoorlijk uiteenlopende beelden bestaan, zowel over hun feitelijke als hun wenselijke inbreng.

Visievorming voor de OV-terminal 
Centraal in de plannen voor het Haagse stationsgebied staat de herontwikkeling van het centraal station tot een integrale OV-terminal. Het architectenbureau Benthem Crouwel heeft van de gemeente, ProRail, de NS en het Ministerie V\&W, opdrachten ontvangen voor het uitvoeren van studies voor een nieuwe OV-terminal. Deze studies hebben uiteindelijk geresulteerd in een Schetsontwerp (SO). Voor het uitwerken van het SO tot een Voorlopig Ontwerp (VO) was op basis van het Europese recht een nieuwe selectieprocedure noodzakelijk. De criteria voor deze selectie zijn door de gemeente in samenwerking met ProRail, uitgewerkt.

Omdat er onduidelijkheid bestond over de investeringsbereidheid van NS en de hoogte van mogelijke schadeclaims voor omzet- en huurderving gedurende de realisatie, is de selectieprocedure tijdelijk stopgezet. NS had in 2003 bij het ondertekenen van de bestuurlijke overeenkomst tussen de gemeente en het Rijk aangegeven alleen bereid te zijn een bijdrage te leveren aan de herontwikkeling van de OV-terminal op basis van een integraal plan waarin ook alle commerciële voorzieningen in de stationshal en Stichthage meegenomen zouden worden. Aan NS is toen gevraagd een bieding te doen voor de realisatie van de commercie in de stationshal en onder Stichthage. De verwachting bestond dat een dergelijke investering samen met de bijdragen van andere partijen voldoende zou zijn om de businesscase voor de OV-terminal sluitend te maken. NS heeft uiteindelijk aangegeven bereid te zijn voor eigen rekening en risico de commerciële ontwikkeling van de onderzijde van Stichthage op te pakken en voor een vaste bijdrage het risico van omzet- en huurderving in de terminal op zich te nemen. Het schetsontwerp voor de nieuwe OV-terminal is daarna uitgewerkt tot een voorlopig ontwerp. In 2007 is vervolgens door het Benthem Crouwel architecten het definitief ontwerp (DO) voor de tweede fase van de OV-terminal opgesteld.

Evenals voor het Masterplan komt op basis de percepties van betrokkenen het beeld naar voren dat de gemeente Den Haag ook in het proces van visievorming voor de OV-terminal een prominente rol heeft gespeeld (zie figuur 6.5).

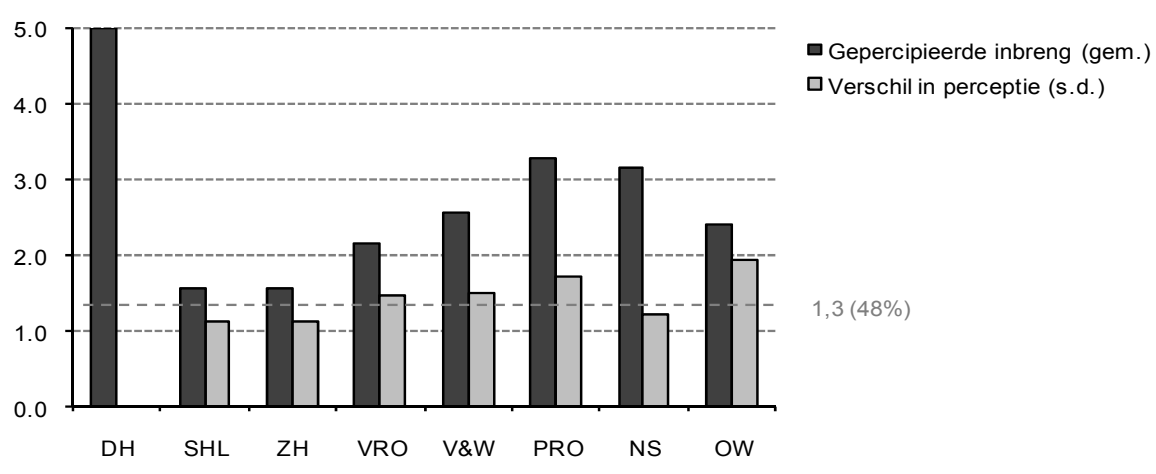

Figuur 6.5 OVT-plan DHNC - inbreng van stakeholders in visievorming en perceptieverschillen

Op zich is deze dominante rol voor de gemeente hier opmerkelijker dan voor het Masterplan. NS is namelijk voor het overgrote deel eigenaar, beheerder en exploitant van de OV-terminal en ProRail is als verzelfstandigde taakorganisatie verantwoordelijk voor de transferfunctie van stations en normaliter gedelegeerd opdrachtgever vanuit het Ministerie van Verkeer en Waterstaat. De inbreng van ProRail en NS blijkt ondanks hun prominente posities aanzienlijk kleiner dan van de gemeente Den Haag. In tegenstelling tot de zeer grote inbreng van de gemeente, waarvan het beeld van 
informanten volledig overeenkomt, wordt de inbreng van de andere partijen behoorlijk uiteenlopend gepercipieerd.

De vraag is of de zeer grote inbreng van de gemeente in dit deelproces ook wenselijk wordt bevonden. Uit figuur 6.6 valt op te maken dat dit niet helemaal het geval is. De gepresenteerde resultaten laten zien dat men van mening is dat een beperktere rol voor de gemeente Den Haag wenselijk zou zijn en dat vrijwel alle andere partijen meer inbreng zouden moeten hebben in dit traject. Uit de meningen van keystakeholders komt naar voren dat vooral het ministerie van Verkeer en Waterstaat en de NS gezien hun positie en verantwoordelijkheid ten aanzien van de OV-terminal een prominentere rol op zich hadden moeten nemen en dat de gemeente zich hier terughoudender zou moeten opstellen. De gemeente voelde - om redenen die in 6.2 .3 al zijn genoemd - zich echter min of meer genoodzaakt deze rol op zich te nemen.

De meningen over de wenselijke inbreng van partijen in dit deelproces blijken wel sterk uiteen te lopen (zie figuur 6.6). Vooral over de inbreng die private ontwikkelaars/eigenaren, ProRail en het ministerie van VROM zouden moeten hebben in de planvorming voor de OV-terminal wordt zeer uiteenlopend gedacht. Zeker voor ProRail is dit opmerkelijk. Waar de meeste partijen juist een zeer grote inbreng van ProRail wenselijk achten zien anderen slechts een zeer beperkte inbreng als wenselijk. ProRail wordt daarbij in enkele gevallen zelfs als incapabel getypeerd voor het managen van de integrale herontwikkeling van de OV-terminal.

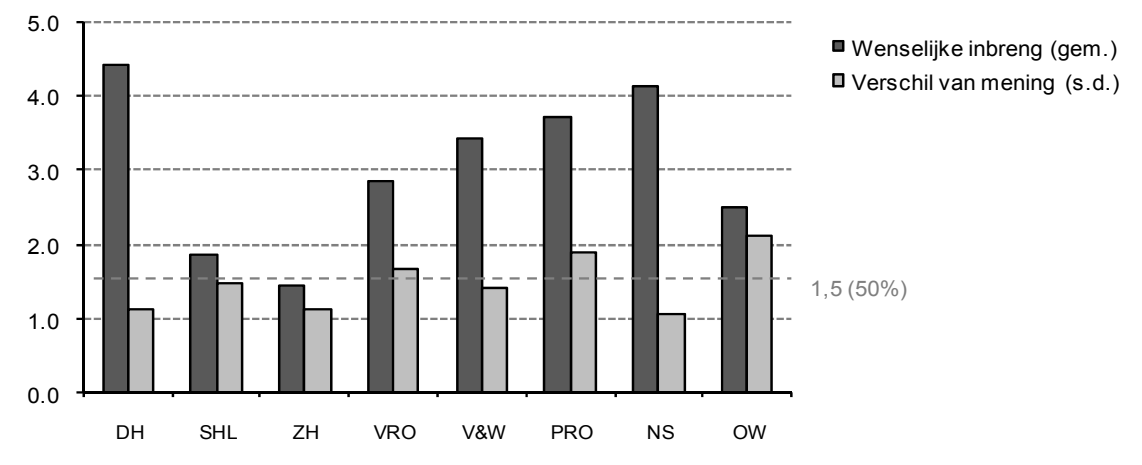

Figuur 6.6 OVT-plan DHNC - wenselijke inbreng van stakeholders in visievorming en meningsverschillen

Er kan worden geconcludeerd dat - evenals voor het Masterplan - ook in het planproces specifiek voor de OV-terminal de gemeente Den Haag een dominante rol heeft gespeeld. Hierover zijn alle partijen het eens. In tegenstelling tot het proces voor het Masterplan Den Haag Nieuw Centraal wordt die dominante rol echter niet door alle partijen als wenselijk beschouwd. Ook de gemeente zelf ervaart dit zo. Voor de overige partijen geldt dat er behoorlijk uiteenlopende beelden bestaan van de feitelijke en wenselijke inbreng van partijen.

\subsubsection{Zeggenschap}

De vorige paragraaf heeft aandacht besteed aan de inbreng van partijen in het proces van visievorming voor het Masterplan Den Haag Nieuw Centraal en voor het deelplan voor de OVterminal. Hier wordt de verdeling van zeggenschap in deze processen bezien. Aan de hand van 
percepties van nauw betrokkenen is de zeggenschap die de diverse partijen hebben gehad bij de totstandkoming van het masterplan en het deelplan voor de OV-terminal bestudeerd. ${ }^{174}$

\section{Zeggenschapsverdeling in het masterplanproces}

Een masterplan is in eerste instantie een gemeentelijk plandocument. Het Masterplan bevat echter diverse onderdelen waarvoor het eigendom of de bestuurlijke verantwoordelijkheid ligt bij andere partijen dan de gemeente Den Haag. Het Masterplan is dan ook opgesteld in gezamenlijke opdracht van de gemeente Den Haag, de NS, Multi Vastgoed, Babylon Den Haag BV en het stadsgewest Haaglanden. Het beeld bij actoren is echter dat vooral de gemeente in de ontwikkeling van het masterplan zeer veel zeggenschap heeft gehad (figuur 6.7).

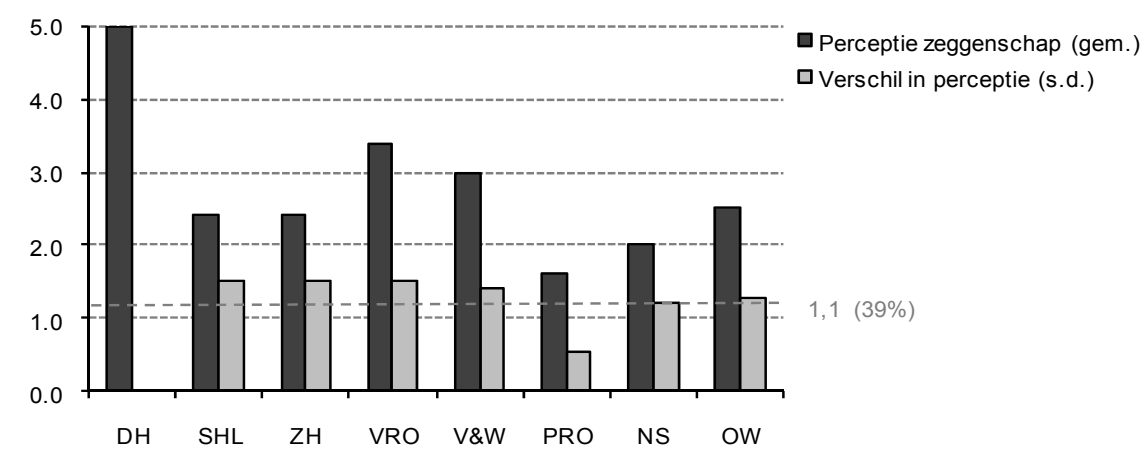

Figuur 6.7 Masterplan DHNC - zeggenschap stakeholders en perceptieverschillen

Hoewel het Rijk niet als opdrachtgever betrokken was bij de ontwikkeling van het masterplan, wordt ook het Ministerie van VROM en het Ministerie van V\&W een substantiële mate van zeggenschap toegedicht in dit proces. In de fasering die het Rijk hanteert voor de sleutelprojecten vormt een toets van de stedenbouwkundige, vervoerskundige en financiële onderbouwing van het masterplan het einde van de planvormingsfase. Het ministerie van VROM toetst het masterplan aan het rijksbeleid voor de sleutelprojecten en geeft bij goedkeuring een beschikking voor het toekennen van gelden uit het NSP-budget toe. De zeggenschap die het Ministerie van Verkeer en Waterstaat wordt toegedicht voor de totstandkoming van het Masterplan lijkt minder goed te beredeneren. Hoewel het Ministerie van Verkeer en Waterstaat verantwoordelijk is voor de transferfunctie van het station ligt haar verantwoordelijkheid minder op het niveau van het Masterplan omdat deze in belangrijke mate ook betrekking heeft op omliggende ontwikkelingen.

De grote mate van zeggenschap van de gemeente Den Haag bij de ontwikkeling van het masterplan wordt zonder uitzondering beschouwd als een wenselijke situatie (zie figuur 6.8). Omdat dit ook het geval was voor het proces van visievorming kan worden geconcludeerd dat de heersende opvatting is dat de gemeente in de totstandkoming van het Masterplan een dominante rol heeft gehad en ook moet hebben. Waar het beeld van de zeggenschap van de gemeente Den Haag volledig duidelijk is, blijkt dit voor andere partijen aanzienlijk minder helder te zijn. Er bestaan zeer uiteenlopende opvattingen over de wenselijke mate van zeggenschap voor andere partijen. De opvattingen over de wenselijke situatie corresponderen ook in lang niet alle gevallen met de gepercipieerde feitelijke situatie. Voor de ontwikkeling van het masterplan komt het beeld naar voren dat NS en private 
ontwikkelaars meer zeggenschap zouden moeten hebben, terwijl voor de rijkspartijen juist het omgekeerde geldt.

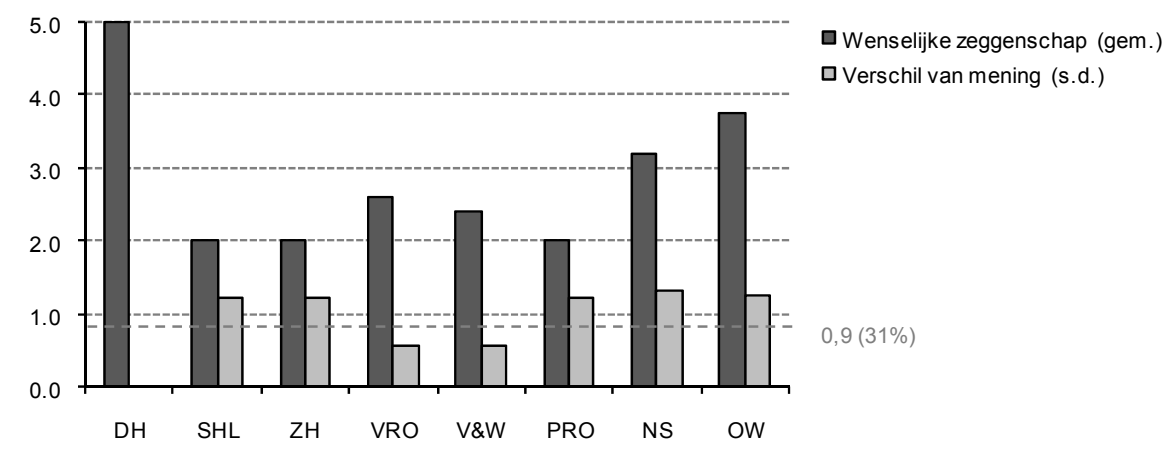

Figuur 6.8 Masterplan DHNC - wenselijke zeggenschapsverdeling en meningsverschillen

\section{Zeggenschapsverdeling in het planproces voor de OV-terminal}

Diverse partijen hebben op grond van eigendom of bestuurlijke verantwoordelijkheden een positie binnen de OV-terminal. NS als eigenaar, beheerder, exploitant en vervoerder. Het ministerie van Verkeer en Waterstaat vanuit haar verantwoordelijkheid voor de basiskwaliteit van stations en de ontwikkeling van de HSL. ProRail vanuit haar verantwoordelijkheid voor de niet commerciële (transfer)voorzieningen op stations. Het Ministerie VROM vanuit het rijksbeleid voor de nieuwe sleutelprojecten. Het stadsgewest Haaglanden voor RandstadRail en als verantwoordelijk overheidsorgaan voor het lokaal en regionaal openbaar vervoer. En de gemeente vanuit haar verantwoordelijkheid voor stedelijke ontwikkelingen op haar grondgebied. ${ }^{175}$

Voor de aanpak van de OV-terminal fungeert de gemeente Den Haag zowel voor OVT-I als voor een deel van OVT-II als risicodragend opdrachtgever. Het projectmanagement voor de eerste fase is uitgevoerd door de projectorganisatie RandstadRail die geplaatst was bij de gemeente Den Haag. Voor de tweede fase van de herontwikkeling heeft de gemeente, in verband met subsidiebepalingen, haar opdrachtgeverschap gedelegeerd aan ProRail. Hiervoor heeft de gemeente een overeenkomst gesloten met ProRail. Ook heeft Den Haag een samenwerkingsovereenkomst (SOK) gesloten met NS waarin is opgenomen dat de commerciële herontwikkeling van de onderzijde van Stichthage voor rekening en risico van de NS plaats vindt. Het beeld bij betrokkenen is ook dat vooral de gemeente Den Haag veel zeggenschap heeft gehad in de planvorming voor de OV-terminal (zie figuur 6.9)

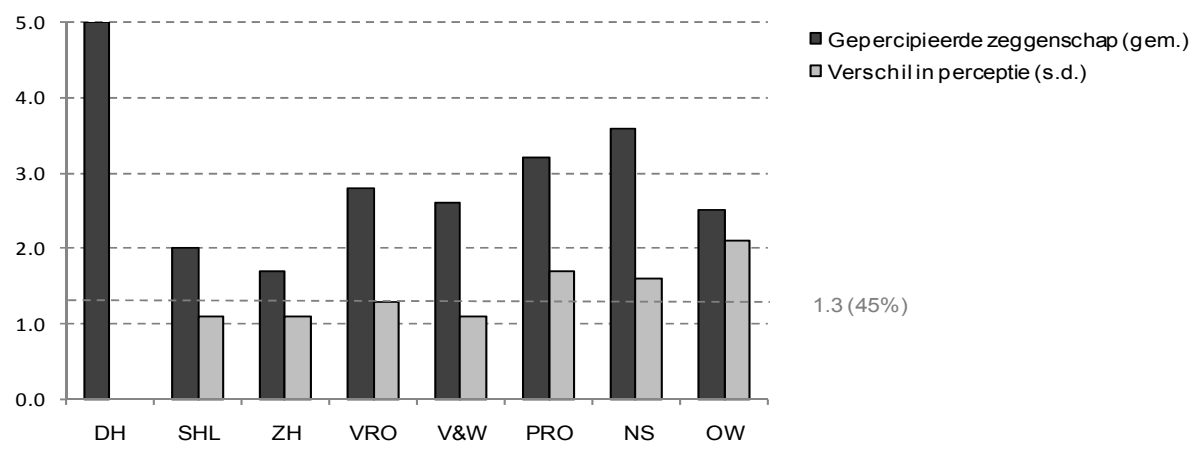

Figuur 6.9 OVT-plan DHNC - zeggenschap stakeholders en perceptieverschillen 
De grote mate van zeggenschap voor de gemeente in dit deelproces wordt niet door allen als wenselijk beschouwd. Men is vooral van mening dat NS als eigenaar, beheerder, exploitant en vervoerder meer zeggenschap had moeten hebben. De meningen over de vraag welke mate van zeggenschap voor welke partij in dit proces wenselijk is, lopen echter sterk uiteen (figuur 6.10).

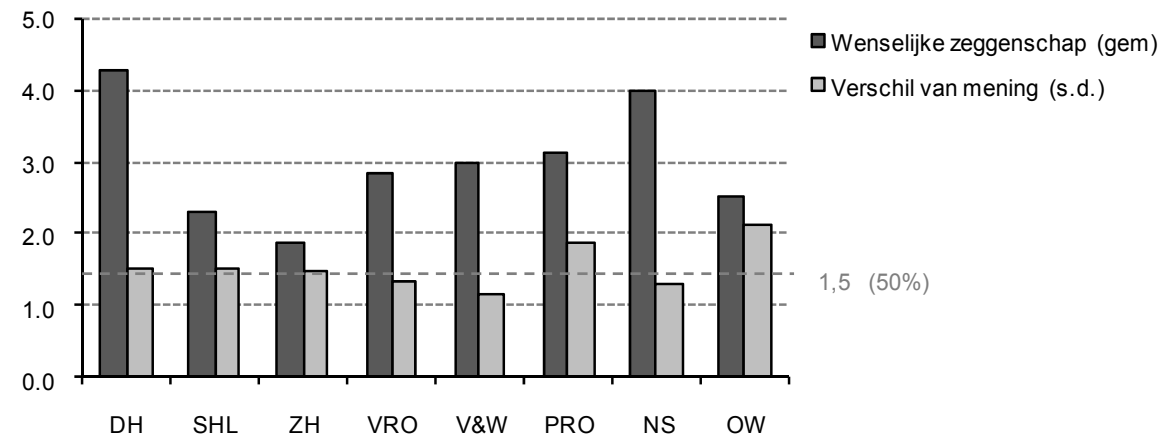

Figuur 6.10 OVT-plan DHNC - wenselijke zeggenschapsverdeling en meningsverschillen

\subsubsection{Middelen}

Zeggenschap hangt samen met de beschikking over middelen die noodzakelijk zijn voor de ontwikkeling en implementatie van plannen. Hier is de inbreng van middelen door partijen bezien. Daarbij is geen onderscheid gemaakt naar de perceptie van de feitelijke en de mening over de wenselijke situatie. Aangenomen wordt namelijk dat men de wenselijke inbreng van middelen, zoals financiële bijdragen, voor andere partijen altijd graag maximaal ziet en voor de eigen organisatie graag minimaal. Daarom is aan de hand van het oordeel van de actoren gekeken naar de evenredigheid in de inbreng van middelen.. Met andere woorden: is er sprake van een grotere dan wel kleinere inbreng door partijen dan op grond van de kenmerken van het project naar de mening van samenwerkende partijen had mogen worden verwacht.

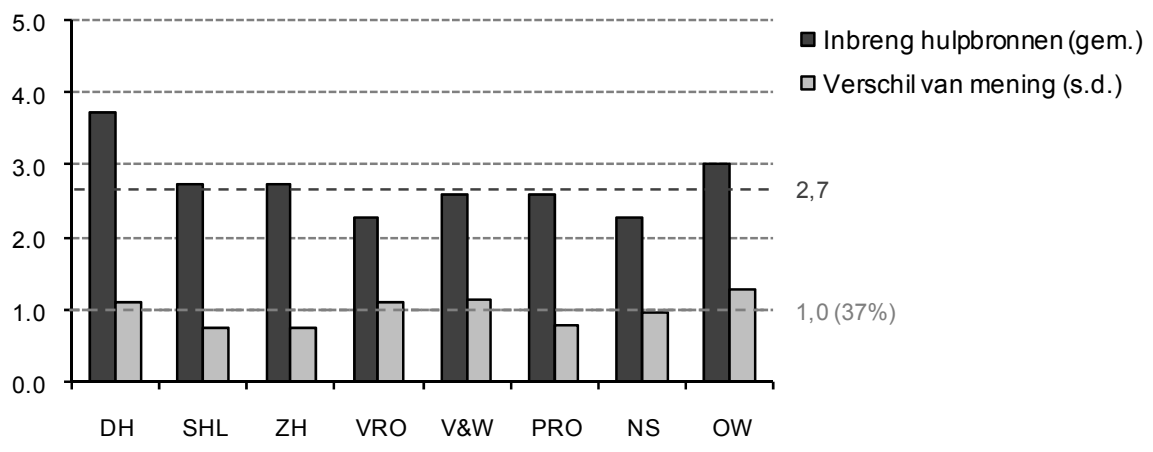

Figuur 6.11 DHNC - Inbreng van middelen door stakeholders en meningsverschillen

Uit de data blijkt dat alleen de gemeente Den Haag meer middelen inbrengt dan van haar zou mogen worden verwacht (zie figuur 6.11). De gemeente draagt ook voor een groot deel het risico voor het project. Slechts indien er sprake is van een onvoorzien en substantieel risico dat naar redelijkheid en billijkheid niet voor rekening van de gemeente kan komen kan de gemeente een verzoek indienen aan de stuurgroep rijk-gemeente om te bepalen hoe om te gaan met de consequenties van dit risico. Ook de projectorganisatie is gevestigd bij de gemeente. Voor alle andere partijen is men van mening dat de 
inbreng minder is dan van deze partijen verwacht zou mogen worden. Het gemiddelde (2.7) laat zien dat er overwegend negatief wordt gedacht over de inbreng van middelen door de diverse keystakeholders. Hierbij moet worden opgemerkt dat de meningen ook hier aanzienlijk uiteenlopen.

\subsubsection{Kenmerken van de actorconstellatie}

Hiervoor is de inbreng van individuele actoren op drie kernthema's in planvorming beschreven. Met gebruik van deze data worden in deze paragraaf de kenmerken van de actorconstellatie beschreven. Tegen de achtergrond van de borging van het publiek belang is in hoofdstuk 3 beargumenteerd dat deze constellatie kan worden getypeerd aan de hand van (a) het aantal actoren; (b) de verhoudingen tussen actoren met uiteenlopende karakters en belangenposities (publiek-privaat; centraal-decentraal; gemeente-overige keystakeholders); en (c) de mate van ambivalentie. Dit is gedaan voor de drie kernthema's.

\section{Aantal actoren}

Uit de data (zie tabel 6.2) komt naar voren dat het aantal keystakeholders dat een grote inbreng (>3) in de planvorming heeft gehad zeer beperkt is. Hoewel het masterplan DHNC diverse onderdelen kent waarbij meerdere actoren op grond van eigendom of bestuurlijke verantwoordelijkheid als keystakeholder aan te merken zijn, blijkt in het proces van visievorming naast de gemeente Den Haag alleen NS een substantiële inbreng te hebben gehad. Ook blijken voor de totstandkoming van het masterplan maar twee partijen een grote mate van zeggenschap te hebben gehad; de gemeente Den Haag en VROM.

In de planvorming voor de OV-Terminal blijken drie partijen een grote inbreng $(>3)$ te hebben gehad. Zowel qua visievorming als qua zeggenschap gaat het om de gemeente Den Haag, NS en ProRail. De gemeente is ook de enige actor die meer middelen heeft ingebracht dan mocht worden verwacht.

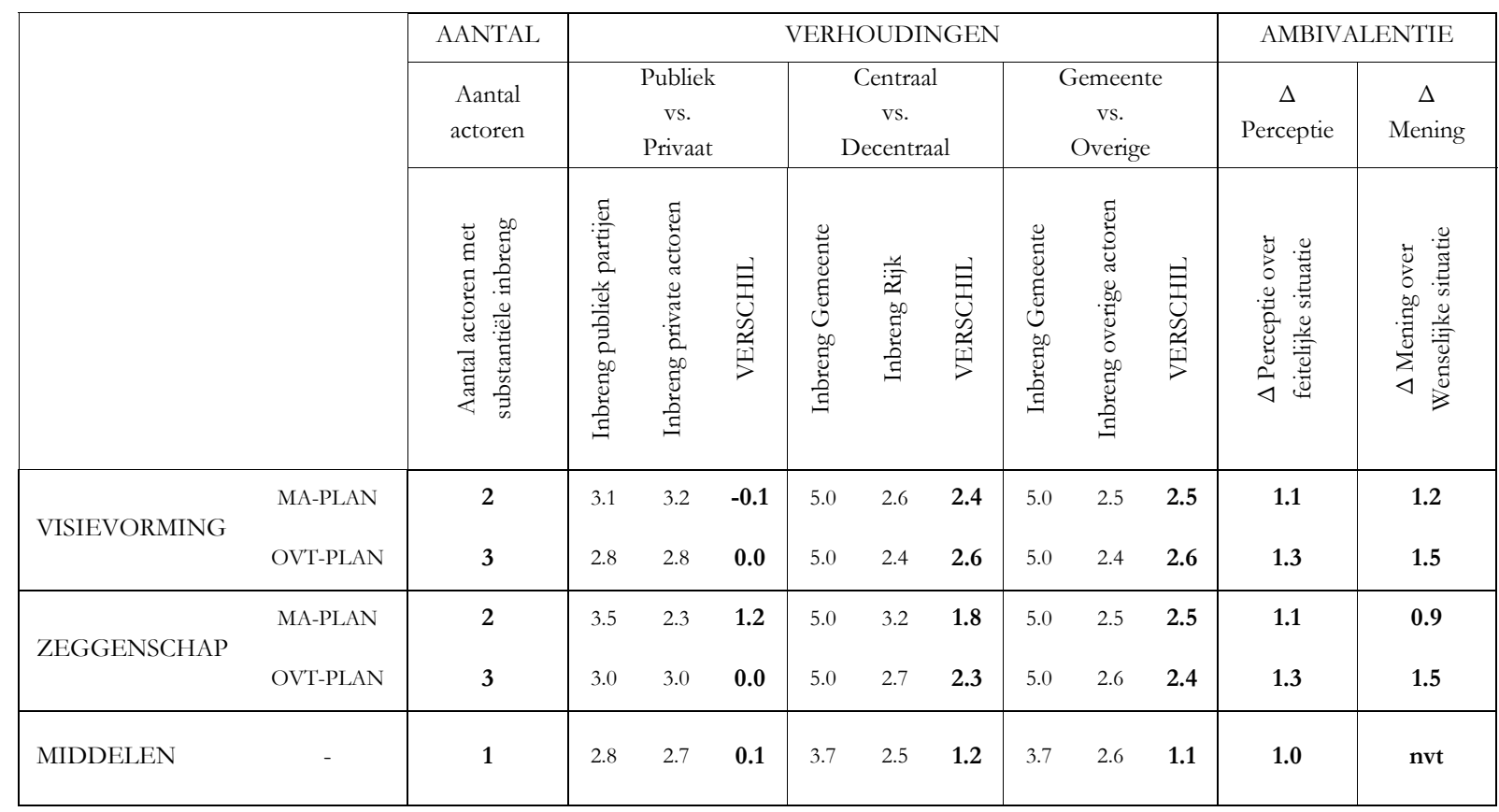

Tabel 6.2 Den Haag Nieuw Centraal - Actorconstellatie 


\section{Verhoudingen tussen actoren}

De wijze waarop de samenwerking tussen actoren in het planproces vorm heeft gekregen is in de eerste paragraaf van dit hoofdstuk kwalitatief beschreven. Op basis van de percepties van actoren kunnen ten aanzien van de verhoudingen tussen partijen een aantal constateringen worden gedaan (zie tabel 6.2).

- De omvang van de inbreng van publieke (gemeente/provincie/rijk) en private (NS/ontwikkelaars) partijen in het proces lijkt redelijk overeen te komen. Enkel de zeggenschap van publieke partijen in de planvorming van het masterplan blijkt aanzienlijk groter te zijn geweest dan die van private partijen. Een kantekening hierbij is dat er tussen publieke partijen onderling grote verschillen bestaan qua inbreng.

- Dit blijkt ook wel als specifiek wordt gekeken naar de verhouding tussen centrale en decentrale overheden. Het laat zich dan aanzien dat de gemeente (decentraal) een aanzienlijk grotere inbreng in het proces heeft gehad dan het Rijk (centraal). Dit geldt voor alle drie de kernthema's (visievorming, zeggenschap, middelen).

- Ook als de inbreng van de gemeente Den Haag wordt afgezet tegen die van alle andere keystakeholders komt uit de data het beeld naar voren dat de gemeente, zowel bij het ontwikkelen van het Masterplan DHNC als in het planproces voor de OV-Terminal, een dominante rol heeft gespeeld. In het planproces van het masterplan wordt deze dominante rol eenduidig als wenselijk gezien. Voor het planproces voor de OV-Terminal is dit niet het geval. Uit de data blijkt dat in dit proces een beperktere rol van de gemeente en een grotere inbreng van NS, ProRail en het ministerie van Verkeer en Waterstaat wenselijk zou zijn.

\section{Ambivalentie}

De ambivalentie in de actorconstellatie is geanalyseerd door te kijken naar de mate waarin (a) percepties van de feitelijke inbreng van actoren verschillen en (b) de mate waarin meningen over de wenselijke inbreng van actoren verschillen.

- De data laat zien dat het beeld van betrokken actoren van de feitelijke situatie sterk uiteen loopt. Er bestaat blijkbaar de nodige onduidelijkheid over de inbreng die diverse partijen hebben gehad in het planproces. Uitzondering hierop vormt de zeer grote inbreng van de gemeente Den Haag waarover een volledig eenduidig beeld bestaat.

- Over de vraag welke inbreng in de planvorming wenselijk is voor verschillende keystakeholders lopen de meningen eveneens sterk uiteen. Dat geldt in het bijzonder voor de OV-terminal omdat daar de opvattingen over de wenselijke inbreng van de gemeente Den Haag eveneens verschillen.

\subsection{Publiek belang}

In de vorige paragraaf zijn op drie thema's de inbreng van individuele keystakeholders en de belangrijkste kenmerken van de actorconstellatie beschreven. Vraag die in deze studie centraal staat is of deze kenmerken verband houden borging van het publiek belang. Deze paragraaf gaat in op de borging van het publiek belang. Zoals in de eerste hoofdstukken is beargumenteerd, wordt daarvoor geanalyseerd in hoeverre de planvorming effectiviteit en legitiem was. 


\subsubsection{Legitimiteit}

Legitimiteit is onderverdeeld in een drietal vormen; inputlegitimiteit, throughputlegitimiteit en outputlegitimiteit. Deze drie vormen zijn aan de hand van indicatoren geanalyseerd. Daarbij is het onderscheid tussen de planvorming gericht op het ontwikkelen van een masterplan voor de gebiedsontwikkeling als geheel en het deelproces van planvorming voor de OV-terminal aangehouden.

\section{Inputlegitimiteit}

De legaliteit en openheid van beide planprocessen zijn gebruikt als maatstaf voor input-legitimiteit. Legaliteit is geëvalueerd an de hand van de mate waarin de keystakeholders van mening zijn dat relevante procedures en regelgeving op correcte wijze zijn toegepast. Zonder uitzondering zijn alle betrokkenen van mening dat dit op correcte tot zeer correcte wijze is geschied.

De openheid van het planproces is geanalyseerd door te kijken of (1) alle relevante partijen toegang hebben gehad tot het planproces en (2) de mate waarin de eigen en andere organisaties mogelijkheden hebben gehad om het proces te beïnvloeden. De resultaten staan gepresenteerd in tabel 6.3.

\begin{tabular}{|c|c|c|c|c|c|c|c|}
\hline \multirow[b]{2}{*}{ Indicator } & \multicolumn{3}{|c|}{$\begin{array}{c}\text { Openheid } \\
\text { Masterplanproces }\end{array}$} & \multicolumn{3}{|c|}{$\begin{array}{c}\text { Openheid } \\
\text { OVT-planproces }\end{array}$} & \\
\hline & 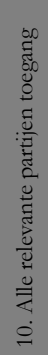 & 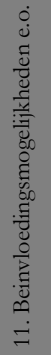 & 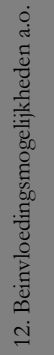 & 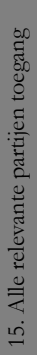 & 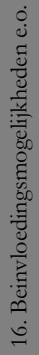 & 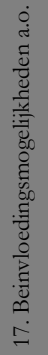 & 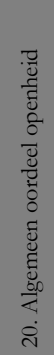 \\
\hline actor 1 & $\mathrm{~J}$ & 5 & 3 & $\mathrm{~J}$ & 5 & 3 & 4 \\
\hline actor 2 & $?$ & $?$ & $?$ & $\mathrm{~J}$ & 5 & 4 & 5 \\
\hline actor 3 & $\mathrm{~N}$ & 5 & 3 & $\mathrm{~N}$ & 5 & 3 & 2 \\
\hline actor 4 & $?$ & 4 & 4 & $\mathrm{~J}$ & 5 & 4 & 5 \\
\hline actor 5 & J & 3 & 3 & J & 3 & 3 & 3 \\
\hline actor 6 & $?$ & ? & ? & $\mathrm{J}$ & 5 & 5 & 5 \\
\hline actor 7 & $?$ & 4 & 4 & $\mathrm{~J}$ & 4 & 4 & 3 \\
\hline GEM. & $\mathrm{x}$ & 4.2 & 3.4 & $\mathrm{X}$ & 4.6 & 3.7 & 3.9 \\
\hline S.D. & $\mathrm{X}$ & 0.8 & 0.5 & $\mathrm{X}$ & 0.8 & 0.8 & 1.2 \\
\hline
\end{tabular}

$$
\begin{aligned}
& \text { LEGENDA } \\
& \mathrm{J}=\mathrm{Ja} \\
& \mathrm{N}=\mathrm{Nee} \\
& ?=\text { Weet miet } \\
& 5=\text { zeer groot } \\
& 4=\text { groot } \\
& 3=\text { neutraal } \\
& 2=\text { klein } \\
& 1=\text { zeer klein }
\end{aligned}
$$

Tabel 6.1. Den Haag Nieuw Centraal - Mate van openheid van het planproces

Uit de data blijkt dat zowel het planproces van het Masterplan DHNC als het planproces voor de OV-Terminal een redelijk open proces is geweest. Vrijwel alle betrokkenen zijn van mening dat alle relevante partijen toegang hebben gehad tot het planproces en zeker de mogelijkheden van de eigen organisatie om het planproces te beïnvloeden worden voor beide planprocessen als meer dan groot beschouwd. Het oordeel hierover is redelijk eenduidig en een enkele uitzondering daargelaten beoordeelt men de openheid positief (meer dan neutraal). Dit correspondeert met het (geaggregeerde) oordeel over de openheid van het planproces in het algemeen (3.9). 


\section{Throughputlegitimiteit}

De transparantie van de planprocessen is gehanteerd als maatstaf voor throughputlegitimiteit. Daarvoor is geanalyseerd; in welke mate het voor partijen duidelijk was wie, waarover en op welk moment in het planproces besliste; in welke mate inhoudelijke wensen en voorkeuren van partijen helder waren; en in welke mate de honorering daarvan in de plannen en de bijbehorende argumentatie helder was. De resultaten staan gepresenteerd in tabel 6.4.

\begin{tabular}{|c|c|c|c|c|c|c|c|c|c|c|c|c|}
\hline \multirow[b]{2}{*}{ Indicator } & \multicolumn{6}{|c|}{$\begin{array}{c}\text { Transparantie } \\
\text { Masterplanproces }\end{array}$} & \multicolumn{6}{|c|}{$\begin{array}{c}\text { Transparantie } \\
\text { OVT-planproces }\end{array}$} \\
\hline & 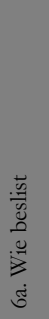 & 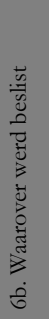 & 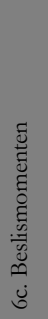 & 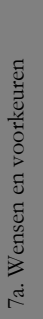 & 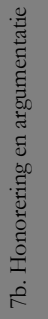 & $\mathbf{T}$ & 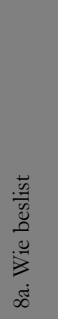 & 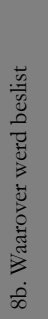 & 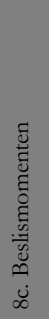 & 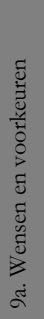 & 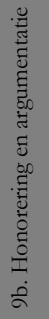 & $\mathbf{T}$ \\
\hline actor 1 & 4 & 4 & 4 & 4 & 4 & 4.0 & 2 & 4 & 4 & 4 & 4 & 3.6 \\
\hline actor 2 & $?$ & $?$ & $?$ & 4 & 4 & 4.0 & 5 & 4 & 4 & 5 & 5 & 4.6 \\
\hline actor 3 & 3 & 5 & ? & 2 & 2 & 3.0 & 4 & 4 & 5 & 2 & 2 & 3.4 \\
\hline actor 4 & 4 & 4 & 4 & 4 & 4 & 4.0 & 4 & 4 & 4 & 4 & 4 & 4.0 \\
\hline actor 5 & 3 & 2 & 3 & 2 & 2 & 2.4 & 2 & 3 & 2 & 2 & 3 & 2.4 \\
\hline actor 6 & $?$ & $?$ & $?$ & $?$ & $?$ & $?$ & 1 & 4 & 4 & 5 & 4 & 3.6 \\
\hline actor 7 & 2 & 4 & 4 & 3 & 4 & 3.4 & 4 & 4 & 3 & 2 & 4 & 3.4 \\
\hline GEM. & 3.2 & 3.8 & 3.8 & 3.2 & 3.3 & 3.5 & 3.1 & 3.9 & 3.7 & 3.4 & 3.7 & 3.6 \\
\hline S.D. & 0.8 & 1.1 & 0.5 & 1.0 & 1.0 & 0.7 & 1.5 & 0.4 & 1.0 & 1.4 & 1.0 & 0.7 \\
\hline
\end{tabular}

$$
\begin{aligned}
& \text { LEGENDA } \\
& 5=\text { zeer helder } \\
& 4=\text { helder } \\
& 3=\text { neutraal } \\
& 2=\text { onhelder } \\
& 1=\text { zeer onhelder } \\
& ?=\text { weet niet } \\
& \mathrm{T}=\text { gemiddelde }
\end{aligned}
$$

Tabel 6.3 Den Haag Nieuw Centraal - Mate van transparantie van het planproces

Uit de data blijkt dat zowel het planproces van het Masterplan als het planproces voor de OVterminal een redelijk transparant proces is geweest. Voor alle indicatoren is het oordeel namelijk overwegend positief (gemiddelde $>3$ ). Niettemin zijn er diverse betrokkenen die het proces op afzonderlijke indicatoren als onhelder beoordelen. Ook tussen indicatoren bestaan wel enige verschillen en lopen de meningen van partijen soms behoorlijk uiteen. Het geheel overziend kan echter worden gesteld dat beide planprocessen redelijk transparant zijn geweest.

\section{Outputlegitimiteit}

Voor outputlegitimiteit is gekeken naar de steun voor de plannen. Deze steun is geanalyseerd aan de hand van het oordeel van betrokkene over; de mate waarin in het Masterplan respectievelijk de plannen voor de OV-terminal rekening is gehouden met hun wensen en doelen; de mate waarin zij zich gecommitteerd voelen aan deze plannen; en de mate waarin zij van mening zijn dat het deze plannen aanvaardbare compromissen zijn voor de in het planproces participerende partijen. Daarnaast is gevraagd een rapportcijfer toe te kennen aan beide plannen. De resultaten staan weergegeven in tabel 6.5. 

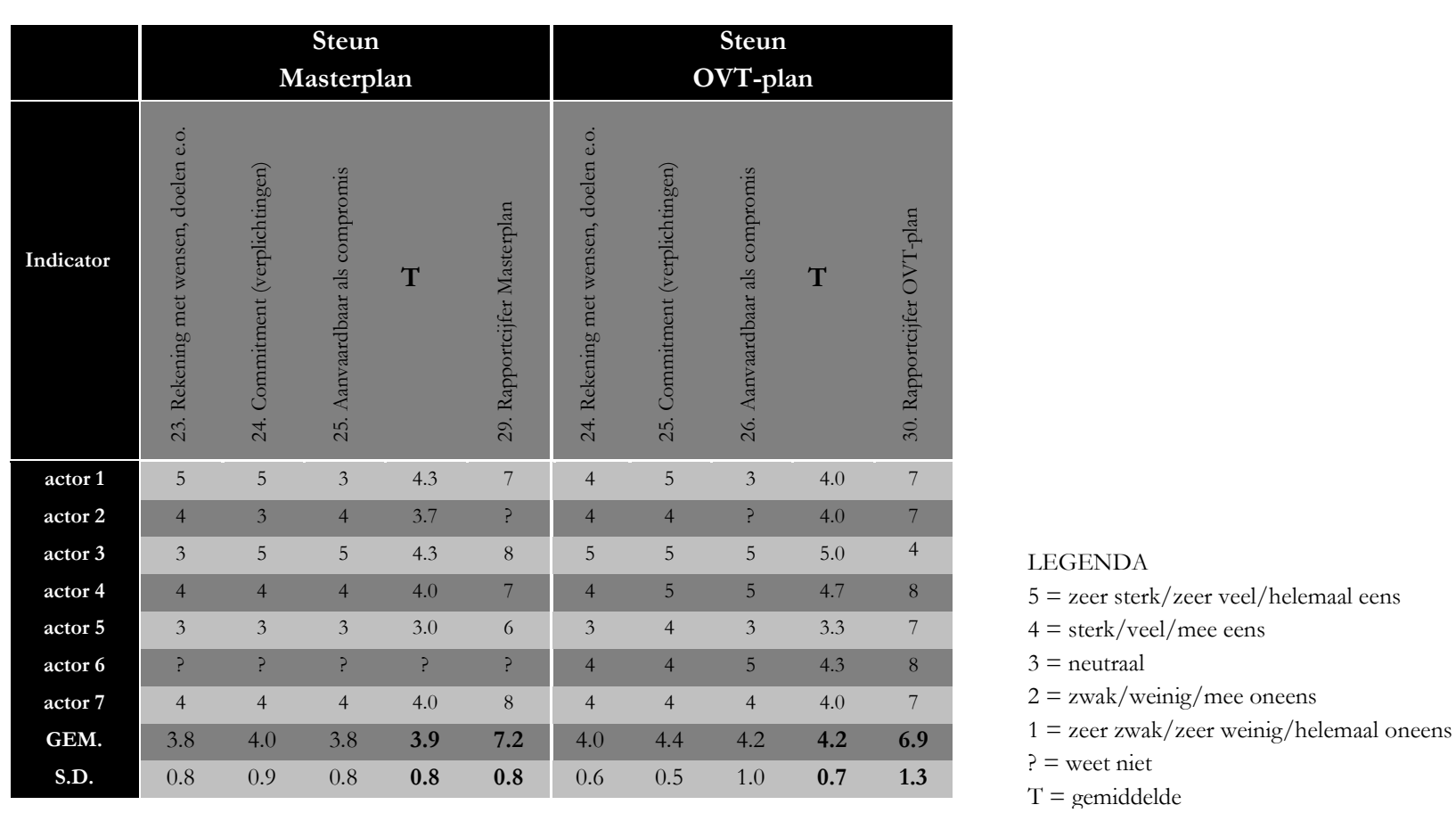

Tabel 6.4 Den Haag Nieuw Centraal - Mate van steun voor plannen

Uit de data blijkt dat de steun voor zowel het Masterplan als het plan voor de OV-terminal behoorlijk groot is. Hoewel er beperkte verschillen bestaan tussen partijen zijn alle partijen tenminste positief (meer dan neutraal). Zeker voor het OVT-plan neigt de mate waarin partijen zich gecommitteerd voelen aan het plan tot zeer sterk. Ook de rapportcijfers voor beide plannen laten, met uitzondering van het oordeel van een enkele partij een overwegend positief beeld zien.

\subsubsection{Effectiviteit}

Naast een oordeel over de legitimiteit van het planproces is tevens gekeken naar het oordeel over de effectiviteit ervan. Daarvoor is de bijdrage die de plannen naar verwachting zullen leveren aan een hogere ruimtelijke kwaliteit in het plangebied als maatstaf gehanteerd. Omdat ruimtelijke kwaliteit niet eenduidig te definiëren valt is in de operationalisering een aantal ontwerpeisen - gebruikerswaarde, belevingswaarde en toekomstwaarde - gekruist met typen belangen - economisch, sociaal, ecologisch - wat leidt tot een negental dimensies van ruimtelijke kwaliteit. Deze dimensies van ruimtelijke kwaliteit zullen door stakeholders in meer of mindere mate van belang worden geacht. Stationslocaties hebben bepaalde kenmerken en dientengevolge zijn er - vanuit de belangen van betrokken stakeholders - bepaalde zwaartepunten in ruimtelijke kwaliteit. Aan keystakeholders is gevraagd wat volgens hun de drie belangrijkste dimensies van ruimtelijke kwaliteit zijn in het project. Dit leidt voor het project Den Haag Nieuw Centraal tot de zwaartepunten zoals weergegeven in figuur 6.12 . 


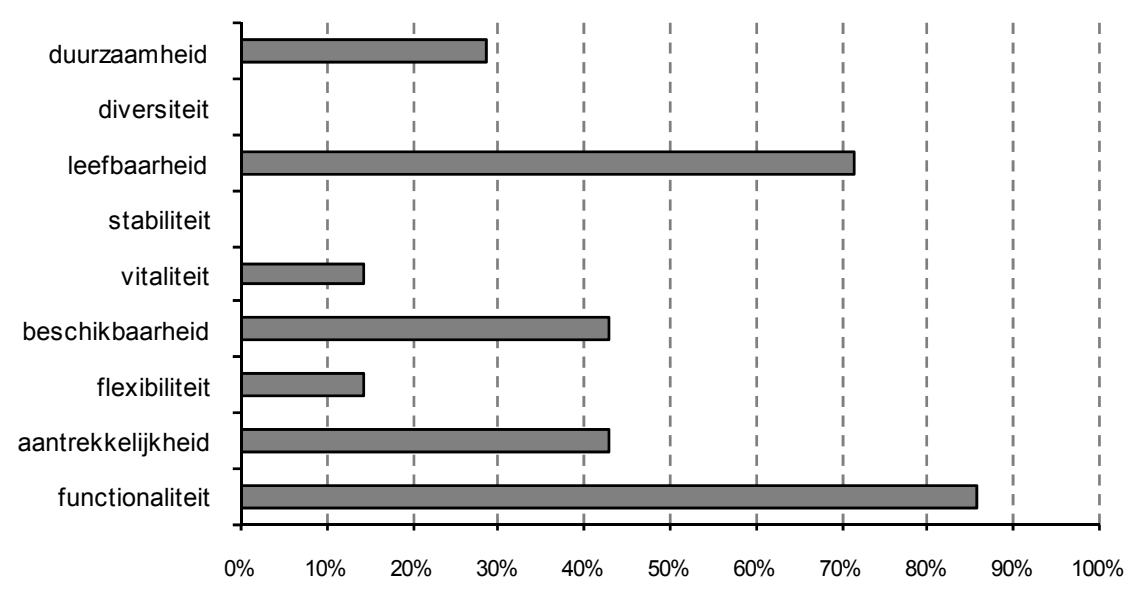

Figuur 6.12 Den Haag Nieuw Centraal - Zwaartepunten in de dimensies van ruimtelijke kwaliteit

Kijken we vervolgens naar de verwachtingen van keystakeholders omtrent de bijdrage van de plannen aan het verhogen van de ruimtelijke kwaliteit, dan blijkt dat op alle genoemde dimensies het oordeel positief is (zie figuur 6.13). Dit geld zowel voor het Masterplan als voor het deelplan voor de OVterminal. De verwachting is wel dat de plannen voor de aanpak van de OV-terminal (3.9) een grotere kwaliteitsimpuls betekenen dan het Masterplan (3.6) waar het deel van uit maakt.

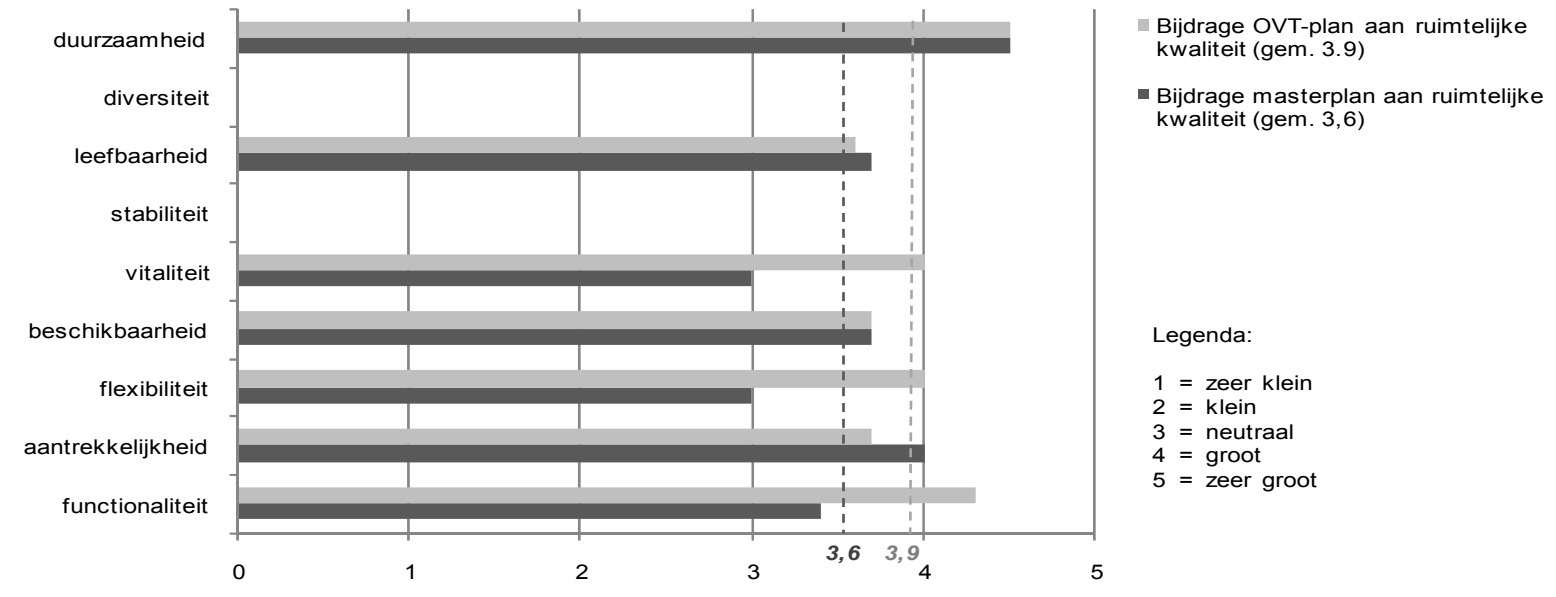

Figuur 6.13 Den Haag Nieuw Centraal - Bijdrage plannen aan dimensies van ruimtelijke kwaliteit

Het oordeel over de verwachte bijdrage van het Masterplan respectievelijk het OV-terminalplan aan de realisatie van ruimtelijke kwaliteit moet worden gezien in het licht van een drietal elementen; het ambitieniveau, de helderheid en de meetbaarheid/evalueerbaarheid van de plannen. Uit de resultaten (figuur 6.14) blijkt dat het ambitieniveau van zowel het masterplan Den Haag Nieuw Centraal als van het deelplan voor de OV-terminal als hoog wordt beschouwd. Ook de helderheid van beide plannen wordt overwegend positief beoordeeld evenals de meetbaarheid/evalueerbaarheid van het OVterminalplan. De meet-/evalueerbaarheid van het Masterplan Den Haag Nieuw Centraal blijkt - in tegenstelling tot het OVT-plan - matig te zijn. 


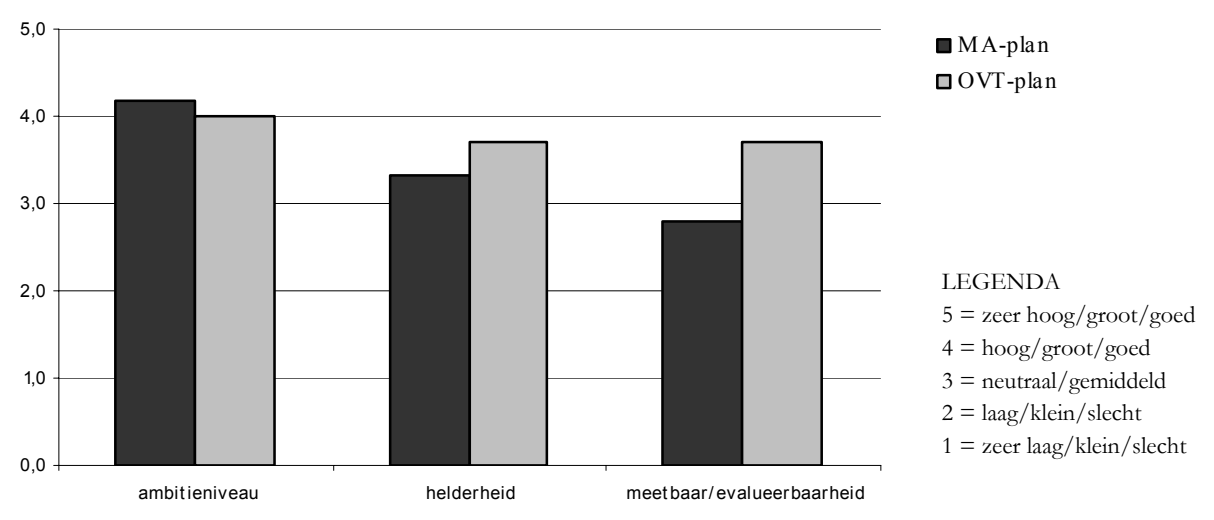

Figuur 6.14 Den Haag Nieuw Centraal - Ambitieniveau, helderheid en evalueerbaarheid van plannen

\subsection{Slot}

Uit de analyse van de constellatie van actoren komt naar voren dat in de planvorming slechts een beperkt aantal keystakeholders een grote inbreng heeft gehad. Vooral de gemeente Den Haag heeft in allerlei opzichten een zeer grote inbreng gehad. Met nadruk geldt echter, dat dit niet betekent dat andere partijen geen rol van betekenis hebben gespeeld of hebben kunnen spelen. Het planproces werd tenslotte door vrijwel alle partijen als toegankelijk en voldoende open beoordeeld. De gemeente Den Haag heeft echter in het proces nadrukkelijk een regie- en trekkersrol op zich genomen. Voor de planvorming voor de gebiedsontwikkeling wordt zoals beschreven deze grote rol van gemeenten door alle betrokkenen als wenselijk beschouwd. Voor de OV-terminal blijkt dat minder het geval. De dominante rol van de gemeente in de planvorming daarvoor alsmede haar opdrachtgeverschap voor de tweede fase van de OV-terminal is ook minder vanzelfsprekend. De stationshal is tenslotte eigendom van de NS die de commerciële onderdelen exploiteert en de transferfunctie is een verantwoordelijkheid van het ministerie van Verkeer en Waterstaat en ProRail. Deze partijen wilden echter de rol van opdrachtgever voor de OV-terminal niet op zich nemen. NS rekent - gegeven haar afspraken met het ministerie van V\&W - de bouw van stations niet tot haar kerntaken. ProRail ontbreekt het aan mogelijkheden om een station te bouwen dat meer is dan 'sober en doelmatig' en het ministerie van V\&W rekent het niet tot zijn verantwoordelijkheid, maar die van lokale partijen en vervoerders om een stationsomgeving aan te bieden die meer is dan de zuivere transferfunctie. Daarnaast was het ministerie van V\&W van mening dat het opdrachtgeverschap van de gemeente goed past bij de NSP filosofie, waarbij de gemeente als initiatiefnemer van de stedelijke vernieuwing in het stationsgebied ook de drijvende kracht is voor de ontwikkeling en bouw van de OV-terminal. Deze zienswijze werd overigens door de gemeente onderschreven. Een andere overweging voor de gemeente was dat hierdoor afstemmingsproblemen met OVT-I, waar de gemeente al opdrachtgever voor was, en de omliggende gebiedsontwikkeling konden worden voorkomen. Een eenduidig opdrachtgeverschap zou kunnen bijdragen aan een soepele procesgang gedurende de verdere planuitwerking. Tenslotte was de inschatting van de gemeente Den Haag dat met de financiële middelen van het Ministerie van V\&W, het Ministerie van VROM en bijdragen van NS en de gemeente zelf, een sluitende business case voor een OV-terminal met 'NSP-kwaliteit' te bereiken was (gemeente Den Haag, 2003b). Aan de uiteindelijke gekozen rolverdeling ging een lange zoektocht vooraf en gedurende het proces heeft de verdeling tot de nodige discussie en strubbelingen geleid. 
Niettemin blijkt dat geen negatief effect te hebben op het oordeel van betrokkenen over de legitimiteit en effectiviteit van het proces. Zowel de planvorming voor de integrale gebiedsontwikkeling, vormgegeven in het masterplan als de planvorming voor de OV-terminal kan worden beschouwd als legitiem in die zin dat de planvorming legaal, en voldoende open en transparant was en de daaruit resulterende plannen op de steun van keystakeholders kunnen rekenen. Beide plannen worden tevens beschouwd als effectief in die zin, dat de verwachting van vrijwel alle betrokkenen is dat de uitvoering ervan een grote bijdrage zal leveren aan de ruimtelijke kwaliteit in het plangebied van Den Haag Nieuw Centraal. 


\section{Hoofdstuk 7}

\section{Case 2: Stationskwartier Breda}

\subsection{Inleiding}

Dit hoofdstuk beschrijft de data die is verzameld voor het project Stationskwartier Breda. Allereerst wordt het project beschreven (7.2). Het tweede deel van het hoofdstuk beschrijft de inbreng van keystakeholders in het planvorming (7.3) en de borging van het publiek belang in termen van effectieve en legitieme planvorming (7.4). Afgesloten wordt met een kort resumé van de bevindingen $(6.5)$

\subsection{Het project}

Deze paragraaf beschrijft het project Stationskwartier Breda. Daarvoor wordt achtereenvolgens de projecthistorie en het procesverloop (7.2.1), de ruimtelijke opgave (7.2.2), de posities van (key)stakeholders (7.2.3) en de samenwerkingsorganisatie (7.2.4) beschreven.

\subsubsection{Projecthisorie en procesverloop}

Het huidige stationsgebied in Breda lag voor de komst van het spoor en het station in 1865 buiten de verdedigingswallen van de stad. Door de eeuwenlange uitbreiding van de stad rondom het centrum ligt het station er nu niet meer buiten maar er middenin. Volgens de gemeente behoort het stationsgebied echter ruimtelijk en functioneel niet tot de omliggende buurten. Het is een restruimte gebleven die wordt gekenmerkt door rangeerterreinen en rommelige bedrijfsbebouwing (Breda, 2003). Eind vorige eeuw achtte de gemeente Breda de tijd daarom rijp om het stationsgebied meer te verweven met de stad.

In 1995 werd een Strategische ontwikkelingsvisie voor de Oost-Westflank en Stationsgebied opgesteld waarin ruimte werd geboden aan de ontwikkeling van een hoogwaardig transport en openbaar vervoerssysteem, in combinatie met een goed vestigingsmilieu voor kantoren en woningen (Gemeente Breda, 1995). Daarna hebben de ideeën voor het stationsgebied een aantal jaren een sluimerend bestaan geleden. De plannen kregen pas een nieuwe impuls toen de Tweede Kamer, naar aanleiding van de motie Verbugt in 1998, Breda toegevoegde aan de lijst met Nieuwe Sleutelprojecten (NSP). Daarbij werd de kanttekening geplaatst dat die status eerst nader onderzocht moest worden. Dit heeft geleid tot een verkenning van de mogelijkheden en kansen voor het ontwikkelen van het station Breda en de directe omgeving daarvan tot een toplocatie voor wonen, werken voorzieningen en een internationaal transferium. Deze studie is uitgemond in de 'Verkenningen Sleutelproject Spoorzone Breda' die door de gemeenteraad van Breda in januari 2000 werd vastgesteld. Uit de verkenningen bleek dat de ontwikkeling van het sleutelproject Breda kansrijk was en kon voldoen aan 
de Rijksdoelstellingen ten aanzien van de Nieuwe Sleutelprojecten. Het Rijk heeft vervolgens in januari 2000 het stationsgebied van Breda definitief erkend als Nieuw Sleutelproject. In april van hetzelfde jaar werd in het kader van de procesarchitectuur voor de Sleutelprojecten een startovereenkomst getekend tussen de gemeente Breda en het Rijk (Breda, 2002). Breda zal met twee spoorbogen en een shuttleverbinding met Rotterdam en Antwerpen worden aangesloten op het HSLnetwerk. De definitieve erkenning als Sleutelproject werd door de gemeente Breda aangegrepen om het Stationskwartier in ontwikkeling te nemen (Breda, 2003a).

Deze fase van verkenning werd opgevolgd door een fase waarin de ambities voor het stationskwartier werden vertaald naar een concreet programma. Op 13 februari 2002 resulteerde dit in de "Intentieovereenkomst NSP Spoorzone Breda" tussen de gemeente Breda en het Rijk. Daarin werden onder andere het plangebied, het beoogde resultaat en de wijze van samenwerking vastgelegd (Ministerie VROM, 2003). Tevens werd voor het ontwikkelen van een masterplan een overeenkomst gesloten tussen de gemeente Breda en NS die eigenaar is van een groot deel van de gronden in het Stationskwartier.

De gemeente Breda en NS hebben vervolgens architectenbureau Atelier Pro opdracht gegeven om een Masterplan in de vorm van een stedenbouwkundig ontwerp voor het station en omgeving te maken. Bij de ontwikkeling van dit masterplan waren naast de gemeente Breda en NS, tevens het Rijk en de provincie Noord-Brabant betrokken. Het 'Masterplan Centraal Breda' schetst de gewenste ontwikkeling van het Stationskwartier. Het Masterplan bestaat uit diverse documenten waarin meerdere parallelle deelonderzoeken zijn verwerkt. Ook is daar het schetsontwerp voor de OVterminal inbegrepen. Samen vormen deze documenten het Masterplan Centraal Breda dat het ruimtelijk kader vormt voor verdere planontwikkeling.

Conform de procesarchitectuur voor Nieuwe Sleutelprojecten, heeft de gemeente het Masterplan Centraal Breda in mei 2003 ter toetsing aangeboden aan het Rijk. In juni van hetzelfde jaar heeft de gemeenteraad van Breda dit Masterplan vastgesteld als kader voor de verdere ontwikkeling van het Stationskwartier en werd de provincie Noord-Brabant verzocht bij te dragen aan het sleutelproject Breda. In september 2003 stemde Gedeputeerde Staten hier mee in en reserveerde 10 miljoen euro uit het Ontwikkelingsfonds Brabant 2050. In december 2003 gaf het Rijk vervolgens aan dat het onder voorwaarden akkoord ging met het Masterplan. Het gaf voldoende vertrouwen voor verdere concretisering van de plannen.

In de periode daaropvolgend werden de plannen verder uitgewerkt. Het schetsontwerp voor de OVterminal werd uitgewerkt tot het concretere niveau van een voorlopig ontwerp (VO). De gemeente, de Minister van VROM, de Minister van V\&W, de provincie Noord-Brabant, ProRail B.V., NS Vastgoedontwikkeling B.V. en NS Stations B.V. tekenden hiervoor in oktober 2005 een tussenovereenkomst. ${ }^{176}$ Daarin werd afgesproken dat de gemeente, mede namens de partijen het voorlopig ontwerp voor het openbaar vervoer terminal complex (OVTC) tot stand zou brengen. Gelijktijdig met de ondertekening van de tussenovereenkomst besloot de minister van Verkeer en Waterstaat dat er in verband met de plannen voor de hogesnelheidslijn een derde perron nodig was om de hogesnelheidstrein in Breda te kunnen ontvangen en om een hogere frequentie van treinen aan 
te kunnen. Voor de aanleg van het derde perron heeft de gemeente in mei 2006 een bouwvergunning verleend aan ProRail en in oktober 2006 is dit perron officieel in gebruik genomen. De aanleg van het derde perron loopt daarmee vooruit op de herontwikkeling van de OV-terminalcomplex. Voor de uitwerking van de plannen voor het OVTC tot een voorlopig ontwerp werd na advies van de Rijksbouwmeester en de Spoorwegbouwmeester het architectenbureau Atelier Quadrat / Koen van Velsen geselecteerd. Eind 2005 werd dit voorlopig ontwerp gepresenteerd en in juni 2006 werd het door de gemeenteraad van Breda vastgesteld.

Voor de bredere ontwikkeling van het gehele NSP project was begin 2005 door Provinciale Staten besloten een maximale bijdrage van 20 miljoen euro te doen. In mei 2005 werd door de gemeente Breda de "Structuurvisie Via Breda Spoorzone 2025" vastgesteld, waarin naast het Stationskwartier de contouren voor het gehele spoorzonegebied zijn beschreven (Gemeente Breda, 2005). Daarnaast werd voor de ontwikkelingen in de gehele Spoorzone een Milieu Effect Rapportage opgesteld. Gelijktijdig met het voorlopig ontwerp voor de OV-terminal werden voor het bredere plangebied het voorontwerp voor het bestemmingsplan Stationskwartier, de Milieu Effect Rapportage Via Breda 177 en bereikbaarheidsvisie Spoorzone vrijgegeven voor inspraak en consultatie (VROM, 2006).

Uiteindelijk heeft de planvorming in 2006 geleidt tot uitvoeringsafspraken tussen Rijk en gemeente. De gemeente Breda en het Rijk (Minister van VROM en Minister van V\&W) hebben hiervoor op 31 mei 2006 de Bestuurlijke Overeenkomst Uitvoering (BOU) NSP Breda getekend, waarin tevens afspraken zijn gemaakt over bijdragen van partijen en de daaraan verbonden voorwaarden.

In mei 2007 heeft de gemeenteraad van Breda het Bestemmingsplan Stationskwartier ${ }^{178}$ en het Beeldkwaliteitsplan ${ }^{179}$ vastgesteld. Het Bestemmingsplan en het Beeldkwaliteitsplan vormen samen met het ontwerp Buitenruimteplan Stationskwartier 180 de drie concrete uitwerkingen van het Masterplan uit 2003. Met het vaststellen van dit laatste plan en de Grondexploitatie NSP Breda voldoet Breda voor een belangrijk deel aan de voorwaarden die het Rijk stelt voor het toekennen van een subsidie zoals overeengekomen in de Bestuurlijke Overeenkomst Uitvoering. In dezelfde periode is tussen de NS en de gemeente Breda een samenwerkingsovereenkomst voor de ontwikkeling van het NSP Breda gesloten en hebben de NS, ProRail en de gemeente Breda een overeenkomst getekend voor het te realiseren OVTC.

In oktober 2007 heeft de gemeenteraad het definitief ontwerp (DO) voor het OVTC vastgesteld en Gedeputeerde Staten van Noord Brabant hebben bij besluit van 18 december 2007 goedkeuring verleend aan het bestemmingsplan 'Stationskwartier'. Op 19 december 2007 hebben Heijmans Betonen Waterbouw B.V. en ProRail B.V. een overeenkomst ondertekend voor het ontwerp en realisatie van de ruwbouw van de perrontunnel van station Breda. Hiermee is de daadwerkelijke bouw van stationsproject Breda van start gegaan. Voor de bouw van het nieuwe OVTC hebben de gemeente Breda, ProRail en NS Poort op 10 juni 2008 een Realisatieovereenkomst getekend en afspraken gemaakt over de verdeling van kosten, risico's, verantwoordelijkheden en beheer van het OVTC. Het definitief ontwerp voor het OVTC is in 2009 aanbesteed en volgens de planning zou het OVTC in 2012 gereed moeten zijn. De omliggende gebiedsontwikkeling kent een langer tijdschema. Figuur 7.1 geeft een schets van het procesverloop in de tijd. 


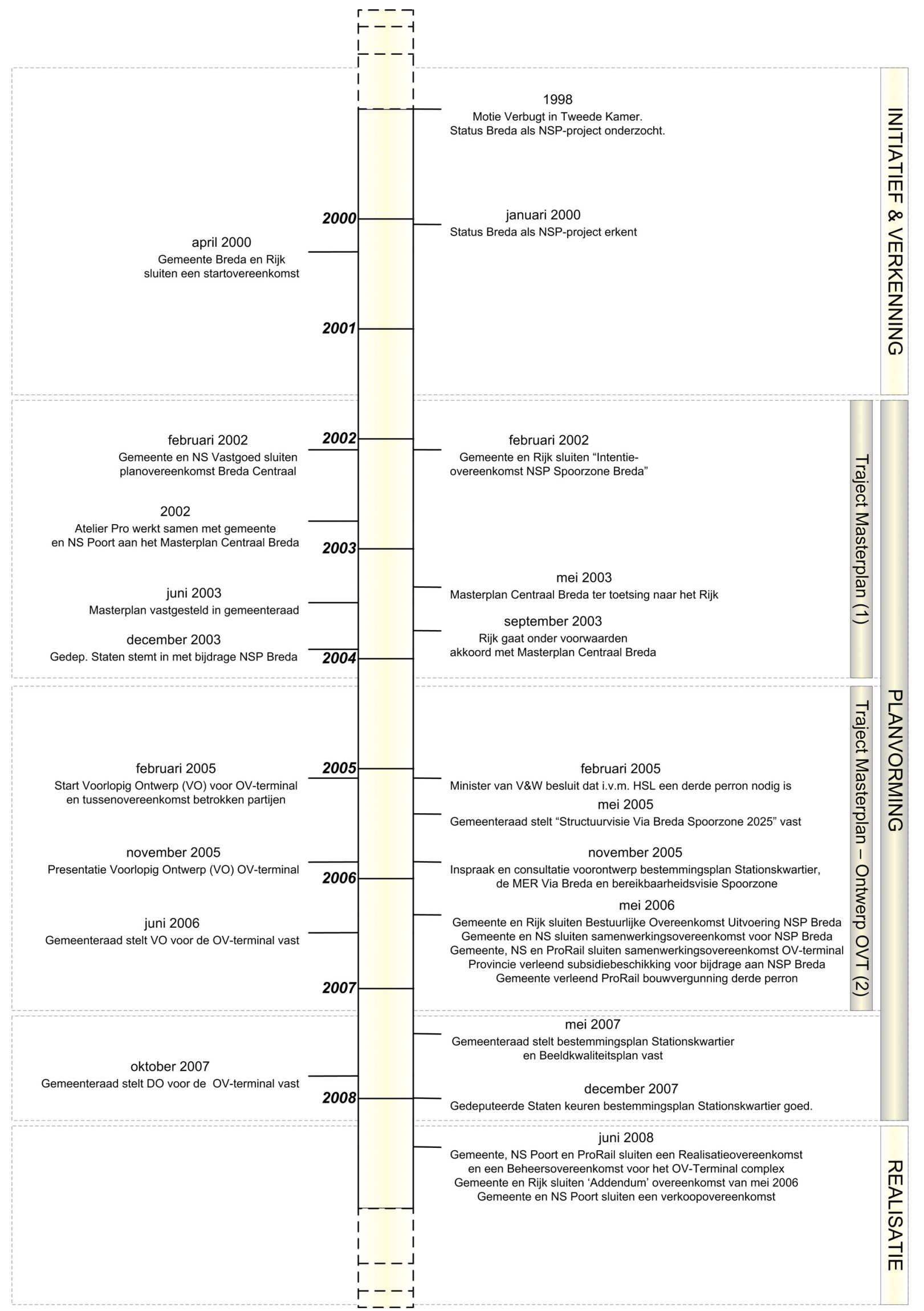

Figuur 7.1 Stationskwartier Breda - Procesverloop 


\subsubsection{De ruimtelijke opgave}

De integrale aanpak van gehele spoorzone in Breda, wordt aangeduid met de naam 'Via Breda'. Het plangebied Via Breda bestaat uit zes ontwikkelingsgebieden (Breda, 2007: p.8). Het 'Stationskwartier' is één van deze ontwikkelingsgebieden en vormt het kerndeel. Binnen het Stationskwartier neemt de ontwikkeling van het OV-terminalcomplex (OVTC) een centrale plaats in. Het 'Masterplan Centraal Breda' vormt het kader waarbinnen de ontwikkeling van het Stationskwartier kan plaatsvinden en het 'Bestemmingsplan Stationskwartier' vormt de planologisch-juridische vertaling daarvan. Het plangebied van het Stationskwartier beslaat ruim 16 hectare (Breda, 2007: p.8). Het programma voor dit gebied voorziet volgens het Masterplan in circa $120.000 \mathrm{~m} 2$ BVO kantoorruimte, 600 woningen en $13.500 \mathrm{~m} 2$ BVO voorzieningen, waaronder een hotel. ${ }^{181}$ Met de ontwikkeling van het Stationskwartier wordt gedurende de looptijd van het project (15-25 jaar) in totaal circa 600 miljoen euro geïnvesteerd in vastgoed, infrastructuur en het nieuwe OVTC. In het plangebied van het Stationskwartier kan een onderscheid worden gemaakt tussen de ontwikkeling van het OVTC en de omliggende gebiedontwikkeling, bestaande uit vastgoedontwikkeling, toeleidende infrastructuur en de openbare ruimte.

\section{OV-terminalcomplex ${ }^{182}$}

Voor de aanpak van het station is, op basis van de normen en richtlijnen die neergelegd zijn in de Nota Basisstations, een referentiemodel opgesteld (Arcadis, 2002). Het huidige station Breda voldoet niet aan deze normen en richtlijnen. Ook het busstation voldoet niet aan de uitgangspunten voor capaciteit en kwaliteit. Daarnaast is door de komst van Hoogwaardig Openbaar Vervoer (HOV) aanpassing in de ligging en kwaliteit van het station gewenst (Masterplan Centraal Breda, OVTerminalplan, 2003). Bovenop de eisen in het referentiemodel is gekeken naar de wensen en ambities van partijen in het kader van de sleutelprojecten. Daarbij gaat het om een toevoeging van kwaliteit in ruimtelijke en functionele zin. Tevens is er door middel van een vastgoedmodel nog gekeken naar de totale ontwikkelingsmogelijkheden van de OV-terminal binnen het Stationskwartier. Uiteindelijk heeft dit geleid tot een ontwerp waarin de OV-terminal wordt ontwikkeld tot een integrale terminal waar alle vervoersmodaliteiten onder een dak samenkomen, maar ook diverse vastgoedruimte wordt ontwikkeld. Concreet omvat de opgave voor de OV-terminalcomplex het volgende (Breda, 2007)

- Uitbreiding en/of aanpassing sporen, (plus opheffing en sanering emplacement);

- Een nieuw (derde) perron (al gerealiseerd);

- Een integrale overkapping over de sporen, passage en busplatform;

- Een tunnel voor fietsers en voetgangers tussen de wijken aan beide kanten van het spoor

- Bijzondere functies (kantoren, winkels, horeca, commerciële functies en wonen);

- Parkeren voor reizigers en parkeren ten behoeve van andere functies;

- Grootschalige fietsenstalling;

- Voorpleinfuncties;

- Uitbreiding en aanpassing infrastructuur ten behoeve van (hoogwaardig) openbaar vervoer, autobereikbaarheid, beheersing van calamiteiten, bevoorrading en taxi's. 
Het definitief ontwerp voor het OVTC behelst een geheel overkapte trein- en busterminal van 7.000 $\mathrm{m} 2,9.000 \mathrm{~m} 2$ BVO bijbehorende commerciële ruimten, 147 woningen, $22.000 \mathrm{~m} 2$ BVO kantoren, 720 parkeerplaatsen op het dak en een bewaakte fietsenstalling van $2.900 \mathrm{~m} 2$.

\section{Gebiedsontwikkeling ${ }^{183}$}

De omliggende gebiedsontwikkeling behelst het overgrote deel van het vastgoedprogramma (circa $200.000 \mathrm{~m} 2$ BVO) in het Stationskwartier. Dit bestaat uit kantoren, woningen, commerciële en publieke voorzieningen en een hotel. De uitgangspunten voor de verdeling van het vastgoed zijn neergelegd in het Stedenbouwkundige Ontwerp. Daarnaast worden toeleidende infrastructuur, parkeervoorzieningen en openbare ruimte aangelegd en aangepast.

\subsubsection{Actoren}

Binnen het plangebied van het Stationskwartier hebben meerdere partijen op grond van eigendom en/of (bestuurlijke) verantwoordelijkheden een positie. Zoals hiervoor aangegeven, kan onderscheid worden gemaakt tussen de ontwikkeling van het OVTC en de omliggende gebiedsontwikkeling.

In de afspraken tussen partijen wordt voor de ontwikkeling van het OVTC onderscheid gemaakt naar diverse deelprojecten. De gemeente is verantwoordelijk voor de realisatie van het Deelproject OVTC Bussen, het Deelproject OVTC Transfer, het Deelproject OVTC Stationserven, het Deelproject OVTC Voorpleinen en de realisatie van NSP-kwaliteit met betrekking tot het project OVTC. ProRail is verantwoordelijk zijn voor het Deelproject OVTC Treinen en het Deelproject OVTC Fietsen. NS is verantwoordelijk voor de realisatie van het Deelproject OVTC Vastgoed, het Deelproject OVTC Stationscommercie en het deelproject OVTC parkeren en zal als zodanig als risicodragend opdrachtgever zijn voor deze deelprojecten (BOU NSP Breda, 2006).

Voor de omliggende gebiedsontwikkeling binnen het Stationskwartier werkt de gemeente Breda samen met NS Poort. Deze partijen zijn samen met ProRail eigenaar van het overgrote deel van de te ontwikkelen gronden in dit gebied. Projectontwikkelaar HeJa had in het plangebied een beperkt aantal strategische posities aangekocht, maar is uitgekocht door de gemeente Breda. ProRail en de NS saneren hun gronden in het plangebied waarna de gemeente de grond van hen koopt. De gemeente sloopt eventuele opstallen, makt de grond bouwrijp en geeft het uit voor verschillende functies. Met NS Poort zijn afspraken gemaakt over deze functies, de bijbehorende grondprijs en de planning voor de te ontwikkelen gronden. De gemeente heeft een globaal bestemmingsplan voor het Stationskwartier vastgesteld en globale stedenbouwkundige eisen voor de gebiedsontwikkeling geformuleerd. NS Poort stelt voor de vier deelgebieden van de gebiedsontwikkeling een gedetailleerd stedenbouwkundig plan op.

De actoren die betrokken zijn bij de ontwikkeling van het OVTC en/of de gebiedsontwikkeling binnen het Stationskwartier staan hierna nader beschreven.

\section{Gemeente Breda}

De gemeente Breda is primair verantwoordelijk voor de voortgang en realisatie van NSP Breda. NSP Breda is het gebied dat ook wel wordt aangeduid met de naam Stationskwartier. De gemeente initieert en sluit overeenkomsten met andere partijen en coördineert de ontwikkeling van het sleutelproject. Met het Rijk is een Bestuurlijke Overeenkomst Uitvoering (BOU) gesloten, waarin de kwalitatieve en financiële kaders voor de ontwikkeling van het Stationskwartier zijn bepaald. Dit betreft onder andere de financiële bijdragen van het ministerie van VROM en het ministerie van V\&W en de bijbehorende 
voorwaarden. Met de Provincie Noord-Brabant heeft de gemeente afspraken gemaakt over haar bijdrage voor het busstation, het $(\mathrm{H}) \mathrm{OV}$-deel van de toeleidende infrastructuur en de kwaliteit van de transferfunctie van de OV-terminal. Met NS Poort, heeft de gemeente een samenwerkingsovereenkomst (SOK) gesloten waarin de stedenbouwkundige ambities, programmatische en financiële uitgangspunten zijn vastgelegd. Hierin zijn o.a. afspraken gemaakt over bijdragen van NS uit grondopbrengsten van de gebiedsontwikkeling. Met de NS en ProRail heeft de gemeente een realisatieovereenkomst (ROK) gesloten specifiek voor de ontwikkeling van het OV-terminalcomplex.

Met het Masterplan Centraal Breda, dat in opdracht van de gemeente en NS Poort is opgesteld en door de gemeenteraad in juni 2003 is vastgesteld, zijn een stedenbouwkundige visie en de functionele en ruimtelijke kaders voor de ontwikkeling van het Stationskwartier als geheel gegeven. Dit bevat tevens een schetsontwerp voor het OVTC. De planologisch-juridische vertaling van het Masterplan is neergelegd in het bestemmingsplan Stationskwartier dat in mei 2007 is vastgesteld door de gemeenteraad. Het Rijk heeft met deze plannen ingestemd. Naast het bestemmingsplan is door de gemeente samen met NS Poort een Beeldkwaliteitsplan opgesteld. Het Beeldkwaliteitsplan heeft ten doel een overallkader te schetsen dat gebruikt kan worden bij de beoordeling van concrete bouwplannen. Daarnaast is voor de openbare ruimte een Buitenruimteplan opgesteld.

Voor het OVTC heeft de gemeente Breda mede namens het Rijk, de provincie Noord-Brabant, ProRail en NS opdracht gegeven voor het uitwerken van het schetsontwerp tot een voorlopig ontwerp. Gemeente, ProRail en NS hebben gezamenlijk opdracht gegeven om vervolgens een definitief ontwerp tot stand te brengen. Voor de realisatie van het DO hebben deze partijen een overeenkomst gesloten. ${ }^{184}$. Hierin is onder meer vastgelegd dat de gemeente verantwoordelijk zal zijn voor de eerdergenoemde onderdelen (Bussen, Transfer, Stationserven, Voorpleinen en de realisatie van NSP-kwaliteit). De gemeente draagt zelf vanuit het Meerjaren Investeringsprogramma (MIP) 22.7 miljoen euro bij an de ontwikkeling van het Stationskwartier. Deze bijdrage is naast het gemeentelijke aandeel in het busstation ${ }^{185}$ vooral voor de financiering van de kosten voor toeleidende infrastructuur. ${ }^{186}$ Daarbovenop draagt de gemeente bij aan het project vanuit een positief saldo op de grondexploitatie.

\section{Provincie Noord-Brabant}

In het Streekplan Noord-Brabant 2002 (Provincie Noord-Brabant, 2002) wordt gepleit voor intensivering rond stedelijke infrastructurele knooppunten. Meervoudig ruimtegebruik geldt daarbij als een van de centrale thema's. Het beleid zoals dat in het Streekplan is vastgelegd, is nader gedetailleerd in het Uitwerkingsplan Breda-Tilburg. Daarin komt onder andere de betekenis van Brabantstad naar voren. Brabantstad is een samenwerkingsverband tussen de provincie Brabant, het samenwerkingsverband regio Eindhoven en de steden Breda, Eindhoven, Helmond 's Hertogenbosch en Tilburg. ${ }^{187}$ In het kader van Brabantstad formuleren provincie en grote steden gemeenschappelijke ambities en een visie op de (inter)nationale bereikbaarheid van de Brabantse steden. Een van de programma's is "Brabantstad Ontsloten". De ontwikkeling van het openbaar vervoer netwerk Brabantstad is één van de speerpunten van het programma. Daarbij wordt ingezet op het ontwikkelen van het station Breda tot 'Poort van Brabant'. Medio 2003 heeft B\&W van Breda in het kader van dat beleid de Provincie Noord-Brabant verzocht bij te dragen aan het sleutelproject Breda. Vanaf dat moment heeft de provincie deelgenomen aan de stuurgroep en het 
projectgroepoverleg. Vanuit het Ontwikkelingsfonds Brabant 2050 draagt de provincie 10 miljoen euro bij aan het OVTC, bedoeld voor een verhoging van de kwaliteit van de transferfunctie. Daarnaast draagt de provincie vanuit de doorgedecentraliseerde rijksmiddelen (BDU) nog eens 10 miljoen bij. Hiervan is 5 miljoen euro bedoeld voor toeleidende businfrastructuur en de overige 5 miljoen aanvullend voor de OVTC en dan met name voor het busstation. In totaal is de bijdrage van de provincie gemaximeerd op 20 miljoen euro. Hiervoor heeft de provincie mei 2006 een subsidiebeschikking afgegeven aan de gemeente Breda. Daarin staan tevens de kwalitatieve eisen en voorwaarden beschreven. ${ }^{188}$ In 2007 zijn hierover aanvullende afspraken gemaakt tussen provincie en gemeente Breda omdat het project een jaar was opgeschoven in de tijd.

\section{Ministerie VROM}

De doelstellingen van het Rijk voor het Stationskwartier Breda zijn neergelegd in het beleid voor de Nieuwe Sleutelprojecten. Vanuit het Rijk treedt de minister van VROM hiervoor op als coördinerend minister. Voor de concrete vertaling van deze doelstellingen naar de ontwikkelingen in het Stationskwartier Breda is tussen Rijk en gemeente een Bestuurlijke Overeenkomst Uitvoering gesloten. Hierin zijn de kwalitatieve en financiële kaders voor de ontwikkeling van het Stationskwartier vastgelegd. In deze overeenkomst is vastgelegd dat het ministerie van VROM vanuit het NSP 1 budget (15.9 miljoen euro) en NSP 2 budget ( 9 miljoen euro) in totaal 24.9 miljoen euro (niet geïndexeerd) bijdraagt aan het project. Daarbij is het NSP 1 budget bedoeld voor het verhogen van de kwaliteit van de openbare ruimte en infrastructuur in het Stationskwartier en het NSP 2 budget voor het verhogen van de kwaliteit van de transferfunctie van het OVTC.

$\mathrm{Na}$ het sluiten van de Bestuurlijke Overeenkomst Uitvoering is de rol van het ministerie van VROM vooral toetsend. Zij toetst de verdere uitwerking van de plannen en de voortgang van het project aan de kaders die in de overeenkomst zijn vastgelegd. De gemeente vraagt in het kader van de Stuurgroep Rijk/Gemeente aan de minister van VROM instemming met diverse plandocumenten, waaronder (ontwerp-)bestemmingsplannen, het definitief ontwerp voor het OVTC, het (ontwerp)buitenruimteplan, en het (ontwerp-)beeldkwaliteitsplan. De Minister van VROM toetst deze plandocumenten aan verschillende kaders, waaronder bijvoorbeeld het Toetsingskader NSP, het geactualiseerde Masterplan en het realiseren van NSP kwaliteit. Voorafgaand aan het verzoek tot instemming vraagt de gemeente advies aan het Bouwmeestersoverleg. Vanuit het Ministerie van VROM is de Rijksbouwmeester verantwoordelijk voor de toets op de stedenbouwkundige kwaliteit. Hierover brengt de Rijksbouwmeester advies uit aan het Directoraat Generaal Ruimte van het Ministerie van VROM.

Als onderdeel van het ministerie van VROM is verder de Rijksgebouwendienst betrokken bij de planvorming voor het Stationskwartier. De bedoeling is namelijk dat in het OVTC de belastingdienst gevestigd wordt en in het Stationskwartier op termijn een gerechtsgebouw gerealiseerd wordt. Hiermee zou de afname van een deel van het vastgoed zeker zijn gesteld.

\section{Ministerie van Verkeer en Waterstaat}

Als gevolg van de shuttleverbinding van Breda met de hogesnelheidslijn was een keerpunt bij het station noodzakelijk. De aanpassing van de bestaande railinfrastructuur van het station inclusief de aanleg van het derde perron valt onder verantwoordelijkheid van het Ministerie van V\&W (Intentieovereenkomst Rijk-Gemeente, 2002). Daarnaast is het ministerie van V\&W verantwoordelijk voor de transferfunctie van stations. Omdat het huidige OV-knooppunt Breda zowel kwalitatief als 
kwantitatief ontoereikend wordt geacht voor het verwerken van het treinverkeer en groeiende reizigersstromen draagt het ministerie van V\&W ter dekking van de stichtingskosten van het transfergedeelte van het referentiemodel dat is opgesteld voor het OVTC bij uit het MIT grote stations. In de bestuurlijke overeenkomst met de gemeente Breda is vastgelegd dat de Minister van Verkeer en Waterstaat zich tegenover de gemeente verplicht maximaal 31.4 miljoen euro (prijspeil 2005) bij te dragen uit het MIT. Deze MIT-subsidie is bedoeld voor het Deelproject OVTC Treinen en het Deelproject OVTC Fietsen en wordt verleend aan ProRail. Daarbovenop wordt een bijdrage gedaan van maximaal 3.5 miljoen euro (prijspeil 2005) voor dezelfde deelprojecten alsmede het Deelproject OVTC Transfer (compensatie voor bestaande stationsgerelateerde commerciële voorzieningen) onder voorwaarde dat dat NS een bijdrage van 6 miljoen ter beschikking stelt aan de gemeente voor het OVTC. Voor toekenning van de bijdragen toetst de Minister de verdere uitwerking van de plannen aan de kaders die in de uitvoeringsovereenkomst zijn vastgelegd.

\section{ProRail}

ProRail is eigenaar van de sporenlay-out en het lager gelegen goederenemplacement. De gronden die daarvan worden ontwikkeld heeft ProRail verkocht aan de gemeente Breda. Belangrijker dan haar positie als eigenaar is de verantwoordelijk die ProRail als takkorganisatie heeft voor de transfervoorzieningen in de stationshal. Vanuit die positie is een overeenkomst gesloten met de gemeente Breda en de NS voor de realisatie van het OVTC. In de bestuurlijke overeenkomst tussen Rijk en gemeente Breda is vastgelegd dat Gemeente, ProRail en NS gezamenlijk opdracht zullen geven voor het definitief ontwerp van het OVTC. ProRail heeft het projectmanagement voor het opstellen van het definitief ontwerp gedaan. Voor de realisatie is ProRail opdrachtgever voor de realisatie van het Deelproject OVTC Treinen en het Deelproject OVTC Fietsen. Hiervoor ontvangt zij MIT-subsidie van het Ministerie van Verkeer en Waterstaat. Voor de realisatie van overige deelprojecten van het OVTC fungeert ProRail als gedelegeerd opdrachtgever en bouwmanager namens de andere opdrachtgevers (NS en gemeente Breda). Daarbij hebben partijen afspraken over de verdeling van uitvoeringsrisico's voor onderdelen vastgelegd in een realisatieovereenkomst.

ProRail stelt eveneens middelen ter beschikking voor de transferfunctie van de OV-terminal en als beheerder van het FENS ${ }^{189}$ stelt het in samenspraak met de NS een bijdrage beschikbaar voor Electronic Ticketing/Beheerste Toegang Stations (ET/BTS). Over de besteding van de FENS middelen legt ProRail periodiek verantwoording af aan het Ministerie van Verkeer en Waterstaat.

\section{Nederlandse Spoorvegen}

NS speelt een belangrijke rol in zowel de gebiedsontwikkeling als voor het OVTC. Ten aanzien van de gebiedsontwikkeling is van belang dat NS Poort eigenaar is van een substantieel deel van de gronden in het Stationskwartier. $\mathrm{Zij}$ is onder andere eigenaar van de parkeerterreinen ten zuiden van de sporen, het Mercurehotel, delen aansluitend aan het laaggelegen emplacement en bedrijfsobjecten in het westelijk deel van het plangebied (Breda, 2007). Met het ontwikkelen van deze gronden wil NS Poort een bijdrage leveren aan het bevorderen van het treingebruik, mede door publieksintensieve en kwalitatief hoogwaardige vastgoedfuncties te realiseren rondom het station (Covernota Masterplan Breda Centraal, 2003: p.19). Samen met de gemeente Breda heeft NS Poort opdracht gegeven een Stedenbouwkundig Ontwerp in de vorm van het Masterplan Centraal Breda op te stellen. Daarnaast heeft zij samen met de gemeente een Beeldkwaliteitsplan opgesteld. Hierin zijn regels voor de 
bebouwing en de openbare ruimte in het stationskwartier neergelegd. De gemeente Breda heeft met NS Poort een samenwerkings-overeenkomst gesloten waarin de stedenbouwkundige ambities, programmatische en financiële uitgangspunten zijn vastgelegd. Voor de realisatie van de gebiedsontwikkeling zijn uitvoeringsafspraken gemaakt tussen gemeente en NS met betrekking tot de grondexploitatie ${ }^{190}$, marketing en informatie ${ }^{191}$ en de planologische procedures ten behoeve van verwerving/onteigening, schadecompensatie en ontwikkeling van concrete bouwplannen. NS Poort stelt voor de vier deelgebieden die worden onderscheiden in de gebiedsontwikkeling buiten het OVTC een gedetailleerd stedenbouwkundig plan op. Voor de vastgoedontwikkeling heeft NS Poort haar gronden overgedragen aan de gemeente Breda die deze bouwrijp maakt en tegen een afgesproken grondprijs afhankelijk van de te realiseren functies weer uitgeeft aan NS. NS heeft vervolgens drie jaar om de ontwikkeling te realiseren. Als zij in die periode nog geen 50\% voorverkocht of verhuurd heeft dan moet zij het in ontwikkeling nemen of afstand doen van de ontwikkelclaim. De grond gaat dan terug naar de gemeente Breda. Omdat wel afspraken zijn gemaakt over de bijdrage vanuit het geraamd voordelig resultaat van de grondexploitatie aan de OV-terminal ligt dat risico uiteindelijk bij de gemeente Breda.

Bij de ontwikkeling van het OVTC is NS verantwoordelijk voor de deelprojecten Vastgoed, Stationscommercie en Parkeren en is als zodanig risicodragend opdrachtgever. Vanuit de residuele grondwaarde van het vastgoed in het OVTC draagt NS bij aan de ontwikkeling van de transferfunctie.

\begin{tabular}{lll} 
Planonderdeel & Actoren & Positie \\
& Gemeente Breda & Regierol, primair verantwoordelijk voortgang en realisatie NSP Breda \\
& Provincie Brabant & Subsidieverlener voor kwaliteit transferfunctie OV-terminal, busstation en HOV \\
& Ministerie VROM & Coördinator NSP beleid vanuit het Rijk. Subsidieverlener voor NSP-kwaliteit terminal (NSP 2) \\
MV-terminal & Ministerie V\&W & Subsidieverlener vanuit MIT en extra NSP-budget \\
& ProRail & Gedelegeerd opdrachtgever DO namens NS en Breda. Beheerder niet comm. voorzieningen \\
& NS & Grond-/vastgoedeigenaar OVT en beheerder en exploitant commerciële voorzieningen \\
& Koen van Velsen & Architect voor het Definitief Ontwerp (DO) voor de OV-Terminal \\
\hline Gemeente Breda & Grond-/vastgoedeigenaar, vergunningverlener, beheer openbare ruimte \\
NS Poort & Grond- / vastgoedeigenaar en ontwikkelaar \\
ProRail & Grondeigenaar \\
Ministerie VROM & Coördinator NSP beleid vanuit het Rijk. Subsidieverlener NSP-kwaliteit op. ruimte (NSP 1) \\
& Atelier Pro & Architect Stedenbouwkundig Ontwerp Masterplan Centraal Breda \\
\hline
\end{tabular}

Tabel 7.1 Stationskwartier Breda - actoren per planonderdeel

\section{Overige actoren}

Naast de hiervoor beschreven partijen die uit hoofde van eigendom of bestuurlijke verantwoordelijkheid betrokken zijn bij de aanpak van het Stationskwartier zijn er ook enkele andere actoren vermeldenswaardig voor de planontwikkeling. Hierbij kan onder andere gedacht worden aan het Bouwmeestersoverleg. Dit overleg bestaat uit de Rijksbouwmeester en het Hoofd Ruimtelijke Plannen van de Gemeente en waar het gaat om het OVTC maakt de Spoorbouwmeester ook deel uit van dit overleg. Het Bouwmeestersoverleg is onafhankelijk en heeft tot taak de Stuurgroep $\mathrm{Rijk} /$ Gemeente te adviseren over de verwezenlijking van ruimtelijke kwaliteit in het plangebied. 
Ook architectenbureau's spelen een rol in de uitvoering van de planontwikkeling. Architectenbureau Atelier Pro heeft in samenwerking met de gemeente Breda en NS Poort het stedenbouwkundig ontwerp voor het Masterplan Centraal Breda gedaan en Bureau Koen van Velsen heeft het definitief ontwerp gemaakt voor het OVTC.

\subsubsection{Samenwerkingsorganisatie}

De organisatie van de samenwerking tussen de in de vorige paragraaf beschreven partijen is voor een belangrijk deel vastgelegd in diverse overeenkomsten. $\mathrm{Na}$ een aantal verkenningsstudies kan als startpunt voor de fase van planvorming de intentieovereenkomst tussen Rijk en gemeente Breda en de planovereenkomst tussen gemeente Breda en de NS, beide van februari 2003, worden genomen. Hierin werden onder andere afspraken vastgelegd over de wijze van samenwerking voor de ontwikkeling van het Masterplan Centraal Breda.

Centraal in de organisatie van de samenwerking staan de afspraken die zijn vastgelegd in de bestuurlijke overeenkomst (BOU) tussen Rijk en gemeente Breda van mei 2006. Deze overeenkomst heeft betrekking op het NSP project (Stationskwartier) als geheel. Er is een stuurgroep Rijk/Gemeente opgericht die toeziet op de uitvoering en de voortgang van het integrale project en die fungeert als primaire overlegvorm tussen partijen. Deze Stuurgroep komt minimaal twee keer per jaar bijeen en bestaat uit een vertegenwoordiger aangewezen door de Minister van VROM, een aangewezen door de Minister van Verkeer en Waterstaat en twee vertegenwoordigers vanuit de gemeente Breda. Het secretariaat berust bij de gemeente en de gemeente rapporteert aan de stuurgroep over de voortgang en besteding c.q. uitputting van subsidiegelden. NS en ProRail kunnen op verzoek van partijen worden uitgenodigd om de stuurgroep te informeren. De stuurgroep wordt voorbereid door het zogenaamde agendaoverleg waarin partijen op ambtelijk niveau samenwerken.

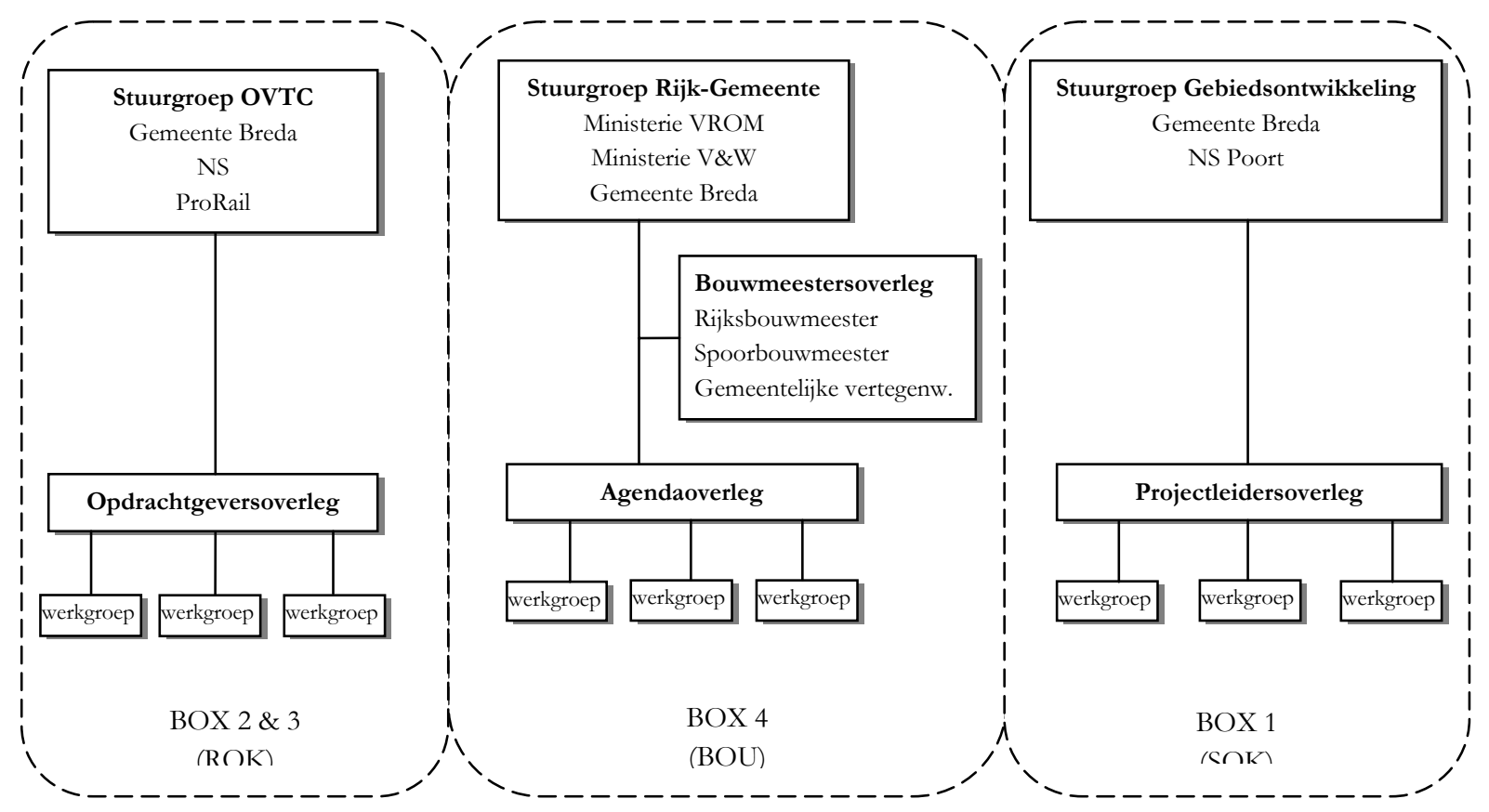

Figuur 7.2 Stationskwartier Breda - Samenwerkingsorganisatie 
De samenwerking voor de gebiedsontwikkeling is primair geregeld in de samenwerkingsovereenkomst (SOK) tussen de NS en de gemeente Breda. De samenwerking voor het OVTC is in belangrijke mate geregeld in de realisatieovereenkomst (ROK) tussen NS, gemeente en ProRail. Voor een goed beeld van verantwoordelijkheden en organisatie van de samenwerking is inzicht in de opzet van de businesscase NSP Breda van belang.

In de business-case NSP Breda worden vier zogenaamde 'boxen' onderscheiden. Box 1 heeft betrekking op de gebiedsontwikkeling in het Stationskwartier. Hiervoor werkt de gemeente Breda samen met NS Poort. Hiervoor bestaat een projectleidersoverleg dat ongeveer maandelijks bijeen komt. Box 2, het bouwrijp maken van de gronden en het ontwerp van de toeleidende infrastructuur naar het OVTC, wordt gedaan door de gemeente Breda. In box 3 zitten de commerciële voorzieningen in het OVTC. De ontwikkeling hiervan wordt gedaan voor rekening en risico van NS Poort. Het opdrachtgeversoverleg voor het OVTC vindt ongeveer een keer per maand plaats. In Box 4 zit het OVTC als geheel. Naast de commerciële voorzieningen bestaat deze uit diverse onderdelen waarvoor de verantwoordelijkheden zijn verdeeld over partijen.

Per box zijn er onderwerpen waarover afspraken zijn gemaakt tussen partijen. In de tijd vindt uitwerking van deze onderwerpen plaats. De stuurgroep Rijk-gemeente moet deze uitwerking vervolgens goedkeuren. Zolang de uitwerking binnen de afspraken ten aanzien van tijd, kwaliteit en geld blijft is die goedkeuring min of meer een formaliteit. Is door de uitwerking aanpassing van de afspraken die voor de betreffende box zijn gemaakt noodzakelijk, dan vereist deze goedkeuring van de stuurgroep Rijk-gemeente. De stuurgroep beslist bij unanimiteit. Wordt door de stuurgroep RijkGemeente goedkeuring onthouden dan moet het probleem binnen de box worden opgelost.

\subsection{Het planproces}

In de vorige paragraaf is een beeld geschetst van het project Stationskwartier Breda. Daarbij zijn de posities van diverse betrokken actoren en de samenwerkingsorganisatie belicht. Deze paragraaf beschrijft de inbreng van keystakeholders in het proces van planvorming. Zoals in hoofdstuk vier beschreven is voor het typeren van de inbreng van keystakeholders in belangrijke mate gebruik gemaakt van de percepties hiervan bij betrokkenen. De inbreng van de keystakeholders is beschreven op drie thema's:

- Visievorming (7.3.1)

- Zeggenschap (7.3.2)

- Middelen (7.3.3)

Nadat de inbreng van de afzonderlijke actoren op deze thema's is beschreven, is het samenstel van actoren getypeerd door te kijken naar (a) het aantal actoren dat een substantiële inbreng heeft; (b) de verhoudingen tussen actoren met uiteenlopende karakters en belangenposities (publiek-privaat; centraal-decentraal; gemeente-overige); en (c) de mate waarin er sprake is van ambivalentie in het beeld bij actoren. Dit is gedaan in paragraaf 7.3.4. 
Belangrijk is de tijdsperiode waarop de analyse betrekking heeft af te bakenen. In deze studie is een onderscheid gemaakt naar (1) het deelproces gericht op de totstandkoming van het masterplan voor de gebiedsontwikkeling als geheel en (2) het deelproces gericht op het ontwikkelen van een ontwerp voor de OV-terminal. Voor het eerste deelproces is de ondertekening van de Intentieovereenkomst NSP Breda tussen Rijk en gemeente Breda in februari 2002 als startpunt genomen en de voorwaardelijke goedkeuring van het Masterplan Centraal Breda door het Rijk in september 2003 als eindpunt. Voor het tweede deelproces is de periode tussen goedkeuring van het Masterplan en de vaststelling van het definitief ontwerp voor het OV-terminal complex beschouwd (zie figuur 7.1)

\subsubsection{Visievorming}

Het vertrekpunt voor de ruimtelijke planvorming voor het Stationskwartier Breda wordt gevormd door de Verkenningen Sleutelproject Spoorzone Breda (resultaat van de verkenningsfase in de procesarchitectuur voor de NSP) en de Programmadoelen Masterplan Spoorzone.

\section{Visievorming in het masterplanproces}

$\mathrm{Na}$ de fase van verkenning is tussen de gemeente Breda en het Rijk de "Intentieovereenkomst NSP Spoorzone Breda" gesloten. In deze intentieovereenkomst werden onder andere het plangebied, het beoogde resultaat en de wijze van samenwerken vastgelegd. Op hetzelfde moment werd tevens een planovereenkomst voor de ontwikkeling van het Masterplan Centraal Breda gesloten tussen gemeente Breda en NS. Deze overeenkomsten vormen min of meer het startpunt voor de planvormingsfase.

Op basis van de Verkenningen en de Programmadoelen zijn de Stedenbouwkundige Uitgangspunten verwoord in een studie van BGSV (2002). Deze zijn door de gemeente Breda gebruikt als ruimtelijk toetsingskader voor het stedenbouwkundig ontwerp. De gemeente Breda en NS Vastgoed hebben vervolgens architectenbureau Atelier Pro opdracht gegeven een stedenbouwkundig ontwerp voor het Stationskwartier inclusief OV-terminal te ontwikkelen. Het Voorlopig Stedenbouwkundig Ontwerp en de Stedenbouwkundige Uitgangspunten zijn vervolgens in consultatie geweest. Atelier Pro heeft naar aanleiding van het commentaar in de consultatieronde en de pre-toetsing door het Atelier Rijksbouwmeester het stedenbouwkundig ontwerp aangepast. De beeldkwaliteit van het Stationskwartier is gedefinieerd in de Visie op de Openbare Ruimte (Gemeente Breda, 2003) en in het Beelkwaliteitsplan voor de inrichting van het Stationskwartier (Atelier Pro, 2003). Beide documenten vormen samen met het Stedenbouwkundig Ontwerp (Atelier Pro, 2003), de Stedenbouwkundige Uitgangspunten (BGSV, 2002) en de Positionering Stationskwartier (Gemeente Breda, 2003) het ruimtelijk kader voor de verdere uitwerking van plannen voor het Stationskwartier.

Het uiteindelijke Masterplan Centraal Breda (2003) bestaat uit diverse documenten waarin de gewenste ontwikkeling van het Stationskwartier wordt neergelegd. Het Masterplan is - conform de inhoud van de intentieovereenkomst - samengesteld uit een Stedenbouwkundig plan en een OVTerminalplan. Het Stedenbouwkundig plan bestaat uit een Programmaplan, Ruimtelijk plan, Ontsluitingsplan, Beeldkwaliteitsplan, Milieuruimteplan en een Realisatiestrategie. Het OVTerminalplan bestaat uit een Functioneel Programma van Eisen en het Schetsontwerp. Om de hoofdlijnen te bewaken is een Covernota opgesteld. 


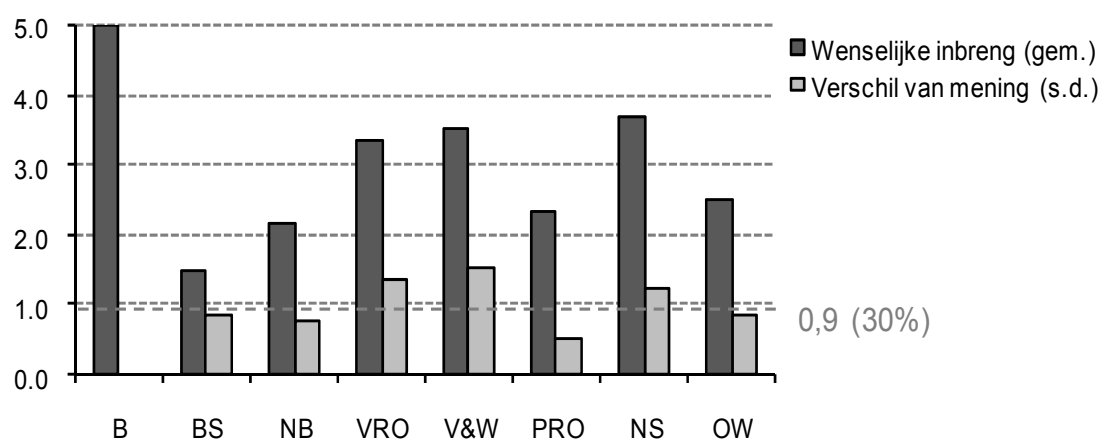

Figuur 7.4 Masterplan Centraal Breda - wenselijke inbreng stakeholders in visievorming en meningsverschil

De conclusie dat de gemeente Breda samen met voornamelijk NS en het ministerie van VROM de visie voor het Masterplan Centraal Breda heeft ontwikkeld, lijkt gerechtvaardigd. De gemeente is daarbij leidend geweest. De grote inbreng van de gemeente wordt ook door alle partijen als wenselijk ervaren. Deze consensus blijkt afwezig als het gaat om de vraag welke inbreng andere partijen zouden moeten hebben in het proces van visievorming.

\section{Visievorming voor de OV-terminal}

Het Functioneel Programma van Eisen en het schetsontwerp voor de OV-terminal maken onderdeel uit van het Masterplan Centraal Breda. Nadat het Masterplan Centraal Breda als kader voor verdere planuitwerking was vastgesteld door de gemeenteraad en onder voorwaarden was goedgekeurd door het Rijk werd voor het OV-terminalcomplex in 2004 gestart met de procedure voor de selectie van een architect voor het uitwerken van het Schetsontwerp tot een Voorlopig Ontwerp (VO). In de Tussenovereenkomst die hiervoor werd getekend door de gemeente, de Minister van VROM, de Minister van V\&W, de provincie Noord-Brabant, ProRail en NS werd afgesproken dat de gemeente Breda mede namens andere partijen het VO tot stand zou brengen. Mede op advies van een selectiecommissie waarvan de Rijksbouwmeester voorzitter was, werd door het college van B\&W van Breda architectenbureau Atelier Quadrat / Koen van Velzen de opdracht verleend tot het opstellen van een Voorlopig Ontwerp.

Eind 2005 werd het voorlopig ontwerp voor de OV-terminal gepresenteerd. Nadat in 2006 de Bestuurlijke Overeenkomst Uitvoering NSP Breda was getekend tussen Rijk en gemeente Breda opereerde het Rijk meer op de achtergrond. In de overeenkomst was vastgelegd dat Gemeente, ProRail en NS gezamenlijk opdracht zouden geven om het Definitief Ontwerp (DO) tot stand te brengen. De rol van het Rijk werd vanaf dat moment meer toetsend. Door de Stuurgroep Rijk/Gemeente werd toegezien op de uitvoering en voortgang van het project.

In oktober 2007 heeft de gemeenteraad het definitief ontwerp (DO) voor de OV-terminal vastgesteld. In de Realisatieovereenkomst zijn afspraken gemaakt over de verdeling van verantwoordelijkheden en risico's bij de uitvoering van het ontwerp van het OVTC.

Uit de percepties van keystakeholders blijkt dat drie partijen een grote inbreng wordt toegedicht bij de ontwikkeling van plannen voor de aanpak van de OV-terminalcomplex (zie figuur 7.5). De gemeente Breda, ProRail en de NS. De Rijksoverheid heeft in de beleving van partijen weliswaar een redelijke 
inbreng gehad, maar zoals zij haar eigen rol in deze fase ook ziet, meer op de achtergrond. Over de inbreng van de rijkspartijen in dit traject blijkt het beeld wel sterker uiteen te lopen dan voor de drie dominante partijen.

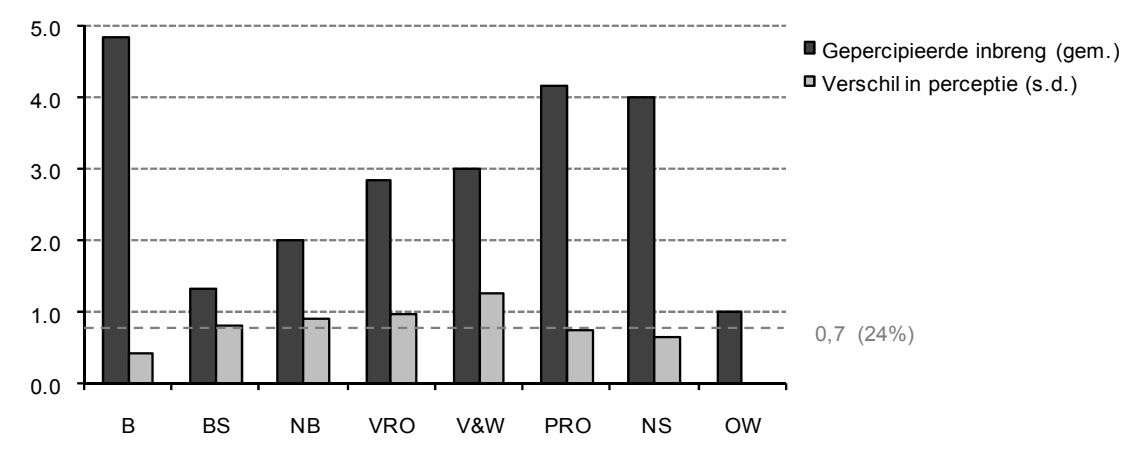

Figuur 7.5 OVT-plan Breda - inbreng van stakeholders in visievorming en perceptieverschillen

Wordt het beeld dat op basis van de percepties ontstaat afgezet tegen wat men wenselijk acht, dan blijkt vooral dat een grotere inbreng van het ministerie van Verkeer en Waterstaat in de planvorming voor het OVTC wenselijk, terwijl voor de gemeente Breda het omgekeerde geldt (zie figuur 7.6). Belangrijke kanttekening is dat het verschil van mening tussen keystakeholders over de wenselijke inbreng van het ministerie van Verkeer en Waterstaat substantieel is.

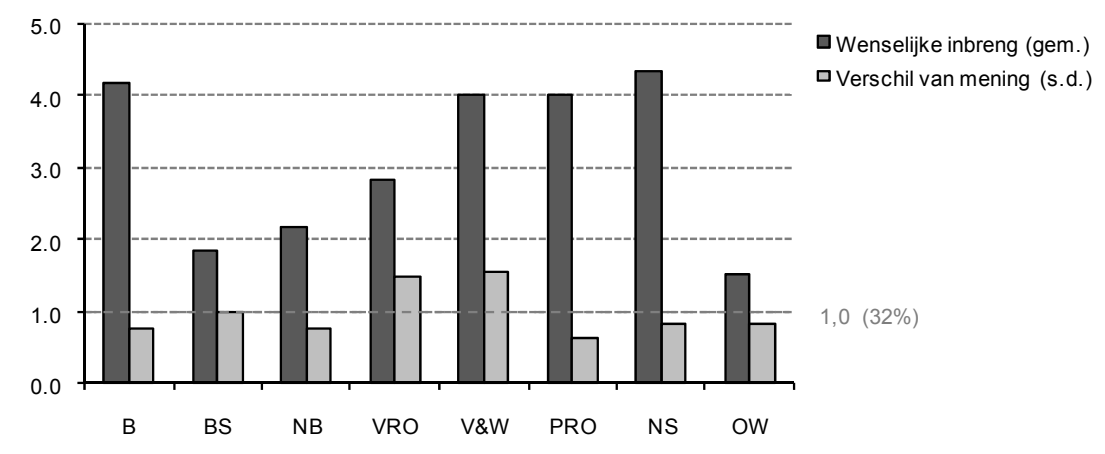

Figuur 7.6 OVT-plan Breda - wenselijke inbreng van stakeholders in visievorming en meningsverschillen

\subsubsection{Zeggenschapsverdeling}

De vorige paragraaf heeft aandacht besteed aan de inbreng van partijen in het proces van visievorming voor het Masterplan Centraal Breda en het deelplan voor het OVTC. Hier wordt de verdeling van zeggenschap in deze processen bezien. Aan de hand van percepties van nauw betrokkenen, is de zeggenschap die de diverse keystakeholders hebben gehad bij de totstandkoming van het masterplan en het deelplan voor de OV-terminal bestudeerd.

\section{Zeggenschapsverdeling in het masterplanproces}

De documenten waaruit het Masterplan Centraal Breda bestaat zijn grotendeels door, of in opdracht van de gemeente Breda en NS Poort opgesteld. Zij hebben architectenbureau Atelier Pro opdracht gegeven een stedenbouwkundig ontwerp en beeldkwaliteitsplan op te stellen voor het station en 
omgeving. NS was eigenaar van een groot deel van de te (her)ontwikkelen gronden en het vastgoed in het plangebied.

Uit de percepties van betrokkenen blijkt dat het ook de gemeente Breda en NS een (zeer) grote mate van zeggenschap hebben gehad bij de totstandkoming van het Masterplan Centraal Breda (zie figuur 7.7). Het beeld hiervan is volledig eenduidig. Over de mate van zeggenschap van andere partijen bestaat wel onduidelijkheid. Dit geldt ook voor het ministerie van VROM, welke in de beleving van keystakeholders ook een behoorlijke mate van zeggenschap gehad in het planproces van het masterplan. Als coördinerend ministerie voor de sleutelprojecten wordt voor de toekenning van middelen vanuit het rijk de inhoud van het masterplan ook getoetst aan het rijksbeleid voor nieuwe sleutelprojecten. Het beeld van de zeggenschap van partijen correspondeert vrijwel volledig met het beeld van de inbreng van partijen in het proces van visievorming. De partijen die een grote inbreng hebben gehad in het proces van visievorming voor het Masterplan Centraal Breda zijn dezelfde als de partijen die hier veel zeggenschap hebben gehad.

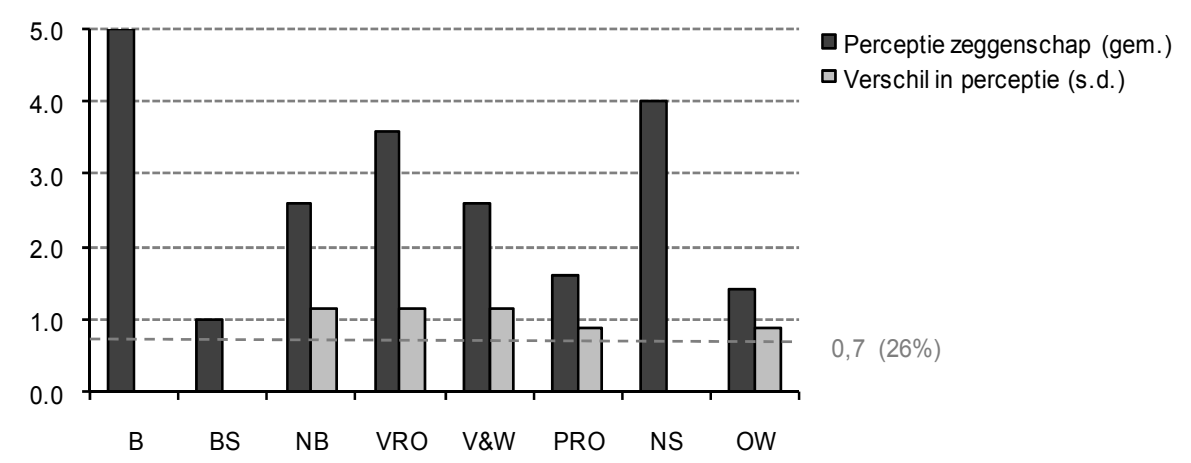

Figuur 7.7 Masterplan Centraal Breda - zeggenschap van stakeholders en perceptieverschillen

Wordt de perceptie van de feitelijke zeggenschapsverdeling vergeleken met wat betrokkenen in dat opzicht wenselijk achten, dan blijkt dat dit grotendeels overeen komt. De (zeer) grote mate van zeggenschap van de gemeente Breda en NS in de planvorming voor de omliggende gebiedsontwikkeling wordt vrijwel zonder uitzondering wenselijk bevonden. Ook voor de andere partijen komt het beeld van de feitelijke en wenselijke inbreng redelijk overeen. Wel bestaat - een weliswaar beperkt - verschil van mening bij betrokkenen. Dit geldt in het bijzonder over de vraag welke mate van zeggenschap voor het ministerie van Verkeer en Waterstaat wenselijk is.

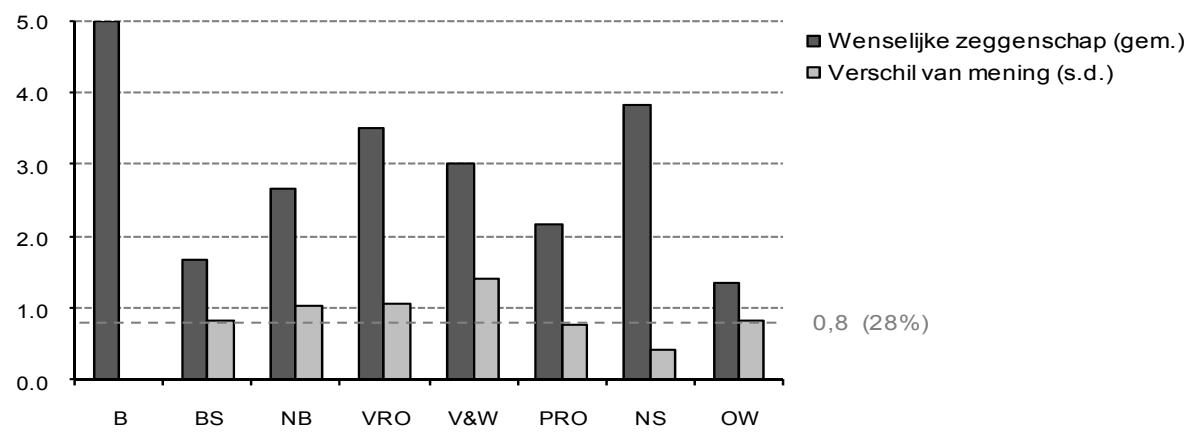

Figuur 7.8 Masterplan Centraal Breda - wenselijke zeggenschapsverdeling en meningsverschillen 
Samengevat kan worden gesteld dat de grote mate van zeggenschap van de gemeente en de NS in de planvorming van het Masterplan Centraal Breda volledig duidelijk en wenselijk was. Dit geldt in mindere mate ook voor het ministerie van VROM. Evenals voor de overige partijen verschillen zowel de percepties als de meningen hierover meer. Dit geldt in het bijzonder voor het Ministerie van Verkeer en Waterstaat.

\section{Zeggenschapsverdeling in het planproces voor de OV-terminal}

In de Bestuurlijke Overeenkomst Uitvoering NSP Breda is vastgelegd wat de verantwoordelijkheden van partijen zijn bij het ontwikkelen van het OVTC. Daarbij wordt beschreven dat de Gemeente verantwoordelijk is voor de deelprojecten Bussen, Transfer, Stationserven, Voorpleinen en de realisatie van NSP-kwaliteit. ProRail is verantwoordelijk voor de deelprojecten Fietsen en Treinen en NS voor het deel Vastgoed, Stationscommercie en Parkeren. ProRail fungeert als gedelegeerd opdrachtgever namens de drie opdrachtgevers. Het Rijk toetst via de Stuurgroep Rijk/Gemeente de voortgang en planuitwerking en de Provincie Noord-Brabant is vooral bij het OVTC betrokken vanuit haar verantwoordelijkheid voor (regionaal) busvervoer.

Evenals voor de totstandkoming van het Masterplan is het beeld van keystakeholders dat de gemeente Breda ook in de planvorming voor het OVTC de meeste zeggenschap heeft gehad (zie figuur 7.9). Daarnaast hebben NS, ProRail, het ministerie van Verkeer en Waterstaat en het ministerie van VROM een behoorlijke mate van zeggenschap gehad in dit proces. Opmerkelijk is de grote mate van zeggenschap van VROM. Weliswaar stelt zij in het kader van het beleid voor sleutelprojecten middelen beschikbaar vanuit het NSP-2 budget voor kwaliteitsverbetering van de OV-terminal, maar zij heeft hier geen directe bestuurlijke verantwoordelijkheid of eigendomspositie. Opmerkelijk is eveneens dat de zeggenschap van beide ministeries aanzienlijk groter is hun inbreng in het proces van visievorming. Zoals hiervoor beschreven is hun rol in deze fase vooral toetsend. Voor NS en ProRail geldt het omgekeerde. Hun inbreng in de visievorming voor het OVTC is relatief groot vergeleken met de mate van zeggenschap in dit proces.

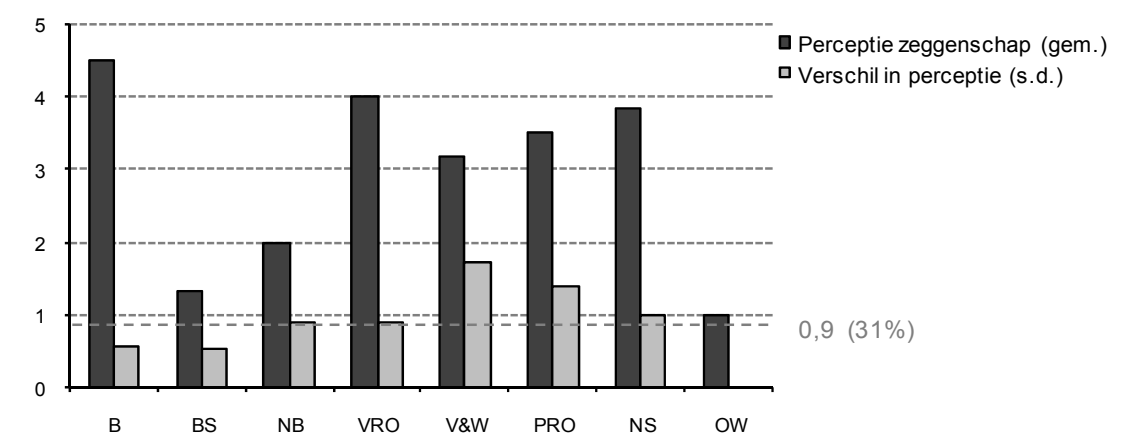

Figuur 7.9 OVT-plan Breda - zeggenschap van stakeholders en perceptieverschillen

Wordt het beeld van de zeggenschapsverdeling dat ontstaat op basis van de percepties van actoren vergeleken met wat zij wenselijk achten (zie figuur 7.10), dan blijkt dit op twee punten substantieel te verschillen. In de eerste plaats zijn betrokkenen van mening dat de grote mate van zeggenschap van het ministerie van VROM wel wat minder had gemogen. In de tweede plaats vindt men dat NS juist meer zeggenschap had mogen hebben. Evenals de grote verschillen in perceptie van de zeggenschap 
van ProRail en het ministerie van Verkeer en Waterstaat blijken ook de meningen over de wenselijke zeggenschap voor deze actoren sterk uiteen te lopen.

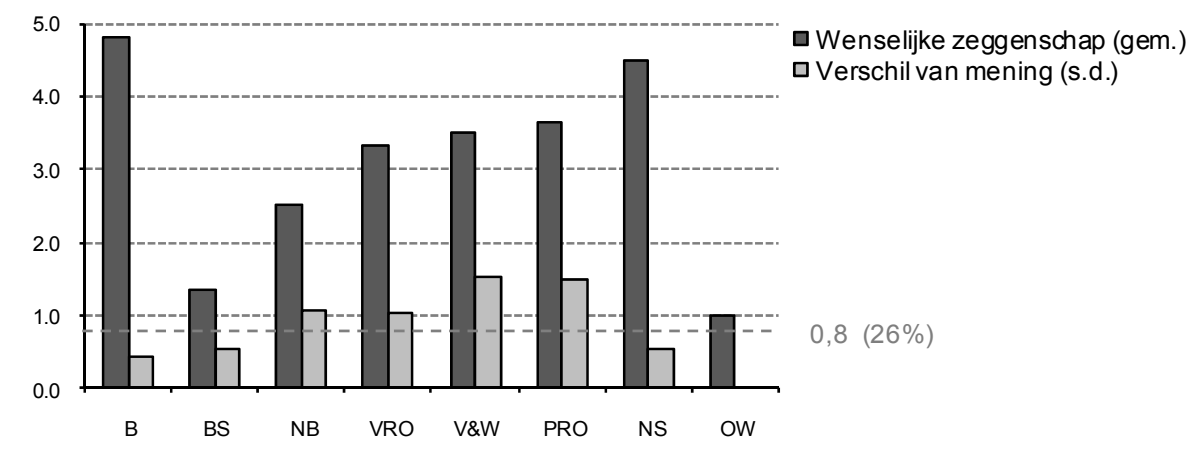

Figuur 7.10 OVT-plan Breda - wenselijke zeggenschapsverdeling en meningsverschillen

Samengevat kan worden gesteld dat vijf partijen een behoorlijke mate van zeggenschap hebben gehad in de planvorming voor het OVTC: De gemeente Breda, ProRail, NS, het Ministerie van VROM en het ministerie van Verkeer en Waterstaat. De rol van de twee rijkspartijen is daarbij meer op afstand en toetsend. Opmerkelijk is de grote mate van zeggenschap van VROM die niet door allen als wenselijk wordt gezien en de grote perceptie- en meningsverschillen over de zeggenschap van ProRail en het ministerie van Verkeer en Waterstaat.

\subsubsection{Middelen}

Voor een goed begrip van de afspraken tussen partijen over de inbreng van middelen is het belangrijk dat een onderscheid wordt gemaakt tussen het OV-Terminalcomplex en de gebiedsontwikkeling binnen het Stationskwartier. Daarnaast is aanpassing van de toeleidende infrastructuur noodzakelijk.

Voor de gebiedsontwikkeling in het Stationskwartier werkt de gemeente Breda samen met NS Poort. Het ministerie van VROM (NSP 1) en de provincie Noord-Brabant (BDU) subsidiëren deze ontwikkeling. De gemeente, NS en ProRail waren de drie grote eigenaren in het gebied. ProRail heeft haar gronden verkocht aan de gemeente Breda. NS heeft de gronden overgedragen aan de gemeente Breda die deze bouwrijp maakt en tegen een afgesproken grondprijs afhankelijk van de te realiseren functies weer uitgeeft aan de NS. Vanuit het geraamd voordelig resultaat van de grondexploitatie wordt door de gemeente bijgedragen aan de ontwikkeling van het OVTC.

Binnen het OVTC kan een onderscheid worden gemaakt tussen het commerciële vastgoed en de transferfunctie. De ontwikkeling van het commerciële vastgoed wordt gedaan voor rekening en risico van NS Poort. Vanuit de residuele grondwaarde draagt NS bij aan de transferfunctie. Naast deze bijdrage is in de bestuurlijke uitvoeringsovereenkomst tussen het Rijk en gemeente Breda opgenomen dat het ministerie van Verkeer en Waterstaat vanuit het MIT 34,9 miljoen euro (prijspeil 2005) bijdraagt aan het OVTC. Deze subsidie wordt afgegeven aan ProRail die daarvoor uitvoering geeft aan de deelprojecten OVTC Treinen en OVTC Fietsen. Het ministerie van VROM draagt vanuit het NSP-2 budget bij aan het verhogen van de kwaliteit van de transferfunctie van de OV-terminal. De gemeente Breda draagt 22,7 miljoen euro bij. Naast het gemeentelijk aandeel in het OVTC is deze bijdrage ook voor aanpassing van toeleidende infrastructuur. Door de provincie Noord-Brabant is een subsidiebeschikking afgegeven voor bijdragen vanuit het Ontwikkelingsfonds Brabant 2050 
bedoeld voor kwaliteitsverhoging van de transferfunctie van de OV-terminal en vanuit de BDU voor toeleidende businfrastructuur en het busstation. In totaal is de bijdrage van de provincie 20 miljoen euro.

De beschrijving van de feitelijke afspraken over de inbreng van financiële middelen door partijen kan worden afgezet tegen de beleving van keystakeholders. Met andere woorden is er volgens direct betrokkenen sprake van een evenredige inbreng van middelen door keystakeholders. Het beeld dat ontstaat op basis van de opvattingen hierover is weergegeven in figuur 7.11.

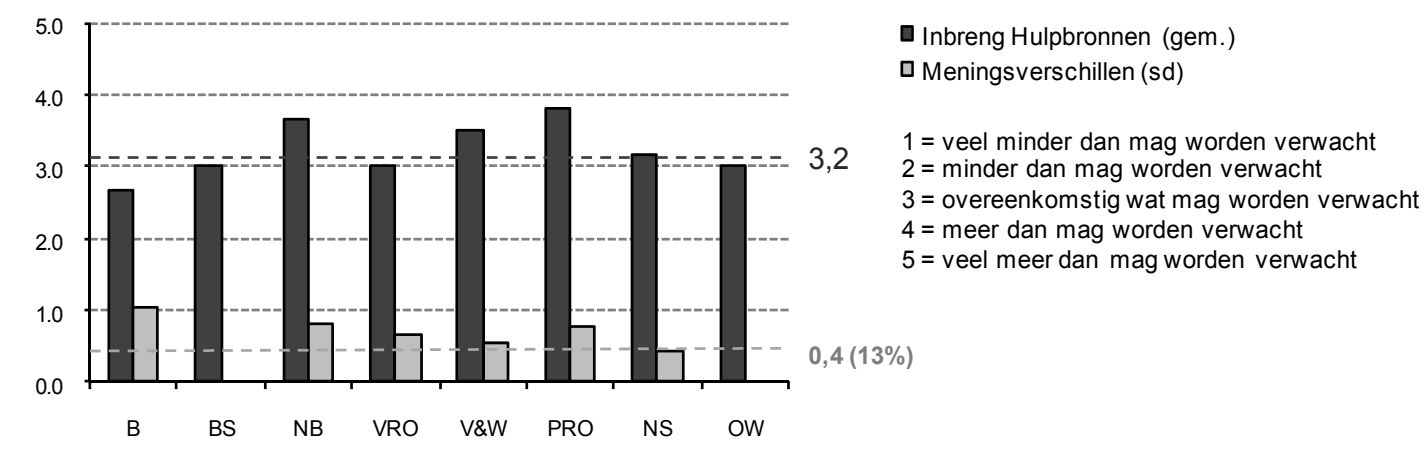

Figuur 7.11 Stationskwartier Breda - Inbreng van middelen door stakeholders en meningsverschillen

Uit figuur 7.11 blijkt dat keystakeholders gemiddeld $(3,2)$ genomen meer middelen hebben ingebracht dan van hen had mogen worden verwacht. Uitzondering hierop vormt de gemeente Breda. Private ontwikkelaars en regio Brabantstad hebben geen middelen ingebracht. Omdat zij niet betrokken zijn bij het project wordt ook geen inbreng van deze partijen verwacht. De inbreng van het ministerie van VROM komt overeen met de verwachtingen. Over de andere keystakeholders is het (gemiddelde) oordeel van betrokkenen positief. $\mathrm{Zij}$ hebben in de beleving van keystakeholders meer ingebracht dan op grond van de projectkenmerken van hen mocht worden verlangd.

\subsubsection{Kenmerken van de actorconstellatie}

Hiervoor is de inbreng van individuele actoren op drie kernthema's in planvorming beschreven. Het bestuderen van de relatie met de borging van het publiek belang noodzaakt ertoe niet enkel de inbreng van individuele actoren te beschrijven, maar aan de hand hiervan eveneens de constellatie van actoren te typeren. Tegen de achtergrond van de borging van het publiek belang is in hoofdstuk 3 beargumenteerd dat deze constellatie wordt getypeerd aan de hand van (a) het aantal actoren; (b) de verhoudingen tussen actoren met uiteenlopende karakters en belangenposities (publiek-privaat; centraal-decentraal; gemeente-overige); en (c) de mate van ambivalentie. Dit is gedaan voor de drie kernthema's.

\section{Aantal actoren}

In het proces van visievorming voor het Masterplan Centraal Breda hebben 3 keystakeholders een grote inbreng (gemiddelde $>3$ ) gehad. Dit waren de gemeente Breda, NS en het ministerie van VROM. Deze 3 partijen hebben eveneens een substantiële inbreng qua zeggenschap toegedicht. 
In het proces van visievorming voor het OVTC zijn het eveneens 3 keystakeholders die een grote inbreng hebben gehad. Dit waren de gemeente Breda, NS en ProRail. Een substantiële mate van zeggenschap in dit proces hadden 5 partijen. Naast de drie genoemde waren dit ook de rijkspartijen VROM en V\&W. Uit de data blijkt verder dat 4 keystakeholders hebben meer middelen ingebracht dan van hen gegeven de kenmerken van het project mocht worden verwacht.

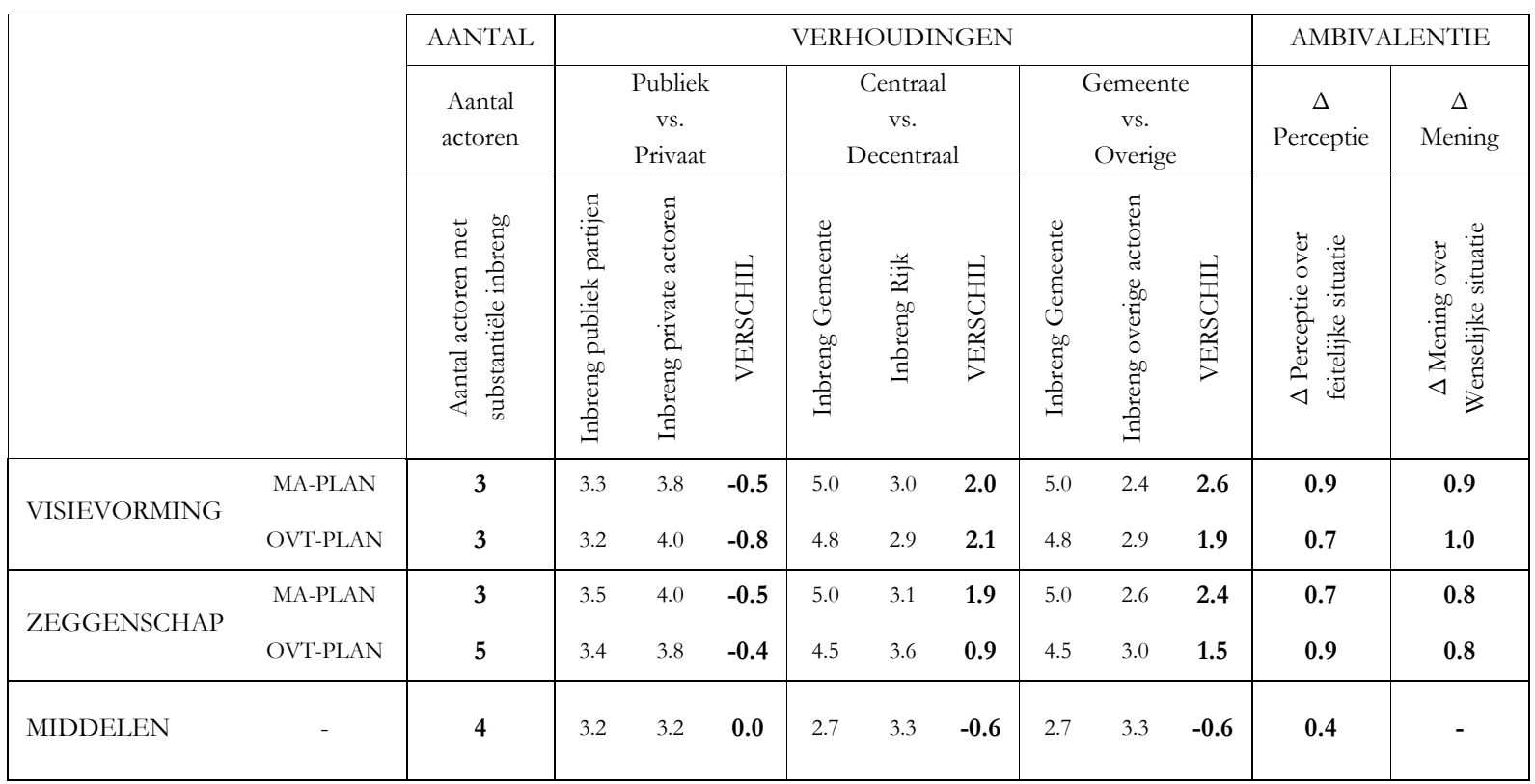

Tabel 7.2 Stationskwartier Breda - Actorconstellatie

\section{Verhoudingen tussen actoren}

De wijze waarop de samenwerking tussen actoren in het planproces vorm heeft gekregen is in de eerste paragraaf van dit hoofdstuk kwalitatief beschreven. Op basis van de percepties van actoren kunnen ten aanzien van de verhoudingen tussen partijen een aantal constateringen worden gedaan (zie tabel 7.2).

- In de verhoudingen tussen publieke (gemeente/provincie/rijk) en private (NS/ontwikkelaars) partijen lijkt qua inbreng in het planproces de private zijde dominant. Dit geldt zowel voor de inbreng in het proces van visievorming als voor de zeggenschap in dit proces. Hierbij zijn twee kanttekeningen essentieel. In de eerste plaats is NS de enige private partij. Zij heeft weliswaar een zeer grote inbreng gehad in de planvorming, maar er zijn geen andere ontwikkelaars met eigendomsposities in het plangebied van het Stationskwartier. Een tweede kanttekening is dat er tussen publieke partijen onderling grote verschillen zitten qua inbreng. De inbreng van de gemeente Breda is erg groot, terwijl de inbreng van de provincie Noord-Brabant in de planvorming juist erg klein is.

- In het planvorming heeft de gemeente (decentraal) volgens betrokkenen een aanzienlijk grotere inbreng gehad dan het Rijk (centraal). Dit geldt zowel voor de bijdrage aan het visievorming als qua zeggenschap. Dit correspondeert niet met de inbreng van middelen. Waar het Rijk meer inbrengt dan 
naar de mening van betrokkenen gegeven de kenmerken van het project van haar mocht worden verwacht, geldt voor de gemeente Breda juist het omgekeerde.

- Ook als de inbreng van de gemeente Breda wordt afgezet tegen die van alle andere keystakeholders komt uit de data het beeld naar voren dat de gemeente in de planvorming een zeer belangrijke rol heeft gespeeld. Haar inbreng in het proces van visievorming en haar zeggenschap in dat proces worden door alle betrokkenen als groot gepercipieerd. In de planvorming van het masterplan heeft de gemeente Breda vooral samengewerkt met NS en VROM. Gezien de sterke grond-/vastgoedpositie van NS in het Stationskwartier lijkt dit niet onlogisch. De sterke betrokkenheid van VROM vloeit voort uit het sleutelprojectenbeleid.

Ook in het planproces voor het OVTC heeft de gemeente Breda een grote inbreng gehad. Daarnaast geldt dat NS, beide rijkspartijen en ProRail een substantiële inbreng hebben gehad. In tegenstelling tot het planproces van het masterplan bestaat geen volledige eenduidigheid beeld bij betrokkenen over inbreng van de gemeente. Ook wordt deze grote inbreng in het planproces voor het OVTC niet door allen wenselijk bevonden. Hoewel de gemeente Breda in het planproces dus een relatief grote rol heeft gespeeld is het opmerkelijk dat zij de enige partij is die naar de mening van keystakeholders minder middelen heeft ingebracht dan op grond van de kenmerken van het project van haar mag worden verwacht.

\section{Ambivalentie}

De ambivalentie in de actorconstellatie is geanalyseerd door te kijken naar de mate waarin (a) percepties van de feitelijke inbreng van actoren verschillen en (b) de mate waarin meningen over de wenselijke inbreng van actoren verschillen.

- De data laat zien dat het beeld bij keystakeholders van de feitelijke situatie beperkt uiteen loopt. Er bestaat enige onduidelijkheid over de inbreng die diverse partijen hebben gehad in het planproces, maar deze onduidelijkheid is beperkt. Over de rol van de gemeente Breda in de planvorming is het beeld vrijwel volledig eenduidig.

- Over de vraag welke inbreng als wenselijk moet worden beschouwd voor diverse actoren lopen de meningen eveneens beperkt uiteen. De grote inbreng van de gemeente in de planvorming van het masterplan Centraal Breda wordt unaniem als wenselijk beschouwd. Over de wenselijk inbreng voor andere actoren bestaat meer verschil van mening. Deze verschillen zijn echter niet enorm.

\subsection{Publiek belang}

In de vorige paragraaf zijn op een drietal kernthema's de inbreng van individuele keystakeholders en de belangrijkste kenmerken van de actorconstellatie beschreven. Vraag die in deze studie centraal staat is of deze kenmerken verband houden borging van het publiek belang. Deze paragraaf gaat in op de borging van het publiek belang. Zoals in de eerste hoofdstukken is beargumenteerd, wordt daarvoor gefocust op de legitimiteit en effectiviteit van het planproces. 


\subsubsection{Legitimiteit}

Legitimiteit is onderverdeeld in een drietal vormen; inputlegitimiteit, throughputlegitimiteit en outputlegitimiteit. Deze drie vormen zijn aan de hand van indicatoren geanalyseerd. Daarbij is het onderscheid tussen de planvorming gericht op het ontwikkelen van een masterplan voor de gebiedsontwikkeling als geheel en het deelproces van planvorming voor de OV-terminal aangehouden.

\section{Inputlegitimiteit ${ }^{192}$}

De legaliteit en openheid van beide planprocessen zijn gebruikt als maatstaf voor inputlegitimiteit. Legaliteit is geëvalueerd aan de hand van de mate waarin betrokkenen van mening zijn dat relevante procedures en regelgeving op correcte wijze zijn toegepast. Zonder uitzondering bleken zij allen van mening dat dit op correcte tot zeer correcte wijze is geschied.

De openheid van het planproces is geanalyseerd door te kijken of (1) alle relevante partijen toegang hebben gehad tot het planproces en (2) de mate waarin de eigen en andere organisaties mogelijkheden hebben gehad om het proces te beïnvloeden. De resultaten staan gepresenteerd in tabel 7.3. ${ }^{193}$

\begin{tabular}{|c|c|c|c|c|c|c|c|c|}
\hline \multirow[b]{2}{*}{ Indicator } & \multicolumn{3}{|c|}{$\begin{array}{c}\text { Openheid } \\
\text { Masterplanproces }\end{array}$} & \multicolumn{3}{|c|}{$\begin{array}{c}\text { Openheid } \\
\text { OVT-planproces }\end{array}$} & \multirow{2}{*}{ 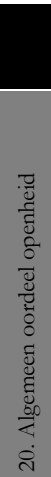 } & \\
\hline & 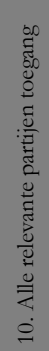 & 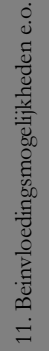 & 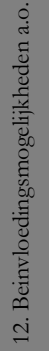 & 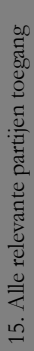 & 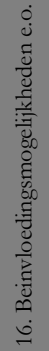 & 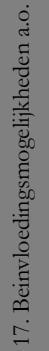 & & \\
\hline actor 1 & $\mathrm{~J}$ & 5 & 4 & $\mathrm{~J}$ & 4 & 3 & 3 & \\
\hline actor 2 & $J$ & 3 & 3 & $\mathrm{~J}$ & 4 & 4 & 4 & LEGENDA \\
\hline actor 3 & $\mathrm{~J}$ & 5 & 5 & $J$ & 4 & 4 & 4 & $\begin{array}{l}J=J a \\
N=\text { Nee }\end{array}$ \\
\hline actor 4 & $\mathrm{~J}$ & 5 & 4 & ? & 4 & 4 & 5 & $?=$ Weet miet \\
\hline actor 5 & $\mathrm{~J}$ & 3 & 4 & $\mathrm{~J}$ & 5 & 4 & 4 & $5=$ zeer groo \\
\hline actor 6 & $?$ & $?$ & $?$ & $\mathrm{~J}$ & 5 & 4 & 4 & $\begin{array}{l}4=\text { groot } \\
3=\text { neutraal }\end{array}$ \\
\hline GEM. & $\mathrm{X}$ & 4.2 & 4.0 & $\mathrm{X}$ & 4.3 & 3.8 & 4.0 & $2=$ klein \\
\hline S.D. & $\mathrm{X}$ & 1.1 & 0.7 & $\mathrm{X}$ & 0.5 & 0.4 & 0.6 & $1=$ zeer klein \\
\hline
\end{tabular}

Tabel 7.3 Stationskwartier Breda - Mate van openheid van het planproces

Uit de data blijkt dat zowel het planproces van het Masterplan Centraal Breda als het planproces voor het OVTC door betrokkenen wordt beschouwd als een open proces. Zonder uitzondering zijn zij van mening dat alle relevante partijen toegang hebben gehad tot beide planprocessen en zeker de mogelijkheden van de eigen organisatie om het planproces te beïnvloeden worden voor beide planprocessen als meer dan groot beschouwd. Het oordeel is redelijk eenduidig en zonder uitzondering beoordelen zij de openheid positief ( 3 of groter). Dit correspondeert met het algemene oordeel over de openheid van het planproces, welke gemiddeld genomen als groot (4.0) wordt gezien. 


\section{Throughputlegitimiteit}

De transparantie van de planprocessen is gehanteerd als maatstaf voor throughputlegitimiteit. Daarvoor is geanalyseerd in welke mate het voor partijen duidelijk was wie, waarover en op welk moment in het planproces besliste; in welke mate inhoudelijke wensen en voorkeuren van partijen helder waren; en in welke mate de honorering daarvan in de plannen en de bijbehorende argumentatie helder was. De resultaten staan gepresenteerd in tabel 7.4.

\begin{tabular}{|c|c|c|c|c|c|c|c|c|c|c|c|c|c|}
\hline \multirow[b]{2}{*}{ Indicator } & \multicolumn{6}{|c|}{$\begin{array}{c}\text { Transparantie } \\
\text { Masterplanproces }\end{array}$} & \multicolumn{6}{|c|}{$\begin{array}{c}\text { Transparantie } \\
\text { OVT-planproces }\end{array}$} & \\
\hline & 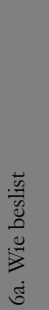 & 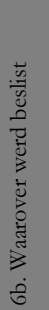 & 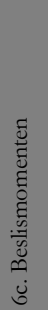 & 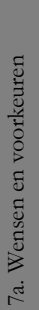 & 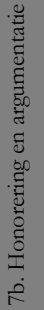 & $\mathbf{T}$ & 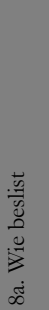 & 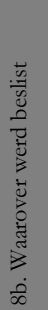 & 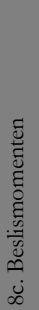 & 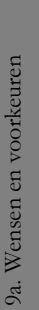 & 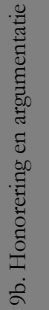 & $\mathbf{T}$ & \\
\hline actor 1 & 4 & 2 & 3 & 3 & 5 & 3.4 & 2 & 4 & 4 & 5 & 3 & 3.6 & \\
\hline actor 2 & 3 & 3 & 2 & 2 & 3 & 2.6 & 4 & 3 & 3 & 4 & 5 & 3.8 & LEGENDA \\
\hline actor 3 & 5 & 5 & 5 & 5 & 4 & 4.8 & 5 & 5 & 5 & 5 & 5 & 5.0 & $\begin{array}{l}5=\text { zeer helder } \\
4=\text { helder }\end{array}$ \\
\hline actor 4 & 4 & 4 & 4 & 4 & 4 & 4.0 & 3 & 4 & 4 & 4 & 4 & 3.8 & $3=$ neutraal \\
\hline actor 5 & 4 & 4 & 4 & 4 & 4 & 4.0 & 4 & 4 & 4 & 4 & 4 & 4.0 & $2=$ onhelder \\
\hline actor 6 & $?$ & $?$ & $?$ & $?$ & $?$ & $?$ & 4 & 4 & 4 & 3 & 4 & 3.8 & $\begin{array}{l}1=\text { zeer onhelder } \\
?=\text { weet niet }\end{array}$ \\
\hline GEM. & 4.0 & 3.6 & 3.6 & 3.6 & 4.0 & 3.8 & 3.6 & 4.0 & 4.0 & 4.2 & 4.2 & 4.0 & $\mathrm{~T}=$ gemiddelde \\
\hline S.D. & 0.7 & 1.1 & 1.1 & 1.1 & 0.7 & 0.8 & 1.0 & 0.6 & 0.6 & 0.8 & 0.8 & 0.5 & \\
\hline
\end{tabular}

Tabel 7.4 Stationskwartier Breda - Mate van transparantie van het planproces

Uit de data blijkt dat zowel het planproces van het Masterplan Centraal Breda als het planproces voor het OVTC een redelijk transparant proces is geweest. Voor alle indicatoren is het beeld op basis van de gemiddelden positief (gemiddelde $>3$ ). Voor enkele direct betrokkenen bleek het proces op een aantal onderdelen echter niet helder. Deze onduidelijkheid had in dat geval betrekking op de wensen en voorkeuren van verschillende partijen, de beslismomenten en de inhoud van hetgeen waarover werd besloten.

\section{Outputlegitimiteit}

Voor outputlegitimiteit is gekeken naar de steun van betrokken voor de plannen. Deze steun is geanalyseerd aan de hand van hun oordeel over; de mate waarin in het Masterplan respectievelijk het OVT-plan rekening is gehouden met hun wensen en doelen; de mate waarin zij zich gecommitteerd voelen aan beide plannen; en de mate waarin zij van mening zijn dat het Masterplan en het OVT-plan aanvaardbare compromissen zijn voor de in het planproces participerende partijen. Daarnaast is gevraagd een rapportcijfer toe te kennen aan beide plannen. De resultaten staan weergegeven in tabel 7.5 . 
Uit de data blijkt dat de steun voor zowel het Masterplan als het plan voor de OV-terminal groot is. Hoewel hierin beperkte verschillen bestaan is geen van de partijen negatief (gelijk of meer dan 3). Over het algemeen is men van mening dat er in beide plannen redelijk veel rekening is gehouden met hun wensen en voorkeuren. Tevens worden de plannen beschouwd als een aanvaardbaar compromis tussen de partijen die hebben geparticipeerd in beide trajecten en voelen vrijwel alle keystakeholders zich in sterke tot zeer sterke mate aan gecommitteerd aan de plannen. Zeker voor het deelplan voor het OVTC wordt dit positieve beeld onderbouwd door het hoge rapportcijfer (8.0) voor dit plan.

\begin{tabular}{|c|c|c|c|c|c|c|c|c|c|c|}
\hline \multirow[b]{2}{*}{ Indicator } & \multicolumn{5}{|c|}{$\begin{array}{c}\text { Steun } \\
\text { Masterplan }\end{array}$} & \multicolumn{5}{|c|}{$\begin{array}{c}\text { Steun } \\
\text { OVT-plan }\end{array}$} \\
\hline & 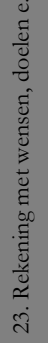 & 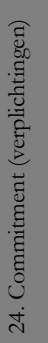 & 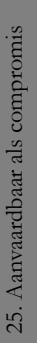 & $\mathbf{T}$ & 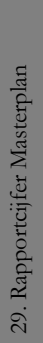 & 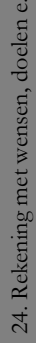 & 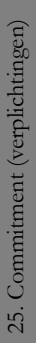 & 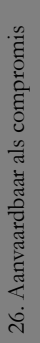 & $\mathbf{T}$ & 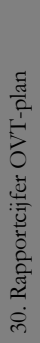 \\
\hline actor 1 & 4 & 5 & 5 & 4.7 & 8 & 3 & 3 & 3 & 3.0 & 8 \\
\hline actor 2 & 3 & 3 & 3 & 3.0 & 7 & 4 & 4 & 4 & 4.0 & 8 \\
\hline actor 3 & 3 & 4 & 5 & 4.0 & 6 & 5 & 5 & 5 & 5.0 & 8 \\
\hline actor 4 & 5 & 5 & 4 & 4.7 & 7 & 4 & 4 & 4 & 4.0 & 8 \\
\hline actor 5 & 3 & 3 & 4 & 3.3 & 7 & 4 & 5 & 4 & 4.3 & 8 \\
\hline actor 6 & 4 & 5 & 4 & 4.3 & 7 & 4 & 5 & 5 & 4.7 & 8 \\
\hline GEM. & 3.7 & 4.2 & 4.2 & 4.0 & 7.0 & 4.0 & 4.3 & 4.2 & 4.2 & 8.0 \\
\hline S.D. & 0.8 & 1.0 & 0.8 & 0.7 & 0.6 & 0.6 & 0.8 & 0.8 & 0.7 & 0.0 \\
\hline
\end{tabular}

Tabel 7.5 Stationskwartier Breda - Mate van steun voor de plannen
LEGENDA

$5=$ zeer sterk $/$ zeer veel $/$ helemaal eens

$4=$ sterk $/$ veel $/$ mee eens

$3=$ neutraal

$2=\mathrm{zwak} /$ weinig $/$ mee oneens

$1=$ zeer zwak/zeer weinig/helemaal oneens $\mathrm{T}=$ gemiddelde

\subsubsection{Effectiviteit}

Naast een oordeel over de legitimiteit is tevens gekeken naar het oordeel over de effectiviteit. Effectiviteit is in het onderzoek geëvalueerd aan de hand van de verwachte bijdrage van de plannen aan de realisatie van ruimtelijke kwaliteit in het plangebied. Omdat ruimtelijke kwaliteit niet eenduidig te definiëren valt is in de operationalisering de reeks van ontwerpeisen - gebruikerswaarde, belevingswaarde en toekomstwaarde - gekruist met belangen - economisch, sociaal, ecologisch - wat leidt tot een negental dimensies. Bepaalde dimensies van ruimtelijke kwaliteit zullen betrokken partijen echter niet of van minder belang vinden. Stationslocaties hebben bepaalde kenmerken en dientengevolge zijn er - vanuit de belangen van betrokken partijen - bepaalde zwaartepunten in deze dimensies. Aan betrokkenen is gevraagd wat voor hun organisatie de drie belangrijkste dimensies zijn in het project. Dit leidt voor het Stationskwartier Breda tot de zwaartepunten zoals weergegeven in Figuur 7.13. 


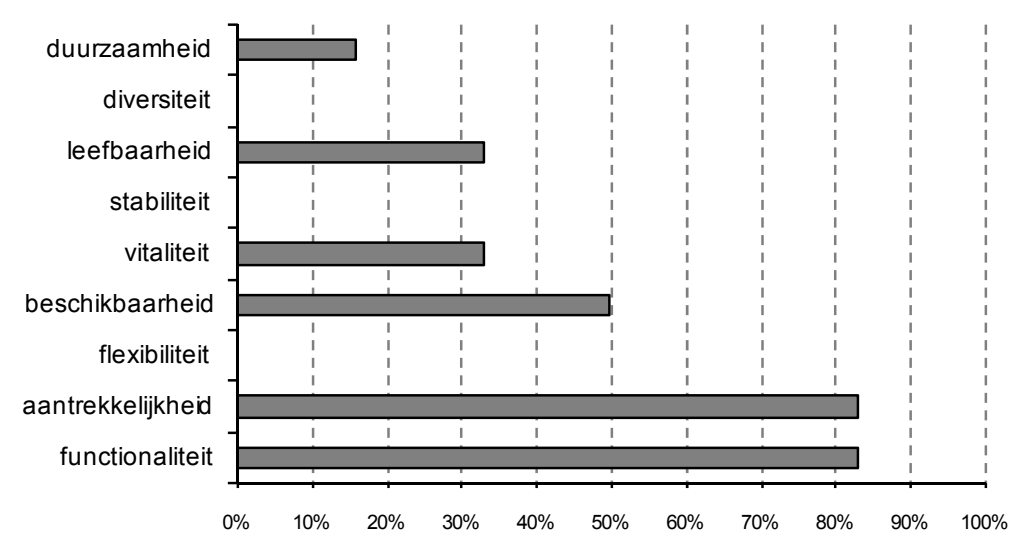

Figuur 7.12 Stationskwartier Breda - Zwaartepunten in de dimensies van ruimtelijke kwaliteit

Hieruit blijkt dat bovenal de bijdrage van de plannen aan de functionaliteit en aantrekkelijkheid van het plangebied van belang wordt geacht. In mindere mate wordt ook het vergroten van de beschikbaarheid van voorzieningen en de leefbaarheid, vitaliteit en duurzaamheid als resultaat van de plannen relevant gevonden. De verwachting is dat de uitvoering van de plannen zoals beschreven in het Masterplan Centraal Breda een redelijk tot grote bijdrage levert aan deze aspecten. Het oordeel over het deelplan voor het OV-terminalcomplex is echter aanzienlijk positiever. Hiervan wordt verwacht dat het een zeer grote bijdrage levert aan het verhogen van de ruimtelijke kwaliteit (zie figuur 7.14).
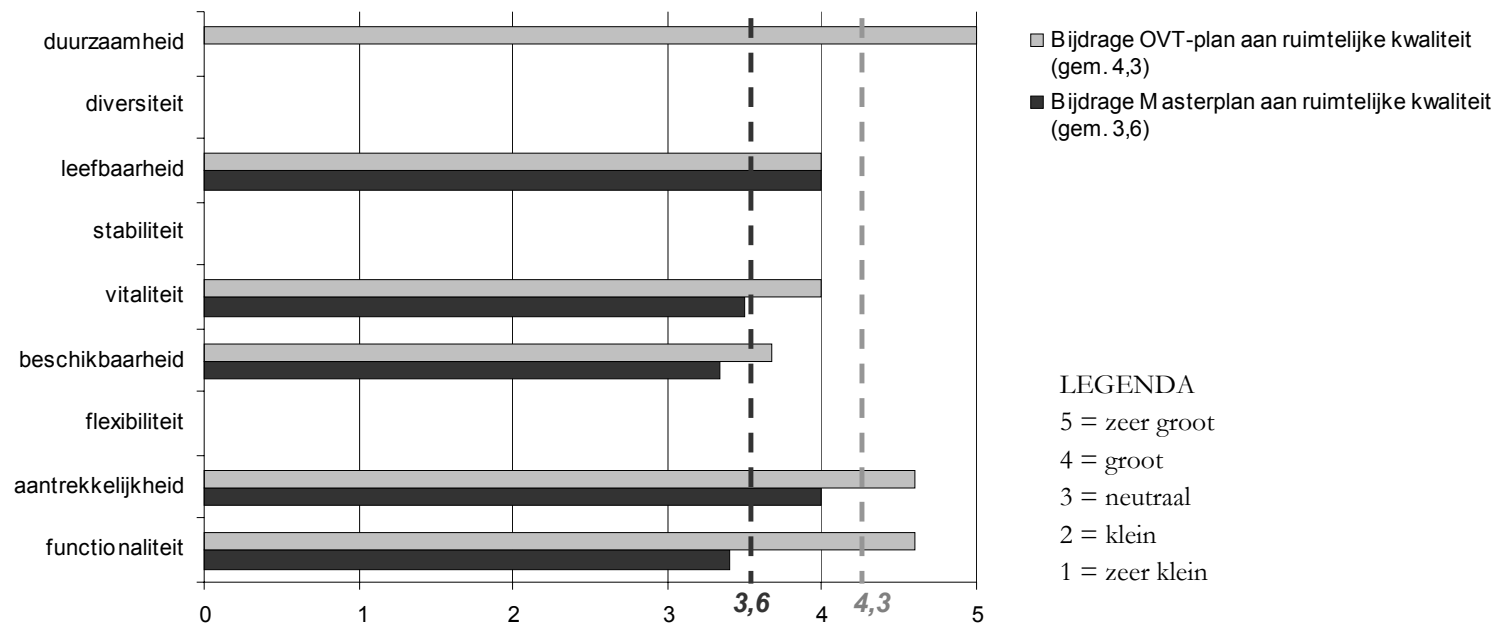

Figuur 7.13 Stationskwartier Breda - Bijdrage van plannen aan de dimensies van ruimtelijke kwaliteit

Het oordeel over de verwachte bijdrage van het Masterplan respectievelijk het plan voor het OVterminalcomplex aan de realisatie van ruimtelijke kwaliteit moet worden gezien in het licht van een drietal elementen; het ambitieniveau, de helderheid en de meetbaarheid/evalueerbaarheid van de plannen. In figuur 7.15 is het oordeel over deze elementen voor beide plannen weergegeven. Uit deze resultaten komt naar voren dat men redelijk neutraal is in het oordeel over het Masterplan. Het deelplan voor het OV-terminalcomplex wordt daarentegen beschouwd als een zeer ambitieus, helder en goed meetbaar en evalueerbaar plan. 


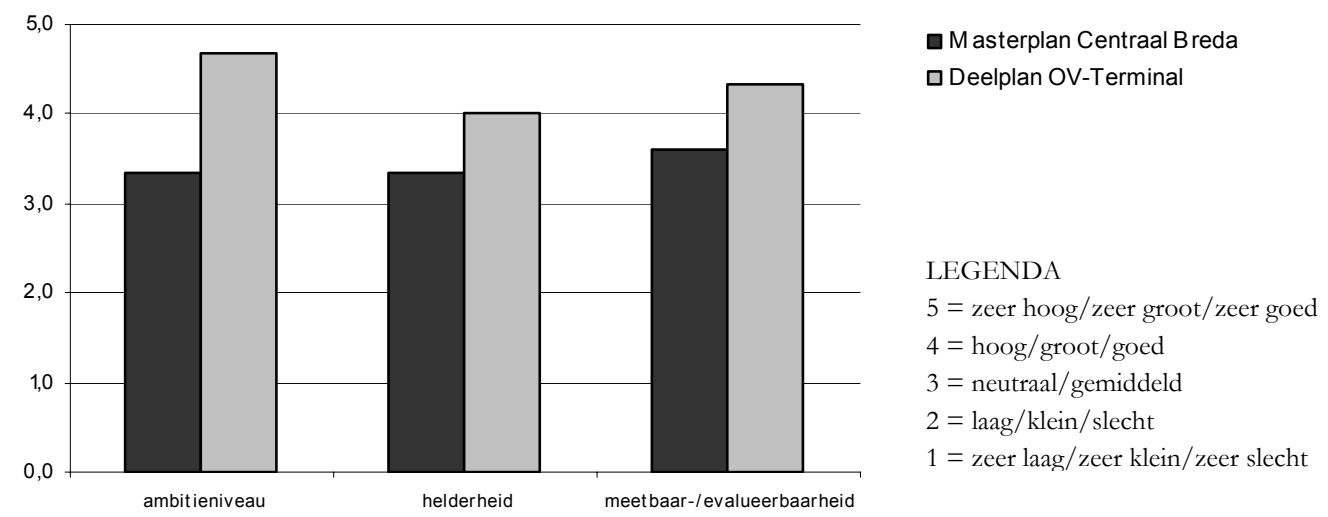

Figuur 7.14 Stationskwartier Breda - Ambitieniveau, helderheid en evalueerbaarheid van plannen

\subsection{Slot}

De aanwijzing als zesde sleutelproject was voor de gemeente Breda de uitgelezen kans om tot herontwikkeling van het Stationskwartier te komen. Een kans die zij heeft aangegrepen om de tot dan toe sluimerende plannen voor het stationgebied nieuw leven in te blazen en daarnaast het oude station te vervangen door een integraal OV-terminalcomplex.

Uit de bevindingen van de vorige paragrafen blijkt dat de gemeente in de planvorming voor de gebiedsontwikkeling hoofdzakelijk heeft samengewerkt met NS, als grote grondeigenaar in het Stationskwartier, en met het ministerie van VROM, als coördinerend ministerie voor het sleutelprojectenbeleid. In de planvorming voor het OVTC werkt de gemeente vooral samen met NS en ProRail, maar hebben beide rijkspartijen op basis van hun toetsende rol eveneens de nodige zeggenschap gehad. Op hoofdlijnen blijkt de gekozen rolverdeling in de planvorming door betrokkenen als wenselijk te worden beschouwd. De coördinatie van de integrale ontwikkeling wordt gedaan door de gemeente Breda en in de perceptie van betrokkenen heeft zij ook de grootste inbreng in de planvorming gehad. Haar inbreng van middelen is volgens betrokkenen echter niet navenant. Hieruit zou kunnen worden afgeleid dat de gemeente Breda voor een dubbeltje op de eerste rang zit. Dit blijkt echter geen negatief effect te hebben op het oordeel over de legitimiteit of effectiviteit. Zoals uit de vorige paragraaf bleek, kan de planvorming voor beide onderscheiden processen als legitiem en effectief worden beschouwd. 


\section{Hoofdstuk 8}

\section{Case 3: Spoorzone Delft}

\subsection{Inleiding}

Dit hoofdstuk beschrijft de data die is verzameld voor het project Spoorzone Delft. Allereerst wordt het project geschetst (8.2). Het tweede deel van het hoofdstuk beschrijft de inbreng van keystakeholders in het planproces (8.3) en de borging van het publiek belang in termen van effectieve en legitieme planvorming (8.4). Er wordt afgesloten met een kort resumé van de bevindingen (8.5).

\subsection{Het project}

Deze paragraaf beschrijft het project Spoorzone Delft. Daarvoor wordt achtereenvolgens de projecthistorie en het procesverloop (8.2.1), de ruimtelijke opgave (8.2.2), de posities van (key)stakeholders (8.2.3) en de samenwerkingsorganisatie (8.2.4) beschreven.

\subsubsection{Projecthistorie en procesverloop}

Het project Spoorzone Delft kent een lange en buitengewoon moeizame historie. Een historie die feitelijk in 1988 begon toen de Nederlandse Spoorwegen (NS) de gemeente Delft liet weten het spoorviaduct waar sinds 1965 het treinverkeer door Delft over loopt te willen gaan vergroten. ${ }^{194}$ In het kader van het zogenaamde Rail21, een toekomstplan van NS, werd spoorverdubbeling, van twee naar vier sporen, noodzakelijk geacht. De toekomstvisie van NS ging er, vanwege de verwachte toename van de intensiteit van het treinverkeer, vanuit dat in de toekomst viersporigheid noodzakelijk was en bekeek de mogelijkheid van bovengrondse spoorverdubbeling. ${ }^{195}$ De gemeente Delft was geen voorstander van bovengrondse verdubbeling, vanwege te verwachten toename van de overlast en nam in 1990 de wens tot een spoortunnel op in het collegeprogramma. In 1991 werd in het eerste rapport over de kansen en bedreigingen van spoorverdubbeling geconcludeerd dat spoorverdubbeling een kans was voor Delft, mits ondergronds uitgevoerd. ${ }^{196}$ Er zou daarmee bovengronds circa 35 hectare grond vrij komen voor binnenstedelijke ontwikkeling. Deze conclusie werd onderschreven in het in december 1993 uitgebrachte rapport van de door minister May-Weggen ingestelde Stuurgroep Ondergrondse Vervoersinfrastructuur. Deze stuurgroep concludeerde dat een viersporige tunnel de enige duurzame oplossing was. Een jaar later was de spoorverdubbeling echter uit de uitwerking van de toekomstvisie (Rail21) van NS geschrapt. Voorlopig was spoorverdubbeling volgens NS niet 
nodig. Inmiddels was de geest echter wel uit de fles. In de jaren daarna zijn, onder andere door de gemeente Delft in samenwerking met Ballast Nedam, verschillende alternatieven voor viersporigheid in beschouwing genomen ook in relatie tot het tracé van de hogesnelheidslijn. Uit onderzoeken kwam herhaaldelijk de conclusie naar voren dat Delft een uniek knelpunt is en er in Nederland geen binnenstedelijke locatie is waar een dergelijke hoge geluidsbelasting door het spoor voorkomt.

In 1996 stelde de Tweede Kamer dat de situatie rond het spoorviaduct in Delft een onaanvaardbaar stedelijk klimaat oplevert. In een motie verzocht de Tweede Kamer het kabinet te overleggen met de gemeente Delft en de provincie Zuid-Holland om te komen tot een gezamenlijke aanpak, inclusief kostenverdeling, opdat in 1997 duidelijkheid kon worden geboden over de termijn waarop het viaduct kan worden vervangen door een tunnel. De Tweede Kamer verzocht verder de spoortunnel op te nemen in de verkenningstabel van het Meerjarenprogramma Infrastructuur Transport (MIT).

In 1998 sloten de gemeente Delft en Ballast Nedam een samenwerkingsovereenkomst waarin zij afspraken gezamenlijk de haalbaarheid van een integrale ontwikkeling van een viersporige tunnel en vastgoed op de locatie van station Delft te onderzoeken. In hetzelfde jaar werd de Spoorzone in Delft geselecteerd als voorbeeldproject in het kader van de Stimuleringsregeling Intensief Ruimtegebruik (StIR) van het ministerie van VROM. Met het bedrag dat Delft hiervoor kreeg van het Ministerie van VROM gaf de gemeente een architect (Joan Busquets) opdracht een stedenbouwkundige visie op de Spoorzone te maken. Deze ontwikkelingsvisie (1999) schepte nabij het centrum van Delft ruimte voor een geheel nieuwe stedelijke invulling met woningbouw, kantoorontwikkeling, nieuw openbaar gebied en infrastructuur.

Nadat deze stedenbouwkundige visie was opgesteld, hebben NS en Ballast-Nedam een intentieovereenkomst getekend met als doel een plan te ontwikkelen voor de spoortunnel en de bovengrondse stedelijke gebiedsontwikkeling. Provinciale Staten van Zuid-Holland verzochten Gedeputeerde Staten om alles in het werk te stellen om de spoortunnel in Delft dichterbij te brengen. Dit deed Gedeputeerde Staten door er bij het Rijk op aan te dringen dat de tunnel er zo snel mogelijk moet komen én door een provinciale bijdrage vrij te maken voor de ontwikkeling van een stedenbouwkundige inpassing van de viersporige tunnel. De Tweede Kamer vroeg in hetzelfde jaar de regering om door verschuivingen binnen het MIT geld vrij te maken voor de spoortunnel in Delft. In 1999 besloot het kabinet om $€ 174$ miljoen te reserveren voor de tunnel in Delft. Daarmee was de uitvoering van de plannen een stuk dichterbij gekomen. De minister van Verkeer en Waterstaat zegde de Kamer toe dat de MIT-verkenningsfase van de spoortunnel Delft begin 2000 zou starten. De gemeente begon vervolgens met het aankopen van panden in de spoorzone die op termijn zouden moeten wijken in verband met de herontwikkeling. In 2000 besloot het kabinet tot een extra investering in de spoortunnel Delft, door $€ 136$ miljoen uit het budget voor het Bereikbaarheidsoffensief Randstad (BOR) hiervoor te bestemmen. Met het eerder gereserveerde bedrag reserveerde het Rijk zo $€ 310$ miljoen voor het tunnelproject. Langzaam maar zeker kreeg het spoorzoneproject vorm en werd duidelijk wat de kosten zouden gaan worden voor tunnel, station en alle benodigde voorzieningen. In de verkenning 'Rijswijk - Schiedam, Spoorzone Delft' uit 2001 werden de kosten voor de tunnel en het station geraamd op ca. $€ 500$ miljoen. Naast de rijks- en provinciale zou een deel van de kosten kunnen worden gedekt door de vastgoedontwikkeling. Dit bleek echter onvoldoende. Uit de opbrengst van de verkoop van aandelen van het Elektriciteitsbedrijf 
Zuid-Holland (EZH) reserveerde de gemeente Delft daarom, na een meningspeiling onder Delftenaren, een bedrag van $€$ 8,6 miljoen voor de Spoorzone en in 2001 besloot de gemeenteraad van Delft tot een gemeentelijke bijdrage aan de spoortunnel van $€ 45$ miljoen.

Minister Netelenbos van V\&W besloot op basis van de resultaten van de MIT-verkenningsfase in juli 2001 het project Spoorzone Delft op te nemen in het Planstudieprogramma Spoor van het MIT. De minister verzocht Delft in samenwerking met ProRail (toen nog Railinfrabeheer) de planstudie ter hand te nemen, vanwege de nauwe relatie tussen het realiseren van de tunnel en de invulling van het binnenstedelijke gebied. De minister stemde vervolgens in met het voorstel van Delft om een milieueffectrapport te laten opstellen voor zowel de spoortunnel als de stedelijke ontwikkeling.

Op 20 februari 2002 tekenden de Ministeries van V\&W en VROM, de provincie Zuid-Holland, het stadsgewest Haaglanden en de gemeente Delft een procesovereenkomst. Daarin werd afgesproken dat de gemeente in opdracht van de andere partijen en onder verantwoordelijkheid van een stuurgroep waarin partijen waren vertegenwoordigd, een Nota van Uitgangspunten zou vaststellen waarin de randvoorwaarden voor de integrale realisatie van een spoortunnel, een station en de stedelijke ontwikkeling in het plangebied Spoorzone Delft zouden worden beschreven. De euforie was op dat moment groot. In 2003 verschoof de minister van Verkeer \& Waterstaat op de begroting echter 24 miljoen van de spoortunnel in Delft naar het spoorproject in Dieren. De minister zegde toe dat het een tijdelijke maatregel is en dat het geld voor Delft er na 2010 weer bij zou komen, maar bij de presentatie van de Miljoenennota in september 2003 dreigde het project Spoorzone nog meer vertraging op te lopen. Vanwege de vele storingen in het treinverkeer wilde het kabinet prioriteit geven aan het onderhoud van bestaand spoor. Dit druiste in tegen de gesloten procesovereenkomst van 20 februari 2002 en de wens van de Tweede Kamer. Voor de gemeente Delft was dit uitstel niet acceptabel en bewoners- en belangenverenigingen richtten het actiecomité Spoortunnel Delft NU op. De actievoerders haalden in een maand tijd ruim tienduizend handtekeningen op van medestanders. Deze petitie werd aangeboden aan de Tweede Kamer voor de behandeling van de begroting van Verkeer en Waterstaat. De Tweede Kamer verzocht de minister in een motie om nu definitief te beslissen over het reserveren van een bedrag van $€ 344$ miljoen, uit te geven na 2010, om de spoortunnel mogelijk te maken. Deze motie Mastwijk werd met algemene stemmen aanvaard en de minister zegde toe de motie te bespreken in het kabinet. In hetzelfde jaar resulteerden onderhandelingen tussen de gemeente Delft en het consortium van NS Vastgoed en Ballast-Nedam in een bod voor de bovengrondse gebiedsontwikkeling voor twee verschillende varianten. In 2003 werd tevens de laatste hand gelegd aan het stedenbouwkundig masterplan voor de Spoorzone. ${ }^{197}$

De regio (provincie Zuid-Holland, stadsgewest Haaglanden, bestuurlijk Platform Zuidvleugel en gemeente Delft) onderzochten vervolgens de mogelijkheid van aanbesteden en bouw van de spoortunnel, binnen randvoorwaarden van motie Mastwijk. Dit initiatief leidde in juni 2004 tot een aanbod van de regio aan het kabinet om de aanbesteding van de Spoortunnel ter hand te nemen. Daarbij werd uitgegaan van een eenmalige rijksbijdrage van $€ 344$ miljoen in 2011 en een bijdrage van de regio van €164 miljoen. Het kabinet presenteerde vervolgens de Nota Mobiliteit, met de investeringsplannen voor de periode 2011-2014. Hierin stond niet dat het kabinet geld wilde uittrekken voor de Spoorzone. Het project kreeg geen prioriteit; volgens het kabinet was het 'geen 
verkeer- en vervoerknelpunt op basis van de Nota Mobiliteit'. Tot 2020 zou in Delft kunnen worden volstaan met twee sporen. De Minister van Verkeer \& Waterstaat meldde de Tweede Kamer echter dat ze alsnog bereid was de motie Mastwijk uit te voeren, waardoor de spoortunnel er toch zou komen.

Op 5 juli 2005 nam de minister van Verkeer en Waterstaat uiteindelijk het projectbesluit voor de aanleg van de spoortunnel en op 5 oktober 2005 ondertekenden de ministers van Verkeer en Waterstaat en VROM en de gemeente Delft de bestuurlijke uitvoeringsovereenkomst Spoorzone Delft. Daarin zijn onder meer afspraken vastgelegd over de bijdrage van het rijk. De afspraken houden in dat Verkeer en Waterstaat in $2011 € 269$ miljoen bijdraagt (prijspeil 2004). Het ministerie van VROM draagt in totaal $€ 75$ miljoen (niet geïndexeerd) bij vanuit het BIRK. Eveneens op 5 oktober 2005 ondertekenden de gemeente Delft en ProRail een samenwerkingsovereenkomst voor de spoorinfrastructuur, maakten de gemeente Delft, het Stadsgewest Haaglanden en de Provincie ZuidHolland afspraken over de financiële bijdragen van laatstgenoemde twee, tekende de gemeente Delft met NS-vastgoed een koopovereenkomst en met NS Vastgoed en Ballast-Nedam Ontwikkelingsmaatschappij tekende zij de raamovereenkomst Spoorzone Delft voor de bovengrondse gebiedsontwikkeling. Op 23 december 2005 werd er vervolgens een overeenkomst gesloten tussen de gemeente Delft, NS Stations en ProRail waarin afspraken werden gemaakt over het eigendom en beheer van de spoortunnel, het station en de fietsenstallingen en de medefinanciering van de NS aan het station.

Op 23 februari 2006 stelde de gemeenteraad het bestemmingsplan Spoorzone Delft vast en ging zij akkoord met de oprichting van een Ontwikkelingsbedrijf Spoorzone Delft BV (OBS). In de afspraken met andere contractpartijen was al vastgelegd dat de gemeente Delft zoveel mogelijk vertegenwoordigd zou worden door het OBS. Het OBS zou de verdere voorbereiding en uitvoering van de ontwikkeling ter hand nemen. Voor het maken van het ontwerp van de nieuwe stationshal gecombineerd met het nieuwe stadskantoor is op basis van schetsontwerpen van diverse architecten op 12 juli 2007 Mecanoo geselecteerd als architect.

Het aanbestedingsproces voor de bouw van de spoortunnel dat in 2006 gestart was, werd in de zomer van 2007 stilgelegd nadat de gemeente aan het Rijk een anvullende bijdrage van $€ 20$ miljoen had gevraagd voor het project. Deze extra bijdrage was bedoeld voor een verlenging van de spoortunnel waardoor een toekomstvastere oplossing moet ontstaan. Deze bijdrage werd in september 2007 door de minister van Verkeer en Waterstaat toegezegd en in november 2007 heeft de minister van Verkeer en Waterstaat nog eens circa 40 miljoen toegezegd voor het ontgraven van een tweede tunnelbuis. Hierdoor ontstaat ruimte voor toekomstige verdubbeling van het aantal sporen van twee naar vier.

Op basis van deze ontwikkelingen zijn de afspraken van oktober 2005, waaronder de financiering en risicoverdeling binnen het project herijkt. Hiervoor hebben Rijk en gemeente Delft op 9 juli 2008 een Addendum op de Bestuurlijke Uitvoeringsovereenkomst van 2005 ondertekend. In 2009 is gestart met sloopwerkzaamheden in de spoorzone. In 2010 is gestart met de bouw van de tunnel en volgens de planning moet de eerste tunnelbuis in 2013 gereed zijn. De start van de bouw van het gecombineerde stadskantoor/station staat gepland voor 2011 en de bouw van woningen en kantoren voor 2013. Een overzicht van deze projecthistorie en procesverloop staat weergegeven in figuur 8.1. 


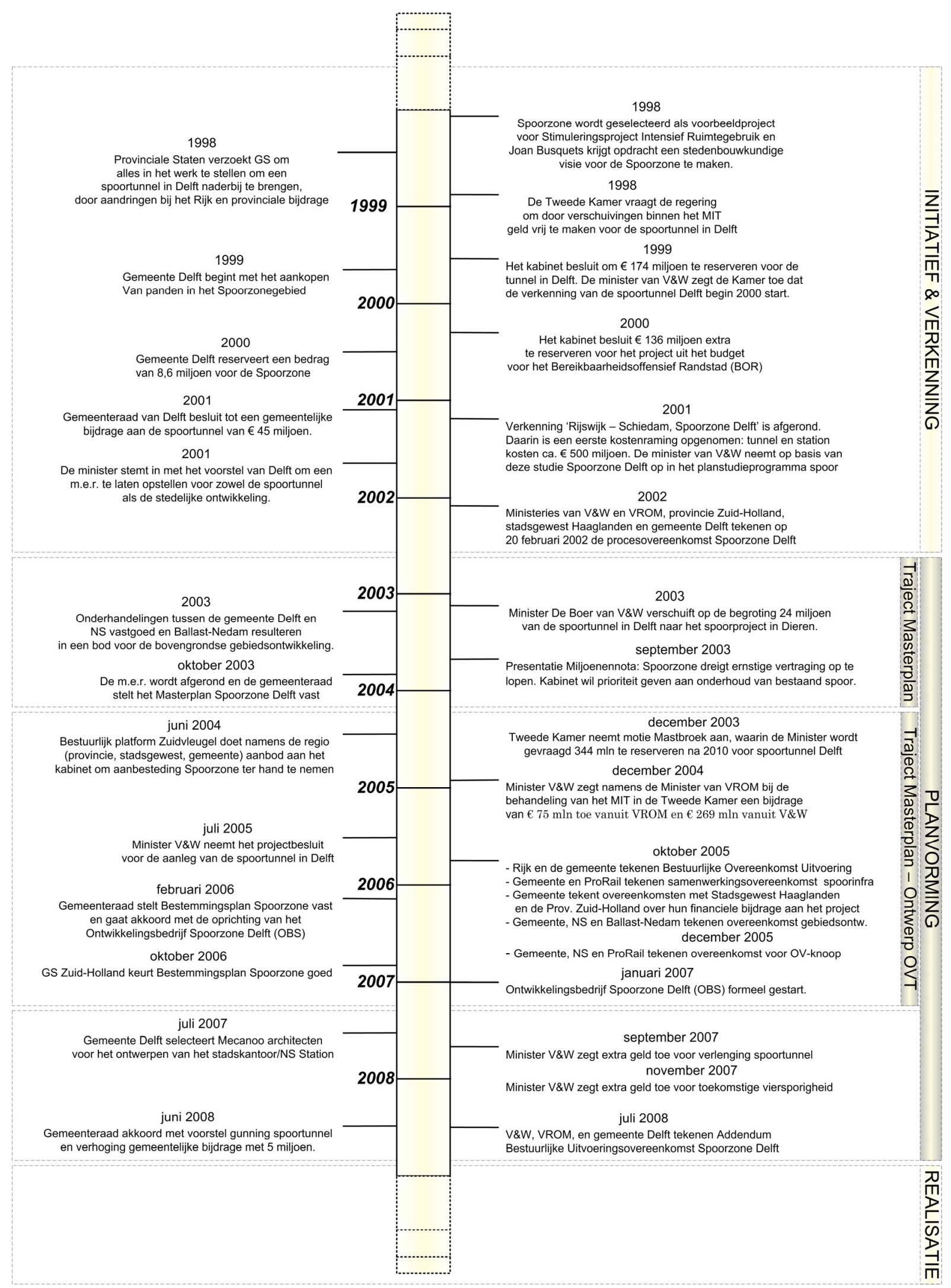

Figuur 8.1 Spoorzone Delft - Procesverloop 


\subsubsection{De ruimtelijke opgave}

Het project Spoorzone Delft betreft de integrale herontwikkeling van een gebied van circa 30 hectare tussen de binnenstad van Delft en de woonwijken ten westen en zuiden daarvan. Het project is gericht op het verbeteren van de leefbaarheid in de spoorzone en tegelijkertijd het verdubbelen van het spoor op het traject Rijswijk-Schiedam (Bestemmingsplan Spoorzone, 2006). In het Masterplan Spoorzone Delft (Delft, 2003) is de gewenste stedenbouwkundige ontwikkeling beschreven. Daarin worden drie onderdelen onderscheiden; de spoorinfrastructuur, de OV-knoop en de bovengrondse stedelijke gebiedsontwikkeling.

\section{Spoorinfrastructuur}

De plannen voor de spoorzone zijn in belangrijke mate ingegeven doordat het spoor steeds meer een bron van hinder werd (geluid, trillingen, sociale onveiligheid, etc.). Het spoortracé door de binnenstad van Delft vormt daarnaast een barrière in de stad en de verwachte toename van de intensiteit van het gebruik van het spoor zorgt ervoor dat spoorverdubbeling in de toekomst noodzakelijk wordt (Bestemmingsplan Spoorzone Delft, 2006). De aanleg van een ruim 2300 meter lange 4-sporige spoortunnel moet een oplossing bieden voor deze problemen. In de toekomstige situatie komt de spoortunnel ten oosten van het huidige spoor te liggen. Vervolgens kunnen het huidige talud en viaduct van het spoor verdwijnen. De tunnel maakt de weg vrij voor een metamorfose van het stationsgebied en het oude emplacementterrein. Centraal in de Spoorzone, boven de tunnel, komt een ruim stadspark: ongeveer 40 meter breed en 600 meter lang. Ook de ruimte boven het zuidelijk deel van de tunnel wordt grotendeels ingenomen door een park. Hoewel er veel nieuwbouw komt, blijft de spoortunnel dus grotendeels vrij van bebouwing. Twee bouwblokken en de nieuwe openbaar vervoersknoop met het stadskantoor komen wel op de tunnel te staan.

\section{OV-knoop ( $O V$-terminal en stadskantoor) ${ }^{198}$}

Centraal in de plannen voor de Spoorzone ligt de zogenaamde OV-knoop. De gemeente Delft wenst in het gebied een nieuw stadskantoor te realiseren. Bijna alle, nu over de stad verspreide, gemeentelijke ambtelijke diensten worden dan gecentraliseerd in een gebouw voor de ongeveer duizend gemeentelijke medewerkers. Het nieuwe stadskantoor en het NS-station worden gezamenlijk gesitueerd in de OV-knoop, waarbij de begane grond zowel de functie van stationshal als die van de centrale publieks - en de loketdiensten van het stadskantoor gaat vervullen. De bedoeling is evenwel dat beide functies hun eigen identiteit houden en dat het ruimtelijk twee afzonderlijk afsluitbare ruimten zullen zijn.

De publieksruimten van het stadskantoor zullen op de begane grond ongeveer $1250 \mathrm{~m}^{2}$ bvo in beslag nemen en totale programma van het stadskantoor voorziet in $29.000 \mathrm{~m}^{2}$ bvo. Ongeveer $1500-2000$ $\mathrm{m}^{2}$ bvo wordt gerealiseerd voor exploitatie van zogenaamde gemaks- en comfortvoorzieningen (winkels, etc.), inclusief een restaurant $\left(2500 \mathrm{~m}^{2}\right)$. Met roltrap en lift kunnen reizigers vanuit de stationshal naar de perrons, ongeveer acht meter onder de grond en 340 meter lang. Onder het stadskantoor/station wordt een openbare, commerciële parkeergarage gebouwd voor circa 290 plaatsen, waarvan $100 \mathrm{P}+\mathrm{R}$ plaatsen. Het stationsplein aan de voorzijde van het oude stationsgebouw zal dienst gaan doen als busstation en reizigers kunnen overstappen op de trams. Op het plein voor het huidige stationsgebouw komt het kiss \& ride-gedeelte. Tenslotte wordt er onder het busstation een overdekte en bewaakte fietsenstalling gerealiseerd die ruimte gaat bieden aan 5000 fietsen en 
direct toegang biedt tot de stationshal en de perrons. ${ }^{199}$ Voor de verantwoordelijkheidsverdeling is het van belang in de OV-knoop een onderscheid te maken naar het spoorse deel en het stadse deel van de OV-knoop.

Het spoorse deel van de OV-knoop bestaat uit de aanleg van twee 340 meter lange ondergrondse perrons, het ondergrondse deel van het basisstation, stijgpunten, ondergrondse stalling voor circa 5000 fietsen, een busstation met 8 platforms, tramhalte en taxiplaatsen (Masterplan Spoorzone Delft en ruimtelijk functioneel ontwerp OV-knoop Delft).

Het stadse deel van de OV-knoop bestaat uit het gecombineerde stationshal/stadskantoor met 1500$2000 \mathrm{~m}^{2}$ commerciële ruimten en circa $29.000 \mathrm{~m}^{2}$ bvo kantoorruimte en een ondergrondse parkeergarage van circa 290 plaatsen, waarvan $100 \mathrm{P}+\mathrm{R}$ (Masterplan Spoorzone Delft en ruimtelijk functioneel ontwerp OV-knoop Delft).

\section{Bovengrondse stedelijke gebiedsontwikkeling}

De Spoorzone Delft is ook een binnenstedelijk ontwikkelingsgebied. Het volledig wegnemen van het bovengrondse spoortracé maakt de bouw mogelijk van ruim 1500 nieuwe woningen en kantoren in het zuidelijk deel van het gebied. Ruim de helft van de geplande $54.000 \mathrm{~m}^{2}$ kantoorruimte wordt benut voor het nieuwe stadskantoor. Naast woningen en kantoren wordt bovengronds tevens de hoofdstructuur voor het wegverkeer aangepast, nieuwe fietspaden aangelegd, staat een parkeergarage voor ruim 400 auto's naast de spoortunnel gepland, komen diverse waterpartijen in het gebied voor waterberging en wordt een stadspark aangelegd boven een deel van de spoortunnel (bestemmingsplan Spoorzone Delft, 2006).

\subsubsection{Actoren}

In de planvorming voor het spoorzoneproject zijn diverse partijen vanuit een (eigendom)positie of op grond van bestuurlijke verantwoordelijkheden betrokken geweest. Deze actoren worden hierna toegelicht.

\section{Gemeente Delft}

Vanuit haar bestuurlijke verantwoordelijkheid voor stedelijke ontwikkeling, haar eigendom van een deel van de gronden in het plangebied en haar plannen voor een nieuw stadskantoor, heeft de gemeente Delft een centrale positie. De doelstelling van de gemeente voor het spoorzonegebied is drieledig; (1) verbetering van de kwaliteit van de leefomgeving in het gebied aan de rand van de binnenstad door het reduceren van de geluidsoverlast van het spoor; (2) verbetering van de bereikbaarheid van de Delftse binnenstad voor het openbaar vervoer en (3) herontwikkeling van het stedelijke gebied in het hart van de stad met een hoog kwaliteitsniveau zoals gevisualiseerd in de stedenbouwkundige visie van 1999, met een goede mix van kantoren, woningen en andere functies (gemeente Delft, 2002).

De gemeente Delft heeft bij raadsbesluit van 28 juni 2001 een bedrag van $€$ 45,5 miljoen beschikbaar gesteld voor de Spoorzone. Met de ondertekening van de contracten met het Rijk, ProRail, het stadsgewest Haaglanden, de Provincie, NS Vastgoed en Ballast Nedam van 5 oktober en 23 december 2005 heeft de gemeente Delft vrijwel het volledige risico voor de ontwikkeling en realisatie van het 
project op zich genomen. Dit betekent tevens dat de gemeente Delft de regie voert over de ontwikkeling en realisatie van het project en kostenoverschrijdingen voor haar rekening zullen zijn. ${ }^{200}$ Voor de uitvoering van de taken die voortvloeien uit de overeenkomsten heeft de gemeente het Ontwikkelingsbedrijf Spoorzone Delft BV (OBS) opgericht dat vanaf 1 januari 2007 operationeel is. Het OBS neemt de voorbereiding en uitvoering van de ontwikkeling ter hand, voert de financiële administratie en beheert de kosten en opbrengsten van het project. De gemeente handelt niet zelf, maar oefent indirect invloed uit als 100 procent aandeelhouder van het OBS. De gemeente draagt het uiteindelijke projectrisico, verleent de publieke vergunningen en neemt na realisatie het openbaar gebied in beheer. Met andere woorden: het OBS bereidt voor en voert uit, de gemeente Delft toetst, verleent vergunningen en treedt op als beheerder. Bij de beslissing van de Minister van Verkeer en Waterstaat om aanvullende middelen beschikbaar te stellen om de spoortunnel in ruwbouw voor vier sporen mogelijk te maken zijn tevens de afspraken tussen Rijk en gemeente van oktober 2005 herzien. Met het ondertekenen van de Addendum Bestuurlijke Uitvoeringsovereenkomst in 2008 is het risico van de gemeente voor de spoorinfrastructuur, het spoorse deel van de OV-knoop en de Stationshal beperkt tot een maximum van 5 miljoen euro.

\section{Stadsgewest Haaglanden}

Doelstelling van het Stadsgewest Haaglanden is het verbeteren van het regionaal openbaar vervoer en de aansluiting daarvan op het landelijke netwerk van railvervoer (Procesovereenkomst Spoorzone Delft, 2002). Het stadsgewest stelt hiervoor onder andere vervoerskundige en civieltechnische randvoorwaarden vast voor regionaal (openbaar) vervoer. In de procesovereenkomst van februari 2002 is opgenomen dat de regio Haaglanden verantwoordelijk is voor de uitwerking van het programma van eisen voor de OV/knoop (busstation, tramlijnen). Het stadsgewest Haaglanden heeft in het budget Bereikbaarheidsoffensief Randstad, regionale fondsen, een verdubbelingsregeling afgesproken met de gemeente Delft: de effectieve bijdrage voor de OV-knoop zal € 11,3 miljoen zijn.

\section{Provincie Zuid-Holland}

Vanuit haar ruimtelijk beleid wil de provincie Zuid-Holland een kwalitatief hoogwaardige stedelijke ontwikkeling ondersteunen door economische ontwikkelingen rondom het knooppunt van openbaar vervoer bij het station Delft te stimuleren (Procesovereenkomst Spoorzone Delft, 2002). Om invulling aan die doelstelling te geven draagt de provincie $€ 30$ miljoen bij aan de ontwikkeling van de spoorzone. Naast haar financiële bijdrage heeft de provincie tevens een actieve rol gespeeld in het proces. Als een van de regionale partijen die in 2004 het anbod aan het Rijk deed om de aanbesteding ter hand te nemen, gaf de provincie nadrukkelijk blijk voorstander van het spoorzoneproject te zijn. Ook in de recente discussie over aanvullende middelen als gevolg van een overblijvend financieringstekort, ondanks de toezeggingen door de Minister van Verkeer en Waterstaat in het najaar van 2007, is de provincie actief om de regionale partners aan tafel te krijgen en te houden.

\section{Ministerie van VROM}

Het project Spoorzone Delft draagt bij aan de uitvoering van het Nota Ruimte beleid. Enerzijds betreft dit binnen de stedelijke context van Delft het bereiken van hoogwaardige ruimtelijke kwaliteit en anderzijds het wegnemen van een knelpunt in de kwaliteit van de leefomgeving via aanzienlijke 
reductie van de bestaande geluidshinder en het waarborgen van veiligheid. Hoogwaardige ruimtelijke kwaliteit kan in de visie van het Ministerie van VROM worden bereikt door het ruimtegebruik te intensiveren middels integratie van functies en door het samenbrengen van verschillende vervoersmodaliteiten in een efficiënte overstapmogelijkheid in het centrum van Delft (Procesovereenkomst Spoorzone Delft, 2002). Het project past dan ook binnen het toepassingsgebied centrumvorming en knooppuntontwikkeling in nationale stedelijke netwerken van het Budget Intensivering Ruimtelijke Kwaliteit (BIRK). In de Bestuurlijke UitvoeringsOvereenKomst (BUOK) van oktober 2005 heeft VROM vanuit dit budget onder voorwaarden een subsidie van $€ 75$ miljoen (niet geïndexeerd) toegezegd. Die subsidie strekt tot een bijdrage in de kosten voor de aanleg van de spoortunnel, het stadspark en/of de ondergrondse fietsenstalling(en). Dit zijn de drie zogenaamde kwaliteitsdragers voor de BIRK-bijdrage. Tot begin 2007 was de Minister van VROM vanuit het Rijk tevens de verantwoordelijke programmaminister voor de Zuidvleugel, een van de programma's van de uitvoeringsagenda van de Nota Ruimte. Spoorzone Delft is een van de projecten in het Zuidvleugel programma. In breder verband wordt hierin ook gekeken naar de uitbreiding van de capaciteit van het spoor Den Haag-Rotterdam waar Delft deel van uit maakt. In de overeenkomst tussen Rijk en gemeente van 9 juli 2008 die een aanvulling vormt op de bestuurlijke overeenkomst van 2005 is vastgelegd dat het Ministerie van VROM nog eens 5 miljoen extra beschikbaar stelt voor het project.

\section{Ministerie van Verkeer en $W$ aterstaat}

Doelstelling van het Ministerie van Verkeer en Waterstaat ten aanzien van het spoorzoneproject is het verminderen van de geluidsoverlast die het vervoer over het spoor veroorzaakt en het mogelijk maken van de capaciteitsuitbreiding op termijn (Procesovereenkomst Spoorzone Delft, 2002). In de bestuurlijke overeenkomst van 2005 is vastgelegd dat Verkeer en Waterstaat 269 miljoen euro (prijspeil 1 januari 2004) bijdraagt aan het project. Deze bijdrage is bedoeld voor de uitvoering van het deelproject Spoorinfrastructuur en het Spoorse deel van de OV-terminal (alsmede de stationshal). Naast deze directe bijdrage voor Delft is de uitbreiding van de capaciteit van het spoor tussen Den Haag-Rotterdam een van de projecten in het kader van het Urgentieprogramma Randstad. Hoewel de spoorzone Delft zelf geen direct onderdeel uitmaakt van dit urgentieprogramma heeft de minister van Verkeer en Waterstaat na bestuurlijk overleg met regio en de minister van VROM (programmaminister voor de Zuidvleugel) recent extra middelen toegezegd. In de Addendum bestuurlijke overeenkomst Spoorzone Delft is vastgelegd dat het ministerie 52,4 miljoen euro (prijspeil 1 januari 2008) extra bijdraagt bovenop de eerdere 269 miljoen euro. Deze extra bijdrage is bedoeld voor het verlengen van de tunnel en een extra tunnelbuis waardoor ondergrondse viersporigheid in de toekomst mogelijk wordt. Daarnaast is het financiële risico voor de spoorinfrastructuur, de OV-knoop en de stationshal met de Addendum voor het overgrote deel verschoven van de gemeente Delft naar het Ministerie van Verkeer en Waterstaat.

\section{ProRail}

Als beheerder van de sporen en perrons en operationeel verantwoordelijke voor de transfervoorzieningen van het nieuwe station speelt ProRail een prominente rol in het project. ProRail is op grond van de Spoorwegwet verantwoordelijk voor de uitvoering van de aanbesteding en aanleg van de spoortunnel en het spoorse deel van de OV-knoop. ProRail is daarom 
subsidieaanvrager naar het ministerie van Verkeer en Waterstaat en werkt samen met de gemeente Delft in het OBS (zie verder).

\section{Nederlandse Spoorwegen}

Bij de splitsing van NS in een taak- en een marktsector heeft NS het expliciete recht voor over- en onderbouwing van het spoor gekregen. Vanwege de plannen voor de aanleg van de spoortunnel betekende dit dat voor de herontwikkeling van de spoorzone in Delft overleg gevoerd diende te worden over dit recht en de andere posities van NS Vastgoed (tegenwoordig NS Poort) in het plangebied. Voorafgaand aan het vaststellen van het masterplan resulteerden onderhandelingen tussen de gemeente Delft en het consortium van NS en Ballast-Nedam in een bod voor de bovengrondse gebiedsontwikkeling voor twee verschillende varianten ${ }^{201}$. Dit bod is in de uitwerking van de plannen onveranderd gebleven en met een overeenkomst tussen de gemeente Delft en de CV Ontwikkelingscombinatie Spoorzone Delft in 2005 bevestigd. In deze CV participeren NS en BallastNedam beiden voor 50 procent. Vanuit de grondwaardestijging wordt een bijdrage aan de tunnelbouw gegarandeerd. In totaal (inclusief de grondbijdragen van de gemeente Delft) komt deze bijdrage uit grondwaardestijging op 78 miljoen euro. Naast de vastgoedtak was NS als beheerder en rechthebbend exploitant van commerciële voorzieningen op stations betrokken bij de plannen voor de OV-knoop.

\section{Ballast-Nedam}

Ballast-Nedam had een intentieovereenkomst met de gemeente Delft voor de ontwikkeling van een deel van de spoorzone. De gemeente Delft en Ballast-Nedam hadden beiden belang bij de aanleg van de spoortunnel en wilden het Ministerie van Verkeer en Waterstaat ervan overtuigen een positieve houding ten opzichte van het project aan te nemen. Ballast-Nedam heeft door ondersteuning van de gemeente in dat proces een belangrijke rol gespeeld. In de eerste ideeen van Ballast-Nedam (en NS) zouden delen van het plangebied vooruitlopend op de realisatie van de spoortunnel ontwikkeld kunnen worden waarna de spoortunnel later ingepast kon worden. Hierdoor zou een deel van de kosten van de realisatie van de spoortunnel gefinancierd kunnen worden. Samen met NS Poort participeert Ballast-Nedam in de CV Ontwikkelingscombinatie Spoorzone Delft die een groot deel van de bovengrondse vastgoedontwikkeling voor haar rekening neemt. Tevens is Ballast-Nedam samen met Strukton een van de vier bouwcombinaties geweest die een bieding hebben gedaan tijdens de aanbesteding van de tunnel. 202

\section{Overige actoren}

De uitwerking van ideeën voor (onderdelen van) het gebied tot ontwerpen wordt veelal uitbesteed aan architectenbureaus. Voor het gehele spoorzonegebied is het stedenbouwkundig masterplan gemaakt door Joan Busquets. Specifiek voor het OV-knoop deel wordt samengewerkt met drie architectenbureaus. Benthem Crouwel is ingehuurd door ProRail voor het ontwerp van het ondergrondse station, Mecanoo architecten is geselecteerd om de gecombineerde stationshal en stadskantoor te ontwerpen en voor het ontwerp van de openbare ruimte is Joan Busquets voor de uitwerking van het stedenbouwkundig Masterplan betrokken. Omdat aanbesteding van de integrale OV-knoop in één contract plaats vindt vergt dit de nodige afstemming tussen visies van architecten, ProRail en gemeente Delft. 
Meer op beleidsmatig niveau kan het Bestuurlijk Platform Zuidvleugel als actor worden genoemd. Dit is een samenwerkingsverband van acht bestuurlijke partners in het zuidelijke deel van de Randstad: de provincie Zuid-Holland, het stadsgewest Haaglanden, de stadsregio Rotterdam, de regio's HollandRijnland, Midden-Holland en de Drechtsteden, en de gemeenten Den Haag en Rotterdam. Het Bestuurlijk Platform Zuidvleugel houdt zich bezig met de bovenregionale belangen van de partners. Een van de prioriteiten in dat verband is de Stedenbaan. Het Bestuurlijk Platform Zuidvleugel wil de stedelijke ontwikkeling beter afstemmen op de bereikbaarheid van knooppunten en stations. Stedenbaan is een centraal beleidsconcept in die ambitie. Met het vaststellen van het beleidsdocument 'Ruimtelijke Ambitie Stedenbaan 2020' benoemt het Bestuurlijk Platform de gewenste ruimtelijke ontwikkeling rond de tweeëndertig bestaande en vier mogelijk gewenste Stedenbaanstations. Met het concept Stedenbaan spant het bestuurlijk platform zich in voor: een beter treinproduct (sneller, hogere frequenter, aansluitingen); betere mogelijkheden voor ketenmobiliteit (voor- en natransport van en naar stations); een beter en intensiever grondgebruik nabij stations (meer woningen, kantoren en voorzieningen; meer ruimtelijke kwaliteit, milieudifferentiatie, functiemenging en levendigheid.

\begin{tabular}{|c|c|c|}
\hline Planonderdeel & Actoren & Positie \\
\hline \multirow{10}{*}{ OV-knoop } & Gemeente Delft & Regisseur en risicodragend opdrachtgever via het OBS voor de integrale ontwikkeling \\
\hline & Stadsgewest Haaglanden & Subsidieverlener vanuit BOR / regionale fondsen \\
\hline & Provincie Zuid-Holland & Subsidieverlener \\
\hline & Ministerie VROM & Subsidieverlener vanuit het BIRK \\
\hline & Ministerie V\&W & Subsidieverlener vanuit het MIT / Basisnota Stations \\
\hline & ProRail & In het OBS verantwoordelijk voor voorbereiden en realiseren spoorse deel OV-knoop \\
\hline & Nederlandse Spoorwegen & Beheerder en rechthebbend exploitant voor commerciele voorzieningen \\
\hline & Mecanoo & Architect stadse deel OV-knoop / stadskantoor \\
\hline & Benthem Crouwel & Architect spoorse deel OV-knoop \\
\hline & Joan Busquets & Architect openbare ruimte \\
\hline \multirow{4}{*}{ Spoortunnel } & Gemeente Delft & Risicodragend opdrachtgever via het OBS voor de integrale ontwikkeling \\
\hline & ProRail & In het OBS verantwoordelijk voor voorbereiden en realiseren van de spoortunnel \\
\hline & Ministerie V\&W & Subsidieverlener vanuit het MIT \\
\hline & Ministerie VROM & Subsidieverlener vanuit het BIRK \\
\hline \multirow{4}{*}{$\begin{array}{l}\text { Gebieds- } \\
\text { ontwikkeling }\end{array}$} & Gemeente Delft & Regisseur, vergunningverlening, beheer openbare ruimte \\
\hline & NS Poort & Ontwikkelaar in CV Spoorzone Delft (50\%) \\
\hline & Ballast-Nedam & Ontwikkelaar in CV Spoorzone Delft (50\%) \\
\hline & Ministerie VROM & Subsidieverlener vanuit het BIRK \\
\hline
\end{tabular}

Tabel 8.1 Spoorzone Delft - Actoren per planonderdeel

\subsubsection{Samenwerkingsorganisatie}

In de procesovereenkomst van 20 februari 2002 was overeengekomen een stuurgroep in te stellen die op hoofdlijnen de regie voert over het gehele proces van planvorming. In deze stuurgroep op bestuurlijk niveau hadden vertegenwoordigers van de gemeente Delft (wethouder duurzaamheid (vz.)) het ministerie van V\&W, het ministerie van VROM, de provincie Zuid-Holland, het stadsgewest Haaglanden en een vertegenwoordiger van het toenmalige Kenniscentrum PPS van het ministerie van Financiën zitting. De directeur Programma's en Projecten van de gemeente Delft was secretaris van de stuurgroep. Deze stuurgroep kwam in principe driemaandelijks bij elkaar. Naast deze stuurgroep werd er tevens een ambtelijke werkgroep opgericht met vertegenwoordigers van de 
gemeente Delft, Rijkswaterstaat Directie Zuid-Holland, Railinfrabeheer (later ProRail), Rijksplanologische Dienst van VROM, afdeling Ruimtelijke Ordening van de Provincie Zuid Holland, afdeling Openbaar Vervoer van het stadsgewest Haaglanden en het Kenniscentrum PPS van het ministerie van Financiën. Deze werkgroep kwam in beginsel maandelijks bijeen. Voor de uitvoering van specifieke takopdrachten werden werk- en taakgroepen ingesteld.

Met de ondertekening van de bestuurlijke uitvoeringsovereenkomst tussen Rijk en gemeente Delft op 5 oktober 2005 werd een vervolg aan de samenwerkingsorganisatie gegeven en werd een stuurgroep Rijk/Gemeente ingesteld. Hierin zit één vertegenwoordiger van het ministerie van VROM, één vertegenwoordiger van het ministerie van V\&W en twee vertegenwoordigers van de gemeente Delft. Het secretariaat ligt bij de gemeente Delft en ProRail heeft zitting in de stuurgroep als informant. De secretaris van de gemeente Delft is voorzitter van een ambtelijk projectteam dat de stuurgroep voorbereidt.

De stuurgroep Rijk/Gemeente heeft tot taak toe te zien op de uitvoering en voortgang van het project en fungeert als de primaire overlegvorm tussen partijen waarbij beslissingen worden genomen op basis van unanimiteit. De stuurgroep wordt daarvoor geadviseerd door het Bouwmeestersoverleg bestaande uit de Rijksbouwmeester, de Spoorbouwmeester en de gemeentelijke Supervisor. Deze adviseren de Stuurgroep Rijk/Gemeente in het kader van de verwezenlijking van de ruimtelijke kwaliteit van de OV-knoop, die is neergelegd in het Masterplan en het Ruimtelijk Functioneel Ontwerp OV-knoop. Ook het formele besluit tot gunning van de bouw van de spoortunnel aan een aannemingscombinatie behoeft goedkeuring van dezelfde stuurgroep.

Voor de voorbereiding en realisatie van het project werken ProRail en de gemeente Delft sinds 1 januari 2007 formeel samen in het OBS. Hiermee werd getracht het project op afstand te zetten van de politiek-bestuurlijke omgeving. Dit werd noodzakelijk bevonden gezien de complexiteit, lange uitvoeringsduur en omdat het project wordt uitgevoerd voor rekening en risico van de gemeente Delft, met subsidies van andere overheden. Het OBS heeft tot taak de overeenkomsten van 5 oktober 2005 en 23 december 2005 tot uitvoering te brengen. Dat komt neer op integraal voorbereiden van en realiseren van het project Spoorzone Delft. Daarbij is, zoals aangegeven, een onderscheid gemaakt in het realiseren van spoorinfrastructuur, de OV-knoop en het realiseren van stedelijk gebiedsontwikkeling.

De gemeente is $100 \%$ aandeelhouder van het OBS. De leiding van het OBS bestaat uit een algemeen directeur, een projectdirecteur Vastgoed/Openbare Ruimte en een projectdirecteur Spoor en wordt ondersteund door een staf. De algemeen directeur wordt benoemd door de gemeente Delft en deze stelt de projectdirecteur vastgoed/openbare ruimte aan. De projectdirecteur Spoor wordt benoemd door de Raad van Bestuur van ProRail en is verantwoordelijk voor het voorbereiden en realiseren van de spoorinfrastructuur en het spoorse deel van de OV-knoop. Qua werkstructuur bestaat er in de samenwerkingsorganisatie een onderdeel Spoorinfrastructuur, OV-knoop en Vastgoed/Openbare Ruimte. Elk onderdeel kent een centrale strategiegroep/planteam die de werkzaamheden coördineert en besluitvorming voorbereidt. Hierin participeren ook andere partijen dan de gemeente Delft en ProRail. Voor het onderdeel vastgoed/openbare ruimte zijn dit bijvoorbeeld de ontwikkelaars van de marktpartijen (Ballast-Nedam en NS Poort) die verantwoordelijk zijn voor de uitwerking van de 
vastgoedplannen. Naast de drie projectonderdelen is er tevens een strategiegroep Procedures te onderscheiden waarin alle gemeenschappelijke procedures worden gemanaged. Het OBS staat onder toezicht van een Raad van Commissarissen. Daarnaast is er een directieoverleg marktpartijen, een klankbord netwerk en legt de algemeen directeur verantwoording af aan het gemeentebestuur. De voorzitter van de Raad van Commissarissen en de algemeen directeur vertegenwoordigen tenslotte de gemeente en het OBS in de stuurgroep Rijk-Gemeente. ${ }^{203}$

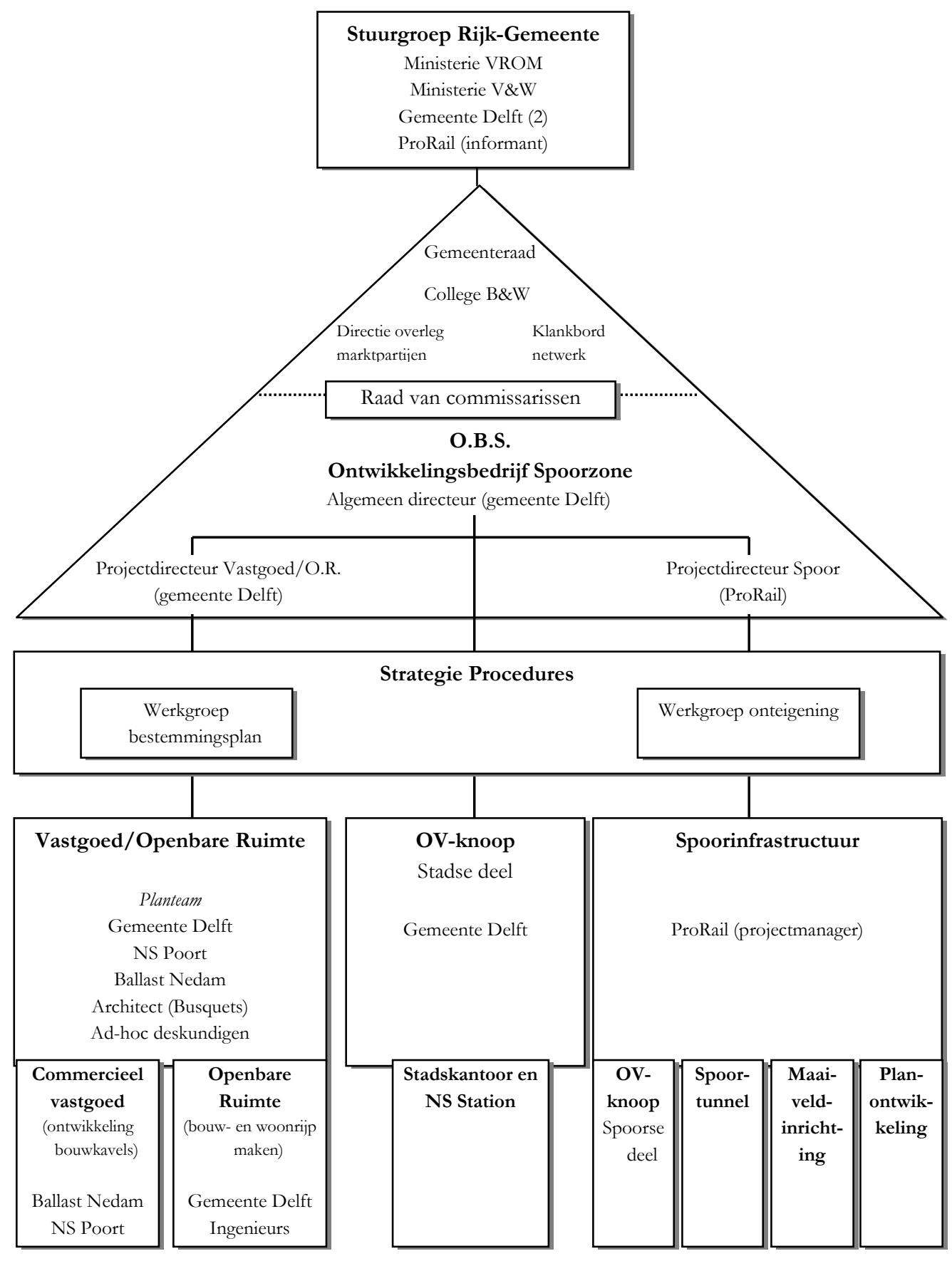

Figuur 8.2 Spoorzone Delft - Samenwerkingsorganisatie 
De spoorinfrastructuur en het spoorse deel van de OV-knoop zijn voorbereid en aanbesteed volgens de afspraken die zijn gemaakt in de samenwerkingsovereenkomst tussen de gemeente Delft en ProRail van 5 oktober en 23 december 2005. In de planuitwerking is samengewerkt met architectenbureau Benthem Crouwel. Besluitvorming over de planuitwerking heeft plaats gevonden in de stuurgroep Rijk-Gemeente.

Voor het stadse deel van de OV-knoop, het stadskantoor en NS-station is de architect Mecanoo geselecteerd door een selectiecommissie bestaande uit de gemeente Delft, NS, de gemeentelijke supervisor en de spoorbouwmeester. Naast het proces van architectenselectie is door de gemeente Delft en NS een Programma van Eisen opgesteld dat als basis geldt voor het Voorlopig Ontwerp.

Voor de stedelijke ontwikkeling, het vastgoed en de openbare ruimte, is op basis van het masterplan dat is opgesteld door Joan Busquets, een Raamovereenkomst gesloten met de ontwikkelaars BallastNedam en NS Poort. Het planteam vastgoed/openbare ruimte heeft hiervoor het Kwaliteitskader, Beeldkwaliteitsplan en het Inrichtingsplan Openbare Buitenruimte ontwikkeld.

\subsection{Planproces}

In de vorige paragraaf is een beeld geschetst van het project Spoorzone Delft. Daarbij zijn de posities van diverse betrokken actoren en de samenwerkingsorganisatie belicht. Deze paragraaf beschrijft de inbreng van keystakeholders in het proces van planvorming. Zoals in hoofdstuk vier beschreven is voor het typeren van de inbreng van keystakeholders in belangrijke mate gebruik gemaakt van de percepties hiervan bij betrokkenen. De inbreng van keystakeholders is beschreven op drie thema's:

- Visievorming (8.3.1)

- Zeggenschap (8.3.2)

- Middelen (8.3.3)

Nadat de inbreng van de afzonderlijke actoren op deze thema's is beschreven, is het samenstel van actoren getypeerd door te kijken naar (a) het aantal actoren dat een substantiële inbreng heeft; (b) de verhoudingen tussen actoren met uiteenlopende karakters en belangenposities (publiek-privaat; centraal-decentraal; gemeente-overige); en (c) de mate waarin er sprake is van ambivalentie in het beeld bij actoren. Dit is gedaan in paragraaf 8.3.4.

In de beschrijving is een onderscheid is gemaakt naar (1) het deelproces gericht op de totstandkoming van het masterplan voor de gebiedsontwikkeling als geheel en (2) het deelproces gericht op het ontwikkelen van een ontwerp voor de OV-terminal. Voor het eerste deelproces is de ondertekening van de procesovereenkomst op 20 februari 2002 als startpunt genomen en het vaststellen van het Masterplan Spoorzone Delft in de gemeenteraad op 30 oktober 2003 als eindpunt. ${ }^{204}$ Voor het tweede deelproces is de periode tussen vaststelling van het Masterplan en de selectie van architect Mecanoo op basis van haar schetsontwerp voor de stationshal annex stadskantoor in juli 2007 geëvalueerd (zie figuur 8.1). Belangrijk is om op te merken dat de gewijzigde afspraken die vastgelegd 
zijn in het Addendum van 2008 op de Bestuurlijke Overeenkomst tussen Rijk en gemeente van 2005 daarmee buiten de scope van deze evaluatie vallen.

\subsubsection{Visievorming}

\section{Visievorming in het masterplanproces}

Zoals eerder in dit hoofdstuk beschreven kent het project Spoorzone Delft een lange en uiterst moeizame voorgeschiedenis. Gaandeweg dat proces kreeg de gemeente Delft meer en meer de overtuiging dat het spoor door de stad ondergronds moest. Er lagen veel vrije kavels langs het spoor waar men vanwege het spoorviaduct niets mee kon en samen met vooral Ballast-Nedam had de gemeente ideeën over de mogelijkheden daarvan in geval van ondertunneling van het spoor. Uiteindelijk wist de gemeente Delft alle publieke partijen te binden aan een serieuze studie naar een spoortunnel. De Minister van Verkeer en Waterstaat verzocht Railinfrabeheer (tegenwoordig ProRail) een planstudie uit te voeren naar mogelijke viersporigheid en verzocht vanwege de samenhang van de spoorinfrastructuur met de invulling van het binnenstedelijke gebied dit te doen in samenwerking met de gemeente Delft. Samenhangend met het uitvoeren van de planstudie tekenden de publieke partijen in de procesovereenkomst Spoorzone Delft.

De procesovereenkomst strekte ertoe dat de gemeente in opdracht van de andere partijen, in samenwerking met Railinfrabeheer (ProRail) en onder verantwoordelijkheid van een stuurgroep waarin deze partijen waren vertegenwoordigd, een Nota van Uitgangspunten zou vaststellen waarin de randvoorwaarden voor de integrale realisatie van de spoortunnel, het station en de stedelijke ontwikkeling in het plangebied Spoorzone Delft zouden worden beschreven. Overeengekomen werd dat partijen vanuit hun eigen verantwoordelijkheid een bijdrage zouden leveren aan het opstellen van deze nota.

- Het Ministerie van Verkeer en Waterstaat zou de vervoerskundige en civieltechnische randvoorwaarden voor de rijks(rail)infrastructuur vaststellen en daarnaast de regie voeren over alle aspecten die de spoorweginfrastructuur en het rijksbeleid inzake verkeer en vervoer betroffen en zorg dragen voor de totstandkoming van het ontwerp en de technische voorwaarden en functionele specificaties voor de tunnel en het station;

- Het Ministerie van VROM zou inhoudelijke en coördinerende ondersteuning bij de planvorming bieden en de relevante delen van de Nota van uitgangspunten in het kader van het BIRK beleid toetsen op ruimtelijke kwaliteit;

- De provincie Zuid-Holland zou binnen het wettelijke kader en de praktische mogelijkheden zorg dragen voor een spoedige afhandeling van ruimtelijke plannen en vergunningen;

- Het Stadsgewest Haaglanden zou vervoerskundige en civieltechnische randvoorwaarden vaststellen voor het regionaal (openbaar) vervoer;

- De gemeente Delft zou de regie voeren over de stedelijke ontwikkeling en om die reden het algemeen procesmanagement verrichten. Dit betekende onder andere dat de gemeente het stedenbouwkundige plan op zou stellen en hiervoor de benodigde studies zou verrichten, dat de gemeente maatschappelijk debat, inspraak en participatie organiseert, dat zij het bestemmingsplan voorbereid en de regie voert voor de samenwerking met private partijen voor de bovengrondse stedelijke ontwikkeling. 
Bij het uitvoeren van de planstudie en het opstellen van een Nota van Uitgangspunten was de opstelling van het Ministerie van Verkeer en Waterstaat erg terughoudend. Wel participeerde het ministerie in overleggen en driemaandelijks kwam in deze periode na de ondertekening van de procesovereenkomst in februari 2002 een stuurgroep bijeen die op hoofdlijnen de regie over de verdere ontwikkeling van de spoorzone voerde.

Voor het Ministerie van VROM paste het project zeer goed bij het beleid dat uitgestippeld was in het kader van de geplande Vijfde Nota Ruimtelijke Ordening en later de Nota Ruimte. De gemeente Delft realiseerde dit en hanteerde een offensieve strategie door richting landelijke politiek druk uit te oefenen om het spoorzoneproject te financieren. Het ministerie van VROM probeerde in die periode bruggen te slaan tussen de offensieve strategie van Delft en de terughoudendheid van V\&W. De discussie in de planvorming ontstond tussen versobering (korte tunnel) en kwaliteit (lange tunnel). Het Ministerie van V\&W en ProRail stonden meer op het standpunt van versobering, terwijl het ministerie van VROM en de gemeente Delft meer voor een langere tunnel pleitten.

Met ruggensteun van marktpartijen NS en Ballast-Nedam die een bieding hadden gedaan voor de bovengrondse stedelijke (vastgoed)ontwikkeling, welke in het geval van een lange tunnel twee keer zo hoog was als voor een korte tunnel, gaf Delft an dat een lange tunnel binnen het gereserveerde budget mogelijk was. Het Ministerie van VROM wilde ook alleen in het geval van een lange tunnel bijdragen aan het project omdat dat een substantiële verbetering van de ruimtelijke kwaliteit zou betekenen passend bij het BIRK-beleid.

Het Ministerie van V\&W en ProRail waren echter minder enthousiast omdat een lange tunnel hogere investeringen en onderhoudskosten met zich mee zou brengen. ProRail was als taakorganisatie loyaal aan het Ministerie van V\&W, maar wilde naast onderhoud van bestaand spoor ook wel graag nieuwe grote projecten. Gemeente en ProRail dachten dat het goedkoper kon dan de ramingen, maar ProRail was voorzichtig omdat eerdere ramingen niet waren gehaald.

Het gevolg was dat de gemeente moest zorgen dat de stedelijke ontwikkeling een aanzienlijke bijdrage zou leveren aan de kosten voor de tunnel. Uiteindelijk kwam uit de planstudie naar voren dat op het traject door Delft tot 2020 kon worden volstaan met twee sporen. Gevolg van de uitkomsten van de planstudie was dat nog geen projectbesluit werd genomen door de Minister van Verkeer en Waterstaat en de spoorzone in Delft geen prioriteit kreeg. Het oplossen van knelpunten op de wegen en het onderhoud van het bestaande spoor had een hogere urgentie voor Verkeer en Waterstaat. In de Tweede Kamer was echter een 'linkse' meerderheid voor meer en beter openbaar vervoer. Na een sterke lobby van Delft en onder druk van de Tweede Kamer besloot de Minister van Verkeer en Waterstaat om toch mee te betalen aan de spoorzone.

Op basis van de uitkomsten uit de planstudie en de randvoorwaarden uit de Nota van uitgangspunten is vervolgens het Masterplan Spoorzone Delft opgesteld dat de hoofdlijnen van de stedelijke ontwikkeling vastlegt en visualiseert.

De actieve offensieve rol van de gemeente Delft die uit de voorgaande schets naar voren komt wordt ondersteund door de percepties van keystakeholders. Hieruit blijkt dat naast de gemeente Delft ook NS en Ballast-Nedam (later samenwerkend in de CV Spoorzone Delft), een behoorlijke inbreng in de planvorming van het Masterplan wordt toegedicht (zie figuur 8.3). 

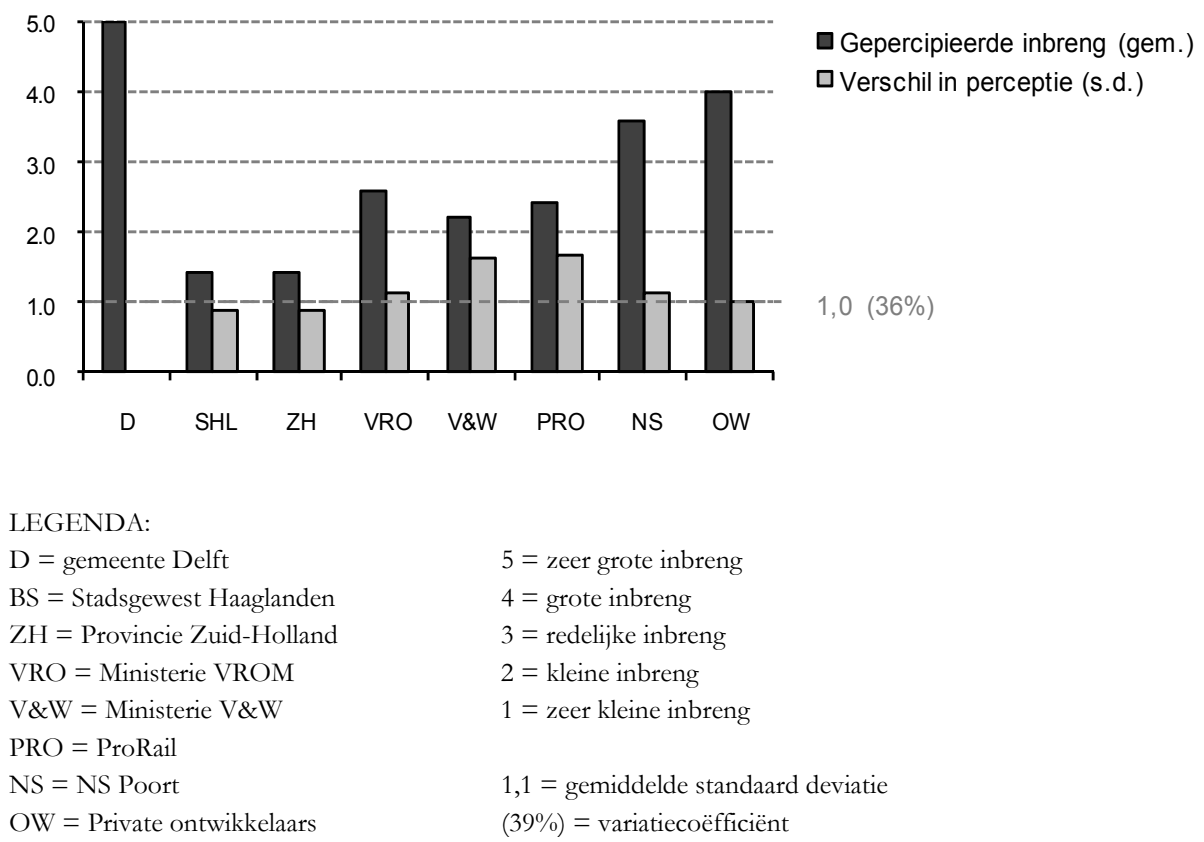

Figuur 8.3 Masterplan Spoorzone Delft - Inbreng van stakeholders in visievorming en perceptieverschillen

De grote inbreng van NS en Ballast-Nedam in dit planproces is te verklaren vanuit de prijsaanbieding voor de afname van gronden die beide partijen gezamenlijk hadden gedaan aan de gemeente Delft voorafgaand aan de vaststelling van het masterplan. Deze partijen hebben vervolgens meegedacht bij het ontwikkelen van het masterplan om te kijken of het bod overeind kon blijven. De terughoudende opstelling die het Ministerie van Verkeer en Waterstaat en ProRail ondanks het grote rijksinfrastructurele deel van het project hebben gehad correspondeert met de percepties van actoren van de inbreng van deze partijen in het proces van visievorming. In tegenstelling tot de volledige unanimiteit over de zeer grote inbreng van de gemeente Delft, blijkt dat over de inbreng van ProRail en het Ministerie van Verkeer en Waterstaat juist een zeer uiteenlopend beeld bestaat bij keystakeholders.

Zoals in eerdere hoofdstukken aangegeven kan de perceptie van de inbreng van keystakeholders ook ingegeven zijn door een bepaalde verwachting of beeld van een wenselijke situatie ${ }^{205}$. De vraag is of de zeer grote inbreng van de gemeente in het proces van visievorming voor het Masterplan ook wenselijk wordt bevonden. Uit de resultaten (figuur 8.4) blijkt dat dit zonder uitzondering het geval is.

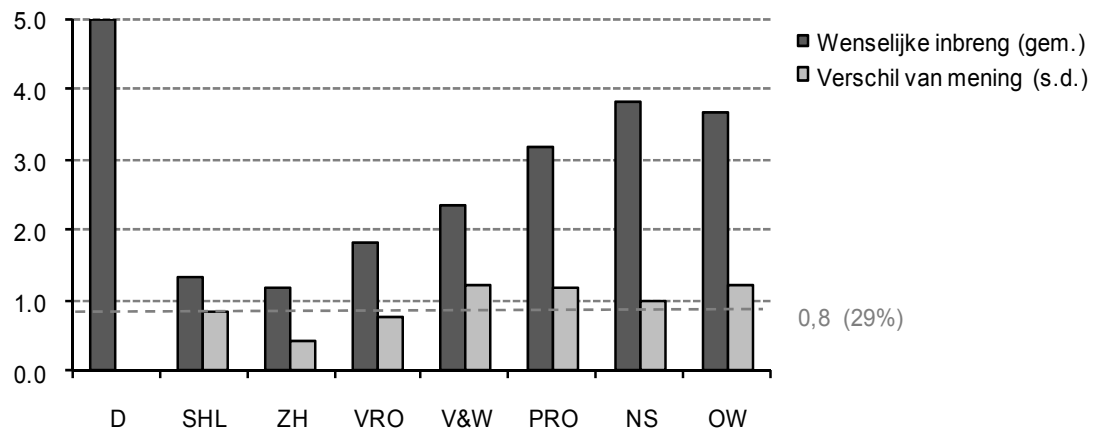

Figuur 8.4 Masterplan Spoorzone Delft - Wenselijke inbreng stakeholders in visievorming en meningsverschil 


\section{Visievorming voor de OV-knoop}

Binnen het OBS is ProRail verantwoordelijk voor het voorbereiden en realiseren van het spoorse deel van de OV-knoop. In de planuitwerking werkt zij samen met architectenbureau Benthem Crouwel. Voor het stadse deel van de OV-knoop, het gecombineerde stadskantoor/NS-station, is na een moeizaam selectieproces 206 door een commissie bestaande uit vertegenwoordigers van de gemeente Delft, NS en de spoorbouwmeester, Mecanoo als architect geselecteerd. Naast het proces van architectenselectie is door de gemeente Delft samen met NS een Programma van Eisen opgesteld dat als basis geld voor het Voorlopig Ontwerp.

Figuur 8.5 geeft weer hoe de inbreng van keystakeholders bij het uitwerken van de plannen voor de OV-knoop door betrokkenen wordt gepercipieerd. Hieruit blijkt dat de gemeente Delft, NS en ProRail de drie partijen zijn die de plannen voor de OV-knoop hebben ontwikkeld. De inbreng van andere partijen wordt door betrokkenen als aanzienlijk kleiner gepercipieerd. Daarbij geldt dat behalve voor de decentrale overheden, het beeld van de inbreng die diverse partijen hebben gehad nogal uiteenloopt.

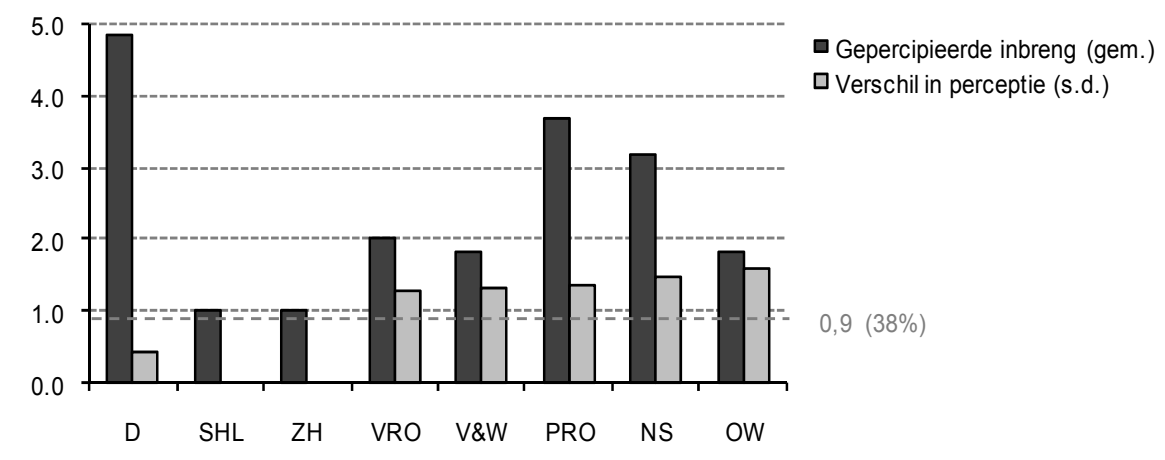

Figuur 8.5 OVT-plan Spoorzone Delft - Inbreng van stakeholders en perceptieverschillen

Als voor dit traject wordt gekeken naar de wenselijke inbreng van partijen dan blijkt uit figuur 8.6 dat de prominente rol van de gemeente in de uitwerking van de plannen wel iets minder had mogen zijn. Voor de overige partijen correspondeert het beeld van de wenselijke situatie redelijk met het beeld dat men heeft van de feitelijke inbreng van partijen in dit proces. Daarbij moet de kanttekening worden geplaatst dat de meningen over de wenselijke inbreng van partijen in dit planproces voor de OVknoop uiteen lopen.

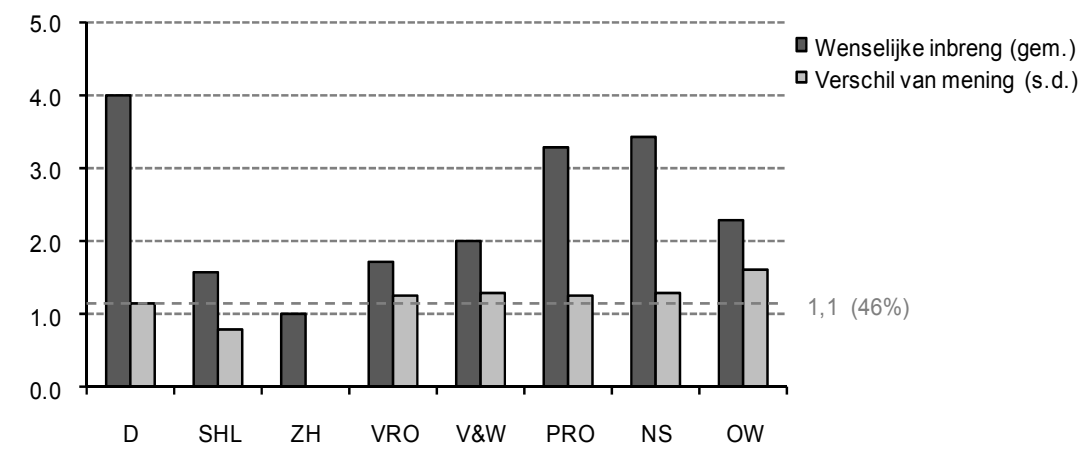

Figuur 8.6 OVT-plan Spoorzone Delft - Wenselijke inbreng van stakeholders en meningsverschillen 


\subsubsection{Zeggenschapsverdeling}

De vorige paragraaf heeft aandacht besteed aan de inbreng van partijen in het proces van visievorming van het Masterplan Spoorzone Delft en voor de OV-knoop. Hier wordt de verdeling van zeggenschap in deze processen bezien. Aan de hand van percepties van direct betrokkenen, is de zeggenschap die de diverse partijen in de planvorming hebben gehad, bestudeerd.

\section{Zeggenschapsverdeling in het planproces voor het masterplan}

Uit figuur 8.7 blijkt dat volgens betrokkenen diverse partijen een aanzienlijke hoeveelheid zeggenschap hebben gehad bij het ontwikkelen van het Masterplan Spoorzone Delft. Belangrijk in dit verband was de procesovereenkomst van februari 2002. Daarin werd vastgelegd dat de gemeente Delft in samenwerking met ProRail en onder verantwoordelijkheid van een stuurgroep, een Nota van Uitgangspunten zou vaststellen waarin de randvoorwaarden voor de integrale realisatie van de spoortunnel, het station en de stedelijke ontwikkeling in het plangebied Spoorzone Delft zouden worden beschreven. In deze stuurgroep die op hoofdlijnen de regie voerde over het gehele proces van planvorming waren alle publieke partijen vertegenwoordigd. De zeggenschap van beide rijkspartijen in dit proces blijkt ook groot te zijn geweest. Omdat de realisatie van het project voor het overgrote deel afhankelijk was van de financiële bijdrage van het ministerie van Verkeer en Waterstaat had het op die basis veel zeggenschap. Het ministerie van VROM had in de eerste fase niet zozeer zeggenschap op inhoud, maar meer door haar rol in het proces als intermediair tussen de gemeente Delft en het ministerie van Verkeer en Waterstaat. Daarnaast levert zij vanuit het BIRK een grote financiële bijdrage aan het project.

Ook NS en Ballast-Nedam wordt bij het ontwikkelen van het masterplan een behoorlijke mate van zeggenschap toegedicht. Beiden partijen participeerden niet in de stuurgroep, maar hadden vooral contact met de gemeente Delft. Verklaringen voor de grote mate van zeggenschap van deze partijen liggen in de eigendomsposities (NS), de goede relatie met de gemeente Delft (Ballast-Nedam) en de prijsaanbieding die deze partijen gezamenlijk deden aan de gemeente voor de afname van gronden voor de bovengrondse vastgoedontwikkeling.

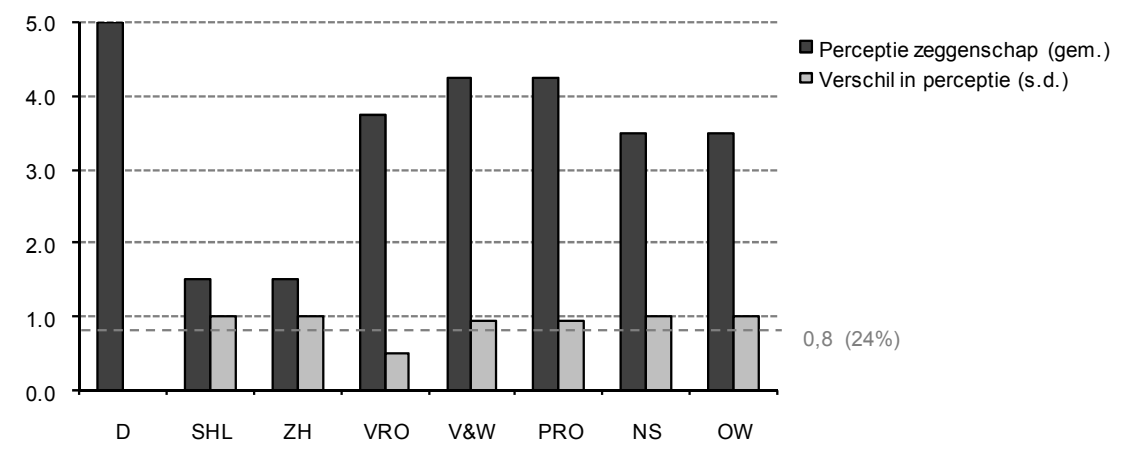

Figuur 8.7 Masterplan Spoorzone Delft - Zeggenschap en van stakeholders en perceptieverschillen

Een vergelijking met de wenselijke situatie volgens betrokkenen (zie figuur 8.8) laat zien dat de grote mate van zeggenschap van de gemeente Delft in de planvorming voor het masterplan unaniem als wenselijk wordt gezien. Dit geldt ten stelligste niet voor de zeggenschap die het ministerie van V\&W, ProRail en VROM volgens betrokkenen hebben gehad. Minder zeggenschap voor deze partijen wordt door vrijwel alle betrokkenen wenselijk geacht. Minstens zo interessant is dat - behoudens voor de 
gemeente - de meningen van betrokkenen ten aanzien van de wenselijke situatie sterk uiteen liggen. Dit geldt in het bijzonder voor V\&W en ProRail (zie figuur 8.8).

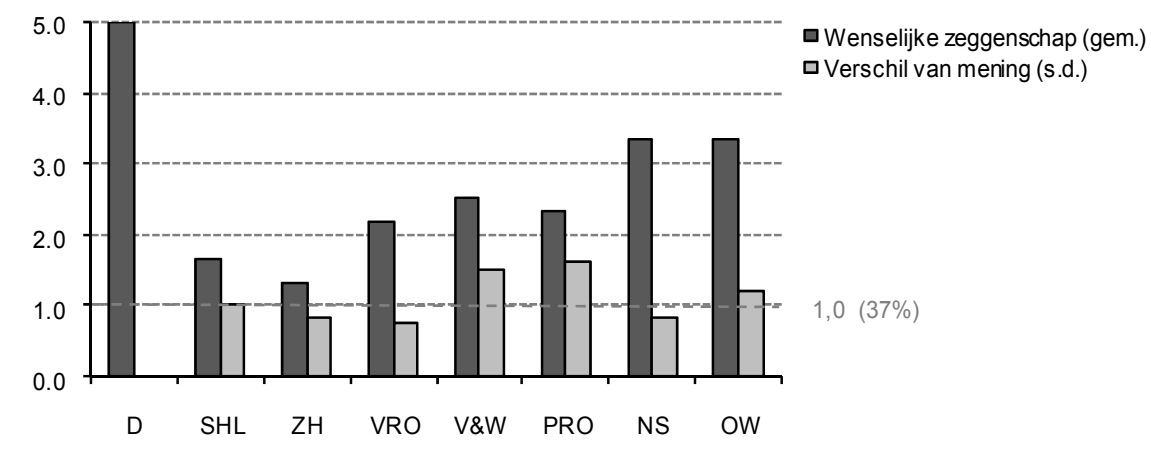

Figuur 8.8 Masterplan Spoorzone Delft - Wenselijke zeggenschapsverdeling en meningsverschillen

\section{Zeggenschapsverdeling in het planproces voor de OV-knoop}

Zoals hiervoor beschreven werken ProRail en de gemeente Delft sinds 1 januari 2007 samen in het Ontwikkelingsbedrijf Spoorzone Delft BV. De gemeente is $100 \%$ aandeelhouder van het OBS. ProRail is binnen het OBS verantwoordelijk voor het voorbereiden en realiseren van de spoorinfrastructuur en het spoorse deel van de OV-knoop. Voor het stadse deel van de OV-knoop werkt de gemeente Delft vooral samen met NS. Zij hebben een Programma van Eisen opgesteld dat als basis geld voor het Voorlopig Ontwerp. Met de provincie Zuid-Holland en het stadsgewest Haaglanden zijn afspraken gemaakt over hun bijdrage en de daaraan gekoppelde voorwaarden. Door een stuurgroep Rijk/Gemeente waarin het ministerie van VROM, het ministerie van Verkeer en Waterstaat, de gemeente Delft vertegenwoordigd waren, werd toegezien op de uitwerking van plannen. ${ }^{207}$

Het beeld van betrokkenen (zie figuur 8.9) is dat bij de uitwerking van de plannen voor de OV-knoop vooral de gemeente Delft en ProRail veel zeggenschap hebben gehad. Opmerkelijk is dat het ministerie van VROM eveneens veel zeggenschap wordt toegedicht, terwijl de eigenaar en exploitant van het oude station, NS ${ }^{208}$, in dit opzicht slechts een beperkte rol heeft gehad. Over de zeggenschap van deze partij in de planvorming voor de OV-knoop bestaan echter sterk uiteenlopende beelden.

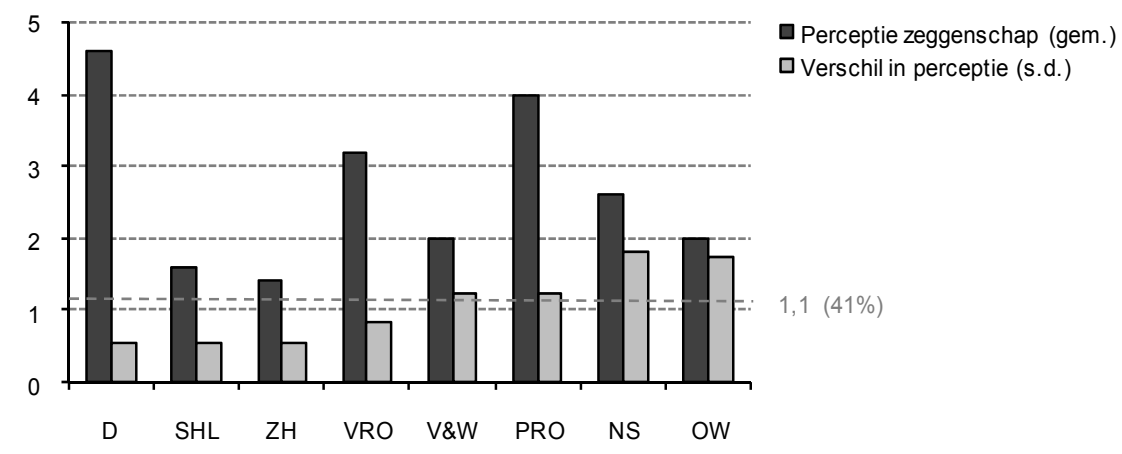

Figuur 8.9 OVT-plan Spoorzone Delft - Zeggenschap van stakeholders en perceptieverschillen 
De grote mate van zeggenschap van VROM in de planvorming voor de OV-terminal blijkt door betrokkenen niet wenselijk te worden geacht. NS had volgens hen daarentegen juist meer zeggenschap moeten hebben in dit traject. Naast Ook hier is het verschil van mening over de zeggenschap die NS en marktpartijen zouden moeten hebben in dit traject echter groot.

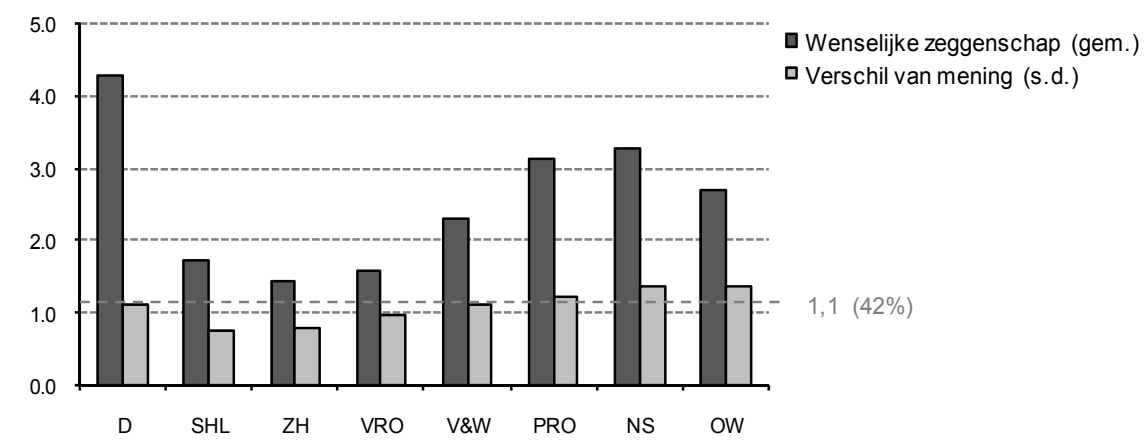

Figuur 8.10 OVT-plan Spoorzone Delft - wenselijke zeggenschapsverdeling en meningsverschillen

\subsubsection{Middelen}

De belangrijkste afspraken over de inbreng van middelen voor de herontwikkeling van de Spoorzone Delft zijn vastgelegd in de overeenkomsten tussen partijen van oktober 2005. In de bestuurlijke uitvoeringsovereenkomst tussen Rijk en gemeente Delft is opgenomen dat de financiële bijdrage van het ministerie van V\&W 269 miljoen euro (prijspeil 1 januari 2004) bedraagt en van het Ministerie van VROM 75 miljoen euro (niet geïndexeerd). Daarnaast subsidieert het stadsgewest Haaglanden voor 11,3 miljoen euro en de provincie Zuid-Holland voor 30 miljoen. De gemeente Delft draagt zelf 45,5 miljoen bij en met marktpartijen zijn afspraken gemaakt over bijdragen vanuit de opbrengst van de stedelijke ontwikkeling. In de Bestuurlijke overeenkomst uit 2005 zijn de afspraken over de financiële bijdragen vanuit het Rijk en de daaraan gekoppelde voorwaarden vastgelegd. In eerste aanleg was daarbij overeen gekomen dat vrijwel de gehele ontwikkeling voor rekening en risico van de gemeente Delft zou geschieden. De gemeente droeg daarmee in eerste aanleg vrijwel het volledige risico voor de spoorinfrastructuur. ${ }^{209}$ De inbreng van middelen door de gemeente Delft wordt door betrokkenen ook als onevenredig groot beschouwd (zie figuur 8.11). Voor het Ministerie van Verkeer en Waterstaat geldt, ondanks de grote financiële bijdrage, juist het omgekeerde.

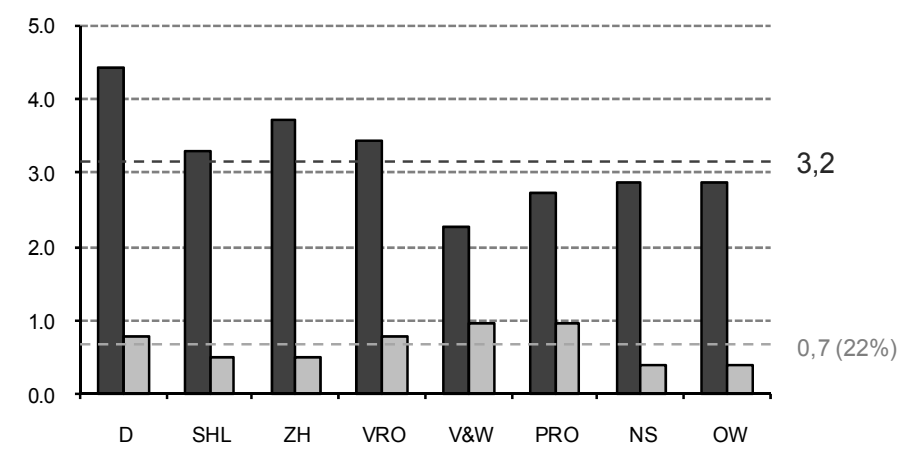

- Inbreng hulpbronnen (gem.)

$\square$ Verschil van mening (s.d.)

$1=$ veel minder dan mag worden verwacht

$2=$ minder dan mag worden verwacht

$3=$ overeenkomstig wat mag worden verwacht

$4=$ meer dan mag worden verwacht

$5=$ veel meer dan mag worden verwacht

Figuur 8.11 Spoorzone Delft - Inbreng van middelen door stakeholders en meningsverschillen 
Een belangrijke kanttekening is dat in deze studie het oordeel over de inbreng van middelen door de diverse keystakeholders betrekking heeft op de periode tot medio 2007. Beleidsmatige verschuivingen in het kader van het Urgentieprogramma Randstad hebben er meer recent voor gezorgd dat het ministerie van Verkeer en Waterstaat aanvullende financiële middelen heeft toegezegd voor verlenging van de tunnel en de voorbereiding voor toekomstige viersporigheid. Tevens heeft een heroverweging van de risicoverdeling plaatsgevonden waardoor de risico's voor de spoorinfrastructuur, het spoorse deel van de OV-knoop en de stationshal niet meer volledig bij de gemeente Delft liggen, maar grotendeels zijn verschoven naar het Ministerie van Verkeer en Waterstaat. ${ }^{210}$ Deze hernieuwde afspraken zijn vastgelegd in een Addendum op de Bestuurlijke Uitvoeringsovereenkomst van 2005 die het Ministerie van V\&W, het Ministerie van VROM en de gemeente Delft in juli 2008 hebben ondertekend.

\subsubsection{Kenmerken van de actorconstellatie}

Hiervoor is de inbreng van individuele actoren op drie kernthema's in planvorming beschreven. Het bestuderen van de relatie met de borging van het publiek belang noodzaakt niet enkel de inbreng van individuele actoren te beschrijven, maar aan de hand hiervan eveneens de constellatie van actoren te typeren. Tegen de achtergrond van de borging van het publiek belang is in hoofdstuk drie beargumenteerd dat deze actorconstellatie wordt getypeerd aan de hand van (a) het aantal actoren dat een substantiële inbreng heeft; (b) de verhoudingen tussen actoren met uiteenlopende karakters en belangenposities (publiek-privaat; centraal-decentraal; gemeente-overige); en (c) de mate van ambivalentie. Dit is gedaan voor de drie kernthema's (zie tabel 8.2)

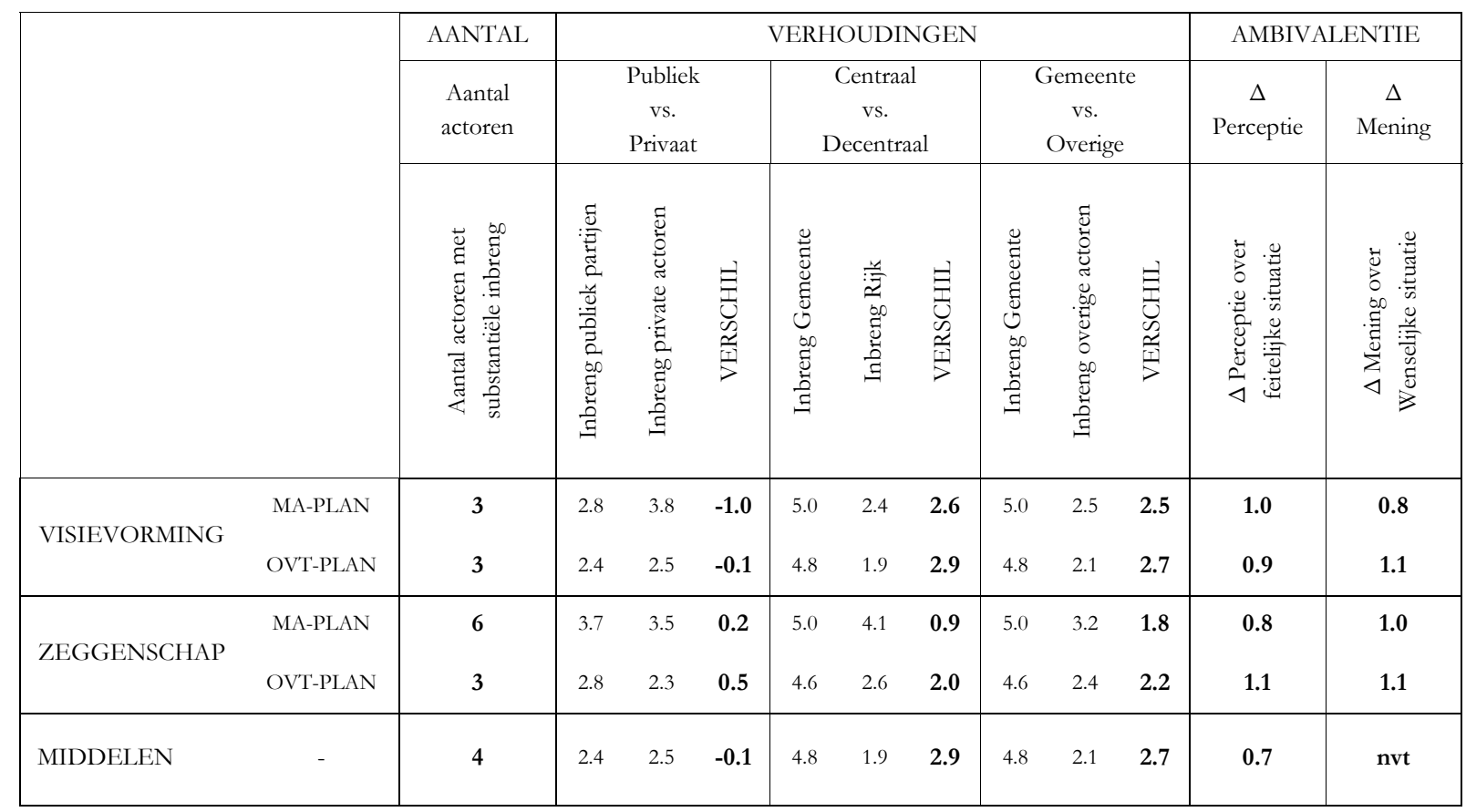

Tabel 8.2 Spoorzone Delft - Kenmerken van de actorconstellatie 


\section{Aantal actoren}

In het proces van visievorming voor het Masterplan Spoorzone Delft hebben drie keystakeholders een substantiële inbreng (gemiddelde > 3) gehad. Dit waren de gemeente Delft, NS en Ballast Nedam. Zes partijen hadden volgens betrokkenen een grote mate van zeggenschap in dit proces. Naast de gemeente Delft, NS en Ballast Nedam waren dit ook het ministerie van VROM, het ministerie van Verkeer en waterstaat en ProRail.

In het proces van visievorming voor de OV-knoop hebben drie keystakeholders een grote inbreng gehad (zie tabel 8.2). Dit waren de gemeente Delft, ProRail en NS. Een grote mate van zeggenschap in dit proces hadden eveneens drie partijen. Dit waren de gemeente Delft, ProRail en het ministerie van VROM.

Uit de data blijkt verder dat vier keystakeholders meer middelen hebben ingebracht dan van hen gegeven de kenmerken van het project mocht worden verwacht. Dit waren de gemeente Delft, het stadsgewest Haaglanden, de provincie Zuid-Holland en het ministerie van VROM.

\section{Verhoudingen tussen actoren}

De wijze waarop de samenwerking tussen actoren in het planproces vorm heeft gekregen is in de eerste paragraaf van dit hoofdstuk beschreven. Op basis van de percepties van actoren in de vorige paragraaf kunnen een aantal constateringen worden gedaan (zie tabel 8.2).

- In de verhoudingen tussen publieke (gemeente/provincie/rijk) en private (NS/ontwikkelaars) lijkt sprake te zijn van een relatief grote inbreng van private zijde in het proces van visievorming. Dit geldt vooral voor het masterplan. Zoals beschreven hebben NS en Ballast-Nedam nadrukkelijk meegedacht bij het ontwikkelen van dit plan om te kijken of de gedane prijsaanbieding voor de bovengrondse stedelijk ontwikkeling gestand kon worden gedaan. De inbreng van deze partijen in de planvorming voor de OV-knoop is beperkter. Ballast-Nedam had hier geen positie en de commerciële belangen van NS bij station Delft zijn relatief beperkt.

Waar in het proces van visievorming private partijen een relatief grote inbreng hebben, lijkt qua zeggenschap min of meer het omgekeerde het geval. De zeggenschap van private partijen in het planproces voor de OV-knoop is volgens betrokkenen zeer beperkt geweest. Qua middelen blijkt de inbreng van publieke en private zijde in balans.

- In de verhouding tussen de centraal (Rijk) en decentraal (gemeente) blijkt qua visievorming en qua middelen de gemeente Delft een aanzienlijk grotere inbreng te hebben gehad dan het Rijk. De zeggenschap van het Rijk in de planvorming van het Masterplan Spoorzone Delft was echter aanzienlijk.

- Ook als de inbreng van de gemeente Delft wordt afgezet tegen die van alle andere keystakeholders komt uit de data het beeld naar voren dat de gemeente in de planvorming een zeer belangrijke rol heeft gespeeld. Haar inbreng in het proces van visievorming, haar zeggenschap in dat proces én haar inbreng van middelen wordt door vrijwel alle betrokkenen als zeer groot bestempeld. 


\section{Ambivalentie}

De ambivalentie in de actorconstellatie is geanalyseerd door te kijken naar de mate waarin (a) percepties van de feitelijke inbreng van actoren verschillen en (b) de mate waarin meningen over de wenselijke inbreng van actoren verschillen.

- De data laat zien dat de perceptie van de inbreng van diverse partijen behoorlijk verschilt. Dat geldt voor alle drie thema's. De zeer grote inbreng van de gemeente Delft in de planvorming wordt wel door vrijwel allen als zodanig gepercipieerd.

- Over de vraag welke inbreng in het planproces als wenselijk moet worden beschouwd voor diverse keystakeholders lopen de meningen eveneens uiteen. De zeer grote inbreng van de gemeente in het planproces van het masterplan Centraal Breda wordt unaniem als wenselijk beschouwd. Over de wenselijke inbreng voor andere actoren bestaat op vrijwel alle thema's meer verschil van mening.

\subsection{Publiek belang}

In de vorige paragraaf is aan de hand van een drietal thema's het samenstel van actoren in het planproces beschreven. Deze paragraaf gaat in op de borging van het publiek belang. Zoals in de eerste hoofdstukken is beargumenteerd, wordt daarvoor gefocust op de effectiviteit en legitimiteit van het planproces.

\subsubsection{Legitimiteit}

In de analyse is legitimiteit onderverdeeld in een drietal vormen; inputlegitimiteit, throughputlegitimiteit en outputlegitimiteit. Deze drie vormen van legitimiteit zijn aan de hand van een aantal indicatoren geanalyseerd. Het onderscheid tussen het planproces van het masterplan en het planproces voor de OV-terminal is daarbij aangehouden.

\section{Inputlegitimiteit ${ }^{211}$}

De legaliteit en openheid van het planproces zijn gebruikt als maatstaf voor inputlegitimiteit. Legaliteit is geëvalueerd aan de hand van de mate waarin relevante procedures en regelgeving naar het oordeel van betrokkenen op correcte wijze zijn toegepast. In de uitvoeringsovereenkomst ${ }^{212}$ tussen Rijk en gemeente is opgenomen, dat de gemeente ervoor zorg draagt dat bij de uitvoering van het project de toepasselijke wet- en regelgeving wordt nageleefd, waaronder het toepasselijke (Europese) aanbestedings- en mededingingsrecht. Uit de analyse van de data blijkt dat alle partijen van mening zijn dat relevante procedures en regelgeving op correcte tot zeer correcte wijze zijn toegepast gedurende het planproces. Op grond van deze oordelen is er geen reden om aan te nemen dat gehandeld is in strijd met van toepassing zijnde procedures en regelgeving.

De openheid van het planproces is geëvalueerd aan de hand van het oordeel van partijen over (1) de vraag of alle relevante partijen toegang hebben gehad tot het planproces; (2) de mate waarin de eigen en andere organisaties mogelijkheden hebben gehad het proces te beïnvloeden. Het oordeel over deze indicatoren voor het traject gericht op het ontwikkelen van het Masterplan Spoorzone Delft en het 
deelplan voor de OV-knoop is geconfronteerd met een algemeen oordeel over de openheid van het planproces als geheel. De resultaten staan weergegeven in tabel 8.3.

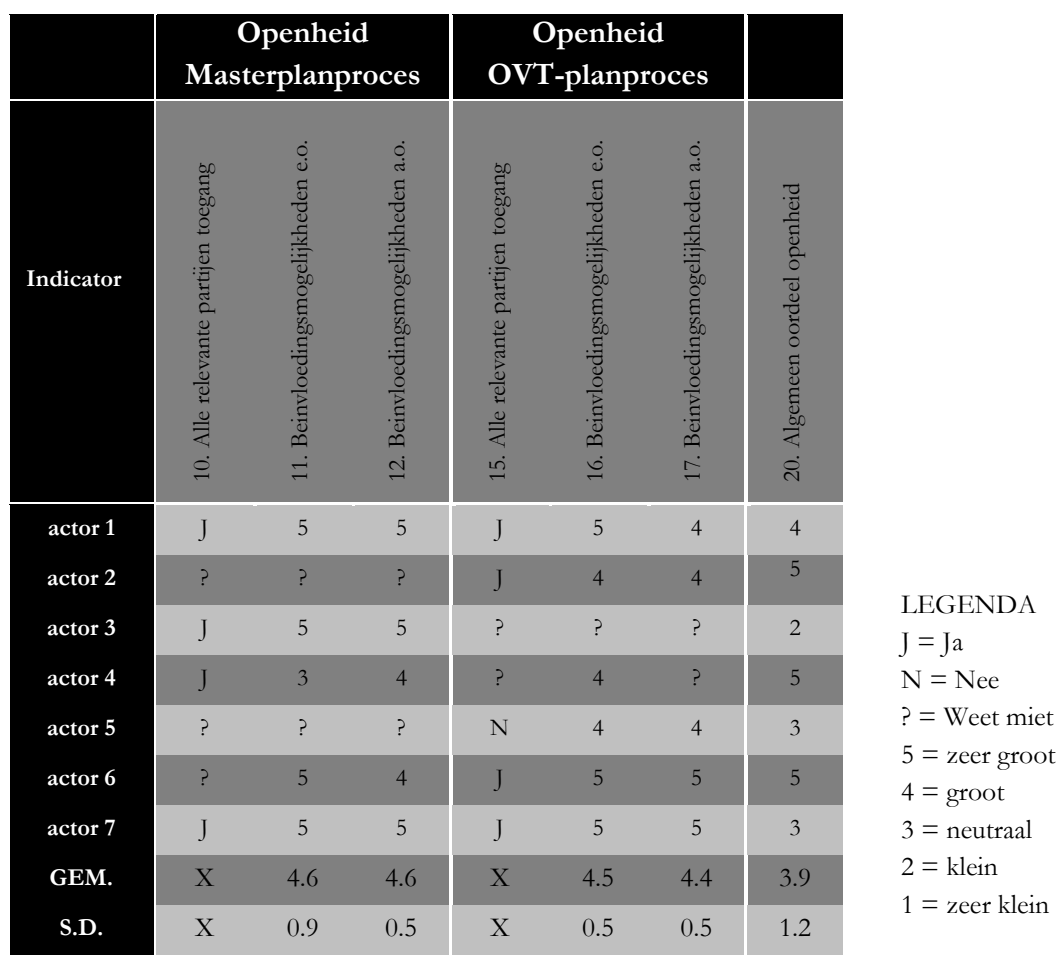

Tabel 8.3 Spoorzone Delft - Mate van openheid van het planproces

Uit de data blijkt dat de openheid van zowel het masterplantraject als het traject voor de OV-knoop behoorlijk groot wordt geacht. Voor zover betrokkenen in staat was hierover te oordelen, waren vrijwel alle betrokkenen van mening dat alle relevante partijen toegang hebben gehad tot het planproces en dat de mogelijkheden van zowel de eigen organisatie als die van andere organisaties om invloed uit te oefenen in het planproces ruim voldoende waren. Hoewel ook het algemene oordeel over de openheid van het planproces als groot (gemiddelde 3,9) wordt gezien komt uit de oordelen over de indicatoren voor beide trajecten afzonderlijk een positiever beeld naar voren. Partijen zijn redelijk eenduidig in hun oordeel hierover. Een enkele uitzondering daargelaten beoordelen zij de openheid van zowel het planproces van het Masterplan Spoorzone Delft als het planproces van het deelplan voor de gecombineerde OV-terminal/stadskantoor positief $(>3)$

\section{Throughputlegitimiteit ${ }^{213}$}

De transparantie van de planprocessen is gehanteerd als maatstaf voor throughputlegitimiteit. Daarvoor is geanalyseerd in welke mate het voor partijen duidelijk was wie, waarover en op welk moment in het planproces besliste; in welke mate inhoudelijke wensen en voorkeuren van partijen helder waren; en in welke mate de honorering daarvan in de plannen en de bijbehorende argumentatie helder was. De resultaten staan gepresenteerd in tabel 8.4. 
Uit de data in de tabel blijkt dat zowel het masterplantraject als het traject gericht op de totstandkoming van het deelplan voor de OV-knoop als redelijk transparant worden beschouwd (beide 3.7). Hoewel - kijkend naar de gemiddelden over de indicatoren - op alle indicatoren een positief beeld naar voren komt, blijkt wel dat voor een aantal direct betrokkenen het planproces op onderdelen juist niet helder was. Er komt echter geen eenduidig beeld naar voren waaruit blijkt dat dit voor een van de indicatoren in sterkere mate het geval is dan voor een andere indicator.

\begin{tabular}{|c|c|c|c|c|c|c|c|c|c|c|c|c|}
\hline \multirow[b]{2}{*}{ Indicator } & \multicolumn{6}{|c|}{$\begin{array}{c}\text { Transparantie } \\
\text { Masterplanproces }\end{array}$} & \multicolumn{6}{|c|}{$\begin{array}{c}\text { Transparantie } \\
\text { OVT-planproces }\end{array}$} \\
\hline & 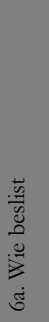 & 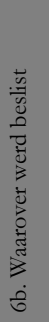 & 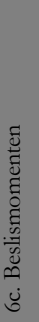 & 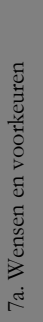 & 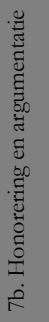 & $\mathbf{T}$ & 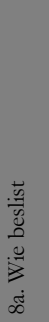 & 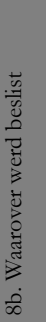 & 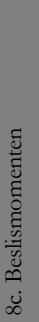 & 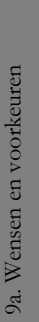 & 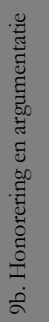 & $\mathbf{T}$ \\
\hline actor 1 & 4 & 4 & 4 & 4 & 4 & 4.0 & 2 & 2 & 3 & 4 & 3 & 2.8 \\
\hline actor 2 & $?$ & $?$ & $?$ & $?$ & $?$ & $?$ & 4 & 4 & 4 & 4 & 4 & 4.0 \\
\hline actor 3 & 2 & 2 & 4 & 2 & 3 & 2.6 & $?$ & $?$ & $?$ & $?$ & $?$ & $?$ \\
\hline actor 4 & 4 & 4 & 4 & 4 & 4 & 4.0 & 4 & 4 & 4 & 4 & 3 & 3.8 \\
\hline actor 5 & 4 & 3 & 4 & 3 & 4 & $?$ & 2 & 4 & 4 & 2 & 4 & 3.2 \\
\hline actor 6 & 4 & 3 & 2 & 2 & 3 & 2.8 & 3 & 4 & 2 & 4 & 4 & 3.4 \\
\hline actor 7 & 5 & 5 & 5 & 5 & 5 & 5.0 & 5 & 5 & 5 & 5 & 5 & 5.0 \\
\hline GEM. & 3.8 & 3.4 & 3.8 & 3.3 & 3.8 & 3.7 & 3.3 & 3.8 & 3.7 & 3.8 & 3.8 & 3.7 \\
\hline S.D. & 1.1 & 1.1 & 1.1 & 1.3 & 0.8 & 1.1 & 1.2 & 1.0 & 1.0 & 1.0 & 0.8 & 0.8 \\
\hline
\end{tabular}

$$
\begin{aligned}
& \text { LEGENDA } \\
& 5=\text { zeer helder } \\
& 4=\text { helder } \\
& 3=\text { neutraal } \\
& 2=\text { onhelder } \\
& 1=\text { zeer onhelder } \\
& ?=\text { weet niet } \\
& \text { T = gemiddelde }
\end{aligned}
$$

Tabel 8.4 Spoorzone Delft - Mate van transparantie van het planproces

\section{Outputlegitimiteit}

Voor outputlegitimiteit is gekeken naar de steun van keystakeholders voor de plannen. Deze steun is geanalyseerd aan de hand van hun oordeel over; de mate waarin in het Masterplan respectievelijk het OVT-plan rekening is gehouden met hun wensen en doelen; de mate waarin zij zich gecommitteerd voelen aan beide plannen; en de mate waarin zij van mening zijn dat het Masterplan en het OVT-plan aanvaardbare compromissen zijn voor de in het planproces participerende partijen. Daarnaast is gevraagd een rapportcijfer toe te kennen aan beide plannen. De resultaten staan weergegeven in tabel 8.5 .

Uit de data blijkt dat de steun voor zowel het Masterplan als het plan voor de OV-knoop gemiddeld genomen behoorlijk groot is (4,2 resp. 4,4). Ook verschillen partijen hierover slechts beperkt van mening en een enkele uitzondering daargelaten is de steun voor beide plannen groot. Beide plannen worden door alle partijen beschouwd als een aanvaardbaar compromis, vrijwel allen voelen zich sterk gecommitteerd aan de plannen en ook is men van mening dat in beide plannen meer dan voldoende rekening is gehouden met hun wensen en voorkeuren. De hoge rapportcijfers voor beide plannen 
onderbouwen dit positieve oordeel verder. Op basis van deze resultaten kan worden geconcludeerd dat de steun voor de plannen zeer groot is.

\begin{tabular}{|c|c|c|c|c|c|c|c|c|c|c|c|}
\hline \multirow[b]{2}{*}{ Indicator } & \multicolumn{5}{|c|}{$\begin{array}{c}\text { Steun } \\
\text { Masterplan }\end{array}$} & \multicolumn{5}{|c|}{$\begin{array}{c}\text { Steun } \\
\text { OVT-plan }\end{array}$} & \\
\hline & 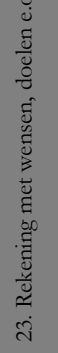 & 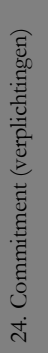 & 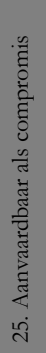 & $\mathbf{T}$ & 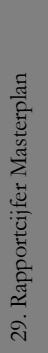 & 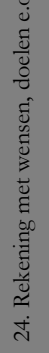 & 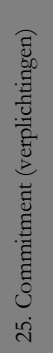 & 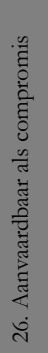 & $\mathbf{T}$ & 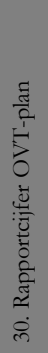 & \\
\hline actor 1 & 5 & 5 & 5 & 5.0 & 9 & 5 & 5 & 4 & 4.7 & 8 & \\
\hline actor 2 & 4 & $?$ & $?$ & $?$ & 8 & 4 & $?$ & $?$ & $?$ & $?$ & \\
\hline actor 3 & 4 & 3 & 4 & 3.7 & 8 & $?$ & $?$ & $?$ & $?$ & ? & \\
\hline actor 4 & 3 & 4 & 4 & 3.7 & 8 & 4 & 4 & 4 & 4.0 & 7 & LEGENDA \\
\hline actor 5 & 4 & 5 & 4 & 4.3 & 7 & 4 & 5 & 4 & 4.3 & 7 & $5=$ zeer sterk $/$ zeer veel $/$ helemaal eens \\
\hline actor 6 & 4 & 5 & 4 & 4.3 & 8 & 4 & 5 & 5 & 4.7 & $?$ & $\begin{array}{l}4=\text { sterk } / \text { veel } / \text { mee eens } \\
3=\text { neutraal }\end{array}$ \\
\hline actor 7 & 4 & 5 & 4 & 4.3 & 8 & 4 & 5 & 4 & 4.3 & 8 & $2=$ zwak $/$ weinig $/$ mee oneens \\
\hline GEM. & 4.0 & 4.5 & 4.2 & 4.2 & 8.0 & 4.2 & 4.8 & 4.2 & 4.4 & 7.5 & $1=$ zeer zwak/zeer weinig/helemaal oneens \\
\hline S.D. & 0.7 & 0.9 & 0.4 & 0.6 & 0.6 & 0.4 & 0.4 & 0.4 & 0.3 & 0.6 & $\begin{array}{l}?=\text { weet niet } \\
\mathrm{T}=\text { gemiddelde }\end{array}$ \\
\hline
\end{tabular}

Tabel 8.5 Spoorzone Delft - Mate van steun voor de plannen

\subsubsection{Effectiviteit}

In de Bestuurlijke Uitvoeringsovereenkomst ${ }^{214}$ staat dat een beschrijving van de ruimtelijke kwaliteit is neergelegd in het Masterplan en het Ruimtelijk Functioneel Ontwerp OV-knoop. Het bouwmeestersoverleg, bestaande uit de rijksbouwmeester, de spoorbouwmeester en de gemeentelijke vertegenwoordiger voor stedenbouwkundige kwaliteit adviseert de Stuurgroep Rijk/Gemeente over de realisatie van de ruimtelijke kwaliteit van de OV-knoop door de gemeente. In deze studie is voor een oordeel over de effectiviteit van de planvorming gekeken naar de verwachtingen van betrokkenen over de bijdrage van het Masterplan respectievelijk het deelplan voor de OV-knoop aan het verhogen van de ruimtelijke kwaliteit in het plangebied.

Omdat ruimtelijke kwaliteit niet eenduidig te definiëren valt is in de operationalisering de reeks van ontwerpeisen - gebruikerswaarde, belevingswaarde en toekomstwaarde - gekruist met belangen economisch, sociaal, ecologisch - wat leidt tot een negental dimensies van ruimtelijke kwaliteit. Stationslocaties hebben bepaalde kenmerken en dientengevolge zijn er - vanuit de belangen van betrokken actoren - bepaalde zwaartepunten in deze dimensies van ruimtelijke kwaliteit. Aan partijen is daarom gevraagd wat voor hun organisatie de drie belangrijkste elementen van ruimtelijke kwaliteit zijn in het project. Dit leidt voor het project Spoorzone Delft tot de zwaartepunten zoals weergegeven in figuur 8.12. 


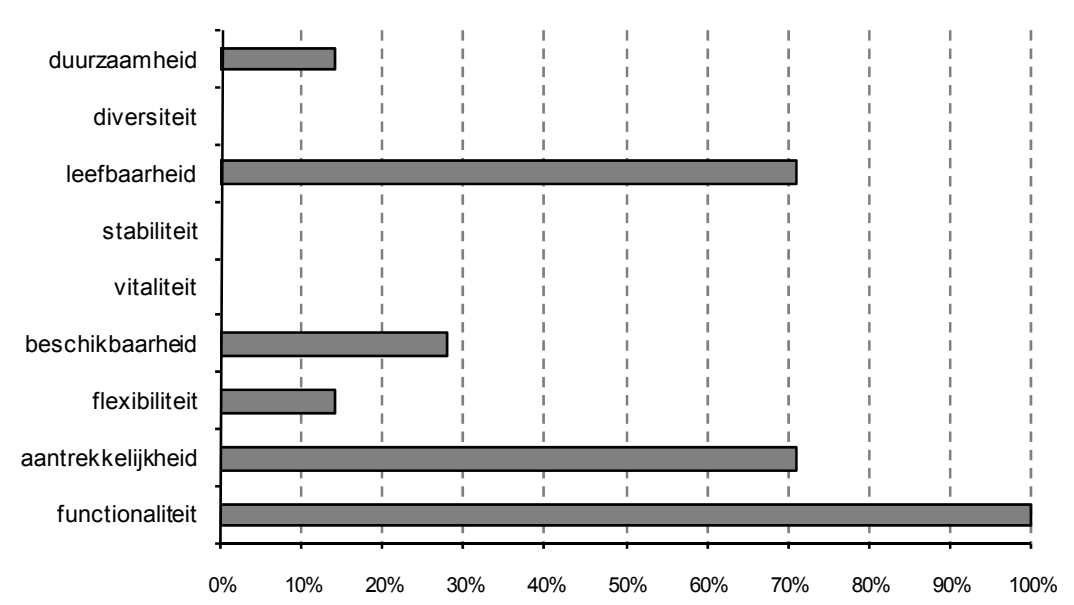

Figuur 8.12 Spoorzone Delft - Zwaartepunten in de dimensies van ruimtelijke kwaliteit

Uit de resultaten gepresenteerd in figuur 8.12 blijkt dat alle actoren het verhogen van de functionaliteit van het plangebied tot de belangrijkste aspecten van ruimtelijke kwaliteit rekenen. Daarnaast blijken het vergroten van de aantrekkelijkheid en leefbaarheid twee andere hoofddragers van ruimtelijke kwaliteit te zijn. De effectiviteit van planvorming is geanalyseerd aan de hand van de bijdrage die het Masterplan respectievelijk het ontwerp voor de OV-knoop levert aan deze dimensies. Op basis van de resultaten in figuur 8.13 kan worden gesteld dat de verwachtingen bij betrokkenen hierover zeer positief zijn (4,4 resp. 4.1).

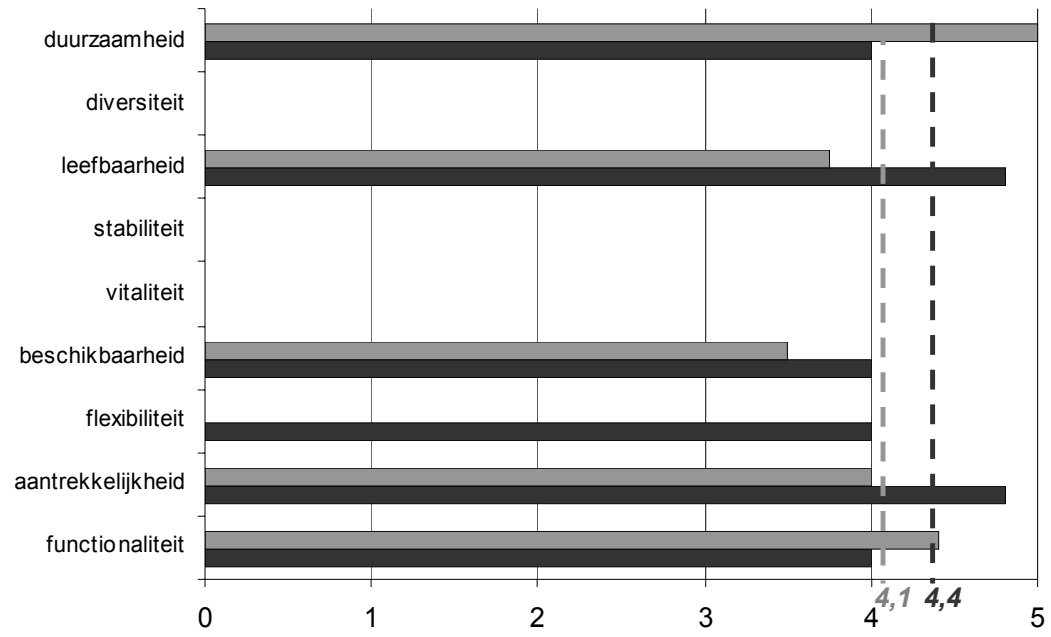

$\square$ Verwachte bijdrage OVT-plan aan ruimtelijke kwaliteit (gem. 4,1)

- Verwachte bijdrage M asterplan aan ruimtelijke kwaliteit (gem. 4,4)

$5=$ zeer groot

$4=$ groot

$3=$ neutraal

$2=\mathrm{klein}$

$1=$ zeer klein

Figuur 8.13 Spoorzone Delft - Bijdrage van de plannen aan de dimensies van ruimtelijke kwaliteit

Het oordeel over de verwachte bijdrage van het Masterplan respectievelijk het plan voor de OVknoop aan de ruimtelijke kwaliteit op de voor het project relevante dimensies moet worden gezien in het licht van een drietal elementen; het ambitieniveau, de helderheid en de meetbaarheid/evalueerbaarheid van de plannen. In figuur 8.14 is het oordeel over deze elementen voor beide plannen weergegeven. Hieruit blijkt dat het ambitieniveau van de plannen vrijwel unaniem als zeer hoog wordt bestempeld, de plannen helder zijn en de beschrijving van de resultaten goed evalueerbaar is. 


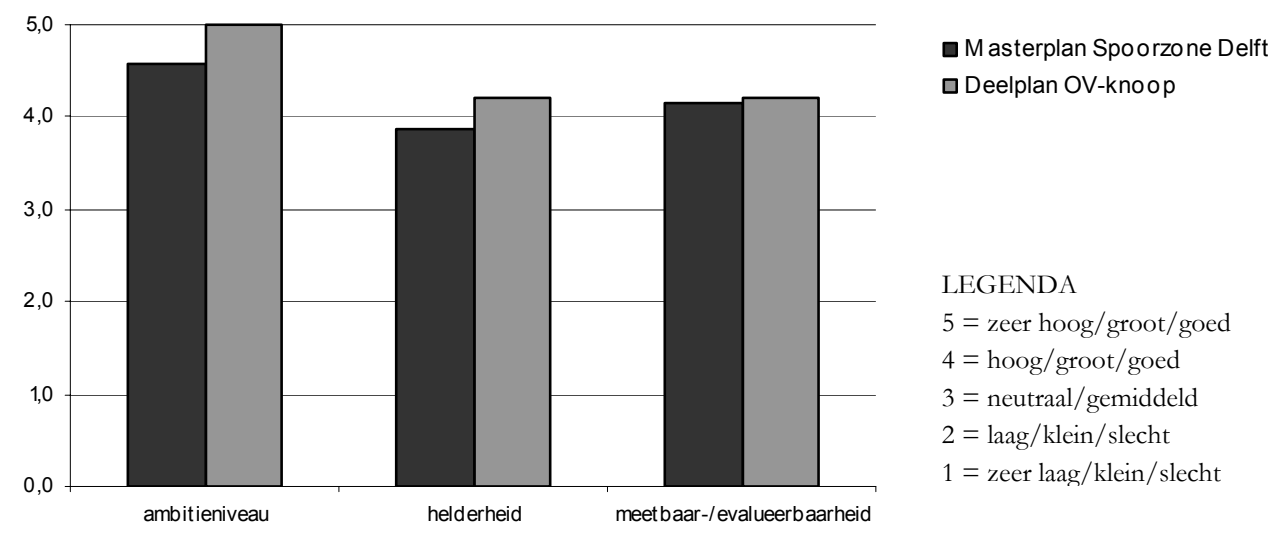

Figuur 8.14 Spoorzone Delft - Ambitieniveau, helderheid en evalueerbaarheid van plannen

\subsection{Slot}

Aan het begin van dit hoofdstuk is al beschreven dat het project Spoorzone Delft een lange en buitengewoon moeizame historie kent. Gedurende dat proces was bij herhaling onzeker of het project daadwerkelijk doorgang zou vinden. De belangrijkste oorzaak hiervoor was de terughoudende opstelling van het ministerie van Verkeer en Waterstaat. Het spoorzoneproject was zogezegd geen project van het ministerie van Verkeer en Waterstaat, maar zij werd door middel van een motie in de Tweede Kamer gedwongen hier uitvoering aan te geven. Een sterke lobby van gemeente en regionale overheden richting politiek ging hieraan vooraf.

Zoals uit de analyse van het planproces naar voren komt heeft het ministerie van Verkeer en Waterstaat ook slechts een beperkte inbreng gehad bij het ontwikkelen van plannen voor de spoorzone. Niettemin was de afhankelijkheid van het ministerie van Verkeer en Waterstaat groot waardoor zij juist wel veel zeggenschap had in het proces. Deze spanning wordt door betrokkenen ook als zodanig gepercipieerd en niet beschouwd als wenselijk. De relatie tussen de gemeente Delft en het ministerie van Verkeer en Waterstaat was zeker in het beginstadium dan ook moeizaam. Om het project toch doorgang te laten vinden heeft de gemeente grote risico's op zich genomen en zelf nadrukkelijk het voortouw genomen. Daarbij heeft zij in de planvorming voor de gebiedsontwikkeling vooral samengewerkt met private partijen (NS en Ballast-Nedam) en voor de OV-knoop met spoorgerelateerde partijen NS en ProRail.

Deze rolverdeling wordt door betrokkenen ook als wenselijk beschouwd, met de kanttekening dat een wat beperktere rol voor gemeente waar het gaat om spoorgerelateerde onderdelen de voorkeur heeft. Het is ook de vraag of een dergelijke voortrekkersrol en de omvangrijke risico's van een project als de Spoorzone Delft volledig horen te liggen bij de gemeente. Vanuit het perspectief van de gemeente heeft het ervoor gezorgd dat het project doorgang vond. Daarentegen heeft het in een later stadium geleid tot stagnaties in het proces. De opvattingen van betrokkenen zijn ook dat het ministerie van Verkeer en Waterstaat hier haar verantwoordelijkheid meer had moeten nemen. $\mathrm{Na}$ heronderhandelingen tussen decentrale overheden en het Rijk is de risicoverdeling meer recent dan ook sterk gewijzigd ten gunste van de gemeente en zijn er extra bijdragen toegezegd vanuit het Rijk. Ondanks het moeizame verloop van het proces wordt de planvorming zowel de planvorming van het Masterplan Masterplan Spoorzone Delft als de planvorming van het deelplan voor de OV-terminal 
als effectief en legitiem beoordeeld. Het planproces is volgens betrokkenen voldoende open geweest, de steun voor de plannen bij deze keystakeholders is erg groot en de verwachting is dat de plannen een grote bijdrage leveren aan vooral de leefbaarheid, aantrekkelijkheid en functionaliteit van het gebied. Slechts de opvattingen over de transparantie van het planproces zijn niet bij alle betrokkenen positief. 


\section{Hoofdstuk 9}

\section{Cross-case analyse}

In de hoofdstukken $6 \mathrm{t} / \mathrm{m} 8$ zijn de cases die in deze studie zijn gebruikt afzonderlijk beschreven. Dit hoofdstuk vergelijkt de resultaten die daaruit naar voren zijn gekomen. Hiermee wordt antwoord gegeven op de vierde onderzoeksvraag: in hoeverre bestaat er een samenhang tussen de inrichting van het proces en de criteria voor het publiek belang? Deze cross-case analyse is uitgevoerd in vier stappen.

1. Analyse van verschillen en overeenkomsten in projectkenmerken (9.1)

2. Analyse van verschillen en overeenkomsten in procesinrichting (9.2)

3. Analyse van verschillen en overeenkomsten in de mate waarin de procesinrichtingen voldoen aan de criteria voor de borging van het publiek belang (9.3)

4. Analyse van mogelijke samenhang tussen de procesinrichting en de criteria voor de borging van het publiek belang (9.4)

Deze stappen worden in de eerste vier paragrafen beschreven. Het hoofdstuk wordt afgesloten met een overzicht van de bevindingen (9.5).

\subsection{Analyse van verschillen en overeenkomsten in projectkenmerken}

In literatuur wordt het belang van de context voor het handelen van actoren veelvuldig benadrukt (zie o.a. Ostrom, 1994; Bryson en Bromiley, 1993; De Graaf, 2005; e.a.). Contextfactoren kunnen als gevolg daarvan van substantiële invloed zijn op het verloop van processen of het resultaat daarvan. Om aan de hand van de empirische data van een beperkt aantal cases gericht de relatie tussen de inrichting van het proces en de borging van het publiek belang te bestuderen, is getracht het verschil in context zo veel mogelijk te beperken. Daarom zijn de drie cases alle projecten die de integrale herontwikkeling van vastgoed, (rijks)infrastructuur en openbare ruimte in en rondom een (zeer) groot treinstation betreffen in het centrum van een (middel)grote stad in Nederland. Deze selectiecriteria zorgen ervoor dat de kenmerken van de projecten grotendeels overeen komen. De relevante partijen, hun posities en afhankelijkheden, de van toepassing zijnde regelgeving en het beleidskader zijn hierdoor in grote lijn hetzelfde. In hoofdstuk vijf zijn deze aspecten voor stationslocatieprojecten binnen de Nederlandse context uitvoerig beschreven. Ondanks dat de drie cases voldoen aan de gehanteerde selectiecriteria, zijn er enkele onderdelen waarop ze verschillen. In deze paragraaf worden twee verschillen, welke relevant kunnen zijn voor de positie en rol van partijen in het proces, toegelicht. Het gaat om de ruimtelijke opgave en het beleidskader op nationaal niveau. 


\subsubsection{Ruimtelijke opgave}

Stationslocatieprojecten onderscheiden zich van andere binnenstedelijke gebiedsontwikkelingen doordat de herontwikkeling van het station als knooppunt van vervoersstromen/modaliteiten een cruciaal onderdeel van het project vormt. In alle drie cases betreft de ruimtelijke opgave dan ook de vernieuwing of upgrade van het centraal station en de directe omgeving daarvan. Niettemin verschilt de opgave op twee onderdelen wezenlijk tussen de cases. ${ }^{215}$

Het eerste onderdeel is het infrastructurele programma. In alle drie cases is er sprake van gehele of gedeeltelijke vernieuwing van de OV-terminal en ingrepen ten behoeve van de verkeerskundige ontsluiting ervan. In Delft maakt daarnaast de aanleg van een 2300 meter lange spoortunnel onderdeel uit van de plannen. Het ministerie van Verkeer en Waterstaat is bestuurlijk verantwoordelijk voor rijksspoorinfrastructuur. ProRail is als verzelfstandigde taakorganisatie belast met de uitvoering van het ministeriële beleid op dit terrein. In Den Haag en Breda is de betrokkenheid van deze twee partijen vooral gebaseerd op de verbondenheid van de plannen met de komst van de hogesnelheidslijn en de directe verantwoordelijkheid van deze partijen voor adequate transfervoorzieningen op beide stations.

Een tweede onderdeel waarop de ruimtelijke opgave wezenlijk verschilt, is het vastgoedprogramma. De totale omvang van de vastgoedprogramma's komt weliswaar redelijk overeen, echter de verdeling over verschillende vastgoedfuncties en de omvang van het commerciële vastgoedprogramma in de plannen voor de OV-terminals, verschilt aanzienlijk. Zo is het woningbouwprogramma in het gehele plangebied van de Spoorzone Delft aanzienlijk groter dan in beide andere cases, terwijl de omvang van het commerciële vastgoedprogramma binnen de OV-knoop in Delft relatief klein is. In Breda bestaat het programma voor het OVTC juist voor een zeer groot deel uit commercieel vastgoed. NS ontwikkelt dit voor haar rekening en risico. Hetzelfde geldt voor de OV-terminal in Den Haag.

\subsubsection{Beleidskader}

Het ligt voor de hand te veronderstellen dat verschillen in ruimtelijke opgave van invloed zijn op de rol van partijen in het proces. Zo kan worden verwacht dat in Delft - vanwege het zeer omvangrijke deel rijksspoorinfrastructuur - een belangrijke rol is weggelegd voor het ministerie van Verkeer en Waterstaat en ProRail. Ook verschillen in beleidskader kunnen relevant zijn voor de rol van partijen. Belangrijk verschil tussen Den Haag Nieuw Centraal en Stationskwartier Breda enerzijds en de Spoorzone Delft anderzijds is dat de laatste niet de status van sleutelproject heeft. De sleutelprojecten moeten in de visie van het Rijk direct bijdragen aan de internationale concurrentiekracht van de Nederlandse economie. In het kader van het beleid voor deze projecten heeft het Rijk een apart budget vrijgemaakt, een specifieke procesarchitectuur ontwikkeld en een rijksprojectorganisatie opgezet. Vanwege het nationale belang dat aan deze projecten wordt toegekend, ziet het Rijk ook een directe rol in de planvorming voor zichzelf weggelegd en toetst het de stedenbouwkundige, vervoerskundige en financiële onderbouwing van het masterplan. Goedkeuring van het masterplan op deze onderdelen is voorwaarde voor de toekenning van middelen door het Rijk. Voor Den Haag en Breda vormde de komst van de hogesnelheidslijn en de daaraan verbonden status als sleutelproject een belangrijke aanleiding voor de aanpak van het station en de omgeving daarvan. Hoewel daarvoor in beide steden ook al plannen waren voor de aanpak van de gebieden, kregen deze plannen door het sleutelprojectenbeleid een nieuwe impuls. 
De Spoorzone Delft is geen sleutelproject. De prioriteit die in het rijksbeleid wordt gegeven aan de sleutelprojecten betekent echter niet dat het spoorzoneproject niet door het Rijk wordt ondersteund. In het beleid van het ministerie van VROM staat het streven naar duurzame kwaliteit van de leefomgeving centraal. De plannen van Delft voor een spoortunnel en gebruik van de bovengronds vrijgekomen ruimte sluiten goed aan bij dit beleid en in het bijzonder bij een van de speerpunten daarvan, de intensivering en herstructurering van ruimtegebruik rond knooppunten van openbaar vervoer. Vanuit het Budget Investeringen Ruimtelijke Kwaliteit (BIRK) worden door het ministerie van VROM projecten van lagere overheden die - door intensivering van ruimtegebruik, functiemenging en het oplossen van knelpunten van externe veiligheid en fysieke barrières - hieraan bijdragen, ondersteund. De Spoorzone Delft is een van deze projecten. Gezien de omvangrijke investering die vereist is voor de aanleg van de spoortunnel was ook steun van het ministerie van Verkeer en Waterstaat voorwaarde. In het beleid van het ministerie van Verkeer en Waterstaat had de spoorzone in Delft echter geen prioriteit. Op basis van studies naar de vervoerscapaciteit bestond er volgens het ministerie van Verkeer en Waterstaat geen noodzaak voor spoorverdubbeling en ondertunneling. Uiteindelijk werd de minister van Verkeer en Waterstaat na een lobby van gemeente, regio en provincie via een motie in de Tweede Kamer gedwongen financieel bij te dragen en uitvoering te geven aan het project. Het project was dus met nadruk geen initiatief van het ministerie van Verkeer en Waterstaat. Deze verschillen in beleidskader tussen cases kunnen leiden tot verschillen in de rol van partijen in het proces die als zodanig niet direct te maken hebben met gemaakte keuzen op projectniveau. De volgende paragraaf analyseert de verschillen en overeenkomsten in de procesinrichting in de drie cases.

\subsection{Analyse van verschillen en overeenkomsten in procesinrichting}

De context en specifieke projectkenmerken geven de setting waarin het proces verloopt. Ze bepalen met andere woorden het speelveld, de actoren die je daarin aantreft en de regels die er gelden. Bij stationslocatieprojecten werken in dat proces gemeenten, provincies, regionale bestuursorganen, rijkspartijen, ProRail, NS en marktpartijen in verschillende configuraties samen. Als gevolg van regelgeving of eigendomsposities is medewerking van deze keystakeholders minimaal noodzakelijk voor de realisatie van plannen. Deze paragraaf vergelijkt de inbreng van deze partijen in het proces op drie kernthema's; visievorming (9.2.1) zeggenschap (9.2.2) en middelen (9.2.3). Daarbij is het onderscheid tussen (a) het deelproces gericht op de totstandkoming van het masterplan voor de gebiedsontwikkeling als geheel en (b) het deelproces gericht op het ontwikkelen van een ontwerp voor de OV-terminal aangehouden.

\subsubsection{Visievorming}

\section{Masterplanproces}

De drie cases kennen allen een lange voorgeschiedenis waarin diverse ideeën en visies voor de aanpak van de gebieden aan de orde zijn geweest. In deze studie is de intentie- of procesovereenkomst tussen het Rijk en de betreffende gemeente als aanvangsmoment in de analyse van het masterplanproces genomen. Eindpunt van dit proces vormt de vaststelling van het masterplan door de gemeenteraad. Voor de sleutelprojecten (Den Haag, Breda) vind vervolgens nog goedkeuring van het plan door het 
Rijk plaats. In tabel 9.1 is de tijdsperiode waarop de analyse van het masterplanproces betrekking heeft voor de drie cases weergegeven.

\begin{tabular}{|lll|}
\hline \multicolumn{2}{|c|}{ Aanvang } & Einde \\
\hline \multirow{3}{*}{ Den Haag } & Oktober 2000: & Juni 2003: \\
& $\begin{array}{l}\text { Intentieovereenkomst CS Kwadrant tussen Rijk } \\
\text { en gemeente }\end{array}$ & $\begin{array}{l}\text { Na goedkeuring ontwerpmasterplan DHNC door B\&W stemt Rijk } \\
\text { onder voorwaarden in }\end{array}$ \\
\hline \multirow{2}{*}{ Breda } & februari 2002: & September 2003: \\
& $\begin{array}{l}\text { Intentieovereenkomst NSP Spoorzone Breda } \\
\text { tussen Rijk en gemeente }\end{array}$ & $\begin{array}{l}\text { Masterplan Centraal Breda vastgesteld en Rijk stemt onder } \\
\text { voorwaarden in. }\end{array}$ \\
\hline \multirow{3}{*}{ Delft } & Februari 2002: & Oktober 2003: \\
& Procesovereenkomst Spoorzone Delft tussen & $\begin{array}{l}\text { Masterplan Spoorzone Delft wordt goedgekeurd door de } \\
\text { gemeenteraad van Delft }\end{array}$ \\
\hline
\end{tabular}

Tabel 9.1 Tijdsinterval procesanalyse Masterplan

De uiteindelijke masterplannen kennen geen identieke verschijningsvorm. In het ene geval bestaat het masterplan uit meerdere documenten en een covernota (Breda). In het andere geval gaat het om een enkel document waarin het ruimtelijk-functioneel ontwerp en het stedenbouwkundig programma van eisen staat beschreven (Den Haag). In alle cases betreft het masterplan echter een beschrijving van de voorgenomen herontwikkeling van het plangebied als geheel en het kader voor de verdere uitwerking van plannen voor deelgebieden of voor specifieke onderdelen.

Voor het reconstrueren van de inbreng van keystakeholders bij het ontwikkelen van het masterplan is gebruik gemaakt van percepties van dezelfde keystakeholders. Juist in een situatie waarin er sprake is van afhankelijkheid, zoals het geval bij stationslocaties, is het beeld dat actoren hebben van de werkelijkheid van belang. ${ }^{216}$ Gevraagd is aan de inbreng van elke keystakeholder een waarde toe te kennen op een 5-punts Likertschaal, waarbij de waarde kan variëren van zeer groot (5) tot zeer klein (1). Op basis van de toegekende waarden is ook elke keystakeholder een gemiddelde berekend. Figuur 9.1 geeft de waarden van deze gemiddelden voor de drie cases weer.

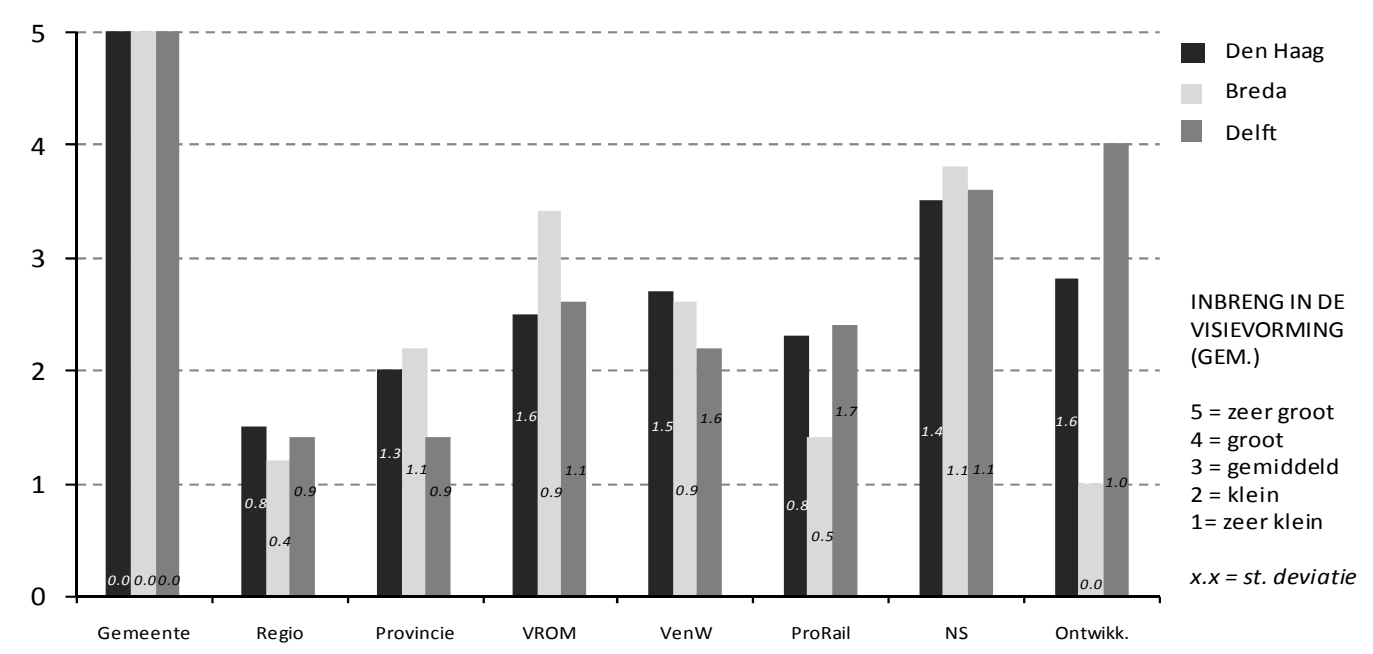

Figuur 9.1 Percepties (gemiddelde) v/d inbreng van stakeholders in visievorming masterplan in drie cases 
Figuur 9.1 laat zien wat in de afzonderlijke case hoofdstukken al helder naar voren kwam; de gemeenten hebben in alle drie cases een zeer grote inbreng gehad bij het ontwikkelen van het masterplan. In tegenstelling tot de inbreng van andere actoren is het beeld hiervan bij keystakeholders volledig eenduidig. In alle cases vervullen gemeenten een regierol in de planvorming voor het integrale project. $\mathrm{Zij}$ zijn eindverantwoordelijk voor het opstellen van een masterplan, ontvangen subsidies, gaan samenwerkingsverbanden aan met ontwikkelaars, maken afspraken met eigenaren en vervoerders en sluiten een overeenkomst met het Rijk over bijdragen en daaraan gekoppelde voorwaarden. De inrichting van de publieke ruimte is in het Nederlandse publieke bestel in eerste instantie ook een takk van de gemeente. In alle cases is de gemeente ook opdrachtgever geweest voor het ontwikkelen van een masterplan. In Delft was de gemeente de enige opdrachtgever, in Breda deed de gemeente dit samen met NS en in Den Haag deelde de gemeente deze opdrachtgeversrol met NS, Multi Vastgoed, Babylon Den Haag BV en het Stadsgewest Haaglanden. Getuige de data uit de figuur 9.1 betekent het medeopdrachtgeverschap van andere partijen in Den Haag en Breda echter niet dat deze partijen dan ook een grote inbreng hebben bij het ontwikkelen van het masterplan.

Voor de vastgoedontwikkeling werken de gemeenten in alle cases samen met één of meerdere ontwikkelaars. NS Poort in alle drie cases als ontwikkelaar is betrokken. Haar eigendomspositie in en rondom stations zorgt ervoor dat haar betrokkenheid om plannen daadwerkelijk gerealiseerd te krijgen onmisbaar is. Haar inbreng bij het ontwikkelen van het masterplan wordt in alle cases als groot gepercipieerd. De inbreng van andere ontwikkelaars blijkt wel sterk te verschillen tussen de cases. Daarbij ontstaat het beeld dat deze inbreng vooral in Delft groot was. Ballast-Nedam was daar vanaf het begin betrokken bij het idee van een spoortunnel en trok voor de bovengrondse ontwikkeling samen op met NS Poort. In Den Haag waren Multi-Vastgoed en Babylon den Haag BV wel vertegenwoordigd in het coordinatieoverleg en medeopdrachtgever voor het masterplan Den Haag Nieuw Centraal, echter hun inbreng bij het ontwikkelen van het masterplan blijkt relatief klein vergeleken met Delft. In Breda waren behoudens NS Poort geen ontwikkelaars met een substantiële eigendomspositie in het plangebied. Bij het ontwikkelen van het Masterplan Breda Centraal hebben zij ook geen inbreng gehad.

Hoewel de publieke ruimte op lokaal niveau in eerste instantie een taak voor de gemeente is, impliceert de koppeling met (inter)nationale infrastructuur en de verbondenheid met doelstellingen van nationaal ruimtelijk beleid ook een rol voor de rijksoverheid. Hoewel het Rijk in alle cases betrokken was bij het opstellen van het masterplan is zij in geen van de cases medeopdrachtgever geweest. In de sleutelprojecten (Den Haag, Breda) kreeg de betrokkenheid van rijkspartijen VROM en Verkeer en Waterstaat vorm in diverse overlegstructuren. In beide cases was er een stuurgroep en een projectleidersoverleg waarin het Rijk vertegenwoordigd was. De frequentie van de bijeenkomsten van deze overlegstructuren verschilt niet wezenlijk van niet-sleutelproject Delft. Ook daar waren rijkspartijen VROM en Verkeer en Waterstaat vertegenwoordigd in een stuurgroep onder wiens verantwoordelijkheid de uitgangspunten voor de integrale realisatie van de spoorzone in Delft werden opgesteld en was er een ambtelijke werkgroep waarin het Rijk deel nam. Uit de resultaten blijkt ook niet dat het nationaal belang dat in het rijksbeleid aan de sleutelprojecten wordt toegekend, betekent dat het Rijk een grotere inbreng heeft gehad in het masterplanproces. Eerdere verwachtingen op basis van verschillen in beleidskader (9.1.2) worden daarmee niet bevestigd door de resultaten. Slechts de inbreng van het ministerie VROM bij het ontwikkelen van het Masterplan Centraal Breda blijkt namelijk relatief groot. 
De inbreng van de regio en provincie in het masterplanproces is in alle cases volgens keystakeholders relatief klein. Hun rol beperkt zich in de regel tot het (financieel) stimuleren van de herontwikkeling voor zover deze bij draagt aan regionaal of provinciaal ruimtelijk beleid. Daarnaast vloeit hun betrokkenheid voort uit de bestuurlijke verantwoordelijkheid voor regionaal openbaar vervoer. Een logische verklaring voor de grotere inbreng van de provincie Noord-Brabant en kleine inbreng van de regio Brabantstad is dat de laatste in tegenstelling tot het Stadsgewest Haaglanden geen zogenaamde plusregio betreft.

Samengevat kan worden gesteld dat:

- In alle drie cases de betreffende gemeente veruit de grootste inbreng heeft gehad bij het ontwikkelen van het masterplan. Hierover is het beeld bij keystakeholders volledig eenduidig.

- Verschillen tussen de cases vooral zitten in de inbreng van andere partijen. Hierbij valt op, dat in Delft de inbreng van ontwikkelaars relatief groot is. Deze perceptie van keystakeholders is plausibel te herleiden tot de feitelijke projectkenmerken en de preferente positie van deze partijen (zie hoofdstuk 8)

- Met uitzondering van de gemeente de inbreng van actoren in het masterplanproces sterk uiteenlopend gepercipieerd wordt. Deze perceptieverschillen zijn het grootst in Den Haag en het kleinst in Breda.

\section{OVT-planproces}

Bij de herontwikkeling van stationslocaties is altijd een onderscheid te onderkennen tussen enerzijds de vernieuwing of upgrade van het station als knooppunt van transportmodaliteiten en anderzijds de herontwikkeling van het omliggende stedelijk gebied. Het masterplan heeft betrekking op het integrale geheel. De aanpak van de OV-terminal is daarin veelal het centrale onderdeel en aanjager voor de stedelijke herontwikkeling. In de eerste fase van de planvorming voor de OV-terminal wordt op basis van een globaal Programma van Eisen een schetsontwerp opgesteld. Deze eerste fase loopt meestal parrallel aan de ontwikkeling van een masterplan. Vervolgens wordt het schetsontwerp voor de OV-terminal uitgewerkt tot een voorlopig/definitief ontwerp. Aanbesteding van het werk gebeurt op basis van dit ontwerp of uitgewerkte bestektekeningen. De analyse van het planproces voor de OV-terminal heeft in deze studie betrekking op de periode tussen de goedkeuring van het masterplan ${ }^{217}$ en de vaststelling van het definitief ontwerp voor de OV-terminal. In tabel 9.2 zijn aanvang en einde van dit deelproces weergegeven voor de drie cases. ${ }^{218}$

\begin{tabular}{|llll|}
\hline & Aanvang & $\begin{array}{l}\text { Bestuurlijke overeenkomst } \\
\text { (Rijk-Gemeente) }\end{array}$ & Einde \\
\hline Den Haag & $\begin{array}{l}\text { Februari 2003: } \\
\text { B\&W keuren masterplan goed en } \\
\text { rijk stemt onder voorwaarden in }\end{array}$ & December 2003 & $\begin{array}{l}\text { Mei 2007: } \\
\text { College B\&W keurt DO voor OV-terminal goed }\end{array}$ \\
\hline \multirow{3}{*}{ Breda } & $\begin{array}{l}\text { September 2003: } \\
\text { Masterplan vastgesteld en rijk gaat } \\
\text { onder voorwaarden akkoord }\end{array}$ & Mei 2006 & Oktober 2007: \\
\hline \multirow{2}{*}{ Delft } & $\begin{array}{l}\text { Oktober 2003: } \\
\text { Masterplan goedgekeurd in } \\
\text { gemeenteraad }\end{array}$ & Oktober 2005 & $\begin{array}{l}\text { Juli 2007: } \\
\text { SO van Mecanoo architecten wordt geselecteerd }\end{array}$ \\
\hline
\end{tabular}

Tabel 9.2 Tijdsinterval procesanalyse OV-terminal 
Uit de percepties (figuur 9.2) blijkt dat bij het ontwikkelen van plannen voor de aanpak van de OVterminals drie partijen in het bijzonder een vooraanstaande rol spelen; de gemeente, ProRail en NS. Hoewel gemeenten - in tegenstelling tot spoorgerelateerde partijen NS en ProRail - nauwelijks directe taken en bevoegdheden hebben binnen de OV-terminal hebben zij volgens keystakeholders in alle drie cases wel veruit de grootste inbreng gehad bij het vormen van een visie op de herontwikkeling ervan. Dat geldt in het bijzonder in Den Haag, waar de inbreng van de gemeente relatief groot en de inbreng van NS en ProRail relatief klein is.

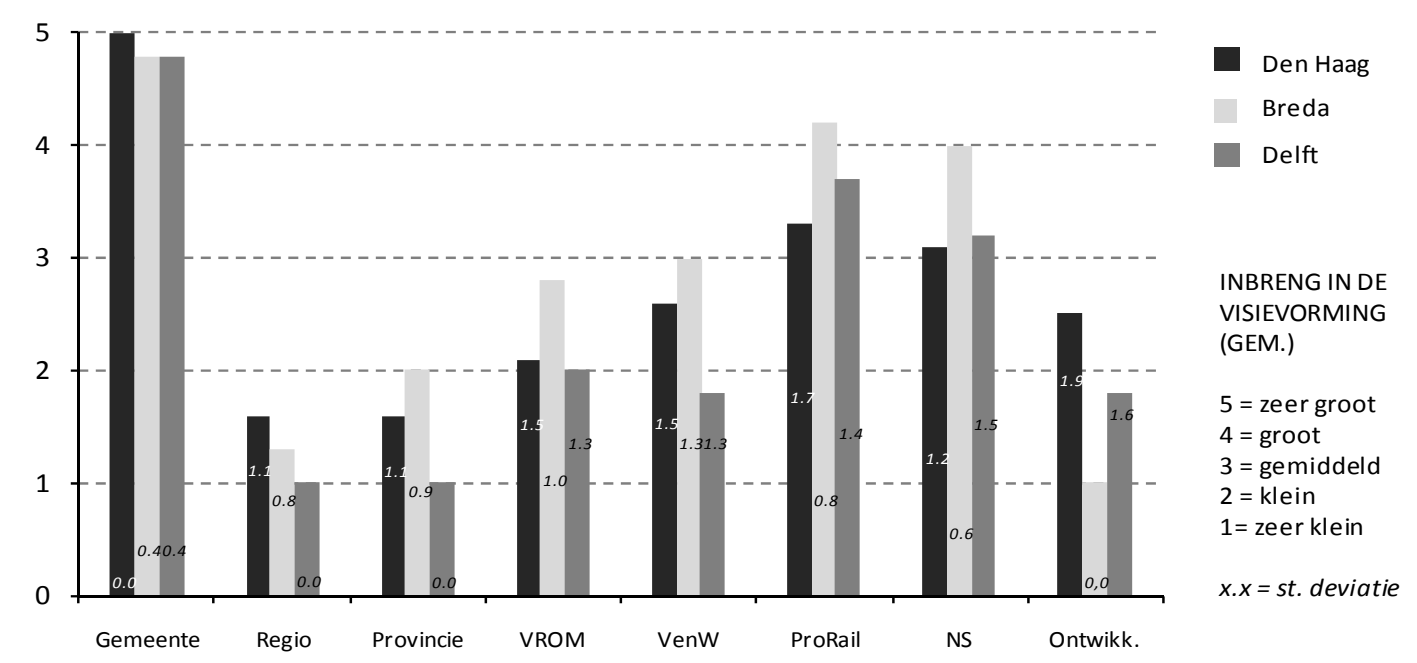

Figuur 9.2 Percepties (gemiddelde) v/d inbreng van stakeholders in visievorming OV-terminal in drie cases

De ontwikkeling van (inter)nationale spoorinfrastructuur (HSL) en de directe verantwoordelijkheid van het ministerie van Verkeer en Waterstaat voor een adequate transfercapaciteit van stations, impliceert een zekere inbreng van rijkspartijen in de planvorming voor de OV-terminals. In alle cases blijkt het beeld van keystakeholders dat deze inbreng aanzienlijk kleiner is dan de inbreng van de gemeente, ProRail en NS. Het Rijk ziet, zeker na het sluiten van uitvoeringsovereenkomsten, ook zelf meer een rol op afstand voor zich weggelegd. Overigens betekent dit niet dat het Rijk zich dan volledig terugtrekt. In alle drie cases participeert het Rijk nog in de stuurgroep Rijk-gemeente, is er periodiek overleg en wordt de mate waarin voldaan wordt aan de afspraken in de bestuurlijke overeenkomst gemonitord. Daarnaast wordt het ministerie van Verkeer en Waterstaat in de planuitwerking vertegenwoordigd door ProRail. Het beeld van keystakeholders is dat de inbreng van het Rijk in Breda het grootst is geweest.

Voor de overige keystakeholders (regio, provincie, ontwikkelaars) geldt dat hun inbreng bij het ontwikkelen van plannen voor de OV-terminal in alle cases volgens keystakeholders klein is. Binnen het station hebben ontwikkelaars geen eigendom. NS heeft hier het alleenrecht op commerciële ontwikkeling. Voor de regio en provincie geldt, behalve indien de plannen voor de OV-terminal een directe relatie hebben met regionaal openbaar vervoer, dat zij hier geen directe taak en verantwoordelijkheid hebben. 
Samengevat kan worden gesteld dat:

- In alle drie cases de betreffende gemeente de grootste inbreng heeft gehad in het proces van visievorming voor de OV-terminal.

- In Breda de inbreng van andere partijen met een bestuurlijke verantwoordelijkheid of eigendomspositie aanzienlijk groter is dan in Den Haag en Delft.

- Percepties van keystakeholders ten aanzien van de inbreng van partijen in de planvorming voor de OV-terminals behoorlijk verschillen. Uitzondering hierop vormt de inbreng van gemeenten, waarover vrijwel volledige eenduidigheid bestaat.

\subsubsection{Zeggenschap}

\section{Masterplanproces}

Wettelijke regels, die bevoegdheden aan partijen toekennen, eigendomsposities en andere hulpbronnen vormen een belangrijke basis voor zeggenschap van actoren. Binnen dit kader bestaat een zekere ruimte voor de wijze waarop de verdeling van zeggenschap in planvorming concreet wordt vormgegeven. Deze paragraaf vergelijkt de zeggenschap van keystakeholders in de drie cases.

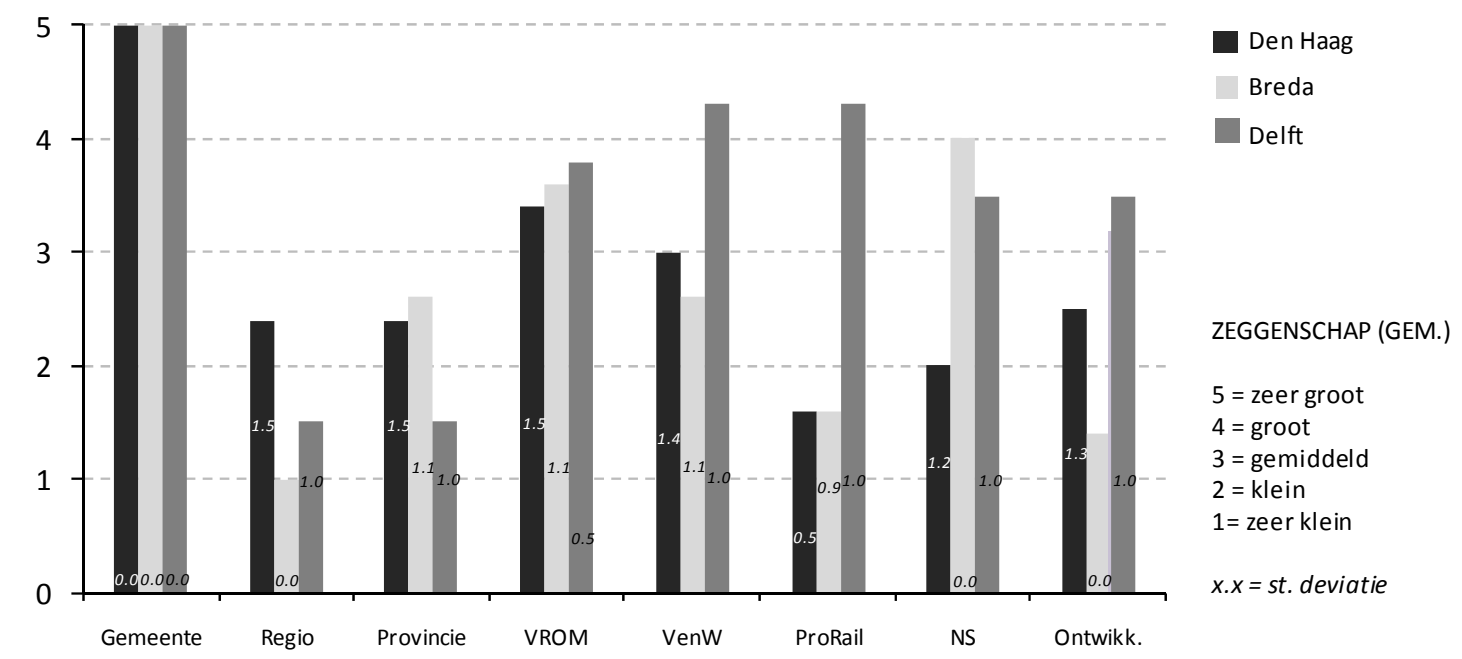

Figuur 9.3 Percepties (gemiddelde) v/d zeggenschap van stakeholders in het masterplanproces in drie cases

Uit figuur 9.3 blijkt dat de gemeenten zeer veel zeggenschap hebben gehad in de planvorming voor een masterplan. Zonder uitzondering wordt dit in alle drie cases als zodanig door keystakeholders gepercipieerd. Hoewel een masterplan in eerste instantie ook een gemeentelijk plandocument is, kennen alle masterplannen diverse onderdelen waarvoor de verantwoordelijkheid of het eigendom ligt bij andere partijen dan de gemeente.

Wordt gekeken naar de zeggenschap van andere partijen dan valt onder meer op dat de zeggenschap van het Rijk en ProRail in Delft relatief groot wordt geacht. Enerzijds is dit opmerkelijk omdat het Rijk juist de sleutelprojecten expliciet benoemt als zijnde van nationaal belang en zij - als onderdeel van de rijksprocesarchitectuur voor de sleutelprojecten - hier ook een toetsende rol heeft in het planproces. Instemming met het masterplan was namelijk voorwaarde voor de toekenning van 
rijksgelden aan sleutelprojecten. Anderzijds is de relatief grote mate van zeggenschap van het Rijk en ProRail in Delft ook weer niet zo opmerkelijk. De ondertunneling en het ondergronds gaan van de OV-knoop zorgt er namelijk voor dat het deel rijksspoorinfrastructuur - waarvoor het ministerie van Verkeer en Waterstaat beleidsmatig verantwoordelijk is en waar ProRail uitvoering aan geeft - in Delft aanzienlijk groter is dan in Den Haag en Breda. Daarnaast maakt toetsing van het masterplan door het Rijk in Delft weliswaar geen onderdeel uit van een speciale procesarchitectuur, maar werden door VROM, als voorwaarde voor toekenning van middelen uit het BIRK, wel eisen gesteld aan de inhoud van het masterplan.

Grote verschillen tussen cases lijken er ook te bestaan in de zeggenschap van private partijen. Deze lijken vooral in Delft veel zeggenschap te hebben gehad bij het ontwikkelen van het masterplan. Het gaat daar om NS Poort en Ballast-Nedam. De grote mate van zeggenschap van deze partijen had onder meer te maken met de goede relatie tussen Ballast-Nedam en de gemeente Delft en de rechten van NS op de grond boven de tunnel. Daarnaast was de haalbaarheid van de prijsaanbieding die beide partijen gezamenlijk hadden gedaan voor de grondafname afhankelijk van de invulling van de stedelijke ontwikkeling die werd beschreven in het masterplan.

In Den Haag blijkt de zeggenschap van private partijen in het planproces van het Masterplan Den Haag Nieuw Centraal aanzienlijk kleiner. Een substantieel deel van het vastgoed binnen het plangebied was wel in eigendom bij ontwikkelaars en vastgoedbeleggers. NS, Multi-Vastgoed en Babylon Den Haag zijn ook medeopdrachtgevers geweest van het masterplan en waren vertegenwoordigd in het coördinatieoverleg en de stuurgroep gemeente-privaat. Het beeld van keystakeholders is echter dat hun zeggenschap bij het ontwikkelen van het masterplan beperkt is geweest. Voor NS staat dat in contrast met de substantiële inbreng die zij volgens dezelfde keystakeholders heeft gehad in het proces van visievorming.

In de planvorming van het Masterplan Centraal Breda hebben - behalve NS Poort - geen ontwikkelaars zeggenschap gehad. Met uitzondering van NS Poort en een enkele ontwikkelaar (HeJa) met een beperkte grondpositie waren er in Breda ook geen ontwikkelaars met eigendom in het plangebied.

Samengevat kan worden gesteld dat:

- In alle drie cases de betreffende gemeente de meeste zeggenschap heeft gehad bij het ontwikkelen van het masterplan.

- In het planproces van het Masterplan Spoorzone Delft meer partijen een aanzienlijke (>3) mate van zeggenschap hebben gehad dan in Den Haag en Breda. Dit is deels plausibel te herleiden naar verschil in ruimtelijke opgave waardoor in Delft, als gevolg van het grote aandeel rijksspoorinfrastructuur, het ministerie van Verkeer en Waterstaat en ProRail relatief veel zeggenschap hebben.

- De percepties van de zeggenschap van keystakeholders behoorlijk blijken te verschillen. Dat geldt vooral in Den Haag. Uitzondering hierop vormt de zeer grote mate van zeggenschap van gemeenten, waarover men in alle cases unaniem is.

\section{OVT-planproces}

Zoals eerder gesteld is bij de aanpak van stationslocaties altijd een onderscheid te onderkennen tussen enerzijds de vernieuwing of upgrade van het station als knooppunt van transportmodaliteiten en 
anderzijds de herontwikkeling van het omliggende stedelijk gebied. Dit onderscheid is zeker voor de zeggenschap van partijen in de planvorming relevant omdat de bevoegde en verantwoordelijke partijen nogal verschillen. Binnen de OV-terminal is er sprake van een complexe verdeling van verantwoordelijkheden en eigendomsstructuur. In hoofdstuk 5 is dit uitvoerig beschreven. Hier wordt de zeggenschap van keystakeholders in het planproces voor de OV-terminals in de drie cases vergeleken.

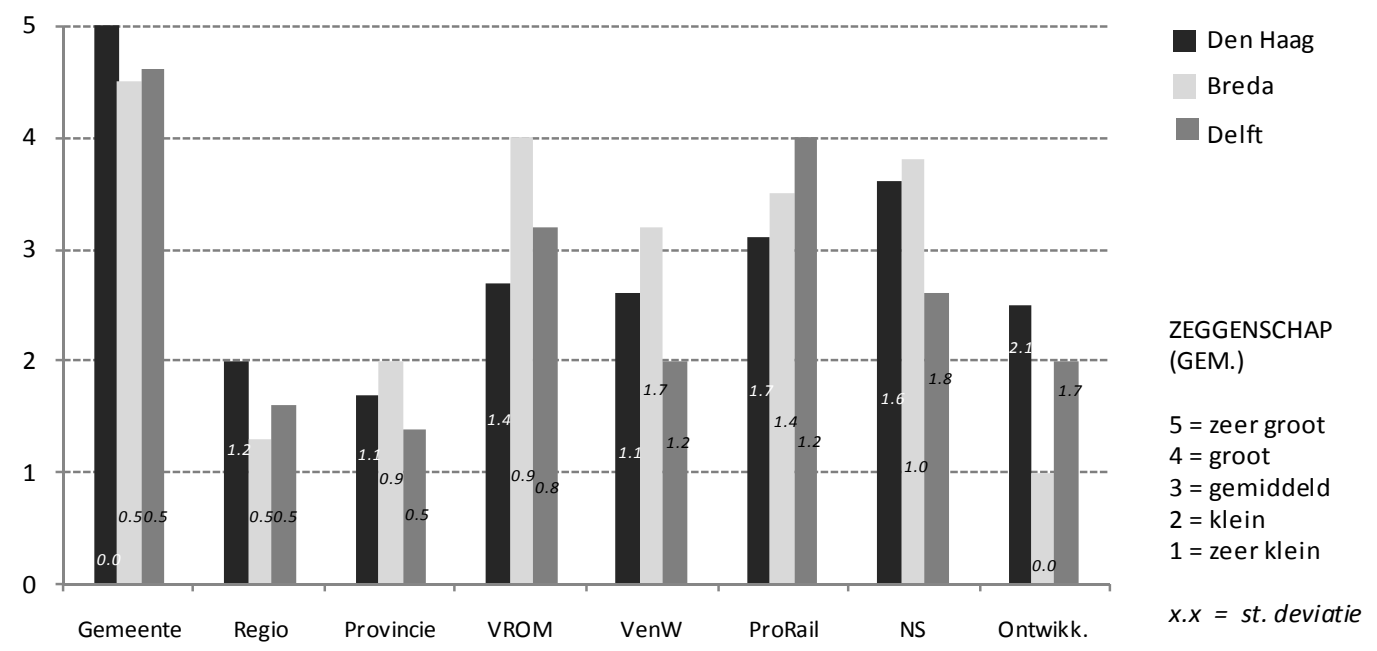

Figuur 9.4 Percepties (gemiddelde) v/d zeggenschap van stakeholders in het OVT planproces in drie cases

Uit figuur 9.4 blijkt dat gemeenten ook in het planproces voor de OV-terminal de dominante partij zijn geweest qua zeggenschap. Behalve voor Den Haag is het beeld echter minder absoluut. De zeer grote mate van zeggenschap van de gemeente in dit proces is opmerkelijk als in ogenschouw wordt genomen dat gemeenten binnen de OV-terminal nauwelijks taken en bevoegdheden hebben. Vergelijking van de cases laat zien dat de gemeente Den Haag qua zeggenschap de meest dominante gemeente is geweest en de gemeente Breda het minst. In Breda hebben naast de gemeente namelijk ook de rijkspartijen (VROM en V\&W) en de spoorgerelateerde partijen (ProRail en NS) een aanzienlijke mate van zeggenschap gehad.

Waar qua inbreng in het proces van visievorming voor de OV-terminal vooral de samenwerking tussen de gemeente, NS en ProRail naar voren kwam, blijken qua zeggenschap de rijkspartijen ook nadrukkelijk van belang te zijn. De zeggenschap van andere partijen (regio, provincie, ontwikkelaars) in de planvorming voor de OV-terminal is volgens keystakeholders klein geweest. De beperkte zeggenschap van ontwikkelaars moet vooral worden gezien tegen de achtergrond van de noodzakelijke afstemming tussen de plannen voor de OV-terminals en de omliggende gebiedsontwikkeling. De afwezigheid van grote eigenaar-ontwikkelaars (behalve NS) verklaard dat deze volgens keystakeholders geen zeggenschap hebben gehad in de planvorming voor het OVTC in Breda.

Opmerkelijk is dat ook qua zeggenschapsverdeling het verschil in perceptie bij keystakeholders erg groot is. Met uitzondering van de zeer grote mate van zeggenschap van de gemeente Den Haag bestaat geen eenduidigheid. Blijkbaar bestaat er zelfs bij direct betrokkenen een zeer uiteenlopend beeld. Dit geldt in het bijzonder in Den Haag. 
Samengevat kan worden gesteld dat:

- In alle drie cases de betreffende gemeente de meeste zeggenschap heeft gehad in het planproces voor de aanpak van de OV-terminal.

- In Breda deze zeggenschap meer gespreid is en de zeggenschap minder ongelijk is verdeeld dan in de andere twee cases.

- De percepties van keystakeholders van de zeggenschap van partijen sterk verschillen. Vooral bij keystakeholders in Den Haag bestaat er verre van een eenduidig beeld van de zeggenschap die partijen hebben gehad in het planproces voor de OV-terminal. Uitzondering hierop vormt de zeer grote mate van zeggenschap van gemeenten.

\subsubsection{Middelen}

Het ontwikkelen en daadwerkelijk realiseren van plannen vraagt om de inzet van middelen. Deze paragraaf vergelijkt de inbreng van middelen door keystakeholders. In analyses ligt veelal de nadruk op de inbreng van financiële middelen. Enkel een analyse van financiële inbreng van partijen zonder aandacht te besteden aan de bijbehorende voorwaarden en onderliggende risicoverdeling zegt echter relatief weinig. Omdat projectkenmerken niet volledig overeen komen heeft alleen een beschrijving in absolute termen voor een vergelijking ook weinig meerwaarde. Zo zorgt de ondertunneling in Delft er voor dat het voor de hand ligt dat het ministerie van Verkeer en Waterstaat hier in absolute termen een grote financiële bijdrage levert. Om deze redenen is er ook hier voor gekozen gebruik te maken van de percepties die direct betrokkenen zelf hebben. Zij zijn gevraagd aan de inbreng van elke keystakeholder een waarde toe te kennen op een 5-punts Likertschaal, waarbij deze waarde kan variëren van 'veel meer dan gegeven de kenmerken van het project van deze actor mag worden verwacht' (5) tot veel minder dan gegeven de kenmerken van het project van deze actor mag worden verwacht' (1). Op basis van de toegekende waarden is voor elke keystakeholder een gemiddelde waarde berekend. Figuur 9.5 geeft de waarden van deze gemiddelden voor de keystakeholders in de drie cases weer. Het beeld dat op basis daarvan ontstaat, is geconfronteerd met een beschrijving van de inbreng in absolute termen.

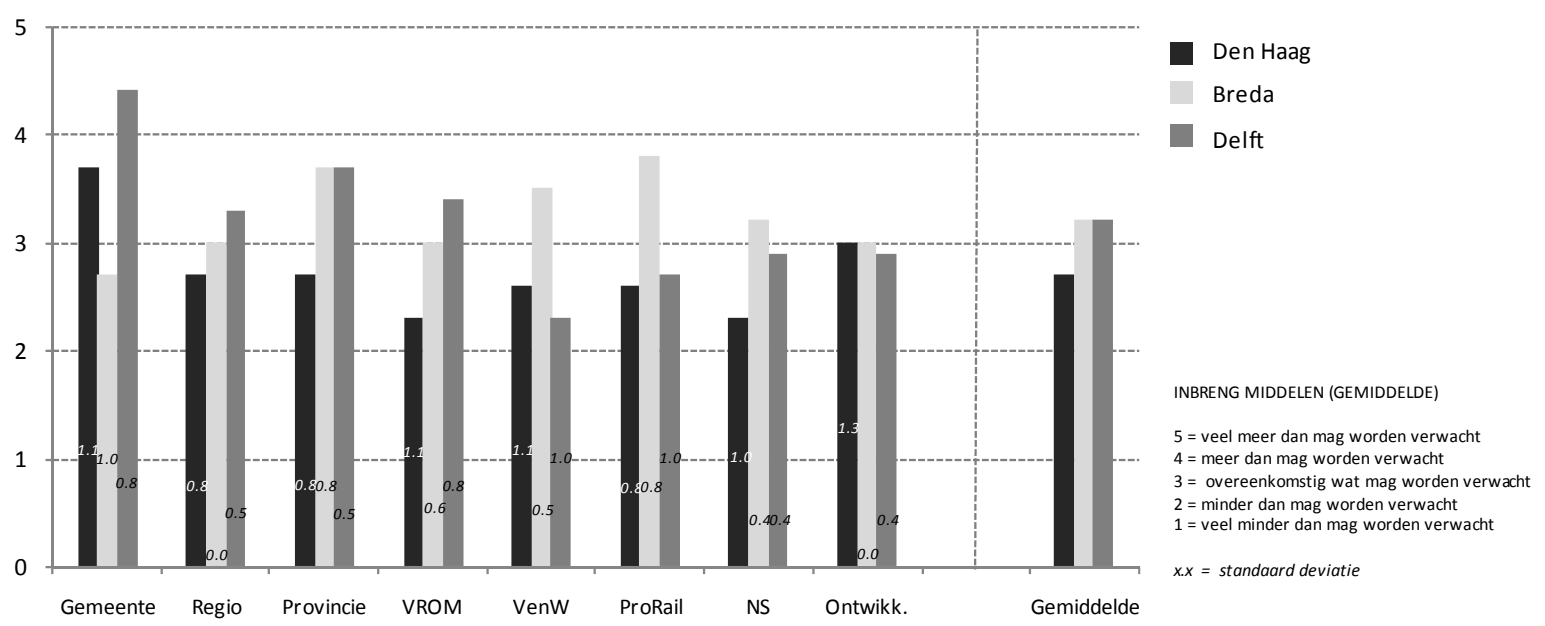

Figuur 9.5 Percepties (gemiddelde) van de inbreng van middelen door stakeholders in drie cases

Een eerste constatering die op basis van de figuur gedaan kan worden is dat de inbreng van middelen door gemeenten in de perceptie van keystakeholders sterk uiteen loopt tussen cases. Waar gemeenten 
in het proces van visievorming en qua zeggenschap in alle cases een zeer grote inbreng hadden is dit qua middelen volgens keystakeholders niet het geval.

In Delft zijn keystakeholders van mening dat de gemeente aanzienlijk meer middelen heeft ingebracht dan op grond van de kenmerken van het project mocht worden verwacht. De gemeente Delft draagt voor de herontwikkeling van de spoorzone 45,5 miljoen euro bij, maar tot het Addendum op de overeenkomst met het Rijk in 2008 droeg de gemeente ook het volledige kostenrisico voor de ontwikkeling van de rijksspoorinfrastructuur.

Ook in Den Haag is het beeld dat de gemeente veel middelen heeft ingebracht. In financiële termen draagt de gemeente circa 100 miljoen bij. Een verklaring voor het beeld van keystakeholders is gelegen in het gegeven dat de gemeente Den Haag voor zowel fase I als fase II van de aanpak van de OV-terminal risicodragend opdrachtgever is.

Zowel Delft als Den Haag zitten volgens de keystakeholders in deze projecten dus niet voor een dubbeltje op de eerste rang qua zeggenschap. Dat lijkt meer te gelden voor de gemeente Breda. Hoewel de gemeente Breda - zo blijkt uit vorige paragrafen - wel een zeer grote inbreng heeft gehad in het proces van visievorming en eveneens een zeer grote mate van zeggenschap heeft gehad in de planvorming, is het beeld van haar inbreng van middelen niet navenant. In absolute financiële termen draagt de gemeente Breda 22,7 miljoen euro bij aan de ontwikkeling van het Stationskwartier.

De inbreng van andere keystakeholders blijkt ook te verschillen tussen cases. Opmerkelijk is de relatief grote inbreng van het ministerie van Verkeer en Waterstaat en ProRail in Breda. Hoewel het ministerie van Verkeer en Waterstaat in Delft en Den Haag in absolute termen een aanzienlijk grotere financiele bijdrage levert dan in Breda (zie tabel 9.4) is het beeld bij keystakeholders juist tegenovergesteld. In Delft lijkt dit ingegeven door het beleid van het ministerie van Verkeer en Waterstaat waarin de Spoorzone Delft geen prioriteit had (zie paragraaf 9.1.2) en de anvankelijke verschuiving van het kostenrisico's voor rijksspoorinfrastructuur naar de gemeente Delft. ${ }^{219}$ Ook in Den Haag draagt de gemeente het kostenrisico voor de integrale herontwikkeling van de OVterminal, terwijl normaliter het ministerie van Verkeer en Waterstaat samen met ProRail verantwoordelijk is voor de bouw van stations. De inbreng van de andere rijkspartij, het ministerie van VROM, wordt door de keystakeholders in Den Haag gepercipieerd als minder dan bij dergelijke opgaven mag worden verwacht. In absolute zin is dit qua financiële bijdrage eveneens niet het geval (tabel 9.3). De absolute bijdrage zegt dus niets over de perceptie bij keystakeholders.

\begin{tabular}{|c|c|c|c|c|}
\hline & & Den Haag & Breda & Delft \\
\hline Rijkbijdrage & VROM & 49 & 25 & $78 *$ \\
\hline (mln.) & V\&W & 105 & 52 & 392 \\
\hline
\end{tabular}

Tabel 9.3 Rijksbijdrage aan de drie cases (MIRT projectenboek 2009)

Naast gemeenten, Rijk en ProRail is ook NS een belangrijke partij bij stationslocatieprojecten. Er bestaat bij de andere partijen nogal eens het beeld dat NS de verbouwing van haar eigendom in de schoot geworpen krijgt. Hoewel stations grotendeels eigendom zijn van NS, is bij de splitsing van NS vastgelegd dat bij aanpassingen aan stations het principe "de veroorzaker betaalt" geldt. Aanpassingen in verband met de komst van de hogesnelheidslijn en uitbreiding van de transfercapaciteit vallen niet onder de verantwoordelijkheid van NS. Dat geldt wel voor de commerciële voorzieningen in de OV- 
terminal en ook in het omliggende gebied heeft NS vaak een grond- of vastgoedpositie. Uit de percepties van keystakeholders komt het beeld naar voren dat alleen in Breda NS meer middelen inbrengt dan van haar mag worden verwacht. Voor de andere twee cases is het overheersende beeld negatiever. Zeker in Den Haag blijkt de inbreng van middelen door NS ruim onder de maat. De inbreng van middelen door (andere) ontwikkelaars is in alle drie cases vrijwel in overeenstemming met de verwachtingen die keystakeholders daarvan hebben.

Hoewel zij qua visievorming en zeggenschap een beperkte rol spelen, dragen provincies en regio's in termen van middelen wel aanzienlijk bij. Zowel in Delft (30 miljoen euro) als Breda (20 miljoen euro) wordt de inbreng van de provincie groter geacht dan mag worden verwacht. In Den Haag is dit niet het geval. Hier is echter de bijdrage van het stadsgewest Haaglanden in absolute termen aanzienlijk (72 miljoen euro). Niettemin is het beeld bij keystakeholders dat de inbreng van het stadsgewest Haaglanden kleiner is dan van haar mag op basis van de kenmerken van het project mag worden verwacht. Dit lijkt onder meer ingegeven te zijn doordat Haaglanden de financiële middelen die het vanuit het Rijk krijgt voor RandstadRail rechtstreeks doorsluist naar de gemeente Den Haag die het projectmanagement doet en het risico draagt. Hoewel de feitelijke financiële inbreng van Haaglanden in Delft veel kleiner is (11,2 miljoen euro), is het beeld dat dit voor dit project juist meer is dan mag worden verwacht. Van inbreng van middelen door een regionaal overheidsorgaan is in Breda geen sprake. Brabantstad is een bestuurlijk samenwerkingsverband van vijf Brabantse steden dat geen aparte status heeft als plusregio (voorheen kaderwetgebieden) zoals het stadsgewest Haaglanden.

Samengevat kan worden gesteld dat:

- De inbreng van middelen door gemeenten in de drie cases behoorlijk uiteen lijkt te lopen. De gemeenten Delft en Den Haag hebben volgens keystakeholders in deze projecten aanzienlijk meer middelen ingebracht dan van hen mocht worden verwacht. In Breda is het omgekeerde het geval

- In Den Haag is het beeld van keystakeholders dat alléén de gemeente meer middelen heeft ingebracht dan bij een dergelijke opgave van haar mag worden verwacht. In Delft en Breda zijn dit volgens keystakeholders meerdere partijen.

- Het type partijen dat meer heeft ingebracht verschilt tussen cases. In Den Haag is het alleen de gemeente. In Delft zijn dit de decentrale overheden en het ministerie van VROM, terwijl het in Breda om de provincie en de spoorgerelateerde partijen gaat.

\subsection{Analyse op de criteria voor de borging van het publiek belang}

$\mathrm{Na}$ een schets van de overeenkomsten en verschillen in de inrichting van het proces is de vervolgstap een vergelijking van cases op de afhankelijke variabele. Daarvoor is bestudeerd in hoeverre de verschillende procesinrichtingen in de drie cases voldoen aan de criteria voor de borging van het publiek belang. Deze paragraaf analyseert daarvoor de overeenkomsten en verschillen in de effectiviteit en legitimiteit in de drie cases.

\subsubsection{Effectiviteit van planvorming}

Om de effectiviteit van planvorming te bepalen, is gekeken in hoeverre de plannen een bijdrage leveren aan het verhogen van de ruimtelijke kwaliteit in het betreffende plangebied. Dit is gebeurd op basis van de percepties van keystakeholders van te 'verwachten' resultaten. Ruimtelijke kwaliteit is in 
deze studie beschouwd als een contextafhankelijk en subjectgebonden begrip. Dit betekent dat door verschillende actoren en in verschillende omgevingen bepaalde dimensies van ruimtelijke kwaliteit anders gewaardeerd worden. Daarom is - voorafgaand aan de vraag naar de verwachte bijdrage van de plannen aan de ruimtelijke kwaliteit - aan alle keystakeholders gevraagd welke dimensies van ruimtelijke kwaliteit voor hun organisatie in het betreffende project het belangrijkst zijn.

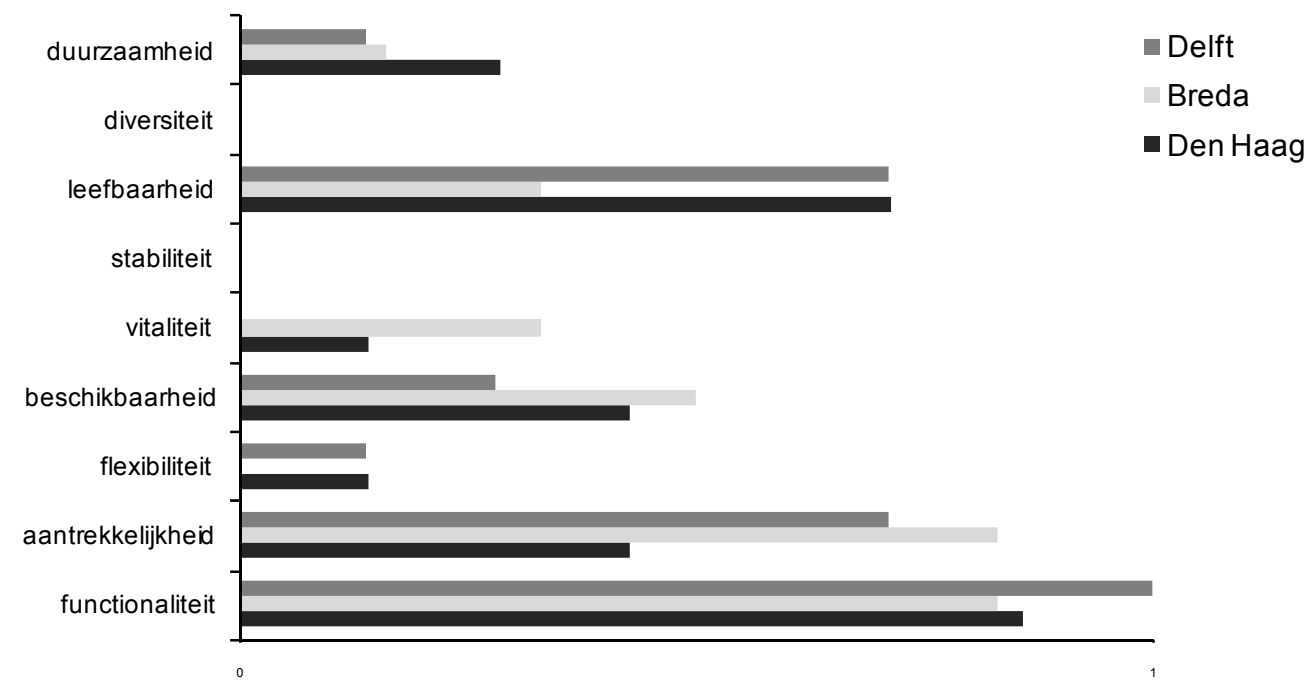

Figuur 9.6 Zwaartepunten in ruimtelijke kwaliteit in drie cases

Uit de resultaten in figuur 9.6 blijkt dat het bij de aanpak van stationslocaties vooral gaat om het verbeteren van de ruimtelijke kwaliteit in termen van functionaliteit, aantrekkelijkheid, leefbaarheid en beschikbaarheid van voorzieningen. De overige dimensies (duurzaamheid, diversiteit, stabiliteit, vitaliteit en flexibiliteit) blijken van ondergeschikt belang. Op de dimensies zijn er verschillen tussen de drie cases. In Delft blijkt het verbeteren van de functionaliteit, aantrekkelijkheid en leefbaarheid in het plangebied voorop te staan. In Den Haag wordt minder waarde gehecht aan het vergroten van de aantrekkelijkheid en in Breda blijkt het vergroten van de leefbaarheid minder belangrijk.

Vervolgens is aan keystakeholders gevraagd in hoeverre zij verwachten dat de plannen een bijdrage leveren aan de door hun genoemde dimensies van ruimtelijke kwaliteit. Naarmate het gemiddelde van de verwachtingen van keystakeholders over deze bijdrage hoger is, wordt gesteld dat de planvorming effectiever is geweest. Figuur 9.7 geeft de gemiddelden voor de drie cases weer.

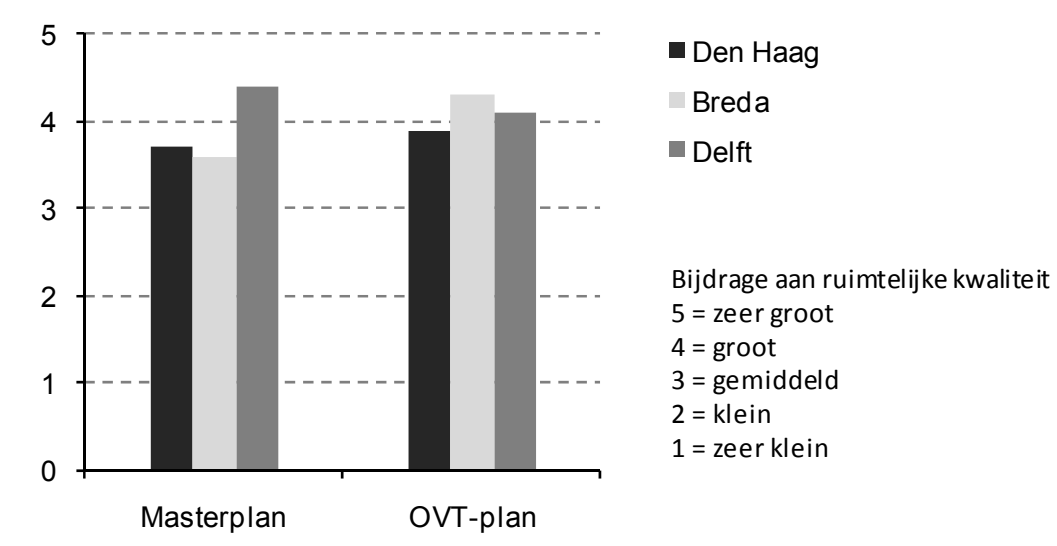

Figuur 9.7 Verwachte bijdrage van de plannen aan de ruimtelijke kwaliteit in drie cases 
In alle drie cases wordt door keystakeholders verwacht dat realisatie van het masterplan een positieve bijdrage zal leveren aan de relevante dimensies van ruimtelijke kwaliteit. Vergelijking van de cases laat zien dat Masterplan Spoorzone Delft op dit punt positiever wordt beoordeeld dan het Masterplan Den Haag Nieuw Centraal en het Masterplan Breda Centraal. Dit beeld wordt bevestigd door de gemiddelden van de rapportcijfers die door keystakeholders aan de masterplannen zijn gegeven. (Delft $(8,0)$, Den Haag $(7,2)$, Breda $(7,0))$. ${ }^{220}$ Op basis van deze resultaten wordt gesteld dat de planvorming van het masterplan in Delft effectiever is geweest dan in Den Haag en Breda.

In alle drie cases wordt eveneens verwacht dat realisatie van het OV-terminalplan een positieve bijdrage zal leveren aan de relevante dimensies van ruimtelijke kwaliteit. De plannen voor het OVterminalcomplex in Breda worden het positiefst beoordeeld. Dit beeld wordt bevestigd door de gemiddelden van de rapportcijfers die door keystakeholders zijn gegeven (Breda $(8,0)$, Delft $(7,6)$, Den Haag $(6,9))$. Met de kanttekening dat de verschillen zeer beperkt zijn wordt gesteld dat de planvorming voor het OV-terminalcomplex in Breda effectiever is geweest dan in Den Haag en Delft.

\section{Belangrijkste conclusies effectiviteit:}

- In alle drie cases is de verwachting dat de plannen een aanzienlijke bijdrage zullen leveren aan het verhogen van de ruimtelijke kwaliteit in de plangebieden.

- De planvorming van het Masterplan Spoorzone Delft wordt als effectiever beoordeeld dan de planvorming van het Masterplan Den Haag Nieuw Centraal en het Masterplan Centraal Breda.

- De verschillen in het oordeel over de effectiviteit van planvorming van de deelplannen voor de OV-terminals zijn zeer beperkt. Breda wordt hier het positiefst beoordeeld.

\subsubsection{Legitimiteit van planvorming}

Naast de effectiviteit van planvorming is tevens de legitimiteit daarvan bestudeerd. In deze studie is een onderscheid gehanteerd naar input-, throughput- en outputlegitimiteit. Aan de hand van de daarvoor benoemde indicatoren is in deze paragraaf de legitimiteit van planvorming voor de drie cases vergeleken.

\section{Inputlegitimiteit}

Inputlegitimiteit heeft betrekking op hoe beslissingen tot stand komen. Beslissingen zijn vanuit dit perspectief legitiem als en omdat ze zijn afgeleid uit de authentieke voorkeuren van stakeholders. Het gaat met andere woorden om de wijze waarop de invoer van wensen, voorkeuren en belangen in het proces plaats vindt.

In hoofdstuk twee is beargumenteerd dat een eerste voorwaarde is dat dit proces legaal moet zijn verlopen. Gesteld is dat aan deze voorwaarde is voldaan, indien democratische procedures voor besluitvorming en relevante wet- en regelgeving op voorgeschreven wijze zijn gehanteerd. Om dit te beoordelen is gebruik gemaakt van de percepties van keystakeholders. Indien álle keystakeholders van mening zijn dat aan deze vereisten is voldaan, is er vanuit gegaan dat het planproces legaal is verlopen. In geen van de drie cases geven de meningen van keystakeholders aanleiding te veronderstellen dat het planproces niet legaal is verlopen. 
Naast juridische normen kunnen er ook niet juridische normen zijn voor de invoer van wensen, voorkeuren en belangen in het proces. Het gaat dan om de vraag of alle belangen ook daadwerkelijk de mogelijkheid hebben gehad om de inhoud van plannen en de beslissingen die daarover worden genomen te beïnvloeden. Openheid van het proces speelt daarom een cruciale rol voor inputlegitimiteit. Om hierover een beeld te vormen, is aangesloten bij het oordeel van keystakeholders over (1) de toegankelijkheid van het planproces, (2) de mate waarin hun organisatie voldoende mogelijkheden heeft gehad om het proces te beïnvloeden en (3) de mate waarin andere relevante partijen voldoende mogelijkheden hebben gehad om het proces te beïnvloeden.

In tabel 9.4 staan de resultaten voor de ontwikkeling van de masterplannen weergegeven. Hieruit blijkt dat dit planproces in alle drie cases als open wordt beoordeeld. Het planproces van het Masterplan Spoorzone Delft komt als meest open proces naar voren. Aan de openheid van het planproces van het Masterplan Den Haag Nieuw Centraal kan het meest worden getwijfeld. Deze twijfel heeft betrekking op a) de vraag of in Den Haag alle relevante partijen wel toegang hebben gehad tot het planproces en b) de vraag of alle relevante partijen in dat proces wel voldoende beïnvloedingsmogelijkheden hebben gehad.

\begin{tabular}{|cccc|}
\hline & $\begin{array}{c}\text { Toegankelijk voor partijen } \\
\text { (ja/nee/weet niet) }\end{array}$ & $\begin{array}{c}\text { Beïnvloedingsmogelijkheden } \\
\text { eigen organisatie }\end{array}$ & $\begin{array}{c}\text { Beïnvloedingsmogelijkheden } \\
\text { andere partijen }\end{array}$ \\
\hline Den Haag & Twijfelachtig $(2 / 1 / 4)$ & 4,2 & 3,4 \\
Breda & Ja (5/-/1) & 4,2 & 4,0 \\
Delft & Ja (5/-/2) & 4,6 & 4,6 \\
\hline
\end{tabular}

Tabel 9.4 Openheid van het masterplanproces in drie cases

De resultaten voor de ontwikkeling van plannen voor de OV-terminals zijn weergegeven in tabel 9.5. Vergelijking van deze resultaten laat zien dat ook dit deelproces in alle cases open wordt geacht. Het proces is volgens keystakeholders toegankelijk geweest voor relevante partijen en de eigen organisatie, maar ook andere partijen lijken voldoende beïnvloedingsmogelijkheden te hebben gehad. Daarbij valt op dat de beïnvloedingsmogelijkheden voor andere partijen dan de eigen organisatie in Delft aanzienlijk groter worden beoordeeld dan in Den Haag en Breda.

\begin{tabular}{|cccc|}
\hline & $\begin{array}{c}\text { Toegankelijk voor partijen } \\
\text { (ja/nee/weet niet) }\end{array}$ & $\begin{array}{c}\text { Beïnvloedingsmogelijkheden } \\
\text { eigen organisatie }\end{array}$ & $\begin{array}{c}\text { Beïnvloedingsmogelijkheden } \\
\text { andere partijen }\end{array}$ \\
\hline Den Haag & Ja (6/1/-) & 4,6 & 3,7 \\
Breda & Ja (5/-/1) & 4,3 & 3,8 \\
Delft & $\mathrm{Ja}(4 / 1 / 2)$ & 4,5 & 4,4 \\
\hline
\end{tabular}

Tabel 9.5 Openheid van het OVT-planproces in drie cases

\section{Belangriikste conclusies inputlegitimiteit:}

- In alle cases is het proces volgens keystakeholders legaal verlopen en hebben alle relevante partijen voldoende mogelijkheden gehad hun wensen, voorkeuren en belangen in het proces in te brengen. Voor het masterplanproces lijken deze mogelijkheden het ruimst te zijn geweest in Delft en het meest beperkt in Den Haag. In het planproces voor de OV-terminal zijn de verschillen beperkt. 


\section{Throughputlegitimiteit}

Voor het bepalen van de throughputlegitimiteit is de transparantie van het planproces als criterium gebruikt. De transparantie van het planproces is bepaald door te kijken naar de mate waarin; (1) helder was welke partij, waarover en wanneer beslissingen nam; (2) helder was wat de inhoudelijke wensen en voorkeuren van partijen waren en, (3) helder was welke van deze wensen en voorkeuren werden gehonoreerd en waarom. De drie cases zijn aan de hand van het oordeel van direct betrokkenen hierover vergeleken. Voor de masterplannen staan de resultaten in figuur 9.8.

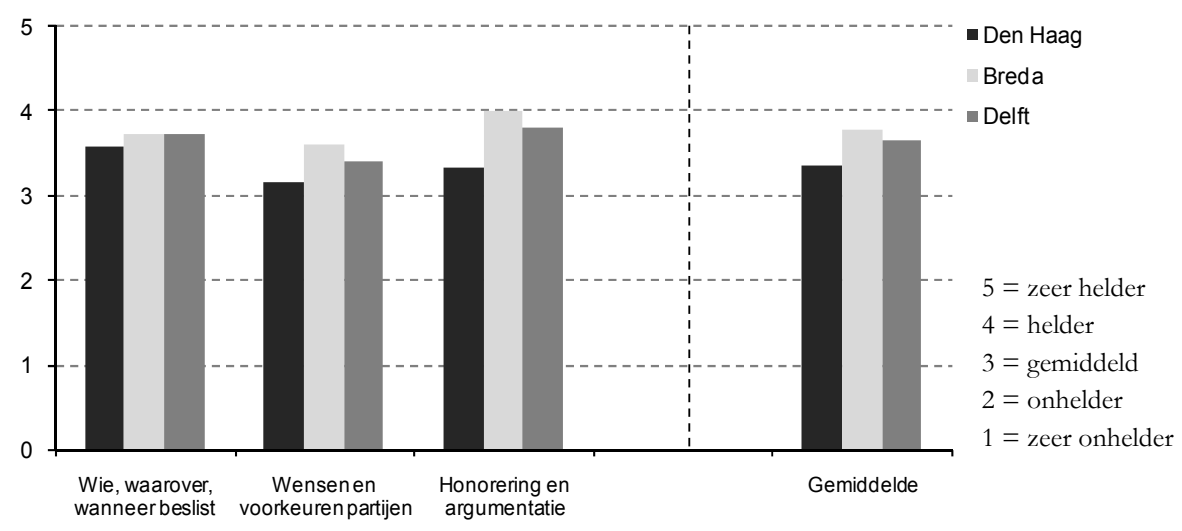

Figuur 9.8 Mate van transparantie van het masterplanproces in drie cases

Het planproces voor het ontwikkelen van het masterplan blijkt in alle drie projecten redelijk transparant geweest. Het planproces van het masterplan stationskwartier Breda was het meest transparant. De helderheid van de wensen en voorkeuren van partijen evenals de honorering daarvan in het uiteindelijke masterplan worden hier groter geacht dan in de andere twee cases. Het planproces van het Masterplan Den Haag Nieuw Centraal is relatief gezien het minst transparant. Vooral de wensen en voorkeuren van de verschillende betrokken partijen blijken voor enkele actoren onduidelijk te zijn geweest. Dit geldt tevens voor de honorering van deze wensen en voorkeuren in het uiteindelijke Masterplan Den Haag Nieuw Centraal en de bijbehorende argumentatie.

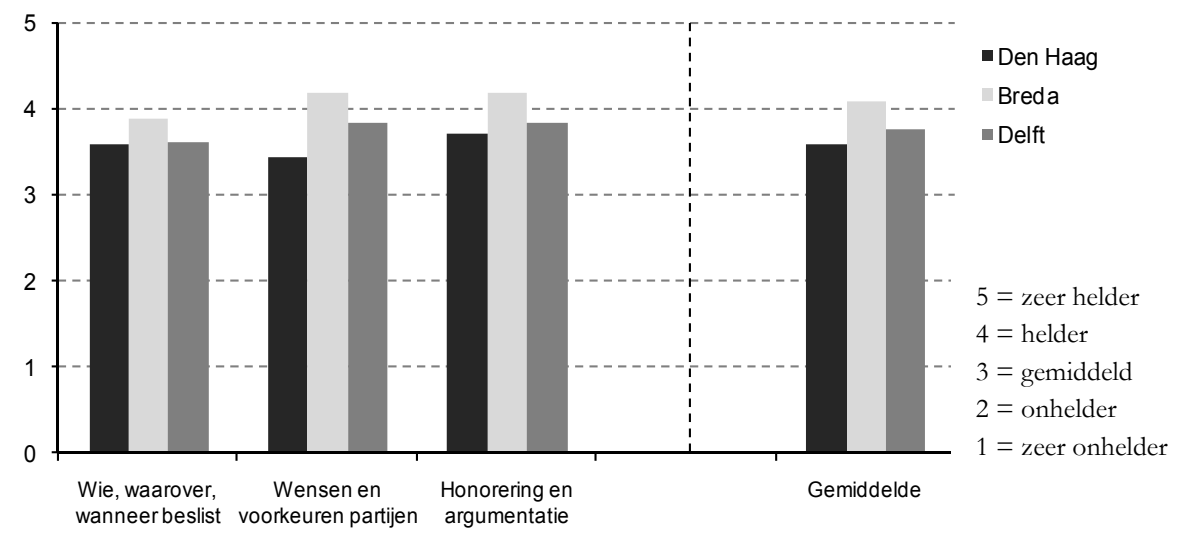

Figuur 9.9 Mate van transparantie van het OVT-planproces in drie cases

Ook de mate van transparantie van het planproces voor de OV-terminal is geanalyseerd. Een vergelijking van de projecten laat eenzelfde beeld zien als voor het masterplanproces (zie figuur 9.9). Voor alle projecten blijkt de transparantie van het planproces voor de OV-terminal gemiddeld tot 
groot te zijn. Ook hier blijkt het planproces voor het OV-terminalcomplex in Breda het meest transparant te zijn en het planproces voor de OV-terminal in Den Haag het minst transparant. Deze relatieve positionering ten opzichte van elkaar is consistent voor de verschillende indicatoren.

\section{Belangriikste conclusies throughputlegitimiteit:}

- In alle drie cases is zowel het planproces van het masterplan als het planproces voor de OVterminal transparant geweest.

- De planvorming in Breda was naar de mening van keystakeholders het meest transparant en de planvorming in Den Haag het minst transparant. Dit geldt voor beide planprocessen.

\section{Outputlegitimiteit}

Legitimiteit van planvorming kan ook gebaseerd zijn op goede resultaten. De steun van keystakeholders voor de plannen die het resultaat zijn van het proces is hiervoor als criterium gebruikt. Daarvoor is geanalyseerd in hoeverre (1) keystakeholders van mening zijn dat in de plannen rekening is gehouden met hun wensen en voorkeuren, (2) keystakeholders zich gecommitteerd voelen aan de plannen en (3) keystakeholders de plannen als aanvaardbare compromissen voor de in het planproces participerende partijen beschouwen. Het beeld dat naar voren komt is vergeleken met het rapportcijfer voor het plan. Voor het masterplan staan de resultaten gepresenteerd in de onderstaande figuur 9.10 .

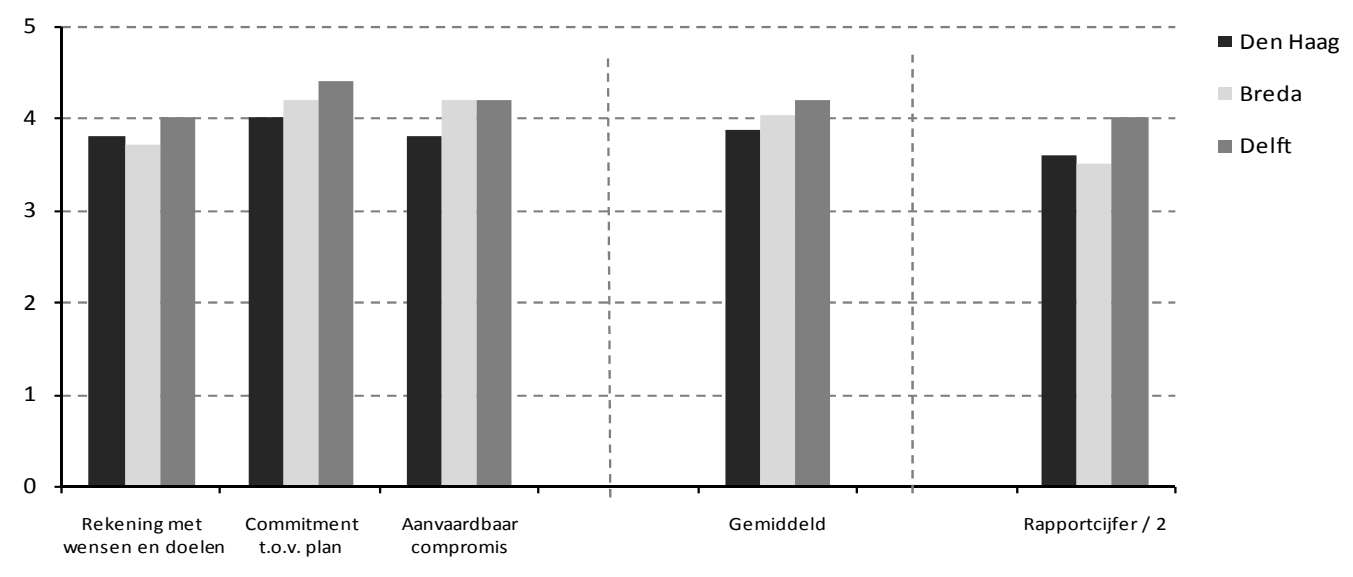

Figuur 9.10 Outputlegitimiteit masterplanproces in drie cases

De belangrijkste conclusie die op basis van een vergelijking van de drie cases kan worden getrokken is dat het Masterplan Spoorzone Delft op de meeste steun kan rekenen. Keystakeholders zijn van mening dat in dit plan veel rekening is gehouden met hun wensen en voorkeuren, zij voelen zich vrijwel zonder uitzondering sterk gecommitteerd aan het plan en zien het als een zeer aanvaardbaar compromis tussen de belangen van partijen die betrokken zijn in de planvorming. Het gemiddelde rapportcijfer (8.0) bevestigt het positieve oordeel over dit masterplan. Ook voor de andere projecten is het beeld dat uit de resultaten naar voren komt positief. Hoewel dit ook voor het Masterplan Den Haag Nieuw Centraal geldt, is de steun voor dit plan kleiner dan in beide andere cases. 


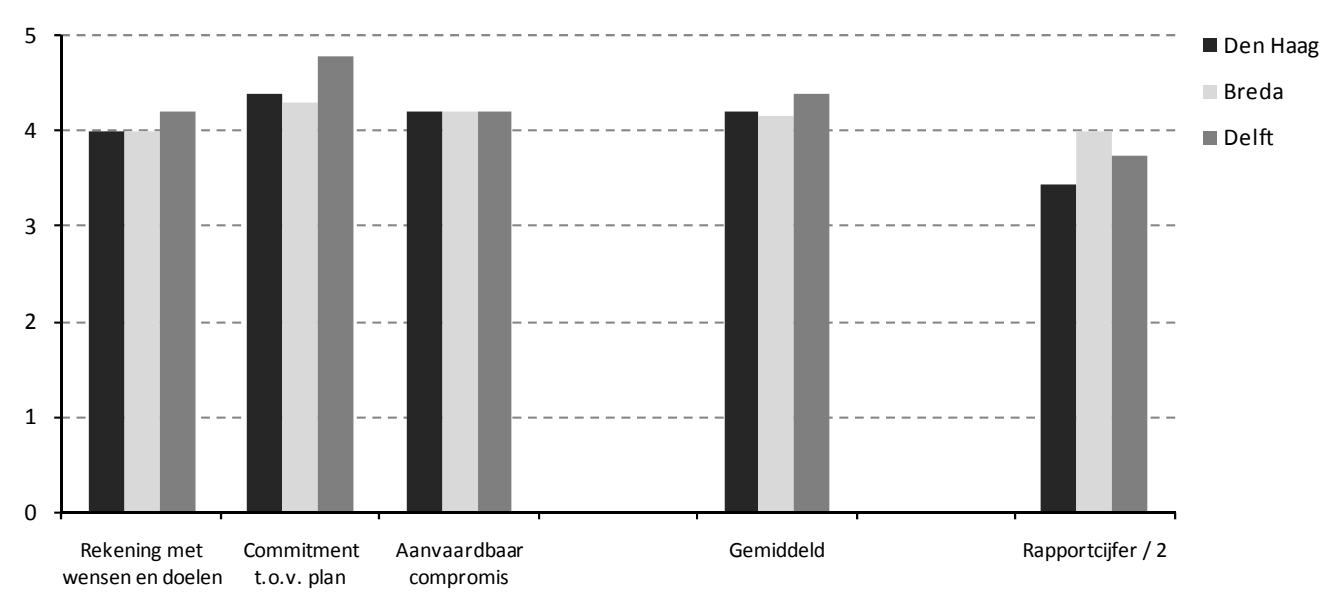

Figuur 9.11 Outputlegitimiteit OVT-planproces in drie cases

Niet alleen het masterplan, maar ook het deelplan voor de OV-knoop in Delft blijkt op de meeste steun te kunnen rekenen (zie figuur 9.11). Vooral de mate waarin keystakeholders zich gecommitteerd voelen aan dit plan is in Delft zeer hoog. Beide andere cases laten eveneens een positief beeld zien. In geen van de cases zijn keystakeholders van mening dat in de plannen (zeer) weinig rekening is gehouden met hun wensen en voorkeuren en vrijwel zonder uitzondering voelen zij zich (zeer) sterk gecommitteerd aan de plannen en zien zij deze als een (zeer) aanvaardbaar compromis. Relatief gezien komt, evenals voor de masterplannen, ook hier het deelplan voor de OV-terminal in Den Haag als minst positief naar voren.

\section{Belangrijkste conclusie outputlegitimiteit}

- In alle drie cases blijken de resultaten van planvorming, zijnde het masterplan en het deelplan voor de OV-terminals, op veel steun te kunnen rekenen van keystakeholders.

- Zowel voor het masterplan als voor het deelplan voor de OV-terminal blijkt de steun in Delft het grootst en in Den Haag het minst.

\section{Overzicht}

In deze paragraaf is de effectiviteit en legitimiteit van planvorming in de drie cases vergeleken. Voor het planvormingsproces gericht op het ontwikkelen van een masterplan staat een overzicht van de resultaten weergegeven in tabel 9.6.

Uit het overzicht blijkt dat de planvorming van het masterplan in alle cases als effectief en legitiem wordt beoordeeld. Daarbij blijkt dat qua legitimiteit in alle cases het oordeel over de wijze waarop de invoer van wensen, voorkeuren en belangen in het planproces heeft plaats gevonden (inputlegitimiteit) en het resultaat (outputlegitimiteit) positiever is dan het oordeel over de transparantie van het planproces (throughputlegitimiteit). In alle cases bleek het planproces, zelfs voor enkele direct betrokken keystakeholders, namelijk niet volledig helder. Uit de vergelijking van de drie cases komt het planproces van het Masterplan Den Haag Nieuw Centraal zowel qua effectiviteit als legitimiteit als minst positief naar voren. Met uitzondering van de throughputlegitimiteit wordt de planvorming van het Masterplan Spoorzone Delft het meest effectief en legitiem beoordeeld. 


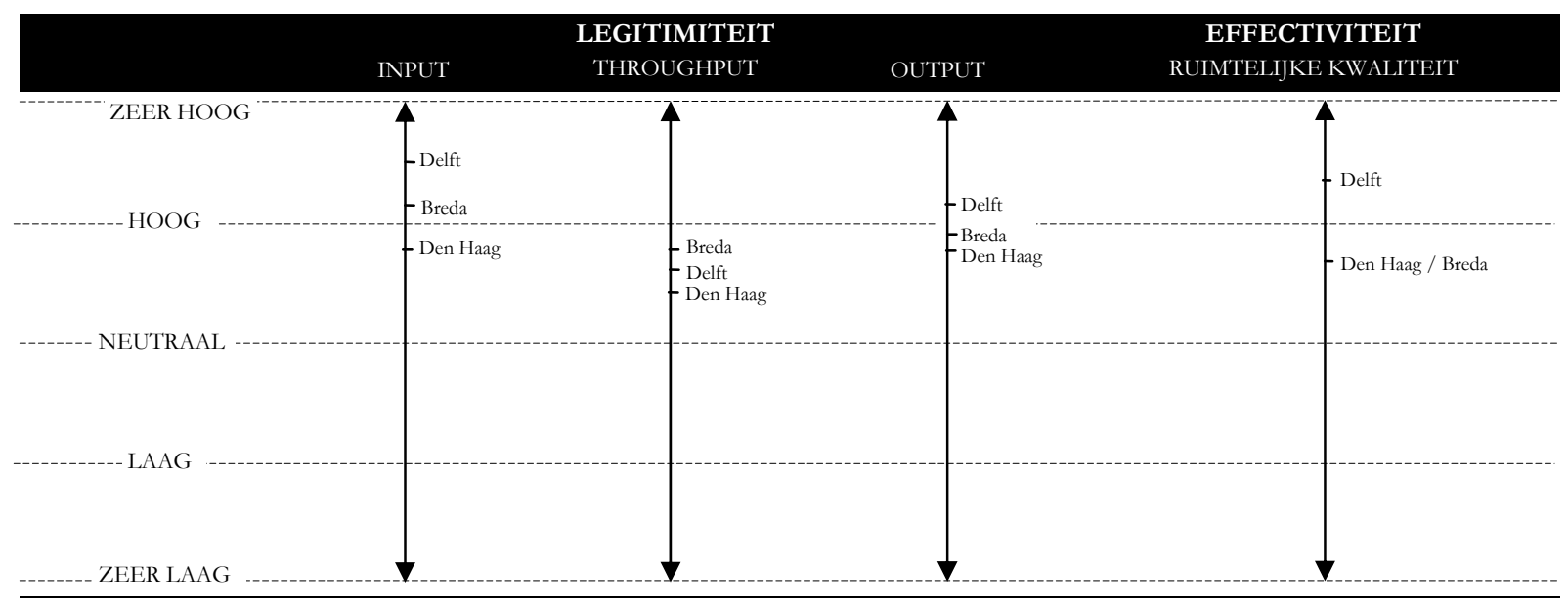

Tabel 9.6 Relatieve positionering cases m.b.t. effectiviteit en legitimiteit van planvorming masterplan

Voor de planvorming voor de OV-terminals is de relatieve positionering van de cases weergegeven in de onderstaande tabel 9.7. Ook de planvorming voor de OV-terminal wordt in alle drie cases als effectief en legitiem beoordeeld. Evenals voor de planvorming van de masterplannen blijkt ook dat de throughputlegitimiteit relatief minder positief wordt beoordeeld dan de twee andere vormen van legitimiteit. Uitzondering vormt het planproces voor de OV-terminal in Breda. In de vergelijking tussen cases komt het planproces voor de OV-terminal in Den Haag zowel qua effectiviteit als legitimiteit als minst positief naar voren. Uitzondering hierop vormt de inputlegitimiteit.

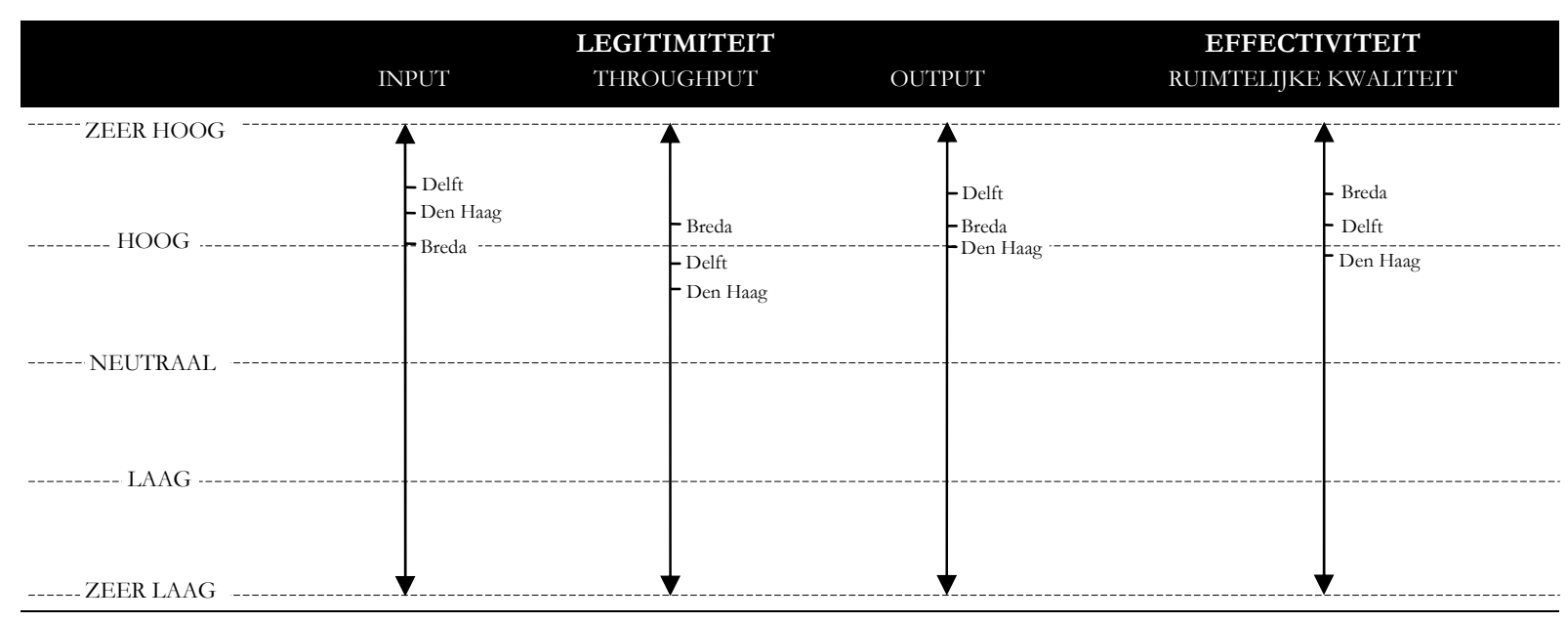

Tabel 9.7 Relatieve positionering cases m.b.t. effectiviteit en legitimiteit van planvorming OV-terminal

\subsection{Analyse van relaties tussen procesinrichting en borging publiek belang}

Literatuur benoemt verschillende factoren die een rol spelen in de relatie tussen de inrichting van processen en de borging van het publiek belang. Over de wijze waarop deze op elkaar ingrijpen, is het beeld in literatuur niet eenduidig. Enerzijds worden diverse argumenten aangedragen die de stelling onderbouwen dat meer samenwerking, participatie en overleg noodzakelijk is om te komen tot 
effectieve en legitieme oplossingen voor ruimtelijke problemen. Anderzijds wordt er vanuit de democratische rechtstaatgedachte op gewezen dat dit tot gevolg heeft dat planvorming deels plaats vindt buiten de macht die is toebedeeld aan representatieve instituties. Deze vervaging van grenzen zou een aantasting kunnen betekenen voor publieke belangen en publieke waarden. In deze paragraaf wordt bestudeerd in hoeverre er een samenhang bestaat tussen de procesinrichting en de criteria voor de borging van het publiek belang.

\subsubsection{Methode voor het analyseren van relaties}

Als hulpmiddel voor de analyse is de case-ordered predictor-outcome matrix van Miles and Hubermann (1994) gebruikt. Eerste stap in deze aanpak is de ordening van de cases naar de afhankelijke variabele. De afhankelijke variable (borging publiek belang) bestaat in deze studie echter uit meerdere subvariabelen waarvan aggregatie in een totaalscore niet wenselijk is. Daarom wordt de ordening per subvariabele bezien. Als de waarden van de afhankelijke (sub)variabele(n) en de waarden van de onafhankelijke variabelen zijn ingevuld ontstaat een verzamelmatrix. Deze (quasi-) kwantitatieve analyse biedt de mogelijkheid een eerste inzicht te verkrijgen in het overheersende beeld dat in de cases te onderkennen is. Vervolgens is de vraag in hoeverre bepaalde patronen zijn te ontdekken die onderling vergelijkbaar zijn of verschillen. Dit kan worden gedaan door per kolom de waarden van de onafhankelijke variabele en de waarde van de afhankelijke (sub)variabele na te gaan. Vervolgens kunnen de kolommen worden vergeleken. In aansluiting hierop kan de analyse verschillende vormen aannemen. Met erkenning van het feit dat er in elke case projectspecifieke contextfactoren te onderkennen zijn, gaat het er bij Miles and Huberman (1994) om dat door ordening, indikking, abstractie en interpretatie gekomen wordt tot uitspraken over verbanden. Uiteindelijk kan de meer variabelen georiënteerde aanpak verschuiven naar een meer casegeoriënteerde aanpak, door eventuele patronen te confronteren met de resultaten uit individuele case beschrijvingen.

\subsubsection{Visievorming en publiek belang}

Met visievorming, wordt gedoeld op het proces waarin een (gemeenschappelijk) beeld wordt gevormd van het probleem, een gewenste en haalbaar geachte toekomstige situatie en het veranderingstraject dat nodig is om daar te komen. In deze studie is gefocust op twee deelprocessen; (1) visievorming voor de herontwikkeling van het gebied als geheel. Dit krijgt inhoudelijk vorm in een masterplan. (2) visievorming specifiek gericht op de aanpak van de OV-terminal.

\section{Aantal actoren}

Een eerste kenmerk van het proces van visievorming is het aantal actoren dat daarin een substantiële inbreng heeft gehad. Gesteld is dat er sprake is van een substantiële inbreng als het gemiddelde van de percepties van de inbreng van een actor een waarde $>3$ heeft. Uit kolom A in de verzamelmatrix (9.8) blijkt dit weinig te verschillen tussen de drie cases. Alleen bij het ontwikkelen van het masterplan Den Haag Nieuw Centraal hebben slechts twee partijen een substantiële inbreng gehad. Hoewel de effectiviteit en legitimiteit van het masterplanproces in Den Haag ook minder positief wordt beoordeeld, zorgen de beperkte verschillen ervoor dat het onmogelijk is op basis hiervan een verband te veronderstellen. 


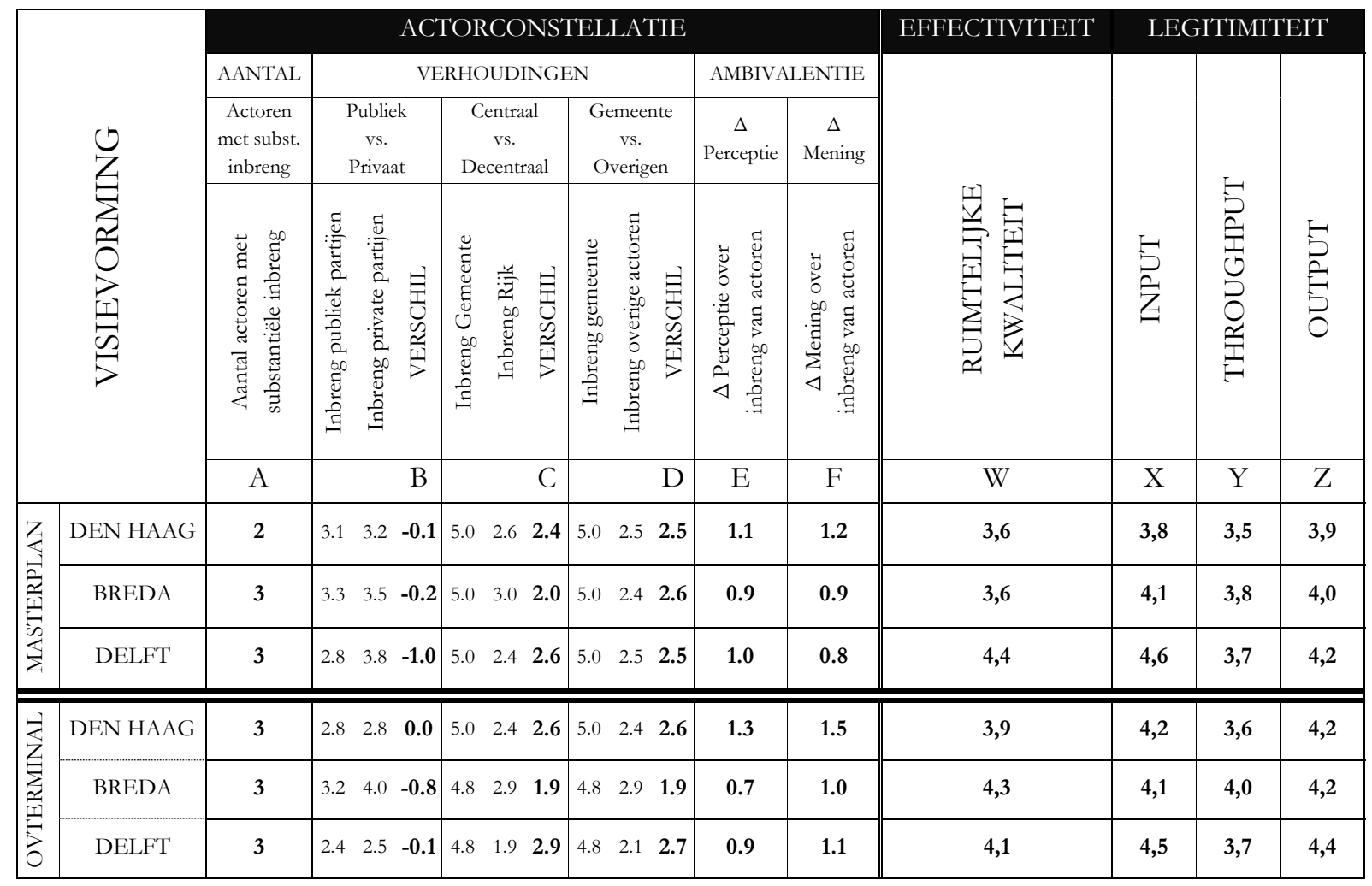

Tabel 9.8 Case-ordered predictor outcome matrix - visievorming en publiek belang

\section{Verhoudingen tussen actoren}

Een tweede kenmerk aan de hand waarvan het proces van visievorming getypeerd kan worden betreft de verhoudingen in de inbreng van actoren met uiteenlopende karakters en belangenposities. Allereerst is gekeken naar de inbreng van publieke en private partijen.

\section{- Publiek vs. Privaat}

Vanuit de publieke sector zijn bij de aanpak van stationslocaties als direct representerende overheden de gemeente, de provincie en het Rijk betrokken. Vanuit de (semi-)private sector is altijd NS betrokken en voor de gebiedsontwikkeling wordt vaak samengewerkt met andere ontwikkelaars. Hier is gekeken of het planproces effectiever en/of legitiemer is als publieke of private partijen daarin een relatief grote inbreng hebben gehad. Dit is gedaan door de inbreng van de gemeente, de provincie en beide ministeries enerzijds en de inbreng van NS en private ontwikkelaars anderzijds tegen elkaar af te zetten. De waarde in kolom B van tabel 9.8 is een indicator voor het verschil tussen de inbreng van publieke en private partijen.

Eerste vraag is of het planproces effectiever is als publieke dan wel private partijen daarin een relatief grote inbreng hebben gehad. Uit vergelijking van kolom B en kolom W valt op te maken dat een relatief grote inbreng van publieke partijen in ieder geval niet op positieve wijze verband lijkt te houden met de effectiviteit van dat proces. Eerder wijzen de resultaten in tegengestelde richting. Voor het ontwikkelen van een masterplan blijkt namelijk dat private partijen (NS, Ballast-Nedam) in Delft relatief de grootste inbreng hebben gehad, terwijl de verwachting is dat het masterplan in Delft 
een grotere bijdrage zal hebben aan het verhogen van de ruimtelijke kwaliteit (en het planproces daarmee effectiever is) dan in de andere twee cases. De resultaten van het planproces voor de OVterminal versterken dit beeld. Naarmate private partijen een grotere inbreng hebben, is de effectiviteit hoger. Hierbij moet de kanttekening worden gemaakt dat de verschillen in effectiviteit van het proces voor de OV-terminal beperkt zijn.

Tweede vraag is of het planproces als legitiemer wordt ervaren als publieke dan wel private partijen daarin een relatief grote inbreng hebben gehad. Uit tabel 9.9 valt op te maken dat de relatief grote inbreng van private partijen in de planvorming van het masterplan in Delft in ieder geval niet heeft geleid tot een proces dat als minder legitiem wordt ervaren. In de eerste plaats blijkt namelijk de openheid (inputlegitimiteit) in Delft groter dan in Breda en Den Haag (tabel 9.9, kolom X). In de tweede plaats blijkt het proces in Delft niet substantieel minder transparant (throughputlegitimiteit) dan in Breda en transparanter dan in Den Haag (kolom Y). In de derde plaats is de steun voor het Masterplan Spoorzone Delft groter dan voor de andere twee masterplannen (kolom Z). De resultaten voor de OV-terminal ontkrachten dit beeld niet. Naarmate private partijen een relatief grote inbreng hebben is de througputlegitimiteit (kolom Y) hoger. Voor beide andere vormen van legitimiteit ontstaat geen eenduidig beeld.

In algemene zin kan worden gesteld dat een mogelijke verwachting dat een relatief grotere inbreng van (publieke) representatieve instituties in het proces van visievorming een noodzakelijke voorwaarde is voor een effectief en legitiem proces in ieder geval niet door de resultaten wordt onderbouwd. Voor de effectiviteit van het proces geldt zelfs eerder het omgekeerde.

\section{- Centraal vs. Decentraal}

Als tweede is gekeken naar de verhouding tussen de inbreng van de centrale en decentrale overheden. Vanuit de centrale overheid zijn het ministeries VROM en het ministerie van Verkeer en Waterstaat het meest direct betrokken bij stationslocatieprojecten. Op decentraal niveau is dit de betreffende gemeente. Geanalyseerd is of het planproces effectiever en/of legitiemer is als centrale dan wel decentrale overheden daarin een relatief grote inbreng hebben gehad. Daarvoor is de inbreng van gemeenten afgezet tegen de inbreng van het Rijk.

Zoals hiervoor al beschreven hebben de gemeenten in alle cases een zeer grote inbreng gehad in het proces van visievorming. Dit geldt zowel voor het ontwikkelen van het masterplan voor de gebiedsontwikkeling als geheel als in het planproces voor de OV-terminal. In de perceptie van keystakeholders is deze inbreng aanzienlijk groter dan die van de rijkspartijen. Dit wijst op een decentraal geregisseerd proces en correspondeert met het rijksbeleid waarin gemeenten primair verantwoordelijk worden geacht voor de integrale ontwikkeling van stationslocaties en hiervoor de regie zouden moeten voeren. Verschillen tussen cases blijken er wel te bestaan in de inbreng van rijkspartijen. De resultaten wijzen er echter niet op dat deze verschillen een mogelijke invloedsfactor zijn voor de effectiviteit of legitimiteit van het proces. Wordt kolom $\mathrm{C}$ namelijk afgezet tegen de effectiviteit en legitimiteit dan komt voor geen van de onderdelen een eenduidig beeld naar voren.

\section{- Gemeente vs. Overigen}

Tegen de achtergrond van de discussie over het publiek belang is expliciet gekeken naar de rol van de gemeente als meest directe representatieve overheidsorgaan in stationslocatieprojecten. Gemeenten hebben in alle cases ook een regierol in het proces. Voor de realisatie van plannen is de gemeente 
echter afhankelijk van andere keystakeholders. Geanalyseerd is in hoeverre de mate van dominantie van de gemeente in het planproces samenhangt met de effectiviteit en legitimiteit ervan. De mate van dominantie is bepaald aan de hand van het verschil tussen de inbreng van de gemeente en de inbreng van alle overige keystakeholders.

Eerste vraag is of het planproces effectiever is als de gemeente een relatief grotere inbreng heeft in het proces van visievorming. Dit blijkt niet het geval. In alle cases waren de gemeenten de dominante partij in het proces van visievorming. Bij het ontwikkelen van een masterplan verschilt de mate van dominantie nauwelijks tussen cases (kolom D). Omdat er wel een verschil is in de effectiviteit van het planproces (kolom W) lijkt de dominantie van de gemeente geen invloedsfactor. Voor de OVterminal verschilt de mate van dominantie van de gemeente meer tussen cases. Worden deze verschillen vergeleken met verschillen in effectiviteit dan geeft dit eveneens geen aanleiding deze als invloedsfactor te veronderstellen.

Tweede vraag is of het planproces als legitiemer wordt ervaren als de gemeente een relatief grotere inbreng heeft in visievorming. Uit een vergelijking van de resultaten in kolom $\mathrm{D}$ met de resultaten in de kolommen $\mathrm{X} / \mathrm{Y} / \mathrm{Z}$ van tabel 9.8 komen hiervoor geen aanwijzingen naar voren.

\section{Ambivalentie}

Een derde kenmerk aan de hand waarvan het proces van visievorming getypeerd kan worden, is de mate van ambivalentie in het beeld bij keystakeholders. De vraag is of het planproces effectiever en/of legitiemer is naarmate er meer consensus bestaat bij keystakeholders over de feitelijke/wenselijke situatie.

\section{- Perceptieverschillen}

De feitelijke inbreng van verschillende keystakeholders in het proces is gereconstrueerd aan de hand van de percepties die de keystakeholders in het betreffende project daar zelf van hebben. Deze percepties blijken lang niet altijd overeen te komen. Voor het verschil daarin is de standaard deviatie als maat genomen. Deze staat in kolom E van tabel 9.8 weergegeven.

Het blijkt dat zowel voor het masterplan als voor de OV-terminal het verschil in perceptie tussen keystakeholders het grootst is in Den Haag en het kleinst is in Breda. Een vergelijking met de resultaten qua effectiviteit en legitimiteit van het proces laat zien, dat naarmate de perceptieverschillen groter zijn de transparantie van het proces (throughputlegitimiteit) minder is. In Den Haag blijkt zowel voor het masterplan als voor het deelplan voor de OV-terminal minder helder wie, wanneer, welke beslissingen nam; wat de wensen en voorkeuren van partijen waren en welke daarvan gehonoreerd werden en waarom. Deze transparantie is het grootst in de case waar de perceptieverschillen het kleinst zijn, te weten Breda.

Voor beide andere dimensies van legitimiteit (input/output) en voor de effectiviteit zijn de aanwijzingen niet krachtig genoeg om een negatief verband te veronderstellen. De omgekeerde redenering dat een ambivalenter beeld van de inbreng van keystakeholders een positief effect heeft op de effectiviteit en input- en outputlegitimiteit lijkt op basis van de resultaten en logisch redeneren vrijwel uit te sluiten.

- Meningsverschillen 
De wenselijke inbreng van verschillende keystakeholders in het proces is bepaald aan de hand van de meningen die de keystakeholders in het betreffende project daar zelf van hebben. Deze meningen blijken lang niet altijd overeen te komen. Voor het verschil daarin is de standaard deviatie als maat genomen. Deze staat in kolom F van tabel 9.8 weergegeven.

Een vergelijking met de resultaten qua effectiviteit en legitimiteit van het proces geeft aanleiding te veronderstellen dat beide in ieder geval niet gebaat zijn bij grotere meningsverschillen tussen keystakeholders. In de eerste plaats geldt namelijk dat naarmate het verschil van mening over de inbreng die deze partijen bij het ontwikkelen van het masterplan zouden moeten hebben groter is, de input- en outputlegitimiteit kleiner is. In de tweede plaats geldt dat naarmate de verschillen van mening over de inbreng die keystakeholders in het planproces voor de OVT-plan zouden moeten hebben groter is, de throughputlegitimiteit en effectiviteit kleiner is.

Deze resultaten ondersteunen een mogelijke verwachting dat naarmate er in een netwerkomgeving een ambivalenter beeld bestaat over de feitelijke en wenselijke inrichting van het proces in termen van de inbreng van keystakeholders daarin, de kans, dat gekomen wordt tot effectieve en legitieme (vorming van) plannen, geringer is.

\subsubsection{Zeggenschap en publiek belang}

Het tweede thema waarop de inrichting van het proces is bestudeerd, is de wijze waarop zeggenschap is verdeeld. Het gaat dan om de mate waarin verschillende actoren het recht hebben gehad mee te beslissen over de inhoud van plannen. Voor de twee onderscheiden deelprocessen wordt in deze paragraaf bestudeerd in hoeverre de zeggenschapsverdeling verband houdt met de borging van het publiek belang. De gehanteerde aanpak is identiek aan de vorige paragraaf. Tabel 9.9 geeft de verzamelmatrix.

\section{Aantal actoren}

Uit tabel 9.9 blijkt, zowel voor het masterplan als voor de OV-terminal, de effectiviteit (kolom W) het hoogst in de cases waar het grootste aantal actoren substantiële zeggenschap (kolom A) heeft. Omdat de andere cases wel verschillen qua aantal actoren, maar niet qua effectiviteit (of andersom), is het beeld echter niet eenduidig. Niettemin wordt een mogelijke verwachting, dat een kleiner aantal actoren met substantiële zeggenschap in het proces op positieve wijze verband houdt met de effectiviteit daarvan, zeker níet door de resultaten onderbouwd.

Op basis van de resultaten voor het masterplan kan een vergelijkbare conclusie worden getrokken voor de legitimiteit. Uit een vergelijking van kolom A met kolom X, Y en Z blijkt namelijk dat naarmate het aantal actoren met substantiële zeggenschap groter is, de openheid (inputlegitimiteit) en steun voor de plannen (outputlegitimiteit) eveneens groter is. Hoewel de transparantie (througputlegitimiteit) het minst is in de case waar het aantal actoren met een substantiële zeggenschap het kleinst is (Den Haag) zorgen de resultaten in de andere twee cases (Breda en Delft) ervoor dat het beeld voor deze vorm van legitimiteit niet eenduidig is. Niettemin wordt een mogelijke verwachting, dat een kleiner aantal actoren met substantiële zeggenschap in het masterplanproces op positieve wijze verband houdt met de legitimiteit daarvan, zeker niet door de resultaten onderbouwd. De resultaten voor de OV-terminal versterken noch ontkrachten dit beeld. Voor geen van de legitimiteitsvormen zijn er aanwijzingen voor enig verband. 


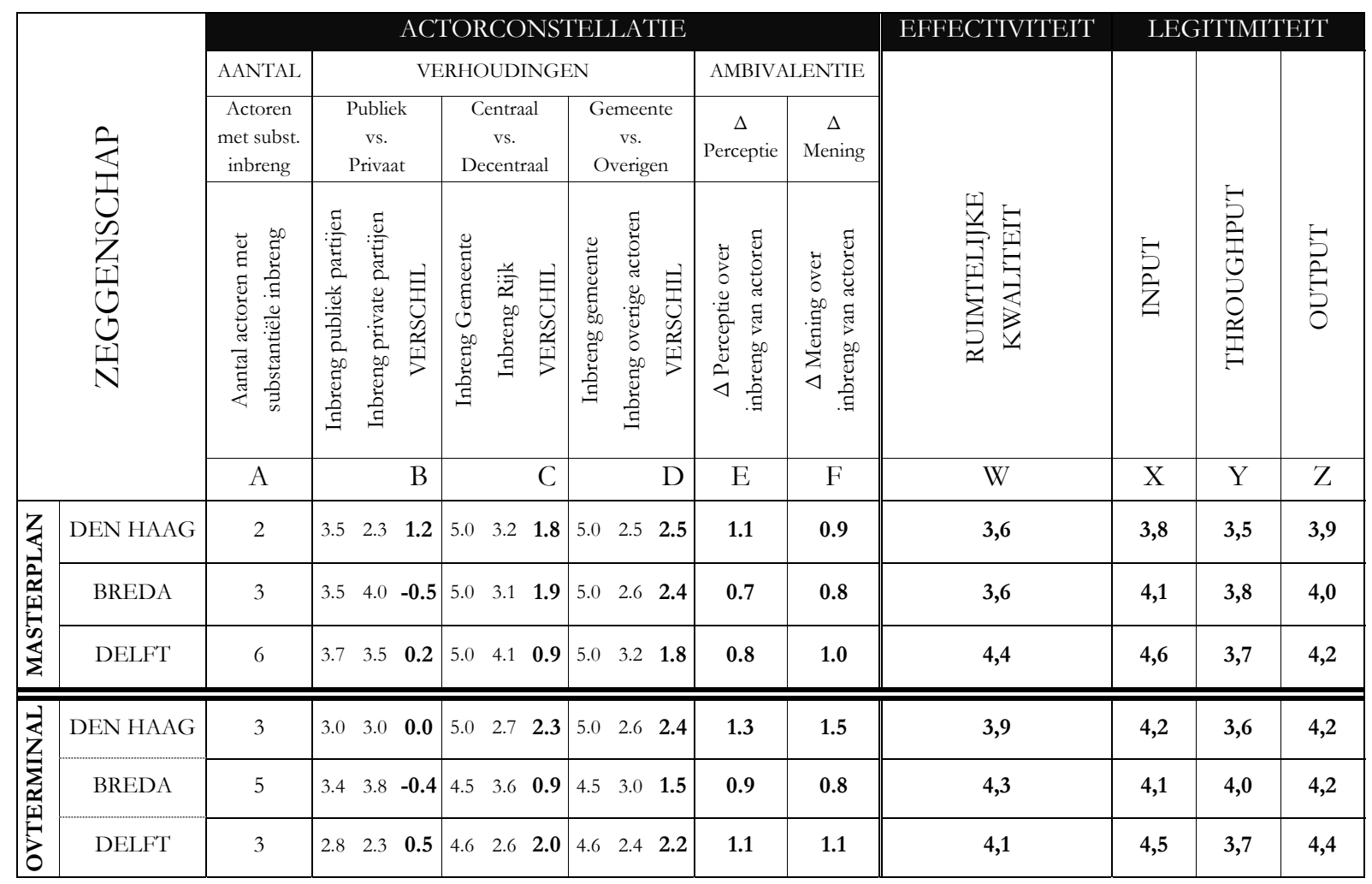

Tabel 9.9 Case-ordered predictor outcome matrix - zeggenschap en publiek belang

\section{Verhoudingen tussen actoren}

Een tweede kenmerk betreft de verhoudingen in zeggenschap tussen actoren met uiteenlopende karakters en belangenposities. De gehanteerde aanpak is identiek aan die in de vorige paragraaf.

- Publiek vs. Privaat

Is het planproces effectiever en/of legitiemer als publieke of private partijen daarin relatief veel zeggenschap hebben gehad? De waarde in kolom B van tabel 9.9 is een indicator voor het verschil in zeggenschap van publieke en private partijen. Uit een vergelijking met de effectiviteit (kolom W) blijkt geen duidelijk verband. Een zelfde conclusie kan worden getrokken waar het gaat om de legitimiteit van het planproces.

\section{- Centraal vs. Decentraal}

Is het planproces effectiever en/of legitiemer als centrale of decentrale overheden daarin relatief veel zeggenschap hebben gehad? In alle drie cases blijkt de betreffende gemeente zeer veel zeggenschap gehad in de planvorming. De zeggenschap van het Rijk verschilt wel aanzienlijk tussen de drie cases. Vergelijking van kolom $\mathrm{C}$ met kolom $\mathrm{W}$ in tabel 9.9 laat zien dat naarmate het verschil tussen de zeggenschap van het Rijk en de gemeente kleiner is, het planproces effectiever is. Dit blijkt zowel voor het masterplan als voor de OV-terminal te gelden. Dit resultaat geeft aanleiding een mogelijk verband tussen verschillen in de verhouding tussen de zeggenschap van Rijk en gemeente en de effectiviteit van het proces nader te bestuderen. 
Een zelfde conclusie kan niet worden getrokken voor de legitimiteit van het planproces. Uit een vergelijking van kolom $\mathrm{C}$ met kolom $\mathrm{X}, \mathrm{Y}$ en $\mathrm{Z}$ komt namelijk geen eenduidig beeld naar voren. Uitzondering vormt de transparantie (througputlegitimiteit) van het planproces voor de OV-terminal. Daarvoor geldt, dat naarmate het verschil qua zeggenschap tussen Rijk en gemeente kleiner is het proces transparanter is. De resultaten voor het planproces van het masterplan ontkrachten deze stelling echter.

\section{- Gemeente vs. Overigen}

Hiervoor is al beschreven dat in alle cases de betreffende gemeente zeer veel zeggenschap in planvorming heeft gehad. Samenwerking met andere keystakeholders is echter noodzaak om plannen ook gerealiseerd te krijgen. De zeggenschap van deze andere keystakeholders verschilt aanzienlijk tussen de cases. De mate van dominantie van de gemeente, beschouwd als het verschil in zeggenschap van de gemeente en de zeggenschap van andere keystakeholders, verschilt daarmee eveneens. Hier speelt de vraag of vergelijking daarvan met de resultaten qua effectiviteit en legitimiteit van het proces aanleiding geven een verband te veronderstellen.

Uit de vergelijking van kolom D met kolom W blijkt, dat naarmate het verschil tussen de zeggenschap van de gemeente en de zeggenschap van de andere keystakeholders kleiner is, het planproces effectiever is. Dit geldt zowel voor het masterplan als voor het planproces voor de OV-terminal.

Uit de vergelijking van kolom $\mathrm{D}$ met kolom $\mathrm{X}, \mathrm{Y}$ en $\mathrm{Z}$ komt geen eenduidig beeld naar voren. Uitzondering vormt de transparantie (througputlegitimiteit) van het planproces voor de OV-terminal. Daar geldt dat naarmate de gemeente minder dominant is, het proces als transparanter wordt ervaren. De resultaten voor het planproces van het masterplan ontkrachten dit beeld echter.

De stelling dat dominantie van de gemeente als meest directe representatieve institutie een noodzakelijke voorwaarde is voor een effectief en legitiem proces wordt niet door de resultaten onderbouwd. In alle cases hebben gemeenten weliswaar een dominante rol gespeeld en in alle cases wordt de planvorming als effectief en legitiem beoordeeld, echter naarmate de rol van de gemeente dominanter is ten opzichte van andere keystakeholders wijzen de resultaten richting een verminderde effectiviteit en ontstaat qua legitimiteit geen eenduidig beeld. Dit spoort wel met de verwachting dat in een netwerkomgeving een al te overheersende rol voor één actor niet bijdraagt aan een hogere effectiviteit en legitimiteit.

\section{Ambivalentie}

Het derde kenmerk is de mate van ambivalentie. De vraag is of het planproces effectiever en/of legitiemer is naarmate er meer consensus bestaat bij keystakeholders over de feitelijke/wenselijke verdeling van zeggenschap.

\section{- Perceptieverschillen}

De feitelijke verdeling van zeggenschap over verschillende keystakeholders is gereconstrueerd aan de hand van de percepties die de keystakeholders in het betreffende project daar zelf van hebben. Voor de mate waarin deze percepties verschillen, is de standaard deviatie als maat genomen. Deze staat in kolom E van tabel 9.9 weergegeven.

Het blijkt dat het verschil in perceptie bij keystakeholders het grootst is in Den Haag en het kleinst is in Breda. Zoals in de vorige paragraaf beschreven was dit eveneens het geval waar het ging om de 
inbreng van keystakeholders in het proces van visievorming. Uit de vergelijking met de effectiviteit en legitimiteit van het proces komen dan ook dezelfde resultaten naar voren. Dat wil zeggen dat naarmate de perceptieverschillen groter zijn, de transparantie van het proces (throughputlegitimiteit) minder is. Voor beide andere dimensies van legitimiteit (input/output) en voor de effectiviteit zijn de aanwijzingen niet krachtig genoeg om een negatief verband te veronderstellen. De omgekeerde redenering, dat grotere perceptieverschillen een positief effect heeft op de effectiviteit, input- en outputlegitimiteit lijkt op basis van de resultaten en logisch redeneren ook hier vrijwel uit te sluiten.

- Meningsverschillen

De wenselijke verdeling van zeggenschap over verschillende keystakeholders is bepaald aan de hand van de meningen die de keystakeholders in het betreffende project daar zelf van hebben. Voor de mate waarin de meningen daarover verschillen is de standaard deviatie als maat genomen. Deze staat in kolom $\mathrm{F}$ van tabel 9.9 weergegeven.

Voor beide deelprocessen blijkt het verschil van mening het kleinst in Breda. Voor het masterplanproces zijn de verschillen hierin tussen cases echter zeer klein. Vergelijking met de resultaten qua effectiviteit en legitimiteit laat hier ook geen eenduidig beeld zien. Voor de OVterminal blijkt, dat naarmate de meningsverschillen over de zeggenschap die verschillende keystakeholders zouden moeten hebben groter zijn, de effectiviteit en transparantie (throughputlegitimiteit) van het proces minder positief beoordeeld wordt. Voor beide andere vormen van legitimiteit ontstaat geen eenduidig beeld. Grotere verschillen van mening tussen keystakeholders hebben geen negatief effect op de openheid van het proces (inputlegitimiteit) en de steun voor de plannen (outputlegitimiteit).

\subsubsection{Middelen en publiek belang}

In de vorige twee paragrafen stond respectievelijk de inbreng van keystakeholders in het proces van visievorming en de zeggenschapsverdeling tussen deze partijen centraal. Het ontwikkelen en daadwerkelijk realiseren van plannen vraagt echter om de inzet van middelen. Partijen die belangen hebben in een gebied maken afspraken over de eisen en wensen waaraan plannen dienen te voldoen en onder welke voorwaarden zij bereid zijn de hun ter beschikking staande middelen voor de realisatie ervan in te zetten. Het derde thema waarop de inrichting van het proces is bestudeerd is de inbreng van middelen door keystakeholders. Voor dit thema is eveneens gekeken of de kenmerken van de actorconstellatie mogelijk verband houden met de borging van het publiek belang. In tegenstelling tot de vorige twee paragrafen is geen onderscheid gemaakt naar het planproces van het masterplan en het planproces voor de OV-terminal. Het gaat om de inzet van middelen voor de ontwikkeling en realisatie van het integrale project. Ook is de mate van consensus/dissensus in de mening over de wenselijke situatie bij dit thema buiten beschouwing gelaten, omdat verondersteld wordt dat een grotere inbreng van middelen door andere actoren dan de eigen organisatie vrijwel altijd wenselijk wordt gevonden. Voor het overige komt de gehanteerde aanpak overeen met de vorige twee paragrafen. Tabel 9.10 geeft de verzamelmatrix.

\section{Aantal actoren}

Uit kolom A in tabel 9.10 blijkt dat het aantal keystakeholders dat meer middelen in heeft gebracht dan mocht worden verwacht in Breda (4) en Delft (4) een stuk groter is dan in Den Haag (1). Zowel 
de effectiviteit (kolom W) als de legitimiteit (kolom X/Y/Z) van het planproces wordt in Den Haag ook als minst positief beoordeeld. Voor de verschillen in effectiviteit en legitimiteit tussen Breda en Delft kan de verklaring echter niet gevonden worden in het aantal actoren. Dit maakt het lastig met enige kracht uitspraken te doen over een mogelijke samenhang. Niettemin lijkt de effectiviteit en legitimiteit er in ieder geval niet bij gebaat als het beeld bij keystakeholders is dat slechts één enkele actor meer middelen inbrengt dan mag worden verwacht. Als - zoals het geval is in Den Haag - het beeld is dat alle andere keystakeholders minder middelen inbrengen dan van hen mag worden verwacht, dan lijkt het 'klimaat' waarin planvorming plaats vindt niet positief.

\begin{tabular}{|c|c|c|c|c|c|c|c|c|c|c|c|}
\hline & & & ACT & [ORCONST & ELLATIE & & & EFFECTIVITEIT & & ITIN & \\
\hline & & AANTAL & & RHOUDINGE & & AMBIV & LENTIE & & & & \\
\hline & Z & $\begin{array}{l}\text { Aantal } \\
\text { actoren }\end{array}$ & $\begin{array}{c}\text { Publiek } \\
\text { vs. } \\
\text { Privaat }\end{array}$ & $\begin{array}{c}\text { Centraal } \\
\text { vs. } \\
\text { Decentraal } \\
\end{array}$ & $\begin{array}{c}\text { Gemeente } \\
\text { vs. } \\
\text { Overigen } \\
\end{array}$ & $\begin{array}{c}\Delta \\
\text { Perceptie }\end{array}$ & $\begin{array}{c}\Delta \\
\text { Mening }\end{array}$ & & & & \\
\hline & 至 & 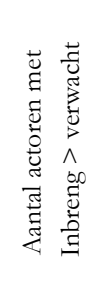 & 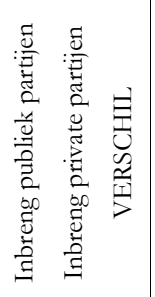 & 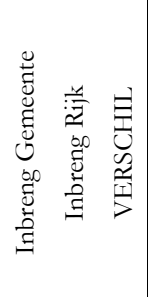 & 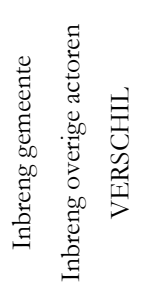 & 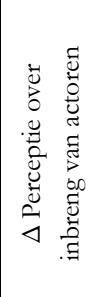 & 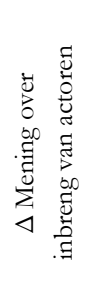 & 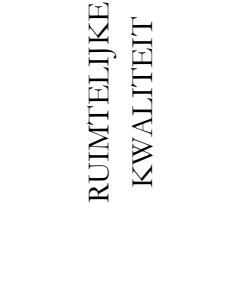 & 定 & 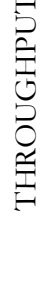 & $\begin{array}{l}5 \\
5 \\
5 \\
5 \\
0\end{array}$ \\
\hline & & A & B & $\mathrm{C}$ & $\mathrm{D}$ & $\mathrm{E}$ & F & W & $\mathrm{X}$ & Y & Z \\
\hline Z & DEN HAAG & 1 & $2.8 \quad 2.7 \quad 0.1$ & \begin{tabular}{|lll}
3.7 & 2.5 & 1.2
\end{tabular} & $\begin{array}{lll}3.7 & 2.6 & 1.1\end{array}$ & 1.0 & nvt & 3,6 & 3,8 & 3,5 & 3,9 \\
\hline$\frac{\pi}{1}$ & BREDA & 4 & $3.2 \quad 3.2 \quad \mathbf{0 . 0}$ & $2.7 \quad 3.3 \quad \mathbf{- 0 . 6}$ & $\begin{array}{lll}2.7 & 3.3 & \mathbf{- 0 . 6}\end{array}$ & 0.4 & nvt & 3,6 & 4,1 & 3,8 & 4,0 \\
\hline$\sum$ & DELFT & 4 & $\begin{array}{lll}3.5 & 2.9 & \mathbf{0 . 6}\end{array}$ & $\begin{array}{lll}4.4 & 2.9 & \mathbf{1 . 5}\end{array}$ & $\begin{array}{lll}4.4 & 3.0 & 1.4\end{array}$ & 0.7 & nvt & 4,4 & 4,6 & 3,7 & 4,2 \\
\hline
\end{tabular}

Tabel 9.10 Case-ordered predictor outcome matrix - middelen en publiek belang

\section{Verhoudingen tussen actoren}

Als tweede kenmerk is gekeken of het type actoren dat meer dan wel minder middelen inbrengt uit maakt voor de effectiviteit en legitimiteit van het proces.

\section{- Publiek vs. Privaat}

Uit kolom B in tabel 9.10 blijkt, dat in de perceptie van keystakeholders in Den Haag en Breda de inbreng van middelen door publieke en private partijen (vrijwel) in evenwicht is. In Delft is het beeld van keystakeholders dat de publieke partijen een relatief grote inbreng van middelen hebben geleverd. Kolom W laat zien dat de effectiviteit het grootst is in Delft en hierin geen verschil bestaat tussen Den Haag en Breda. Dit betekent dat een verband tussen de verhouding in de inbreng van publieke en private partijen en de effectiviteit van het planproces op basis van deze resultaten niet kan worden uitgesloten.

Vergelijking van de data in kolom B met het oordeel over de legitimiteit (kolom X/Y/Z) geeft geen aanwijzingen op basis waarvan een verband kan worden verondersteld. Weliswaar is het oordeel over de input- en outputlegitimiteit het positiefst in Delft, echter de resultaten voor de andere twee cases zorgen ervoor dat geen eenduidig beeld ontstaat. 
- Centraal vs. Decentraal

Als tweede is gekeken naar de verhouding in de inbreng van middelen door de centrale en decentrale overheid. Uit de data in kolom C blijkt dat vooral in Delft, maar ook in Den Haag de gemeente aanzienlijk meer middelen heeft ingebracht dan gegeven de kenmerken van het betreffende project mag worden verwacht, terwijl de inbreng vanuit het rijk in deze twee cases juist minder is dan volgens keystakeholders mag worden verwacht. In Breda is de perceptie van keystakeholders dat de situatie juist omgekeerd is. In de beleving van keystakeholders hebben rijkspartijen VROM en Verkeer en Waterstaat vergeleken met de gemeente een relatief grote inbreng van middelen geleverd. Vergelijking met het oordeel over de effectiviteit en legitimiteit van het proces geeft echter geen aanleiding te veronderstellen dat deze verschillen een invloedsfactor hiervoor zijn.

\section{- Gemeente vs. Overigen}

In de vorige paragrafen is al beschreven dat gemeenten in alle cases een zeer grote inbreng hebben gehad in het proces van visievorming en in dat proces ook zeer veel zeggenschap hebben gehad. Qua inbreng van middelen door gemeenten zijn er wel grote verschillen. Vergelijking van deze verschillen met het oordeel over de effectiviteit en legitimiteit van het proces geeft geen aanleiding te veronderstellen dat deze verschillen een invloedsfactor hiervoor zijn.

\section{Ambivalentie}

De vraag of verschillende keystakeholders meer dan wel minder middelen hebben ingebracht dan van hen gegeven de kenmerken van de specifieke opgave mocht worden verwacht, is beantwoord aan de hand van de percepties van betrokken keystakeholders zelf. Deze percepties blijken behoorlijk uiteen te lopen. Dat geldt in het bijzonder in Den Haag (kolom E). Waar het beeld daar bij sommigen is dat een bepaalde actor meer middelen heeft ingebracht dan mag worden verwacht, stellen anderen dat juist het omgekeerde het geval is. Uit de vergelijking met de resultaten qua effectiviteit en legitimiteit blijkt, dat naarmate de verschillen in perceptie tussen betrokken keystakeholders groter zijn het proces als minder transparant (througputlegitimiteit) wordt ervaren. Voor de overige vormen van legitimiteit (input/output) en de effectiviteit van het proces geeft de vergelijking geen eenduidig beeld.

\subsection{Overzicht bevindingen}

In dit hoofdstuk stond de vraag, in hoeverre er een samenhang bestaat tussen de inrichting van het proces en de criteria voor het publiek belang, centraal. Om deze vraag te beantwoorden is in vier stappen een cross-case analyse uitgevoerd. Tabel 9.11 geeft in hoofdlijn de bevindingen die daaruit naar voren komen weer. Een ' + ' in de tabel geeft een mogelijk positief verband aan en een '-' een mogelijk negatief verband. Indien de cel niet is ingevuld wijzen de resultaten niet op enige samenhang. Indien er een '?' bij staat zijn er wel aanwijzingen die een bepaalde richting op wijzen, maar zijn deze niet volledig consistent. Nadere interpretatie van deze resultaten en confrontatie met (theoretische) verwachtingen vindt plaats in slothoofdstuk 10. 


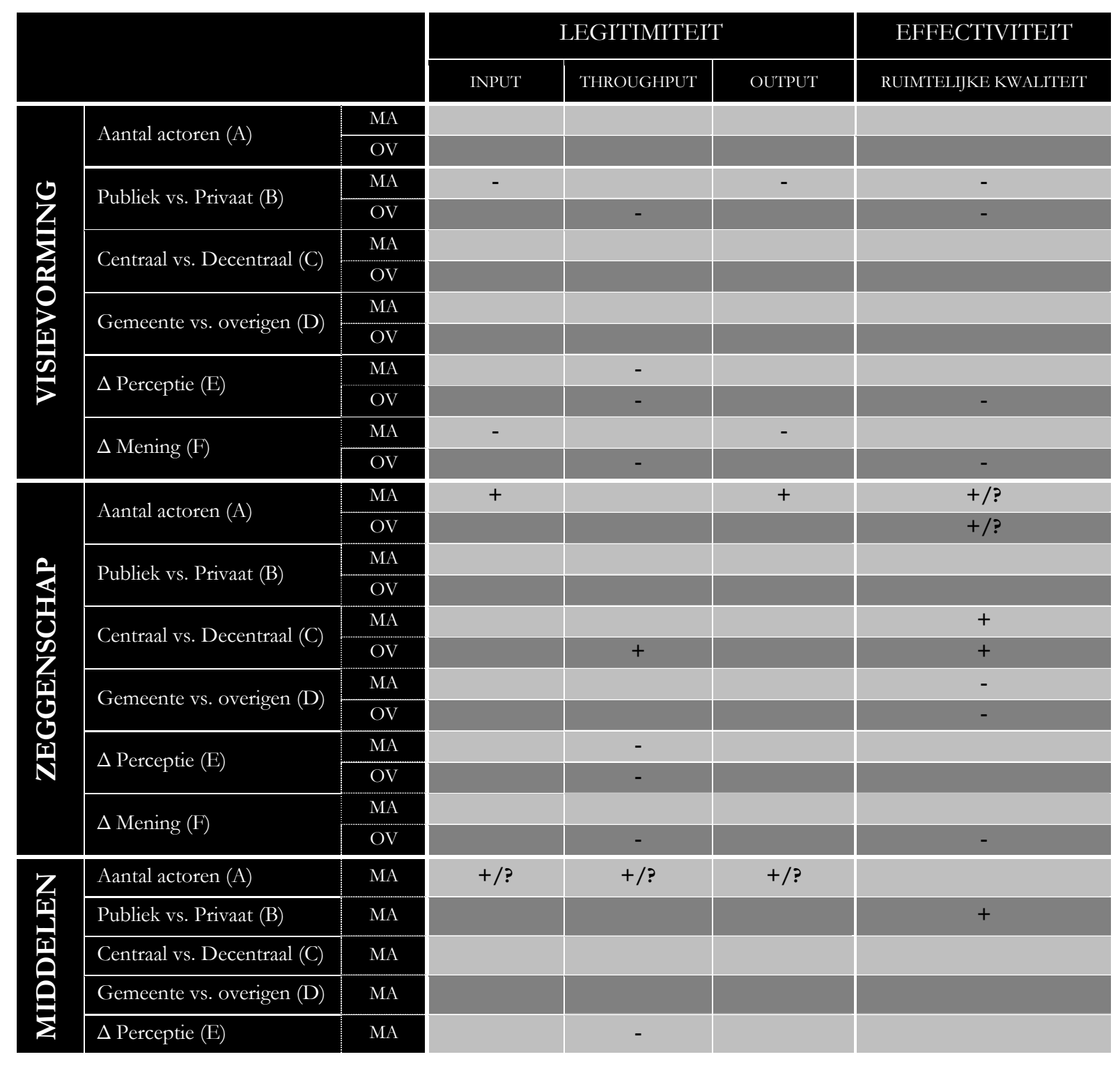

Tabel 9.11 Overzicht cross-case bevindingen 


\section{Hoofdstuk 10 \\ Conclusie en discussie}

\subsection{Inleiding}

In dit onderzoek staat de borging van het publiek belang in ruimtelijke projecten centraal. In literatuur en in het publieke debat wordt de borging van het publiek belang onlosmakelijk verbonden met een rol voor de overheid. Zoals in het eerste hoofdstuk is beschreven, hebben ontwikkelingen in de samenleving er echter voor gezorgd dat de context waarin de overheid functioneert de afgelopen decennia sterk is veranderd. Domeinen van overheid, markt en burgers zijn meer en meer verweven geraakt. Het beeld van de overheid die unicentrisch en top-down de normen stelt, heeft afgedaan en in plaats daarvan wordt in toenemende mate de nadruk gelegd op het samenspel tussen verschillende actoren. Deze verschuiving wordt wel aangeduid als de 'shift van government naar governance'.

In veel recente studies die - mede ingegeven door deze verschuiving - aandacht besteden aan de borging van het publiek belang staat de structurele toedeling of herordening van taken en verantwoordelijkheden tussen overheid en markt in verschillende netwerksectoren centraal (Raad voor Openbaar Bestuur, 1998; Algemene Rekenkamer, 1998; WRR, 2000; Raad voor Verkeer en Waterstaat, 2000; Van Damme, 2001; Stout, 2007; Heldeweg, 2010; e.a.). Dit onderzoek richt zich op projecten in de ruimtelijke sector. Het gaat daarmee - in tegenstelling tot structurele toedeling vooral om de wijze waarop rollen van partijen en hun onderlinge verhoudingen op projectniveau worden vormgegeven.

In het openbaar bestuur en in planvormingsliteratuur wordt veel aandacht besteed aan de veranderende rollen en verhoudingen in ruimtelijke projecten. Met verschillende benamingen, zoals PPS, interactieve planvorming (Glasbergen en Driessen, 2005) en stakeholder involvement (Edelenbosch en Klijn, 2005), wordt de toegenomen participatie van meerdere partijen met uiteenlopende belangenposities benadrukt. In de discussie hierover wordt als het gaat om het publiek belang vooral de nadruk gelegd op de verhoudingen tussen publieke en private partijen. Veelal wordt als voorwaarde gesteld dat bepaalde arrangementen van publieke en private partijen moeten bijdragen aan de behartiging van publieke belangen (Canoy e.a., 2001; Van der Heijden en Spiering, 2002). Het is echter zelden duidelijk wat het publiek belang is en of die verwachtingen worden waargemaakt. 221 Met dit onderzoek is getracht deze leemte zowel conceptueel als empirisch te vullen. Daarvoor is een studie uitgevoerd naar de relatie tussen de procesinrichting en de borging van het publiek belang bij de herontwikkeling van stationslocaties. De inzichten die daaruit naar voren komen, zijn gebaseerd op een theoretische en empirische analyse. Op basis van literatuurstudie is een conceptueel raamwerk opgesteld dat is gebruikt voor het uitvoeren van drie case studies, bestaande uit interviews met stakeholders en documentenanalyse.

Dit hoofdstuk is als volgt opgezet. Paragraaf 10.2 vat de conclusies van het onderzoek samen. Vervolgens wordt in paragraaf 10.3 gereflecteerd op het gehanteerde conceptueel raamwerk en de gebruikte onderzoeksmethodologie en worden enkele aanbevelingen voor praktijk en nader onderzoek gedaan. 


\subsection{Conclusie}

In hoofdstuk 1 is de volgende centrale onderzoeksvraag geformuleerd: bij welke procesinrichting is de kans op succesvolle borging van het publiek belang bij de herontwikkeling van stationslocaties groot. Voorts is een aantal subvragen geformuleerd aan de hand waarvan de centrale vraag kan worden beantwoord. In deze paragraaf worden de vragen beantwoord op basis van de bevindingen uit voorgaande hoofdstukken.

\subsubsection{Kenmerken van stationslocaties}

Eerste onderzoeksvraag was 'wat zijn de kenmerken van stationslocaties?' Deze vraag is als eerste gesteld omdat de kenmerken van dit type projecten de mogelijkheden voor de inrichting van het proces inkaderen.

Stationslocaties zijn op verschillende manieren te typeren (zie Bertolini en Spit, 1998; Peek, 2006). In deze studie zijn stationslocaties beschouwd als binnenstedelijke herontwikkelingsopgaven. Bij deze benadering is de stationslocatie gelijk aan het gebied waarvoor sprake is van een specifiek herontwikkelingsinitiatief met een directe relatie met het station. Voor de vergelijkbaarheid van de onderzoeksresultaten is enkel gekeken naar herontwikkelingsinitiatieven die betrekking hebben op (zeer) grote treinstations en de directe omgevingen daarvan in het centrum van een (middel)grote steden in Nederland.

In fysiek-ruimtelijke zin onderscheiden stationslocaties zich van andere binnenstedelijke herontwikkelings-opgaven doordat de OV-terminal als knooppunt van vervoersstromen/modaliteiten een cruciaal onderdeel van het project is. Veelal heeft de vernieuwing of upgrade van de OV-terminal en de daaraan gekoppelde voorzieningen een aanjagende functie voor de aanpak van het omliggende gebied. In dat omliggende gebied zijn vaak ook meerdere deelgebieden of deelprojecten te onderscheiden. Stationslocaties worden daarmee per definitie gekenmerkt door multifunctionaliteit en de betrokkenheid van meerdere actoren. Vooral het fysiek-ruimtelijke onderscheid tussen enerzijds de OV-terminal en anderzijds het omliggende stedelijk gebied is relevant voor het proces, omdat de partijen, die op grond van bevoegdheden, verantwoordelijkheden of eigendom een belangenpositie hebben, wezenlijk verschillen. Integrale herontwikkeling van het gebied impliceert dat arrangementen van publieke en private actoren die vanuit verschillende niveaus en sectoren bij de diverse functies betrokken zijn noodzakelijk zijn.

De institutionele kenmerken van stationslocaties spelen een belangrijke rol voor de betrokkenheid van actoren in het proces. Binnen de Nederlandse context geeft de Wet Ruimtelijke Ordening het algemeen juridisch kader voor ruimtelijke planvormingsprocessen en verzorgen de Spoorweg- en Concessiewet in belangrijke mate het kader voor de institutionele ordening in de spoorsector. De fragmentatie van procesbenodigdheden binnen deze context zorgt ervoor dat bij de herontwikkeling van grote stationslocaties in Nederland altijd meerdere partijen op enigerlei wijze betrokken zijn.

Vanuit de rijksoverheid zijn dit in ieder geval het ministerie van Verkeer en Waterstaat en het ministerie van VROM. Het ministerie van Verkeer en Waterstaat is bij stationslocaties verantwoordelijk voor de realisatie van een doelmatig basisstation met adequate transfercapaciteit. Het ministerie van VROM is verantwoordelijk voor het ruimtelijk beleid op nationaal niveau. In dat kader streeft zij naar de realisatie van hoogwaardige stations en stationsomgevingen (VROM, 2004). Decentrale overheden (provincie, regio of gemeente) zijn verantwoordelijk voor andere vormen van infrastructuur in het plangebied, zoals busstations, light-rail verbindingen, e.d. De kwaliteit van openbaar stedelijk gebied is primair de verantwoordelijkheid van de gemeente. Zij zijn in dat verband 
onder meer verantwoordelijk voor het beheer en onderhoud van de openbare ruimte rondom stations, zoals stationspleinen. Ook ProRail en NS zijn belangrijke partijen. Als verzelfstandigde taakorganisatie van het ministerie van Verkeer en Waterstaat is ProRail verantwoordelijk voor de bouw, het onderhoud en het beheer van transfergerelateerde voorzieningen op stations. NS is eigenaar van de niet-transfergerelateerde onderdelen van stations, zij doet het dagelijks beheer en onderhoud op stations en exploiteert de commerciële ruimten. Daarnaast heeft zij in de directe omgeving van stations veelal grond of vastgoed in eigendom. Tenslotte zijn er in de directe omgeving nog vaak andere private partijen met een eigendomspositie.

Fysiek-ruimtelijk bezien gaat het bij stationslocaties dus om de integrale herontwikkeling van het fysieke object, het station, en de omliggende ruimte, bestaande uit vastgoed, (toeleidende) infrastructuur en openbare ruimte. Procesmatig bezien betekent herontwikkeling van deze locaties, dat handelen van meerdere actoren, in een situatie waarin er sprake is van onderlinge afhankelijkheid, noodzakelijk is. De wijze waarop dat proces is ingericht, staat in deze studie centraal.

\subsubsection{Inrichting van planprocessen}

Tweede onderzoeksvraag was 'welke procesinrichtingen worden in deze context gehanteerd?' Beantwoording van deze vraag vereist een raamwerk om processen te beschrijven. In deze studie is daarvoor het model van Ostrom et al. (1994) als algemeen conceptueel kader gebruikt.

Kern van het model van Ostrom et al. (1994) is dat alle handelingen van actoren plaats vinden binnen een bepaalde arena. Deze arena bestaat uit actoren en een actie situatie en wordt beïnvloed door drie sturende factoren: kenmerken van de gemeenschap, kenmerken van de fysieke omgeving en van toepassing zijnde regels. De institutionele benadering van planvorming besteedt veel aandacht aan deze institutionele factoren die het handelen van actoren sturen (March en Olson, 1994; Ostrom, 1994; Scharpf, 1999). Deze factoren geven met andere woorden de context waarin actoren handelen en hebben dimensies die algemeen geldend zijn, onafhankelijk van de projectspecifieke situatie en dimensies die specifiek voor een bepaald project van toepassing zijn. De eerste categorie kan de algemene context worden genoemd. Deze context is in hoofdstuk vijf beschreven aan de hand van de fysiek-ruimtelijke kenmerken van stationslocaties, het beleidskader, relevante regelgeving en de actoren die bij de aanpak van dit type projecten betrokken zijn (zie ook 10.2.1). Voor zover factoren specifiek betrekking hebben op een bepaald project kan gesproken worden van de projectspecifieke context. Per project zijn daarvoor de projectgeschiedenis, het procesverloop, de ruimtelijke opgave en de keystakeholders beschreven.

Basisassumptie in deze studie is dat er weliswaar sprake is van een institutionele beperking van de handelingsmogelijkheden, maar dat het feitelijk handelen van actoren in een vergelijkbare setting kan verschillen (Mayntz en Scharpf, 1995; Scharpf, 1999). De nadruk in deze studie ligt op het feitelijk handelen van actoren in het proces. De perceptie van afhankelijkheid om tot realisatie van hun doelen te komen, is wat actoren in een netwerkomgeving - zoals het geval bij stationslocaties - motiveert om te interacteren. Vertaald naar het model van Ostrom et al. (1994) betekent dit dat acties van actoren leiden tot interacties tussen actoren die vervolgens bepaalde uitkomsten hebben. Deze uitkomsten zijn in planvorming te zien als planproducten die het resultaat zijn van een proces waarin diverse actoren in verschillende vorm en in meer of mindere mate een inbreng hebben gehad. Analyse van literatuur over planvorming in ruimtelijke projecten laat zien dat de focus daarin tegenwoordig vooral ligt op benaderingen die uitgaan van een stakeholdersperspectief en zich daarmee richten op de 
inbreng van verschillende stakeholders in het proces (Salet en Fauldi, 2000; Driessen e.a., 2001; Albrechts, 2004, De Kort, 2009; e.a.). Diverse (normatief) theoretische benaderingen van planvorming leggen verschillende nadrukken ten aanzien van de wijze waarop deze inbreng er op een aantal thema's uit dient te zien (De Graaf, 2005). Drie kernthema's waarop benaderingen verschillen, zijn: (1) visievorming; (2) zeggenschap; en (3) middelen.

Visievorming betreft het proces waarin een beeld wordt gevormd van het probleem, een gewenste en haalbaar geachte toekomstige situatie en het veranderingstraject dat nodig is om daar te komen. Ondanks het iteratieve karakter van visievorming zijn in dat proces wel verschillende fasen of deelprocessen te onderkennen met elk haar eigen plannen. Samenhangend met de ruimtelijkfunctionele kenmerken van stationslocaties zijn twee (deel)processen onderscheiden. Het eerste proces heeft betrekking op het plangebied als geheel. De uiteindelijke visie daarvoor wordt veelal vervat in een masterplan waarin de programmatische uitgangspunten en de kwaliteitsambities voor de integrale herontwikkeling worden beschreven. Het tweede proces heeft betrekking op de OVterminal. Dit onderdeel van de integrale herontwikkeling is kenmerkend voor stationslocaties en binnen de Nederlandse context hebben juist hier meerdere publieke en private partijen een positie en belang waardoor interactie noodzakelijk is.

Gedurende het proces van visievorming worden beslissingen genomen die de randvoorwaarden voor het vervolg geven. Deze beslissingen worden al dan niet vastgelegd in overeenkomsten, plannen, vergunningen, e.d. Zeggenschap heeft betrekking op de mate waarin verschillende stakeholders in het proces de mogelijkheid hebben (mee) te beslissen.

Het initiëren, uitwerken en daadwerkelijk realiseren van een visie vraagt om de inzet van middelen. Middelen zijn de instrumenten of hulpbronnen die stakeholders gebruiken om het bereiken van hun doeleinden te bevorderen en zijn cruciaal om actie te kunnen ondernemen. De allocatie van middelen over verschillende actoren zorgt voor afhankelijkheidsrelaties en de noodzaak tot interactie om daadwerkelijk tot herontwikkeling te komen. In deze studie gaat het om de mate waarin stakeholders naar evenredigheid middelen inbrengen. ${ }^{222}$

Tegen de achtergrond van het debat over de borging van het publiek belang (zie 10.2.3) is beargumenteerd dat deze drie thema's kunnen worden gekenmerkt aan de hand van; (a) het aantal keystakeholders dat een substantiële inbreng heeft; (b) de verhoudingen in de inbreng van keystakeholders met uiteenlopende karakters en belangenposities (publiek-privaat; centraal-decentraal; gemeente-andere keystakeholders); en (c) de mate van ambivalentie in de perceptie van keystakeholders ten aanzien van de feitelijke en wenselijke situatie (zie figuur 10.1)

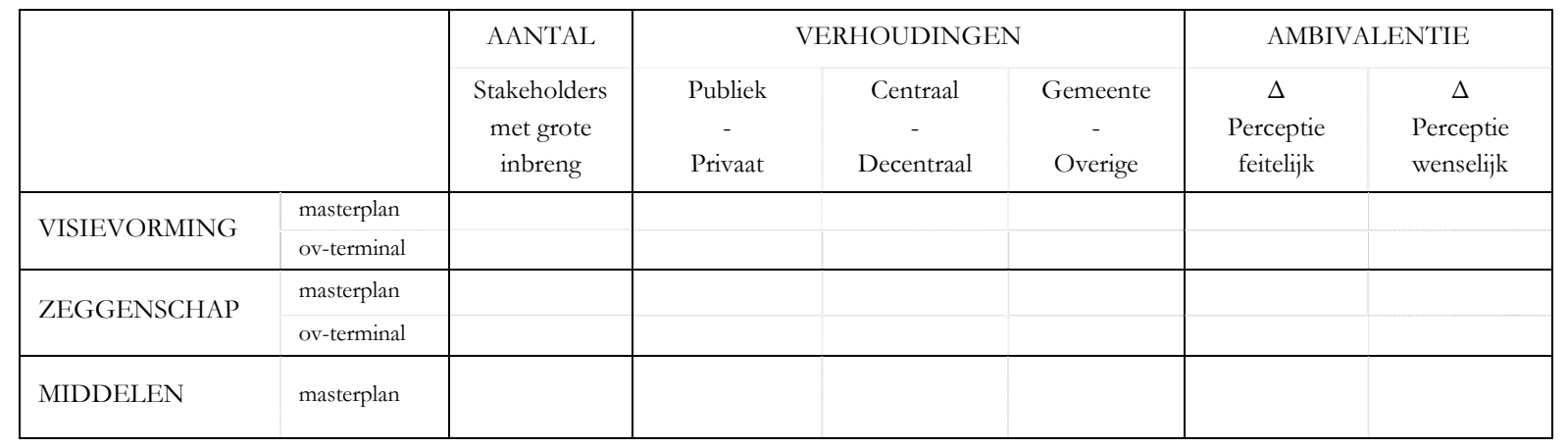

Tabel 10.1 Matrix voor de analyse van planprocessen 


\subsubsection{Borging van het publiek belang}

Derde onderzoeksvraag was: in hoeverre voldoen de stationslocatieprojecten aan de criteria voor de borging van het publiek belang?' Voordat hier op basis van empirische data uitspraken over worden gedaan, wordt eerst antwoord gegeven op twee voorafgaande vragen; Is het publiek belang überhaupt te evalueren; en zo ja, welke criteria kunnen dan voor de borging van het publiek belang worden gehanteerd.

Voor het beantwoorden van de vraag, of het publiek belang überhaupt te evalueren valt, zijn inzichten in politiek-filosofische en economische literatuur bestudeerd. In economische literatuur wordt het falen van de markt gezien als grondslag voor een publiek belang en overheidsingrijpen (Musgrave,1959; Teulings et al, 2003; e.a.). Eenduidigheid over de behoefte aan bepaalde (quasi-) collectieve goederen en welke externe effecten moeten worden ondervangen, ontbreekt echter. In politieke wetenschappen (Downs, 1957; Pfiffner en Presthus, 1967; Dahl, 1994; e.a.) wordt het publiek belang vooral gezien als uitkomst van een politiek proces. Zonder een normatief uitgangspunt te hanteren, kan hier echter moeilijk inhoud aan worden gegeven. Analyse van beide concepties laat zien dat de suggestie dat het publiek belang objectief, onveranderlijk en universeel te specificeren valt problematisch is. Wat in een bepaalde sector in het ene land een publiek belang is, kan in dezelfde sector in een ander land gekenmerkt worden als een privaat belang. Hetzelfde geldt voor verschillende tijdsperiodes. Daarom kan het publiek belang slechts subjectief worden bepaald op basis van een zekere mate van consensus (of intersubjectiviteit). Fundamentele strijdigheid van belangen zorgt ervoor dat die consensus, zeker op het niveau van ruimtelijke projecten, veelal afwezig is. De mate van consensus is groter als het gaat om criteria betreffende de inrichting van de besluitvorming over hetgeen onder verwijzing naar het publiek belang moet worden ondernomen. ${ }^{223}$ Wordt het publiek belang echter alleen gedefinieerd in termen van dergelijke procescriteria dan zouden alle resultaten van de interactie tussen actoren in dat proces - mits tot stand gekomen via de gehanteerde procescriteria - per definitie in het publiek belang zijn. Een dergelijke puur procedurele omschrijving van het publiek belang wordt evenwel onbevredigend geacht (Dahl en Lindblom, 1997). Ook het resultaat dient een rol te spelen. Als het gaat om resultaten op het niveau van concrete ruimtelijke projecten is dit gezien een gebrek aan consensus over wat 'goede' resultaten vormen vrijwel onmogelijk. Op een hoger abstractieniveau daarentegen lijkt er binnen een bepaalde setting meer overeenstemming en zijn mogelijk wel min of meer breed gedragen criteria voor (ruimtelijke) kwaliteit te ontwikkelen. De analyse van theoretische inzichten heeft geleid tot de conclusie dat het publiek belang slechts in evaluatieve zin gebruikt kan worden, als de evaluatie betrekking heeft op - binnen een bepaalde institutionele en situationele setting - intersubjectief gedeelde waarden, waarbij naar criteria vertaalde waarden zowel betrekking dienen te hebben op de vormgeving van het proces als op het uiteindelijke resultaat.

Tweede vraag is dan, welke criteria, met de voorgaande conclusie als uitgangspunt, voor de borging van het publiek belang kunnen worden gehanteerd. Met andere woorden, welke proceswaarden en inhoudelijke waarden worden binnen de institutionele en situationele setting van Nederlandse stationslocaties intersubjectief gedeeld. Voor de specificatie is angesloten bij het idee van de democratische rechtstaat waarvan de maatschappelijke en politieke aanvaarding stevig verankerd is. De intersubjectief gedeelde waarden van de democratische rechtstaat geven een aantal criteria voor de operationalisering van de proceswaarden. Door publieke instellingen (WRR, 2001; ROB, 1998), in 
governance literatuur en in verschillende relevante wetenschappen (Downs, 1957; Buchanan and Tullock, 1962; Ostrom, 1973), worden hiervoor de criteria legitimiteit, effectiviteit, efficiency, rechtsgelijkheid en rechtszekerheid expliciet dan wel impliciet als uitgangspunt gehanteerd. In deze studie is gefocust op effectiviteit en legitimiteit. 224

Legitimiteit wordt vaak in verband gebracht met aanvaarding, acceptatie of steun door diegenen die de gevolgen ondervinden (Weber, 1922; Easton, 1965; Hoogerwerf, 1989; e.a.). In deze studie gaat het om legitieme planvorming. Op basis van literatuurstudie is beargumenteerd dat een onderscheid kan worden gemaakt naar input-, throughput- en outputlegitimiteit (Scharpf, 1999; Bekkers en Edwards, 2007).

Inputlegitimiteit heeft betrekking op de wijze waarop beslissingen tot stand komen. Vanuit dit perspectief is planvorming legitiem als en omdat beslissingen zijn afgeleid uit de authentieke voorkeuren binnen een bepaalde gemeenschap (Scharpf, 1997). Omdat voorkeuren van stakeholders in ruimtelijke projecten verschillen gaat het om de procedures en mechanismen die worden gebruikt om de uiteenlopende voorkeuren gedurende het proces te vertalen in beslissingen over de te realiseren output. Voldoet het proces aan van toepassing zijnde rechtsbeginselen (legaliteit) en hebben alle relevante partijen voldoende mogelijkheid gehad hun wensen en voorkeuren kenbaar te maken (openheid).

Throughputlegitimiteit heeft betrekking op de transparantie van processen (Haus et al., 2000; Bekkers, 2007). Transparantie van het proces wordt wel gezien als een vorm van openheid (Pröpper en Steenbeek, 1999; Edelenbos, 2000). Door inzicht te geven in de wijze waarop uiteenlopende wensen en voorkeuren van stakeholders zijn vertaald naar beslissingen over de te realiseren output en welke argumentatie daaraan ten grondslag ligt, kan de legitimiteit worden bevorderd. Dit vereist dat helder is wat de wensen en voorkeuren van verschillende stakeholders zijn en welke partij waarover en op welk moment in het proces beslissingen neemt (Van den Hof, 2006).

Zoals beargumenteerd kan het publiek belang niet enkel worden gedefinieerd in termen van procescriteria, maar gaat het ook om het resultaat van dat proces. Positieve legitimiteitsoordelen van ruimtelijke planprocessen worden ook bevorderd als de uitkomsten van het planproces bijdragen aan de effectieve realisatie van de wensen en voorkeuren van stakeholders (Boedeltje, 2009). Het gaat dan om outputlegitimiteit (Scharpf, 1997). Outputlegitimiteit is dus een afgeleide van de subjectieve perceptie van de effectiviteit van het planproces op het niveau van individuele stakeholders.

In een netwerkomgeving waar belangen uiteen lopen maar samenwerking noodzakelijk is om tot resultaten te komen, is het belangrijk effectiviteit op meerdere niveaus te beschouwen (Provan en Milward, 2001). Het publiek belang gaat soms verder dan de directe belangen van stakeholders. ${ }^{225}$ Om 'publiek' te zijn, wordt beargumenteerd dat een belang een bepaalde collectiviteit of aggregatieniveau moet dienen (De Bruin en Dicke, 2006). De effectiviteit van het planproces is daarom (tevens) op het niveau van het project beschouwd. Gesteld is, dat de mate waarin plannen (naar verwachting) bijdragen aan de relevante dimensies van ruimtelijke kwaliteit in het plangebied, als maatstaf kan worden gehanteerd. Deze stelling is gebaseerd op een aantal argumenten. In de eerste plaats kan in de ruimtelijke sector ruimtelijke kwaliteit worden gezien als een inhoudelijke typering van een intersubjectief gedeelde waarde. Ruimtelijke kwaliteit is sinds lange tijd hoofddoelstelling van ruimtelijk beleid (Ministerie VROM, 1988; RPD, 1996; WRR, 1998; Ministerie VROM, 2004). In de tweede plaats is ruimtelijke kwaliteit - evenals het publiek belang - geen objectief, onveranderlijke en universeel concept, maar subjectgebonden, contextafhankelijk en heeft een relatief karakter 
(Reijndorp, 1998; Hooimeijer, 2001; Nota Ruimte, 2004). Dit betekent dat eerst een subjectieve analyse nodig is om de relevante dimensies in specifieke projecten te bepalen (WRR, 1998). Tenslotte kan de mate waarin plannen bijdragen aan de realisatie van ruimtelijke kwaliteit op deze dimensies pas daadwerkelijk worden vastgesteld als het project gerealiseerd is. De lange doorlooptijd van de projecten zorgt ervoor dat dit niet haalbaar is binnen dit onderzoek en impliceert dat slechts aangesloten kan worden bij verwachtingen van stakeholders.

In de praktijk liggen de verschillende vormen van legitimiteit en effectiviteit dicht bij elkaar (Scharpf, 1999). Outputlegitimiteit kan deels worden ontleend aan de effectiviteit van plannen voor individuele stakeholders. De effectiviteit van plannen op het niveau van individuele stakeholders hangt direct samen met de effectiviteit op het niveau van het project (Provan en Milward, 2001). Effectiviteit op het niveau van het project heeft ook slechts betekenis als het in relatie staat tot de wensen en voorkeuren van individuele stakeholders. Om effectieve plannen te produceren zijn daarom procedures en mechanismen nodig om wensen en voorkeuren te vertalen in beslissingen over de inhoud, waarbij transparantie door inzicht te verschaffen over de wijze waarop dit gebeurt, bijdraagt aan de aanvaarding of acceptatie ervan. Figuur 10.2 geeft het raamwerk dat is gebruikt voor de evaluatie van de borging van het publiek belang.

\begin{tabular}{|l|l|}
\hline Criterium & Maatstaf \\
\hline Inputlegitimiteit & Legaliteit \& openheid van het proces \\
\hline Throughputlegitimiteit & Transparantie van het proces \\
\hline Outputlegitimiteit & Steun van stakeholders voor de plannen \\
\hline Effectiviteit & Verwachte bijdrage van plannen aan ruimtelijke kwaliteit \\
\hline
\end{tabular}

Tabel 10.2 Raamwerk voor de analyse van de borging publiek belang

In drie case studies (Den Haag Nieuw Centraal, Stationskwartier Breda, Spoorzone Delft) is geanalyseerd in hoeverre de planvorming effectief en legitiem was. Op basis van de empirische analyse kan een aantal conclusies worden getrokken.

Een eerste hoofdconclusie is dat het verloop van de planvorming in alle cases als legitiem is ervaren. Daarbij bleek het oordeel over de wijze waarop de invoer van wensen en voorkeuren in het planproces heeft plaats gevonden (inputlegitimiteit) en het resultaat (outputlegitimiteit) in alle projecten positiever dan het oordeel over de transparantie van het planproces (throughputlegitimiteit). Zelfs voor een aantal direct betrokken keystakeholders bleek niet in alle gevallen helder welke partij(en), wanneer en waarover besliste(n), wat de wensen en voorkeuren van verschillende partijen waren en welke afwegingen ten grondslag lagen aan gemaakte keuzen. Hoewel in alle cases het planproces als legitiem wordt ervaren en de spreiding tussen cases gering is, zijn er wel verschillen. Hieruit kan geconcludeerd worden dat zowel de planvorming van het Masterplan Den Haag Nieuw Centraal als de ontwikkeling van plannen voor de OV-terminal in Den Haag qua legitimiteit als minst positief naar voren komt. ${ }^{226}$ Met uitzondering van de throughputlegitimiteit wordt de planvorming van het Masterplan Spoorzone Delft als het meest legitiem beoordeeld.

Een tweede hoofdconclusie is, dat in alle cases het planproces als effectief kan worden beschouwd. Dit geldt zowel voor het planproces van het masterplan, als voor de planvorming voor de OVterminal. Deze effectiviteit blijkt voor stationslocaties vooral betrekking te hebben op de bijdrage van 
de plannen aan het verbeteren van de functionaliteit, aantrekkelijkheid en leefbaarheid in het plangebied en het vergroten van de beschikbaarheid van voorzieningen. Andere dimensies van ruimtelijke kwaliteit worden van minder of geen belang geacht. In alle cases is de verwachting dat de plannen effectief zullen zijn in termen van de bijdrage aan deze dimensies. Hoewel de spreiding tussen cases gering is, blijkt het oordeel over de bijdrage van de plannen in het project Den Haag Nieuw Centraal het minst positief. Dit geldt zowel voor het Masterplan Den Haag Nieuw Centraal als voor de plannen voor de OV-terminal.

\subsubsection{Samenhang tussen procesinrichting en publiek belang}

De vraag is of deze verschillen samenhangen met de inrichting van het proces. De vierde en laatste onderzoeksvraag luidt daarom: 'in hoeverre bestaat er een samenhang tussen de inrichtingen van het proces en de criteria voor de borging van het publiek belang? In het vorige hoofdstuk is deze relatie op basis van empirische data geanalyseerd. In deze paragraaf worden de empirische resultaten geconfronteerd met theoretische verwachtingen. Het gaat dan om 'pattern matching' (Yin, 1994).

Zoals in de inleiding van dit hoofdstuk beschreven, wordt in governance- en planvormingliteratuur veel aandacht besteed aan (veranderende) rollen en verhoudingen tussen stakeholders. Over de wijze waarop deze rollen en verhoudingen met het oog op een effectief en legitiem planproces moeten worden vormgegeven, wordt echter uiteenlopend gedacht (De Graaf, 2005; De Kort, 2009). In de discussie daarover wordt een aantal stellingen betrokken.

Een eerste onderdeel in de discussie is het aantal stakeholders dat een substantiële inbreng zou moeten hebben in het planproces. Met verwijzing naar de toenemende complexiteit en afhankelijkheden tussen actoren wordt beargumenteerd dat meer samenwerking en participatie noodzakelijk is om te komen tot effectieve en legitieme oplossingen voor ruimtelijke vraagstukken. Op deze manier wordt gegarandeerd dat alle relevante feiten, omstandigheden en belangen in ogenschouw worden genomen (vgl. De Bruijn e.a. 2002). Een meer hiërarchische benadering leidt vaak tot de dominantie van een bepaald belang of redeneerwijze, en tot de uitsluiting van andere, zo wordt gesteld (Van Gestel e.a., 2008). Dit zou kunnen leiden tot slechte resultaten (Koppenjan en Klijn, 2004). Als keerzijde wordt er in literatuur op gewezen, dat intensieve betrokkenheid van een groot aantal stakeholders een grote variëteit aan wensen of eisen impliceert, wat kan leiden tot een ongecontroleerd proces (Dewulf, 2001). Complexe gebiedsontwikkelingen kennen een groot aantal stakeholders met uiteenlopende percepties en preferenties en een grote inbreng van veel stakeholders heeft tot gevolg dat planvorming ook deels plaats vindt buiten de macht die is toebedeeld aan representatieve instituties.

Uit het eerstgenoemde perspectief kan simpel gesteld de verwachting worden afgeleid dat een grotere inbreng van meer stakeholders in het planproces de effectiviteit en legitimiteit ten goede komt. Deze verwachting wordt door de empirische resultaten van dit onderzoek niet ontkracht. Uit de resultaten bleek, dat naarmate meer stakeholders een substantiële mate van zeggenschap hadden bij het ontwikkelen van het masterplan, het (geaggregeerde) oordeel over de effectiviteit, input- en outputlegitimiteit positiever was. Voor het planproces van de OV-terminal was het beeld niet eenduidig. Voor de planvorming van het masterplan en voor de OV-terminal is ook bezien of het aantal stakeholders met een grote inbreng in de visievorming en qua middelen van invloed waren op de legitimiteit en effectiviteit. Noch bij de masterplannen, noch bij de OV-terminal bleek dit het 
geval. Niettemin bleek het omgekeerde, te weten dat een kleiner aantal intensief betrokken stakeholders leidt tot een effectiever en legitiemer proces, zeker niet door de resultaten te worden onderbouwd.

De discussie in literatuur richt zich niet enkel op het aantal stakeholders, maar vooral ook op de wijze waarop rollen en verhoudingen tussen actoren met verschillende karakters en belangenposities moeten worden vormgegeven. Veel aandacht gaat daarbij uit naar de wijze waarop verhoudingen tussen publieke en private actoren moeten worden vormgegeven (Canoy et al, 2001; Van der Heijden en Spiering, 2002; e.a.). In de discussie daarover wordt de noodzaak en de meerwaarde van intensieve betrokkenheid van private partijen veelvuldig benadrukt (Adviescommissie Gebiedsontwikkeling, 2005; Commissie Fundamentele Verkenning Bouw, 2008; e.a.). Een gangbare veronderstelling daarbij is dat het benutten van private kennis en capaciteiten de effectiviteit en efficiency van de behartiging van het publiek belang ten goede komt, omdat in dat geval de voordelen van het marktmechanisme kunnen worden gebruikt (vgl. WRR, 2000: p.31). Hiertegenover wordt vaak ingebracht dat democratische legitimatie en sturing beter uit zijn als het publiek belang door publieke partijen wordt behartigd. In dit verband wordt benadrukt dat door samenwerking met private partijen de overheid een deel van haar zeggenschap inruilt en vervagende grenzen tussen het publiek en private domein in potentie een aantasting betekenen van zaken als verantwoordelijkheid en toerekenbaarheid, transparantie en democratische keuze (Bovens en Scheltema, 1999; WRR, 2000; Van Wijk et al, 2002). Deze aspecten liggen in lijn met wat in deze studie is begrepen onder inputlegitimiteit en throughputlegitimiteit.

De empirische bevindingen van dit onderzoek doen niet vermoeden dat een relatief grotere inbreng van private partijen op negatieve wijze samenhangt met de legitimiteit van het proces. In de eerste plaats bleek het planproces niet als minder legaal, open en/of transparant te worden ervaren naarmate de inbreng van private partijen ten opzichte van publieke partijen groter werd. ${ }^{227}$ In de tweede plaats werd de steun van stakeholders (outputlegitimiteit) voor de plannen in dat geval niet minder. Daarnaast bleek dat bij de projecten met een relatief grote inbreng van private partijen in visievorming het (geaggregeerde) oordeel over de effectiviteit positiever was. In algemene zin geven de resultaten daarmee geen aanleiding te veronderstellen dat legitimiteit toeneemt naarmate (publieke) representatieve instituties een dominantere inbreng hebben. Dat een 'dominante' positie niet noodzakelijk is, betekent niet dat publieke instituties geen rol zouden moeten spelen. De empirische bevindingen sluiten daarmee aan bij de gedachte in literatuur dat het benutten van private kennis en capaciteiten de effectiviteit van de behartiging van het publiek belang ten goede komt.

Naast verhoudingen tussen publieke en private actoren kriigen ook de verhoudingen tussen actoren met enkel een publiek karakter de nodige aandacht in literatuur (Teisman et al, 2001; Ministeries VROM, LNV, V\&W en EZ, 2004; e.a.). Zeker bij grootschalige gebiedsontwikkelingen zoals stationslocaties is er veel discussie over de wijze waarop - met het oog op een integrale anpak invulling moet worden gegeven aan de rollen van verschillende overheden (TK 2002-2003, 28753; Laverman, 2003; Van Hoof, 2003; Ministerie VROM, 2009; e.a.). Enerzijds is er de gedachte dat gemeenten taken effectiever en democratischer kunnen vervullen, omdat zij beter zicht hebben op de lokale situatie en daardoor beter tot maatwerkoplossingen in staat zijn (Boogers, 2009). Het beginsel van subsidiariteit stelt ook dat belangen waarvoor de overheid zich verantwoordelijk acht bij voorkeur 
dienen te worden verricht door de bestuurslaag die het dichtst bij de burger staat, tenzij er argumenten zijn het (publieke) belang en de daaruit voortvloeiende taak op een hoger schaalniveau of door een functionele bestuursvorm te laten uitvoeren. Anderzijds wordt gewezen op de regionale of zelfs nationale betekenis van dergelijke projecten en wordt gepleit voor een actieve rol van Rijk, regio en provincie. Daar komt bij dat voor gemeenten de herontwikkeling van stationslocaties unieke projecten zijn waar zij eenmalig mee te maken hebben en minder goed mee bekend zijn.

In lijn met deze discussie is verkend of de mate waarin er in de projecten sprake is van een centraal dan wel decentraal planproces mogelijk effect heeft op de effectiviteit of legitimiteit ervan. Uit de empirische data kwam naar voren, dat de gemeenten in alle drie bestudeerde projecten een zeer grote inbreng hebben gehad in de planvorming van het masterplan én in de planvorming voor de OVterminal. Deze inbreng was in alle cases aanzienlijk groter dan de inbreng vanuit het Rijk. In alle drie cases werden beide planprocessen ook als effectief en legitiem ervaren. De spreiding op de variabelen is daarmee klein. Niettemin bleek wel, dat naarmate de gemeente qua zeggenschap in het planproces nog dominanter was ten opzichte van het Rijk, het planproces niet als legitiemer werd ervaren en dit de effectiviteit zeker niet ten goede leek te komen. Een zelfde beeld kwam naar voren als de inbreng van de gemeente werd bezien in relatie tot die van alle andere keystakeholders. Omdat bij elk van de cases sprake is van een sterke gemeentelijke betrokkenheid en ook de legitimiteit en effectiviteit van de planvorming redelijk tot goed te noemen valt, zijn er geen aanwijzingen dat een stevige rol van gemeenten per se een negatieve uitwerking heeft. Wel lijkt het erop dat een àl te grote dominantie van gemeenten negatief kan inwerken op de legitimiteit en effectiviteit, omdat hiermee de noodzakelijke inbreng van andere keystakeholders in het gedrang dreigt te komen.

Deze conclusies sluiten aan bij het idee dat complexe ruimtelijke opgaven plaats vinden in een netwerk van wederzijds afhankelijke actoren. Zeker bij stationslocaties zorgt de complexe eigendomen verantwoordelijkheidsverdeling er voor dat het effectief en legitiem komen tot een oplossing voor deze opgaven niet slechts een intellectuele ontwerpactiviteit, maar tevens een strategisch spel in een multi-actor setting, waarbij diverse belangen, doelen en interpretaties samenkomen. De verschillende actoren die betrokken zijn bij stationslocaties moeten interacteren om plannen te ontwikkelen maar hebben tegelijkertijd uiteenlopende en soms conflicterende percepties van het probleem en de wijze waarop tot een oplossing moet worden gekomen. Het handelen van actoren wordt sterk bepaald door hun perceptie van de werkelijkheid (Scharpf, 1997) 228 Indien percepties uiteen lopen is er sprake van ambivalentie (Hommes, 2008). ${ }^{229}$ Voor de uitkomsten van de planvorming is het van belang in hoeverre de diverse keystakeholders een eenduidig beeld (perceptie) hebben van de feitelijke verhoudingen binnen het netwerk. Is dit beeld niet eenduidig dan dreigen misverstanden over de vraag wie welke rol vervuld, hetgeen ten koste kan gaan van bijvoorbeeld de transparantie en de effectiviteit.

Voor de uitkomsten is het tevens van belang in hoeverre de diverse keystakeholders een eenduidig oordeel hebben over de wenselijke verhoudingen binnen het netwerk. Bestaan er meningsverschillen over de wenselijke rolverdeling in het netwerk dan zou dat kunnen leiden tot spanningen en conflicten die een legitieme en effectieve planvorming in de weg zullen staan.

Uit de empirische data bleek dat de percepties van de feitelijke inbreng van diverse keystakeholders, behoorlijk uiteen liepen. De enige uitzondering hierop vormt de inbreng van de gemeente waarover 
een volledig eenduidig beeld bestond. Op basis van een vergelijking van deze constateringen met de (beperkte) verschillen tussen cases qua effectiviteit en legitimiteit kan in hoofdlijn worden gesteld dat beide niet gebaat zijn bij grotere perceptieverschillen. In de eerste plaats bleek namelijk, dat naarmate de perceptieverschillen over de feitelijke inbreng van diverse keystakeholders groter waren, het (geaggregeerde) oordeel over de transparantie van het proces (throughputlegitimiteit) minder positief was. In de tweede plaats bleek, dat naarmate de perceptieverschillen over de feitelijke inbreng van keystakeholders in de planvorming voor de OV-terminal groter waren, het (geaggregeerde) oordeel over de effectiviteit van dit proces minder positief was.

Niet alleen bleken de percepties over de feitelijke inbreng van keystakeholders in de planvorming te verschillen, ook de oordelen over de wenselijke situatie bleken sterk uiteen te lopen. Dat gold voor de planvorming van de masterplannen, maar sterker nog voor de planvorming voor de OV-terminal. Ook hier bleek enkel over de rol die de gemeente zou moeten hebben in de planvorming een behoorlijke mate van consensus te bestaan. Op basis van een vergelijking met de legitimiteit en effectiviteit van planvorming kan worden gesteld dat de mate van waarin meningen verschillen niet op positieve wijze samenhangen met de mate waarin het planproces als effectiever en legitiemer wordt ervaren. In de eerste plaats bleek namelijk dat naarmate de meningen over de wenselijke inbreng van keystakeholders in de planvorming voor de OV-terminal meer uiteen liepen, het (geaggregeerde) oordeel over de transparantie van dit proces (throughputlegitimiteit) minder positief was. In de tweede plaats bleek, dat naarmate de percepties van de wenselijke inbreng van keystakeholders in de planvorming van het masterplan meer uiteen liepen, het (geaggregeerde) oordeel over de input- en outputlegitimiteit minder positief was.

De verwachting dat indien bij keystakeholders een zeer uiteenlopend beeld bestaat van de feitelijke of wenselijke situatie, de kans op effectieve en legitieme planvorming geringer is, lijkt dan ook door de empirische resultaten te worden bevestigd.

\subsubsection{Centrale onderzoeksvraag}

De centrale onderzoeksvraag die in het eerste hoofdstuk is geformuleerd luidt: Bij welke inricbting van het planproces is de kans op succesvolle borging van het publiek. belang bij de herontwikekeling van stationslocaties groot? Voor het succes in het borgen van het publiek belang is gekeken naar de mate waarin de planvorming effectief en legitiem was. In alle bestudeerde cases bleek de planvorming effectief en legitiem. De verschillen tussen cases waren gering. Voor de wel aanwezige verschillen is bestudeerd of deze te relateren zijn aan verschillen in de kenmerken van de actorconstellatie in het planproces. Deze kenmerken kwamen in hoofdlijn ook redelijk overeen. Zo bleken bijvoorbeeld de gemeenten in alle cases een dominante rol te hebben gehad in planvorming. Niettemin bleken er ook hier wel beperkte verschillen te bestaan tussen cases. Op basis van de analyse kan een aantal conclusies worden getrokken aan de hand waarvan de centrale onderzoeksvraag wordt beantwoord.

- Een grote inbreng in het planproces van een groter aantal keystakeholders lijkt de kans op succesvolle borging van het publiek belang eerder te vergroten dan te verkleinen.

- Een relatief grote inbreng van private partijen ten opzichte van publieke partijen lijkt geen ondermijning te betekenen voor de legitimiteit of effectiviteit en daarmee niet voor de waarborging van het publiek belang. 
- Naarmate gemeenten qua zeggenschap minder dominant zijn ten opzichte van het Rijk en andere partijen lijkt de kans dat het planproces effectief is groter. Een grote inbreng van de gemeente zou een noodzakelijke voorwaarde voor een effectief en legitiem planproces kunnen zijn, maar het lijkt zeker geen voldoende voorwaarde.

- De kans op succesvolle borging van het publiek belang lijkt groter te zijn naarmate de verschillen in perceptie tussen keystakeholders ten aanzien van de feitelijke situatie en de verschillen van mening tussen keystakeholders over de wenselijke situatie, geringer zijn.

In de volgende paragraaf worden de antwoorden op de onderzoeksvragen en de conclusies die daaruit naar voren komen bediscussieerd. Daarbij wordt ook gekeken hoe de geringe spreiding op de variabelen te duiden is.

\subsection{Discussie}

In dit onderzoek is getracht zowel conceptueel als empirisch bij te dragen aan de kennis over de borging van het publiek belang. Meer specifiek ging het er om dat kennis zou worden vergaard die ondersteunend zou zijn voor afwegingen over de wijze waarop planprocessen vormgegeven worden. Dit met als oogmerk het publiek belang in de constellatie van actoren die betrokken zijn bij stationslocaties te waarborgen. Gegeven de in de vorige paragrafen gepresenteerde conclusies is het onderzoek hier in zekere mate in geslaagd. Op basis van theoretische analyse is een conceptueel raamwerk opgesteld dat kan worden gebruikt voor de evaluatie van de borging van het publiek belang. Daarnaast geeft het casestudie onderzoek uitvoerig inzicht in het verloop van de planprocessen en laat het voor een aantal factoren de mogelijke relatie met het publiek belang zien.

In deze paragraaf vindt discussie plaats. De beperkingen van de gehanteerde onderzoeksstrategie en de gemaakte keuzes worden belicht en enkele aanbevelingen voor de inrichting van planprocessen en voor vervolgonderzoek worden gegeven. De paragraaf is opgesplitst in twee delen. In het eerste deel wordt gereflecteerd op het conceptueel raamwerk. Het tweede deel reflecteert op de empirische resultaten en de implicaties daarvan.

\subsubsection{Borging van het publiek belang}

Het conceptueel raamwerk dat in deze studie is ontwikkeld, bevat uitgangspunten voor een heldere omschrijving van voor de bepaling van het publieke belang relevante begripsdimensie. Verder biedt het ontwikkelde kader ook een basis om aan de hand van meetbare indicatoren vast te stellen in hoeverre in concrete gevallen het publiek belang wordt gediend. In dit proefschrift is dit kader gehanteerd om te bepalen wat bij ruimtelijke projecten onder het publiek belang kan worden verstaan en in welke mate dit belang in de betreffende projecten is gewaarborgd. In deze paragraaf wordt gereflecteerd op de gehanteerde uitgangspunten en werkwijze voor het bepalen prestaties in termen van de borging van het publiek belang.

In het Nederlandse debat over het publiek belang kunnen ruwweg twee denkrichtingen worden onderscheiden. ${ }^{230}$ Aan de ene kant is er de benadering die stelt dat het bepalen van het publiek belang de uitkomst kan zijn van een wetenschappelijke analyse van complexe externe effecten in een specifieke situatie. Teulings et al. (2003) hebben hiervoor vanuit welvaartseconomisch perspectief een 
raamwerk ontwikkeld. Zij kiezen in hun benadering (het falen van) de markt als vertrekpunt. Hoewel het nut van welvaartstheoretische gezichtspunten voor de discussie over het publiek belang wordt benadrukt (zie o.a. Van Damme en Schinkel, 2009), stellen diverse auteurs dat een dergelijke benadering te beperkt is en verwerpen zij de stelling dat het identificeren van het publiek belang het resultaat kan zijn van een wetenschappelijke analyse (De Bruijn et al, 2004; e.a.).

Aan de andere kant kan de benadering van de WRR (2000) worden geplaatst die de overheid als vertrekpunt neemt. De benadering van de WRR (2000) rust op het idee dat het publiek belang de uitkomst is van het politieke proces en daarom geen abstracte specificatie nodig is. ${ }^{231}$ De kritiek op deze benadering is dat door de politiek in beginsel alles tot publiek belang verklaard kan worden en het publiek belang daarmee een 'ongrijpbaar begrip' wordt (Baarsma en Theeuwes, 2009).

In paragaaf 10.2.3 is beargumenteerd dat een procedurele benadering van het publieke belang, zoals de WRR voorstelt, niet bevredigend is en dat - naast procedurele elementen - een zinvolle omschrijving van het publiek belang ook inhoudelijke maatstaven behoeft die betrekking hebben op de resultaten van het besluitvormingsproces. Daarom is in ons kader zowel aandacht voor legitimiteit als voor effectiviteit.

Bij de andere invulling van deze criteria is vervolgens uitgegaan van de constatering dat bij de behartiging van het publieke belang overheid en markt nauw zijn verweven. De benaderingen van Teulings et al. (2003) en de WRR (2000) verschillen weliswaar in de keuze van hun startpunt, maar beide benaderingen hebben gemeen dat ze trachten vervolgens conclusies te formuleren die als basis kunnen dienen om uitspraken te doen over de rolverdeling tussen overheid en markt bij de behartiging van het publiek belang. In deze studie wordt eveneens uitgegaan van de verwevenheid van overheid en markt. De institutionele ordening rondom stationslocaties zorgt ervoor dat betrokkenheid van verschillende publieke en (semi-)private partijen een gegeven is. Het gaat dan niet zozeer om de vraag overheid of markt, maar om de vraag welke 'mix' het meest geschikt is. Afhankelijkheidsrelaties zorgen ervoor dat diverse partijen op elkaar aangewezen zijn om überhaupt tot resultaten te komen. Een realistische benadering start met dit gegeven en dat - zeker in deze context - de concrete inhoudelijke specificatie van het publiek belang noch door marktfalen, noch door de politiek een gegeven is. Onder andere De Bruijn \& Dicke (2006) en Koppenjan et al. (2008) wijzen op het relatieve en onstabiele karakter van publieke belangen, omdat het afwegingen tussen verschillende belangen vereist en deze afwegingen dynamisch zijn. Daarbij speelt de setting een belangrijke rol. Deze zienswijze is in deze studie als uitgangspunt genomen bij het ontwikkelen van het raamwerk. Dit impliceert dat bij een oordeel over het succes in het borgen van het publiek belang een aantal aandachtspunten in ogenschouw moet worden genomen.

Allereerst betekent het dat het om tijdelijke oordelen gaat. Wat in het publiek belang is, kan veranderen als de economische, sociale of morele context verandert. In de tweede plaats betekent het dat er niet één beoordelaar is die kan vaststellen of het publiek belang succesvol gewaarborgd is. Ten derde impliceert het dat het publiek belang in verschillende domeinen een andere invulling kan krijgen. Het 'publiek' verschilt namelijk afhankelijk van de specifieke omgeving en daarmee ook het publiek belang. Succesvolle borging van het publiek belang kan daarom ook niet worden gebaseerd op algemene ideeën hierover. De kenmerken van de institutionele en situationele omgeving geven richting aan keuzes over publieke belangen en de wijze waarop evaluatie van die keuzes plaats dient te vinden (vgl. Goodin, 1996). 
Uitgaande van de zienswijze dat het publiek belang als een relatief en dynamisch concept moet worden beschouwd, is gekeken hoe prestaties in termen van succesvolle borging kunnen worden bepaald. In de werkwijze daarvoor zijn twee niveaus te onderscheiden; de keuze voor de te hanteren criteria en het bepalen van de scores op deze criteria. Op beide niveaus kan een 'objectieve' en een 'subjectieve' aanpak worden gehanteerd (vgl. Brown en Coulter, 1983). Een objectieve aanpak verwijst naar vaststelling door een onderzoeker. Een subjectieve aanpak verwijst naar vaststelling door subjecten.

De keuze voor de criteria is in deze studie gedaan door de onderzoeker. Tegen de achtergrond van de netwerkomgeving waarin complexe ruimtelijke projecten tot stand moeten worden gebracht, is beargumenteerd dat zowel legitimiteit als effectiviteit van planvorming relevante criteria zijn voor een oordeel over de borging van het publiek belang (zie paragraaf 10.2.3). De keuze om deze criteria als onderzoeker te specificeren is mede ingegeven vanuit de veronderstelling dat criteria meer potentie hebben voor evaluatie naarmate ze helderder en meer eenduidig zijn geformuleerd, zodat de kans op interpretatieverschillen kleiner wordt (Stipak, 1979). ${ }^{232}$ Om waardevol te zijn veronderstelt deze aanpak evenwel dat er minimaal een zekere consensus (intersubjectiviteit) bestaat over de door de onderzoeker geselecteerde criteria. Zoals beargumenteerd zal in een bepaalde setting slechts op een zeker abstractieniveau consensus bestaan over wat het publiek belang is en daarmee welke criteria relevant zijn. Er dient dus in ogenschouw te worden genomen dat er een zekere spanning bestaat tussen de mate van specificiteit in de operationalisering en de mate waarin waarden intersubjectief worden gedeeld.

Voor het bepalen van de scores op de aldus geformuleerde criteria is de subjectieve aanpak gehanteerd. Legitimiteit heeft betrekking op de aanvaarding, acceptatie of steun voor de plannen door betrokkenen (vgl. Weber, 1922; Easton, 1965; e.a.). Dit impliceert dat voor een oordeel over de legitimiteit van planvorming aangesloten dient te worden bij hun opvattingen. Effectiviteit in termen van de mate waarin plannen bijdragen aan de ruimtelijke kwaliteit in het plangebied kan pas daadwerkelijk worden vastgesteld als het project gerealiseerd is. Dit impliceert dat voor de empirische bepaling van de effectiviteit noodzakelijkerwijs slechts kan worden gekeken naar verwachtingen van diverse betrokkenen. Daarom kan ook hier slechts worden aangesloten bij de subjectieve oordelen van actoren die de betreffende projecten van nabij kennen. In deze studie is daarom op basis van de opvattingen van betrokkenen een oordeel geveld over de effectiviteit en legitimiteit van het planproces. ${ }^{233}$

We menen dat aldus een werkwijze is ontwikkeld die niet alleen mogelijkheden biedt om bij ruimtelijke projecten, maar in aangepaste vorm ook bij andere projecten op een eenduidige en navolgbare wijze de bijdrage aan het publieke belang te bepalen. Niettemin zijn bij de wijze waarop in deze studie het publiek belang is bepaald, minimaal twee kanttekeningen op zijn plaats. Een eerste kanttekening heeft betrekking op de keuze om legitimiteit en effectiviteit van planvorming als hoofdcriteria te hanteren. Men kan het publiek belang vanzelfsprekend ook breder opvatten. Zo zijn naast de (effectieve) realisatie van ruimtelijke kwaliteit ook de kosten die daarmee voor 'het publiek' gemoeid zijn van belang. Kostenefficiency is (om praktische redenen: haalbaarheid van het onderzoek) niet als criterium in onze analyse meegenomen. Bij de verdere ontwikkeling van een kader voor de beoordeling van de bijdrage van projecten aan het publiek belang verdient het aanbeveling dit criterium eveneens in beschouwing te nemen. 
Een tweede kanttekening heeft betrekking op de gehanteerde werkwijze bij de bepaling van de scores op de maatstaven voor legitimiteit en effectiviteit. Daarbij is gevraagd naar het oordeel van een aantal betrokkenen. In deze studie is dat gebeurd op basis van de opvattingen van personen vanuit organisaties die als keystakeholder aangemerkt zijn. Deze partijen representeren direct dan wel indirect verschillende 'publieken'. We hebben ervoor gekozen om de meest rechtstreeks betrokken partijen te bevragen, mede omdat zij zich op basis van hun betrokkenheid ook een goed beeld van de onderzochte projecten hebben kunnen vormen. Dit betekent echter dat de opvattingen van andere, minder nauw betrokken stakeholders, zoals burgers, reizigers of toekomstige vastgoedgebruikers, buiten beschouwing zijn gelaten. In toekomstig onderzoek zou ook kunnen worden bezien hoe de opvattingen van deze andere stakeholders een plaats zouden kunnen krijgen in het beoordelingskader.

Een derde verwante kanttekening betreft de keuze om bij de bepaling van de beoordelingsscores bij de keystakeholders te kiezen voor het organisatieniveau. Daarmee zien we voorbij aan het feit dat binnen organisaties diverse actoren zijn te onderscheiden. Zo zijn meerdere organisatieonderdelen van NS betrokken bij de aanpak van stationslocaties. Evenzo kunnen binnen de gemeentelijke organisatie onder andere het college van $\mathrm{B} \& \mathrm{~W}$, de gemeenteraad en het ambtelijk apparaat worden onderscheiden. Het verdient aanbeveling in vervolgonderzoek naar de borging van het publiek belang hier aandacht aan te besteden, zeker als het gaat om de diverse organen van het gemeentebestuur. Met name het oordeel van de gemeenteraad als direct gekozen volksvertegenwoordiging is hierbij relevant. Tenslotte gaat het bij het publiek belang onder andere om publieke verantwoording.

\subsubsection{Inrichting planvorming}

Het op basis van theoretische inzichten opgestelde conceptueel raamwerk bevat naast indicatoren voor de evaluatie van de borging van het publiek belang tevens een kader met behulp waarvan de actorconstellaties in het proces kan worden beschreven. Deze actorconstellaties zijn beschreven op basis van de percepties die de keystakeholders hebben van de feitelijke situatie in de planvormingarena's en hun (normatieve) opvattingen over de wenselijke situatie daarin. Deze keuze is gebaseerd op de theoretische veronderstelling dat actoren hun gedrag vormgeven op grond van hun percepties en oordelen. De actoren die een substantieel belang hebben bij de herontwikkeling van stationslocaties en waarvan minimaal toestemming en/of investeringen nodig zijn om tot implementatie van plannen te komen, zijn beschouwd als keystakeholders (vgl. Mendelow, 1981; Johnson en Scholes, 1999; Verbart, 2004). ${ }^{234}$

In de empirische analyse is vervolgens bestudeerd in hoeverre de kenmerken van de actorconstellatie in het proces samenhangen met de criteria die zijn gehanteerd voor de borging van het publiek belang. Daarvoor is gebruik gemaakt van de methode van casestudie. Deze methode is gekozen omdat ruimtelijke projecten in hun context moeten worden bezien en het aantal projecten dat bestudeerd kan worden in relatie tot het aantal factoren dat een rol kan spelen in genoemde relatie klein is (vgl. Yin, 1994; Hutjes en Van Buuren, 1992). Bij onderzoek dat is gericht op het ontwikkelen van theorie dient het replicatieprincipe ${ }^{235}$ de basis te zijn voor de selectie van cases. Zoals in hoofdstuk vier is beargumenteerd is het hanteren van dit principe in deze studie om een aantal redenen problematisch. De onmogelijkheid cases te selecteren op de afhankelijke variabele, de 
borging van het publiek belang, zorgt ervoor dat de mogelijkheid bestaat dat de spreiding hierop gering is, zoals in deze studie het geval.

In dit onderzoek zijn drie cases bestudeerd. Om de relatie tussen X (actorconstellatie in het proces) en $\mathrm{Y}$ (legitimiteit en effectiviteit) te onderzoeken, is gekozen om de context waarbinnen de planvorming plaatsvindt zo weinig mogelijk te doen variëren. Om die reden is ervoor gekozen het onderzoek te richten op de totstandkoming van grootschalige stationslocaties in Nederland. Deze keuze heeft echter als onbedoeld neveneffect geleid tot een aanzienlijke reductie van de variantie op de onafhankelijke variabelen (kenmerken van de actorconstellatie). De institutionele context van stationslocaties in Nederland zorgt ervoor dat bepaalde actoren altijd als keystakeholders betrokken zijn in deze projecten en lijkt tevens sterk sturend te zijn voor de rol van deze partijen in het planproces. Zo coördineren en regisseren gemeenten in alle gevallen het integrale proces en spelen in de planvorming voor de OV-terminal in alle gevallen ook het ministerie van Verkeer en Waterstaat, ProRail en NS een prominente grote rol. Slechts de rol van private eigenaren/ontwikkelaars in het planproces wordt vrijwel niet gestuurd door regelgeving. Zij zijn ook de enige partij die een reële 'exit-mogelijkheid' heeft. Een voorbeeld hiervan is de ontbinding van de samenwerkingsovereenkomst tussen de gemeente Den Haag en CV KJ voor de ontwikkeling van vastgoed op het Koningin Julianaplein. Het beperkte aantal cases samen met de geringe spreiding op de variabelen maakt het aantonen van verbanden niet eenvoudig. Ondanks de beperkingen is door procesanalyse aan de hand van meerdere databronnen en gebruik van bepaalde analysetechnieken (case-ordered predictor-outcome matrices, pattern-matching) gekomen tot een aantal plausibele uitspraken over verbanden. Op basis van deze bevindingen kan een aantal aanbevelingen worden gedaan.

\section{Aanbevelingen voor de inrichting van planprocessen}

Een eerste aanbeveling heeft betrekking op de rol van gemeenten. Gemeenten hebben hoge ambities bij het ontwikkelen van plannen, maar het is niet altijd duidelijk of die ambities in de praktijk ook gerealiseerd kunnen worden. Voor de realisatie van die ambities zijn gemeenten bij stationslocaties sterk afhankelijk van andere partijen. NS is eigenaar van stations, ProRail is bevoegd waar het gaat om transfergerelateerde voorzieningen en het Rijk moet samen met de provincie of regio voor het overgrote deel van de benodigde financiële middelen zorgen. Niettemin spelen gemeenten in alle bestudeerde gevallen een min of meer dominante rol in het proces. Zij zijn (een van de) opdrachtgever(s) voor het opstellen van een masterplan, gaan samenwerking aan met private eigenaar/ontwikkelaars, tekenen overeenkomsten over bijdragen en bijbehorende voorwaarden met de rijksoverheid, regio en provincie en zijn in alle drie cases (mede-)opdrachtgever voor de OVterminal. Enerzijds is deze dominante rol niet verwonderlijk want in de context van het Nederlandse ruimtelijke beleid zijn gemeenten ook de partijen die primair verantwoordelijk zijn voor de realisatie van stedelijke projecten. In de visie van het Rijk zijn zij ook bij de herontwikkeling stationslocaties eindverantwoordelijk voor het integrale project (VROM, 2004). Anderzijds zijn dergelijke projecten van regionale of zelfs nationale betekenis en zijn stationslocaties unieke projecten voor gemeenten waar zij eenmalig mee te maken hebben en dus minder goed mee bekend zijn. De hoge ambities en verwachtingen van gemeenten omtrent bijdragen vanuit het Rijk en verklaren voor een deel de trekkersrol van gemeenten. Ook overwegingen van afstemming en coördinatie om de integraliteit van 
planontwikkeling te bewaken zijn hiervoor van belang. Het blijft echter zeer de vraag of gemeenten een dergelijke rol voldoende kunnen waarmaken en of een dergelijke dominante rol van gemeenten in de planvorming wenselijk is. Hoewel in alle projecten gemeenten een dominante rol in het proces hebben gespeeld en in alle projecten het (geaggregeerde) oordeel over de effectiviteit en legitiem van planvorming positief was, bleek dat naarmate de gemeenten qua zeggenschap dominanter waren ten opzichte van andere keystakeholders het planproces niet als legitiemer werd ervaren en dit de effectiviteit zeker niet ten goede leek te komen. Vanuit het perspectief van de borging van het publiek belang lijkt een grotere inbreng van andere keystakeholders in het planproces aan te bevelen. ${ }^{236}$

Een tweede aanbeveling is dat men in dergelijke projecten niet te bang zou moeten zijn voor een grote inbreng van private partijen in de planvorming. De angst dat intensievere betrokkenheid van private partijen een ondermijning betekent van publieke waarden zoals openheid en transparantie en daarmee voor de legitimiteit van planvorming blijkt, gegeven de resultaten uit deze studie, niet gegrond. Hetzelfde geldt min of meer voor het aantal partijen dat een grote inbreng heeft. Een grote inbreng van veel keystakeholders in de planvorming lijkt zeker geen negatief effect te hebben op de effectiviteit en legitimiteit.

Een derde aanbeveling is dat er meer aandacht zou moeten worden besteed aan het transparant maken van het planprocessen. In dit onderzoek werd de transparantie van het planproces in vergelijking met de andere criteria in alle cases als relatief laag ervaren. Zelfs voor een aantal direct betrokkenen bleek onhelder welke partij(en), wanneer en waarover besliste(n), wat de wensen en voorkeuren van verschillende partijen waren en welke afwegingen ten grondslag lagen aan gemaakte keuzen. Inzicht in de wijze waarop uiteenlopende wensen en voorkeuren van partijen worden vertaald naar beslissingen over het te realiseren resultaat en welke argumentatie daaraan ten grondslag ligt is een essentieel onderdeel van legitimiteit. De mate van transparantie lijkt negatief samen te hangen met de mate waarin percepties van de feitelijke en opvattingen over de wenselijke situatie tussen betrokkenen verschillen. Naarmate deze sterker uiteen liepen, werd het proces als minder transparant ervaren. Als het planproces al niet transparant is voor direct betrokkenen vanuit keystakeholders geeft dit aanleiding te veronderstellen dat dit in nog sterkere mate geldt voor niet direct betrokken stakeholders. Des te meer is het van belang om hier nadrukkelijk aandacht aan te besteden.

Constaterende dat grotere perceptieverschillen en meningsverschillen een negatief effect blijken te hebben op de transparantie van het planproces en ook zeker geen positief effect hebben op de overige vormen van legitimiteit en de effectiviteit, pleit dit ervoor om gedurende het proces nadrukkelijk discussie te voeren over welke partij welke rol in het planproces zou moeten hebben. Planvorming voor stationslocaties vereist integrale en creatieve oplossingen waardoor niet enkel uit kan worden gegaan van rollen en verhoudingen op basis van regelgeving. In de cases blijken bij direct betrokkenen vanuit keystakeholders sterk uiteenlopende opvattingen te bestaan over de wenselijke rolverdeling. Discussie hierover gedurende het proces kan mogelijke conflicten in een latere fase voorkomen en kan er ook voor zorgen dat perceptieverschillen minder groot zijn en de transparantie toeneemt. 


\section{Aanbevelingen voor nader onderzoek}

Naast enkele praktische aanbevelingen willen we deze discussie afsluiten met enige suggesties voor nader onderzoek naar de effecten van actorconstellaties en de inrichting van planvormingsprocessen op de kwaliteit van het proces en de procesuitkomsten. Een eerste suggestie heeft betrekking op het aantal cases dat is bestudeerd. In deze studie waren dat er drie. De geringe spreiding op de variabelen samen met het beperkte aantal cases maakt het aantonen van verbanden niet eenvoudig. Niettemin komen er uit de analyse wel degelijk aanwijzingen naar voren dat de actorconstellatie in het proces en de procesinrichting van belang is. Omdat onderzoek naar dergelijke effecten zich nog in de verkennende fase van het ontwikkelen van theorie bevindt, is meer onderzoek nodig om de bevindingen betrouwbaarder vast te stellen en te generaliseren. Het bestuderen van een groter aantal cases kan hieraan bijdragen. Het raamwerk dat in deze studie is opgesteld kan daarbij als basis dienen.

In lijn met het voorgaande is een tweede suggestie om dergelijk onderzoek in internationaal verband vorm te geven. In deze studie zijn drie Nederlandse stationslocaties bestudeerd. Uit de empirische data bleek dat de kenmerken van de actorconstellatie in de drie bestudeerde planprocessen in hoofdlijn overeen komen. Voorgeschreven regelgeving en beleid blijken van substantiële invloed op de betrokkenheid en inbreng van verschillende actoren in het proces. Dit pleit ervoor te kijken of voor de samenhang tussen de kenmerken van de actorconstellatie en de effectiviteit en legitimiteit van planvorming in andere institutionele contexten, waar bijvoorbeeld de positie van gemeenten in ruimtelijke projecten compleet anders is, andere resultaten naar voren komen.

Een derde suggestie heeft betrekking op het niveau waarop de samenhang tussen de inrichting van het proces (in termen van de kenmerken van de actorconstellatie) en de borging van het publiek belang is bestudeerd. In dit onderzoek is deze samenhang bestudeerd op case-niveau en niet op actorniveau. Gezien de probleemstelling is deze keuze logisch. Maar dat neemt niet weg dat het voor een goed inzicht in samenwerkingsprocessen ook relevant is om inzicht te krijgen in de factoren die het gedrag van individuele deelnemers in het proces beïnvloeden. Daarom is het ook zinvol om in toekomstig onderzoek na te gaan of er een verband bestaat tussen hoe actor $\mathrm{X}$ de inbreng van partijen in de planvorming percipieert en hoe een en ander doorwerkt in de oordelen van actor $\mathrm{X}$ over de effectiviteit en de legitimiteit van het proces. 


\section{Verwijzingen}

\section{A}

Addendum Bestuurlijke Uitvoeringsovereenkomst spoorzone Delft (2008)

Adriaansens, H.P.M. en A.C. Zijderveld (1982), Over erosie van legitimiteit, publieke opinie en vrijblijvendheid in de verzorgingsstaat, in: Overheidsbemoeienis, opstellen uitgegeven ter gelegenheid van het 11de lustrum van de Katholieke Hogeschool te Tilburg, Deventer

Alexander, E.R. (2000) Inter-organisational coordination and strategic planning, in: Salet, W. \& A.

Faludi, the revival of strategic planning, KNAW, Amsterdam

Algemene Rekenkamer, (1998) Toezicht op uitvoering van publieke taken”, Tweede kamer, vergaderjaar 1997-1998, 25 956, Den Haag

Altshuler, A., (1965), The Goals of Comprehensive Planning, in Faludi, Andreas. 1973. A Reader in Planning Theory. Pergamon Press.

Arcadis, Referentiemodel OV-terminal, 15 januari 2002

Arnstein, S., (1969). A ladder of citizen participation, American Institute of Planners 35 (4): p.216 e.v.

Arrow, K., (1951) Social Choice and Individual Values, John Wiley and Sons: New York

Australian national Audit Office (2003), Public sector governance. Volume 1 Better practice guide

B

Baarsma, B. en J. Theeuwes (2009). Publiek belang en marktwerking: Argumenten voor een welvaartstheoretische aanpak. In: Van Damme, E. en M.P. Schinkel (red.). Marktwerking en Publieke Belangen. Koninklijke Vereniging voor Staatshuishoudkunde Preadviezen 2009.

Amsterdam, Koninklijke Vereniging voor Staatshuishoudkunde. P.23-86

Barnes, M. (1999). Researching public participation', in: Local government studies, vol. 25, no. 4 : p.60-75

Bartlett, F., (1954). Remembering: A study in Experimental and Social Psychology. Harvard Universuity Press, Cambridge, MA

Beetham, D. (1991). The legitimation of power, macMillan, Hampshire.

Bekkers, V. (2007), Imago en legitimiteit. in: liefde voor het openbaar bestuur en liefde voor de bestuurskunde, Kickert, W. e.a. (red), Eburon, Delft. p.31-44

Bentley, A.F. (1908), The Process of Government.

Bertolini, L. (1999), Spatial Development Patterns and Public Transport: The Application of an Analytical Model in the Netherlands, Planning Practice \& Research 14 (2), p. 199-210.

Bertolini, L. en T. Spit (1998), Cities on Rails: The redevelopment of Railway Station Areas, E\&FN Spon, London.

Bestuurlijke Uitvoeringsovereenkomst Spoorzone Delft (2005)

Bestuursakkoord Rijk en gemeenten, Samen aan de slag, 4 juni 2007.

Blokland, H. (2005), Pluralisme, Democratie en Politieke kennis; de politiek, gerehabiliteerd. Assen 
Blumstein, W. (1999), Public interest research and interest in electric and gas utility industries. Utilities Policies, 7, 4, p. 191-1999

Bouma, G. (2005), Stedelijke vernieuning. In: G.M.A. van der Heijden en A.F.L. Slob (red.), Meervoudig ruimtegebruik, enkelvoudig recht. Eburon, Delft.

Bovenberg, A.L., \& Teulings, C.N. (2000). De grenzen van de publieke sector. Tijdschrift voor Politieke Ekonomie, 22(2), 32-41

Bovens, M.A.P. en Scheltema M. (1999), Rechtsstatelijke redeneerpatronen. In: Derksen, W. et al., Over publieke en private verantwoordelijkheden. WRR, 1999.

Boogers, M. (2009). Decentralisatie in perspectief. In: SCP (red: S. Keuzenkamp), Decentralisatie en de bestuurskracht van de gemeente, Den Haag, oktober 2009

Brandsma, J. (ed.) (2001), Het spoor bijster, Trouw Dossier NL, No. 14

Braybrooke, D. (1962), The Public Interest: The present and the future of the concept, in: Nomos V: The Public Interest, ed. Carl J. Friedrich, New York, 46, 129

Braybrooke, D. and Ch. E. Lindblom, (1963) A strategy of decision, New York: Free Press, pp. 4850 en pp 111-143.

Bressers, J. et al. (1994), Networks as Models of Analysis: Water Policy in Comparative Perspective, in: Environmental Politics, vol. 3, nr. 4, pp. 3-24.

Bruijn, J.A. de (2001), Prestatiemeting in de publieke sector: Tussen professie en verantwoording, Lemna

Bruijn, J.A. de en E. ten Heuvelhof, (1991) Sturingsinstrumenten voor de overheid. Over complexe netwerken en een tweede generatie sturingsinstrumenten, Stenfert Kroese, Leiden/ Antwerpen.

Bruijn, J.A. de, E.F. ten Heuvelhof en R.J. in 't Veld (2002). Procesmanagement: over procesmanagement en besluitvorming. Schoonhoven: Academic Service.

De Bruin, H., E. ten Heuvelhof and M. van Twist (2004), Calculeren voorbij de calculus, in:

Essays over de Calculus van het Publiek Belang, Den Haag: Kenniscentrum voor

Ordeningsvraagstukken.

Bruil, A.W., F.A.M. Hobma, G.J. Peek, en G. Wigmans (red.) (2004), Integrale gebiedsontwikkeling. Het stationsgebied 's Hertogenbosch. Amsterdam, Sun

Bruinsma, G.J.N. en M.A. Zwanenburg (1992), Methodologie voor bestuurskundigen: stromingen en methoden, Muiderberg

Bryson, J.M., W.D. Roering (1987), Applying Private Sector Strategic Planning in the Public Sector., Journal of the American Planning Association.

Bryson, J.M., Bromiley, P. (1993). Critical factors affecting the planning and implementation of major projects, Strategic management Journal 14 (5): 319-337

Buchanan, J. en G. Tullock, (1962) The calculus of consent - Logical foundations of constitutional democracy, Ann Arbor.

Budge, I. (1996), The new challenge of direct democracy, Polity Press, Cambridge

Bult-Spiering W.D. en G.P.M.R. Dewulf (2005), Straegic Issues in Public-Private Partnerships: An International Perspective, Blackwell Publishing

Bult-Spiering, W.D. (2003). Publiek-Private Samenwerking: de interactie centraal. Lemma, Lochem

\section{C}

Canoy, M., Janssen, M. en B. Vollaard, (2001) PPS: een witdagend huwelijk; publiek-private samenwerking bij combinatieprojecten, $\mathrm{CPB}$ documenten No. 2a 
Cassinelli, C.W. (1962), The Public Interest in Political Ethics, in: Nomos V: The Public Interest, ed. Carl J. Friedrich, New York, 46, 129

Castells, M. (1996). The rise of the network society. Blackwell Publishers

Charles, Ch. B., W. Dicke, J. Koppenjan, N. Ryan (2007), Public Values and Safeguarding Mechanisms in Infrastructure Policies: a conceptual and theoretical exploration. Introductory paper for the IRSPM panel on Public Values in Infrastructure, Potsdam, April 2-4, 2007

Chisholm, D. (1989). Coordination without Hierarchie; Informal Structures in Multiorganizational Systems. University of California Press, Berkely and Los Angelos, California.

Coalitieakkoord CDA, PVDA en CristenUnie, "Samen Werken, Samen Leven", Kamerstukken II 2006/07, 30 891, nr. 4

Cochran, Clarke E. (1974) Political Science and "The Public Interest" in Journal of Politics, Vol. 36, Issue 2, p. 327-355

Coleman, J.S. (1990). Foundations of Social Theory. The Belknap Press of Harvard University Press. Cambridge, Massachusetts, and London, England.

Commissie marktordening in relatie tot economische sectoren, (2005) Overheid en markt: "van goede intenties naar goede interventies" Den Haag

Committee on Financial Aspects of Corporate Governance (1992), Financial aspects of Corporate Governance, London

Cook, Th. D. and Campbell, D.T., (1979) Quasi-Experimentation; Design and Analysis Issues for Field Settings, Rand Mc. Nally College Publishing Company, Chicago

CPB (1997) werkdocument no. 103 Kiezen of delen; ICES-maatregelen tegen het licht, Centraal Planbureau, Den Haag

CPB (1999), De grondmarkt; Een gebrekkige markt en een onvolmaakte overheid, Den Haag

CROW kenniscentrum voor verkeer, vervoer en infrastructuur (2002), Leidraad categorisering van knooppunten. Hulpmiddel voor het ontwerp. Publicatie 170, Ede

\section{D}

Dahl, R.A. and Charles E Lindblom (1953), Politics, Economics and Welfare, New York: Harper and Brothers

Dahl, R.A. (1956), A preface to democratic theory. Chicago: The University of Chicago Press.

Dahl, R.A., (1961). Who Governs? Democracy and power in an American city, Yale University Press, New Haven en Londen.

Dahl, R.A. en Ch.E. Lindblom (1976), Politics, Economics \& Welfare, New Brunswick, New Jersey, Tweede druk, 2000.

Dahl, R.A., (1985), A Preface of Economic Democracy. Berkeley: University of California Press.

Damme van, E (2001), Marktwerking vereist Maatwerk, CentER, KUB

Denters, S.A.H., Grootstedelijk bestuur: over stedelingen en stadsbestuurders, inaugurele rede, Universiteit Twente, 2002

Denters, S.A.H. en P.-J. Klok, (2003), Rebuilding Roombeek, an institutional analysis of interactive governance in the context of representative democracy, in: The rise of interactive governance and quasi-markets, Denters S.A.H. e.a., ed., Kluwer, Dordrecht/ Boston/ London, pp. $91-110$. 
Dewulf G.P.M.R.(2001), 'Praatjes vullen geen gaatjes': De spanning tussen participatie en innovatie, Inaugurele rede, Universiteit Twente

Dewulf, A., Craps, M. Bouwen, R., Taillieu, T., en Pabl-Wostl, C. (2005). Integrated management of natural resources: dealing with ambiguous issues, multiple actors and diverging frames. Water Science and Technology, p.115

Dorée, A.G. (2001). Dobberen tussen concurrentie en co-development; de problematiek van samenwerken in de bouw. Universiteit Twente, Enschede

Douma, S. en H. Schreuder, (1998). Economic Approaches to Organizations, 2nd edition, London etc: Prentice Hall, 1998.

Dowding, K. (1995). Model or Metaphor? A Critical Review of the Policy Network Approach. Political Studies, XLIII, 136-158

Dowling, J. en Pfeffer, J (1975), 'Organisational legitimacy: Social values and organisational behaviour', Pacific Sociological Review, Vol. 18, Iss. 1, pp. 122-136.

Downs, A. (1957), An economic theory of democracy, New York

Driesen en Glasbergen, (2002) Milieu, samenleving en beleid, Elsevier

Driesen, P. Glasbergen, P. en C. Verdaas (2001). Interactive policy-making: a model of management of for public Works, European Journal of Operational Research 128, p. 155-178

Dror, Y., (1967). Policy analysts: a new professional role in government service, Public administration Review 43 (5): p.447-452

Dubbink, W., Duurzaambeid als patstelling. Over de onvriendelijke betrekkingen tussen openbaar bestuur, markt en civil society. Utrecht: Eburon, 1999

\section{$\mathbf{E}$}

EC (2004), White paper on services of general interest, COM (2004) 374 final. Brussels, available at: http://europa.eu.int/eur-lex/en/com/wpr/2004/com2004_0374en01.pdf

Edelenbosch, J. (2000), Proces in vorm. Procesbegeleiding van interactieve beleidsvorming over lokale ruimtelijke projecten. Dissertatie, Utrecht: Lemna

Eisenhardt, Kathleen M. (1989), Building theories from case study research, Academy of Management Review.; 14(4):p.532-550.

Energieraad (2001). De rol van de overhead in een vrije energiemarkt; advies aan de minister van economische zaken, Den Haag

Enthoven M.E.E. (2004). Samen voor de buis. Advies over het dossier buisleidingen, Den Haag

Etzioni, A. (1967). "Mixed Scanning: A Third Approach to Decision Making." Public Administration Review 27: 387-392.

Europese Commissie (2005). Networks for peace and development, Extension of the major trans-European transport axes to the neighbouring countries and regions p. 81

\section{F}

Faludi, A. (1973). A Reader in Planning Theory. Pergamon Press.

Fenger, H., (2001) Sturing van samenwerking. Institutionele veranderingen in het beleid voor werk en inkomen, Enschede, Universiteit Twente.

Flathman, R. E., (1966) The Public Interest, New York 
Forester, J. (1989), Planning in the Face of Power. University of California Press.

Friedmann, J. (1987). Planning in the Public Domain: from knowledge to action. Princeton University Press.

\section{G}

Gemeente Breda (1995). Strategische ontwikkelingsvisie Oost-Westflank en Stationsgebied

Gemeente Breda (2000). Verkenningen Sleutelproject Spoorzone Breda

Gemeente Breda (2002), Programmadoelen Masterplan spoorzone Breda

Gemeente Breda (2003). Masterplan Centraal Breda, Voorlopig Stedenbounkundig Ontwerp

Stationskwartier

Gemeente Breda (2003a). Covernota Masterplan Centraal Breda: een stap voor Brabant, een sprong voor Breda

Gemeente Breda (2006). Ontwerp bestemmingsplan Stationskwartier, Breda

Gemeente Breda (2007), Bestemmingsplan Stationskwartier, Breda

Gemeente Delft (2006), Bestemmingsplan Spoorzone, Delft

Gemeente Den Haag (1997) Masterplan Hoog Hage.

Gemeente Den Haag (2001) Binnenstadplan 2000-2010; binnenstad buitengewoon. Gemeentelijk beleids- en ontwikkelingskader binnenstad.

Gemeente Den Haag (2001). Voortgangsrapportage Den Haag Nieuw Centraal, november 2001

Gemeente Den Haag (2002). Voortgangsrapportage Den Haag Nieuw Centraal, mei 2002

Gemeente Den Haag (2003). Voortgangsrapportage Den Haag Nieuw Centraal, februari 2003

Gemeente Den Haag (2003a). Voortgangsrapportage Den Haag Nieun Centraal, oktober 2003

Gemeente Den Haag (2003b). Voortgangsrapportage Den Haag Nieuw Centraal, december 2003

Gemeente Den Haag (2004). Voortgangsrapportage Den Haag Nieun Centraal, augustus 2004

Gemeente Den Haag (2005). Voortgangsrapportage Den Haag Nieun Centraal, februari 2005

Gemeente Den Haag (2007). Factsheet Den Haag Nieun Centraal, juli 2007

Gemeente Den Haag (2009). Voortgangsrapportage Den Haag Nieuw Centraal, mei 2009

Genugten, M.L. van (2008), The Art of Alignment; Transaction Costs Economics and the provision of public services at a local level, Enschede

Goodin, R.E. (ed) (1996), The Theory of Institutional Design, Cambridge University Press, Cambridge

Graaf, R. de (2005). Strategic Urban Planning; Industrial area development in The Netherlands, to direct or to interact, Enschede

Groenendijk N.S. (2005), De Lissabon-strategie: overmoed of onmacht? Concurrentiekracht en het bestuurlijk tekort van de Europese Unie, Inaugurele rede, Universiteit Twente, 2005

Guy Peters, B., (2005), Institutional Theory in Political Science: 'The New Institutionalism'. Second Edition, The Continuum International Publishing Group, London/New York. 


\section{$\mathbf{H}$}

Hagen, M. van en M. de Bruyn (2002), Typisch NS, Elk station zijn eigen rol. Colloquium Vervoersplanologisch Speurwerk 2002: de kunst van het verleiden, november 2002, Delft, 15071526

Hakansson, H. (1989). Corporate Technological Behaviour: Cooperation and Networks, Routledge, London

Haus, M., H. Heinelt en M. Steward (red.) (2005), Urban Governance and Democracy: Leadership and community involvement, Routledge, London/New York

Healey, P. (2006). Collaborative Planning; Shaping places in fragmented societies, Basingstoke Palgrave Macmillan.

Heijden, J. van der en Spiering, B. (red.), Publiek opdracbtgeverschap. De burger als klant. Een verkenning naar trends rondom publiek private samenwerking en Rijkswaterstaat. Den Haag: Eburon, 2002 Heldeweg, M.A. (2010), Smart Rules and Regimes: Publiekrecbterlijk€ ontwerpen voor privatisering en technologische innovatie, Oratie, Universiteit Twente, Enschede

Hermans, L.M. (2005) Actor Analysis for water resource management, Eburon, Delft

Hobma, F.A.M. (2000). Rijkswegen en ruimtelijke ordening: planologische inpassing van rijkswegtracés door Nederlandse gemeenten. Delft, Eburon

Hodge, G. (1991), Planning Canadian Communities, 2nd edition. Nelson Canada.

Hof, J. van den (2006) PPS in de polder: de betekenis van publiekprivate samenwerking voor de borging van dunrzame ruimtelijke kwaliteit op VINEX lokaties. Utrecht

Hommes, S. (2008), Conquering complexity; dealing with uncertainty and ambiquity in water management, Universiteit Twente, Enschede

Hoof, van L.M. (2003), Geen stationslocaties zonder procesmanagement. in: Boss magazine, nr. 20, juli 2003

Hoogendijk, F.A. (2000), De verzorgingsstaat: institutionele vernieuwing en publieke belangen, memorandum Ministerie van Economische Zaken, Den Haag

Hoogerwerf, A. (1987). De levensloop van problemen: Definiëring, precisering en oplossing. In:

Beleidswetenschap, 1987, 1 (2), p. 159-181

Hoogerwerf, A. (red.) (1989), Overheidsbeleid: Een inleiding in de beleidswetenschap, Samson H.D. Tjeenk Willink, Alphen a/d Rijn.

Hoogerwerf, A. (red.) (1993), Overbeidsbeleid, Een inleiding in de beleidswetenschap Vijfde druk, Samson H.D. Tjeenk Willink Alphen a/d Rijn.

Hoogerwerf, A. en M. Herweijer (1998), Overheidsbeleid, een inleiding in de beleidswetenschappen,

Alphen

aan den Rijn

Hooimeijer, P., H. Kroon, J. Luttik (2001), Kwaliteit in meervoud: Conceptualisering en operationalisering van ruimtelijke kwaliteit voor meervoudig ruimtegebruik. Habiforum, Gouda

Hoppe, R., M. Jeliazkova, H van der Graaf en J. Grin (1998), Beleidsnota's die (door)werken, handleiding voor geslaagde beleidsvoorbereiding, Bussum.

Hudson, B. (1979). "Comparison of Current Planning Theories: Counterparts and Contradictions". Journal of the American Planning Association, p. 387-398.

Hutjes J.M. en J.A. van Buuren (1992). De gevalstudie: strategie van kwalitatief onderzoek. Meppel 
Instituut voor Bouwrecht (2000). Bouwrecht in kort bestek, Kluwer, Den Haag

Interdepartementale Taskforce Integrale Gebiedsontwikkeling (2003), Kamerstukken Tweede Kamer 2002/2003 28753 nr. 3 brief Minister van Financiën, d.d. 10 juli 2003

Interbestuurlijke taakgroep gemeenten (2008). Vertrouwen en verantwoorden. Den Haag

International Federation of Accountants (IFAC) (2001), Public Sector Committee, Governance in the Public Sector: A Governing Body Perspective, Study 13

\section{J}

Jensen, J. L. and R. Rodgers (2001), Cumulating the intellectual gold of case study research. Public Administration Review 61(2): 236-246

Jessop, B. (2002). Governance and metagovernance: On Reflexivity, Requisite, Variety, and Requisite Irony, in: H. Heinelt, P. Getimis, G. Kafkalas, R. Smith and E. Swyngedouw (eds). Participatory Governance in Multi-level Context: Concepts and Experience, Opladen: Leske + Budrich: p. 33-58

Johnson G, en K. Scholes (1999), Exploring corporate strategy. London: Pentice Hall Europe

Jong W.M. de, W.G.M. Salet (ed.) (2001); Institutionele condities voor meervoudig ruimtegebruik; stimulansen en belemmeringen op regionaal niveau, Amsterdam: Centre for the Metropolitan Environment/Habiforum.

Jong, M. de (1999), Institutional transplantation. How to adopt good transport infrastructure decision-making ideas from other countries. Delft: Eburon.

\section{K}

Kaplan, R.S. en D.P. Norton, (2004). Strategy Maps: Converting Intangible Assets into Tangible outcomes. Harvard Business School Publishing Corporation.

Kenis, P. en V. Schneider (1991), Policy Networks and Policy Analisis. Scrutinizing a New Analytical Toolbox, in: Marin, B. en R. Mayntz (eds.), Policy Networks. Empirical Evidence and Theoretical Considerations, Campus Verlag, Frankfurt am Main, pp 25-59.

Kickert, W.J.M.; Koppenjan, J.F.M., and Klijn, E.H. (1997) Managing complex networks: strategies for the public sector. London: Sage publications

King, G., R.O. Keohane, and S. Verba. (1994), Designing social inquiry: scientific inference in qualitative research. Princeton: Princeton University Press

Kirlin, J. (1996), What government must do well: creating value for society. Journal of Public Administration Research and Theory, 6, 1, p. 161-185

Klaassen, H.L. \& G.R. Teisman, Nieuwe arrangementen van problemen en oplossingen, Het corridorconcept als startpunt voor een andere benadering, Stedebouw \& Ruimtelijke Ordening, jg. 78, nr. 3, pp. 41-45, 1997

Klausen, J.E. en D. Sweeting (2005), Legitimacy and community involvement in local governance. in: Haus, Heinelt and Steward, Urban Governance and Democracy, Routledge, New York, p. 214233

Klijn, E.H. en G.R. Teisman (2002), Publiek-private samenwerking bij transportinfrastructuur. Wenkend of wijkend perspectief? Utrecht: Lemma. 
Klijn, E-H., (2001), Districts in Two Cities. Rules as Institutional Context for Decision Making in Networks: The Approach to Post-war Housing Districts in Two Cities, Vol. 33 No. 2, May 2001 133-164, Sage Publications

Klijn, E.H. en J. Koppenjan (1998). Tussen representatieve democratie en directe democratie: interactieve beshitvorming en 'de politiek', Bestuurskunde (7)

Klijn, E.H., (1997) Policy networks: an overview, in: Kickert, W.J.M.; Koppenjan, J.F.M., and Klijn, E.H., Managing complex networks: strategies for the public sector. London, Sage publications

Kohnstam, P.P. en L.J. Regterschot, (1994). De manager als bouwheer, de rol van de bestuurder bij de realisatie van nieune huisvesting, ten Hagen \& Stam, Den Haag

Kooiman, J. (1993). Modern governance, New government-society interactions. Sage Londen

Koppenjan, J., M.B. Charles, N. Ryan (Eds.) (2008). Managing Competing Public Values in Public Infrastructure Projects. Journal of Public Money and Management, June 2008, p. 131-134

Koppenjan, J. en E.H. Klijn (2004). Managing uncertainty in networks, Routledge, London/New York

Kouwenhoven, V., (1991). Publiek Private Samenwerking: mode of model?, Eburon, Delft

Kreukels, A.M.J. (1999) Stedelijke Vernieuwing en de Vernieuning van het Bestuur - bestuurlijke verboudingen in een aangepast ruimtelijk beleid. In: Opstellenbundel over stedelijke vernieuwing

Krings, U. (1985), Babnhofsarchitectur, Deutsche Großbabnböfe des Historismus, Prestel, München

Kuhn, Th. S. (1970). The Structure of Scientific Revolutions, University of Chicago Press, Chicago

\section{$\mathbf{L}$}

Laverman, W. (2003). Nieuwe Sleutelprojecten: schirofreen, bureaucratisch, vragen om moelijkheden. In: Building Business, nr.12, april 2003

Le Galès, P. (2002) European Cities: Social Conflicts and Governance, Oxford: Oxford University Press.

Lenhning, P.B. (1991). In: Hedendaagse Democratie. J.J.A. Thomassen (ed.). Samson, Alphen a/d Rijn, 1991

Lindblom, Ch. E (1959) “The Science of Muddling Through”, Public Administration Review, vol. 19

Lindblom, Charles E, The Intelligence of Democracy, New York, Free Press, 1965

\section{$\mathbf{M}$}

March, D., (1998). Comparing policy networks. Buckingham: Open university Press, 1998

March, J.G., J.P. Olsen, (1989). Rediscovering Institutions. The Organizational Basis of Politics. The Free Press, New York.

Mc Gowan, R.P. en J.M. Stevens (1983), Local government initiatives in a climate of uncertainty. Public administration review 43, 2: p.127-136

Mendelow A. (1981), Environmental scanning: the impact of stakeholder concept. In Proceedings of the second international conference on information systems, December, 1981, Cambridge Mass.

Miles, M.B. and A.M. Hubermann (1994). Qualitative data-analysis: An expanded sourcebook. Thousand Oaks, London, New Delhi: Sage Publications 
Ministerie van Economische Zaken (2003), Ruimtelijke kwaliteit en bedrijventerreinen, analyse van het planvormingsproces. Den Haag

Ministerie van Economische zaken, (1999) Nota Ruimtelijk Economisch beleid, dynamiek in netwerken', Den Haag

Ministerie van Economische Zaken, (2004) Publieke belangen en Marktordening: liberalisering en privatisering in netwerksectoren, Den Haag

Ministerie van Financiën (1999), Voortgangsrapportage PPS, Den Haag

Ministerie van Financiën (2004), Inrichting van het PPS-proces bij gebiedsontwikkeling, Den Haag

Ministerie van Financiën (2004), Van Incidenteel naar Structureel: Voortgangsrapportage PPS, Kenniscentrum PPS, Den Haag

Ministerie van Financiën e.a., (2007), Publiek Private samenwerking: samen werken aan meerwaarde. Voortgangsrapportage 2007 en vooruitblik 2008, Den Haag

Ministerie van Verkeer en Waterstaat (1999), Nota Derde Eeuw Spoor, Den Haag

Ministerie van Verkeer en Waterstaat (2004), Nota Mobiliteit; Naar een betrouwbare en voorspelbare bereikbaarheid, Den Haag

Ministerie van Verkeer en Waterstaat (2004), Nota Mobiliteit; Naar een betroumbare en voorspelbare bereikbaarheid, Den Haag

Ministerie van Verkeer en Waterstaat (2005), beheersconcessie hoofdspoorweginfrastructuur, Den Haag

Ministerie van Verkeer en Waterstaat (2006), Evaluatie Spoorwegwet en Concessiewet, Den Haag

Ministerie van Verkeer en Waterstaat (2007), Actieplan 'Groei op het Spoor', Den Haag

Ministerie van Verkeer en Waterstaat (2007a), Landelijke Markt en Capaciteitsanalyses Spoor, Wegen en Regionaal OV, Den Haag

Ministerie van VROM (2000), Ruimte maken, Ruimte delen: Vijfde Nota over de ruimtelijke ordening 2000/2020, Den Haag

Ministerie VROM, Ministerie V\&W, Gemeente Den Haag (2000), Intentieovereenkomst CS

Kwadrant, 11 oktober 2000

Ministerie VROM (2002), Voortgangsrapportage Nieuwe Sleutelprojecten, Den Haag

Ministerie VROM (2003), Nieuwe Sleutelprojecten in aantocht, Voortgangsrapportage, Den Haag

Ministerie VROM, Ministerie V\&W, Gemeente Den Haag (2003), Bestuurlijke overeenkomst uitvoering, 18 december 2003

Ministeries VROM, LNV, V\&W en EZ (2004), Nota Ruimte: ruimte voor ontwikkeling, Den Haag

Ministerie VROM (2005), Ontwikekel kracht; eindrapport van de Adviescommissie Gebiedsontwikkeling, Den Haag

Ministerie VROM (2006), Stationslocaties; Kathedralen van de nieune tijd, Den Haag

Ministerie VROM, (2006a). Nieune Sleutelprojecten op stoom: Voortgangsrapportage maart 2006, Den Haag

Ministerie van VROM (2008) Structuurvisie Randstad 2040. Naar een duurzame en concurrerende Europese Topregio. Den Haag.

Ministerie VROM (2009), Evaluatie Sleutelprojecten. Onderzoek uitgevoerd door Bureau Stedelijke Planning. 
Montfort, van C., (2004), Ruimte voor goed bestuur: tussen Prestatie, Proces en Principe. WRR, Den Haag

Musgrave P.B. en R.A. Musgrave (1976), Public Finance in Theorie and Practice. New York, McGraw-Hill

Musgrave R.A. (1959) The Theory of Public Finance: A study in Public Economy. New York, Mc Graw-Hill

\section{$\mathbf{N}$}

Nederlandse Spoorwegen (1988), Rail 21: sporen naar een nieuwe eeuw

Noam, E. and Nishuilleabhain, A. (Eds.) (1996), Private Networks, Public Objectives (Elsevier, Amsterdam)

NS Commercie (2001). Handboek ketenmobiliteit, bereikbaarbeid van het station, NS B.V., Utrecht, p. 66

\section{O}

Oosten, W (2002), Politieke theorie ingeleid, Utrecht, Uitgeverij Lemna

Oosten, W, (2005) Ruimte voor een democratische rechtstaat; geschakelde sturing bij ruimtelijke investeringen, Rotterdam

ORI (Overleg over Ruimtelijke Investeringen) (1991), Publiek-Private Samenwerking bij grootstedelijke projecten

Ostrom, E., Gardner, R., en Walker, J., (1994). Rules, games and common-pool resources, University of Michigan Press, Ann Arbos.

Ostrom, V., (1973) The Intellectual Crisis in American Public Administration. Tuscaloosa, The University of Alabama Press

\section{P}

P3BI (2001), Publiek-Private Samenwerking bij infrastructurele en stedelijke projecten: rapportage resultaten enquête, Enschede

P3BI (2002), De publieke visie op PPS: rapportage resultaten enquête en workshop, Enschede

Pawson, R and N. Tilly (1997) Realistic Evaluation, Sage Publications, London

Peek, G.J. (2006), Locatiesynergie; Een participatieve start van de herontwikekeling van binnenstedelijke stationslocaties. Eburon, Delft

Percy B. Lehning, De theorie van het pluralisme, in: Hedendaagse Democratie, J.J.A. Thomassen (red.)

Pierre, J., (2000), Debating governance. Authority, steering and democracy, Oxford University Press, Oxford

Pierre, J., en B. Guy Peters, (2000), Governance, politics and the state, MacMillan Press, London

Pfiffner, J.M. en R. Presthus (1967), Public Administration, Ronald Press Corporation, New York, 5 e druk

Porter, M. (1990), The Competitive Advantage of Nations, Simon and Schuster, New York

Potman, H. en M. Wolters (1992), Soevereiniteit, legitimiteit en acceptatie van beleid, in:

Democratie en beleid in de Europese Gemeenschap, Alphen aan den Rijn. 
Powell, W. (1991) Neither market nor bierarchie: network forms of organisation. In: Thompson, Graham ; Frances, Jennifer; Levacic, Rosalind and Mitchell, Jeremy. Markets hierachies and networks; the coordination of social life. London: Sage Publications; 1991

Procesovereenkomst Spoorzone Delft (2002)

Propper, I., en Steenbeek, D. (1998). Interactieve beleidsvoering: typering, ervaringen en dilemma's, Bestuurskunde (7): p.292-301

Pröpper, I.M.A.M., Steenbeek, D., (1999). De aanpak van interactief beleid: elke situatie is anders,

Coutinho, Bussum

Provan, K.G. en H.B. Milward (2001), Do Networks Really Work? A Framework for Evaluating Public Sector Organizational Networks. Public Administration Review, July/August 2001, Vol. 61, No. 4

\section{$\mathbf{R}$}

Raad voor Openbaar Bestuur, (1998) De overbeid de markt in- of uitprijzen, Den Haag

Raad voor Verkeer en Waterstaat (1996), Knooppunten in openbaar vervoernetwerken, Den Haag

Raad voor Verkeer en Waterstaat (1998), Ambities Bundelen, Advies over de inpassing van infrastructuur, Den Haag

Raad voor Verkeer en Waterstaat (2000). Meer markt, andere overheid, Den Haag

Railned (1999), Basisstation, Functionele normen en richtlijnen voor stations / OV-knopen, Railned, Utrecht

Reijndorp, A., en I. Nio (1997), Groeten wit Zoetermeer. Stedebouw in discussie. Rotterdam: nai

Uitgevers

Rhodes, R.A.W. en D. March (1992), New directions in the study of policy networks. European Journal of Political Research 21 (1-2), 181-205.

Rhodes, R.A.W., (2000), Governance and public administration, in: Pierre (ed.), p. 54 - 90

Riker, William H., (1988) Liberalism Against Populism: A Confrontation Between the Theory of Democracy and the Theory of Social Choice.

Rittel, W. en Webber, M. (1973) Dilemmas in a general theory of planning, Policy Sciences 4: 155-169

Rosenthal, U., A.B. Ringeling, M.A.P. Bovens, P. 't Hart en M.J.W. van Twist (1996), Openbaar bestuur, beleid organisatie en politiek, Alphen aan den Rijn

\section{S}

Salet, W.G.M. en Faludi, A. (Red.) (2000). The revival of Strategic Planning, Amsterdam, Royal Netherlands Academy of Arts and Sciences

Salet, W.G.M., A. Kreukels en A. Thornley (2003). Metropolitan governance and spatial planning; comparative case-studies of European city-regions. Spon Pess, London/New York

Scharpf, F.W. (1997), Games Real Actors Play; Actor-Centered Institutionalism in Policy Reseach. Westview Press, Oxford

Scharpf, F.W. (1999) Governing in Europe. Effective and Democratic? Oxford/New York: Oxford University Press

Schmitter, P. (2002) Participation in Governance Arrangements', in: J.R. Grote and B. Gbikpi (eds) p.51-69 
Schubert, Glendon A., Jr. (1957), "The public interest In Administrative decision making: Theorem, Theosophy, or Theory?”' The American Political Science Review, Volume 51, Issue 2

Schumpeter (1942), Capitalism, socialism and democracy

Scott, W.R. (1992), Organizations: Rational, natural and open systems (3 ${ }^{\text {rd }}$ ed.). Englewood Cliffs, NJ: Prentice Hall

Scott, W.R. (2001), Institutions and Organizations. London: Sage.

Scott, W.R. en J.W. Meyer (1991), The organization of societal sectors. In: W.W. Powell en P.J. DiMaggio (Eds.), The new institutionalism in organizational analysis: 390-422. Chicago: University of Chicago Press.

Shleifer, Andrej (1998) "State versus private ownership", Journal of Economic Perspectives, p.133150

Simon, H. A. (1945). Administrative Behavior. A Study of Decision-Making Processes in Administrative Organization. Third Edition, 1976. The Free Press, New York.

Simon, H.A., (1957). Models of Man: Social and Rational. John Wiley \& Sons, New York.

Smit, M, G.P.M.R. Dewulf, (2002) Public sector involvement; a comparison between the role of the government in private Finance Initiatives (PFI) and Public Private Partnership in spatial development projects, Paper for the $8^{\text {th }}$ international conference on Public and Private Sector Partnerships: Exploring Co-operation, Karlstad, Sweden

Sorauf, F. J. (1957) The Public Interest reconsidered, The journal of Politics, Volume 19, Issue 4, p. 616-639

Spanjer, A.R. (2006), "Gasbankieren in het publieke belang", Tijdschrift voor Openbare Financiën, 38(1), p. 4-13.

Steunenberg, B., (2000). Institutionele verandering: naar een bestuurskunde bewegend tussen 'vloeibare' en 'gestolde' voorkeuren, Leiden

Steward, M. (2005), Collaboration in multi-actor governance. in: Haus, Heinelt and Steward, Urban Governance and Democracy, Routledge, New York, p. 149-167

Stiglitz, J.E. (2000), Economics of the public sector, (derde editie), W.W. Norton \& Company, New York, 2000

Stoker, G. (1998), Governance as theory: five propositions: International Social Science Journal, nr. 155, Unesco.

Stone, M.M. en C.G. Brush (1996), Planning in ambiguous contexts: the dilemma of meeting needs for commitment and demands for legitimacy. Strategic management Journal, vol. 17, 633652

Stout, H. (2007), Weerbare waarden, borging van publieke belangen in nutssectoren, oratie, Den Haag:

Boom Juridische uitgevers

Suchman, M.C. (1995), Managing Legitimacy: Strategic and Institutional Approaches. In: The Academy of Management Review, Vol. 20, No. 3 (Jul., 1995): p.571-610.

Swanborn, P.G. (1987). Methoden van sociaal-wetenschappelijk onderzoek. Amsterdam, Meppel: Boom

Swanborn, P.G. (1994)., Het ontwerpen van case-studies: enkele keuren. Mens en Maatschappij, 69e jaargang, nr.3 
Taskforce Gebiedsontwikkeling, (2003), Het gebied verkent; Het Rijk en PPS bij gebiedsontwikkeling: Tweede kamer, vergaderjaar 2002-2003, 28 753, nr. 1

Tatenhoven, van J. en Leroy, (2000) Political Modernisation and the Environment. The Renewal of Environmental Policy Arrangements. Dordrecht: Kluwer

Teisman, G.R. (1992), Complexe besluitvorming. Een pluricentrisch perspectief op besluitvorming over ruimtelijke investeringen. VUGA, Den Haag

Teisman, G.R., (1997) Sturen via creatieve concurrentie; een innovatie-planologisch perspectief op ruimtelijke investeringsprojecten, Nijmegen: KUN

Teisman, G.R., J. Edelenbosch, E.H. Klijn, J. Verbart (2001), Ruimtelijke ontwikkelingsprocessen. In: G.R. Teisman (red.), Besluitvorming en Ruimtelijk Procesmanagement, Eburon, Delft

Teulings, C.N., A.L. Bovenberg, H.P. Van Dalen, (2003). De calculus van bet publiek belang, i.o.v ministerie van Economische zaken en Ministerie van Financiën.

Theeuwes, J. (2004), Een kritische beschouwing van de 'Calculus van het publiek belang, in:

Essays over de Calculus van het Publiek Belang, Den Haag: Kenniscentrum voor

Ordeningsvraagstukken.

Tirion, H.B. (2006). Beleidseffectmeting en legitimiteit; een studie over reflectie, objectiviteit, betrekkeelijkheid en de provinciale beleidspraktijke, Enschede

Thompson, J.D., (1967). Organizations in action: Social Science Bases of Administrative Theory. McGraw-Hill, New York

Truman D.B. (1951), The governmental process: Political interests and public opinion, New York

Tweede Kamer, vergaderjaar 2002-2003, 28 753, nr. 1 en nr. 3

Twist, van, M.J.W., M.B. Kort, M. Timmerman (2004), STIP-studie 'Organiserend vermogen in de grote stad'. In opdracht van NWO en Kenniscentrum Grote Steden. Nijmegen/Den Haag

\section{V}

Vákár, L.I. \& Snijder, H.H. (2001), Railway station structures designed for densely populated urban areas, in: Structural Engineering International, Volume 11, No. 2, p. 128-138.

Velde, Van der (2000), Dutch and Japanese Railway reforms and exchanges. Japan Railway \& Transport Review, 24 (juli): 10-16

Verbart, J.S. (2004) Management van Ruimtelijke kwaliteit. De ontwikkeling en verankering van inrichtingsconcepten in het Utrechtse stationsgebied. Dissertatie, Delft: Eburon

Vereniging van Nederlandse Gemeenten (vng) (2006). Commissie toekomst lokaal bestuur. Wil tot verschil: gemeenten in 2015, Den Haag

Vereniging van Nederlandse Gemeenten (vng) (2007). Commissie Gemeentewet en Grondwet, Eerste overheid. Den Haag

VROM-raad (2009), Grond voor kwaliteit; Voorstellen voor verbetering van overheidsregie op (binnen)stedelijke ontwikkeling. Den Haag

\section{W}

Wagenaar, M. (1998). Stedebouw en burgerlijke vrijheid, De contrasterende carrières van zes Europese boofdsteden, Uitgeverij Thoth, Bussum, p. 279 
Walter, A.I. en R.W. Scholz (2007), Critical success conditions of collaborative methods: a comparative evaluation of transport planning projects. In: Journal of Transportation, volume 34, number 2, p.195-212, Springer, Netherlands

Weber, M. (1976). Wirtschaft und Gesellschaft. GrundriB der verstehende Soziologie, Tübingen

Wetenschappelijke Raad voor Regeringsbeleid (2000), Borging van publieke belangen, SDU, Den Haag

Wetenschappelijke Raad voor Regeringsbeleid (1998), De kern van ruimtelijk beleid, een onderzoek naar het begrip ruimtelijke kwaliteit, SDU, Den Haag

Wijk, H.D. van et al. (2002), Hoofdstukken van bestuursrecht. Den Haag: Elsevier.

Van Wijnbergen, S. (2002), Staat of privaat: Het intellectuele failliet van Paars-II, in: De Ru, H. en J. Peters (eds.), Verzelfstandiging en Marktwerking: Stand van Zaken en Perspectieven, Den Haag: Sdu, pp. 11-19.

Wille, A. (2001). Politieke participatie en representativiteit in het interactieve beleidsproces. In: Edelenbosch, J. en Monnikhof R. (ed.), Lokale interactieve beleidsvorming: een vergelijkend onderzoek naar de consequenties van interactieve beleidsvorming voor het functioneren van de lokale democratie, Lemna, Utrecht, p. 87-115

Wilmink, H (1998) Overbeid en markt; een vierboeksverbouding, in: Openbaar Bestuur, 1998

Wolf, Ch. (1990), Markets or Governments; Choosing between Imperfect Alternatives, Cambridge, Mass.: MIT Press

Wouden, van der H.C (red.). (1999), De stad op straat; de openbare ruimte in perspectief, Sociaal Cultureel Planbureau/Elsevier Bedrijfsinformatie

$\mathbf{Y}$

Yin, R.K. (1989). Case study research: design and methods. Newbury Park, London, New Delhi: Sage Publications

Yin, R.K. (1993), Applications of case study research, Newbury Park, London, New Delhi: Sage Publications

Yin, R.K. (1994), Case study research. design and methods, Second Edition, Thousand Oaks: Sage Publications

Yin, R.K. (2003). Case study research, design and methods, Third Edition, Thousand Oaks, London, New Delhi: Sage Publications

\section{Z}

Zundert Van J. (2001). Het bestemmingsplan, 10 edn, Kluwer, Alphen aan de Rijn 


\section{Lijst van figuren}

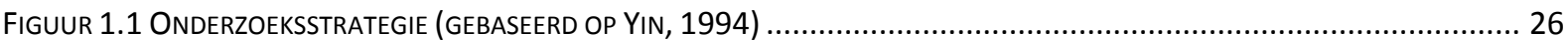

FIGUUR 2.1 CRITERIA VOOR BORGING PUBLIEK BELANG IN RUIMTELIJKE PROJECTEN........................................................5 50

FigUUR 3.1 InStitutional ANALYSIS AND DEVELOPMENT FrameWORK (OSTROM E.A., 1994)......................................... 59

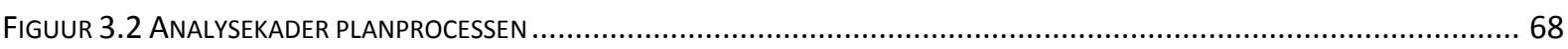

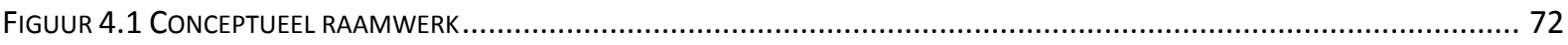

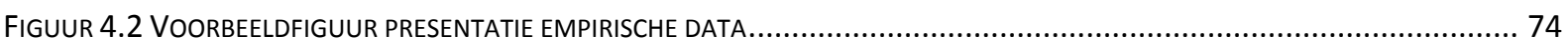

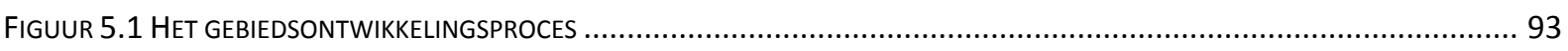

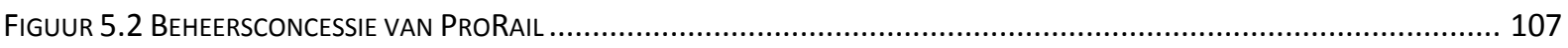

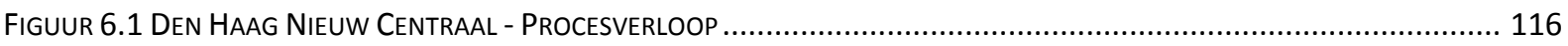

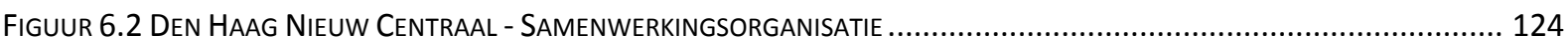

FIGUUR 6.3 MASTERPLAN DHNC - INBRENG VAN STAKEHOLDERS IN VISIEVORMING EN PERCEPTIEVERSCHILLEN ........................ 126

FIGUUR 6.4 MASTERPLAN DHNC - WENSELIJKE INBRENG VAN STAKEHOLDERS IN VISIEVORMING EN MENINGSVERSCHILLEN.......... 126

FIGUUR 6.5 OVT-PLAN DHNC - INBRENG VAN STAKEHOLDERS IN VISIEVORMING EN PERCEPTIEVERSCHILLEN........................... 127

FIGUUR 6.6 OVT-PLAN DHNC - WENSELIJKE INBRENG VAN STAKEHOLDERS IN VISIEVORMING EN MENINGSVERSCHILLEN ............. 128

FIGUUR 6.7 MASTERPLAN DHNC - ZEGGENSCHAP STAKEHOLDERS EN PERCEPTIEVERSCHILLEN ........................................... 129

FIGUUR 6.8 MASTERPLAN DHNC - WENSELIJKE ZEGGENSCHAPSVERDELING EN MENINGSVERSCHILLEN.................................. 130

FIGUUR 6.9 OVT-PLAN DHNC - ZEGGENSCHAP STAKEHOLDERS EN PERCEPTIEVERSCHILLEN ............................................. 130

FIGUUR 6.10 OVT-PLAN DHNC - WENSELIJKE ZEGGENSCHAPSVERDELING EN MENINGSVERSCHILLEN ................................... 131

FIGUUR 6.11 DHNC - INBRENG VAN MIDDELEN DOOR STAKEHOLDERS EN MENINGSVERSCHILLEN .................................... 131

FiguUR 6.12 Den HAag NieUW CENTRAal - ZWAaRTEPUNTEN IN DE DIMENSIES VAN RUIMTELIJKE KWALITEIT ......................... 137

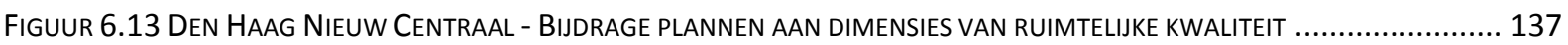

Figuur 6.14 Den HaAg NieuW Centraal - Ambitieniveau, helderheid en eValueerbaARheid van Plannen.................... 138

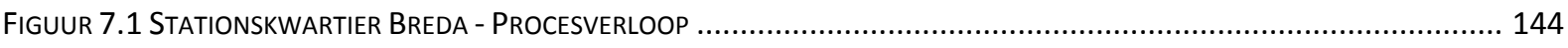

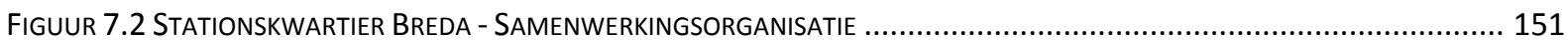

FiguUR 7.3 MASTERPLAN CENTRAAL BREDA - INBRENG VAN STAKEHOLDERS IN VISIEVORMING EN PERCEPTIEVERSCHILLEN ........... 154

FIGUUR 7.4 MASTERPLAN CENTRAAL BREDA - WENSELIJKE INBRENG STAKEHOLDERS IN VISIEVORMING EN MENINGSVERSCHIL....... 155

FIGUUR 7.5 OVT-PLAN BREDA - INBRENG VAN STAKEHOLDERS IN VISIEVORMING EN PERCEPTIEVERSCHILLEN ............................ 156

FIGUUR 7.6 OVT-PLAN BREDA - WENSELIJKE INBRENG VAN STAKEHOLDERS IN VISIEVORMING EN MENINGSVERSCHILLEN.............. 156

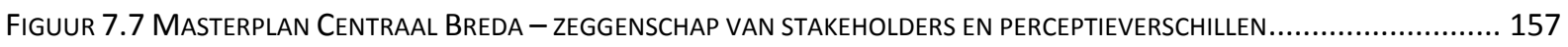

FigUUR 7.8 MASTERPLAN CENTRAAL BREDA - WeNSELIJKE ZEGGENSCHAPSVERDELING EN MENINGSVERSCHILLEN ..................... 157

FIGUUR 7.9 OVT-PLAN BREDA - ZEGGENSCHAP VAN STAKEHOLDERS EN PERCEPTIEVERSCHILLEN ......................................... 158

FIGUUR 7.10 OVT-PLAN BREDA - WENSELIJKE ZEGGENSCHAPSVERDELING EN MENINGSVERSCHILLEN ................................. 159

FIGUUR 7.11 StATIONSKWARTIER BREDA - INBRENG VAN MIDDELEN DOOR STAKEHOLDERS EN MENINGSVERSCHILLEN ................ 160

FIGUUR 7.12 StATIONSKWARTIER BREDA - ZWAARTEPUNTEN IN DE DIMENSIES VAN RUIMTELIJKE KWALITEIT ............................. 166

FigUUR 7.13 StATIONSKWARTIER BREDA - BIJdRAge VAN PLANNEN AAN DE DIMENSIES VAN RUIMTELIJKE KWALITEIT ................. 166

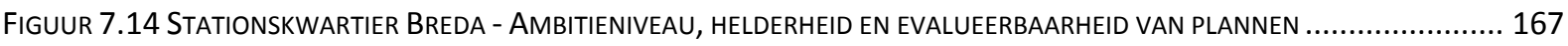

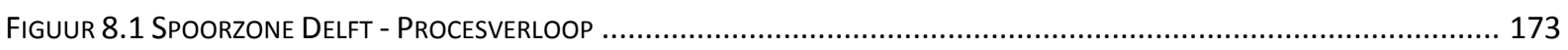

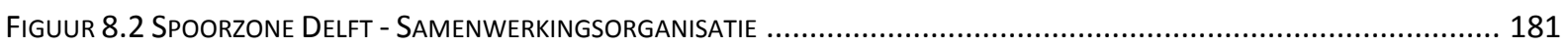

FIGUUR 8.3 MASTERPLAN SPOORZONE DELFT - INBRENG VAN STAKEHOLDERS IN VISIEVORMING EN PERCEPTIEVERSCHILLEN .......... 185

FIGUUR 8.4 MASTERPLAN SPOORZONE DELFT - WENSELIJKE INBRENG STAKEHOLDERS IN VISIEVORMING EN MENINGSVERSCHIL .... 185

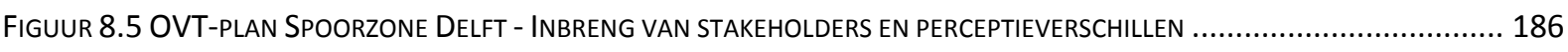

FIGUUR 8.6 OVT-PLAN SPOORZONE DELFT - WENSELIJKE INBRENG VAN STAKEHOLDERS EN MENINGSVERSCHILLEN................... 186 
FIGUUR 8.7 MASTERPLAN SPOORZONE DELFT - ZEGGENSCHAP EN VAN STAKEHOLDERS EN PERCEPTIEVERSCHILLEN ....... 187

FIGUUR 8.8 MASTERPLAN SPOORZONE DELFT - WENSELIJKE ZEGGENSCHAPSVERDELING EN MENINGSVERSCHILLEN. 188

FIGUUR 8.9 OVT-PLAN SPOORZONE DELFT - ZEGGENSCHAP VAN STAKEHOLDERS EN PERCEPTIEVERSCHILLEN ...... 188

FIGUUR 8.10 OVT-PLAN SPOORZONE DELFT - WENSELIJKE ZEGGENSCHAPSVERDELING EN MENINGSVERSCHILLEN ...................... 189

FIGUUR 8.11 SPOORZONE DELFT - INBRENG VAN MIDDELEN DOOR STAKEHOLDERS EN MENINGSVERSCHILLEN ........................... 189

FIGUUR 8.12 SPOORZONE DELFT - ZWAARTEPUNTEN IN DE DIMENSIES VAN RUIMTELIJKE KWALITEIT ...................................... 196

FIGUUR 8.13 SPOORZONE DELFT - BIJDRAGE VAN DE PLANNEN AAN DE DIMENSIES VAN RUIMTELIJKE KWALITEIT ....................... 196

FigUUR 8.14 SPOORZONE DELFT - AMBITIENIVEAU, HELDERHEID EN EVALUEERBAARHEID VAN PLANNEN ................................ 197

FIGUUR 9.1 PERCEPTIES (GEMIDDELDE) V/D INBRENG VAN STAKEHOLDERS IN VISIEVORMING MASTERPLAN IN DRIE CASES ............ 202

FIGUUR 9.2 PERCEPTIES (GEMIDDELDE) V/D INBRENG VAN STAKEHOLDERS IN VISIEVORMING OV-TERMINAL IN DRIE CASES .......... 205

FIGUUR 9.3 PERCEPTIES (GEMIDDELDE) V/D ZEGgENSCHAP VAN STAKEHOLDERS IN HET MASTERPLANPROCES IN DRIE CASES ......... 206

FIGUUR 9.4 PERCEPTIES (GEMIDDELDE) V/D ZEGGENSCHAP VAN STAKEHOLDERS IN HET OVT PLANPROCES IN DRIE CASES.............208

FIGUUR 9.5 PERCEPTIES (GEMIDDELDE) VAN DE INBRENG VAN MIDDELEN DOOR STAKEHOLDERS IN DRIE CASES...........................209

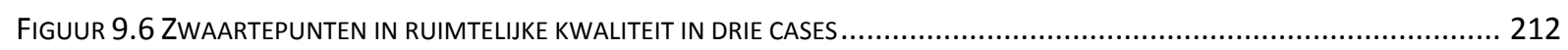

FIGUUR 9.7 VERWACHTE BIJDRAGE VAN DE PLANNEN AAN DE RUIMTELIJKE KWALITEIT IN DRIE CASES..................................... 212

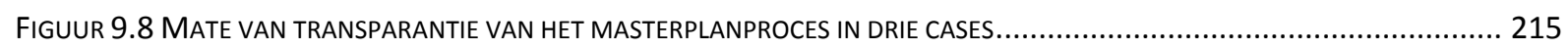

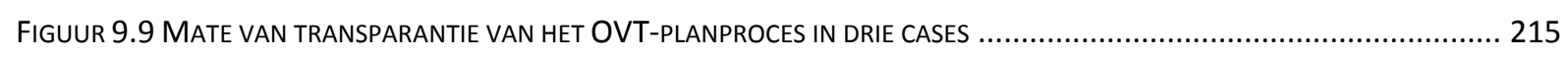

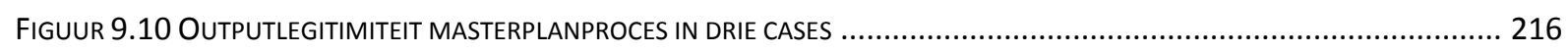

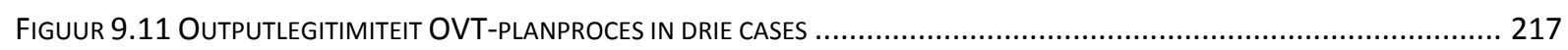




\section{Lijst van tabellen}

TABEL 2.1 VoORBEELDEN VAN CRITERIA VOOR GOOd GOVERNANCE (OVERGENOMEN UIT VAN MONTFORT, 2004)...................... 38

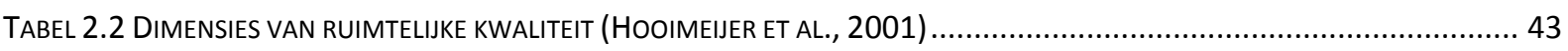

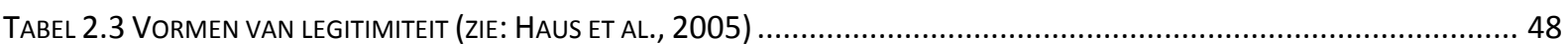

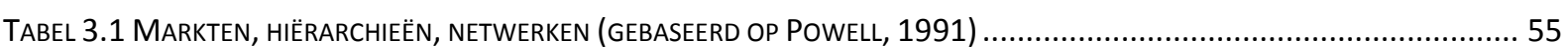

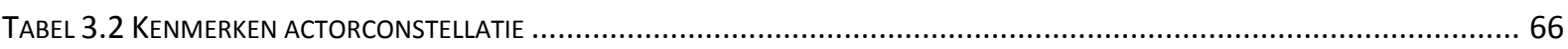

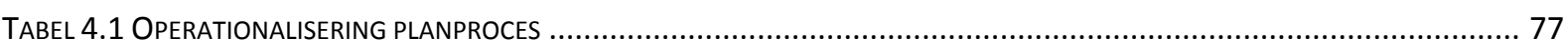

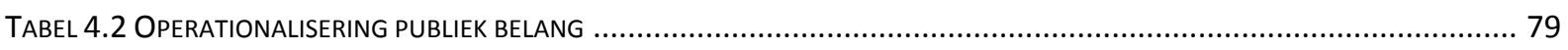

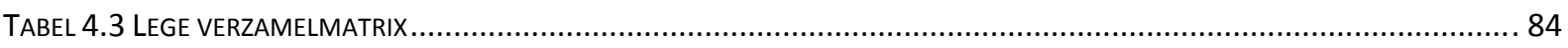

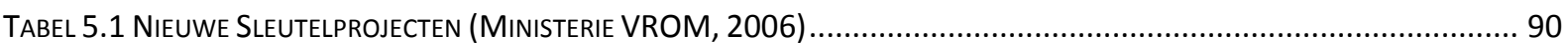

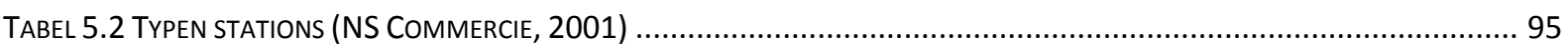

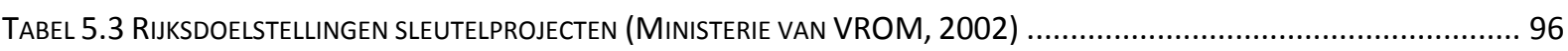

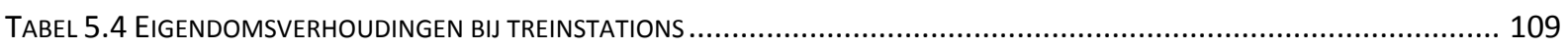

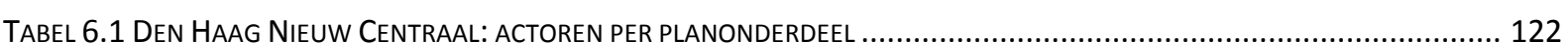

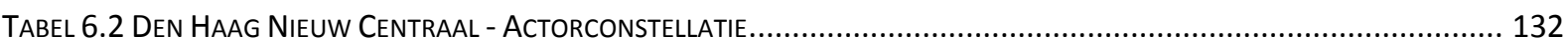

Tabel 6.3 Den haAg Nieuw Centraal - Mate van transparantie Van het Planproces ............................................. 135

TABel 6.4 Den HaAg NieuW CentraAl - Mate VAN Steun Voor Plannen ............................................................. 136

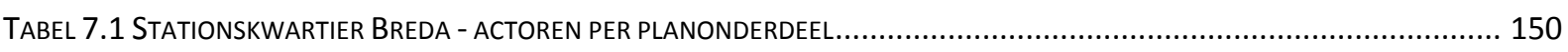

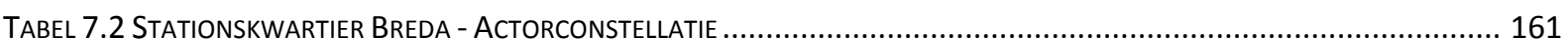

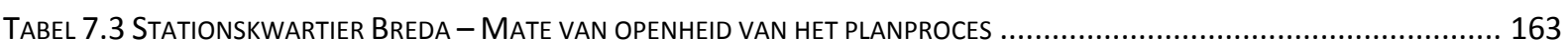

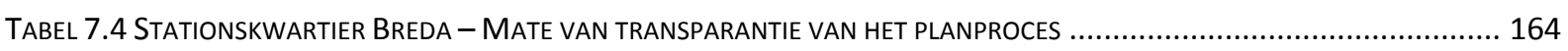

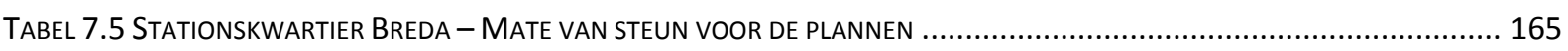

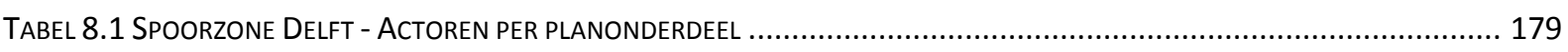

TABEL 8.2 SPOORZONE DELFT - KENMERKEN VAN DE ACTORCONSTELLATIE ................................................................. 190

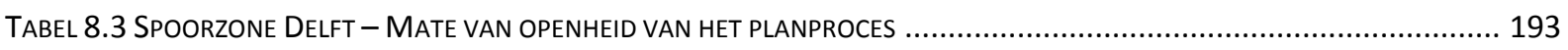

TABEL 8.4 SPOORZONE DELFT - MATE VAN TRANSPARANTIE VAN HET PLANPROCES .................................................... 194

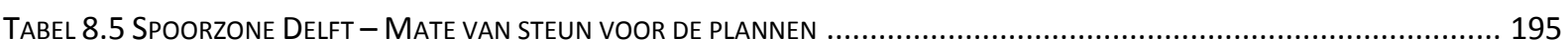

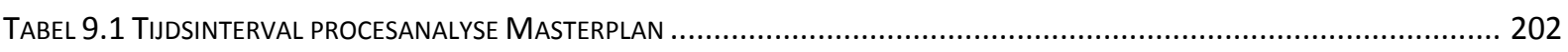

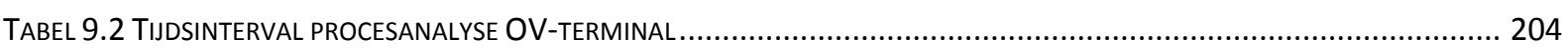

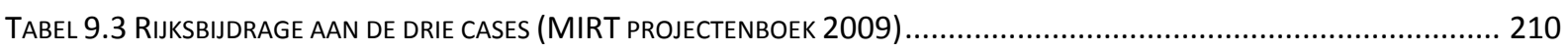

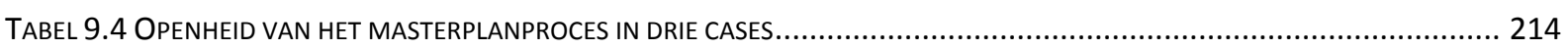

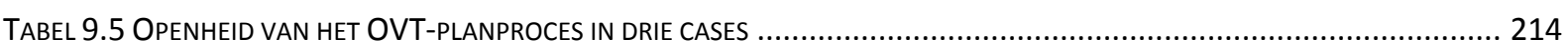

TABEL 9.6 RELATIEVE POSITIONERING CASES M.B.T. EFFECTIVITEIT EN LEGITIMITEIT VAN PLANVORMING MASTERPLAN ................ 218

TABEL 9.7 ReLATIEVE POSITIONERING CASES M.B.T. EFFECTIVITEIT EN LEGITIMITEIT VAN PLANVORMING OV-TERMINAL ...............2 218

TABEL 9.8 CASE-ORDERED PREDICTOR OUTCOME MATRIX - VISIEVORMING EN PUBLIEK BELANG ........................................220

TABEL 9.9 CASE-ORDERED PREDICTOR OUTCOME MATRIX - ZEGGENSCHAP EN PUBLIEK BELANG ...........................................224

TABEL 9.10 CASE-ORDERED PREDICTOR OUTCOME MATRIX - MIDDELEN EN PUBLIEK BELANG..............................................227

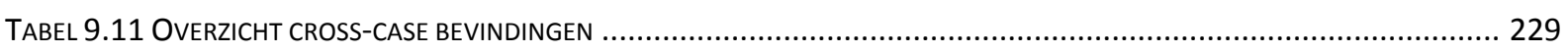

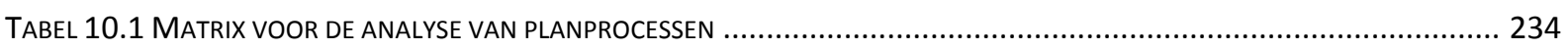

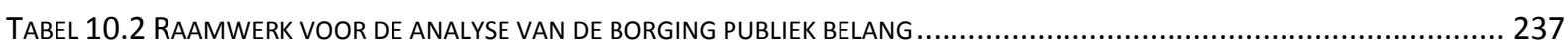




\section{Samenvatting}

\section{Achtergrond van het onderzoek}

Deze studie gaat over de borging van het publiek belang in ruimtelijke projecten. In literatuur en in het publieke debat wordt het publiek belang onlosmakelijk verbonden met een rol voor de overheid. De rol van de overheid in het ruimtelijke domein is de afgelopen decennia echter sterk veranderd. Ontwikkelingen in de samenleving en in de ruimtelijke sector hebben ervoor gezorgd dat de traditionele domeinen van overheid, markt en burgers meer en meer verweven zijn geraakt. Het tot voor kort overheersend beeld van de overheid die unicentrisch en top-down de normen stelt voor ruimtelijke ontwikkelingen heeft afgedaan. In plaats daarvan wordt in toenemende mate de nadruk gelegd op de noodzaak van een goed samenspel tussen overheden en andere actoren in het speelveld om oplossingen te vinden voor hedendaagse ruimtelijke vraagstukken. Met verschillende benamingen, zoals publiek-private samenwerking, interactieve planvorming en stakeholder involvement, wordt dit benadrukt.

In het openbaar bestuur en in planvormingliteratuur wordt tegenwoordig veel aandacht besteed aan de toegenomen afhankelijkheden en de inter-organisatorische setting waarin veel ruimtelijke ontwikkelingen plaatsvinden. Naar de gevolgen van andere arrangementen voor het borgen van het publiek belang is echter weinig onderzoek verricht. In het debat wordt er op gewezen dat mogelijk conflicterende belangen en vervaging van grenzen binnen andere arrangementen de borging van het publiek belang kunnen ondermijnen. Zelden is echter duidelijk wat het publiek belang is en of dit belang al dan niet gewaarborgd is. Met dit onderzoek wordt bijgedragen aan de leemte in kennis op dit terrein. Dit is gedaan door (1) op basis van theoretische inzichten een conceptueel raamwerk te ontwikkelen dat als basis kan dienen voor de evaluatie van het publiek belang in concrete ruimtelijke projecten en (2) een empirische analyse van de relatie tussen de inrichting van planprocessen en de borging van het publiek belang. Voor het tweede deel is een aantal herontwikkelingen van stationslocaties bestudeerd.

\section{Basis concepten}

De centrale vraag in het onderzoek is als volgt geformuleerd: "Bij welke inrichting van het planproces is de kans op succesvolle borging van het publiek belang bij de herontwikkeling van stationslocaties groot?" Om deze vraag te kunnen beantwoorden, is op basis van theoretische analyse een conceptueel raamwerk opgesteld. Dit raamwerk benoemt de factoren die relevant zijn bij het bestuderen van de relatie tussen de inrichting van planprocessen en de borging van het publiek belang.

Het eerste element in het conceptueel raamwerk is 'borging van het publiek belang'. Om de centrale onderzoeksvraag te kunnen beantwoorden, dient duidelijk te zijn wat het publiek belang is en welke criteria gehanteerd kunnen worden voor een oordeel over de borging daarvan. Hiervoor zijn inzichten uit politiek-filosofische en economische literatuur bestudeerd. Op basis daarvan is gesteld dat het publiek belang moet worden beschouwd als een relatief en dynamisch concept. In evaluatieve zin kan het concept slechts gebruikt worden, als de evaluatie betrekking heeft op - binnen een 
bepaalde institutionele en situationele setting - intersubjectief gedeelde waarden. Daarbij dienen de naar criteria vertaalde waarden zowel betrekking te hebben op de vormgeving van het proces als op het uiteindelijke resultaat. Er is vervolgens beargumenteerd dat binnen de institutionele en situationele setting van Nederlandse stationslocaties legitimiteit en effectiviteit van planvorming relevante criteria zijn voor een oordeel over de borging van het publiek belang. Voor de legitimiteit van planvorming is een onderscheid gemaakt naar input-, throughput- en outputlegitimiteit. Inputlegitimiteit heeft betrekking op de wijze waarop in het proces beslissingen tot stand komen. Vanuit dit perspectief is planvorming legitiem als en omdat beslissingen zijn afgeleid uit de authentieke voorkeuren binnen een bepaalde gemeenschap. Het gaat er daarmee om dat het proces voldoet aan de van toepassing zijnde rechtsbeginselen (legaliteit) en relevante partijen voldoende mogelijkheden hebben hun wensen en voorkeuren kenbaar te maken (openheid). Throughputlegitimiteit heeft betrekking op de transparantie van processen. Door inzicht te geven in de wijze waarop uiteenlopende wensen en voorkeuren van stakeholders zijn vertaald naar beslissingen over de te realiseren output en welke argumentatie daaraan ten grondslag ligt, kan de legitimiteit worden bevorderd. Oordelen over de legititimiteit van ruimtelijke planprocessen worden tenslotte ook positiever als de uitkomsten van het planproces bijdragen aan de effectieve realisatie van de wensen en voorkeuren van stakeholders. Het gaat dan om outputlegitimiteit. Het tweede criterium is de effectiviteit van planvorming. Daarvoor is in deze studie de mate waarin plannen (naar verwachting) bijdragen aan de relevante dimensies van ruimtelijke kwaliteit in het betreffende plangebied, als maatstaf gehanteerd.

Het conceptueel raamwerk bevat naast indicatoren voor de evaluatie van de borging van het publiek belang tevens een kader met behulp waarvan het tweede element van de onderzoeksvraag, 'de inrichting van planprocessen', kan worden beschreven. De inrichting van planprocessen is beschreven aan de hand van de kenmerken van de actorconstellatie op drie thema's; visievorming; zeggenschap; en middelen. Visievorming verwijst naar het proces waarin actoren een beeld vormen van het probleem, de gewenste en haalbaar geachte toekomstige situatie en het veranderingstraject dat nodig is om daar te komen. Zeggenschap heeft betrekking op de mogelijkheden die actoren in dat proces hebben om (mee) te beslissen. Het thema 'middelen' verwijst naar de hulpbronnen die actoren ter beschikking stellen voor de ontwikkeling en realisatie van plannen.

De actorconstellatie is op deze drie thema's gekenmerkt aan de hand van; het aantal keystakeholders; de verhoudingen tussen keystakeholders met uiteenlopende karakters en belangenposities (publiekprivaat; centraal-decentraal; gemeente-overige); en de mate van ambivalentie ( $\Delta$ perceptie; $\Delta$ mening) bij keystakeholders. Dit is gedaan voor twee te onderscheiden fasen in de planvorming voor stationslocaties. De eerste fase heeft betrekking op het ontwikkelen van het masterplan voor de gebiedsontwikkeling als geheel. De tweede fase heeft betrekking op een onderdeel daarbinnen, de planvorming specifiek voor de OV-terminal.

\section{Onderzoeksmethode}

Het conceptueel raamwerk is gebruikt als basis voor de structurering van de empirische dataverzameling en -analyse. In de empirische analyse is gebruik gemaakt van de case studie methode. Om de relatie tussen $\mathrm{X}$ (actorconstellatie in het planproces) en $\mathrm{Y}$ (legitimiteit en effectiviteit) te onderzoeken, is gekozen om de context waarbinnen de planvorming plaatsvindt zo weinig mogelijk te doen variëren. Om die reden is ervoor gekozen het onderzoek te richten op de integrale 
herontwikkeling van grootschalige stationslocaties in Nederland. Juist deze projecten kennen een hoge mate van inhoudelijke en procesmatige complexiteit. Stationslocaties worden per definitie gekenmerkt door multifunctionaliteit en de betrokkenheid van een groot aantal uiteenlopende actoren. Integrale herontwikkeling van deze locaties noodzaakt tot arrangementen van publieke en private actoren die vanuit verschillende niveaus en sectoren bij de diverse functies betrokken zijn. Deze kenmerken zorgen ervoor dat bij dit type projecten naast effectiviteit ook legitimiteit van planvorming een belangrijke rol speelt. In het onderzoek zijn drie stationslocaties uitvoerig bestudeerd. Dit zijn: Den Haag Nieuw Centraal, Stationskwartier Breda en Spoorzone Delft.

Voor de dataverzameling in deze cases is gebruik gemaakt van projectdocumentatie en interviews. De factoren die in het conceptueel raamwerk zijn benoemd, zijn vertaald naar een vragenlijst. De hanteerbaarheid van de vragenlijst is getest in een aantal pilot interviews. Op basis hiervan is het protocol voor de interviews en de vragenlijst enigszins aangepast. Vervolgens is voor de drie cases een uitgebreide interviewronde uitgevoerd. Daarvoor zijn in totaal 21 interviews gehouden met direct betrokken projectmanagers van organisaties die een substantieel belang bij de herontwikkeling van de betreffende stationslocatie hebben en waarvan toestemming en/of investeringen noodzakelijk zijn voor de implementatie van plannen. Deze organisaties zijn beschouwd als keystakeholders. Concreet betekent dit dat voor elke case interviews zijn gehouden met personen vanuit de betreffende gemeente, de regio en/of de provincie, het ministerie van Verkeer en Waterstaat, het ministerie van VROM, ProRail, NS Poort en een of meerdere private ontwikkelaar(s).

De data uit projectdocumentatie en interviews is vervolgens voor elke case afzonderlijk geanalyseerd om bekend te raken met elke case als op zichzelf staande onderzoekseenheid (individuele case analyse) en daarnaast zijn de bevindingen in de drie cases vergeleken met elkaar (cross-case analyse).

\section{Individuele case analyse}

De individuele case analyse start met een beschrijving van het project. Hiervoor zijn per case (1) de projectgeschiedenis en het procesverloop; (2) de kenmerken van de ruimtelijke opgave; (3) de actoren en hun (organisatorische) posities; en (4) de samenwerkingsorganisatie, beschreven. Voor deze beschrijving zijn verschillende informatiebronnen gebruikt (o.a. intentie-, proces-, en samenwerkingsovereenkomsten, bestemmingsplannen, masterplannen, bestuurs- en voortgangsrapportages en organisatieschema's)

Het tweede deel van de individuele case analyse beschrijft de inrichting van het planproces aan de hand van de inbreng van individuele keystakeholders en de kenmerken van de actorconstellatie op de drie thema's (visievorming, zeggenschap, middelen). Deze actorconstellaties zijn beschreven op basis van de percepties die projectmanagers van keystakeholders in het project hebben van de feitelijke situatie en hun (normatieve) opvattingen over de wenselijke situatie. Deze keuze is gebaseerd op de theoretische veronderstelling dat actoren hun gedrag vormgeven op grond van hun percepties en oordelen.

Het derde deel van de individuele case analyse belicht de borging van het publiek belang. De criteria aan de hand waarvan een oordeel wordt gevormd over de borging van het publiek belang zijn hiervoor beschreven. Het gaat dan om een analyse van de legitimiteit en effectiviteit van het planproces voor de gebiedsontwikkeling dat wordt vervat in een masterplan en de legitimiteit en effectiviteit van het planproces voor de vernieuwing van de OV-terminal. Vanuit het uitgangspunt dat 
legitimiteit betrekking heeft op de aanvaarding, acceptatie of steun door betrokkenen en effectiviteit pas daadwerkelijk kan worden vastgesteld als het project is gerealiseerd, is voor de empirische bepaling uitgegaan van de subjectieve oordelen van actoren die de betreffende projecten van nabij kennen.

\section{Cross case analyse}

De individuele case analyse is opgevolgd door een cross-case analyse. In de cross-case analyse zijn de bevindingen uit de individuele case analyses vergeleken. Deze analyse is uitgevoerd in vier stappen.

De eerste stap was een analyse van de verschillen en overeenkomsten in context en projectkenmerken. Deze analyse is uitgevoerd omdat verschillen in de setting waarin het planproces verloopt van invloed kunnen zijn op verschillen in de inbreng van actoren in dit proces. Tweede stap was een analyse van verschillen en overeenkomsten in de actorconstellatie in het proces. Daarvoor is de inbreng van keystakeholders op de drie onderscheiden thema's tussen de drie cases vergeleken. Derde stap was een analyse van overeenkomsten en verschillen op de criteria voor de borging van het publiek belang. Hiervoor zijn de oordelen over de legitimiteit en effectiviteit in de drie cases vergeleken. Als laatste stap is bestudeerd of verschillen in de kenmerken van de actorconstellatie op de drie onderscheiden thema's samenhangen met de verschillen in de legitimiteit en effectiviteit van planvorming. Als hulpmiddel voor deze laatste analyse is de zogenaamde 'case-ordered predictor-outcome matrix' gebruikt. Voor de drie thema's (visievorming, zeggenschap, middelen) zijn in kolommen de waarden van de afhankelijke (sub)variabele(n) en de waarden van de onafhankelijke variabelen ingevuld, waardoor drie verzamelmatrices ontstaan. Vervolgens is, door per kolom de waarden van de onafhankelijke variabele en de waarde van de afhankelijke (sub)variabele na te gaan, gekeken of er bepaalde patronen zijn te ontdekken die onderling vergelijkbaar zijn of verschillen. Op basis van deze (quasi-)kwantitatieve analyse is een eerste inzicht verkregen in mogelijke patronen. Indien de analyse aanleiding gaf bepaalde patronen te veronderstellen, is op het niveau van de individuele case(s) gekeken of er een logische verklaring was. Vervolgens zijn de empirische bevindingen geconfronteerd met theoretische verwachtingen (pattern matching).

\section{Conclusies}

Uit het onderzoek kwam als overheersend beeld naar voren dat in alle bestudeerde cases de planvorming legitiem en effectief is geweest. De verschillen tussen cases op de gehanteerde indicatoren waren gering. Voor de wel aanwezige verschillen is bestudeerd of deze te relateren zijn aan verschillen in de inrichting van het planproces. Op basis van de bevindingen is een aantal conclusies getrokken over de relatie tussen de inrichting van het planproces en de borging van het publiek belang.

De eerste conclusie heeft betrekking op de relatie tussen het aantal keystakeholders dat een grote inbreng heeft in de planvorming en de legitimiteit en effectiviteit. Hierover is geconcludeerd dat een grote inbreng in het planproces van een groter aantal keystakeholders de kans op succesvolle borging van het publiek belang, in termen van legitieme en effectieve planvorming, eerder lijkt te vergroten dan te verkleinen. Dit lijkt zeker te gelden bij de ontwikkeling van masterplannen voor de gebiedsontwikkeling als geheel. 
De tweede conclusie heeft betrekking op de relatie tussen de verhoudingen binnen de actorconstellatie en de legitimiteit en effectiviteit van planvorming. Waar het gaat om de verhoudingen tussen publieke en private partijen wordt vaak in het publieke debat gesteld dat door samenwerking met private partijen de overheid een deel van haar zeggenschap inruilt en vervagende grenzen tussen het publiek en private domein een aantasting kunnen betekenen van zaken als verantwoordelijkheid en toerekenbaarheid, transparantie en democratische keuze. De complexe eigendom- en verantwoordelijkheidsverdeling binnen de huidige institutionele ordening rondom stationslocaties zorgt ervoor dat samenwerkingsarrangementen van diverse publieke en private partijen onvermijdelijk zijn om te komen tot herontwikkeling. De bevindingen van dit onderzoek doen niet vermoeden dat een relatief grotere inbreng van private partijen in planvorming op negatieve wijze samenhangt met de legitimiteit daarvan. Regels en procedures voor democratische besluitvorming bleken niet minder correct gevolgd c.q. doorlopen te zijn in de projecten waar private partijen een relatief grote inbreng hadden. Ook werd het proces in dergelijke gevallen niet als minder open of transparant ervaren en was de steun van stakeholders voor de plannen niet minder groot. In algemene zin geven de resultaten daarmee geen aanleiding te veronderstellen dat legitimiteit toeneemt naarmate (publieke) representatieve instituties een dominantere inbreng hebben in de planvorming. Dat een 'dominante' positie niet noodzakelijk is, betekent niet dat publieke instituties geen rol zouden moeten spelen. Een relatief grote inbreng van private partijen ten opzichte van publieke partijen in de planvorming lijkt echter geen ondermijning te betekenen voor de legitimiteit of effectiviteit en daarmee niet voor de waarborging van het publiek belang.

De derde conclusie heeft betrekking op de verhoudingen tussen actoren met enkel een publiek karakter (centraal-decentraal). In alle drie bestudeerde projecten bleek de gemeente een zeer grote inbreng te hebben gehad in de planvorming. Deze inbreng was in alle cases aanzienlijk groter dan de inbreng vanuit het Rijk. In alle cases werd de planvorming ook als effectief en legitiem ervaren. De spreiding op de variabelen was daarmee klein. Niettemin bleek wel, dat naarmate de gemeente een grotere zeggenschap had dan het Rijk, het planproces niet als legitiemer werd ervaren. De effectiviteit werd hiermee dan ook niet bevorderd. Eenzelfde beeld kwam naar voren als de inbreng van de gemeente werd bezien in relatie tot de inbreng van alle andere keystakeholders. Omdat bij elk van de cases sprake is van een sterke gemeentelijke betrokkenheid en ook de legitimiteit en effectiviteit van de planvorming redelijk tot goed te noemen valt, zijn er geen aanwijzingen dat een stevige rol van gemeenten automatisch een negatieve uitwerking heeft. Wel lijkt het erop dat een àl te grote dominantie van gemeenten negatief kan inwerken op de legitimiteit en effectiviteit omdat hiermee de noodzakelijke inbreng van andere keystakeholders in het gedrang dreigt te komen.

De vierde conclusie heeft betrekking op de relatie tussen de mate van ambivalentie bij keystakeholders en de effectiviteit en legitimiteit van het proces. De actorconstellaties zijn in deze studie beschreven op basis van de percepties die projectmanagers van keystakeholders in het project hebben van de feitelijke situatie. Tevens zijn hun(normatieve) opvattingen over de wenselijke situatie bestudeerd. Met uitzondering van de rol van de gemeente, bleken deze percepties en opvattingen behoorlijk uiteen te lopen. Op basis van een vergelijking met de verschillen tussen cases qua effectiviteit en legitimiteit is geconcludeerd dat de kans op succesvolle borging van het publiek belang groter is naarmate de verschillen in perceptie tussen keystakeholders ten aanzien van de feitelijke 
situatie, geringer zijn. Eenzelfde conclusie is getrokken voor de mate waarin de opvattingen over de wenselijke situatie verschillen.

Hoewel in het conceptueel raamwerk factoren zijn benoemd die relevant zijn bij een oordeel over de borging van het publiek in ruimtelijke projecten en in de empirische analyse een aantal relaties zijn gevonden met de kenmerken van de actorconstellatie in planvorming, bieden de bevindingen van dit onderzoek slechts een eerste aanzet voor verdere theorieontwikkeling op dit specifieke terrein. In deze verkennende fase van theorieontwikkeling is het nog niet mogelijk om causale relaties, verklaringen daarvoor, en de omstandigheden waaronder de inrichting van het planproces leidt tot succesvolle borging van het publiek belang, samen te voegen tot een samenhangend geheel dat door kan gaan als theorie. Niettemin biedt het onderzoek wel aanknopingspunten voor verder onderzoek dat hiertoe kan leiden. Voor bepaalde kenmerken van de actorconstellatie geldt namelijk dat deze wel degelijk gevolgen hebben voor de effectiviteit en legitimiteit van planvorming en daarmee voor de borging van het publiek belang in ruimtelijke projecten.

\section{Aanbevelingen}

Op basis van de bevindingen van het onderzoek is een aantal aanbevelingen gedaan voor de inrichting van planprocessen en voor verder onderzoek.

Een eerste aanbeveling heeft betrekking op de rol van gemeenten. Gemeenten hebben hoge ambities bij het ontwikkelen van plannen, maar het is niet altijd duidelijk of deze in de praktijk ook gerealiseerd kunnen worden. Voor de realisatie van hun ambities zijn gemeenten bij stationslocaties sterk afhankelijk van Rijk, provincie en/of regio, NS, ProRail en marktpartijen. Niettemin spelen gemeenten in alle bestudeerde projecten een min of meer dominante rol in het planproces. Enerzijds is deze dominante rol niet verwonderlijk want in de context van het Nederlandse ruimtelijke beleid zijn gemeenten ook de partijen die primair verantwoordelijk zijn voor de realisatie van stedelijke projecten. Anderzijds zijn dergelijke projecten van regionale of zelfs nationale betekenis en zijn stationslocaties unieke projecten voor gemeenten waar zij eenmalig mee te maken hebben en dus minder goed mee bekend zijn. Hoge ambities en verwachtingen van gemeenten over bijdragen vanuit het Rijk en overwegingen van afstemming en coördinatie om de integraliteit van planontwikkeling te bewaken, vormen tevens verklaringen voor de dominante rol van gemeenten in planvorming. Gezien de zeer sterke afhankelijkheidssituatie is het echter zeer de vraag of gemeenten een dergelijke rol voldoende kunnen waarmaken en of een dergelijke dominante rol van gemeenten in de planvorming wenselijk is. Vanuit het perspectief van de borging van het publiek belang lijkt bij de herontwikkeling van stationslocaties meer zeggenschap voor andere keystakeholders in het planproces aan te bevelen.

Een tweede aanbeveling is dat men in dergelijke projecten niet te bang zou moeten zijn voor een grote inbreng van private partijen in de planvorming. De angst dat intensievere betrokkenheid van private partijen een ondermijning betekent van publieke waarden zoals openheid en transparantie en daarmee voor de legitimiteit van planvorming blijkt, gegeven de bevindingen van deze studie, niet gegrond.

Een derde aanbeveling is meer aandacht te besteden aan de transparantie van planprocessen. Uit de resultaten kwam naar voren dat zelfs voor direct betrokkenen lang niet altijd helder is, welke partij(en), wanneer en waarover beslissen, wat de wensen en voorkeuren van verschillende partijen zijn en welke afwegingen ten grondslag liggen aan gemaakte keuzen. Inzicht in de wijze waarop 
uiteenlopende wensen en voorkeuren van partijen worden vertaald naar beslissingen over het te realiseren resultaat en welke argumentatie daaraan ten grondslag ligt, is echter essentieel voor verantwoording en toerekenbaarheid en daarmee voor de legitimiteit van het planproces. Als dit proces al niet transparant is voor een aantal direct betrokkenen geeft dit aanleiding te veronderstellen dat dit in nog sterkere mate geldt voor stakeholders die niet direct betrokken zijn. Een van de bevindingen van het onderzoek is dat grotere perceptieverschillen en meningsverschillen over de feitelijke resp. wenselijke rolverdeling in planvorming een negatief effect heeft op de transparantie van dat proces (throughputlegitimiteit) en ook zeker geen positief effect heeft op de overige vormen van legitimiteit en de effectiviteit. Dit pleit ervoor om gedurende het proces nadrukkelijk discussie te voeren over welke partij welke rol in het planproces zou moeten hebben. Planvorming van stationslocaties vereist integrale en creatieve oplossingen waardoor niet enkel uit kan worden gegaan van rollen en verhoudingen op basis van bestaande regelgeving. In de cases blijken bij direct betrokkenen vanuit keystakeholders sterk uiteenlopende opvattingen te bestaan over de wenselijke rolverdeling. Discussie hierover gedurende het proces kan mogelijke conflicten in een latere fase voorkomen en kan er ook voor zorgen dat perceptieverschillen minder groot zijn en de transparantie toeneemt.

Naast enkele praktische aanbevelingen worden tevens suggesties voor nader onderzoek gedaan. Een eerste suggestie heeft betrekking op het aantal cases dat is bestudeerd. In deze studie waren dat er drie. De geringe spreiding op de variabelen samen met het beperkte aantal cases maakt het aantonen van verbanden niet eenvoudig. Niettemin komen er uit de analyse wel degelijk aanwijzingen naar voren dat de actorconstellatie in het proces en de procesinrichting van belang is. Omdat onderzoek naar dergelijke effecten zich nog in de verkennende fase van het ontwikkelen van theorie bevindt, is meer onderzoek nodig om de bevindingen betrouwbaarder vast te stellen en te generaliseren. Het bestuderen van een groter aantal cases kan hieraan bijdragen. Het raamwerk dat in deze studie is opgesteld kan daarbij als basis dienen.

Een tweede suggestie is om dergelijk onderzoek in internationaal verband vorm te geven. In deze studie zijn drie Nederlandse stationslocaties bestudeerd. Uit de empirische data bleek dat de kenmerken van de actorconstellatie in de drie bestudeerde planprocessen in hoofdlijn overeen komen. Voorgeschreven regelgeving en beleid blijken van substantiële invloed op de betrokkenheid en inbreng van verschillende actoren in het proces. Dit pleit ervoor te kijken of voor de samenhang tussen de kenmerken van de actorconstellatie en de effectiviteit en legitimiteit van planvorming in andere institutionele contexten, waar bijvoorbeeld de positie van gemeenten in ruimtelijke projecten compleet anders is, andere resultaten naar voren komen.

Een derde suggestie heeft betrekking op het niveau waarop de samenhang tussen de inrichting van het proces (in termen van de kenmerken van de actorconstellatie) en de borging van het publiek belang is bestudeerd. In dit onderzoek is deze samenhang bestudeerd op case-niveau en niet op actorniveau. Gezien de probleemstelling is deze keuze logisch. Maar dat neemt niet weg dat het voor een goed inzicht in samenwerkingsprocessen ook relevant is om inzicht te krijgen in de factoren die het gedrag van individuele deelnemers in het proces beïnvloeden. Daarom is het ook zinvol om in toekomstig onderzoek na te gaan of er een verband bestaat tussen hoe een actor de inbreng van partijen in de planvorming percipieert en hoe een en ander doorwerkt in de oordelen van dezelfde actor over de effectiviteit en de legitimiteit van het proces. 


\section{Summary}

\section{Research background}

This thesis is about safeguarding the public interest in spatial projects. In the literature and in the public debate, the public interest is considered as inherently involving a role for the government. However, the role of government in the spatial domain has changed significantly in recent decades. Developments in society and in the spatial sector have led to the traditional domains of government, market and citizens becoming increasingly interwoven. The view which until recently has predominated - of a government that centrally, and in a top-down way, sets the standards for spatial developments - is no longer applicable. Today, the need for cooperation between governments and other actors in the field in order to find solutions for contemporary spatial issues is increasingly emphasised. Using various names, such as public-private partnerships, interactive planning and stakeholder involvement, the increasingly participatory nature is recognised.

Nowadays, public administration and planning literature pay much attention to the growing interdependencies and the inter-organisational setting in which spatial developments take place. However, little research has been done on the impact of these new arrangements in terms of safeguarding the public interest.

In the wider debate on this subject, it is pointed out that conflicting interests and blurred boundaries can undermine the ability to safeguard the public interest. However, it is rarely clear what exactly the public interest is, and whether or not this interest is safeguarded. This research contributes to filling this knowledge gap. This is achieved through (1) developing a conceptual framework - based on theoretical insights - that can serve to evaluate the public interest in specific spatial projects, and (2) an empirical analysis of the relationship between the design of planning processes and the safeguarding of the public interest. In this second part, a number of redevelopments of station areas in the Netherlands are studied.

\section{Basic concepts}

The main research question is formulated as follows: 'which planning process designs give a high likelihood of successfully safeguarding the public interest in the redevelopment of station areas?' In order to answer this question, a conceptual framework is developed based on a theoretical analysis which is subsequently used in an empirical analysis. This framework describes those factors which are relevant when studying the relationship between the design of the planning process and the safeguarding of the public interest.

The first element in the framework is 'safeguarding the public interest'. To answer the main research question it needs to be clear what the public interest is, and what criteria can be used for evaluating this interest. For this, insights from political philosophy and economic literature are drawn. Based on this study of the literature, we argue that the public interest should be regarded as a relative and dynamic concept. It can only be used in evaluations if these evaluations cover shared values within a certain institutional and situational setting. The criteria used for these values should relate to both the design of the process as well as to the final outcome. It is then argued that - within the Dutch 
institutional and situational setting of station areas - the legitimacy and effectiveness of planning are relevant criteria for evaluating the public interest. A distinction is made between input-, throughputand output- legitimacy. Input legitimacy refers to the manner in which decision-making occurs. From this perspective, planning is legitimate if, and because, decisions are derived from the authentic preferences of a certain community. As such, the process needs to comply with applicable legal principles (legality) and relevant parties need to have sufficient opportunities to express their wishes and preferences (openness). Throughput legitimacy refers to the transparency of processes. By providing insight into how the different stakeholders' preferences are translated into decisions related to the realised output, and the reasoning underlying these decisions, legitimacy can be increased. Finally, referring to output legitimacy, positive judgments on the legitimacy of spatial planning processes are also assisted if the outcome of the process contributes to the effective realisation of the wishes and preferences of stakeholders. The second criterion used is the effectiveness of planning. In this study, the extent to which plans are expected to contribute to relevant dimensions of site spatial quality are used as a measure of effectiveness.

In addition to indicators for evaluating the public interest, the conceptual framework also contains factors used to describe the second element of the research question, 'the design of planning processes'. The design of planning processes is described using characteristics of the constellation of actors on three themes: vision development; control; and resources. 'Vision development' refers to the process through which actors picture the problem, the feasible and desired future situation and the changes needed to get there. 'Control' refers to the opportunities actors have to make decisions within that process. The theme 'resources' refers to the means that actors make available for the development and implementation of plans.

The constellation of actors involved in these three themes can be characterised by the number of actors; the relationships between actors with different interest positions (public-private, centraldecentralised, municipality-other actors); and their degree of ambivalence ( $\Delta$ perception; $\Delta$ opinion). This characterisation was carried out for two distinct phases of the planning process for station areas. The first phase covered the development of a master plan for the area as a whole; the second phase relating to a specific element - the planning for the public transport terminal.

\section{Research method}

The conceptual framework is used as a basis for structuring the empirical data collection and for the data analysis. In the empirical analysis, the case-study method is used. To study the relationship between $\mathrm{X}$ (the constellation of actors in the planning process) and $\mathrm{Y}$ (the legitimacy and effectiveness of the planning process) we have chosen to vary the context in which planning takes place as little as possible. Consequently, we chose to focus the research on the comprehensive redevelopment of large-scale station areas in the Netherlands. These projects are characterised by the redevelopment of an entire area rather than a single object; the (re)development of multiple functions in a mutually coherent way; the involvement of multiple principals and other stakeholders; a long and dynamic planning process; and the need for large-scale financial investments. The comprehensive redevelopment of such areas necessitates arrangements of public and private actors, from different levels and sectors, that are involved in the various functions. These characteristics imply that, besides its effectiveness, also the legitimacy of the planning plays an important role. In this research project, 
three station areas have been extensively studied: Den Haag Nieuw Centraal, Stationskwartier Breda and Spoorzone Delft.

In acquiring data on these cases, we used project documentation and interviews. The factors in the conceptual framework were translated into a questionnaire. The usefulness of the questionnaire was tested in a number of pilot cases. Based on the findings, the protocol for the interviews and the questionnaire were slightly modified. Subsequently, an extensive interview round was carried out for each of the three case studies. In total, 21 interviews were held with project managers of directly involved organisations with a substantial interest in one of the projects and whose permission and/or investment are necessary for the plans to be implemented. More specifically, this means that, for each case study, interviews were held with people from the municipality, the regional authority and/or the province, the Ministry of Housing, Spatial Planning and the Environment, the Ministry of Transport, ProRail, the Dutch Railway Company and one or more private real estate developers. These organisations are viewed as the key stakeholders. The data from the interviews and the project documentation were then analysed for each case separately to gain an understanding of the project as an independent unit of analysis (within-case analysis); and subsequently the findings from the three cases were compared (cross-case analysis).

\section{Within-case analysis}

The within-case analysis starts with a description of the project. For each case, (1) the project history and procedures; (2) the spatial characteristics of the project; (3) the actors involved and their roles; and (4) the project organisation were described. Several sources of information were used in producing these descriptions, including intention-, process- and cooperation- agreements, zoning plans, master plans, management and progress reports and organisational charts.

The second part of the within-case analysis describes the design of the planning process. This was achieved by describing the inputs of the individual key stakeholders and the characteristics of the constellation of actors on each of the three identified themes (vision development, control and resources). These descriptions are based on the perceptions of the project managers from the key stakeholders on the actual situation and on their (normative) views of the desirable situation. This approach is based on the theoretically supported assumption that actors shape their behaviour based on their perceptions and opinions.

The third part of the within-case analysis focuses on the public interest. The criteria used to evaluate the extent to which the public interest is safeguarded were outlined above. This involves an analysis of the legitimacy and effectiveness of the planning process for the master plan, and the legitimacy and effectiveness of the planning process for the renewal of the public transport terminal. Based on the premise that legitimacy concerns the acceptance or support by stakeholders, and that effectiveness can only really be determined once a project is realised, we used the subjective judgments of actors closely involved as a basis for this empirical determination.

\section{Cross-case analysis}

The within-case analysis was followed by a cross-case analysis. The cross-case analysis compares the findings from the individual case analyses. This analysis was carried out in four steps. 
The first step was an analysis of the differences and similarities among the three developments in terms of context and project characteristics. This analysis was necessary because differences in the settings in which planning takes place could be behind differences in the inputs of actors in this process. The second step was an analysis of the differences and similarities in the actor constellations in the planning process. Stakeholder inputs were compared among the cases in terms of the three themes. The third step was an analysis of the differences and similarities in the judgments on the appropriate criteria to be used in assessing the public interest. As a final step, we analysed whether differences in the characteristics of the actor constellations, in terms of the three themes considered, related to differences in the legitimacy and effectiveness of the planning. The 'case-ordered predictoroutcome matrix' was used as a tool in this analysis. For each of the three themes (vision development, control and resources), the values of the dependent (sub-) variable(s) and independent (sub-) variable(s) were entered in columns. This created three matrices. Subsequently, by analysing the values of the independent variable for each column, and the values of the dependent (sub-) variables, we investigated whether certain consistent patterns could be found or whether these differed. Based on this (quasi-) quantitative analysis, a first insight into possible patterns was obtained. If the analysis suggested certain patterns, we then looked back to the level of the individual case to see if there was a logical explanation. Finally, the empirical findings were confronted with expectations based on theory (pattern matching).

\section{Conclusions}

The research has shown that, in all the cases studied, the planning process was effective and legitimate. The differences between the individual cases, in terms of the indicators used, were limited. For the differences that were found, it was analysed whether these could be related to differences in the constellation of actors involved in the planning process. Based on the findings, several conclusions can be drawn about the relationship between the design of the planning process and the extent to which the public interest is safeguarded.

The first conclusion concerns the number of key stakeholders that have a strong input into the planning process and the consequent legitimacy and effectiveness. It is concluded that strong inputs into the planning process by a large number of key stakeholders seem to increase the likelihood of successfully safeguarding the public interest, in terms of legitimate and effective planning, rather than decreasing it. This certainly seems to be the situation when developing master plans for integrated area developments.

The second conclusion concerns the relationship between the inputs of public and private parties in the planning process and the public interest. In the debate on this topic, it is often argued that, with intense cooperation with private parties, government control decreases and boundaries between the public and the private domains become blurred, and that this could diminish accountability, transparency and democratic choice. The complex division of ownership and responsibilities within the current institutional organisation surrounding Dutch stations means that cooperation arrangements between various public and private parties are inevitable if these areas are to be redeveloped. The findings of this research do not suggest that a relatively strong involvement of private parties in the planning process negatively influences its legitimacy. Rules and procedures for democratic decision-making did not prove to be applied any less correctly in the projects in which private parties had rather large inputs into the planning process. This process was also not considered 
to be any less open or transparent and stakeholder support was not diminished. In general, the results give no reason to suppose that legitimacy is higher if institutions representing the public have a more dominant input in planning. However, the fact that a 'dominant' position is not essential does not mean that public institutions should play no role at all. Rather, a relatively strong involvement of private parties compared to public parties does not seem to undermine legitimacy and effectiveness and, with that, weaken the public interest.

The third conclusion concerns the relationships between the purely public actors. In all the cases studied, the municipality appeared to have had a strong input into the planning process, and much greater than that of central government. In all the processes studied, the planning process was also considered as legitimate and effective. Consequently, the variance in the variables was rather limited. Nevertheless, it did seem that a greater say by the municipality, relative to the central government, did not lead to the planning process being perceived as more legitimate. A greater local role also did not seem to have a positive effect on planning effectiveness. A similar picture emerged when the input of the municipality was contrasted with the inputs of other key stakeholders. Given that all the processes studied included a strong involvement by the municipality, and that the legitimacy and effectiveness of the planning process was perceived as reasonable or better, there is no evidence to suggest that a strong role for the municipality automatically has a negative effect. However, it does seems that an overly dominant role for municipalities can negatively affect legitimacy and effectiveness because it can threaten the necessary inputs by other key stakeholders.

The fourth conclusion concerns the relationship between the degree of ambivalence and the effectiveness and legitimacy of planning. In this study, the actor constellations have been described based on the perceptions that the project managers of key stakeholders have of the actual situation. Further, their normative opinions about the desirable situation have been studied. Except for the role of the municipalities, these perceptions and opinions appeared to differ substantially. Based on a comparison of the differences between the cases, in terms of legitimacy and effectiveness, it is concluded that the likelihood of successfully safeguarding the public interest increases if the perceptual differences among the key stakeholders are limited. A similar conclusion was drawn regarding the desirability of stakeholders sharing opinions on the desirable situation.

Although the conceptual framework describes factors which are relevant when evaluating the public interest in spatial redevelopment projects, and some relationships have been found in the empirical analysis with the characteristics of the actor constellation involved in the planning process, the findings of this study only provide an initial indication of a theory on this relationship. In this exploratory stage of theory building, it is not possible to tie the relationships, the explanations and the conditions under which the design of the planning process influences the likelihood of safeguarding the public interest together into a cohesive whole that could be called a theory. Nevertheless, the findings of this research do suggest a direction for further research that could lead to a more robust theory. Some characteristics of the actor constellation do seem to be related to the legitimacy and effectiveness of the planning process.

\section{Recommendations}

Based on the findings, several recommendations have been formulated for the design of planning processes and for further research. 
A first recommendation concerns the role of municipalities. Municipalities are very ambitious in developing plans for their station areas. However, it is not always clear whether these can be actually realised. In order to realise their ambitions in such areas, municipalities are heavily dependent on the central government, the province and/or the regional authority, ProRail, the Dutch Railway Company and various market parties. Nevertheless, in all the cases studied, the municipality did play a fairly dominant role in the planning process. On the one hand, this dominant role is not surprising given that municipalities are primarily responsible for the realisation of urban projects in the context of Dutch spatial policy. On the other hand, such projects are of regional or even national significance, and station redevelopments are usually unique projects for municipalities that have little related experience. Grand ambitions and expectations of financial contributions from the central government, and the desire for harmonisation, coordination and integrity in developing a plan, also explain the dominant role of municipalities. Given their extreme dependence on other stakeholders, it is highly questionable whether municipalities can adequately fulfil such a role and whether such a dominant role for municipalities in the planning process for station areas is desirable. From the perspective of safeguarding the public interest, greater control by other key stakeholders in the planning process for the redevelopment of station areas seems desirable.

A second recommendation is not to be afraid of private parties becoming substantially involved in the planning process of such projects. The fear that the greater involvement of private parties will undermine public values such as openness and transparency, and thus the legitimacy of planning, is, on the basis of the findings of this study, unfounded.

A third recommendation is to pay greater attention to the transparency of planning processes. The research results show that, even for those directly involved, it was not always clear which parties decided what and when, what the wishes and preferences of the various parties were, and what considerations underpinned decisions made. Understanding how different parties' preferences are translated into decisions regarding the result to be achieved, and the reasoning which underlies this, is essential for accountability and thus for the legitimacy of the planning process. If the planning process is not fully transparent to those directly involved, it seems reasonable to suppose that the situation is even less clear to stakeholders that are not directly involved. One of the findings of this research is that greater differences within the perceptions and the opinions of the actual and desirable roles of key stakeholders in the planning process negatively relates to the transparency of that process (throughput legitimacy) and also seems to lack any positive effect on the other bases for legitimacy and on the effectiveness. This would seem to suggest that explicit discussions should continue throughout the process as to which parties should have what roles in the planning process. Planning for station areas requires integrated and creative solutions and, consequently, roles and relationships should not be based solely upon existing regulations. The key stakeholders directly involved in the cases studied appeared to have widely differing views on the desirable roles of the various parties. Discussions on this subject throughout the process could prevent potential conflicts at a later stage and could also reduce perceptual differences and increase transparency.

This research also suggests some directions for further research. A first suggestion concerns the number of cases studied. In this research, only three processes were studied. The limited range of variables, combined with the limited number of cases, makes it difficult to detect clear relationships. Nevertheless, the analysis revealed clear indications that the actor constellation is of some importance 
in the planning process. Since the research on these effects was in the exploratory phase of theory building, more research is needed to establish more reliable findings enabling one to generalise. Studying a larger number of cases would contribute to this process, and the framework that has been developed in this study could serve as a basis.

A second suggestion is to carry out similar research in an international perspective. In our research project, three station areas in the Netherlands were studied. The empirical data show that the characteristics of the actor constellations were very similar in the three planning processes studied. Prescribed regulations and policies appear to substantially determine the involvement and input of various actors in these processes. This suggests that one should study the relationships between the actor constellations and the legitimacy and effectiveness of planning in other institutional contexts where, for instance, the position and role of municipalities is very different, to see whether distinct results emerge.

A third suggestion concerns the level at which the relationship between the design of the planning process, in terms of the characteristics of the actor constellation, and the safeguarding of the public interest has been studied. This study examined this relationship at the case level rather than at the actor level. Given the central problem tackled by this research, this choice was logical but, for a proper understanding of collaborative processes, it is useful to understand the factors that influence the behaviour of individual participants in the process. Therefore, it would be useful in future research to study whether there is a relationship between how an actor perceives the inputs of various other actors in the planning process and that actor's judgments of the legitimacy and effectiveness of the process. 


\section{Appendix 1 geinterviewde personen}

\section{Pilot-interviews}

Aan het begin van het onderzoek zijn vijf pilot-interviews uitgevoerd met professionele experts om inzicht te krijgen in de problematiek die in de praktijk speelt bij de herontwikkeling van stationslocaties. De focus van de interviews was er in het bijzonder gericht op gericht meer inzicht te krijgen in de positie van verschillende organisaties in dergelijke projecten en de moeilijkheden die zich voordoen in hun onderlinge samenwerking.

\begin{tabular}{|l|l|l|l|}
\hline Naam & Organisatie & Professionele expert als & Datum gesprek \\
\hline Dhr. T. Holscher & Gemeente Den Haag & Projectleider OV-terminal DHNC & $20-12-2005$ \\
\hline Dhr. P. Rodenberg & Gemeente Den Haag & Projectleider DHNC vanuit gemeente & $9-1-2006$ \\
\hline Dhr. D. Bax & Ministerie VROM & Coordinator Sleutelprojecten & $16-12-2005$ \\
\hline Dhr. H. Meeldijk & Ministerie V\&W & Projectmanager DG Spoor & $15-12-2005$ \\
\hline Dhr. J. Dijkstra & Gemeente Groningen & Projectleider Europapark Groningen & $11-1-2006$ \\
\hline
\end{tabular}

\section{$\underline{\text { Case-studie interviews }}$}

De hoofdstukken 6, 7 en 8 rapporteren over de uitgevoerde case-studies. Naast documentenanalyse zijn daarvoor interviews met nauw betrokkenen als informatiebron gebruikt. Per project zijn zeven personen geinterviewd. Per case staan hieronder de namen, organisaties, betrokkenheid en datum van het interview beschreven.

Den Haag Nieuw Centraal

\begin{tabular}{|l|l|l|l|}
\hline Naam & Organisatie & Betrokken bij project als & Datum gesprek \\
\hline Dhr. P. Rodenberg & Gemeente Den Haag & Projectleider DHNC vanuit gemeente & 5-6-2007 \\
\hline Dhr. D. Bax & Ministerie VROM & Projectleider/Coord. Sleutelprojecten & $29-5-2007$ \\
\hline Dhr. H. Meeldijk & Ministerie V\&W & Projectmanager vanuit DG Spoor & $30-5-2007$ \\
\hline Dhr. R. Sirks & Stadsgew. Haaglanden & Beleidsmedewerker Openbaar Vervoer & $29-5-2007$ \\
\hline Dhr. I. Hermans & ProRail & Projectmanager infraprojecten & $29-5-2007$ \\
\hline Dhr. P. Akkermans & NS Poort & Projectmanager NS Poort Ontwikkel. & $30-5-2007$ \\
\hline Dhr. M. Praagman & Multi Vastgoed & Adjunct-Directeur Techniek & $4-6-2007$ \\
\hline
\end{tabular}

\section{Stationskwartier Breda}

\begin{tabular}{|l|l|l|l|}
\hline Naam & Organisatie & Betrokken bij project als & Datum gesprek \\
\hline Dhr. B. van Rooijen & Gemeente Breda & Programmamanager Via Breda & 12-6-2007 \\
\hline Dhr. R. van der Bolt & Ministerie VROM & Projectleider vanuit VROM & $4-6-2007$ \\
\hline Dhr. L. Postma & Ministerie V\&W & Projectleider vanuit DG Spoor & 6-6-2007 \\
\hline Dhr. E. Wieme & Provincie N-Brabant & Beleidsmedewerker Openbaar Vervoer & $9-5-2007$ \\
\hline Dhr. T-J. Noomen & ProRail & Projectmanager vanuit ProRail & $1-6-2007$ \\
\hline Dhr. S. Sjerps & NS Poort & Ontwikkelaar vanuit NS Poort Ontw. & $21-5-2007$ \\
\hline Dhr. P.van Heteren & HEJA & Senior Ontwikkelaar (marginale rol) & $10-7-2007$ \\
\hline
\end{tabular}




\section{Spoorzone Delft}

\begin{tabular}{|l|l|l|l|}
\hline Naam & Organisatie & Betrokken bij project als & Datum gesprek \\
\hline Dhr. J-G. van der Post & Gemeente Delft/OBS & Projectleider en directiesecretaris & 1-6-2007 \\
\hline Dhr. M. Leuvenink & Ministerie VROM & Projectleider vanuit VROM & $14-6-2007$ \\
\hline Dhr. L. Postma & Ministerie V\&W & Projectleider vanuit DG Spoor & $6-6-2007$ \\
\hline Dhr. H. Kleij & Provincie Z-Holland & Programmadirecteur prioritaire project. & 23-6-2007 \\
\hline Dhr. R. Hoeboer & ProRail & Projectmanager vanuit ProRail & $12-6-2007$ \\
\hline Dhr. R. Ates & NS Poort & Ontwikkelaar vanuit NS Poort Ontw & $1-6-2007$ \\
\hline Dhr. W. de Wijs & Ballast Nedam & Ontwikkelaar vanuit Ballast Nedam & 4-6-2007 \\
\hline
\end{tabular}




\section{Appendix 2 Interviewprotocol}

\section{Doel en achtergrond van de vragenlijst}

Deze vragenlijst maakt onderdeel uit van een promotieonderzoek aan de Universiteit Twente, afdeling Bouw/Infra. Het onderzoek bestudeert de relatie tussen de inrichting van het planproces en de borging van het publiek belang. Voor het praktijkgedeelte van het onderzoek, de evaluatie van projecten, wordt samengewerkt met de PPSafdelingen van het Ministerie van Verkeer en Waterstaat en het Ministerie van VROM.

\section{Projecten}

De empirische analyse richt zich op projecten die (1) de integrale (her)ontwikkeling van infrastructuur, vastgoed en openbare ruimte in en rondom een binnenstedelijk stationslocatie betreffen (2) in de Nederlandse context (3) waarvan het proces bevindt zich (deels) nog in de planvormingfase bevindt en (4) data toegankelijk is.

\section{Informanten}

De actoren die betrokken kunnen zijn bij de aanpak van stationslocaties kunnen worden ingedeeld in vier groepen: overheden, spoorwegpartijen, eigenaren/ontwikkelaars en belangengroeperingen. Al deze partijen zijn stakeholders in het project. De partijen die het project concreet aanpakken en investeringen kunnen doen behoren tot de eerste drie categorieën. Om tot implementatie van plannen te komen zijn minimaal toestemming en/of investeringen van deze partijen noodzakelijk. Deze partijen worden in deze studie keystakeholders genoemd. Interviews worden afgenomen met informanten vanuit deze organisaties. De informanten zijn de meest direct betrokken personen op projectniveau. Veelal gaat het om projectleiders. Zij worden geacht te spreken vanuit hun functie binnen de organisatie waarin zij werkzaam zijn.

\section{Resultaten}

De resultaten van de vragenlijsten worden verwerkt en worden ter controle op feitelijke onjuistheden voorgelegd aan informanten. Informanten kunnen indien gewenst t.z.t. worden geïnformeerd over de resultaten van het onderzoek.

\section{Projectnaam + datum}

Project:

Datum interview:

\section{Respondent}

Naam:

Organisatie:

Organisatieonderdeel:

Functie:

Betrokken bij project als:

Telefoon:

E-mail:

\section{Onderdelen}

De vragenlijst bestaat uit drie delen. In deel A wordt ingegaan op de inhoud van het project. Deel B gaat in op het publieke belang en deel $\mathrm{C}$ richt zich op de inbreng van keystakeholders in het proces. De antwoordmogelijkheden zijn voor sommige vragen open en voor sommige vragen gesloten. De verwachting is dat het geheel ruim anderhalf uur in beslag zal nemen. 


\section{DEEL A: INHOUD V/H PROJECT (5 VRAGEN)}

De vragen in dit onderdeel richten zich op de inhoud van....project X....In deze vragen wordt onder 'het project' de (her)ontwikkeling van de onderdelen in het gebied zoals beschreven in het (ontwerp-) Masterplan verstaan. Indien gesproken wordt over het 'deel-/uitvoeringsplan wordt daaronder verstaan de herontwikkeling van het projectonderdeel OV-terminal. Dit onderscheid zal in de gehele vragenlijst gehanteerd worden. Ter verduidelijking staat bij de vragen soms een korte toelichting.

1. Wat was volgens u de aanleiding voor het project?

2. Welke partij was volgens u initiatiefnemer voor het project?

3. Welke verschillende deelprojecten zijn er volgens u te onderkennen?

4. Wanneer worden de verschillende deelprojecten volgens u gerealiseerd?

5. Zou u in de tabel kunnen aanvinken welke functies er in het project worden (her)ontwikkeld?

\begin{tabular}{|c|c|c|c|c|}
\hline Hoofdcategorie & \multicolumn{2}{|l|}{ Subcategorie } & $\sqrt{ }$ & Omvang (projectdocumentatie) \\
\hline \multirow{7}{*}{ Vastgoed } & \multicolumn{2}{|l|}{ - woningen } & & \\
\hline & \multicolumn{2}{|l|}{ - bedrijfsruimte } & & \\
\hline & \multicolumn{2}{|l|}{ - winkel en leisure } & & \\
\hline & \multicolumn{2}{|l|}{ - hotel } & & \\
\hline & \multicolumn{2}{|l|}{ - scholen } & & \\
\hline & \multicolumn{2}{|l|}{ - ziekenhuis } & & \\
\hline & \multicolumn{2}{|c|}{ - overig nl. ............ } & & \\
\hline \multirow{9}{*}{ Infrastructuur } & \multicolumn{2}{|l|}{ - railinfrastructuur } & & \multirow{9}{*}{ Opmerkingen: } \\
\hline & \multirow{3}{*}{ - weginfrastructuur } & landelijk & & \\
\hline & & regionaal & & \\
\hline & & lokaal & & \\
\hline & \multicolumn{2}{|l|}{ - waterinfrastructuur } & & \\
\hline & \multicolumn{2}{|l|}{ - stationshal } & & \\
\hline & \multicolumn{2}{|l|}{ - perrons } & & \\
\hline & \multicolumn{2}{|c|}{ - overig nl............. } & & \\
\hline & \multicolumn{2}{|c|}{$\begin{array}{l}\text { - ict-voorzieningen/faciliteiten } \\
\text { - energievoorzieningen } \\
\text { - water (drinkwater/riolering) }\end{array}$} & & \\
\hline \multirow{6}{*}{ Openbare ruimte } & \multicolumn{2}{|l|}{ - parkeren } & & \multirow{6}{*}{ Opmerkingen: } \\
\hline & \multicolumn{2}{|l|}{ - pleinen } & & \\
\hline & \multicolumn{2}{|l|}{ - groenvoorziening } & & \\
\hline & \multicolumn{2}{|l|}{ - water } & & \\
\hline & \multicolumn{2}{|l|}{ - cultuur } & & \\
\hline & \multicolumn{2}{|l|}{ - overig nl. } & & \\
\hline
\end{tabular}

Tabel 1: projectonderdelen

\section{ONDERDEEL B/C - INLEIDING}

In de studie waarvoor deze vragenlijst is opgesteld, staat de wijze waarop de planvorming is verlopen centraal. In de planvorming bij stationslocaties is een onderscheid gemaakt naar:

(1) het planproces gericht op het ontwikkelen van een Masterplan op niveau van het gehele plangebied

(2) het planproces gericht op het ontwikkelen van een (geografisch) deelplan voor de OV-terminal

Voor (1) wordt als startpunt in de analyse in dit project ...................genomen. Eindpunt vormt de vaststelling en/of goedkeuring van het Masterplan.

Voor (2) wordt als startpunt de vaststelling van het Masterplan genomen en als eindpunt het vastgestelde ontwerp (schets/voorlopig/definitief) voor de aanpak van de OV-terminal.

In de volgende twee onderdelen (B en C) zullen de vragen soms gericht zijn op traject (1) en soms op traject (2). Dit zal voorafgaand aan de vragen expliciet worden vermeld. 


\section{DEEL B: PUBLIEK BELANG (30 VRAGEN)}

\section{B1: THROUGPUTLEGITIMITEIT}

Het gaat hier om de transparantie van het proces. Was het verloop van de processen, de afwegingen die daarin plaats vinden, de prioriteiten die worden gesteld bij die afwegingen en de argumenten die worden gebruikt, helder.

6a. Was in het proces van ontwikkelen van het Masterplan voor u voldoende helder wie besliste? zeer helder gemiddeld zeer onduidelijk weet niet/geen mening

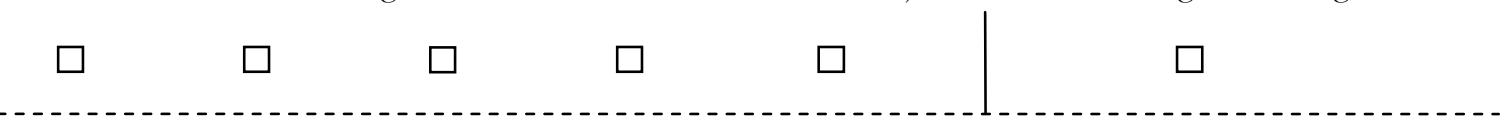

6b. Was in het proces van de totstandkoming van het Masterplan voor u voldoende helder waarover werd besliste?

zeer helder gemiddeld zeer onduidelijk weet niet/geen mening

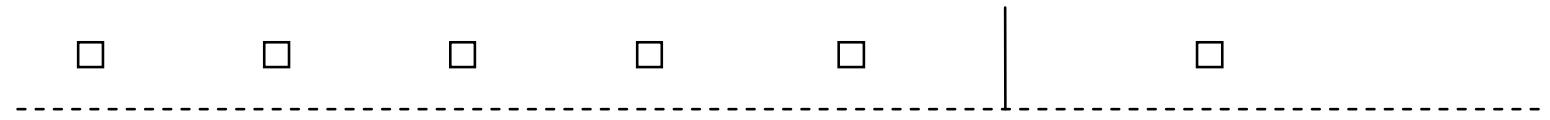

6c. Was in het proces van de totstandkoming van het Masterplan voor u voldoende helder wanneer werd beslist?

zeer helder gemiddeld zeer onduidelijk weet niet/geen mening

7a. Was voor $\mathrm{u}$ in het proces van de totstandkoming van het Masterplan voldoende helder wat de inhoudelijke wensen/voorkeuren van de verschillende partijen waren?

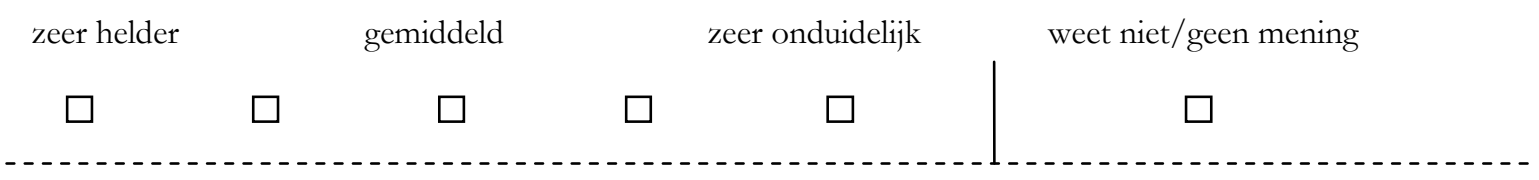

7b. Was voor $\mathrm{u}$ in het proces van de totstandkoming van het Masterplan voldoende helder welke van die inhoudelijke wensen/voorkeuren van partijen werden verwerkt c.q. gehonoreerd in het uiteindelijke Masterplan en waarom?
zeer helder
gemiddeld
zeer onduidelijk
weet niet/geen mening

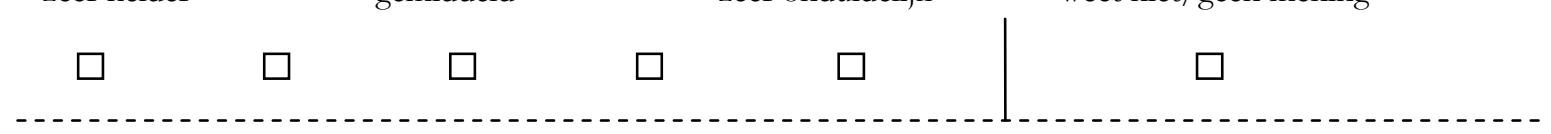

8a. Was voor $\mathrm{u}$ in het proces van de totstandkoming van het deelplan OV voldoende helder wie besliste?

zeer helder gemiddeld zeer onduidelijk weet niet/geen mening 
8b.Was voor $\mathrm{u}$ in het proces van de totstandkoming van het deelplan OV voldoende helder waarover werd beslist?

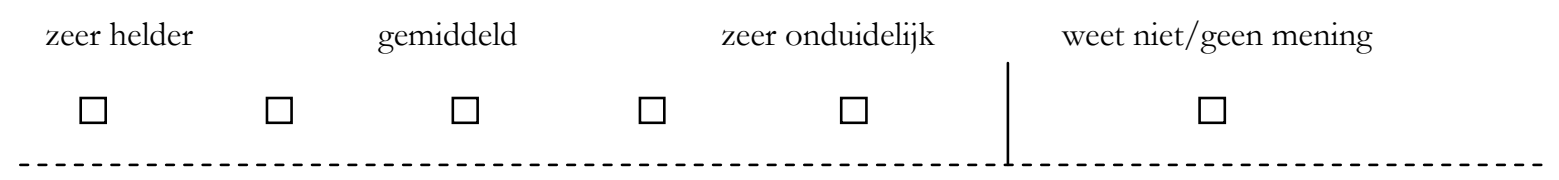

8c.Was voor $\mathrm{u}$ in het proces van de totstandkoming van het deelplan OV voldoende helder wanneer werd beslist?

zeer helder gemiddeld zeer onduidelijk weet niet/geen mening

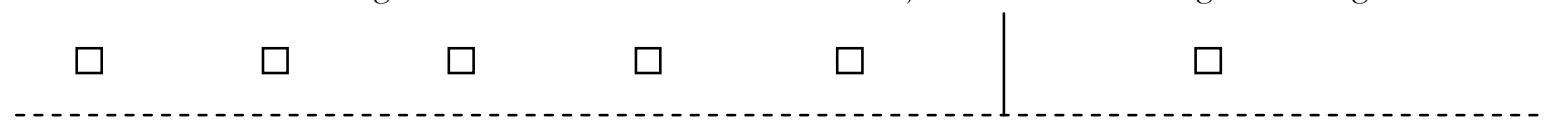

9a.Was voor $\mathrm{u}$ in het proces van de totstandkoming van het deelplan OV voldoende helder wat de inhoudelijke wensen/voorkeuren (of inbreng) van de verschillende partijen waren?

zeer helder gemiddeld zeer onduidelijk weet niet/geen mening

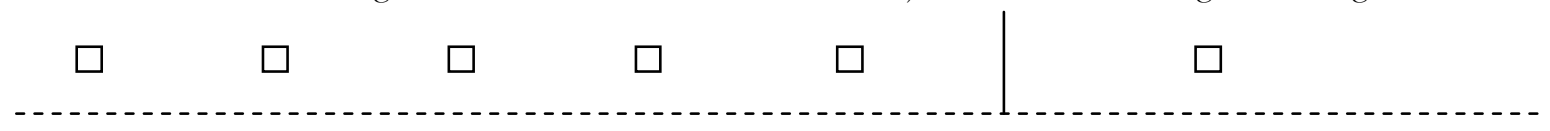

9b.Was voor $\mathrm{u}$ in het proces van de totstandkoming van het deelplan OV voldoende helder welke van de inhoudelijke wensen/voorkeuren (of inbreng) van de verschillende partijen werden verwerkt c.q. gehonoreerd in het uiteindelijke deel-/uitvoeringsplan OV en waarom?

zeer helder gemiddeld zeer onduidelijk weet niet/geen mening

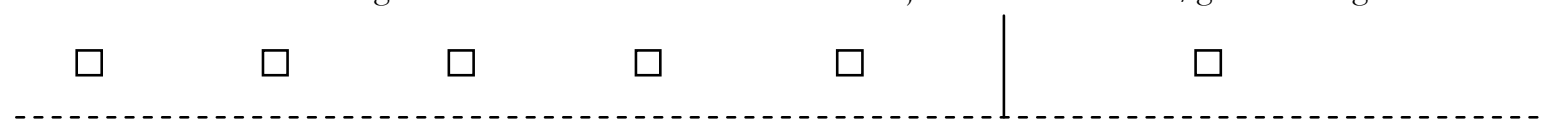

\section{B2: INPUTLEGITIMITEIT}

Het gaat hier om legaliteit en openheid van het proces. |ijn democratische procedures van besluitvorming op correcte wijze doorlopen en in welke mate kunnen actoren hun visie inbrengen of participeren in het proces. Worden ze slechts geïnformeerd of is het zelfs mogelijk actief te participeren in het proces van planvorming. Drie trappen kunnen bij het laatste worden onderscheiden (1) toegankelijkheid; (2) beinvloedingsmogelijkheden; (3) gebruik beinvloedingsmogelijkheden

10. Hebben in uw ogen alle relevante partijen toegang gehad tot het planproces van de totstandkoming van het Masterplan?

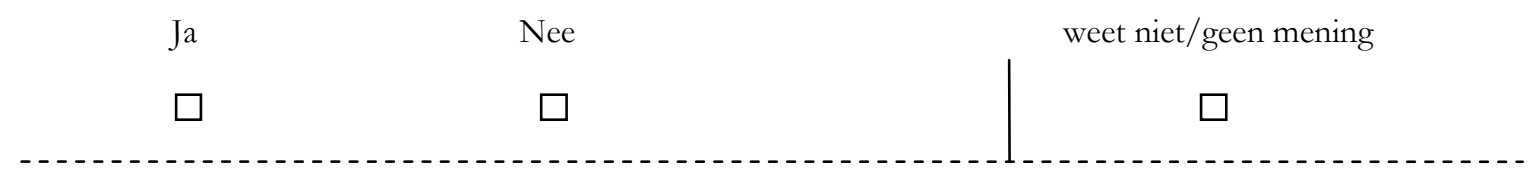

In geval van "Nee", welke partijen in uw ogen niet?

In geval van "Ja", hebben er in uw ogen daarnaast ook niet relevante partijen aan tafel gezeten? 
11.Heeft in uw ogen uw organisatie voldoende mogelijkheden gehad om het proces van de totstandkoming van het Masterplan te beïnvloeden?
ruim voldoende
gemiddeld
ruim onvoldoende
weet niet/geen mening

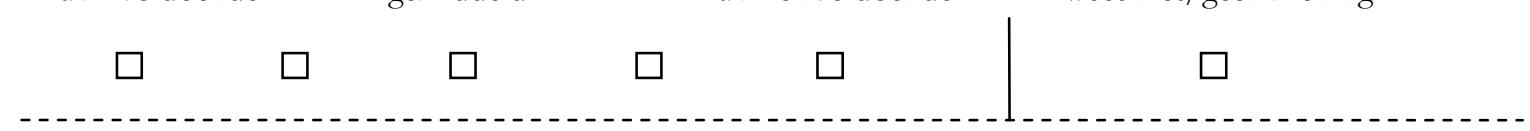

12. Hebben in uw ogen andere partijen voldoende mogelijkheden gehad om het proces van de totstandkoming van het Masterplan te beïnvloeden?
ruim voldoende
gemiddeld
ruim onvoldoende
weet niet/geen mening

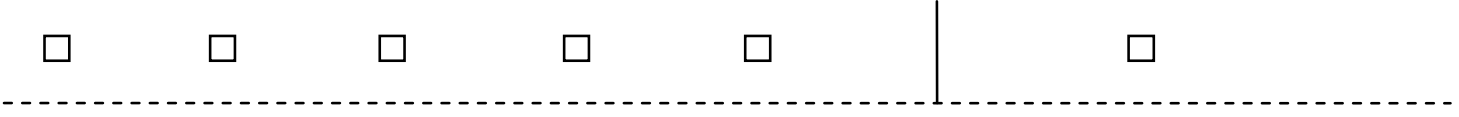

In geval van (ruim) onvoldoende, om welke partijen gaat het dan?

13. In welke mate is door uw organisatie in het planproces van de totstandkoming van het Masterplan gebruik gemaakt van de mogelijkheden om het te beïnvloeden?

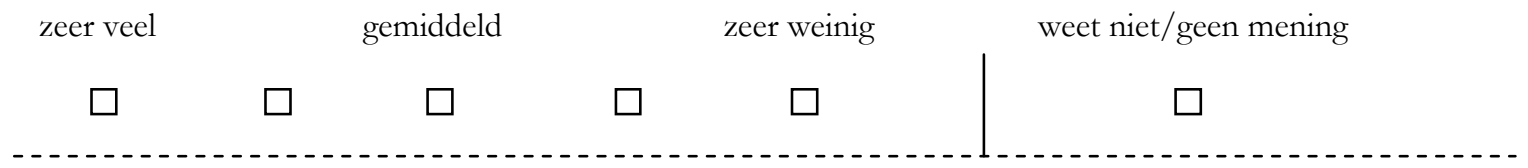

14.Zou u de volgende partijen willen rangschikken naar de mate waarin ze Meest iproces van de totstandkoming van het Masterplan gebruik hebben gemaakt van hun moguщnмиими om het te beïnvloeden?

Gemeente
Regio
Provincie
Ministerie V\&W
Ministerie VROM
Prorail
NS
Marktpartijen/ontwikkelaars
Belangengroepering(en) (naam)
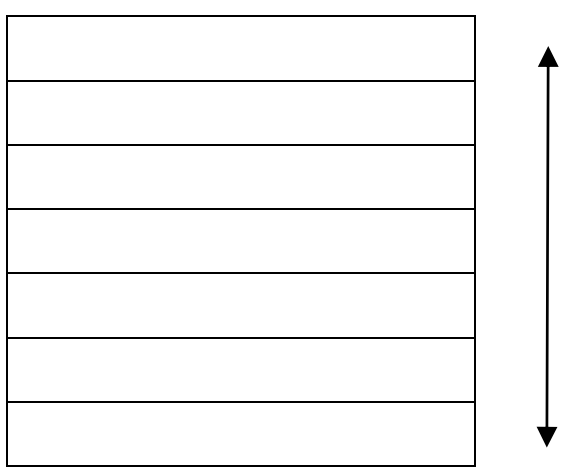

Minst

15. Hebben in uw ogen alle relevante partijen toegang gehad tot het planproces van de totstandkoming van het Deelplan OV?

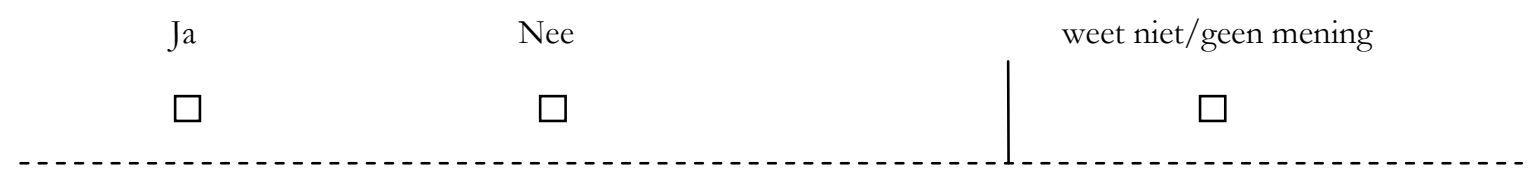

In geval van "Nee", welke partijen in uw ogen niet?

In geval van "Ja", hebben er in uw ogen daarnaast ook niet relevante partijen aan tafel gezeten? 
16. Heeft in uw ogen uw organisatie voldoende mogelijkheden gehad om het proces van de totstandkoming van het Deelplan OV te beïnvloeden?

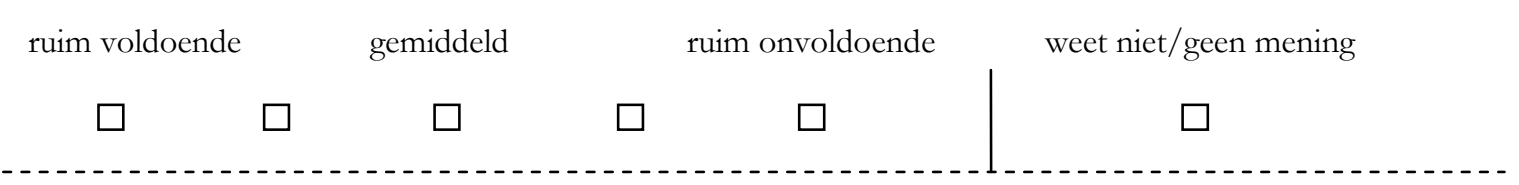

17. Hebben in uw ogen andere partijen voldoende mogelijkheden gehad om het proces van de totstandkoming van het Deelplan OV te beïnvloeden?

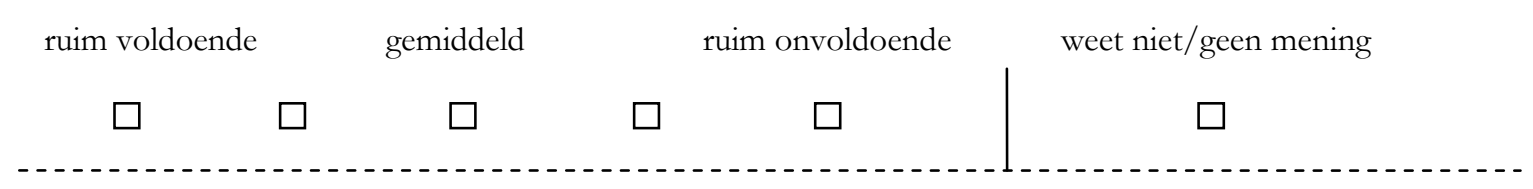

In geval van (ruim) onvoldoende, om welke partijen gaat het dan?

18. In welke mate is door uw organisatie in het planproces van de totstandkoming van het Deelplan

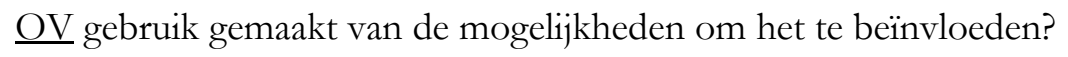

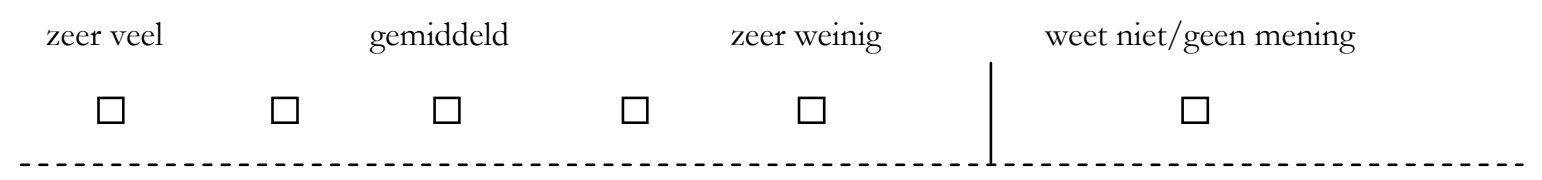

19. Zou u de volgende partijen willen rangschikken naar de mate waarin ze_in het planproces van de totstandkoming van het Deelplan OV gebruik hebben gemaakt van hun mogelijkheden om het te beïnvloeden?

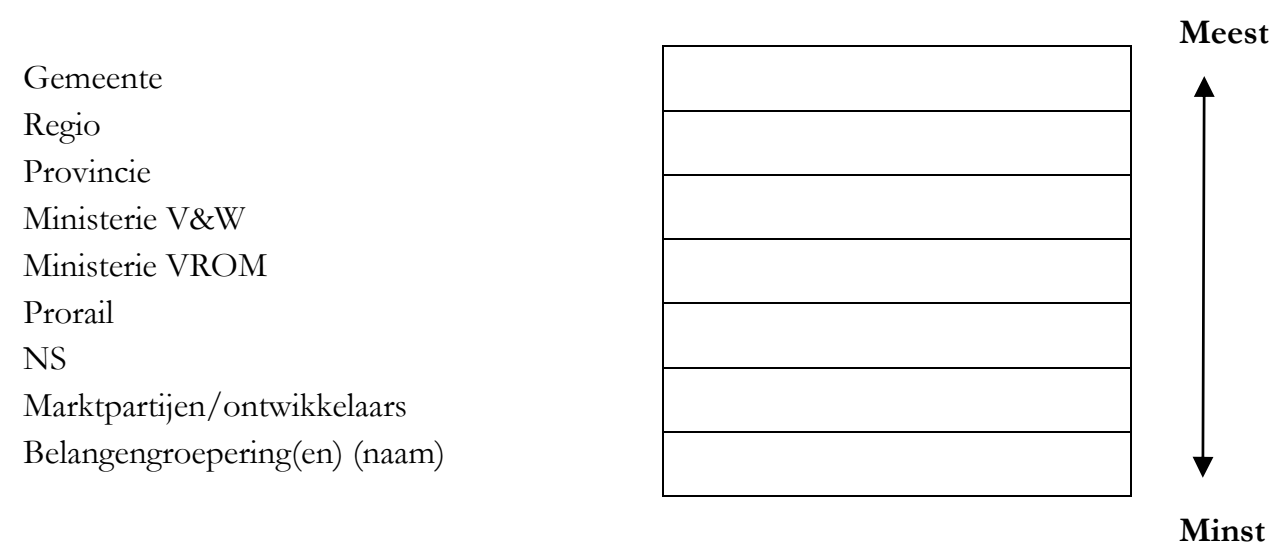

20. Wat is in algemene zin uw oordeel over de openheid van het planproces?

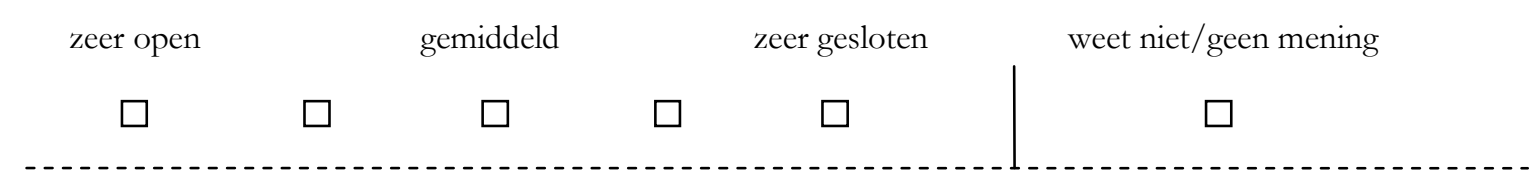

Opmerkingen: 
21. Bij ruimtelijke (her)ontwikkelingen gelden diverse regels en procedures om te komen tot democratische besluitvorming. Zijn deze volgens $u$ in dit project op een correcte wijze gevolgd c.q. doorlopen?

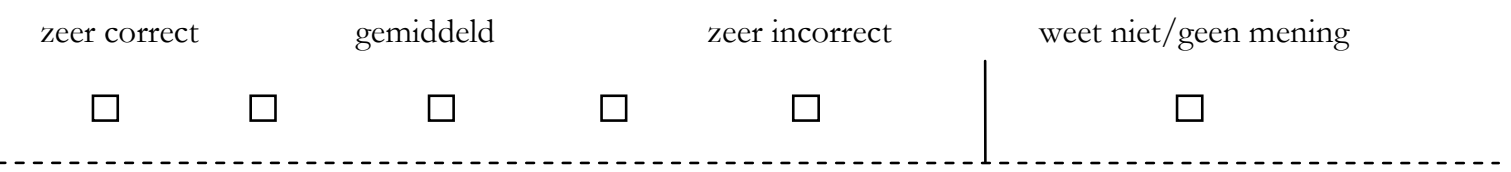

In geval van (zeer) incorrect, kunt $\mathrm{u}$ dit kort toelichten?

\section{B3: OUTPUTLEGITIMITEIT}

Het gaat hier om de steun van stakeholders voor de resultaten (prestaties) van het planproces.

23. In hoeverre is er naar uw mening in het Masterplan rekening gehouden met uw wensen/doelstellingen van uw organisatie?

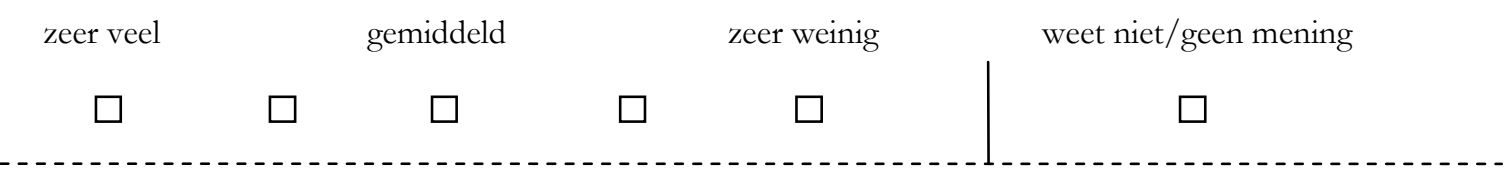

24. In welke mate heeft uw organisatie zich gecommitteerd aan het Masterplan?

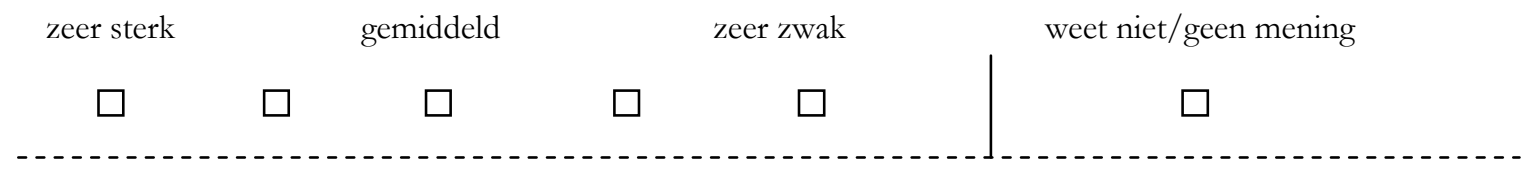

In geval van (zeer) sterk, uit welke verplichtingen blijkt dat?

25. Stelling: het Masterplan is een aanvaardbaar compromis van de deelnemers aan het planproces/bijeenkomsten?

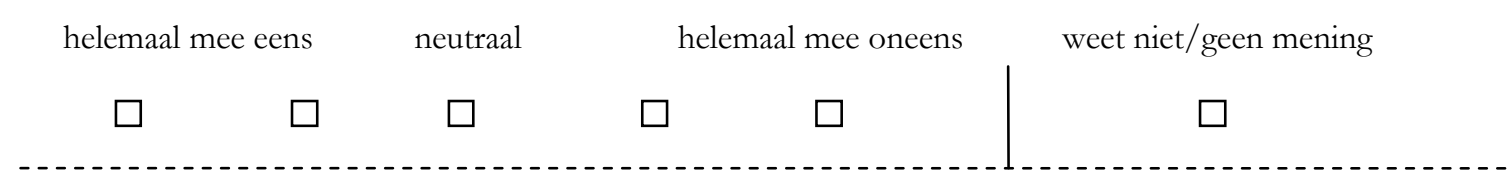

26.In hoeverre is in het deelplan OV rekening gehouden met uw wensen/doelstellingen van uw organisatie?

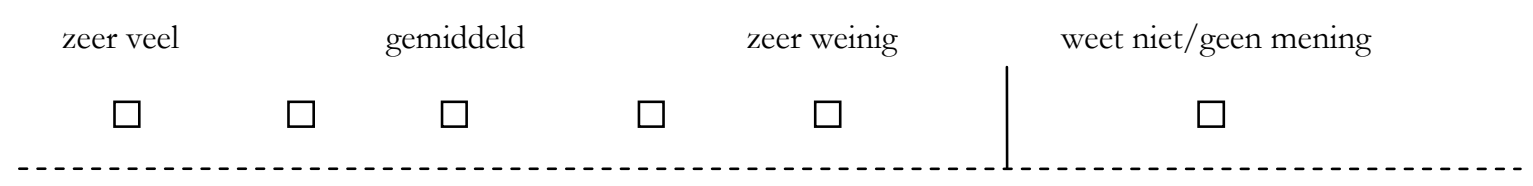

27. In hoeverre heeft uw organisatie zich gecommitteerd aan het deelplan OV?

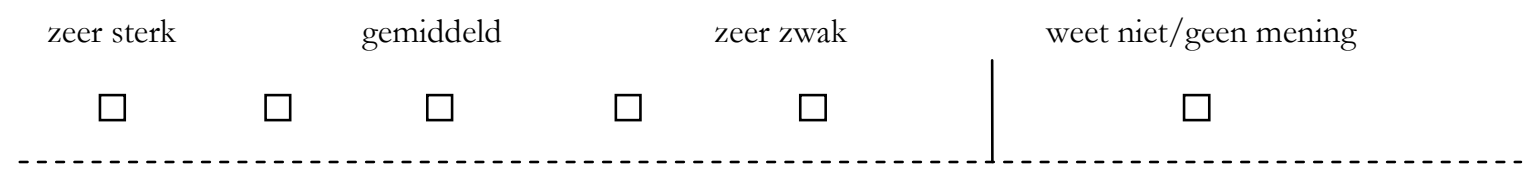

In geval van (zeer) sterk, uit welke verplichtingen blijkt dat? 
28. Stelling: het deelplan OV is een aanvaardbaar compromis van de deelnemers aan het planproces/bijeenkomsten?

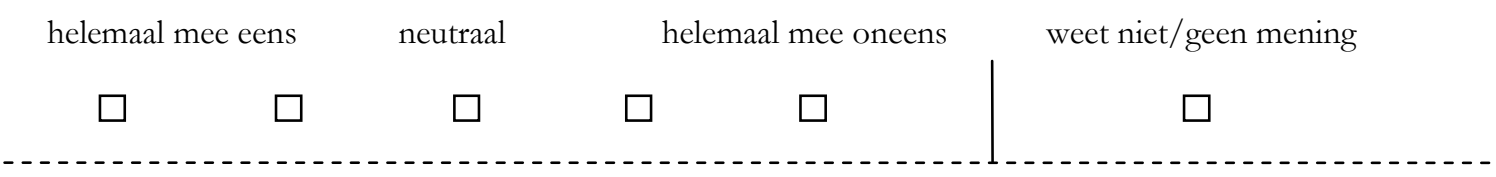

Inleiding op vraag 29 en 30:

We hebben het net gehad over transparantie, de openheid en de legaliteit van het proces van totstandkoming van het Masterplan en van het Deel-/uitvoeringsplan. Tevens hebben we gesproken over de aansluiting tussen de inhoud van het plan en de eisen, wensen en het commitment van uw organisatie. Alles overziend zou ik u willen vragen.....

29. Met welk rapportcijfer (1-10) zou u het uiteindelijke Masterplan willen beoordelen?

30. Met welk rapportcijfer (1-10) zou u het uiteindelijke Deelplan OV willen beoordelen?

\section{B4: EFFECTIVITEIT}

De mate waarin de plannen naar verwachting een bijdrage zullen leveren aan de ruimtelijke kwaliteit in het plangebied wordt in dit onderzoek als maatstaf voor effectiviteit gehanteerd. Omdat verschillende stakeholders, gegeven de verschillende belangen die zij representeren, de nadruk leggen op verschillende aspecten van ruimtelijke kwaliteit is dit begrip geoperationaliseerd in negen dimensies (geef een korte toelichting op de negen dimensies).

\begin{tabular}{|l|l|l|}
\hline 1. Functionaliteit & 2. Aantrekkelijkheid & 3. Flexibiliteit \\
\hline 4. Beschikbaarheid & 5. Vitaliteit & 6. Stabiliteit \\
\hline 7. Leefbaarheid & 8. Diversiteit & 9. Duurzaamheid \\
\hline
\end{tabular}

31. Als u kijkt naar de tabel, wat zijn dan volgens u de drie belangrijkste aspecten in dit project? Noteer nummers:

32a. In hoeverre verwacht $u$ dat het Masterplan een bijdrage levert aan de realisatie van...eerste genoemde aspect..?

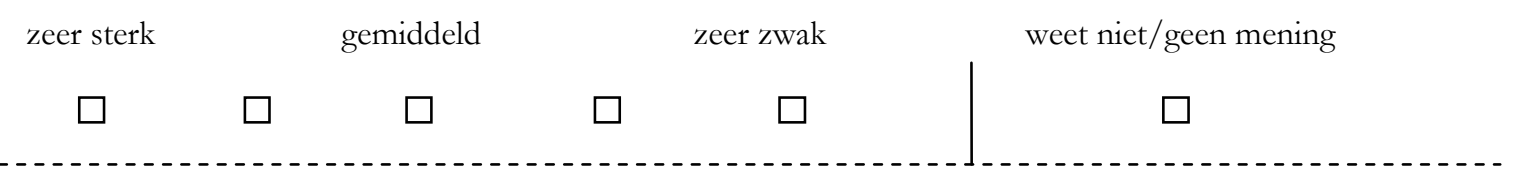

32b. In hoeverre verwacht $\mathrm{u}$ dat het Masterplan een bijdrage levert aan de realisatie van...tweede genoemde aspect..?

$\begin{array}{llll}\text { zeer sterk geer zwak weet niet/geen mening } & \text { gemiddeld }\end{array}$

32c. In hoeverre verwacht $\mathrm{u}$ dat het Masterplan een bijdrage levert aan de realisatie van...derde genoemde aspect..?

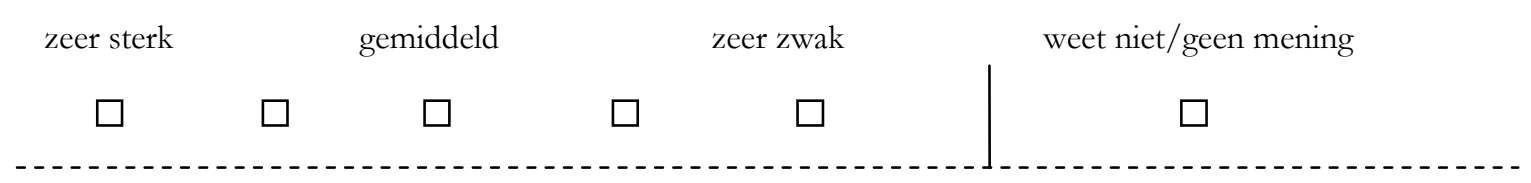


33. Wat is uw mening over het ambitieniveau van het Masterplan?

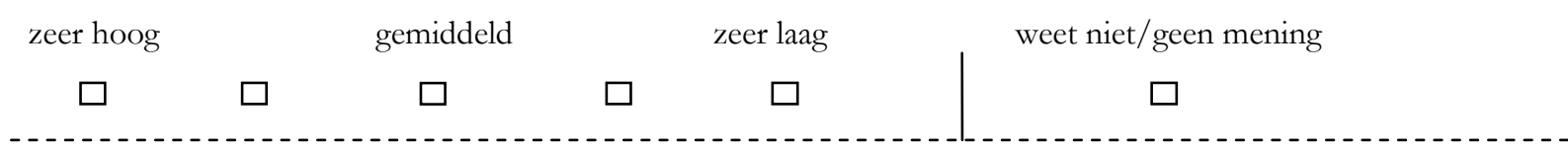

34. Wat is uw mening over de helderbeid van het Masterplan?

zeer helder gemiddeld zeer onhelder weet niet/geen mening

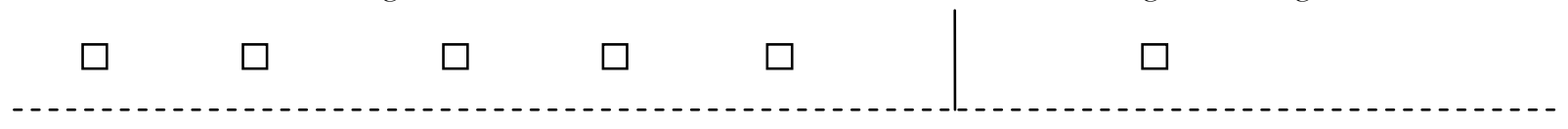

35. Wat is uw mening over de meetbaarbeid/evalueerbaarbeid van het Masterplan?

zeer goed gemiddeld zeer slecht weet niet/geen mening

\begin{tabular}{|c|c|c|c|c|c|}
\hline$\square$ & $\square$ & $\square$ & $\square$ & $\square$ & $\square$ \\
\hline
\end{tabular}

36a. In hoeverre verwacht $u$ dat het Deelplan OV een bijdrage levert aan de realisatie van...eerste genoemde aspect...?

zeer sterk $\quad$ gemiddeld zwak weet niet/geen mening

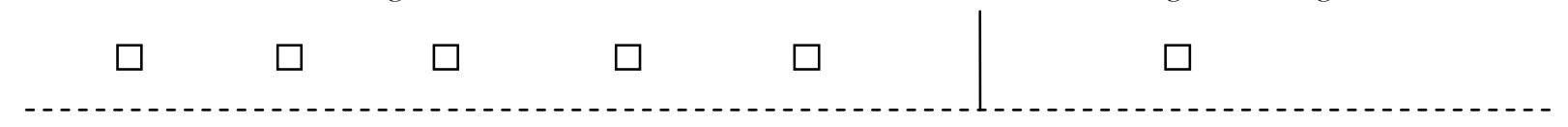

36b. In hoeverre verwacht $u$ dat het Deelplan OV een bijdrage levert aan de realisatie van.. tweede genoemde aspect...?

zeer sterk $\quad$ gemiddeld zwak weet niet/geen mening

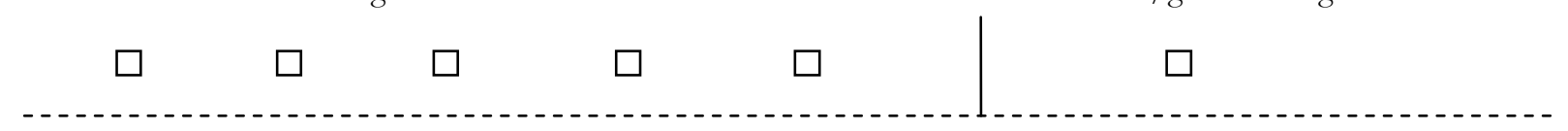

36c. In hoeverre verwacht $u$ dat het Deelplan OV een bijdrage levert aan de realisatie van... derde genoemde aspect...?

$\begin{array}{llll}\text { zeer sterk } & \text { gemiddeld } & \text { zeer zwak } & \text { weet niet/geen mening }\end{array}$

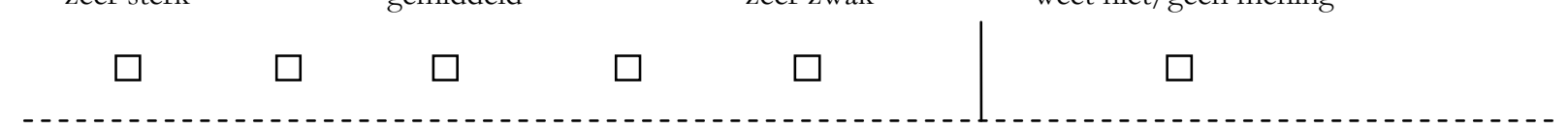

37. Wat is uw mening over het ambitieniveau van het Deelplan OV?

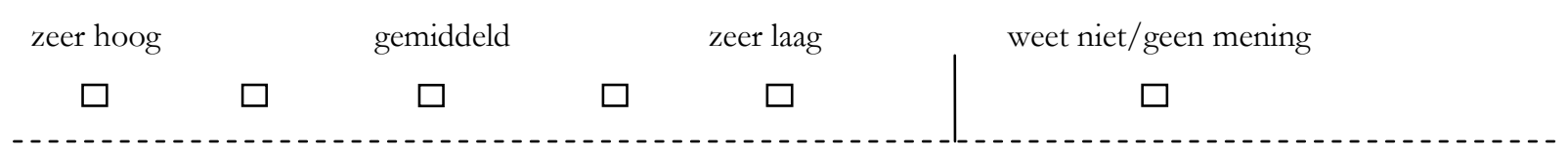

38. Wat is uw mening over de helderbeid van het Deelplan OV?
zeer helder
gemiddeld
zeer onhelder
weet niet/geen mening

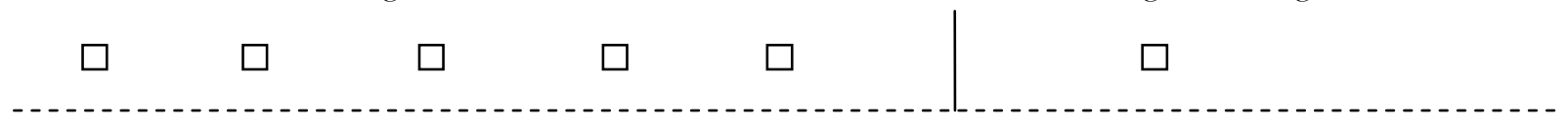


39. Wat is uw mening over de meetbaarheid/evalueerbaarheid van het Deelplan OV?

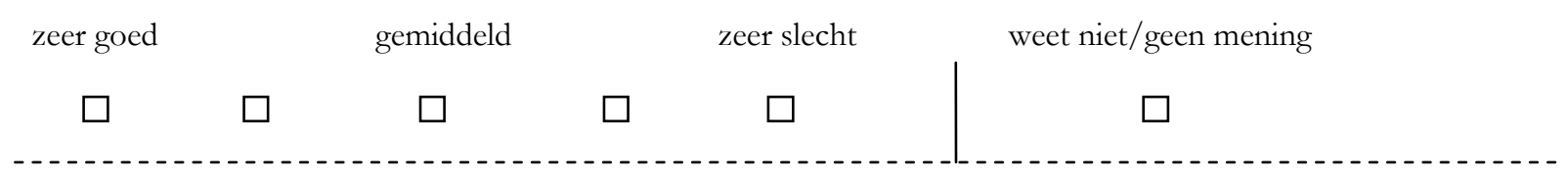

40. Als u kijkt naar de tabel, wat is naar uw mening dan het belangrijkste aspect in dit project voor de onderstaande partijen?

\begin{tabular}{|l|l|}
\hline Keystakeholder & Nr. \\
\hline Gemeente & \\
\hline Regio & \\
\hline Provincie & \\
\hline Min. V\&W & \\
\hline Min. VROM & \\
\hline NS & \\
\hline ProRail & \\
\hline Ontwikkelaars & \\
\hline
\end{tabular}

Opmerkingen:

\section{DEEL C: HET PROCES (29 VRAGEN)}

\section{ALGEMEEN}

41. Wat zijn de doelstellingen van uw organisatie ten aanzien van het project?

42. Welke rol speelt uw organisatie in het project?

43. Met welke partijen werkt uw organisatie samen in het project?

44. Hoe is de organisatie van deze samenwerking vormgegeven?

45. Wie vertegenwoordigt uw organisatie?

46. Welke partijen nemen nog meer deel in de samenwerkingsorganisatie en welke rol vervullen zij?

\section{INLEIDING VERVOLG}

Hiervoor hebben we aandacht besteed aan de rol van uw organisatie en de samenwerkingsorganisatie. Stationslocaties zijn projecten die veelal bestaan uit meerdere deelprojecten/onderdelen en waarin meerdere functies worden ontwikkeld. Dit noodzaakt dus tot afstemming tussen de diverse publieke en private stakeholders. Hiervoor heb ik al een aantal vragen gesteld over de procesinrichting die beschrijvend van aard waren. Ik zou nu graag met $u$ praten over hoe het eventueel anders zou kunnen of wat volgens u het optimale 'plaatje' is. Daarbij wil ik graag ingaan op een aantal thema's in het proces, te weten visievorming, zeggenschap van partijen en de inbreng van middelen. Ook hier onderscheid ik twee trajecten. Het planproces gericht op het ontwikkelen van het masterplan en het (vervolg)proces gericht op het ontwikkeling van het deelplan OV.

\section{C1: HET PROCES VAN VISIEVORMING}

Visievorming is een belangrijk onderdeel in planvorming. Bij stationslocaties zijn diverse publieke en private partijen betrokken. In de onderstaande tabel zijn de keystakeholders in deze projecten weergegeven. Over het proces van visievorming en de inbreng van deze partijen daarin zou ik u een aantal vragen willen voorleggen. Enkele daarvan 
hebben betrekking op wat naar uw mening wenselijk zou zijn en een aantal vragen zijn gericht op uw beeld (perceptie) van de feitelijke situatie in dit project.

- Vraag 47,48: één of meerdere keystakeholders aankruisen

- Vraag 49-52: per keystakeholder een score toekennen van 1 (zeer klein) tot 5 (zeer groot) aan de inbreng van deze partij. Indien een partij niet betrokken is geweest in het traject dan hoeft geen score te worden toegekend.

\begin{tabular}{|c|c|c|c|c|c|c|c|c|}
\hline VISIEVORMING & Gem & Regio & Prov & $\mathrm{V} \& \mathrm{~W}$ & VROM & NS & Prorail & Ontw \\
\hline $\begin{array}{l}\text { 47. Wie zou naar uw mening als eerste een visie } \\
\text { moeten formuleren voor het project? } \\
\text { (aankruisen) }\end{array}$ & & & & & & & & \\
\hline $\begin{array}{l}\text { 48. Is er in het project een startvisie geweest? En zo } \\
\text { ja, wie heeft die geformuleerd? } \\
\text { (aankruisen) }\end{array}$ & & & & & & & & \\
\hline $\begin{array}{l}\text { 49. Hoe groot zou naar uw mening de inbreng } \\
\text { moeten zijn van genoemde keystakeholders bij het } \\
\text { ontwikkelen van een Masterplan? (score } 1-5 \text { ) }\end{array}$ & & & & & & & & \\
\hline $\begin{array}{l}\text { 50. Hoe groot is in het project de inbreng van } \\
\text { genoemde keystakeholders bij het ontwikkelen van } \\
\text { een Masterplan geweest? (score 1-5) }\end{array}$ & & & & & & & & \\
\hline $\begin{array}{l}\text { 51. Hoe groot zou naar uw mening de inbreng } \\
\text { moeten zijn van genoemde keystakeholders bij het } \\
\text { ontwikkelen van een deelplan OV? (score 1-5) }\end{array}$ & & & & & & & & \\
\hline $\begin{array}{l}\text { 52. Hoe groot is in het project de inbreng van } \\
\text { genoemde keystakeholders bij het ontwikkelen van } \\
\text { het deelplan OV geweest? (score 1-5) }\end{array}$ & & & & & & & & \\
\hline
\end{tabular}

\section{C2: ZEGGENSCHAPSVERDELING}

Zeggenschap heeft net als visievorming betrekking op verschillende fasen van het herontwikkelingsproces. In iedere fase dienen beslissingen te worden genomen die al dan niet worden vastgelegd in overeenkomsten, plannen, vergunningen, e.d. Deze beslissingen hebben onder andere betrekking op wat gerealiseerd moet worden en welke rol verschillende partijen daarbij vervullen. Hier wordt ingegaan op de zeggenschap die keystakeholders in het planproces van het masterplan en het planproces voor het deelplan OV hebben gehad.

Invulinstructie: vraag 53-58: Per keystakeholder een score toekennen voor de mate van zeggenschap van de betreffende partij variërend van 1 (zeer weinig) tot 5 (zeer veel). Indien een keystakeholder niet betrokken is geweest in het proces dan geen score toekennen.

\begin{tabular}{|l|l|l|l|l|l|l|l|l|}
\hline ZEGGENSCHAP (MASTERPLAN) & Gem & Regio & Prov & V\&W & VROM & NS & Prorail & Ontw. \\
\hline $\begin{array}{l}\text { 53. Zou u per keystakeholder kunnen aangeven welke } \\
\text { zeggenschap u in dit proces naar uw mening wenselijk } \\
\text { zou zijn? }\end{array}$ & & & & & & & & \\
\hline $\begin{array}{l}\text { 54. Zou u kunnen aangeven hoe de verdeling van } \\
\text { zeggenschap aan het einde van dit proces was? }\end{array}$ & & & & & & & & \\
\hline $\begin{array}{l}\text { 55. Zou u dan kunnen aangeven hoe de verdeling van } \\
\text { zeggenschap aan het begin van dit proces was? }\end{array}$ & & & & & & & & \\
\hline
\end{tabular}




\begin{tabular}{|l|l|l|l|l|l|l|l|l|}
\hline ZEGGENSCHAP (DEELPLAN OVT) & Gem & Regio & Prov & V\&W & VROM & NS & Prorail & Ontw. \\
\hline $\begin{array}{l}\text { 56. Zou u per keystakeholder kunnen aangeven welke } \\
\text { zeggenschap u in dit proces naar uw mening wenselijk } \\
\text { zou zijn? }\end{array}$ & & & & & & & & \\
\hline $\begin{array}{l}\text { 57. Zou u kunnen aangeven hoe de verdeling van } \\
\text { zeggenschap aan het einde van dit proces was? }\end{array}$ & & & & & & & & \\
\hline $\begin{array}{l}\text { 58. Zou u kunnen aangeven hoe de verdeling van } \\
\text { zeggenschap aan het begin van dit proces was? }\end{array}$ & & & & & & & & \\
\hline
\end{tabular}

\section{C3: INBRENG VAN MIDDELEN}

Het initiëren, uitwerken en daadwerkelijk realiseren van plannen vraagt om de inzet van middelen. Keystakeholders maken afspraken over de eisen en wensen waaraan plannen dient te voldoen en onder welke voorwaarden zij bereid zijn de hun ter beschikking staande middelen voor de realisatie ervan in te zetten. Hier wordt gevraagd naar uw beeld van de inbreng van middelen door diverse keystakeholders. Omdat deze inbreng in sterke mate afhankelijk zal zijn van de kenmerken van het specifieke project gaat het hier om de vraag in hoeverre actoren meer dan wel minder inbrengen dan op grond van deze kenmerken van de betreffende actor mag worden verwacht.

Invulinstructie: vraag 59: Per keystakeholder een score toekennen variërend van 1 (veel minder inbreng dan mag worden verwacht) tot 5 (veel meer inbreng dan mag worden verwacht).

\begin{tabular}{|l|l|l|l|l|l|l|l|l|}
\hline MIDDELEN & Gem & Regio & Prov & V\&W & VROM & NS & Prorail & Ontw. \\
\hline $\begin{array}{l}\text { 59. Zou u kunnen aangeven of er naar uw mening, } \\
\text { gegeven de specifieke kenmerken, in dit project sprake is van } \\
\text { een relatief grote dan wel kleine inbreng van de } \\
\text { genoemde keystakeholders? }\end{array}$ & & & & & & & & \\
\hline
\end{tabular}

\section{ALGEMEEN/AFSLUITING}

60. Als u vanuit uw functie als projectleider naar de inbreng van diverse keystakeholders kijkt, wat is er dan in dit specifieke project naar uw mening erg positief en wat is naar uw mening voor verbetering vatbaar?

61. Hebt u nog op- of aanmerkingen ten aanzien van het project of ten aanzien van dit interview? 


\section{Over de auteur}

Marnix Smit (1975) studeerde in 2001 af aan de Universiteit Twente, bij de opleiding bestuurskunde. Sindsdien is hij, naast een professionele voetbalcarrière bij Heracles Almelo, werkzaam bij de afdeling Bouw/Infra van de faculteit Construerende Technische Wetenschappen van dezelfde universiteit. Nadat zijn voetbalcarrière in 2009 eindigde, is hij volledig werkzaam bij deze afdeling als post-doc onderzoeker. Zijn onderzoeksinteresses liggen op het vlak van procesmanagement en verevening in complexe gebiedsontwikkelingen. Op dit moment houdt hij zich vooral bezig met onderzoek naar vereveningsstrategieen voor ruimtelijke projecten waarin de transformatie van cultureel erfgoed een centraal onderdeel vormt. Naast onderzoeksactiviteiten is Marnix tevens betrokken bij het verzorgen van onderwijs voor masterstudenten van het pakket procesmanagement en de begeleiding van afstudeerders.

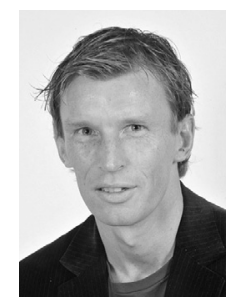




\section{NOTEN BIJ HOOFDSTUK 1}

${ }^{1}$ De VROM-raad noemt in haar advies 'Gereedschap voor Ruimtelijke Ontwikkelingspolitiek' (2004) onder andere; de toegenomen mondigheid van de burger; de toegenomen emancipatie van partijen in het speelveld van de ruimtelijke ordening; de veranderende posities op de grondmarkt; en de toegenomen afhankelijkheid van private geldstromen.

${ }^{2}$ Castells (1996) beschrijft de ontwikkeling richting een netwerksamenleving en de factoren die daaraan ten grondslag liggen uitvoerig in zijn klassieke boek 'The Rise of Network Society'.

${ }^{3}$ Pierre, J. en B. Guy Peters (2000) geven een opsomming van factoren die hieraan ten grondslag liggen.

${ }^{4}$ Giulani (2001) geeft een overzicht van verschillende toepassingen van het concept 'governance'.

${ }^{5}$ De eerste variant wordt ook wel benoemd als traditioneel, government of bestuur, centraal of hiërarchisch instrumenteel en de tweede variant als nieuw, governance of sturing, decentraal, horizontaal of onderhandelend of coproductie, communicatief (Politt, 2003; Kalders e.a. 2004, Oosten, 2002).

${ }^{6}$ Zie: WRR (1998), Ruimtelijke Ontwikkelingspolitiek. Sdu, 1998

7 Voorbeelden hiervan zijn het Investeringsbudget Stedelijke Vernieuwing (ISV-2), het Investeringsbudget Landelijk Gebied (ILG) en de Brede Doel Uitkering (BDU) voor regionaal mobiliteitsbeleid.

8 Kreukels (1999) stelt, dat "de huidige tijd van marktwerking en maatschappelijke initiatieven vraagt om een open, snel en een - in de politiek als zodanig aangewezen gevallen - pro-actief en adequaat strategisch opererend bestuur. Dit komt neer op een omslag in concepties en instrumenten, waardoor beleidsinterventie meer direct aansluit bij de krachten van zelfsturing in de samenleving. Dat betekent een versneld afscheid van een in ons land nog steeds hardnekkige sturing vanuit een overheidscentrisch standpunt."

${ }^{9}$ In literatuur (o.a. Koppenjan, 2008; Charles, 2007, e.a.) wordt ook wel verwezen naar een verschuiving van een Keynesiaanse naar een NeoKlassieke visie op de economie.

${ }^{10}$ Zie o.a. regeerakkoord Lubbers II (1986-1989) en regeerakkoord Kok II (1998-2002).

${ }^{11}$ Bij infrastructuurprojecten groter dan 112,5 miljoen euro wordt standaard een Publiek-Private Comparator (PPC) uitgevoerd - het instrument om verschillende contractvormen naast elkaar te vergelijken. Dit geldt eveneens voor rijksvastgoedobjecten boven 25 miljoen euro.

12 Veronderstellingen - theorieën zijn er nauwelijks - over de meerwaarde van de inschakeling van marktpartijen bij de borging van publieke belangen richten zich in het bijzonder op de rol van de overheid. Zo zou kwaliteit geen doorslaggevend motief zijn om voor samenwerking te kiezen en zou het publiekrechtelijke instrumentarium tekort schieten. In de gemeentelijke praktijk komt het kwaliteitsmotief zeker niet op de eerste plaats. Risicoverdeling, zeggenschap, marktomstandigheden, financiële en fiscale overwegingen lijken meer gewicht in de schaal te leggen (Akro Consult/IBR, 1997; Arts, 2000). Toch ligt volgens twee op de drie gemeenten die halverwege de jaren negentig al ervaring met PPS hadden, de meerwaarde in een hogere kwaliteit en een marktgerichter product (AkroConsult/IBR, 1996).

13 Onder corporatisme verstaat Dubbink (1999) het slaan van bruggen tussen marktpartijen en overheid; het gevaar van corporatisme schuilt volgens deze auteur in een al te innige samenwerking wat ten koste kan gaan van het publieke belang.

${ }^{14}$ Lid van de Tweede Kamer, dhr. Korstenhorst (CDA) wijst er in het algemeen overleg van de commissie voor de Rijksuitgaven van 15 mei 2003 over de brief van de minister van Financiën d.d. 20 december 2002 inzake PPS $(28$ 753, nr.1) en het rapport van de Algemene Rekenkamer "nieuwe financiële instrumenten in PPS (28 $472 \mathrm{nr}$. 1-4)) op dat er in diverse rapporten brede kritiek is op de vage vertaling van het kerndoel van bevordering van publieke dienstverlening in toetsbare criteria. Hij geeft daarbij aan, dat wanneer men niet in staat is de kerndoelen te vertalen in concrete objectief toetsbare criteria het PPS besluit gereduceerd wordt tot louter een financieringszaak.

${ }^{15}$ In hoofdstuk 5 wordt uitvoeriger ingegaan stationslocaties als vorm van integrale gebiedsontwikkeling.

${ }^{16}$ Zie: Building Business, Dossier Nieuwe Sleutelprojecten, Nieune sleutelprojecten: schirofreen, bureaucratisch, vragen om moeilijkheden, Nummer 1 februari 2003 ; Building Business, Dossier Nieuwe Sleutelprojecten, Nog nooit zo schril onvermogen vastgesteld. ; Binnenlands Bestuur, De stations die er nooit kwamen, week 14, 4 april 2003.

${ }^{17}$ In wetenschapsfilosofische literatuur worden de ideeen van Kuhn veelal afgezet tegen die van Popper. Volgens Popper moest een theorie worden getoetst aan de hand van een basiszin (potentiële falsificator). Popper suggereerde dat wetenschappers een theorie die gefalsificeerd wordt door tegenbewijs onmiddellijk laten vallen en vervangen door een betere. Kuhn daarentegen stelde dat dit niet correspondeerde met de praktijk en wetenschappers tijdens zogenaamde perioden van normale wetenschap aan hun theorieën blijven vasthouden, ook als deze door waarnemingen weersproken worden. Popper erkende dat nieuwe, betere theorieën in eerste instantie soms niet met bestaande theorieën en de waarneming in overeenstemming waren. Maar waar volgens Popper wetenschappers deze anomalieën zullen proberen te verklaren of, uiteindelijk, gebruiken om hun theorieën aan te passen, daar stelde Kuhn dat goede wetenschappers deze tegenbewijzen simpelweg zullen negeren totdat deze openlijk worden onderkend en een revolutie in de wetenschap ontstaat waarna een paradigmaverschuiving plaats vindt en een nieuwe normale wetenschap met eenstemmigheid ontstaat. Lakatos probeerde de standpunten van Popper en Kuhn met elkaar te verenigen door te stellen dat wat we normaal als één (wetenschappelijke) theorie beschouwen in feite een aantal verschillende opeenvolgende theorieën is, die een onderliggende gedachte (een barde kern) met elkaar gemeen hebben. Inconsequentie tussen waarneming en theorie kan opgelost worden zonder de kerntheorie te laten vallen, maar door de aanvullende hypotheses aan te passen. Lakatos noemt dit een problem shift (probleemverschuiving). Echter, niet alle problem shiffs in aanvullende hypothesen zijn even zinvol. Problem shifts moeten volgens Lakatos beoordeeld worden op de mate waarin ze in staat zijn onverwachte waarnemingen te verklaren en de mate waarin ze in staat zijn om nieuve feiten aan het licht te brengen. Doen ze beide, dan zijn ze progressief. Doen ze dat niet, dan zijn ze volgens Lakatos niet productief.

${ }^{18}$ In Yin's terminologie, an exploratory case study in tegenstelling tot 'descriptive’ of explicatory one (Yin 1994). 
${ }^{19}$ Hierin verschilt het onderzoek van een 'grounded theory' en ethnografische benadering.

Grounded theory is een vorm van vergelijkende case-georienteerd opbouwen van verklaringen die populair werd in de sociologie door Glaser en Strauss (1967). De onderzoeker onderzoekt cases die gelijk zijn op een aantal variabelen, maar verschillen op een afhankelijke variabele om unieke causale factoren te onderscheiden. Op een zelfde manier kan de onderzoeker cases bestuderen die gelijk zijn op een afhankelijke variabele om gezamenlijke causale factoren te onderscheiden. Grounded theory pleit op deze manier voor een continu samenspel tussen data verzameling en theoretische analyse. Waar de 'conventionele' wetenschappelijke methoden a piori starten met te testen theorie en dan over gaan tot dataverzameling, start grounded theory met data-verzameling om van daaruit te induceren naar theorie. Hoewel het geen strict onderdeel uitmaakt van de methodologie impliceert 'grounded theory' tevens een focus op het genereren van bepaalde categorieen door de onderzoekssubjecten zelf en niet een a priori creatie van typologieën door de onderzoeker. De onderzoeker kan zelfs de variabelen labelen in termen van de terminologie die wordt gebruikt door de subjecten in hun perceptie van het te bestuderen fenomeen. Grounded theory is dus zeer goed geschikt voor het ontwikkelen van op context-gebaseerde, process-georienteerde beschrijvingen en verklaringen van het fenomeen in studie (zie: Orlikowski, 1993). De data voor 'grounded theory' kan ook breder zijn dan bij traditionele case-studies en kunnen tevens de observaties van participanten, notities, chronologieen van gebeurtenissen of andere tekstuele werken bevatten. Omdat analyse van dergelijke tekstuele werken een centraal element van de theorie is vormt het coderen een belangrijk onderdeel hoewel dit verschilt van informeel tot op een kwantitatief gestructureerde wijze.

Etnograpy is een vorm van onderzoek dat zich richt op de sociologie van betekenis door veldobservaties van sociaal-culturele fenomenen. Kenmerkend is dat de etnograaf zich richt op een gemeenschap en informanten selecteert waarvan bekend is dat zij een overzicht hebben van de activiteiten van de gemeenschap. Deze informanten worden weer naar andere informanten gevraagd die representatief zijn voor de gemeenschap zodat via 'keten samples' een bevredigend beeld wordt gekregen van informanten in alle empirische onderdelen waar het onderzoek betrekking op heeft. Informanten worden meerdere keren geïnterviewd, waarbij de informatie van voorgaande informanten wordt gebruikt voor verduidelijking en verdieping. De bedoeling is om op deze wijze de gezamenlijke visie op het fenomeen van onderzoek naar voren te krijgen. Deze subjectieve maar gezamenlijke visie wordt vaak van groter belang geacht dan de objectieve interpretatie van data.

${ }^{20}$ In sociaal-wetenschappelijk evaluatie onderzoek worden grofweg twee tradities te onderscheiden: een quasi-experimentele aanpak en een small N-design op basis van cases (zie: Pawson \& Tilly 1997).

${ }^{21}$ Voor het doen van onderzoek naar causale verbanden wordt case studie als onderzoeksmethode in sociale wetenschappen over het algemeen niet zeer hoog aangeslagen (Swanborn, 1987: p.317). Veelal is de kritiek dat het aantal eenheden te klein is om verantwoorde uitspraken te kunnen doen over causale verbanden. In de praktijk worden echter regelmatig cases gebruikt voor de beantwoording van causale onderzoeksvragen. Het gaat dan om een verschil in causaliteitsopvatting. Sommigen menen zelfs dat kwalitatieve studies juist zeer geschikt zijn voor het vinden van causale relaties. Zo stellen Miles and Hubermann (1994: p.147):

"We consider qualitative analyses to be a very powerful method for assessing causality. Let's look at the features of causality we have identified. Qualitative analyses with its close-up look can identify mechanisms, going beyond sheer association. It is unrelentingly local, and deals well with complex networks of events and processes in a situation. It can sort out the temporal dimension, showing clearly what preceeded, either through direct observation or retrospection. It is well equipped to cycle back and forth between variables and processes - showing that 'stories' are not capricious, but include underlying variables and that variables are not disembodied, but have connections over time."

22 Volgens Stake (1994) is case-studie geen methodologische keuze. Case studie betreft slechts een keuze omtrent wat zal worden bestudeerd. Het is onafhankelijk van het feit of een kwalitatieve of kwantitatieve (of beide) methodologie wordt gebruikt. Stake (1994) heeft het over 'instrumental study' or 'intrinsic case-study'. Hiermee bedoelt hij dat het onderzoek is gericht op het geven van enig inzicht in een onderwerp of het opnieuw trekken van een generalisatie en niet slechts het beschrijven en begrijpen van een bestudeerde case.

23 Om te kunnen spreken van causale relatie dient: (a) er een zekere samenhang bestaan tussen twee kenmerken (variabelen X en Y); (b) de 'oorzaak' variabele vooraf zijn gegaan aan de 'gevolg' variabele; en (c) mag deze samenhang tussen X en Y niet zijn ontstaan door een derde variabele. Het bestaan van een verband betekent dus nog geen causaliteit (zie o.a. Swanborn, 1987: p. 90).

${ }^{24}$ In zijn eerdere boek onderscheid Yin (1994: 106-119) vijf technieken voor het analyseren van de resultaten uit case studies: pattern matching, explanation building, time-series analyses, logic models en cross-case synthese.

${ }^{25}$ Vergeleken met een volledig gespecificeerde theory bevat een raamwerk minder informatie in de zin dat minder vragen direct worden beantwoord en meer vragen moeten worden beantwoord op basis van empirische data. Op deze wijze gezien is het een gradatieverschil. Een theorie bevat meer constanten.

\section{NOTEN BIJ HOOFDSTUK 2}

${ }^{26}$ Beck Jorgensen en Bozeman (2007) gebruiken 'public values' als centrale term.

27 'Anders' verwijst volgens Heldeweg (2010) naar activiteiten in de privésfeer van familie en vrienden, in de sfeer van het 'maatschappelijke middenveld' of de 'civil society' van niet op winst gerichte vrijwillige maatschappelijke organisaties of netwerken, en in de sfeer van markt voor commerciële ruiltransacties.

28 Artikelen 19-23 van de Nederlandse Grondwet

${ }^{29}$ Van Wijnbergen (2002) stelt dat het probleem van veel privatiserings- en dereguleringsoperaties niet zozeer ligt bij de wijze waarop het publiek belang kan worden gewaarborgd, maar dat het echte probleem is dat de politiek geen idee heeft hoe het publiek belang moet worden gedefinieerd.

30 De Bruijn en Dicke (2003) gebruiken de term 'emergentie' om aan te duiden hoe publieke belangen zich continu ontwikkelen en bijgevolg veranderen. Heldeweg (2010) gebruikt de term 'poreusheid' in verband met enerzijds het beschrijvende probleem (de definitie van het publiek 
belang in termen van kwaliteitseisen is nooit compleet) en anderzijds de mogelijkheid van zich wijzigende inzichten betreffende (lees dynamiek van) de aard en rijkweidte van publieke belangen (zoals door toedoen van maatschappelijke en/of technologische ontwikkeling)

${ }^{31}$ Blokland (2000) stelt dat beide auteurs tot de eersten behoren die het pluralismedebat hebben gestart.

32 Bentley (1908) benadrukt, dat de belangen van een groep niet moeten worden verward met wat een groep zegt dat haar belangen zijn. Aan de andere kant moeten onderzoekers ook niet trachten "objectieve" belangen aan groepen te hangen. Volgens Bentley is het belang van een groep exact de activiteit van de groep. Een groep kan dus nooit handelen in tegenspraak met zijn eigen belang, omdat de handeling het belang definieert.

${ }^{33}$ Bentham (1776) definieerde het utilitarisme als de numerieke aggregatie van geluk van individuen (geluk is het surplus van genot over pijn). Bentham was de eerste om een utilitaristische calculus te gebruiken en aggregeert hierbij de persoonlijke belangen van verschillende individuen in de vorm van hun respectievelijke nuttigheden om een oordeel te bekomen over het sociaal belang. Vanuit dit perspectief was het belangrijkste doel het bereiken van het maximaal mogelijke geluk van de samenleving als een geheel. Hoe vervolgens de som wordt verdeeld onder de mensen is onbelangrijk, enkel de som is belangrijk. Utilitarisme wordt daarom ook vaak samengevat in de slagzin "the greatest happiness for the greatest number"

${ }^{34}$ Een compleet statement van deze positie is gemaakt door Howard E. Smith.

${ }^{35}$ Schumpeter (1942) wordt beschouwd als een van de belangrijkste grondleggers van het pluralisme. Zijn pluralistische theorie zet hij af tegen wat hij de "klassieke leer van de democratie noemt". Deze klassieke leer vat hij als volgt samen: "De democratische methode is die institutionele regeling om tot (politieke) besluitvorming te komen, waarbij ten behoeve van het algemeen welzijn het volk zelf over strijdpunten beslist door de verkiezing van individuen die bijeen moeten komen om de wil van het volk uit te voeren". De kritiek van Schumpeter richt zich vooral op het idee dat er consensus zou bestaan tussen de burgers over de vraag wat 'het algemeen welzijn' inhoudt. Er is'(...) niet zo iets als een ondubbelzinnig algemeen welzijn, waar alle mensen het over eens zijn of door redelijke betogen het over eens kunnen worden". Dahl (1956) heeft de opvattingen van Schumpeter verder theoretisch uitgewerkt. Hij formuleert daarbij de polyarchie-theorie. Dahl (1956) definieert het begrip polyarchie met behulp van een aantal kenmerken waaraan voldaan moet zijn wil er sprake zijn van een polyarchale democratie. De kern van Dahl's polyarchietheorie is, dat in de besluitvorming winnende coalities worden gesmeed door uiteenlopende groepen. Er is dan ook geen sprake van een permanente meerderheidstirranie, omdat de combinaties van belangengroepen kunnen verschillen. Juist een polyarchie garandeert concurrentie tussen belangen en het bestaan van concurrerende belangen vormt een garantie voor democratische besluitvorming. Het algemeen welzijn waarop de moderne overheid zich richt is geen werkelijk beleidsdoel, maar het resultaat van allerlei beslissingen, dat niet noodzakelijk de wil van de meerderheid reflecteert.

${ }^{36}$ Dahl en Lindblom (1976) constateren in hun latere werk, dat de praktijk grotere tekortkomingen ten opzichte van hun ideaalbeeld vertoont, dan zij aanvankelijk voor mogelijk hadden gehouden. De kern van hun veranderde opvattingen blijkt uit het volgende citaat: "We cannot move a great deal closer to political equality without moving closer to equality in acces to political resources. We cannot move closer to greater equality in acces to political resources without greather equality in the distribtion of -among other things - wealth and income. And if certain options like voting, free speech, and due proces have to be established as "rights" to make democracy work, so also does a fair share of income and wealth have to become a right."

${ }^{37}$ Het onmogelijkheidstheorema van Arrow (1951) stelt dat er geen sociale welvaartsfunctie is die voldoet aan de voorwaarden van onbeperkt domein, het Pareto principe, onafhankelijkheid van irrelevante alternatieven en afwezigheid van een dictator. Onbeperkt domein (universal admissibility); Alle logisch mogelijke ordeningen kunnen voorkomen/elk individu moet kunnen bijdragen aan de collectieve keuze. Het Pareto principe; Als ieder individu de voorkeur geeft aan alternatief $\mathrm{X}$ boven alternatief $\mathrm{Y}$, dan moet de procedure leiden tot een collectieve voorkeur van $\mathrm{X}$ boven Y. Onafhankelijkheid van irrelevante alternatieven; De uiteindelijke keuze tussen twee alternatieven mag alleen afhangen van individuele voorkeuren met betrekking tot deze twee mogelijkheden. Afwezigheid van een dictator; Het mag niet zo zijn dat de voorkeuren van een enkel individu altijd de collectieve keuze bepalen

38 In zijn meer recentere werk (neopluralisme) houdt Dahl min of meer een pleidooi voor het hanteren van normatieve beginselen om beleidsresultaten te beoordelen. Zo merkt Dahl (1985, p.16-17) bijvoorbeeld op, dat een aanvaardbare procedure tot een onrechtvaardig resultaat kan leiden.

39 Teulings, Bovenberg and Van Dalen (2003) definieren een publiek belang als een complex extern effect waarvan de realisatie wordt voorkomen door free-rider gedrag.

${ }^{40}$ Zie eindnoot 38. Belangrijk onderdeel vormt de stemparadox. Deze behelst dat individuele transitiviteit bij meer dan twee alternatieven niet altijd leidt tot collectieve transitiviteit.

${ }^{41}$ Een verdieping in economische theorie door behandeling van zaken als het prijsmechanisme, (quasi-collectieve goederen in relatie tot begrippen als (non-)uitsluitbaarheid en (non-)rivaliteit wordt hier achterwege gelaten. Zie hiervoor Cornes and Sandler (1986).

42 Staatscourant 28 oktober 1982, nr. 208, p.2.

43 Staatscourant 11 juli 1986, nr. 131, p.4-9.

${ }^{44}$ Tweede Kamer, 1999-2000, 26800, A

${ }^{45}$ De WRR (2000) heeft deze beginselen uitgewerkt in een aantal indicatoren: Democratische legitimatie: (1) algemeen (actief en passief) kiesrecht, (2) democratische sturing (vertegenwoordigende lichamen geven sturing aan de uitoefening van publieke bevoegdheden en/of de besteding van publieke middelen, (3) democratische verantwoording (verantwoording bestuur aan vertegenwoordigende lichamen). Vereist niet dat belang binnen publieke domein wordt uitgevoerd, maar dat besluitvorming democratisch gelegitimeerd is. De publiek gekozen organen moeten de aard van het publiek belang bepalen alsmede de wijze van behartiging. Rechtszekerheid: (1) eis van legaliteit (optreden van de overheid moet een wettelijke grondslag hebben, (2) eis van kenbaarheid (burgers moeten op de hoogte kunnen zijn van hun verplichtingen), (3) verbod op 
terugwerkende kracht. Rechtsgelijkheid. Gelijke gevallen dienen gelijk behandeld te worden. Bevorderd via: legaliteitsbeginsel, scheiding der machten, scheiding van politiek en bestuur binnen uitvoerende macht en het gelijkheidsbeginsel. Effectiviteit: De mate waarin een bepaald beleid of bepaald middel bijdraagt tot het bereiken van een bepaald doel. (zie ook: Hoogerwerf). Het vereist dus duidelijkheid over de doelen die worden nagestreefd. Efficiency: weinig eenduidigheid in literatuur. Allocatieve efficiency gaat om vragen als "hoe bereiken we een bepaald resultaat tegen zo laag mogelijke individuele of maatschappelijke kosten? En 'in hoeverre komen de geleverde prestaties overeen met de voorkeuren van de burgers. Met andere woorden: komt het geld daar terecht waar het de grootste bijdrage levert aan het publiek belang. Bij kostenefficienty gaat het slechts om de vraag of er tegen minimale kosten wordt geproduceerd, oftewel of de behartiging van het publieke belang zo weinig mogelijk vermijdbare kosten met zich mee brengt.

46 Zie Van Montfort (2004) waarin nader in wordt gegaan op de manier waarop de Algemene Rekenkamer het begrip "goed bestuur" gebruikt.

${ }^{47}$ Steunenberg (2000) stelt dat binnen het institutionalisme een onderscheid kan worden gemaakt tussen twee benaderingen; het rationele-keuze institutionalisme en het sociologisch institutionalisme. De eerste benadering ziet gedrag als een gevolg van individuele voorkeuren die door instituties kunnen worden begrensd. De tweede benadering neemt aan dat instituties het gedrag vormen. Gedrag wordt gezien als een consequentie van bepaalde instituties.

${ }^{48}$ Vaak wordt verwezen naar machtenscheiding (trias politica); rechtsbescherming tegen de overheid en rechtshandhaving.

${ }^{49}$ Ook wel SMART-criteria genoemd.

${ }^{50}$ Het ministerie van Economische Zaken (2003: p.11) gedefinieerd ruimtelijke kwaliteit als 'de positieve publieke beleving van een plek' welke ontstaat in de interactie tussen mens (sociaalmaatschappelijke aspecten), gebruik (functionele aspecten) en ruimte (ruimtelijke aspecten). Deze definitie houdt in dat het publiek, in de breedste zin van het woord, bepaald of een plek ruimtelijke kwaliteit heeft.

${ }^{51}$ De reeks van belangen komt voort uit het advies van de VROM-raad bedoelt voor de Vijfde Nota Ruimtelijke Ordening

52 Van der Wouden (1999) stelt, dat ruimtelijke kwaliteit samenhangt met een hoge mate van diversificatie en dat functiemenging een belangrijke indicator van diversificatie is.

${ }^{53}$ Garvin (1984) onderscheid vijf benaderingen om (product)kwaliteit te bepalen. De transcendente benadering, waarin kwaliteit wordt benaderd vanuit een ideaalbeeld dat niet gedefinieerd kan worden. De tweede benadering is de productbenadering, waarin kwaliteit meetbaar is door het vaststellenvan de kwantiteit waarmee een bepaald kenmerk of eigenschap voorkomt in een product. In de derde benadering, de gebruikersgerichte benadering, wordt de kwaliteit door gebruikers bepaald. In de vierde benadering, de productiegerichte benadering, is er sprake van kwaliteit als de productie zo min mogelijk afwijkt van de daaraan gestelde eisen. De vijfde benadering is de waardegerichte benadering waarin kwaliteit direct wordt gekoppeld aan een prijs.

${ }^{54}$ Hoogerwerf (1998) onderscheid drie bronnen van legitimiteit. Volgens hem kan legitimiteit ontleend worden aan het bestaan van een gedeelde ideologie (ideologische legitimiteit); democratische besluitvormingsprocedures (procedurele legitimiteit) en effectieve overheidsprestaties (taaklegitimiteit).

55 Suchman (1995) stelt dat studies die ingaan op legitimiteit kunnen worden onderverdeeld in twee te onderscheiden groepen; de strategische en de institutionele. Studies die zich richten op strategische legitimiteit zien legitimiteit als een operationele hulpbron die organisaties gebruiken om hun doelen te bereiken. In tegenstelling tot deze strategische benadering zien institutionele onderzoekers legitimiteit niet als een operationele hulpbron, maar als een set van constitutieve waarden.

${ }^{56}$ De vier typen morele legitimiteit liggen in lijn met het werk van Weber (1922) die in zijn 'Wirtschaft und Gesellschaft' drie soorten gezag onderscheid. 'Consequential legitimacy' en 'procedural legitimacy' corresponderen met Weber's 'legal-rational authority', hoewel het eerste meer instrumenteel-rationeel is (gebaseerd op het najagen van bepaalde doelen), terwijl laatstgenoemde meer waarde-rationeel is (gebaseerd op het voldoen aan bepaalde regels van gepast gedrag). 'Structural legitimacy' weerspiegelt de 'traditional authority', gebaseerd op het gegeven dat een aantal actoren al sinds lange tijd gezien worden als achtenswaardig om bepaalde macht toe te vertrouwen.

57 Soms wordt ook nog 'feedback legitimiteit' onderscheiden. Daarbij gaat het om de mate waarin erin geslaagd wordt terugkoppeling van de resultaten te organiseren naar het inputproces. Omdat deze studie zich richt op de planvormingsfase is deze vorm van legitimiteit niet te evalueren en wordt derhalve in verdere beschouwingen niet meegenomen.

${ }^{58}$ In lijn met het onderscheid van Scharpf (1997) ligt het onderscheid dat Weber (1976) makt tussen enerzijds personen die overheidshandelen of overheidsbesluiten als geldig voor hun handelen zien (Weber, 1976, p.19) en anderzijds de mogelijkheid dat legitimiteit kan worden opgeëist (Weber, 1976, p.122). In het laatste geval beschouwt iemand het overheidsbesluit of handelen als legitiem hoewel hijzelf anders zou hebben beslist. Een essentieel verschil in een democratische rechtstaat en vanuit sociologisch perspectief interessant is de vraag wat de kans vergroot dat een persoon een overheidsbeslissing of overheidshandelen als legitiem ziet.

59 Beetham (1991; p.17) stelt als tweede voorwaarde voor rechtvaardigheid dat de wettelijke regels in overeenstemming zijn met door leiders en onderdanen gedeelde opvattingen. Omdat de nadruk in deze studie ligt op projectniveau wordt deze voorwaarde buiten beschouwing gelaten.

${ }^{60}$ Ook wordt wel beargumenteerd dat representatieve instituties alleen onvoldoende zijn voor democratische besluitvorming, omdat zij er onvoldoende in slagen om stakeholders op een effectieve manier invloed te laten uitoefenen (Budge, 1996). Daarnaast beargumenteerde Riker (1982) al dat geen enkele besluitvormingsregel een adequate vertaling vormt van de individuele voorkeuren in een 'sociale keuze'.

${ }^{61}$ In dit licht wordt in literatuur vaak gesteld dat participatie leidt tot betere resultaten omdat hierdoor gebruik kan worden gemaakt van meer kennis en informatie die noodzakelijk is voor het oplossen van complexe problemen (Pröpper en Steenbeek, 1999; Kooiman, 1993; e.a.). 
${ }^{62}$ Vaak wordt tevens de mate waarin actoren open staan voor de argumenten van andere actoren als aparte vorm van openheid genoemd. Hier wordt de opvatting gehanteerd dat deze vorm van openheid sterk in lijn ligt met inhoudelijke openheid en wordt om die reden niet als aparte vorm in beschouwing genomen.

${ }^{63}$ Dit is de kern van de klassieke theorie over politieke representatie zoals geformuleerd door Edmund Burke in zijn klassieke toespraak voor de burgers van Bristol

64 "In democratic nation states, however, input- and output-oriented legitimacy coexist side by side, reinforcing, complementing, and supplementing each other - which is why the theoretical distinction introduced here can be extracted from close reading of normative treatises but is not usually explicated in the praxis of political discourse. (Scharpf, 1999: p.12)"

${ }^{65}$ In een veel geciteerd artikel heeft Dahl (1994) beargumenteerd dat voor collectieve actie in een moderne samenleving horizontale coördinatie tussen publieke en private actoren noodzakelijk is om systems capacity - de gepercipieerde mogelijkheid om om te gaan met beleidsveranderingen - te bereiken, echter direct ten koste van effectieve representatie.

${ }^{66}$ Smitter (2002: p.62-63) heeft bijvoorbeeld een typologie van zeven gronden voor legitieme claims voor participatie opgesteld. Deze zijn: rights (derived from citizenship), spatial location (all those living in an certain area), knowledge (experience or skills), share (as related to ownership), stake (being materially or spiritually affected), interest (as a spokesperson for some constituency), and status.

${ }^{67} \mathrm{Zie}$ noot 65

\section{NOTEN BIJ HOOFDSTUK 3}

${ }^{68}$ In besluitvormingstheorie wordt de vergelijkbare benadering ook wel als 'synoptisch-rationeel' aangeduid (Hoogerwerf, 1993)

69 In de traditionele beleidsanalyse heeft het ideaaltypische besluitvormingsmodel zeven te onderscheiden "fasen” (Friedman, 1987): (1) Formuleren van doelen; (2) Identificeren en ontwerpen van belangrijke alternatieven voor het bereiken van de in de gegeven besluitvormingssituatie geïdentificeerde doelen; (3) Voorspellen van de belangrijkste consequenties die kunnen worden verwacht als gevolg van het gebruiken van dat alternatief; (4) Evalueren van de consequenties in relatie tot de gewenste doeleinden en andere belangrijke waarden; (5) Besluitvorming gebaseerd op informatie uit voorgaande stappen; (6) Implementatie van de besluiten door de gepaste instituties; en (7) Feedback van feitelijke resultaten en de evaluatie daarvan in het licht van de nieuwe besluitvormingssituatie.

70 "The capacity of the human mind for formulating and solving complex problems is very small compared with the size of the problems whose solution is required for objectively rational behavior in the real world or even for a reasonable approximation to such objective reality." (Simon, 1957, p. 198.) Simon en March opperden dat besluitvormers feitelijk te maken hebben met (1) meerduidige en slecht gedefinieerde alternatieven; (2) incomplete informatie over alternatieve; (3) incomplete informatie over de achtergrond van het probleem; (4) incomplete informatie over de consequenties van de voorgestelde alternatieven; (5) incomplete informatie over het scala en de inhoud van waarden, voorkeuren en belangen; en (6) beperkte tijd, vaardigheden en hulpbronnen (Forester, 1989).

${ }^{71}$ Lindblom ging zelfs zover dat hij stelde dat de onmogelijkheid om de benadering in de praktijk te implementeren elk nut om het te gebruiken wegneemt (Faludi, 1973, p.117). Hij argumenteerde dat het moeilijk is voor planners om plannen te maken die sterk afwijken van de bestaande situatie. Hij stelde voor om planvorming incrementeel te laten plaats vinden, waarbij slechts een beperkt aantal alternatieven die beperkt afwijken van de bestaande situatie in beschouwing hoeven te worden genomen. Voor deze alternatieven hoeft slechts naar de belangrijkste consequenties te worden gekeken. Het probleem wordt steeds opnieuw bekeken en stapje bij stapje wordt naar vooruitgang gestreefd ('piecemeal engineering'). Er is niet één juiste oplossing, maar een oneindige serie van 'aanvallen' op het voorliggende probleem door continue analyse en evaluatie. Als zodanig is de benadering dan ook meer gericht op het verbeteren van de huidige situatie dan op het streven naar vastgelegde toekomstige doelen zoals in de rational-comprehensive benadering. Beslissingen zijn niet gebaseerd op een vorm van een masterplan, maar doelen en acties worden bepaald op basis van de op dat moment beschikbare middelen en geldende ideeën.

72 De mixed scanning benadering onderscheidt fundamentele beslissingen van incrementele. Fundamentele beslissingen worden genomen door actoren door vanuit de doelstellingen te kijken naar de belangrijkste alternatieven. Echter in tegenstelling tot de rational-comprehensive benadering worden details en nauwkeurige specificaties achterwege gelaten, zodat een overzicht mogelijk is. Incrementele beslissingen worden genomen binnen de context die gevormd is door de fundamentele beslissingen. De kern van mixed scanning is dus dat het op hoger abstractieniveau de beperkingen van de rational-comprehensive aanpak tracht te ondervangen met de deugden van het incrementalisme. Op het minder omvattende niveau tracht het de 'oogkleppen' van het incrementalisme zoveel mogelijk te vermijden door een contextgebonden rationalisme (Hoogerwerf, 1993). De gevolgde strategie wordt volgens de benadering noch door waarden noch door informatie bepaald, maar door de posities en machtsverhoudingen tussen partijen die betrokken zijn bij het maken van de plannen. De omgeving en de capaciteiten van de actor spelen daarmee een belangrijke rol (Etzioni, 1967).

${ }^{73}$ De Graaf (2005) onderscheid vier oriëntaties: de systeembenadering, de rationele procesbenadering, procedurele planning en planning als politiek proces.

${ }^{74}$ Er was behoefte aan een nieuwe benadering die politieke en sociale aspecten van planvorming in haar benadering mee nam. Een doorbraak kwam van een studie van de Chicago Housing Autority. Deze 'Chicago School' (Tugwell en Banfield, 1951) verschilde in die zin dat het er vanuit ging dat doelen politiek werden bepaald en niet in het ontwerpproces. Daarnaast was er meer aandacht voor besluitvorming en werden de relaties tussen doelen, middelen en het gebruik van technieken niet als bekend verondersteld, maar werden empirisch getest. Hoewel de benadering van de Chicago School planners meer bewust makte van de beperkingen in termen van rationaliteit en alomvattendheid was de kritiek van in het bijzonder Lindblom dat het onderliggende idee nog steeds gebaseerd was op rationaliteit. 
${ }^{75}$ Bij het bestuderen van netwerken gebruiken wetenschappers vaak een typologie van netwerken als diagnostisch hulpmiddel. Die typologieën zijn dan gebaseerd op kenmerken als het aantal actoren en hun typen belangen in het netwerk, de frequentie en de aard van de interactie tussen actoren en de verdeling van macht in een netwerk (Rhodes en March, 1992, p. 187).

${ }^{76}$ Ook zijn er verschillende vormen van afhankelijkheid. Godfroij, 1981: p116-117) maakt een onderscheid tussen symbiotische en competitieve afhankelijkheidsrelaties (Godfroij, 1981, p.116-117). Symbiotische afhankelijkheidsrelaties bestaan tussen actoren die elkaar aanvullen door hun verscheidenheid. Bij competitieve afhankelijkheidsrelaties gaat het om actoren die afhankelijk zijn van dezelfde hulpbronnen. Indien er sprake is van symbiotische afhankelijkheidsrelaties is de kans op bereidheid tot intensieve samenwerking relatief groot. Competitieve afhankelijkheidsrelaties sluiten samenwerking niet uit. Samenwerking beperkt zich dan echter in veel gevallen tot de uitwisseling van informatie en andere hulpbronnen. Pas op het moment dat kosten, risico's en externe bedreigingen een in de ogen van de betrokken actoren onaanvaardbare omvang hebben bereikt, bestaat er een kans dat men tot meer intensieve samenwerking komt (Alter en Hage, 1993: 57-59). In de praktijk kennen afhankelijkheidsrelaties tussen actoren dikwijls symbiotische en competitieve componenten.

77 Forester (1989: p. 60) argumenteerd dat de machtsongelijkheid samen hangt met de positie van actoren in historische, politieke, sociale en economische structuren

${ }^{78}$ Binnen het institutionalisme kunnen twee benaderingen worden onderscheiden (Steunenberg, 2000, p.7). De eerste benadering is het rationele kenæe institutionalisme. Die benadering kiest het individu als uitgangspunt in de analyse en geeft aan dat gedrag gebaseerd kan worden op zijn of haar persoonlijke bedoelingen. Instituties, in deze visie, beperken het individu in de zin dat niet meer alle denkbare handelingsopties of combinaties daarvan tot de mogelijkheden behoren. Dat wil zeggen, gedrag is een gevolg van de individuele voorkeuren die door instituties kunnen worden begrensd. De tweede benadering is het sociologisch institutionalisme. Die benadering neemt aan dat instituties het gedrag vormen. Gedrag wordt nu gezien als een consequentie van bepaalde instituties.

79 In de literatuur bestaan verschillende opvattingen over de vraag wat 'instituties' zijn (Steunenberg, 2000). 79 Ostrom e.a. (1994) leggen bijvoorbeeld de nadruk op regels die de kosten en baten van bepaalde acties voor actoren beinvloeden. Anderen verbreden het concept en zien daarbovenop ook entiteiten die in staat zijn tot doelgericht handelen als instituties (vgl. March en Olson, 1989). Om een onderscheid te houden met termen als 'organisatie' en 'actoren met rechtspersoonlijkheid' pleit Scharpf (1997) ervoor het concept institutie te beperken tot het systeem van regels die de handelingen die een set van actoren kan kiezen, structureren. Dan kan het gaan om formele regels die onder een bepaald rechtssysteem vallen, maar eveneens om algemeen aanvaarde informele normen die bijvoorbeeld verlies aan reputatie of het einde van een samenwerking tot gevolg kunnen hebben. In alle gevallen blijven de definities op een erg hoog abstractieniveau. Een complete systematische beschrijving van institutionele factoren zou het volledige programma aan relevante wettelijke regelgeving en het volledige programma aan mogelijk relevante informele regels en normen moeten bevatten.

${ }^{80} \mathrm{In}$ reactie op de institutionele benadering kwamen in de politieke wetenschappen na de Tweede Wereldoorlog twee andere benaderingen op die meer nadruk legden op het individu; behaviouralism en rationele keuze. Beide benaderingen veronderstellen dat individuen autonoom handelen als individuen, gebaseerd op sociaal psychologische kenmerken of rationele calculatie van hun persoonlijke nut. In beide theorieën werden individuen niet serieus beperkt door formele of informele instituties (Guy Peters, 2005: p.1)

${ }^{81}$ Een zelfde kijk op institutionalisme is o.a. ook te vinden bij Scott (1995) die drie pijlers van instituties onderscheid: regulatieve, normatieve en cognitieve. Gedrag wordt niet alleen beïnvloed door wetten en formele regels en puur economisch rationele factoren (regulatieve pijler), maar tevens door normen die worden bekrachtigd door sociale controle (normatieve pijler), als door het vanzelfsprekende karakter van allerhande denk- en gedragswijzen (cognitieve pijler). Dit onderscheid ligt in lijn met de drie vormen van borging van publieke belangen door inschakeling van de markt die de WRR (2001) onderscheid, borging met behulp van regels, institutionele borging door middel van het versterken van waarden en normen en borging door middel van concurrentie.

82 Mayntz \& Scharpf (1995) en Scharpf (1997) stellen dat een analyse van structuren zonder referentie naar actoren gaat net zo mank als een analyse van het handelen van actoren in een proces zonder referentie naar structuren

${ }^{83}$ Deze komen overeen met de kenmerken van de actie-situatie die Ostrom onderscheid. Opgemerkt dient te worden dat de zeven typen regels wel analytisch te onderscheiden zijn, maar niet los van elkaar gezien kunnen worden. Zo bepalen de toegangsregels welke posities worden ingenomen (positieregels), en hebben daarmee ook betrekking op de handelingsruimte van individuele actoren (autoriteitsregels), of de informatie die voor hen beschikbaar is (informatieregels). Daarnaast kunnen bijvoorbeeld autoriteitsregels weer invloed hebben op de aggregatieregels. Ook hangen de kosten- baten regels nauw samen met de reikwijdteregels. Kortom: de zeven typen regels zijn wel te onderscheiden, maar niet te scheiden.

${ }^{84}$ Deze auteurs geven overzichten van netwerkmanagement en procesmanagement.

85 "In our framework, therefore the concept of the 'institutional setting' does not have the status of a theoretical defined set of variables that could be systematized and operationalized to serve as a explanatory factors in empirical research. Rather, we use it as a short hand term to describe the most important influences on those factors that in fact drive our explanations - namely, actors with their orientation and capabilities, actor constellations, and modes of interaction" (Scharpf, 1997, p.39).

${ }^{86}$ Het ACI gaat er vanuit dat de feiten die actoren waarnemen kloppen, en dat hun hypothesen en de causale verbanden waarin zij denken worden bepaalde door de op dat tijdstip in die institutionele setting heersende ideeën (Scharpf, 1997: 62-63).

${ }^{87}$ De perceptie van actoren kennen, voor zover het gaat om basisveronderstellingen over de werkelijkheid, een zekere stabiliteit, maar kunnen in de loop van de tijd ook veranderen onder invloed van interacties in het netwerk of daarbuiten, toetreding van nieuwe actoren, onvoorziene gevolgen van handelen of externe gebeurtenissen (Klijn, 1996). 
88 Scharpf, 1997: p.84-89) onderscheidt een aantal interactieoriëntaties; individualisme, solidariteit, competitie, altruïsme en vijandigheid. In de praktijk van gebiedsontwikkeling zullen de laatste twee niet snel voorkomen.

89 De Graaf (2005) onderscheidt de 'transactive' (Friedman, 1973), communicatieve (Healey, 1994; Innes, 1995), interactieve (Klijn en Koppenjan, 1998; Pröpper en Steenbeek, 1998) en de strategische (Thompson, 1967; Bryson e.a., 1987; Salet en Faludi, 2000) benadering van planvorming.

${ }^{90}$ De bron is het Latijnse woord 'videre' dat 'zien, inzien, of inzicht hebben betekend.

${ }^{91}$ Om het onderscheid met planvorming voor specifieke deelplannen, zoals het masterplan, te houden wordt in deze studie in plaats van planvorming de term visievorming gehanteerd.

92 De term 'zeggenschap' is daarmee sterk gerelateerd aan het concept macht. Macht is het vermogen invloed uit te oefenen en kan wel worden gemeten door te kijken naar wie welke beslissingen neemt (Dahl, 1961). Bij invloed gaat het meer om de mate waarin een actor zijn belangen weet te vertalen in concrete beslissingen.

${ }^{93}$ De WRR (2000) argumenteert dat dit beeld aanzienlijke nuancering behoeft.

${ }^{94}$ Naar aanleiding van de bouwfraude is de roep om een zwaardere controlefunctie van de overheid in het bouwproces weer harder geworden. Ook negatieve evaluatierapporten versterken dit geluid.

${ }^{95}$ Freeman (1984) stelt dat een strategie alleen succesvol kan zijn als daarmee de behoeften van keystakeholders worden bevredigt.

\section{NOTEN BIJ HOOFDSTUK 4}

\section{Zie voetnoot 96}

97 Onderzoeksmatig is het van belang dat het handelen en de percepties van individuele projectmanagers kan worden gerelateerd aan de grotere eenheid (groep, organisatie, etc.) namens welke zij handelen en vanuit welkes perspectief intentionele keuzes kunnen worden verklaard (Scharpf, 1997: p.61). Uitgangspunt in deze studie is dat projectmanagers in staat zijn zich te identificeren met en te handelen vanuit het perspectief van de grotere eenheid en dat daarmee hun handelen en percepties in belangrijke mate ingegeven zijn vanuit de organisatie die zij in het betreffende project representeren.

98 De variantie is in de statistiek een maat voor de spreiding van de betrokken waarden. Onder de spreiding van de waarden verstaat men de mate waarin de waarden onderling verschillen. Hoe groter de variantie, hoe meer de afzonderlijke waarden onderling verschillen, en dus ook hoe meer de waarden van het "gemiddelde" afwijken. De variantie meet min of meer het gemiddelde van het kwadraat van deze afwijkingen. Die waarden kunnen de waarden van een populatie zijn, dan spreekt men van de populatievariantie. Betreft het de waarden van een verdeling, dan is de variantie een maat voor de "breedte" van deze verdeling, en spreekt men meestal gewoon van de variantie van deze verdeling. Betreft het de uitkomsten van een steekpoef, dan spreekt men van steekproefvariantie

${ }^{99} \mathrm{Om}$ gevaren voor de validiteit van retrospectieve data tegen te gaan suggereren Miller e.a. (1997) meerdere bronnen te gebruiken, te kijken naar feitelijke gebeurtenissen, te zoeken naar convergentie in interpretaties en door review van case data door informanten.

${ }^{100}$ Hoewel ProRail als eigenaar van de sporenlayout en het transfergedeelte van de stations een belangrijke actor is kan het - als verzelfstandigde taakorganisatie met veelal het ministerie van Verkeer en Waterstaat als opdrachtgever - niet worden aangemerkt als representatieve institutie. Voor regio's die de status hebben van plusregio's (voorheen kaderwetgebieden) geldt dat zij een aantal taken en bevoegdheden op het terrein van regionaal openbaar vervoer hebben en hierdoor aangemerkt kunnen worden als een extra bestuurslaag, maar dat zij vanwege het ontbreken van een rechtstreek gekozen bestuur niet als representatieve instituties worden aangemerkt.

101 Bij pattern matching (Yin, 2003: p. 116) vergelijkt een onderzoeker een patroon dat uit empirische data naar voren komt met een vooraf op grond van theorie voorspelt patroon. Pattern matching veronderstelt derhalve het kunnen formuleren van een of meer patronen aan de hand van een of meer theorieën. Voor het onderhavige onderzoek is, zoals in het eerste hoofdstuk geconstateerd, een bruikbare theorie over de effecten van procesaanpakken op de borging van het publiek belang niet direct voorhanden. Naast andere complicaties, zoals de mogelijkheid dat er alternatieve verklaringen bestaan voor een bepaald patroon, wordt om deze reden in deze studie geen gebruik gemaakt van pattern-matching technieken.

Bij explanation building start de onderzoeker niet met een te onderzoeken theorie, maar tracht theorie te ontwikkelen vanuit gekozen voorbeeldprojecten die verscheidenheid vertonen op de afhankelijke variabele (hier: de borging van het publiek belang). Een lijst met mogelijke oorzaken voor de afhankelijke variabele wordt geconstrueerd door literatuurstudie en brainstormen en informatie wordt verzameld voor elke oorzaak voor elke geselecteerde case. Vervolgens inventariseert de onderzoeker (causale) kenmerken die gemeenschappelijk voor elke case gelden, die gemeenschappelijk gelden voor cases die hoog scoren op de afhankelijke variabele en die gemeenschappelijk gelden voor cases die laag schoren op de afhankelijke variabele. De onderzoeker komt tot de voorlopige conclusie dat de verschillende kenmerken de belangrijke oorzaken vormen, terwijl dat niet geldt voor de kenmerken die gemeenschappelijk gelden voor alle cases. Explanation building kan vooral interessant zijn als er plausibele rivaliserende verklaringen zijn die door middel van deze methode weerlegt kunnen worden (zie Yin, 2003, p. 120-122). Yin (2003: p. 122) wijst er wel op dat deze methode vol gevaren is. Zo bestaat het gevaar dat de onderzoeker gedurende het iteratieve proces wegschuift van het oorspronkelijke doel van het onderzoek. De analytische complexiteit (mogelijke verwevenheid van relaties) maakt explanation building een minder aantrekkelijke wijze van onderzoek.

Het gebruik van (programm) 'logic models' als analysetechniek bestaat uit het matchen van empirisch geobserveerde gebeurtenissen aan theoretische voorspelde gebeurtenissen. Het 'logic model' stelt met opzet als voorwaarde dat er sprake is van een complexe opeenvolging van gebeurtenissen in de tijd. De gebeurtenissen worden daarbij gerangschikt als herhaalde oorzaak-gevolg-oorzaak-gevolg patronen, waarbij een afhankelijke variabele (gebeurtenis) in een beginfase de onafhankelijke variabele (causale gebeurtenis) voor het volgende stadium vormt. Wholey (1979) 
bevorderde het idee van een 'program' logic model, waarin gebeurtenissen werden getraceerd indien een interventie door een publiek programma de bedoeling had bepaalde uitkomsten of een opeenvolging van uitkomsten te produceren. De interventie kon in eerste instantie bepaalde activiteiten tot gevolg hebben met hun eigen directe uitkomsten. Deze directe uitkomsten konden op hun beurt weer intermediaire uitkomsten tot gevolg hebben, en op hun beurt konden werden de intermediaire uikomsten geacht definitieve of ultieme uitkomsten te produceren.

Bij factor theory wordt gestart met een lijst van onafhankelijke variabelen. Vervolgens wordt bepaald welke van deze variabelen het hoogst correleren met de afhankelijke variabele. De onafhankelijke variabele die het hoogst correleren worden geacht (causaal) gerelateerd te zijn aan de afhankelijke variabele. Een sterk punt van factor theory is dat factoren (onafhankelijke variabelen) in de diepte onderzocht kunnen worden en dat gegevensverzameling vanuit verschillende bronnen plaats kan vinden (Hobma, 2000). ${ }^{101}$ Yin (1993: p. 16) constateert op basis van de toepassing van factor theory echter tevens een aantal minpunten bij gebruik van de techniek. Zo bleek het niet mogelijk factoren in volgorde van belangrijkheid te zetten, bleken interacties tussen factoren moeilijk vast te stellen en kon niet vastgesteld worden of de factoren deel uitmaakten van een meer algemene factor. Voor causale uitspraken beschouwt Yin (1993: p. 15) het niet als de meest aangewezen manier om tot uitspraken te komen, maar stelt aan de andere kant dat indien er geen verklarende theorie voor handen is (voor het gebruik van pattern matching) men al snel aangewezen is op factor theory.

\section{NOTEN BIJ HOOFDSTUK 5}

102 In spreektaal bedoelt men met het woord "station" vaak alleen het stationsgebouw en niet zozeer de overige infrastructuur (sporen, seinen en perrons, etc). Het station Amsterdam-centraal in haar huidige vorm is overigens gebouwd in de periode 1881-1889

103 Station Antwerpen centraal was gereed in 1905, Victoria Station in 1868 en Gare du Nord in 1865

104 Bertolini en Spit (1998) onderscheiden vijf drijvende krachten achter de (her)ontwikkeling van stationslocaties: 1) twee te onderscheiden vormen van overheidsbeleid, namelijk het bevorderen van milieuvriendelijk duurzaam transport en ruimtegebruik aan de ene kant en het stimuleren van locale economieën door het herstructureren van stedelijk gebied aan de andere kant, 2) positieve en negatieve technologische ontwikkeling, of de ontwikkeling van modaliteiten zoals HSL-systemen en regionale netwerken, 3) institutionele verandering, of privatisering en commercialisering, 4) de eigendomscirkel, of de ontwikkeling van de vastgoedmarkt, 5) internationalisering en metropolisering, vanuit welk perspectief stationsgebieden zijn gerelateerd aan Manuel Castell's 'space of flows'.

105 In Engeland en de Verenigde Staten krijgen benaderingen als Transport Development Areas (TDA) en Transit Orientated Development (TOD) veel aandacht. Hine (2000) definieert een Transport Development Area als: “an integrated land use/transport planning approach, centred on urban public transport interchanges or nodal points well served by public transport, in which a more specific relationship between development density and public transport service level is instituted." Transit Orientated Development is een vergelijkbaar planvormingsprincipe die in Amerika een enorme groei heeft doorgemaakt en waarvan het gebruik vrij standaard is waar het gaat om het combineren van grootschalig publiek transport en stedelijke ontwikkeling met een hoge dichtheid om congestie en 'urban sprawl' tegen te gaan.

106 Redenen hiervoor zijn o.a. dat hoge bevolkingsdichtheden insteden in Azie railvervoer aantrekkelijk maken en dat de eigenaar, exploitant van de rails en de vastgoedontwikkelaar in één bedrijf zijn gecombineert (Van der Velde, 2000)

107 De gemiddelde groei van het personenvervoer per spoor is sinds 1990 (na de invoering van de OV-studentenkaart) jaarlijks minder dan 1\% geweest.

108 De Nota Mobiliteit gaat voor de periode 2000-2020 uit van een ontwikkeling van het goederenvervoer per spoor van 28 naar $55-80$ miljoen ton per jaar.

${ }^{109}$ De verwachting is dat de Nederlandse samenleving tussen 2002 en 2020 ongeveer 110.000 hectare nodig heeft voor kantoren en huisvesting.

110 Voor 24 van de 33 stations met meer dan 15.000 in- en uitstappers per dag in 2004-2005 en voor diverse binnenstedelijke stationslocaties met meer dan 5.000 in- en uitstappers per dag in 2004-2005 zijn grotere of kleinere herontwikkelingsplannen al dan niet in uitvoering (Peek, 2006)

111 Kwaliteit van een multifunctioneel project kan dus worden opgevat als de perceptie die gebruikers hebben van de samenhang binnen het project, en van het project als geheel in een groter ruimtelijk perspectief (ORI, 1991)

112 Andere nota's zijn; Agenda voor een Vitaal Platteland (AVP); Nota Gebiedsgerichte Economische Perspectieven (GEP) en het Actieprogramma Ruimte en Cultuur.

113 In dit verband wordt in de Nota Ruimte ook wel de term 'ontwikkelingsplanologie' gehanteerd.

114 Ministerie van VROM, Wet Stedelijke Vernieuwing, Tweede Kamer, vergaderjaar 1997-1998, 25 427, nrs. 1-21. De Wet Stedelijke Vernieuwing is sinds 1 januari 2000 van kracht. Het doel van deze wet is om door middel van fysieke maatregelen de kwaliteit van de leefomgeving in steden te verbeteren. In de Nota Stedelijke Vernieuwing (Ministerie VROM, 1997) werd namelijk gesignaleerd dat in steden werkeloosheid, gebrek aan leefkwaliteit en het wegtrekken van bedrijven elkaar dreigen te versterken en het vestigingsklimaat voor bewoners en bedrijven dientengevolge verslechtert. De signalering van deze ontwikkeling in de Nota Stedelijke Vernieuwing geeft de aanleiding weer voor de ontwikkeling van het Investeringsbudget Stedelijke Vernieuwing (ISV)

115 ISV I liep van 2000-2004 en ISV II loopt van 2005-2009. Het ISV is één van de drie pijlers van het grotestedenbeleid (GSB). Naast de fysieke ISV-pijler omvat het GSB een sociale en een economische pijler. In het kader van het GSB gaat het bij een samenhangende aanpak dus om integratie van het beleid en de geldstromen op deze drie gebieden. Naar analogie van het ISV is door de bewindslieden van VROM en LNV in augustus 2002 besloten tot het instellen van een Investeringsbudget Landelijk Gebied (ILG). Voor een bijdrage uit het ISV stellen gemeenten een meerjaren ontwikkelingsprogramma (MOP) of een projectplan op die wordt getoetst aan het Beleidskader stedelijke vernieuwing. Dit beleidskader wordt per ISV-periode opgesteld. In de MOP's moeten de gemeenten aangeven op welke wijze zij invulling geven aan de doelstellingen uit het 
beleidskader. Het Rijk toetst de voorstellen in de MOP's en vraagt advies aan de provincie. Aan het einde van de budgetperiode van vijf jaar stelt de ISV-gemeente een verantwoordingsrapportage op. Op basis hiervan beoordelen het Rijk en de provincies of de voorlopige toekenning van ISV-budget definitief kan worden vastgesteld.

${ }^{116}$ De Raad voor Verkeer en Waterstaat (1998) stelt dat de huidige inpassingpraktijk voor infrastructuur te beperkt is, meer moet worden gekeken naar kansen voor een gebied en niet moet worden bezuinigd op het zoeken naar integrale oplossingen. Ook het voormalig kenniscentrum PPS van het Ministerie van Financiën gaf aan dat het kabinet zich zal blijven richten op projecten op het vlak van gebiedsontwikkelingen en die waarin gebiedsontwikkeling gecombineerd wordt met de aanleg van infrastructuur (Kenniscentrum PPS, 2002). Binnen de Rijksoverheid zijn er daarnaast verschillende initiatieven ontplooid waarin andacht werd besteed aan integrale gebiedsontwikkeling. Voorbeelden hiervan zijn de Adviescommissie Gebiedsontwikkeling bij het ministerie van VROM en de opgerichte interdepartementale Taskforce PPS en gebiedsontwikkeling.

${ }^{117}$ Het Ministerie van Financiën (2004) noemt deze fasen: initiatief, haalbaarheid, realisatie en beheer.

${ }^{118}$ Het station als 'plaats' beschrijft een fysieke omgeving. In deze fysieke omgeving zijn vier typen functies te onderscheiden, die Bertolini en Spit (1998) ruimtelijk te scheiden in zogenaamde schillen. Deze functies zijn 1) de kern (overstapactiviteiten), 2) commerciële functies, 3) ontmoetingsfunctie en 4) stadsactiviteiten.

119 Naast een indeling aan de hand van hun functionele arrangement worden stations ook wel ingedeeld aan de hand van de verticale positie van de sporen. Onder de grond, op maaiveldhoogte of verhoogt.

120 Artikel 2.3 Wro. Onder de 'oude' WRO (tot 1 juli 2008) werd het geheel van nota's, structuurschetsen en schema's waarin het nationaal ruimtelijk beleid was vastgelegd, aangeduid als 'planologische kernbeslissingen' (pkb's).

${ }^{121}$ Aanleiding hiervoor vormde de audit Luteijn in 2001 naar de rol van het het Rijk in de nieuwe sleutelprojecten. Het bleek dat gemeenten een 'zwaar' aanspreekpunt aan rijkszijde misten, de samenwerking tussen betrokken partijen moeizaam verliep, er een verschil van inzicht bestond over het functioneren van de Rijksoverheid en dat rollen en verantwoordelijkheden niet helder waren (Berenschot, 2005).

122 Voor de beoordeling werd een checklist van 34 vragen gehanteerd.

${ }^{123}$ Uitzondering hierop vormt NSP Amsterdam Zuidas waar het Rijk in een gezamenlijke ontwikkelingsmaatschappij betrokken blijft.

124 Met ingang van de begroting 2008 verschijnt er jaarlijks een Meerjarenprogramma Infrastructuur, Ruimte en Transport (MIRT). Dit is afgesproken in het Coalitieakkoord van 2007. Het MIRT komt in de plaats van het MIT (Meerjarenprogramma Infrastructuur en Transport) en verschijnt voortaan jaarlijks als onderdeel van de begrotingen van de ministeries van Verkeer en Waterstaat, Volkshuisvesting, Ruimtelijke Ordening en Milieubeheer, Economische Zaken en Landbouw, Natuur en Voedselkwaliteit.

${ }^{125}$ Het BIRK is uitgewerkt in een beleidsregeling gebaseerd op artikel 50a van de Wet op de Ruimtelijke Ordening (WRO) en artikel 38a e.v. van het Besluit op de Ruimtelijke Ordening (Bro).

126 Artikel 50a lid c van de 'oude' WRO

127 Tilburg Spoorzone, Groningen Europapark, Heerlen Stadspark Oranje Nassau, Haarlem Spoorzone, Amsterdam Zuidas.

128 Andere voorbeelden gericht op het stimuleren van ruimtelijke kwaliteit rond de aanleg van infrastructuur zijn: Hart voor Dieren, ondertunneling van spoor en weg, Hoogmade, HSL passage over de A4, Leiderdorp, W4-Masterplan, Maastricht, A2-passage door de stad, Midden-Delfland, groene impuls

${ }^{129}$ Voor Stationslocaties zijn in dit verband titel IIa, gericht op onteigening voor de aanleg van onder andere spoorwegwerken en titel IV, gericht op onteigening voor de realisatie of handhaving van bestemmingsplannen mogelijk relevant.

${ }^{130}$ Indien dit noodzakelijk is kan het opstellen van een m.e.r. onderdeel uit maken van de fase waarin een masterplan voor het stationsgebied wordt ontwikkeld en de procedure m.e.r. kan gekoppeld worden aan het vaststellen van een bestemmingsplan voor een gebied.

131 Per 1 juli 2008 vervangt deze de 'oude' Wet op de Ruimtelijke Ordening (WRO)

132 Art 2 Wro

${ }^{133}$ In de periode waarop de evaluatie van de casusssen in deze studie betrekking heeft was de nieuwe Wro nog niet van toepassing. Deze is in werking getreden vanaf 1 juli 2008. Daarom vinden in de casussen mogelijk verwijzingen plaats naar regelgeving die onder de 'oude' WRO van toepassing was.

134 Artikel 3.8 Wro

135 Artikel 3.26 Wro, respectievelijk artikel 3.28 Wro

${ }^{136}$ Vroeger was dit het college van B\&W en tegenwoordig kan de gemeenteraad de in het artikel genoemde bevoegdheid delegeren aan het college van $B \& W$.

137 Onder een goede ruimtelijke onderbouwing wordt bij voorkeur een gemeentelijk, intergemeentelijk of regionaal structuurplan verstaan. Indien er geen structuurplan is of wordt opgesteld, wordt bij de ruimtelijke onderbouwing in elk geval ingegaan op de relatie met het geldende bestemmingsplan, dan wel wordt er gemotiveerd waarom het te realiseren project past binnen de toekomstige bestemming van het betreffende gebied.

138 Artikel 3.10 Wro

${ }^{139}$ Het vereiste van een goede ruimtelijke onderbouwing is echter gedetaileerder uitgewerkt in het Besluit ruimtelijke ordening en het besluit moet binnen een jaar plaologisch-juridisch vertaald worden in een bestemmingsplan. 
${ }^{140}$ In het Besluit ruimtelijke ordening zijn categorieën van bouwwerken opgenomen, waarvoor een ontheffing van het geldende bestemmingsplan, te verlenen door het college van B\&W, mogelijk is.

${ }^{141}$ Per 1 oktober 2010 is de Wet algemene bepalingen omgevingsrecht (Wabo) in werking getreden. Deze wet regelt de omgevingsvergunning. De omgevingsvergunning is een geïntegreerde vergunning voor bouwen, wonen, monumenten, ruimte, natuur en milieu. In de meeste gevallen is het college van B\&W het bevoegd gezag voor het afgegevn van een beschikking.

${ }^{142}$ Het goederenvervoer heeft een andere status aangezien dit in Europees verband geliberaliseerd is.

143 Samen met de Spoorweg- en Concessiewet wordt het kader voor de spoorsector gevormd door acht (voornamelijk op de Spoorwegwet gebaseerde) algemene maatregelen van bestuur, twee Koninklijke besluiten (het Besluit aanwijzing hoofdspoorwegen en het Besluit hoofdrailnet) en enkele ministeriële regelingen.

144 In de Spoorwegwet art 26 lid 2 wordt een station gedefinieerd als: “ een gebouw of werk dat blijkens zijn constructie en inrichting geheel of gedeeltelijk is bestemd voor aankomst en vertrek van spoorvoertuigen met het oog op het in-, uit of overstappen van reizigers.”

145 Per 1 oktober 2010 zijn toestemmingen op grond van diverse wetten (Wro, Woningwet, Monumentenwet, e.d.) geintereerd in één omgevingsvergunning. De Wet algemene bepalingen omgevingsrecht regelt dit. In vele gevallen is het college van B\&W bevoegd tot het afgeven van de beschikking. Daarvoor was het college onder meer bevoegd tot het afgeven van bouwvergunningen.

${ }^{146}$ Per 1 januari 2008 is dit het Meerjarenprogramma Infrastructuur Ruimte en Transport (MIRT)

147 Artikel 5 Spoorwegwet

148 Als enige aandeelhouder van Railinfratrust BV is de Nederlandse Staat teven eigenaar van deze stationsdelen

${ }^{149} \mathrm{Zo}$ is een aan het aantal reizigers gekoppelde formule opgenomen voor het bepalen van het aantal zitplaatsen in de wachtruimte.

${ }^{150}$ Het ministerie van Verkeer en Waterstaat toetst onder andere op vervoerswaarde, investeringsbijdrage, kosten van exploitatie en inpassing in de dienstregeling.

151 Artikel 16, lid 1 Spoorwegwet

152 NS Railinfratrust BV is bij de verzelfstandiging van de NS in 1995 opgericht als houdstermaatschappij van de drie organisaties Railinfrabeheer (RIB), Railned en NS Railverkeersleiding. Op 1 juli 2002 is Railinfratrust uit de NS holding gehaald. Sinds 1 januari 2003 gebruikt Railinfratrust BV de handelsnaam 'ProRail'. Op 1 januari 2005 fuseerden de drie Railinfratrust-dochters Railinfrabeheer BV, Railverkeersleiding BV en Railned BV tot ProRail BV

153 In de concessie is opgenomen dat ProRail zorg draagt voor de kwaliteit, betrouwbaarheid en beschikbaarheid van hoofdspoorweginfrastructuur, zorgt voor een eerlijke verdeling van de beschikbare capaciteit van de hoofdspoorweginfrastructuur zowel ten behoeve van NS als ten behoeve van andere gerechtigden, en het verkeer over de hoofdinfrastructuur leidt. Onder de zorg voor de hoofdspoorweginfrastructuur wordt tevens verstaan het voorbereiden en uitbreiden van hoofdspoorweginfrastructuur die een nauwe samenhang heeft met de bestaande hoofdspoorweginfrastructuur.

154 Artikel 1 Spoorwegwet

155 Vanuit het belang van aansluitend vervoer voor het verkeers- en vervoersbeleid stelt de rijksoverheid ten aanzien van fietsenstallingen kwantitatieve en kwalitatieve voorwaarden, vergelijkbaar met die voor de transferfunctie. Financiering vindt tevens plaats vanuit de rijksoverheid.

156 Voor 1 januari 2005 werden de aandelen beheerd door het Ministerie van Verkeer en Waterstaat

157 De functionele eisen zoals beschreven in het rapport Basisstation waarborgen dat op twee manieren. Op de eerste plaats doordat ze duidelijkheid geven over de aard en de omvang van de nodige publieke reizigersvoorzieningen. Op de tweede plaats doordat ze op sommige punten expliciet ingaan op de manier waarop beide voorzieningen in voorkomende gevallen gecombineerd zouden moeten worden.

158 In de zogenaamde Nieuw voor Oud-regeling conform de Intentienotitie DZI (Definitie Zeggenschap infrastructuur), wordt gesteld dat de veroorzaker van aanpassingen aan de transferfunctie (de Rijksoverheid) zich maximaal zal inspannen deze wijzigingen niet ten koste te laten gaan van de bestaande commerciële functies. De eventueel hiervoor te maken kosten zijn dan voor rekening van de Rijksoverheid.

\section{NOTEN BIJ HOOFDSTUK 6}

159 Een procedure voor een m.e.r. werd in de Intentieontwikkelingsovereenkomst niet noodzakelijk geacht. Deze m.e.r. procedure is echter toch wel doorlopen. De m.e.r. procedure voor Den Haag Nieuw Centraal wordt doorlopen op basis van de te verwachten bezoekersaantallen (500.000 bezoekers per jaar) van de recreatieve inrichtingen in het plangebied. Bij dit aantal is een m.e.r.-procedure in alle gevallen verplicht.

${ }^{160}$ Het bestemmingsplan DHNC is in september 2008 in werking getreden en in maart 2009 onheroepelijk geworden.

161 Eigenlijk wordt de herontwikkelingsopgave Den Haag Nieuw Centraal verdeeld in negen blokken. Daarvan maken vijf planonderdelen deel uit van het CS Kwadrant, waaronder de OV-terminal. In de exploitatie is de OV-terminal losgekoppeld van de overige vier vastgoedprojecten. Verder wordt in sommige stukken het Haags Startstation Erasmuslijn (HSE) en Bellevue als deelprojecten genoemd. Deze staan echter niet als zodanig genoemd in het Masterplan DHNC.

162 Het Stadsgewest Haaglanden en de Stadsregio Rotterdam zijn opdrachtgever voor de aanleg van de RandstadRail. Voor de uitvoering van het project RandstadRail zijn twee projectorganisaties ingericht. PORR (ProjectOrganisatie Randstadrail) onder de Dienst Stads Beheer van de gemeente Den Haag (DSB) voor het Haagse deel. En PbRR (PorjectBureau RandstadRail) onder de RET voor het Rotterdamse deel.

${ }^{163}$ Naast het doel van de samenwerking, regelt de overeenkomst financiële aspecten, de overlegstructuren, de wijze van opdrachtverstrekking aan derden, aanbesteding methode en contractering, ontbinding- en uittredingsregelingen bij eventueel het staken van het project, alsmede de geheimhoudingsplicht. Verder vormt de samenwerkingsovereenkomst, met het definitief ontwerp onderdeel van: 
- de door ProRail aan te vragen MIT beschikking, af te geven door het ministerie van Verkeer \& Waterstaat en;

- het uitvraagdossier voor het Engineering \& Construct (E\&C) contract, te sluiten met een of meerdere aannemers of een combinatie van aannemers voor de realisatie van OVT Terminal.

164 Het stadsgewest Haaglanden is een zogenaamde plusregio (voorheen kaderwetgebied) dat functioneert op grond van de Wet Gemeenschappelijke Regelingen plus. Het stadgewest kan worden gezien als een extra bestuurslaag, echter zonder rechtstreeks gekozen bestuur.

165 De bijdrage van het miniserie van V\&W bedraagt 79 miljoen euro (bestuurlijke overeenkomst Rijk-Gemeente, december 2003). Deze bijdrage is van prijspeil 2002 en wordt geïndexeerd conform de Index Bruto OverheidsInvesteringen (IBOI). Daarmee komt inclusief de bijdrage van het ministerie van VROM (49 mln euro) de totale rijksbijdrage geindexeerd voor 2007 op $145 \mathrm{mln}$.

166 Stichthage is gedeeltelijk eigendom van Shell Pensioenfonds, maar NS Vastgoed streeft ernaar het gebouw geheel in eigendom te krijgen en er een herontwikkelingsplan voor op te stellen.

167 Volgens de Intentieverklaring met de gemeente is de NS officieel 'eerste gegadigde' als belegger van de geplande bebouwing op en onder het KJ-plein.

168 Voorheen waren dit IMCA en Bouwfonds Property Finance. IMCA is in oktober 2005 verder gegaan als Maeyveld BV. Maeyveld BV is in juni 2007 overgenomen door Fortress. Bouwfonds Property Finance, onderdeel van ABN AMRO Bouwfonds is in 2006 overgenomen door SNS Reaal en gaat verder als SNS Property Finance

${ }^{169}$ De gemeenteraad stelt een welstandscommissie samen of stelt een Stadsbouwmeester aan. Deze nemen de welstandsnota als uitgangspunt voor de beoordeling van bouwplannen.

${ }^{170}$ De Rijksbouwmeester adviseert de regering over het architectuurbeleid en de rijkshuisvesting. De Rijkbouwmeester is lid van het College van Rijksadviseurs. Het atelier Rijksbouwmeester is onderdeel van het Ministerie van VROM. De Rijksbouwmeester adviseert het Directoraat Generaal Ruimte van het Ministerie van VROM over de zogenaamde Nieuwe Sleutelprojecten. Alvorens de afzonderlijke projecten subsidie ontvangen, vindt een aantal toetsen plaats. De Rijksbouwmeester is verantwoordelijk voor de toets op de stedenbouwkundige kwaliteit.

171 De Spoorbouwmeester adviseert de directie van ProRail en de NS over architectuur, stedenbouw en stationsinrichting en geeft richting aan het Spoorbeeld: een eenduidige en begrijpelijke beeldtaal waarmee de spoorbranche de onderlinge samenhang en eigen identiteit communiceert.

172 De standaard deviatie is een indicatie voor de mate van overeenstemming die er bestaat in de toegekende scores. In de statistiek wordt de variatiecoëfficiënt gebruikt als spreidingsmaat. Deze is gedefinieerd als het coëfficiënt van de standaard deviatie en het gemiddelde. De variatiecoëfficiënt is dimensieloos en daarom goed geschikt om verschillende populaties te vergelijken, zeker wanneer deze variaties zeer uiteenlopende gemiddelden hebben.

173 In dat geval is de perceptie meer een psychologisch proces

174 De verdeling van zeggenschap tussen partijen kan gedurende het planproces veranderen. Om dit dynamische aspect mee te nemen in de analyse is naast de zeggenschapsverdeling gevraagd twee jaar voor het vaststellen van het Masterplan te kijken en aan het begin van het traject tot vorming van de deelplannen. Uit de analyse van de percepties was stakeholders hierover blijkt dat men 1) of niet in staat was dit aan te geven of 2) de gegeven antwoorden vrijwel niet afweken van de antwoorden ten aanzien van de zeggenschapsverdeling ten tijde van het vaststellen van het masterplan respectievelijk OV-Terminalplan.

Twee manieren voor de verwerking van de resultaten: 1) het gemiddelde van beide of 2) alleen de meest recente.

Omdat er diverse respondenten niet in staat zijn het te beantwoorden en uit methodologische literatuur blijkt dat retrospectief kijken sowieso al lastig is ligt optie 2 meer voor de hand. Dit staat in de voorgaande tabel. Als er markante verschillen bestaan en er een aanzienlijke verschuiving van zeggenschap zich heeft voorgedaan in het proces wordt dit expliciet aangegeven.

175 Daarnaast zijn diverse andere partijen te noemen zoals winkelexploitanten, vervoerders (HTM/Connexion), belangenverenigingen (Locov/Rover, etc.), reizigers. Deze hebben echter geen directe eigendomspositie of bestuurlijke verantwoordelijkheid.

\section{NOTEN BIJ HOOFDSTUK 7}

176 Tussenovereenkomst Voorlopig-Ontwerp OV-Terminalcomplex Breda CS nsp.

177 De resultaten van de milieubeoordeling worden op korte termijn vertaald in het bestemmingsplan Stationskwartier, het voorlopig ontwerp voor het OV-Terminalcomplex Breda CS, het voorlopig stedenbouwkundig ontwerp voor het deelgebied Drie Hoefijzers en de Bereikbaarheidsvisie Spoorzone. De inspraak op het Milieueffectrapport Spoorzone is gekoppeld aan het voorontwerp bestemmingsplan Stationskwartier.

178 Het bestemmingsplan Stationskwartier geeft een planologisch-juridische vertaling van het Masterplan Centraal Breda en biedt daarmee de planologisch-juridische basis voor verdere planontwikkeling

${ }^{179}$ Het ontwerp Beeldkwaliteitsplan beschrijft de stedenbouwkundige en architectonische uitgangspunten van het gebied. In het plan staan zaken omschreven als maximale bouwhoogtes, zichtlijnen, de manier waarop het gebied ontsloten wordt en de verdeling van de verschillende bouwhoogtes.

${ }^{180}$ Het ontwerp Buitenruimteplan geeft een omschrijving van de kwaliteit van de niet-bebouwde (openbare) ruimte.

181 De Voortgangsrapportage nieuwe sleutelprojecten van VROM (2006) geeft de volgende gegevens: $117.000 \mathrm{~m} 2$ BVO kantoorruimte, 595 wooneenheden, $13.500 \mathrm{~m} 2$ BVO voorzieningen. In het Bestemmingsplan Stationskwartier wordt aangegeven dat het gaat om $120.000 \mathrm{~m} 2$ kantoorruimte met een flexibiliteit naar $140.000 \mathrm{~m} 2$ BVO, om tenminste 400 woningen en maximaal 650, waarbij in het Stedenbouwkundig 
Ontwerp wordt uitgegaan van 605 woningen $(72.500 \mathrm{~m} 2 \mathrm{BVO}), 50.000 \mathrm{~m} 2$ gebouwde parkeerruimte, 4200 stallingplaatsen voor fietsen en diverse andere voorzieningen.

182 De uitgangspunten voor de OV-terminal zijn neergelegd in het OV-Terminalplan

183 Uitgangspunt voor de gebiedsontwikkeling is het Stedenbouwkundig Ontwerp.

184 Realisatieovereenkomst OV Terminal Complex

185 Onderdeel van de integrale OV-Terminal.

${ }^{186}$ Samen met bijdragen van andere partijen komt de totale investeringen in het gebied uit op ongeveer 170 miljoen euro. (Breda, 2006)

${ }^{187}$ In het kader van de Vijfde Nota Ruimtelijke Ordening is Brabantstad aangewezen als een van de nationale stedelijke netwerken In hoofdstuk 4 is ingegaan op het beleid dat hiervoor is neergelegd in de Nota Ruimte.

188 Voor het HOV Etten-Leur-Breda-Oosterhout is aanvullend nog een bedrag van 10,0 mln. euro gereserveerd. Dit valt buiten de scope van NSP-Breda. Wel is het HOV geconcentreerd op de OV-terminal.

189 Fonds Eenmalige bijdragen NS. Dit zijn middelen die aan NS ter beschikking zijn gekomen uit de financiële resultaten van verkochte telecombelangen. Deze hebben, met toestemming van de rijksoverheid als aandeelhouder, in het OV-veld een specifieke bestemming gekregen. In het contract tussen NS en ProRail is vastgelegd dat de FENS-gelden deels geïnvesteerd moeten worden in Beheerste toegang stations en electronic ticketing.

${ }^{190}$ Hierbij gaat het om vorm en verantwoordelijkheden inclusief exploitatieovereenkomsten en 'benefit sharing'.

191 o.a. samenwerking met de Brabantse Ontwikkelingsmaatschappij (BOM) en het Regionaal Werkgelegenheidsinstituut (REWIN) en het inrichten van een informatiecentrum

192 Analyse idem als transparantie. Daarnaast is nog een algemeen oordeel gevraagd over de openheid van het planproces.

193 Opgemerkt dient te worden dat het gaat om het oordeel van de respondenten of het proces in voldoende mate open is geweest. Het kan namelijk zo zijn dat de procesfase vraagt om een zekere geslotenheid (vertrouwelijkheid) bijvoorbeeld in verband met concurrentiegevoelige informatie. Veronderstelt wordt dat respondenten dit in hun oordeel meenemen.

\section{NOTEN BIJ HOOFDSTUK 8}

$194 \mathrm{Al}$ in 1847 werd de spoorlijn langs Delft in gebruik is genomen. Het huidige stationsgebouw dat in 1885 gerealiseerd werd is dus al het tweede in Delft. Delft zal na uitvoering van het Spoorzoneproject dus al aan een derde station toe zijn. In het kader van projectbeheersing en management was juist de aanleg nabij Delft in 1847 erg interessant omdat een grondeigenaar net ten zuiden van het huidige station weigerde zijn grond ter beschikking te stellen voor de spooraanleg. Dit noopte de ingenieurs toen tot een noodgreep: een omrijspoor om het gewraakte stuk grond heen: De Kromme Lijn om het "Laantje van Van der Gaag" heen. Spotprenten uit die tijd herinneren aan dit geschil. Overigens werd binnen een week na de ingebruikname van de omgelegde spoorlijn alsnog een akkoord bereikt over het weer rechttrekken van de lijn over het "Laantje van Van der Gaag" heen

195 In 2006 passeerden ongeveer 350 treinen per etmaal Delft en de verwachting is dat dit er in 2015 circa 550 zullen zijn. (Gemeente Delft, 2006).

196 Onderzoek van Frits Palmboom

197 Ondanks een verlegging van het tracè hebben partijen geconstateerd dat een tracèwetprocedure niet noodzakelijk was. Voor de aanleg van de spoortunnel bestaat op basis van het besluit m.e.r. geen plicht tot het maken van een MER. Voor het realiseren van het stedelijke programma bestond een m.e.r./beoordelingsplicht. Besloten is voor zowel de tunnel als de stedelijke ontwikkeling de milieueffecten in kaart te brengen.

198 Het station Delft krijgt is een redelijk groot station waar elke dag ongeveer 20.000 reizigers in - en uit stappen en het ligt in het centrum van een middelgrote stad. NS verwacht in 2010 om en nabij de 40.000 in-/uitstappers te verwerken in Delft.

199 Voor de beschrijving is gebruik gemaakt van officiële documenten die bestuurlijke goedkeuring hebben (m.n. bestemmingsplan Spoorzone Delft). Inmiddels is echter duidelijk dat een aantal van deze elementen anders uitgevoerd moet worden dan in het bestemmingsplan opgenomen. Zo blijkt de parkeergarage onder het stadskantoor te duur en te inefficiënt om voor uitvoering in aanmerking te komen en is ook al duidelijk dat de fietsenstalling met 5000 plaatsen niet zal volstaan. De groei van het voor- en natransport op de fiets is, zoals overal in Nederland, boven de verwachtingen. Gezocht wordt naar aanvullende ingrepen in het plangebied ter grootte van 2000 extra plaatsen. Onderzoek naar alternatieven is nog gaande. Hiervoor bestaat echter nog geen financiële en planologische onderbouwing en bestuurlijke goedkeuring.

200 Met de Addendum Bestuurlijke Uitvoeringsovereenkomst Spoorzone Delft van 2008 is deze risicoverdeling gewijzigd. Zie verderop in de tekst.

201 De lange en de korte tunnelvariant

202 ProRail heeft de realisatie van de spoortunnel gegund aan Crommelijn VOF. Crommelijn is een consortium dat bestaat uit drie bedrijven. CFE NV, Haverkort Voormolen BV TBI Infra en Dura Vermeer.

203 In de uitwerking van de organisatie is op dit punt een essentiële aanpassing doorgevoerd. De wethouder voor de Spoorzone is niet langer lid van de Raad van Commissarissen, laat staan voorzitter. Voorzitter is inmiddels ex-minister en ex-Tweede Kamerlid Klaas de Vries. De wethouder is nog wel de gemeentelijke vertegenwoordiger in de Stuurgroep Rijk-gemeente.

204 In tegenstelling tot de analyse van Den Haag Nieuw Centraal en Stationskwartier Breda is als eindpunt van het eerste traject niet de (voorwaardelijke) goedkeuring van het Rijk met het Masterplan als eindpunt genomen, maar de vaststelling ervan door de gemeenteraad van Delft. 
Reden hiervoor is dat in tegenstelling tot de Nieuwe Sleutelprojecten, waarbij toetsing van het Masterplan door het Rijk aan het NSP-beleid onderdeel uitmaakt van de procesfasering, deze toetsing bij de Spoorzone Delft niet van toepassing is. Hier gelden voor toekenning van middelen vanuit het Rijk naast de MIT procedure de procedure vanuit het BIRK-beleid.

205 In dat geval is de perceptie meer een psychologisch proces

${ }^{206}$ Begin 2006 werden vier architectenbureaus uitgenodigd om een schetsontwerp te maken. Een procedure waarin zowel een selectiecommissie als een groep bewoners het beste schetsontwerp mocht kiezen leverde uiteindelijk twee winnaars op. Nadat door de verschillende architectenbureaus om uiteenlopende redenen kort gedingen werden aangespannen trok de gemeente het voornemen tot gunning terug en kondigde aan de ontwerpen te gaan herbeoordelen. Nadat herbeoordeling niet direct tot een winnaar leidde startte de gemeente in april 2007 een vervolgprocedure waarin de vier architecten hun ontwerp konden vervolmaken.

${ }^{207}$ In de Addendum Bestuurlijke Uitvoeringsovereenkomst van 9 juli 2008 is opgenomen dat er teven een vertegenwoordiger van het OBS als informant zitting heeft in de Stuurgroep Rijk-Gemeente

${ }^{208}$ Een mogelijke reden zou kunnen liggen in het feit dat de nieuwe OV-terminal op een andere plek komt te liggen.

${ }^{209}$ Zie artikel 4 Bestuurlijke Uitvoeringsovereenkomst Spoorzone Delft

${ }^{210}$ Het risico voor de gemeente Delft is gemaximeerd op 5 miljoen Euro.

211 Analyse idem als transparantie. Daarnaast is nog een algemeen oordeel gevraagd over de openheid van het planproces.

212 Artikel 9 lid 4

213 Analyse aan de hand van:

Algemeen gemiddelde voor de transparantie van het Masterplantraject (SD in voetnoot). Idem voor OVT-traject.

Kijken of het gemiddelde per kolom redelijk overeenkomt met het algemeen gemiddelde

Standaard deviatie per rij (vergelijk de standaard deviatie per rij met het gemiddelde, dan kan worden beoordeeld of er op die punten sprake is van relatief veel onenigheid en op andere punten wellicht relatief weinig onenigheid

${ }^{214}$ Artikel 6.2

215 Vergelijking op basis van indicatieve programma's zoals beschreven in de masterplannen

${ }^{216}$ Zie 4.1.3 voor een toelichting op de keuze voor het gebruik van percepties.

${ }^{217}$ In Delft de vaststelling door de gemeenteraad, omdat Delft geen NSP project betreft en dientengevolge goedkeuring door het Rijk geen onderdeel uitmaakt van de procesarchitectuur.

${ }^{218}$ Het is relevant op te merken dat in Delft de selectie van achitect Mecanoo op basis van een schetsontwerp voor het stadse deel van de OVknoop het eindpunt is, in plaats van een vastgesteld definitief ontwerp. Reden hiervoor is dat in Delft de planvorming voor de OV-knoop ten tijde van de uitvoering van de interviews in een minder vergevorderd stadium verkeerde. Voor het ondergrondse (spoorse) deel een van de OV-knoop is er overigens een andere architect dan voor het bovengrondse (stadse) deel. Hier is uitgegaan van het ontwerp voor het bovengrondse deel.

${ }^{219}$ Met een Addendum op de bestuurlijke overeenkomst tussen Rijk en gemeente in 2008 is deze risicoverdeling gewijzigd. De analyse heeft echter betrekking op de periode voorafgaand aan dit Addendum.

${ }^{220}$ Het oordeel over de bijdrage van het masterplan an de dimensies van ruimtelijke kwaliteit is vergeleken met het algemene rapportcijfer dat betrokken actoren hebben gegegeven aan de inhoud van het betreffende masterplan.

\section{NOTEN BIJ HOOFDSTUK 9}

geen

\section{NOTEN BIJ HOOFDSTUK 10}

221 Van Montfort (2008) stelt de vraag welke publieke waarden in het geding zijn in specifieke publiek-private arrangementen en of (en hoe) deze publieke waarden in deze arrangementen zijn geborgd. Hij geeft daarbij aan dat over de prestaties van publiek-private arrangementen nog niet zoveel bekend is. Van Genugten (2008: p.5) stelt dat er geen duidelijke definitie van het publiek belang is en verre van consensus bestaat over wat publieke belangen in specifieke situaties zijn. Provan en Milward (2001) stellen in een bredere context, dat in veel studies waarin coördinatie tussen actoren in een netwerk centraal staat onderzoek naar de relatie tussen de interorganisationele samenwerking en maatstaven voor de effectiviteit, ontbreken.

222 Het gaat hier om de inbreng van middelen voor de integrale herontwikkeling van het plangebied zoals beschreven in het Masterplan. Uit een aantal pilot-interviews bleek dat het voor geïnterviewden onmogelijk was om bij de inbreng van middelen door sommige keystakeholders een onderscheid te maken naar de OV-terminal en het project als geheel.

223 De publieke waarden die Bozeman (2002) noemt hebben vooral betrekking op procesgerelateerde criteria

224 Naast pragmatische overwegingen van beschikbare tijd liggen twee inhoudelijke argumenten ten grondslag aan deze keuze. In de eerste plaats vormt in governance literatuur, de discussie over de wijze waarop veranderende rollen en verhoudingen dienen te worden vormgegeven met het oog op meer effectiviteit en legitimiteit de rode draad (Scharpf, 1997; Pierre, 2000; Haus et al, 2005; e.a.). Dat geldt ook voor de ruimtelijke sector waar de kritiek op de 'traditionele' top-down wijze van planvorming vanuit de overheid vooral werd geuit in termen van een gebrek aan legitimiteit en effectiviteit (Teisman, 1997; Kreukels, 1999). Een tweede argument is gelegen in de samenhang tussen de concepten. Zo draagt efficiency bij aan de legitimiteit en is legaliteit een basis voor rechtszekerheid en rechtsgelijkheid en een voorwaarde voor legitimiteit (vgl. Rosenthal, 1996). 
225 Dit is de kern van de klassieke theorie over politieke representatie zoals geformuleerd door Edmund Burke in zijn klassieke toespraak voor de burgers van Bristol

226 Uitzondering hierop vormt de openheid van het planproces voor de OV-terminal.

${ }^{227}$ Het gaat hier dus met nadruk om de verbouding tussen de inbreng van publiek en privaat.

228 Scharpf (1997: p.19) stelt dat het handelen van actoren gebaseerd is op hun subjectieve perceptie van de werkelijkheid, de veronderstelde oorzaak-gevolg daarin en hun subjectieve voorkeuren.

${ }^{229}$ Ambivalentie kan ontstaan als gevolg van verschil in kaders op basis waarvan actoren de werkelijkheid interpreteren of als gevolg van een overvloed aan informatie, verwarring en conflicterende kennis of informatie (Koppenjan en Klijn, 2004; Dewulf et al, 2005).

${ }^{230}$ Charles et al. (2008) onderscheiden drie benaderingen van 'public values' die ze aanduiden met de termen 'universalistic approach',

'stakeholder approach' en 'institutional perspective'.

231 Onder andere Van Wijnbergen (2000; 2004) en Teulings et al. (2003) bekritiseren het WRR rapport 'Het borgen van het publiek belang' omdat dit teveel aandacht zou schenken aan de vraag hoe het publiek belang geborgd kan worden, maar vrijwel geen aandacht schenkt aan de vraag wat het publiek belang is.

232 Een alternatieve of anvullende werkwijze had kunnen zijn in het voorleggen van de 'performance' vraag. "Is het publiek belang naar uw mening gewaarborgd"? Confrontatie van het antwoord met de resultaten op de onderscheiden dimensies effectiviteit en legitimiteit laat dan zien of deze dimensies in de beleving van de actoren staan voor de borging van het publiek belang. Stel namelijk dat het antwoord zou zijn dat het publiek belang naar de mening van de betreffende actor niet gewaarborgd, maar de projecten zijn wel effectief en legitiem, dan correspondeert het niet (construct- of inhoudsvaliditeit).

${ }^{233}$ De scores die de betrokkenen toekenden aan de gehanteerde indicatoren bleken wel te verschillen. Uit analyse van deze verschillen kwam geen patroon naar voren waaruit bleek dat de opvattingen in een van de cases meer uiteen liepen dan in andere cases. Met uitzondering van de transparantie van het planproces (throughputlegitimiteit) waren in alle cases op alle indicatoren de oordelen van alle betrokkenen ook niet negatief ( 3 en groter).

${ }^{234}$ Freeman (1984) stelt dat een strategie alleen succesvol kan zijn als daarmee de behoeften van keystakeholders worden bevredigd.

235 Letterlijke replicatie - om gelijke resultaten te voorspellen - of theoretische replicatie - om verschillende resultaten te produceren op basis van vooraf gespecificeerde plausibele redenen - dient de basis zijn voor de selectie van meerdere cases (Cook and Campbell, 1979: p.78; Yin, 1994: p.47; e.a.).

236 Dat geldt in het bijzonder voor de planvorming voor de OV-terminal. Gemeenten zijn hier voor het overgrote deel van de financiële middelen afhankelijk van het ministerie van verkeer en Waterstaat, hebben een beperkt risicodragend vermogen en hebben binnen de OV-terminal te maken met NS en ProRail met hun eigen bevoegdheden en verantwoordelijkheden. Niettemin zijn gemeenten in alle drie cases (mede)opdrachtgever voor de OV-terminal. In Den Haag, maar ook in Delft hebben heronderhandelingen tussen het ministerie van Verkeer en Waterstaat en de gemeenten over kosten- en risicoverdeling geleid tot vertragingen in het proces. ${ }^{236}$ Ook in andere Nederlandse stationslocatieprojecten, zoals Rotterdam Centraal en Arnhem Centraal, heeft de spanning tussen hoge kwaliteitsambities van vooral gemeenten en het ministerie van VROM en de kosten daarvan, die voor het overgrote deel gedragen moeten worden door het ministerie van Verkeer en Waterstaat, een prominente rol in het proces gespeeld. 